$$
\begin{aligned}
& \text { 7) } 1 \text { it }
\end{aligned}
$$

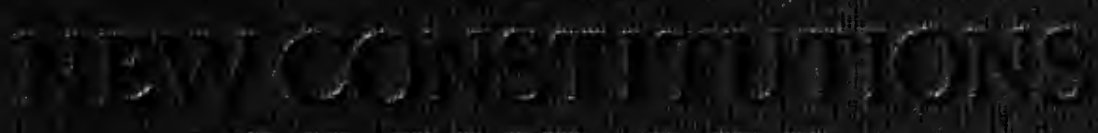

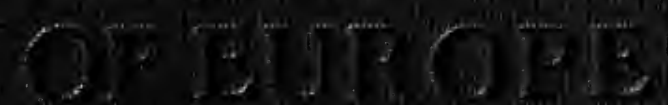

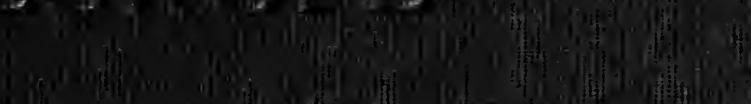

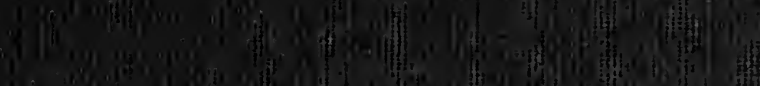

$$
\begin{aligned}
& \text { (19. }
\end{aligned}
$$

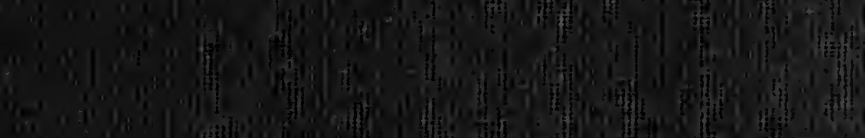

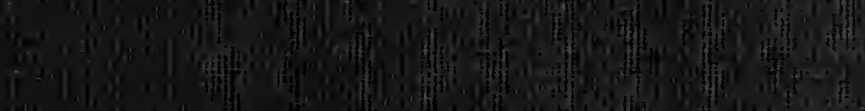

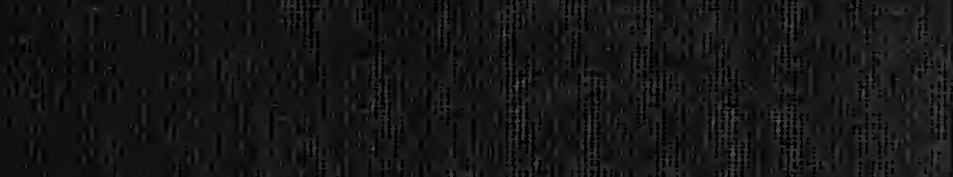

$$
\begin{aligned}
& \text { (19.5) }
\end{aligned}
$$

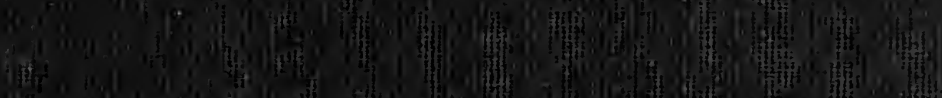

$$
\begin{aligned}
& \text { The }
\end{aligned}
$$

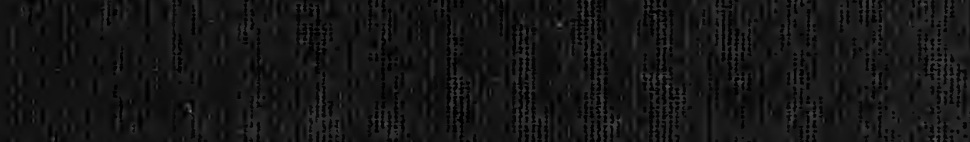

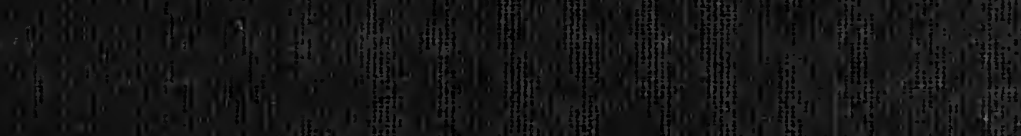

$$
\begin{aligned}
& \text { 1. }
\end{aligned}
$$

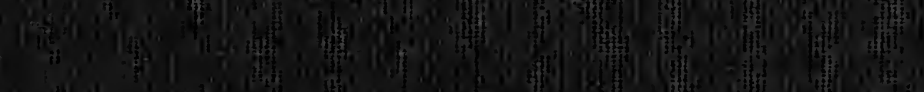




\section{LIBRARY}

UNIV RITY OF CALIFORNIA SAN DIEGO 

Digitized by the Internet Archive in 2007 with funding from

Microsoft Corporation 


\section{THE NEW CONSTITUTIONS \\ OF EUROPE}




\title{
THE \\ NEW CONSTITUTIONS \\ OF EUROPE
}

\author{
B Y \\ HOWARD LEE MCBAIN
}

Eaton Professor of Municipal Science and

Administration in Columbia University

AND

LINDSAY ROGERS

Associate Professor of Government in Columbia University

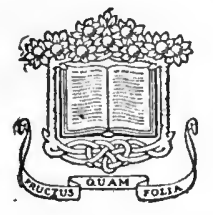

GARDEN CYTY NEW YORK

DOUBLEDAY, PAGE \& COMPANY 1922 


\section{COPYRIGHT, 1922, BY \\ DOUBLEDAY, PAGE \& COMPANY}

ALL RIGHTS RESERVED, INCLUDING THAT OF

TRANSLATION INTO FOREIGN LANGUAGES,

INCLUDING THE SCANDINAVIAN

PRNTED IN THE UNITED STATES

THE COUNTRY LIFE PRESS, GARDEN CITY, N. $Y$.

First Edition 


\section{PREFACE}

Constitutions are at best only the skeletons of bodies politic. But like most skeletons they are of fundamental importance. They determine the height, the solidity, and something concerning the shape, general contour, and functional possibilities of the bodies they support. It requires the superb imagination of a Mr. Wells to be fairly certain that, when 200,000 or 250,000 years ago the Heidelberg man was in operative possession of his now famous jaw-bone, "the sabre-toothed tiger was declining and the lion was spreading over Europe;" or to construct a convincing story of the "civilization" of the Neanderthal men from the skeleton of a youth who "apparently" was "deliberately interred" in a "sleeping posture" with his head "on a number of flint fragments." But it requires no osteologist to tell us that living bones are of importance, not only in respect to their articulation one to another but also in respect to the motive forces that govern their activities. An exhibit of skeletons is not devoid of interest and of instructional potentialities; the veriest layman can distinguish the frame of a quadruped from that of a biped, or the skull of an ichthyosaurus from that of a man.

It has seemed to us desirable and useful, therefore, to bring the constitutional skeletons of the new governments of Europe together in a single volume where they could be conveniently analyzed and compared. Not all of these constitutions have been heretofore translated into English, and many of them have been difficult of access in any version. They are indispensable first materials for any comparative study of the remodeled political institutions of Europe. 
A word or two is necessary in explanation of our plan of inclusion and exclusion. In addition to the constitution of the German Reich, we have included the constitution of the important state of Prussia and a brief description of the constitutions of several of the other German states. In Russia, in spite of a written constitution, apparently no distinction is made between fundamental and ordinary law. The constitution here incorporated has been modified by laws that have not been specifically enacted as constitutional amendments. In essence, however, it probably portrays the general scheme of organization that is in operation. Of the new or succession states, we have included the constitutions of Finland, Esthonia, Poland, Danzig, Czechoslovakia, Jugoslavia, and Austria, which is a new state in all but name. No new constitution has been adopted in the new state of Hungary. Latvia is still governed by a constituent assembly elected in April, 1920; it is anticipated that a permanent constitution will be promulgated during the summer of 1922. Lithuania is still operating under a provisional constitution adopted April 4, 1919. D'Annunzio's constitution for Fiume was proclaimed in August, 1920; but since the 'Treaty of Rapallo (November, 1920), by which the Free State of Fiume was legally recognized, a constituent assembly has been called; and although this body has been far from harmonious, it seems probable that D'Annunzio's unique document, which has not been here included, will shortly be replaced by a more adequate instrument. Absorbed in armed conflict with the Italians and the Serbs until the summer of 1920, Albania, likewise, has not yet perfected a permanent form of government.

Of the old countries that have not succumbed to revolutions, Belgium is the only one in which the constitution has been subjected to important revision since the war. For this reason-and because it served as a model for the drafting committees in the new states-it has been in- 
cluded in the Appendix, with the new provisions translated into English for what is, we believe, the first time. Although France and Italy have enacted important new electoral laws, no changes have been made in their "constitutional laws." Even so, it has seemed to us that the usefulness of this volume for purposes of comparison would be increased by incorporating the French and Italian constitutions in the Appendix. Certain other documents of interest are also printed in the Appendix. The voluminous footnotes throughout the introductions make unnecessary any separate bibliographical apparatus.

Of the constitutions embraced within this volume those of Prussia, Austria, and Finland have not, so far as we know, been previously translated into English. In the official or semi-official English texts of certain other constitutions we have ventured to make a few corrections that seemed to us imperative. The constitutions of the Central Powers presented some special difficulties. Whatever may be thought of the democratic features of the German constitution, linguistically it leaves something to be desired, and, to speak mildly, it is rather inclusive. On the other hand, the Prussian document, although obviously modeled on the constitution of the Reich, substitutes simplicity for complexity and is in consequence a well-drafted instrument of government. It is the Austrian constitution, however, that has no competitor for the post of primacy in the matter of anfractuous verbiage. For assistance in translating the German, Prussian, and Austrian documents we are deeply indebted to Mr. Ellwood Wadsworth Kemp, Jr., and Mr. Ruidiger Bilden.

In the introductory chapters of this volume we have discussed certain principles of politics and public law that seem to us to be pertinent to a study of the new fundamental laws of democratic states. In many instances we have discussed these principles with special reference to English practices and problems; for England, without a 
written constitution, is after all the mother country of parliamentary government. We have also in some instances discussed matters that supplement the new constitutions in important particulars. We have made no attempt, however, to digest the constitutions themselves, and with few exceptions we have made no detailed comparison of the institutions which they set up. In other words, the texts of the constitutions are not merely a referential appendix: they are an integral part of this book. From them the interested student may make his own comparative study and draw his own inferences and conclusions. We have sought to supply the materials for study rather than a fabricated product.

H. L. McB.

L. R. 


\section{CONTENTS}

PAGE

\section{PART I. INTRODUCTION}

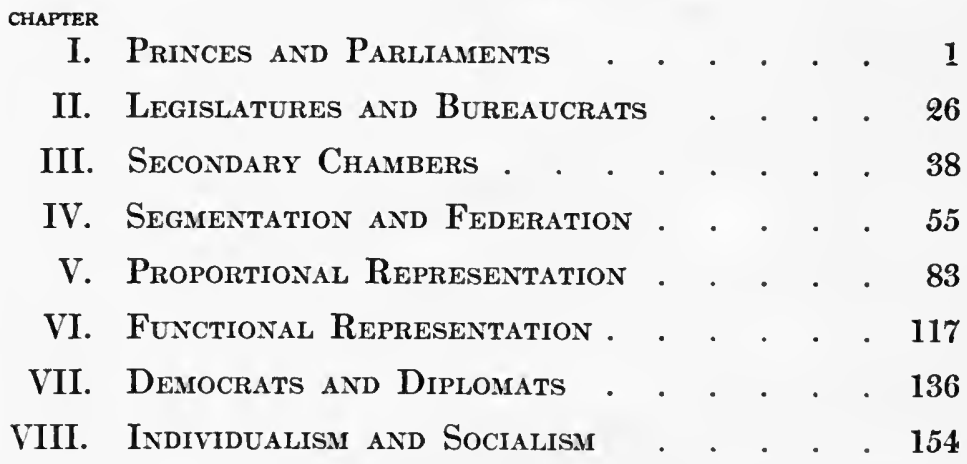

PART II. THE NEW CONSTITUTIONS OF EUROPE

IX. Germany

1. Historical Note . . . . . . . . 167

2. Constitution of the German Reich . . 176

X. Prussia

1. Historical Note . . . . . . . . . 213

2. Constitution of the Free State of Prussia . 217

XI. Bavaria, Württemberg, and Baden . . . 233

XII. Austria

1. Historical Note . . . . . . . . . 241

2. Constitution of Austria . . . . . . 256

XIII. Czechoslovakia

1. Historical Note . . . . . . . . 307

2. The Constitutional Charter of the Czechoslovak Republic . . . . . . . 310 is 


\section{CONTENTS}

CHAPTER

XIV. Jugoslavia

1. Historical Note . . . . . . . . 343

2. Constitution of the Kingdom of the Serbs,

Croats, and Slovenes (Jugoslavia) • . 348

XV. Russia

1. Historical Note . . . . . . . . 379

2. The Russian Constitution . . . . . 385

XVI. Poland

1. Historical Note . . . . . . 401

2. Constitution of the Republic of Poland 405

XVII. The Free City of Danzig

1. Historical Note . . . . . . . . 426

2. Constitution of the Free and Hanseatic City of Danzig .

3. Resolution Adopted by the Council of the League of Nations, November 17, 1920 .

XVIII. Esthonia

1. Historical Note . . . . . . . 452

2. The Constitution of the Esthonian Republic 454

XIX. Finland

1. Historical Note . . . . . . . . 465

2. The Constitution of Finland : . . 468

Appendices

I. Belgium

1. Historical Note 499

2. Constitution of Belgium, February 7, 1831, with Amendments of 1893 and 1921 501

II. France

1. Historical Note

2. Fundamental Laws of France . . . 523

III. ItALY

1. Historical Note . . . . . . . . 550

2. Fundamental Statute of March 4, 1848 . 551

3. Law of Guarantees of May 13,1871 . . 561

IV. The Recognition of New States since 1913

1. Note on Recognition of Certain States . . 565

2. List of Recognition of New States . . . 570

V. Report of the Second Chamber Conference 573

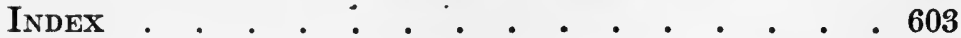


PART I

INTRODUCTION 



\section{THE NEW CONSTITUTIONS OF EUROPE}

\section{CHAPTER I \\ PRINCES AND PARLIAMENTS}

To THE student of politics the World War was of striking interest entirely apart from its international aspects and the question of victory or defeat. The democracies at war considered themselves justified in temporarily adopting the autocratic principles and methods of their adversaries in order more efficiently to pursue the struggle. Enormous powers were delegated to cabinets and presidents who became practical dictators. Legislative control was in abeyance; the principal functions vouchsafed to parliaments were to open the purse and to grant the necessary freedom of action to the executive. Individual liberty comprehended little more than the liberty to do as the government required. Measures of socialization and nationalization were resorted to on a staggering scaleindustry, food, fuel, clothing, transport, communications - all were under the control of the state; and if life was conscripted more freely than property, the difference was one of degree rather than of principle.

Statesmen recognized the inconsistency of requiring men to fight and women to make munitions when they could not enter the polling booth, and so, almost as a matter of course, there were vast extensions of the electorate. Woman's suffrage and proportional representation-two long, hard-fought causes - were no longer debated but were given legislative approval; and problems of democracy 
such as the control of foreign relations and the regulation of vast bureaucracies thrust themselves forward for new and more serious consideration.

Effects even in neutral countries
Nationality and political organization

Increase in number of states
The political dislocation was felt in neutral as well as belligerent countries. As early as the autumn of 1914, for example, the Swiss Federal Council was given an ordinance-making authority more in keeping with the decree of the Roman Senate authorizing the consuls "to see that the Republic took no harm" than with the decentralized traditions of Swiss constitutional law. These modifications of political theory and governmental arrangements and the new emphasis on certain mechanisms were due primarily to the magnitude of armed conflict. To some extent, however, the tendency was one of acceleration rather than of origination and it is certain that the pendulum will never make a full swing backward. The return to the political status quo ante will be as difficult, if less pressing, as the return to economic normalcy is proving to be.

But of chief interest, perhaps, is the fact that during the war four great empires crumbled and a fifth was profoundly affected. The Peace Conference in attempting to resettle Europe recognized the principle of nationality as the basis of political organization and created out of old empires a number of new states. An altered attitude was evident also in the British Empire. The right of the Dominions to control in effect their own foreign policies, and the right of the "subject" peoples of India, Egypt, and Ireland to have a greater measure of selfgovernment, were no longer seriously questioned.

The creation of new political entities out of the ruins of the European empires was, on the surface at least, at variance with what seemed to be a fairly constant tendency in the development of world politics. From hundreds of members - after the Peace of Westphalia Germany alone had more than 300 states-the community of states had 
been reduced to barely more than fifty. The United States, the British Empire, Germany, Austria-Hungary, Russia, Italy, and Turkey were all composite systems. There were only seven European states which did not contain within their continental boundaries more than one nation. These were Andorra, Denmark, San Marino, Liechtenstein, Monaco, Holland, and Portugal. ${ }^{1}$ As a result of the war, Poland, Esthonia, Czechoslovakia, Austria, Finland, and Danzig have all adopted written instruments of government with some markedly demoGrowth of democratic principle cratic features. Germany and the German states abandoned the monarchical principle (John II of Liechtenstein is the only prince remaining in Central Europe). Hungary continues her old form of government (without a king, however, for the present); and Jugoslavia (the Kingdom of the Serbs, Croats, and Slovenes), although a constitutional monarchy, has adopted a very liberal constitution. In Russia, apart from the economic philosophy of communism, the soviet principle of government is, to quote a conservative critic, "ingenious and interesting as a novel form of constitution" and "deserves to be studied, apart from any doctrines, on its own merits." In Asia, four new states will attempt republican governmentsthe Far Eastern Republic, Georgia, Armenia, and Azer-

\footnotetext{
'The list is that in The Statesman's Year-Book, 1915. "In July, 1914, a map of Europe showed that there were on the continent twenty-two separate states, counting Germany as one; to-day there are thirty-five, again counting Germany as one. The states that were neutral in the Great War have not suffered any changes save only Denmark, which in November, 1918, became separated from Iceland. Iceland has been recognized by Denmark as a sovereign state, the only connection between the two being Christian X, who is King of Denmark and also King of Iceland." Two other states, though technically neutral, were influenced by the results of the war. Luxemburg is no longer part of the German Zollverein and a referendum in 1919 declared in favor of an economic union with France. Before the war, also, Liechtenstein was practically a dependency of Austria, but on November 7, 1918, its Diet resolved on complete independence. "The States of Modern Europe," The New Europe, September 30, 1920.

'Bryce, Modern Democracies, Vol. II, p. 583 (New York, 1921). A less conservative critic thinks that the experiment involves "the most vital question of political theory and practice in Central and Eastern Europe to-day." The New Statesman, January 17, 1920.
} 
Increase in number of republics

baijan, the last named being particularly interesting as marking the first democratic' experiment in a Mussulman country.

A century ago there was in the Old World only one spot in which the working of democracy could be studied. In 1914 there were five republics. Within a few months the number has been trebled. ${ }^{1}$ It has been a remarkable period of constitution drafting. That so many peoples unaccustomed to self-government should thus accept the democratic principle is a genuine tribute to that principle. It is none the less a danger. It will subject republican government to a terrific strain. ${ }^{2}$ This will not be any the less so because of the more socialistic schemes of distributive justice that the new democracies are attempting to evolve.

${ }^{1}$ In 1916 an English writer classified existing methods of government as follows: Europe -5 republics (Switzerland, Portugal, San Marino, France, Andorra); 14 constitutional monarchies (Austria, Bulgaria, Rumania, Serbia, Montenegro, Greece, Italy, Spain, Holland, Belgium, Denmark, Sweden, Norway, Luxemburg), and 3 despotic monarchies (Russia, Germany, and Turkey). In Asia he listed one republic (China); 2 limited monarchies (Japan and Siam), and 5 despotic monarchies (Persia, Afghanistan, Nepaul, Oman, and Bhutan). The inclusion of Japan as a "limited" monarchy and Germany as a "despotic" monarchy shows the influence of the war psychology. In Africa there were one republic (Liberia) and two despotic monarchies (Abyssinia and Morocco), America had 21 republics. Of the fifty-four governments mentioned, 28 were republics (only seven outside of America), 16 limited and 10 despotic monarchies. A. E. Duchesne, Democracy and Empire, p. 109 (Oxford, 1916). This enumeration does not include the self-governing British Dominions.

${ }^{2}$ "Neither the conviction that power is better entrusted to the people than to a ruling One or $\mathrm{Few}$, nor the desire of the average man to share in the government of his own community, has in fact been a strong force inducing political change. Popular government has been usually sought and won and valued, not as a good thing in itself, but as a means for getting rid of tangible grievances or securing tangible benefits, and when those objects have been attained, the interest in it has generally tended to decline. . . . Nevertheless, although democracy has spread, and although no country that has tried it shows any signs of forsaking it, we are not yet entitled to hold with the men of 1789 that it is the natural and therefore in the long run the inevitable form of government. - . Popular government has not yet been proved to guarantee, always and everywhere, good government. If it be improbable, yet it is not unthinkable that as in many countries impatience with tangible evils substituted democracy for monarchy or oligarchy, a like impatience might some day reverse the process." Bryce, Modern Democracies, Vol. I, pp. 41-42. In most democracies, however, it is probable that any possible reversal to a monarchy or oligarchy will be by way of an attempted dictatorship of the proletariat. 
The results of the war were so decisive, the crumbling of the empires was so complete that in most of the new states the "founding fathers" were at liberty to fashion their governmental arrangements as they wished. ${ }^{1}$ Tradition had been so rudely shaken that they felt little obligation toward or respect for existing institutions. They were footloose. They could borrow and adopt from the written constitutions of the world. They could even improvise out of hand. Even so, before discussing some of the more striking features of the new instruments of government, it may be worth while to venture a few generalizations on what had gone before; for the abruptness of a break in institutional life is often more apparent than real. In politics a generalization is not infrequently a theft from the truth; there are, nevertheless, tendencies that show their heads above the forest of details.

The age of constitution making that may be compared with the recent period in Europe was in the early part of the nineteenth century. It resulted largely from the influence of Montesquieu. ${ }^{2}$ In the seventeenth and eighteenth centuries "it appeared to be essential to the modern notion of the state that there should be somewhere a power capable of making laws, and which, accordingly, being

1"Another danger of which a Peace Conference will, we may hope, beware, is that of assuming responsibility for framing constitutions and erecting governments in States which the treaty of peace will call into existence. . . . It would be better to let the peoples of those regions settle for themselves their relations with one another and their form of government rather than for the treaty-making Powers to undertake the task. If the latter were to attempt it, they could hardly escape liability for maintaining and guiding the course of whatever government they had set up, a thing always full of risks for all parties concerned, and specially difficult when undertaken by a Concert of Powers. - . The new States so constituted or enlarged will doubtless have plenty of troubles to face, but each had better face those troubles for itself and learn by its own experience." Lord Bryce, Essays and Addresses in War Time, pp. 170171 (New York, 1918). With one or two exceptions as to Germany and Austria the Peace Conference followed Lord Bryce's advice. For questions as to the protection of minorities and the case of Danzig, see below, Chapters V, XVII.

'Sir John Seeley calls the period that commenced with American independence "preemminently the constitutional period of the modern world." Introduction to Political Science, p. 209 (London, 1896).

Constitutions of serenteenth and eighteenth centuries 
Advantages of monarchy
Defects of absolute monarchy the source of law, could not be bound by any laws: and it was essential to the ideal of the modern state-in a normal and not anarchical condition-that this power should be supreme; that it should receive the complete obedience of an overwhelming majority of the citizens, and through their obedience be able to bring the organized force of the community to crush any open resistance of individuals or groups."1 This ideal was realized by the concentration of authority in one individual and it was deemed that the disadvantages of monarchy were outweighed by the advantages of order and the avoidance of anarchy.

Such a system, however, could not perdure, for, in the language of Professor Sidgwick, "there are two different kinds of defects in absolute monarchy. It is not only a defect that the supreme power of law-making is in the hands of an individual, who may not use it in the interests of the community: it is a further defect that the execution of the laws being under the control of the same person, there is no sufficient guarantee that he will observe even his own laws, if passion or favor urge him to break them." It follows, then, that "there is an obvious gain in separating legislative from executive and judicial functions in such a way that those who execute the law are as much bound to obey it as those on whom they execute it; and that the question whether they have obeyed it or not may always be brought before impartial judges for decision."'2 This separation of powers was realized to a degree in the

'Henry Sidgwick, The Development of European Polity, p. 141 (London, 1903).

${ }^{2}$ Ibid., p. 413. Cf. Sidgwick, The Elements of Politics, Chapter XX, p. 361 (London, 1891). "But there is no certainty that a representative legislature, chosen by universal suffrage, will not interfere with the free action of individuals more than an absolute monarch would: the essential difference is merely that under absolute monarchy a majority of sane adults may be forced to submit to laws that they permanently dislike, whereas, if a popularly elected assembly is supreme in legislation, this coercion can only be applied to a minority. To this extent constitutional freedom affords a security for civil freedom; but a priori reasoning and experience combine to show that there is no further connection between the two." 
English constitution. ${ }^{1}$ By erroneously describing it, Montesquieu transformed the English constitution into an idea. His inaccuracy did not lessen-no doubt it increased-the influence of his L'Esprit des Lois. In any event, it may truthfully be said that England had the "mother of parliaments."'

On the continent constitutional monarchy developed two general types-there being, of course, many minor differences with regard to the suffrage, second chambers, legislative powers, and the control of the executive. Bluntschli called the types "true" and "false," which was on a par with his characterization of the state as "masculine" and the church as "feminine." Suffice it to say that in the one case, Germany being the best example, the hereditary monarch had real executive and legislative authority, the latter being partly indirect. He governed as well as reigned, even though he had octroyed a constitution and had permitted certain formal limitations on his powers. The accepted philosophy of the state was that political power was possessed, not by the people, as in England after 1688, but by the monarch; and the constitutional arrangements did little to contradict this theory. ${ }^{3}$

The other type was the English type. This was the more prevalent type, especially in the Romance countries. Belgium in 1831; Portugal after 1852; Sardinia in 1848 (extended to the rest of Italy by 1870); Holland after 1848, and Spain after 1876-all drew in large measure on England. Even greater borrowings were made by France

English type

1"'Theological theory having fixed the principle of kingship, practice was to settle the problem of the control of the kingship by constitutional government - the special contribution of England to the political systems of history. The solution emerged in the English way, fortuitously, out of the party situation developed under William and Anne, and further under George I, and finally crystallized, as it were, by the personality of Walpole. Contrary to the common account of it, the solution was not planned. It came about." J. M. Robertson, Bolingbroke and Walpole, p. 33 (London, 1919).

'See A. F. Pollard, The Evolution of Parliament, Chapter XII (London, 1920).

'See Willoughby and Rogers, An Introduction to the Problem of Government, Chapter XX (New York, 1921). 
Political doctrines 1815-1880

and the British Dominions. France embodied the English cabinet system in a republican constitution, where it came to be profoundly modified in actual practice by multiple parties, a strong second chamber, and the enforcement of executive responsibility without the complement of dissolution. The Dominions employed cabinet government in federal systems, where the powers of the titular executive became even more attenuated than in England or in France. The federal republics of the United States and Switzerland stand outside the European development although they learned from it in the earlier stages and influenced it in its later modifications. ${ }^{1}$

Great Britain adapted her constitution to the requirements of the nineteenth century in comparative calm; but progress on the continent of Europe was accompanied by much violence. ${ }^{2}$ "From the fall of Napoleon's empire for full two-thirds of a century agitation was continuous and wars were not infrequent for the realization on the Continent of political ideas that had been made prominent by the French Revolution. Until the middle of the century the history of the period is punctuated with insurrections; after 1850 the type of disturbance changes to international war." From the point of view of political philosophy, these sixty-five years (1815-1880) of strenuous statecraft show "three bodies of doctrine occupying successively the chief place in the current of speculation. The first was constitutionalism, which dominated thought till the middle of the century. The second was national-

${ }^{1}$ There is an admirable though unsympathetic summary of this constitutionmaking in the first essay of Sir Henry Maine's Popular Government (London, 1885). He has some interesting remarks on "two events, one of which greatly encouraged, while the other in the end greatly discouraged, the tendency of popular government to diffuse itself." These events were the foundation of the United States and the French Revolution.

2"In England, as we all know, succession to the throne rests upon a revolution - the result of one of those political expediencies that amount to a necessitythough masters of reasoned eloquence, from Burke to Macaulay, have put upon it a saving face of continuous law and order. In Italy, Belgium, Sweden, Norway, the sovereign wears a revolutionary crown." Lord Morley, Notes on Politics and History, p. 40 (New York, 1914). 
ism, which reached the climax of its sway over men's minds in the sixties. The third was socialism, which was on the high road to universal absorption of philosophy when the period closed."

The belief was especially strong that a constitution or fundamental law was necessary for a rational and workable system of government. The demand for such a document was part of the programme of every liberal movement, and concessions came quickly. Only Austria, Russia, and Prussia resisted energetically. After 1848 the Hohenzollerns and Hapsburgs yielded. By 1880 only Russia was governed without a written constitution.

During the agitations and conflicts that attended the progress to this end, theoretical debate developed new and striking doctrines only as to the content, not as to the desirability of the written code. There was the greatest diversity among the actual constitutions as to the organization and action of the governments. In every state there was continuous strife between parties devoted to the application of liberal and conservative interpretations respectively to the fundamental law, or to the expansion of it in the sense of their interests. As to the essential requirements of constitutional government, theory was practically unanimous in holding that there must be some guarantee of rights to the individual and some reciprocal check and balance among the legislative, executive, and judicial powers. It was further held by all but the ultra-conservatives that rational government required the participation of some form of deliberative assembly, representing in some way the body of the population. All these requirements had been understood and met in France in 1789 and the following years, but the swift progress of those years into anarchy remained a potent warning to the Liberals of the next generation and interposed a barrier for decades against every suggestion of republicanism. Hence the chief problem of those who speculated on the theory of constitutional government was to find a safe and useful niche in the system for the monarch.

Thus until after 1848 the theories of the constitutional state, Rechtsstaat, as the Germans called it, were largely concerned with the effort to reconcile the functions of a representative assembly with those of a hereditary monarch, to insure the lib-

\footnotetext{
'Dunning, Political Theories from Rousseau to Spencer, pp. 247, 250 (New York, 1921).
}

Doctrine of constitutionalism 
erty of the subject individual against the historical and traditional omnipotence of the reigning individual, and to partition sovereignty neatly between the prince and the people or banish the troublesome concept from the ken of philosophy. ${ }^{1}$

Problems of the new constitutions

Slow growth of republicanism
Such theories, as we shall see, have apparently not bothered the framers of the new European constitutions. They have been concerned with safeguarding the rights of individuals and minorities; with various expedients (the initiative, referendum, proportional representation) to insure governmental obedience to the popular will; with special arrangements to give their second chambers only a mildly suspensory veto, and to provide for the control of diplomacy; and with stipulations for extensive agrarian and industrial reforms. This new orientation of constitutional problems has come about for a number of reasons, but not the least important is the fact that the republican principle was almost as a matter of course substituted for that of constitutional or limited monarchy.

But for the crash of the war this substitution would have been greatly delayed. Republicanism, perhaps, was spreading, but very slowly. Indeed, a distinguished English historian ${ }^{2}$ could say in 1911 that since 1870 the cause of republicanism had made little progress in Europe. $^{3}$ Democracy had been busy capturing parliaments and securing extensions of the suffrage; ${ }^{4}$ but it had not been assaulting crowns.

'Dunning, op. cit., pp. 252-253.

${ }^{2}$ H. A. L. Fisher, now President of the Board of Education.

${ }^{3}$ “'The accepted formula of political progress seems, if we are to be guided by the recent examples of Russia and Turkey, to be constitutional monarchy rather than republicanism. The republican movement has done its work. Its ideals have been appropriated and used with more or less of completeness into the political system of Europe, and most of the domestic programme of 1848 is now fixed and embodied in the institutions of the Continent which, save only in France, Switzerland, and Portugal, retains an explicit devotion to hereditary monarchy." Fisher, The Republican Tradition in Europe, p. 337 (New York, 1911).

${ }^{4}$ Universal male suffrage was adopted in elections to the Reichstag in 1871, in Spain in 1890, and in Austria in 1907. 
France [said Mr. Fisher] is still the only great European republic, and the political history of France under her new régime has not been such as to invite imitation. The position of the monarchies, which seemed so precarious in 1848 , has been considerably, indeed progressively, improved since the failure of that great and generous outburst of high but ill-calculated ideals. In part this change has been due to personal causes. The level of political intelligence among monarchs, which was very low in the generation preceding 1848, has certainly improved; and the virtues of Queen Victoria and King William I of Prussia have had some share in dispelling the clouds of criticism which had collected around the representatives of their respective Houses. How thick those clouds were in England no student of Thackeray's "Four Georges" or of the old newspapers is likely to forget. ${ }^{1}$

Mr. Fisher considered that the urgency of social and economic questions had also been of great importance in distracting attention from the monarchical principle. "The question of the relations of capital and labor is in truth, and has been discovered to be, far more important than the precise form assumed by the executive in a democratic state. - . . The Austrians, the Germans, and the Belgians content themselves with advancing propositions which are thought to be immediately relevant to the material well-being of the lower classes, and are careful to abstain from language which might be construed as revolutionary or seditious. Republican feeling may be widely diffused, but it has undergone an allopathic change. A vague, all-pervading discontent with the economic structure of society has taken the place of the simple and direct protest against the costliness of crowns and the profligacy of courts."'2

Three other factors were listed by $\mathrm{Mr}$. Fisher as contributing to the decline of European republicanism. $\mathrm{He}$ gave first place to the success of Bismarck's statesmanship in Germany. "Finding Germany poor, weak, divided, Bismarck left it the greatest military and industrial power

Due to social and economic problems
Due to Bismarck's success

\footnotetext{
'Fisher, op. cit., p. 320.
}

'Ibid., pp. 326-327. 
Due to imperialism

on the Continent." The principal instrument he made use of was "the force of the Prussian Monarchy," and Bismarck deliberately set himself "to affront all those liberal principles which enlightened Germans had derived from the political history of France or England." As a result a great gulf divided "the German mind of 1888 from the German mind forty years before, when the Frankfort Parliament was painfully and passionately elaborating the rights of man."

Mr. Fisher placed the growth of imperialism second in his category of the influences that had rehabilitated or strengthened monarchy. The British crown was necessary to keep the Empire together. ${ }^{1}$ Whatever may be said about the political psychology of Dominions that are satisfied with such an imperial tie, it is undeniably true that the principle of monarchy is an important element in the political philosophy of the British Empire.

The taste for ritual, for playthings, for make-believe, is deeply rooted in human nature, and monarchy appeals to the deferential instincts of the ordinary human being. Overthrow the monarchy, replace the King with an elective president, and what would become of the loyalty of Australia, New Zealand, or Canada? The British Colonists have no particular respect for the Mother of Parliaments, and a very particular and not ill-grounded aversion to the rule of Downing Street; but they regard the Crown with feelings of simple and passionate veneration. The King, having been deprived of political power, cannot harm them; and having little ritual themselves; they are

\footnotetext{
'On this point see H. Duncan Hall, The British Commonwealth of Nations, Chapter IX (London, 1920); Graham Wallas, Our Social Heritage, Chapter X (New Haven, 1921); and the classic statement in Bagehot, The English Constitution, Chapters III and IV (2d Amer. ed., New York, 1877). Sidney and Beatrice Webb, arguing for radical changes in the present form of government, are nevertheless willing to keep the King. They say: "If we pass from the constitutional theory of the text-books to the facts as we see them to-day, what we have to note is that the particular function of the British Monarch-his duty as king-is not the exercise of governmental power in any of its aspects, but something quite different, namely, the performance of a whole series of rites and ceremonies, which lend the charm of historic continuity to the political institutions of the British race, and which go far, under present conditions, to maintain the bond of union between the races and creeds of the Commonwealth of Nations that still styles itself the British Empire." A Constitution for the Socialist Commonwealth of Great Britain, p. 61 (London, 1920).
} 
the more fascinated by the pomp of an ancient and dignified institution which they have no means of reproducing in their several communities, but which they regard as the joint and several possession of the British race. ${ }^{1}$

The third factor that Mr. Fisher enumerated in support of monarchy is highly questionable. "It is now," he said in 1911, "a very general belief that the cause of European peace is assisted by the social and family ties which subsist between the monarchs of Europe." However widely this general belief may have prevailed a decade ago, it is certainly no longer held. Indeed it is arguable that the monarchical principle as it operated in foreign policy was in no small part responsible for the cataclysm that resulted in its almost complete extinction. ${ }^{2}$

Mr. Fisher was a greater historian than prophet. His vision of the ending of the republican movement and of peace resting upon dynastic bonds proved to be a delusion. ${ }^{3}$ But his analysis of the forces working to preserve monarchy is sufficiently acute to warrant the extended

\footnotetext{
'Fisher, op. cit., p. 329. Sir Henry Maine, in his criticism of popular institutions, admitted that the United States "disproved the once universal assumptions that no Republic could govern a large territory, and that no strictly Republican government could be stable." Popular Government, p. 12. Mr. Fisher also says that the success of the United States proves that an elective President may govern a continent that is geographically continuous; but it does not prove that the republican system is adapted for disjoined communities. He suggests also that the monarchy in the Iberian Peninsula has been permanently weakened by the loss of the American colonies of Spain and Portugal. But it may be pointed out that this sentimental factor, while it may have strengthened the monarchy in England, had little or no effect on the continent of Europe.
}

${ }^{2}$ On this point, see Chapter VII. At the time of the French Revolution it was a widely held belief that Europe would become a federation of republics and that this would ensure peace. The theory, of course, went back to Kant's little treatise On Perpetual Peace (1795). According to Kant, four conditions were essential: "(1) monarchs being largely responsible for war, every state must have popular government; (2) international law must be backed by a federation of free states; (3) men must be permitted to visit everywhere, but, as if to obviate one of the subsequent evils of the industrial revolution, ownership must not be allowed in foreign lands; and (4) no state may violently interfere with the constitution and internal administration of another." C. J. H. Hayes, "The Historical Background of the League of Nations," in Duggan, Ed., The League of Nations: The Principle and the Practice, p. 32 (Boston, 1919).

${ }^{3}$ See his own essay on Political Prophecies (Oxford, 1919) and Willoughby and Rogers, An Introduction to the Problem of Government, p. 6.

Monarchs did not preserve peace 
Mr. Wells on the use of monarchy
Popular control over monarchs

quotations that have been made. To the factors that he mentions, certain other not unimportant influences may be added. As Mr. Wells has put it:

In support of the dynastic system was the fact that it did exist as the system in possession, and all prosperous and intelligent people are chary of disturbing existing things. Life is full of vestigial structures, and it is a long way to logical perfection. Let us keep on, they would argue, with what we have. And another idea which, rightly or wrongly, made men patient with the emperors and kings was an exaggerated idea of the civil insecurity of republican institutions. ${ }^{1}$

Moreover, for the most part kings were behaving themselves; and although conflicts with legislatures were frequent, ${ }^{2}$ there were popular as well as royal victories. Despite some doubts as to whether the royal veto power had really fallen into desuetude ${ }^{3}$ and some alarms as to the share of Edward VII in foreign policy, ${ }^{4}$ the English King was, as Sir Henry Maine said, a monarch who reigned but did not govern. In spite of the frankly undemocratic character of the German constitutions and extreme language from the Emperor as to his "divine right," there were a sufficient number of incidents like that of the Daily Telegraph interview to create an impression of royal reasonableness and to confine agitation for the republican principle to the programs of the smaller, radiical parties. This moderation in the use of the royal prerogative and the occasional victories of representative bodies were appreciable factors in upholding the monarchical tradition. When the Hohenzollerns and Hapsburgs were finally defeated and their prestige was utterly de-

\footnotetext{
'H. G. Wells, "The Future of Monarchy," The New Republic, May 19, 1917.

2"Prince and representative body were in almost every state of Central Europe in strife as to the scope of their respective powers; neither would concede the right of the other to partition the disputed field; an authority with competence to determine competence was inevitably suggested." Dunning, Political Theories from Rousseau to Spencer, pp. 289-290.
}

3See Wallas, Our Social Heritage, Chapter X.

${ }^{4}$ See below, Chapter VII. 
stroyed, it would have been understandable, perhaps, if their peoples had in desperation turned wholly against monarchy as such; but even in this dire circumstance the really effective stimulus toward republicanism appears to have come from the outside. The primary cause of such a complete change was probably the hope that thereby better peace terms might be secured. In states like Esthonia and Czechoslovakia, released from control by oppressive monarchies, there was a good deal of democratic fervor; but this was not the case with the Central Powers-their constitutions to the contrary notwithstanding.

Two Emperor-Kings, five Kings, five Grand Dukes, six Dukes, and seven Princes-all reigning sovereigns under the old régime in Germany and Austria-Hungary-lost their royal jobs as a result of the World War. ${ }^{1}$ Most of the abdications, however, were peaceful, even friendly. In all the countries affected strong monarchical parties exist; and it is entirely possible that, as in Greece, thrones will be occupied again, with no great outcry from powerful objecting groups. As a recent writer says:

To interpret these political developments as the triumph of the Peoples' Will in conflict with the monarchic, or the militarist, or any other reactionary principle, would be misleading. . . The issue of Republicanism versus Monarchy in the small States had not in fact been on the tapis of practical politics in Germany any time in the last fifty years. In many or most of them it would probably never have been raised after the collapse, had not the Allies, or rather President Wilson-for, so far as is known, the Allies made no pronouncement on the subject-indicated their desire for the establishment of re-

\footnotetext{
IIn Central Europe one German sovereign remains-Prince John II of Liechtenstein. "The Principality is mostly the private property of the Prince, who, as he draws almost all of the revenue, also defrays almost all of the expenditure. The victory of Republicanism would accordingly imply the introduction of taxes, from which this fortunate state is at present entirely immune; and also, if it were to join Germany or Switzerland, some form of military service. In these circumstances competent observers incline to the view that Prince John can continue to count on the dutiful allegiance of his subjects." "Monarchism in Central Europe," Quarterly Review, January, 1922.
}

Wilson's influence against monarchy
Monarchical sentiment in Central Europe

Friendly abdications 
publican institutions in Germany as a preliminary to the negotiation of peace. ${ }^{1}$

Faith

in the

representa-

tive

principle
Radical

attacks on parliamentary principle

One further point of general interest remains to be noted. Despite the use of direct government (initiative, referendum, etc.), the political children of the Peace Treaty are putting their faith in legislatures and the representative principle. They are doing this at a time when, in England and France, as well as in the United States, considerable discontent with parliamentary government is being voiced. The attacks come from both the Left and the Right. The radicals stress the bankruptcy of political methods and the impossibility of securing the kind of economic distribution that they desire through the existing political state. Some of them urge direct action - that is, the use of their economic power for political purposes. In the words of one of their chief spokesmen:

Arguments against direct action drawn from the fact of political democracy are no arguments at all, for they obscure the point that there can be no real "government of the people, by the people, for the people," in what is called politics unless that government finds full expression in the economic life of a community. The road to freedom lies not through the polling booth, but through the workshop gates. . . . Just in so far as the workers rely on the vote as the primary weapon, they will fail to win freedom; just in so far as they recognize that the value of the vote is in proportion to their industrial and economic strength they will succeed.2

The direct actionists have certainly not intended to give aid and comfort to the parliamentary régime. Even so it is probable that the extremeness of their propaganda has alienated to the support of parliamentary government more persons than have been converted to a belief in the wisdom of its destruction. But not all of the radical critics of parliamentary government are direct actionists.

1"Monarchism in Central Europe," Quarterly Review, January, 1922.

"William Mellor, Direct Action, pp. 51-52 (London, 1920). 
A number of those ${ }^{1}$ who desire extensive social changes put their faith in political methods. They seek reform by the process of capturing the parliament itself. Moreover, there are many conservative critics $^{2}$ who, while refusing to accept the glibly flung accusation that parliamentary democracy is bankrupt, have nevertheless grave doubts whether the representative principle will continue to be adhered to without extensive modifications. These critics, instead of dropping the ploughshare of reform and retiring to speculate on the woes of the existing order and the beneficences of some one or other of numerous impending millenniums, are concerned with analyzing the causes of the trouble and with suggesting possibilities of improvement. And even if they are not able to keep the business of representative government, as we now know it, out of the bankruptcy court, they hope to enable it to liquidate some of its liabilities and to "carry on at the old stand" upon a somewhat different basis.

In his Modern Democracies Lord Bryce discounted the general belief in the decline of legislative authority. $\mathrm{He}$ cited, nevertheless, "some general causes" that "have been tending to reduce the prestige and authority of legislative bodies." He suggested that "the spirit of democratic equality has made the masses of the people less deferential to the class whence legislators used to be drawn, and the legislatures themselves are to-day filled from all classes except the very poorest." This, as he points out, is in some respects a gain, for the popular wishes can be

${ }^{1}$ E.g., Sidney and Beatrice Webb, $A$ Constitution for the Socialist Commonwealth of Great Britain (London, 1920); J. R. MacDonald, Parliament and Revolution (London, 1919).

2To cite a Liberal critic: "It is a fact of universal admission that the prestige of the British Parliament has not been at so low an ebb in living memory as it is to-day. We should have, I think, to go back to the time when George III, in his pursuit of personal government, packed the House of Commons with his creatures, to parallel the disrepute into which the present Parliament has fallen. The House of Commons has lost its authority over the public mind and its influence upon events." A. G. Gardiner, "The Twilight of Parliament," The Atlantic Monthly, August, 1921.

Lord Bryce on decline of representative government
Some who oppose direct action

Criticism by conservatives also 
better expressed; but "members of legislatures stand more than heretofore on the same intellectual level as their constituents. . . . The defect perpetuates itself, because men are apt to live up to no higher standard than that which they find. The less the country respects them, the less they respect themselves. If politicians are assumed to move on a low plane, on it they will continue to move till some great events recall the country and them to the ideals which inspired their predecessors."1

Effect on public business

Lord Bryce thought that "the disappearance of this sense of social responsibility" is important because it "has affected the conduct of business. Every rule of procedure, every technicality is now insisted upon and worked for all it is worth." This stiffening or hardening of the modes of carrying on public business has made parliamentary

\footnotetext{
1Mr. Hilaire Belloc has recently written a book that seeks to establish the following thesis:

"The House of Commons, though containing a representative element, was, and is, essentially not a representative body, but an Oligarchy; that is, a small body of men segregated from the mass of the citizens and renewing itself. But no Oligarchy works (that is, can be morally accepted or exercise authority) unless it be an Aristocracy. Mere Oligarchy, the mere rule of a clique without the excuse of an imputed excellence, will never be tolcrated among men. The whole meaning of Aristocracy is the provision of a sort of worship addressed to the few that govern. Therefore the House of Commons was vigorous and healthy in its function only so long as it was the Aristocratic organ of an Aristocratic State.

"For the definition of 'The Aristocracy' in an Aristocratic State is, not a body recruited by birth or even from wealth, not a caste (though it may be a caste), least of all a plutocracy, but essentially an Oligarchy enjoying a Peculiar Respect from its fellow citizens. Upon the failure of the Aristocratic quality in the House of Commons, upon the decline of that body into a clique no longer respected, its moral authority disappeared; and with that moral authority disappeared its power of government." Meanwhile the functions of the state were rapidly increasing and a double evil existed: "the rapid accretion of material power in something which, as rapidly, was growing morally unfitted to exercise that power." Mr. Be!loc thinks that "if some form of Monarchy does not succeed to the lost inheritance of the House of Commons, the State will lose its greatness." The House of Commons and Monarchy, pp. 13-14 (London, 1920).

There is a half truth in this analysis; but the case is vastly overstated, and Lord Bryce's version is probably much more accurate. Mr. Belloc suggests the rule of a single man-a Monarch (not necessarily hereditary); but one of the causes of the decline of the English House of Commons is Mr. Lloyd George's dictatorship, and to argue for a monarchical restoration is almost grotesque. Mr. Ernest Barker, commenting on Mr. Belloc's book, thinks that Parliament will continue as it is, with a modified upper chamber, which perhaps will represent interests; that there will be a good deal of devolution; that the
} 
deliberations seem more and more of a game, and less and less a consultation by the leaders of the nation on matters of public welfare. "A like tendency is seen in the stricter party discipline enforced in the British self-governing Dominions. As party organizations are stronger, the discretion of representatives is narrowed: they must vote with their leaders. The member who speaks as he thinks is growing rare in English-speaking countries. Whips called him a self-seeker, or a crank, yet his criticisms had their value." All this is true enough; but it would seem to be a symptom rather than the disease itself. And so it is with the payment of members, which, to Lord Bryce's mind, has lowered their status and fettered their freedom. Payment, however, was inevitable in the United States where the distances are so great and residence in Washington requires that business and home be left for the conEffect of paying legislators gressional session. It was inevitable, also, in Europe, for it was natural enough that enfranchised wage earners should often wish to exercise the right of electing representatives from their own economic and social class.1 Moreover, if, under cabinet government, the payment of members has made the less opulent sometimes reluctant to risk their seats and their incomes by voting against the Government, such an evil is doubtless less than that of making it impossible for members of the wage-earning class to serve in Parliament, or of compelling them to rely

restoration of the party system will mean government by discussion, and that "there will be, organized and unorganized (probably organized), a sort of fifth estate." "Besides the Press (freed, one hopes, from the incubus of proprietors' control) there may well be an industrial or labour council, not as a formal part of the legal constitution, but informally suggestive, consultative, advisory to Parliament and the Cabinet.

"The 'deferential' spirit being dead, we are likely to have the electorate, when it has recovered from its present temporary paralysis, asserting itself more vigorously than in the past. It is possible that we may come to experiment with the referendum; it is possible, on the other hand, that a purified fourth estate, and a new fifth estate, may provide sufficient channels." "The Origin and Future of Parliament," Edinburgh Review, July, 1921.

${ }^{1}$ See the provisions in the constitutions below (e.g., Prussia and Belgium) requiring the acceptance of government allowances. 
upon payments made by the industrial organizations from which they come.

Other organizations compete with legislatures

Lord Bryce called attention also to the fact that "other organizations occupying themselves with public questions and influencing large sections of opinion, have arisen to compete with legislature for the attention of the nation."' Party conventions or conferences are not very important; but "the meetings of industrial sections and of the new class parties, such as the Trades Union Congress in England and the Congress of the Peasant Party in Switzerland, the Socialist Congresses in France, and the Labor Union Congresses or assemblies representing the farmers or miners in the United States, the gatherings of farmers in Canada, and the still more powerful meetings of Labor organizations in Australia-all these are important, for they represent a large potential vote and their deliverances serve as a barometer showing the rise or fall of opinion on

\footnotetext{
'One interesting resort to extra-governmental agencies was Mr. Lloyd George's experiment with a committee of business men (under the chairmanship of Sir Eric Geddes, then a member of the House of Commons but not of the Cabinet) to advise on questions of finance and to report to the Cabinet. The Committee was dubbed the "super-axe" committee and stringent economy was its object. The Committee was apparently responsible to no one except the Prime Minister and, sitting in private, was put in the possession of facts and information of wider scope than the Estimates Committee of the House of Commons was allowed to have. The Prime Minister thus had two financial advisers-the Chancellor of the Exchequer and the Geddes Committee. A fact of prime importance was that the proposals of the latter could be made without the Cabinet's being responsible for them.

"However worthy may have been the motives of the Government in the institution of a Committee of 'business men' to advise the Cabinet on the cost of contemplated policy, there can be no doubt that the existence of this body will be a grave innovation on Constitutional usage and in derogation of the authority of Parliament. This Committee will be the collaborators with the Cabinet on public policy and an authority overriding or being overridden by the Cabinet, with the result that Parliament, within the ambit of its privileges, will have the invidious task of discriminating between the policy of the Cabinet and the Committee.

"So long as the vote of the House of Commons on proposals of the Government involves the fate of a Ministry and the hostile speech of a member may ruin his political career, so long will Government and the country lack the effective deliberative services of Parliament, where growing impotence keeps pace with the steady advance of bureaucracy." Judge Atherley-Jones, London Times (weekly edition), August 12, 1921 .

The Committee reported in February, 1922, and some of its proposals were accepted and some rejected by the Government.
} 
industrial issues. Those who lead them may win and wield a power equal to that of all but the most outstanding Parliamentary chiefs."

To what is probably one of the most important considerations bearing upon the impairment of parliamentary prestige, Lord Bryce gave but scant notice. He menEffect of influence of the press tioned the encroachment of the newspaper press "on the province of the Parliamentary orator," and added: "Only the strongest statesmen can command an audience over the whole country, such as that which a widely read newspaper addresses every day. The average legislator fears the newspaper, but the newspaper does not fear the legislator, and the citizen who perceives this draws his own conclusions."

But surely the question is much more important than this. In the opinion of certain critics of the House of Commons, the press has been a most vital factor in the decline of parliamentary authority. ${ }^{2}$ One eminent writer has even suggested that popular representation-that is, the delegation of legislative power-had for its basis the illiteracy of the people and the absence of sources of politi-

\footnotetext{
'Bryce, Modern Democracies, Vol. II. p. 340. "The issues of policy which now occupy legislatures are more complex and difficult than those of half a century ago. The strife of classes and formation of class parties were not foreseen, nor the vast scale on which economic problems would present themselves, nor the constant additions to the functions of governments, nor that immense increase of wealth which has in some countries exposed legislators to temptations more severe than any that had assailed their predecessors. The work to be done then was largely a work of destruction. Old abuses had to be swept away, old shackles struck off, and for effecting this a few general principles were thought to suffice. The next generation was confronted by constructive work, a remodelling of old institutions in the effort to satisfy calls for social reorganization, a difficult task which needed more hard thinking and creative power than were forthcoming. Thus while the demands on representative assemblies were heavicr the average standard of talent and character in their members did not rise. Never was it clearer than it is to-day that Nature shows no disposition to produce men with a greatness proportioned to the scale of the problems they have to solve.

"Taking all these causes into account, whatever decline is visible in the quality and the influence of legislatures becomes explicable without the assumption that the character of free peoples has degenerated under democracy." Ibid., Vol. II, pp. 341-342.
}

'See the references in Willoughby and Rogers, An Introduction to the Problem of Government, pp. 141, 219, 313. 
cal information. "Newspapers and the capacity of the constituent masses to read them," he says, "have sapped the foundations of representative government, as it has been understood in England, and 'public opinion' seems about to require more 'direct working' than the parliamentary system has hitherto afforded, or is likely to afford."' This, it should be noted, was written before the war and before the convulsions of the conflict had any effect on parliamentary institutions and cabinet controlbefore, indeed, the country had witnessed Mr. Lloyd George's political legerdemain and his peculiar relations with the press. ${ }^{2}$

The case has been more recently stated by another acute English critic:

Mr. Sidebotham's view

It may be that the representative system was only a temporary expedient adapted to small electorates and an illiterate age, and that the printing press will transfer our politics back to the stage at which the fortunes of nations were determined by a forum speech. The printing press, in fact, does enable a prominent politician to gather forty million people in a forum and address them as though they were a crowd of a few

\footnotetext{
${ }^{1}$ Lord Esher, The Influence of King Edward and Other Essays, p. 103 (London, 1915).

"The rapid development in the means of communication; the marvelous organization for the supply of information, if not of intelligence; the extension of the parliamentary franchise, and the diffusion of education; the increasing subordination of politics to economics; the substitution of vocation for locality as the basis of association; - all these have tended towards the weakening of the representative principle and to the institution of methods appropriate to a more direct form of democracy. The press, the platform, the trade union, and the caucus, have unquestionably done something to decentralize political activity and to transfer discussion from Westminster to the constituencies, be they local or vocational." Marriott, "The Party System," Edinburgh Review, October, 1921.

" "A press man was much more important to him [Mr. Lloyd George] than a Parliamentary colleague or a prince of the blood. He might forget to reply to an archbishop, but he would never forget to reply to a journalist. His acquaintance among the craft was more various and peculiar than that of any politician of this day or any other day. There was no newspaper man so poor that he would not do him reverence and entertain him to breakfast. While his former colleague, Mr. Asquith, studiously ignored the press and would no more have thought of bargaining with Northcliffe and Beaverbrook for their support than of asking his butler to write his speeches, Mr. George lived in the press world, knew every leading journalist's vulnerable point, humored his vanity, and gave him a knighthood or a peerage as readily as his breakfast." A. G. Gardiner, "The Twilight of Parliament," The Atlantic Monthly, August, 1921.
} 
hundreds. . . This is the real menace to the representative system, and to the authority of Parliament. ${ }^{1}$

It is a menace which might be somewhat lessened in England by allowing the House of Commons to express its opinion without the constant threat of dissolution if the opinion should be adverse to that of the Cabinet. A certain number of legislative proposals could be made party measures - the Government to stand or fall on them; and on all other questions (including expenditure) the House might be permitted to express an independent judgment. Or, it has been suggested that dissolutions during the early part of a parliament should not take place at the will of the Government alone, but only if approved, say, by three-fifths of the House of Commons. Some such adjustment may possibly be made. Certainly the probable advantages seem sufficient to warrant experimentation. ${ }^{2}$ Concessions of this kind, however, will not be wrung from the Cabinet without a stubborn fight. The Government will not willingly relinquish the dominance that it now has over the House of Commons.

These considerations-the Press, the decline of parliamentary ability, the extensions of the suffrage, the increase of executive power, direct action by labor, and extra-constitutional organizations-will all have great influence upon the workings of constitutional government in

Similar difficulties in the new states

${ }^{1}$ Herbert Sidebotham, Political Profiles, pp. 251, 252 (Boston, 1921). Mr. Sidebotham says that the contention is "between Parliamentary authority and the representative system in politics on the one hand, and what may be called the principle of direct action in government. The direct action party in Labor politics, which seeks to accomplish its ends by economic pressure without reference to the slower methods of Parliamentary persuasion, everyone knows. But there has grown up in Government quarters a direct action party which likes to appeal to the sovereign people direct, through the Press now that the platform is losing its power, and over the heads of its constitutional representatives in the Commons. . . Between the vast ochlocracy of the electorate which is easiest reached through the megaphone of the newspapers, and the Triumvirate of the Inner Cabinet, the representative system is in danger of being crushed out."

${ }^{2}$ Note the methods of dissolution that have been provided in some of the new constitutions.

Possible improvements in England 
the new states of Europe. These new states have borrowed from England, France, and the United States political machinery which now seems to be functioning with questionable efficiency. ${ }^{1}$ These factors would cause difficulty even if the peoples were accustomed to selfgovernment, which they are not. Moreover, although the line that could formerly be drawn between economics and politics is rapidly becoming blurred and indistinct, nevertheless, to the extent that the distinction obtains, emphasis in the new states must of necessity be laid upon economics rather than politics. This will be true to a far greater extent than in England or France, and even in those countries there are the beginnings of a new orientation that cannot fail to influence representative government as we hitherto have known it.

New emphasis on economic problems
The nineteenth century was mainly occupied in the conquest of political equality. The right to the franchise, the right to combine, the right to education, the right to a full religious freedom -it was upon the attainment of these that the minds of

'Discussion of the weaknesses of, and methods of strengthening, parliamentary institutions is not confined to England. Thus, an anonymous French critic observes a number of faults in the French system. The first is that Parliament delegates its power, but is either unwilling or unable to control its use. The ministers have not the time to exercise it themselves, so they delegate it in turn to their subordinates. The responsibility, however, is Parliament's, for the ministers remain in office on its sufferance. The writer proposes a commission composed partly of Senators and Deputies and partly of non-officials which would view the administration as a whole, unify policies, attempt to insure efficiency, and strive for continuity. The second count in the indictment is that every minister is above all a politician rather than an administrator or a man of action. This of course raises the whole question of competence in politics. Here also the writer suggests another wheel in the machine-a council of administration in each department, and the association of a well-equipped under-secretary with the political head.

The third weakness is that the chambers do their work by themselves and never call in experts to help them. Members are poorly prepared for parliamentary tasks and yet it would cost them dearly to admit this to constituencies blessed by universal suffrage. Parliament must call on specialists in legislative drafting, in economics, and in budget accounts. Only by securing expert advice can the ignorance of members be kept from continuing to be responsible for a decline of legislative authority. Finally, special machinery should be set up to inform Parliament how public funds are spent. There should be a corps of auditors and functionaries and inspectors to report to the chambers. Thus Parliament would secure knowledge that would permit it to make wise economies and justifiable reductions in personnel. "Justin," La responsabilité du Parlement sous le régime parlementaire (Paris, 1918). 
men were concentrated; the prestige of the House of Commons in large part derives from the fact that it was the agency through which they were secured. To-day the demand has drifted to the economic sphere; and for the first time in its history the House of Commons is squarely confronted by a demand that the concept of property be fundamentally changed. What has so far emerged with clearness in the struggle is the fact that the demand for economic equality is in substance different from the demand for political equality; and the doubt accordingly arises whether the House is fitted for that effort. ${ }^{1}$

Whether the parliaments of the new states are fitted for such an effort is perhaps the most important question that will be answered by eventualities in the new democracies. Lord Morley once remarked pessimistically that although over three hundred constitutions had been promulgated in Europe between 1800 and 1880, men had been very slow "in discovering that the forms of government are much less important than the forces behind them. Forms are only important as they leave liberty and law to awaken and control the energies of the individual man, while at the same time giving its best chance to the common good." It is with this "common good" that the new states are chiefly concerned, and at the moment, "common good" may almost be written "common goods."

${ }^{1}$ The Nation (London), January 22, 1921.

2Morley, “Democracy and Reaction," Miscellanies (Fourth Series), p. 300 (London, 1908).

How important are forms of government 


\section{CHAPTER II \\ LEGISLATURES AND BUREAUCRATS}

"Popular" government

Relation of executive to legislature

For reasons that have already been discussed, the attempt has been made in all of the constitutions to create "popular" governments. " From this point of view the constitutions contain a number of interesting features. Two of these deserve special consideration: the relation of the executive to the legislature and the control of administration. The direct government features which appear in most of the constitutions do not require special treatment. ${ }^{2}$

It is a striking fact that in all of the new constitutions the attempt is made to secure some form of responsible parliamentary government. " "The relation of the $\mathrm{Su}$ preme Executive to the Legislative organ is one of the

${ }^{1}$ The new states have avoided, so far as was possible, copying from the Russian constitution both as to economic and governmental theory. The legislatures have ample authority (as will be pointed out later) to interfere with private property, but whatever measures are taken will be matters of statutory rather than constitutional enactment. The new states point with pride, as Poland has done, to the fact that their constitutions contain "the liberal provisions of the Western European and American Constitutions" but nevertheless afford "a striking contrast to the communism of the Soviet Russian Government." Poland's law makers "succeeded in the difficult task of combining the better features of the constitutions of the republics of the world and adapted them to the peculiar needs of the Polish Republic."

'They are, however, considered incidentally in this Chapter and in Chapter IV.

3" For the modern world the choice virtually lies between Parliamentary, Presidential, and Soviet Democracy. The third is not, perhaps, wholly inconsistent with the first, although the partisans of Soviet Russia denounce representative democracy with a fervor equal to that which distinguished Rousseau's criticism of the English Constitution. Essentially, however, the basic principle of Soviet Government is merely the substitution of organized industries for locality as the unit of representation, or rather of delegation. The incredible confusion in which the Soviet has involved Russia-whether the confusion be due or not to the form of government-is likely to discredit any further experiment in that direction for some time to come." J. A. R. Marriott, "Conservative Principles," Fortnightly Review, March, 1922. 
knottiest points in constitutional construction; it is variously conceived by different theoretical politicians who agree in accepting the principle of popular control over legislation, and variously determined in different modern states in which a popularly elected assembly is actually a main element of the legislature."1 Before the recent experiments in Europe, it could be said, generally, that governments were divided into four types determined by the manner in which they treated this matter of the relation of the executive and the legislature.

There was, first of all, the English parliamentary system. The Cabinet retained office so long as it maintained the confidence of the House of Commons. "Caprice," said Bagehot, "is the characteristic vice of miscellaneous assemblies, and without some check their selection of executives would be increasingly mutable."'2 Equilibrium was maintained in England by the ministerial prerogative of dissolving the legislature. Secondly, there was the rigid system of a separation of powers-best illustrated by the United States-under which the Administration had no responsibility to the chambers. There was, thirdly, the Swiss collegial executive, elected by the Federal Assembly but not responsible to it. ${ }^{3}$ Finally, there was the German constitutional system, with a cabinet not responsible to the legislature but to the monarch who both reigned and governed. France, it may be said, finds herself midway between the British and Swiss systems. The ministry is responsible but has no unrestricted power of dissolution; and the ability of the legislature to have its way makes the French system more nearly assimilable to that of Switzerland. ${ }^{4}$

'Sidgrick, The Elements of Politics, p. 406 (London, 1891).

${ }^{2}$ The English Constitution, pp. 49-50.

see Lowell, Governments and Parties in Continental Europe, Vol. II, p. $198 \mathrm{ff}$. (Boston, 1896).

'Redslob, "La constitution prussienne," Reoue du droit public ct de la science politique, Vol. XXXVIII, p. 191 (Avril-Mai-Juin, 1921). 
Types in the new states
Recent changes in English type

The relative borrowings of the new states from these four types of government are significant. The rigid system of the United States apparently had no attractions. Jugoslavia is the only instance in which the titular executive is a king. Czechoslovakia and Poland took for their models the French constitution; they have presidents elected by the chambers but with powers somewhat greater than those of the President of France. Germany has a president elected by the people but a cabinet responsible to the legislature. ${ }^{1}$ Most interesting of all, however, is the arrangement in Esthonia and the German states (Länder). The ceremonial executive is dispensed with; the Swiss collegial executive is the model that is most closely followed, with the important difference that it is responsible to the legislature, and that, in determining the result of conflicts, the people are to be consulted directly.

The framers of the new constitutions sought rather obviously to avoid the extremes of the English and French systems. For in England, as has been suggested, ministerial responsibility, however nice in theory, has been sadly attenuated in practice. As Mr. Strachey felicitously said, the English constitution is "a living thing, growing with the growth of men and assuming evervarying forms in accordance with the subtle and complex laws of human character. It is the child of wisdom and chance." It happens, therefore, that Bagehot's incisive analysis of a government that was really responsible is far from being true of existing political arrangements; it is what he himself inveighed against as "literary theory." England has come in part to a separation of powers. The Prime Minister has become more like the American President. He has thrown off a large part of his dependence on the House of Commons, where he appears only occasionally to deliver a "message." Mr. Lloyd George deals

\footnotetext{
II Austria the president is elected by the legislature. The Federal Ministry is also elected on nominations by the main committee of the Nationalrat.
} 
with the press rather than with Parliament. It is the electorate rather than the division lobby that is the arbiter of the fate of ministries. Since 1870 (leaving the war changes out of account, for they do not affect the argument) only one English ministry that could normally command a majority in the House of Commons has been dismissed by the independent action of the House. The vast extensions of the suffrage, the payment of salaries to members, the decline (or is it merely difference?) in the character of public men, the number of placemen that a Cabinet has in the Commons and can always rely upon, the recrudescent menace of "direct action," the general weakening of faith in the efficacy of parliamentarismthese among other causes may be indicated. Mr. Lloyd George's own opportunism and the nadir of political morality reached in the $\mathbf{1 9 1 8}$ election are not responsible for the development; they merely accentuated it.

In striking contrast is the rapid panorama of Cabinet crises and changing personalities which gives perennial interest to French political institutions. M. Clemenceau, The French type an ex-Prime Minister, breaks a long silence; the Chamber of Deputies is excited, and the Government trembles. Mr. Wilson or Mr. Asquith could cause nothing so troublous; and the difference is not one of personalities but of constitutional structure. In England and the United States, office-holders if they escape scandal have some assurance about the immediate future; but in France the Government is always facing a precarious to-morrow. Indeed, changes of government in England are now so rare that those who hold office are able to work in careless security, while those in opposition criticize with faint hope of success. In the United States the popular will is always subject to the calendar; but in France parliamentary government is subject to the headline news of any day.

As has been indicated, the development in France has been different from that in England because the French 
Reasons for English and

French differences
Types in the new states
Ministry does not have the power to dissolve the Chamber of Deputies. Responsibility without the complementary power of dissolution results in a truncated parliamentary system. This is the crux of the matter, although the group system of parties in France would under any conditions be a formidable obstacle to the smooth working of parliamentary government. This is an obstacle, also, with which the new states of Europe are confronted. The average tenure of Cabinets under the Third Republic has been less than eight months. Some critics have considered this as anarchic rather than efficient; they have cited it as demonstrating the political incapacity of the French. More sympathetic (and more accurate) observers have stressed the fact that these recurrent crises do not cause breaks in the continuity of policies; a Cabinet change means a new deal of the same cards rather than a different game. Not infrequently more than half the members of a new government had places under the old. Indeed, judged by results, which is the only real test, the French system cannot be said to be measurably inferior to that of England or the United States. In some important matters - control of the administration, for example-its superiority is arguable. Nevertheless, in their search for a nicely balanced parliamentary system the new states have avoided the extremes of both England and France.

In Germany it was no doubt advisable to have a rather powerful chief of state. Not only were the people accustomed to authoritarianism, but during the revolutionary transition a strong executive authority was almost indispensable. ${ }^{1}$ The President of the Reich has larger powers than the President of the French Republic, ${ }^{2}$ particularly

\footnotetext{
'See, for example, Article 48 of the constitution which gives the President the right to declare a state of siege. On the state of siege in continental law, see Willoughby and Rogers, An Introduction to the Problem of Government, Chapter VI.

${ }^{2}$ For an interesting discussion of recent developments in France, with references to the literature on proposals of change, see Soltau, "The Present Position of the French President," Economica, May, 1921.
} 
with regard to legislation. He has no direct veto power, but when a law has been passed he may, before promulgation, order a referendum upon it. In cases of disagreement between the Reichstag and Reichsrat he may order a referendum; and under Article 72 he may promulgate a law that the Reichstag and Reichsrat have declared urgent even if a third of the Reichstag has demanded that the promulgation be deferred in order to allow a referendum. The President, moreover, has the right to dissolve the Reichstag, although this is not the only way in which dissolution may be effected. But the President's power in this regard may be a very material factor in preventing such frequent Cabinet changes as occur in France; for the authority to dissolve the Reichstag, coupled with the discretion that he has with regard to a referendum, will probably give the German President a dominating position with respect to the responsibility of the Cabinet to the Reichstag. In Austria the President appears to have much less authority, and the general adjustment of relationships is such that ministries will probably not enjoy great stability.

Poland's President, on the other hand, more nearly resembles the French executive. He has no right of veto, nor may he, like the President of France, initiate legislation and demand a reconsideration of a law to which he objects. ${ }^{1}$ There is ministerial responsibility, but the power of dissolution is much more limited than in Germany. The Assembly (Sejm) may dissolve itself by a two-thirds majority vote; or it may be dissolved by the President with the consent of three-fifths of the statutory number of members of the Senate, which is dissolved at the same time (Article 26). This penalty which the Senate must suffer if it exercises its prerogative may be an effectual deterrent. It seems likely, therefore, that these constitutional adjustments in Poland will allow a legislative

\footnotetext{
${ }^{1}$ Sait, Government and Politics of France, p. 44 (Yonkers, 1920).
} 
Czechoslovakia

Esthonia

dominance over the ministry similar to that which prevails in France.

In Czechoslovakia the advantage is with the executive. The President is the strongest executive of any of the new states. He may dissolve the Chamber of Deputies, and he also appoints and dismisses the ministers, who, however, are responsible to the Chamber. His powers of veto and of patronage, together with this power of dissolution, are likely to constitute an adequate protection of the Cabinet against the caprice of the legislature.

As has been mentioned, however, the most novel arrangements are found in Esthonia and the German states. Esthonia has the simplest of the new constitutions-a unicameral legislature with a collegial executive responsible to it, and with the initiative and referendum to determine conflicts between the two branches. The Government is elected by the legislature, not necessarily from among its own members, and must resign when a vote of no-confidence is passed. The legislative term is three years, and dissolution before the end of this period may take place only by the action of the people. Article 32 of the constitution provides that "if the people reject a law passed by the State Assembly or accept a law rejected by the Assembly, new elections of the State Assembly shall be proclaimed, these elections to take place not later than seventy-five days after the plebiscite." In other words:

If non-promulgation is carried, a vote of no-confidence is thus carried in the electoral body against the Assembly, which is ipso facto dissolved. The initiative procedure demands similarly 25,000 electors. They submit a request that a new law shall be enacted or an old one cancelled or amended. The request, in the form of an elaborated draft, goes to the Assembly, and the Assembly either passes the draft, in which case it acquires the force of a law, or rejects it. If rejected the draft is submitted to a plebiscite, and if it is carried again the Assembly is dissolved. It is thus the duty of the Assembly, when the draft comes before 
it, to gauge the popular feeling, and act in accordance with it. If, having gauged it, the Assembly defies it, or if the Assembly gauges it wrongly, the Assembly is judged an unworthy instrument of the popular will and dissolution is justified. Dissolution is thus parallel to the Government's compulsory resignation after a vote of no-confidence has been passed, and the control of the Assembly by the people is analogous to the control of the Government by the Assembly. In this very simple control-system a President is out of place. To fit him into the system would require a further elaboration, which, by confusing the ordinary citizen, would weaken his actual grip on legislation, and a President is therefore dispensed with, his routine duties being part of the heavy burden borne by the Riigiwanem (Government).1

Prussia's constitutional arrangements, which with minor differences are found in most of the other members of the German Reich, provide for the Swiss collegial executive; but they seek to approach Great Britain in allowing an adequate power of dissolution as a complement to ministerial responsibility. Dissolution may be effected in any one of three ways: by a committee consisting of the Minister President, the President of the Landtag, and President of the Staatsrat; by a referendum initiated by the people or by the Staatsrat; or by a decision of the Landtag itself. This gesture of self-abnegation will probably be made only when the Landtag is reasonably confident of its support in the country or when it sees that dissolution is to be forced upon it by one of the other available methods. But the ability of the Minister President to threaten dissolution if he can secure the coöperation of one of the legislative presidents seems likely to make for a measure of ministerial stability. ${ }^{2}$

\footnotetext{
'R. T. Clark, "The Constitution of Esthonia," Journal of Comparative Legislation and International Law, Third Series, Vol. III, p. 249 (October, 1921). It may be pointed out that, while provision is made for interim ministers when members of the Government resign (Article 59), the Government apparently perishes with the Assembly if the latter is dissolved as the result of a plebiscite. Some amendment of the constitution would seem to be necessary.
}

"See Redslob, "La constitution prussienne," Revue du droit public et de la science politigue, Vol. XXXVIII, p. 192 (Avril-Mai-Juin, 1921).

Prussia and the other German states 
Legislative control during parliamentary recesses

In Czechoslovakia

All of the new constitutions devote some attention to the problem of legislative control of the administration. Questions and interpellations addressed to the ministers are provided for, and parliamentary commissions are created on the model of the French commissions to exercise a day-by-day control of the executive." "Private members, like Governments," it has been said with particular reference to England, "have all got legislation on the brain and think that the primary business of Parliament is to legislate, whereas in fact it is to look after the administration of existing laws so well that no new laws or very few are necessary." 2 Cabinet responsibility, interpellations that lead to publicity, and commissions, either permanent or for particular investigations, are the expedients that governments have usually used for the supervision of the administrative authorities. For the most part, however, they are expedients that operate only while the legislature is in session. It is interesting to note, therefore, that the new governments provide for a continuance of this control during parliamentary recesses. As a commentator on the Czechoslovak constitution says:

The democratic spirit of our constitution is likewise shown in Article 54 of the Charter of the Constitution. This paragraph provides for the setting up of a permanent Committee-twothirds of the members of which are taken from the House of Deputies and one-third from the Senate-which shall take the place of the National Assembly when the latter is unable to sit. Governmental and executive authority is thus, in principle, devoid of such power as was possessed, for example, by the Government of the former Austrian Empire in virtue of the notorious Article XIV of the law relating to the representation of the Empire. The Charter of the Constitution does not per-

'See Willoughby and Rogers, op. cit., pp. 215, 251.

${ }^{2 *}$ "A Student of Politics" in the London Times, April 17, 1920. Mr. C. D. Burns has called attention to the fact (noted by the Temps, April 5, 1920) that of thirty-six sittings of the French Chamber before April 5, 1920, nineteen were devoted to "interpellations" as against seventeen to legislation. Government and Industry, p. 62 (London, 1021). 
mit the Government of our state to remain for one moment without the control nor yet the aid of the legislative body. ${ }^{1}$

A similar committee is provided for in the German constitution. It was formed on the model of a committee In already in existence in the Grand-Duchy of Baden before the revolution. Its purpose is to safeguard the right of popular representation against the Cabinet when the Reichstag is not in session. Monarchical traditions of an executive exercising extensive ordinance-making powers give warrant for precautions of this kind. (The emasculation of the executive authority under early American constitutions may be pertinently recalled.) When the German constitution was being framed such a committee "was the subject of much lively opposition. Some held that the Cabinet, so long as it enjoyed the confidence of the Reichstag, did not require a special organ of surveillance. This committee, its opponents went on, was only an application of the conception that assumed an opposition between the Cabinet and popular representation. It was incompatible, therefore, with the principle of parliamentarism that rests on a harmony of the Cabinet and the Parliament. But the majority of the Constituent Assembly held, on the contrary, that this committee would correspond fully in character to the Reichstag as an organ of control, and would be consistent with the confidence and the good will on which the Cabinet depends."2 In Prussia, also, there is a permanent commission to represent the legislature in the intervals between sessions; the ministers will thus never be without some measure of parliamentary control. ${ }^{3}$

Attention should also be directed to the attempt that

\footnotetext{
${ }^{1}$ Hoetzl, The Constitution of the Czechoslovak Republic, p. 15 (Prague, 1920). For the text of the Austrian article referred to, see Willoughby and Rogers, op. cit., p. $377 \mathrm{n}$.
}

'René Brunet, The New German Constitution, p. 152 (New York, 1922).

${ }^{3}$ See Redslob, op. cit., p. 193.

In Prussia 
Democratization of administration

The new states try experiments

has been made in some of the new states to democratize the public administration. Thus, the Czechoslovak constitution declares that the "civic element" shall be as far as possible represented in the subordinate offices of state. "The law creating special administrative bodies for the counties and the districts represents an effort to put this constitutional principle into practice. It is a bold step toward reorganizing public administration in a more democratic direction. The civic element thus participates in all political administration (interior) in the subordinate offices (ministries are an exception). This participation is particularly conspicuous in the organization of the administrative Courts . . . where it is a matter of the protection of the rights and interests of citizens."'1

The results of these several experiments to create new adjustments as between executives, legislatures, and peoples will be of great interest to the student of comparative politics. 'In some cases, no doubt, judgment will have to be suspended for the reason that popular government is being tried for the first time by peoples who have had little or no experience in governing themselves. Political incapacity will probably be responsible for some criticism of governmental arrangements that are theoretically sound. On the other hand, constitutional adjustments that appear to be faulty and cumbersome will not inevitably result in political mismanagement. The laws, as Burke said, reach but a little way. Every government is a government of men as well as of laws. No matter how

\footnotetext{
${ }^{1}$ Hoetzl, op. cit., pp. 16,17. As another writer has said: "To the many political cries that disturb the, in any case, uncertain tranquillity of the Continent a new one has now been added, starting from Central Europe and making itself heard to the west, south, and north-the cry for democratization of administration. By this is meant a shifting of the distribution of power in every branch of public administration. Administration is ultimately to rest in the hands of the people, not in the hands of the authorities in the State and Commune. The authorities hitherto in charge are to be degraded to the position of mere advisers or even of servants. They no longer give commands, they carry out the commands of the people. The people no longer wishes to be governed, but to govern itself." Carl Brockchausen, "Administrative Democracy: A Continental Aspiration," The New Europe, May 20, 1920.
} 
a government is constituted, much depends on the wisdom and discretion of those who have it in charge. The relation between executive and legislature is important but not decisive. ${ }^{1}$

The framers of the new constitutions of Europe have sought to secure arrangements that would be flexible, but not too flexible; that would be sufficiently rigid, but not too rigid. The supreme test will be what these governments actually do. The chief concern of the new states is for legislation based on sound principles of distributive justice.

${ }^{1}$ This fact finds illustration in two recent books on constitutional changes in the United States and England.

An American writer, William MacDonald, in a tractate entitled $A$ New Constitution for a New America (New York, 1921), urges the adoption of Cabinet government in the United States. The argument pays no attention to the fact that in England and France the present phase of Cabinet responsibility can be objected to just as forcibly as the author objects to the separation of powers in the United States, and that in the United States public administration could be improved and Congress made more efficient and responsible without laying impious hands on the ark of the covenant.

In England Sidney and Beatrice Webb, in $A$ Constitution for the Socialist Commonwealth of Great Britain (London, 1921), have written of their own institutions in much the same way that Mr. MacDonald has written of America. They are, however, more concerned with economics than with politics. Nationalized industries and services, district councils, works committees, the reorganization of local government, industrial and public services by the local authorities, the coopperative movement and other voluntary associations of consumers, the trade-union movement and other vocational organizations-these are the things that the Webbs stress. However people may differ in their conceptions of what constitutes the "common good," it is probably a fact that vocational ethics and technique and the spirit and efficiency of the public service are of more importance to the average man than the constitutional relation between the executive and the legislature. Progress is possible whatever may be the finical adjustment of governing agencies. 


\section{CHAPTER III SECONDARY CHAMBERS}

Most new legislatures are bicameral

Second chambers are also secondary

ONE of the most interesting features of the new constitutions of Europe is found in the provisions relating to second chambers. Most of the legislatures are bicameral. Only Finland, Esthonia, and Jugoslavia have been bold enough to dispense with the time-honored check of an upper and usually less popular legislative body. ${ }^{1}$

\section{Various methods are employed for electing the members} of these second chambers, and their powers and relative positions in the several schemes of government are by no means identical. But on one point of principle they practically all agree: these upper chambers, far from being superior to the lower chambers, as was, for example, the Bundesrat of the former German Empire, are not even coördinate with them. They are placed in a distinctly subordinate position. They are not only second but also secondary chambers. For the constitutional distribution of power is such that, while they may impede and delay, they cannot ultimately withstand the determined will of the lower and more popular body. Deadlocks are care-

\footnotetext{
'Sixteen of the Swiss cantons, sixteen of the smaller German states (before the revolution), and six of the provinces of Canada are cited as adherents of the unicameral principle. Experiments in Bulgaria, Montenegro, and Norway, and a few Latin-American states should also be mentioned. H. W. V. Temperley, Senates and Upper Chambers, p. 9 (London, 1910).

The recent action of the Queensland Government in abolishing its legislative council attracted some attention. The Council, the Prime Minister of Queensland said, "was the home of reactionary interests. Few will mourn its fate, and few hope for its resurrection." The abolition of the Council was of some interest to the English House of Lords which adopted a motion calling on the Government for all the papers relating to the Royal Assent in the matter. Viscount Chelmsford, a former Governor of Queensland, said he did not "suggest that the British Parliament should interfere in any way with the self-governing power of the Dominions, but in a matter of such importance it would be well that information should be given." The London Times, March 29, 1922.
} 
fully guarded against. If the upper house refuses consent to a bill, repassage by the lower house or ratification by the voters upon a referendum is commonly sufficient to enact the rejected proposal into law.

It is unnecessary to digest and compare the constitutional provisions relating to these second chambers. Reference to the texts of the several constitutions will disclose their family resemblance and their individual differences. Until the debates and documentary materials of the various constituent assemblies are available, the motives which determined their special characteristics will be uncertain. On the "face of the returns," however, one or two points seem fairly certain. In the first place, the upper chambers in such countries as Germany and Austria were doubtless, to an extent at least, adjuvant parts of the federal scheme that was adopted; the attempt was made to provide in the second chamber representation of the component states as political entities. In the second place, speaking generally, the creation of second chambers was doubtless not due to opposition to the "democratic idea." So far as appearances go, most of these constitutions are ultra-democratic; and if two houses are desired merely in the interest of deliberateness and delay, it is quite as easy, though perhaps not as reasonable, to create a popular upper house as a popular lower house. The motive, therefore, for the establishment of upper chambers was probably not anti-democratic. Apart from special considerations, it was no doubt a matter of habit, of conscious or unconscious regard for the habits of others, and of genuine belief in the value of the check that is afforded by requiring that identical action shall be taken by two separated and quasi-independent groups of representatives.

In the third place, whatever may have been the reasons for the adoption of the bicameral principle, the reason for the subordination of upper chambers to lower chambers

Reasons for second chambers 
Reason for subordination of second chambers
Illustrated by House of Lords is fairly apparent. All of these constitutions provide for governments under which the ministry is responsible to parliament. A ministry responsible to two coequal assemblies is a cumbersome and well-nigh unworkable institution. Ministerial responsibility implies a unitary system of representative control. A ministry cannot serve two masters. Witness the experience of France or of Italy or of any other country in which the upper chamber had been placed in a position in which it could interfere in the relation of responsibility between the ministry and the lower chamber. The result has always been a weakening of the foundations of the system. In England, where the system originated, the Ministry has never been regarded as in any respect responsible to the Lords. Nevertheless, before 1911 the House of Lords was in legal theory a coördinate branch of parliament. ${ }^{1}$ In case of disagreement with the Commons and the Ministry, it could, by actually asserting its coequality of powers, utterly destroy the effectiveness of the system. The Ministry might still be responsible to the Commons; but what purpose could such responsibility serve, if the machinery of its operation could be suddenly stopped by the action of a body that had no part whatever in the scheme of responsible relationships? A resignation of the Ministry or a dissolution of the Commons would be futile as against the legal powers of the Lords to obstruct. This was the situation that developed in England in 1909; and as a result the House of Lords was by the Parliament Act of 1911 placed definitely in a position of legal subordination to the Commons - in a position in which it could cause delay but not defeat. This act was a clear admission of the difficulty, not to say impossibility, of satisfactorily combining a scheme of ministerial responsibility with a scheme

\footnotetext{
'There was some dispute as to the "constitutional" competence of the Lords to alter money bills. Moreover, in case of recalcitrance there was, of course, the more or less remote possibility of the Lords being whipped into line by the creation of new peers - a power which lay in the hands of the Ministry.
} 
of coequal legislative chambers. Even with an upper chamber that is periodically renewed by election or in some other manner, the possibility of a deadlock would remain. And in the face of a deadlock between the chambers, ministerial responsibility would simply fail to function.

Those who drafted the new constitutions of Europe were probably not ignorant of the institutional history of parliamentary government in other countries. They must have known the difficulties that second chambers had caused. Whether or not they actually borrowed from the British Parliament Act of 1911, their schemes for controlling second chambers were directed toward similar ends. It is of interest, therefore, to study the schemes that are provided in these new constitutions in the light of the situation that prevails in England as well as in the light of current discussions and proposals for further "reform" of the House of Lords. For the Parliament Act of 1911 was admittedly a temporary measure. ${ }^{1}$

Prior to 1832 England was really ruled by an oligarchy of landowners. The House of Lords was powerful; but it did not insist on legislative primacy or even equality. Its control was exerted more indirectly but none the less effectively. The great offices of state were held by peers, and a large proportion of the members of the House of Commons were nominated by the noble landowners.

\footnotetext{
II the jockeying that took place in the first weeks of 1922 over the advisability of a general election, the Conservative section of Mr. Lloyd George's coalition interposed objections which were based very largely on this matter of the Parliament Act. Mr. Lloyd George was lukewarm. His instinct is probably against a strong second chamber as a bulwark of conservatism. He may feel also that he would be better off under existing circumstances' if the political situation made him desire to sponsor a program of radical legislation comparable to that of 1909 . There is, furthermore, the question of the position of the executive in a truly bicameral system which is discussed below. "An English Liberal" outlined the issue as follows:

"In particular they [the Conservatives] demand the reform of the House of Lords, which Mr. George included in his election compact with the Tories in 1918. Reform of the House of Lords is a thing which the real Conservatives care very much about. It means, no doubt, the abandonment of the hereditary principle and the substitution of a comparatively democratic House, but this
}

Parliament Act of 1911

Position of the Lords 1832-1886 
From 1832 to 1886 , the suffrage was gradually extended and legal democracy arrived. Nevertheless, popular discontent manifested itself in Chartism and Trade Unionism; for the political power of the legal democracy remained where it had been formerly, or else was so manipulated that it was nugatory. In the struggle for political supremacy between the landed aristocracy and the new industrial plutocracy, the second chamber lived serenely on. There was, indeed, for several reasons, little or no discussion of its composition and constitutional authority.

Reasons for noninterference with the Lords
In the first place, "the attacking force of the new plutocracy was led by a group of the greatest landowning magnates, the Whigs; who, never doctrinaire in their Liberalism, and proud of their order (for they were always the most exclusive of aristocrats), were, on the one hand, loath to overthrow the House that had once been their stronghold, and were, on the other hand, able to make the political reconstruction easier for their fellow peers to accept." In the second place, the House of Lords "accepted the guidance of leaders who recognized when defeat must be admitted." There was, as a consequence, no real second chamber at all; the Lords simply did not

House will be conservative in character and its reconstitution will be accompanied, in the Conservative plan, by the abolition of the Parliament Act. Now the Parliament Act is the guarantee to any Liberal or Labor government-and it is the possibility of a Labor government that the Conservatives keep in viewthat they can get any large piece of reform substantially unchanged through the House of Lords, for any bill sent up by the House of Commons can only be rejected twice with effect by the Lords; at its third appearance, whether accepted or rejected by them, it goes on the statute book. Really, therefore, the Tory party through Sir George Younger are asking that the Parliament Act, the hope of the Labor party, should be repealed before the present government go to a general election." "Lloyd George and the Ides of March," The New Republic, February 1, 1922.

The King, in his speech opening Parliament on February 7, 1922, said: "Proposals will be submitted to you for the reform of the House of Lords and for the adjustment of differences between the two Houses." Substantially the same pledge was given the previous year: "My Ministers further trust that the work of the Committee now examining the question of the Reform of the Second Chamber will be finished in time to permit of proposals being submitted to Parliament during the course of the present Session." February 15, 1921. The Committee referred to was presumably within the Cabinet, for the Bryce Report of 1918 had already been published, and no announcement had been made of the appointment of any other body to consider the problem. 
assert their legal competence. There was "no check or effective criticism on the measures of one party, and only vexatious, timid, and partisan delays on the measures of the other. The second chamber seemed to be so weak as to be scarcely worth abolishing, and most men thought it was doomed to be merely one of those picturesque and useless forms with which the British system abounds." And, finally, it has been suggested that the commercial plutocrats of the Liberal party "had their full share of the characteristic British virtue of snobbery, and longed to become members of a class which they had for two generations been attacking."

After 1886 the House of Lords rejected certain Liberal measures, but its own composition and powers were not brought into serious question. During the Unionist ascendThe parliament act temporary ancy there was, of course, no trouble; and the issue was not drawn until the Liberals came into power in $1906 .{ }^{2}$ Thereafter the issue was joined and reached its climax in 1909-1911. As has been said, however, the Parliament Act of 1911 was a temporary expedient. Its preamble declared that a second chamber would be "constituted on a popular instead of hereditary basis"; and Mr. Asquith in a debate in the House of Commons declared that the pledge was a "debt of honor."’3

The war intervened before the Liberals could proceed

'Ramsay Muir, Peers and Bureaucrats, pp. 102-104 (London, 1910).

${ }^{2}$ "In 1869 Lord Russell carried to a second reading a Life-Peerage Bill. In 1884 Lord Rosebery presided over a Select Committee which recommended certain changes in regard to the Scotch and Irish Peers. The same statesman tried to interest the Lords in larger schemes in 1884, and again in 1888, but on both occasions in vain. Iord Salisbury, in 1888, did actually embody certain definite proposals in a Bill which was read twice in the House of Lords, but he did not persevere, and thus the Tory party lost an opportunity of 'reform from within,' which will never recur." In December, 1908, a Committee headed by Lord Rosebery made recommendations, but they were very conservative and in any event it was too late for them to receive a hearing. J. A. R. Marriott, "The Problem of a Second Chamber," Edinburgh Review, July, 1917.

${ }^{3}$ On the issues raised by the Parliament Act, see McKechnie, Reform of the House of Lords (London, 1909); Lord Rosebery, The Reform of the House of Lords (London, 1910); Lord Selborne, The State and the Citizen (London, 1913); and "Second Chamber Supplement," The New Statesman, February 7, 1914. 
The Second

Chamber

Conference

of 1917

Opposition

to Bryce

Conference

Report with their program. Nothing was done until August 25, 1917, when the Prime Minister appointed a Second Chamber Conference, composed of peers and commoners, under the chairmanship of Lord Bryce. The members were so far from unanimous that the report took the form of a letter from Lord Bryce to the Prime Minister, arguing at some length concerning the kind of second chamber that England should have and making recommendations as to its composition. ${ }^{1}$

Democracy was so diluted in the scheme proposed that the Coalition Government hesitated to press for reform within the limits indicated by the Bryce Conference. The Unionists, however, would doubtless have welcomed such a pis aller in order to have a line of defense against a possible Labor majority in the Commons. The powers that Lord Bryce proposed for the second chamber would do much to nullify the victory won by the Commons in the 1909-1911 struggle. Since that time there has certainly been no retrogression in the democratic movement in Great Britain. If the war seemed to result in some increase of prestige for the Lords, ${ }^{2}$ this was due not to any change in the character or position of the upper house, but to a relative decline in the prestige of the Commons. ${ }^{3}$

'The letter is reprinted below, Appendix V.

${ }^{2}$ "For long years Liberals have been fighting for a thoroughly representative system and for imposing restraint upon the reactionary tendencies of the Upper House. And having accomplished their aim, they find that they have to turn, for the experience of whatever remnant of enlightened and liberal-minded opinion there remains, from the House of Commons to the House of Lords. There at least an occasional weighty voice is heard in protest against the follies of the government. There at least is some reminiscence of the spirit of independent criticism, which has certainly vanished from a House of Commons that exists simply to register the decrees of a ministry." A. G. Gardiner, "The Twilight of Parliament," The Atlantic Monthly, August, 1921.

'Lord Esher quotes C. F. G. Masterman on the condition of England: "The rather ignoble rôle played by the House of Lords during the past decade reveals its weaknesses. It will allow changes which it profoundly dislikes when compelled by fear. It will resist changes in action when that fear is controlled. It will altogether abandon the effort to initiate changes where change is essential. It can do little but modify, check, or destroy other men's handiwork. It has no single constructive suggestion of its own to offer to a people confronting diff- 
The wide extension of the suffrage under the Representation of the People Act of 1918 assuredly does not lend aid and comfort to those who would find place for a powerful upper chamber, "different" but none the less undemocratic. Even so, Lord Bryce's proposals are of great interest; and they are none the less significant from the point of view of the alternatives that were passed over. For example, nomination for life, as in Canada and Italy, was rejected; so likewise was indirect election by local bodies. ${ }^{1}$

The Bryce report suggested the recruitment of the second chamber by a mixed process of derivation and coöptation. The Bryce proposal The greater part of the members would be chosen by, though not from, the House of Commons, divided into geographical groups. The smaller part would be named by a joint committee of the two houses, in the fixed proportions of those great interests from which the House of Lords originally sprang: the Church and the Land. To this body, which would probably consist of aged or middleaged members, predominantly conservative, would be given material powers, but not a veto on acts passed

cult problems and harassed by the obligations of necessary reorganizations. It can neither breed leaders nor ideas."

But, says Lord Esher, "what more could the most exacting reformer demand from a Second Chamber?" The Influence of King Edward and Other Essays, pp. 61-62 (London, 1915).

'The proposal of indirect election, says Professor Ramsay Muir, "is radically vicious. County Councils were not designed as electoral but as administrative bodies. It is highly important that, so far as possible, their members should be elected solely on the ground of their fitness for their work, and not on the ground of their opinions on national politics, which can have nothing to do with their work. Hitherto party politics have been largely kept out of these elections, or, at the most, have only been a secondary consideration.

The electoral function of the County Council would come to outweigh the administrative. . . . The candidates of each side for the Second Chamber would be nominated by the party caucuses, and the candidates for the County Council would be required to pledge themselves beforehand to vote for A or IB. Thus the malign influence of the party caucus will be still further extended; the partisan character of the Second Chamber will be still more accentuated; and the administrative efficiency of a series of important public bodies will be seriously impaired. . . . And what applies to County Councils applies equally to all other methods of indirect election; for in a country dominated by party divisions any body which has an electoral function imposed upon it will lie open to the same dangers." Peers and Bureaucrats, pp. 181-183. 
The

Standing Conference Committee
Criticism by the London Nation by the Commons. Disagreements between the two houses would be referred to a Standing Conference Committee composed of sixty members chosen in equal proportions from the two houses. This Committee would sit in secret and would make its reports to each of the houses. A proposal from the Committee must be rejected or accepted without amendment. If one chamber accepted and the other rejected a bill, the final decision would rest with the Committee, acting by a majority of three. In other words, as Lord Haldane expressed it in the House of Lords debate, the Bryce scheme "proposed to get rid of the Parliament Act and to substitute for it power for the House of Commons to pass whatever measures it desired, provided it could obtain a majority of three on the Standing Joint Committee of the two Houses."' Reference to the two houses in joint and open session, or a referendum on the measure, or the machinery provided in some of the new constitutions were all rejected in favor of the device of the so-called Free Conference.

The debate in the House of Lords in March, 1921, showed great solicitude for a virile second chamber but no great enthusiasm for the Bryce report. The chief critics of the report are those whom the House of Lords fears. For example, the London Nation said:

Now we cannot imagine the country emerging from the war and finding the ultimate control of legislation given over to a small body of elderly Notables, elected and derived, peers and commoners, clerical and lay. We cannot even see either House surrendering its forces into such hands. Whom does the Bryce scheme satisfy? Not the Conservatives, who prefer the independent dignity of the House of Lords to a Chamber owing its greater proportion to the House of Commons. Not, of course, the Single Chamber men, who reject the whole theory of the need of a bi-cameral "check" to democracy. Not the Radicals, who would sweep away hereditary peers and legislative bishops, and are indisposed to give a casting vote in legislation to any

'Parliamentary Debates (Lords), Fifth Series, Vol. XLIV, col. 706 (March 21, 1921). 
body founded on indirect election and nomination. The device of the Free Conference is not in itself an objectionable one, and Lord Bryce and his colleagues have come to the sound view of making the Second Chamber derive, in the main, from the First. Their mistake has been to create too large a body, and to endow it with undue powers, which in turn bring it into conflict with the representative principle. A Second Chamber which is the creature of the First cannot even indirectly aspire to become its master. If a Second Chamber is deemed necessary, we see no overwhelming objection to giving it a purely consulting and conciliatory function. But we see no reason for endowing it with votes, or if votes are conferred upon it, for creating a larger body than 100 or 120 members, chosen mainly from the House of Commons, but on a proportional system. Such a Second Chamber would never be able to upset the choice of the people, for under the method of proportional representation, the majority in a Joint Session would almost always be of the same party as the majority in the House of Commons, though the strength of that majority might be reduced. ${ }^{1}$ Therefore the element of conflict is eliminated. Under the Bryce scheme the conflict remains, but is masked by the intervention of the Joint Committee. This body will move inevitably towards compromises, and the House of Commons, deprived of the power of reasserting its full original will, is automatically reduced to the alternative of submission or a total shipwreck of its plans, maybe of the chief work of a session or the issue of a great electoral conflict.

\footnotetext{
'In its issue of July 18, 1914, The Nation suggested the following plan for the reform of the House of Lords:

"We would, therefore, invite the Government and the Liberal Party to follow the general example of modern States, and to set up a small Second Chamber, sharply contrasted with the mere undistinguished volume of the House of Lords. This would conveniently consist of 100 members, elected by, but not from, the House of Commons. The latter course would lower the new Chamber to the level of a Committee of the Commons, and might therefore be treated as an evasion of the preamble of the Parliament Act. Such a Senate would be a Rump Parliament rather than a fresh organ of political thought and action, and would therefore be almost useless for the special purposes of revision and reconsideration to which we would invite it. The Second Chamber would properly include the Lord Chancellor, the ex-Lord Chancellor, and the Law Lords as ex officio members, and its non-partisan character would free the latter class from the repressed and shadowed existence which they lead in the House of Lords. An element of variety and distinction could also be secured by adding to the 100 elected members a small quota of nominated Senators, chosen either by the Executive or by the Chamber itself. But the number of elected, nominated, and ex officio members should not exceed 120."

Under a system that provided for a joint session "between a Second Chamber so constituted and the House of Commons, the elected majority in the latter House could only have been once disturbed since 1837 . This was in 1847 , when the Liberals had only a majority of one in the Commons. Under this scheme it would have been turned into a Conservative majority of six-an exception which may easily be held to prove the rule."
}

Proposed

Chamber is

too large

and

powerful 
Even finance, the historic right of the Commons, seems to us to be held under the Bryce scheme by a single strand. The Conference may attack it in detail, eviscerate it, or truncate it. This is to ignore the effort of 1906 to 1914 to reintegrate the democratic power and secure it against future encroachments by the Lords. Not to such issues will the after-war nation be touched, when once it resumes the broken thread of its political life."1

The

Bryce report seeks analogies

In the Bryce report constitutional theory and practice in other countries are cited as showing that only a few unimportant governments, by taking the risk of a unicameral legislature, fail to allow an appeal from "Philip drunk to Philip sober." And this argument for the check of one house against the other is reinforced by reference to the absence in England of the check of a written constitution. As the Earl of Selborne recently said in the House of Lords: "In this country alone of all civilized countries could a minority enact these things [the revolutionary program of a Labor Government] under the forms of the Constitution and against the wish of the majority. Here alone can the fundamental basis of society or the whole of our Constitution be changed by the same process as is applied to the passage of a Drainage Act."'2 These considerations, however, overlook, it would seem, fundamental differences in the whole legislative process in England as compared with most other countries. In the

${ }^{1}$ The Nation (London), May 4, 1918.

${ }^{2}$ Parliamentary Debates (Lords), Fifth Series, Vol. XLIV, col. 694 (March 21, 1921). This debate was of great interest, as the following excerpts show:

The Earl of Selborne: "I want to put the matter before your Lordships and the country in the bluntest possible form, and I do not think that I am guilty of the least exaggeration when I say that all that has been done in Russia to destroy the constitution, the liberty, and the property of the people, could be done in England under the forms of the Parliament Act, some of it in one session, all of it within the space of a little more than two years."

Viscount Bryce: "The problem is a double one. It is a problem of the powers which have to be given to the reconstituted House, and of the method of constituting that House. These two questions are closely interconnected. Lord Selborne observed that there ought to be large powers. I agree with him in thinking that there is no use in having a Second Chamber unless you give it substantial powers; but it is to be remembered that the more powers you give, the more popular must be the composition of the Chamber. You will not suc- 
United States, for example, there is a deplorable lack of centralization of control over the process of legislation. Depending upon the strength of his personality and his party position, the President exercises a more or less external, but on occasion none the less powerful, influence. As between the two coequal houses, at any rate, he is, in important law-making, the principal focus of unity that exists. Moreover, strange as it may seem, although the constitution vests in him "the executive power of the United States," it is chiefly upon his success in legislative matters that he is held to accountability by the people. Apart from this changeful and somewhat extra-constitutional control of the President, there is in neither house of Congress any large degree of power and responsibility with respect to a program of legislation. Indeed, one can scarcely imagine legislative processes that would offer greater contrast than those of England and the United States. The methods by which and the conditions under

ceed in having any considerable powers allotted to a Second Chamber unless there is a considerable popular element in the composition of the Chamber, in order to make sure that it represents adequately what I may call the best deliberate, popular sentiment.

“. . a Second Chamber which is to be successful and is to win the confidence of the country must not be a Party body. It should not be a body composed in such a way as to contain a permanent majority governed by Party feeling or subservient to Party organization. It must be a body in which every Party can have representation and every type of view can be freely and fairly stated. Lastly, a Second Chamber ought to possess, if possible, the largest measure of moral authority. By moral authority I mean besides the legal authority which may be vested in it, be that greater or smaller, the influence exerted on the mind of the nation which comes from the intellectual authority of the persons who compose the Chamber, from their experience, from their record in public life and from the respect which their characters and their experience inspire. If an Assembly possesses that moral authority in large measure, its legal powers need not be quite so extensive as they might otherwise have to be.

Viscount Haldane: If "the Government were to propose a measure for enlarging the powers of the House of Lords and correspondingly curtailing the powers of their own representatives, what would be the effect? I think the effect would be that you would, at last, have one among a number of things which would stir that democracy, and which would bring about the very state of things which you want to avoid. The one thing about which the Englishman is really sersitive is the violation of those traditional usages, which in a vague way he understands, and which he always has more or less in his mind.

"If you want to bring forward a Labour majority I know of no better plan than that of proposing to put restrictions on the House of Commons." 
which legislative proposals are introduced into and carried through the American House of Representatives are so utterly different from those obtaining in the House of Commons that arguments for the need of a second chamber in the United States can be applied to the English situation only by ignoring striking differences of importance.

Defect in analogy of France
Rôle of the French Senate

Or take the situation in France, where the constitutional system more nearly approximates that of England. The French Senate acts as frequently in support of the Ministry as against it; the Ministry sometimes uses the Senate to restore appropriations refused by the chambers. Under the operation of Lord Bryce's scheme, such an eventuality in England would be scarcely thinkable. The French Ministry occupies no such position toward the Chamber of Deputies as does the British Ministry toward the House of Commons, for the simple reason that it cannot dissolve the Chamber without the consent of the Senate; which means that the upper chamber, not the Ministry, has the power of dissolution. This is a point of no mean significance. The Bryce report does not argue for a second chamber vested with power to interpose itself between the Ministry and the lower chamber. It does not contemplate an emasculated or hair-trigger Ministry that may be hurried out of office over night, because, forsooth, it lacks the power to seek its own justification by appealing to the electors to turn the recalcitrant chamber out. Such an arrangement cannot fail to weaken the Ministry, to strengthen both houses as against the Ministry, to approximate the system of fixed terms for legislative bodies, to decentralize responsibility - in a word, to dilute the essential virtues of cabinet responsibility and parliamentary government.

It may reasonably be argued that the instability of cabinet government in France is due to the existence of a second chamber vested with this power over dissolution. 
But it certainly cannot be argued that a second chamber that is not vested with such power is necessary simply because France has a second chamber. The French Senate does not act as a check upon the Deputies; as the case may be, it acts as a check upon, or aid to, a Ministry pitted against the Deputies. It is, in short, a stabilizer of ministerial instability. The multiple party system and the French Senate's failure to exercise its power over dissolution are responsible for the kaleidoscopic changes of cabinets. But it is open to question whether the sanity and wisdom of French law and policy may properly be referred to the check of this second chamber.

In any scheme of government the arguments for a second chamber can be tested only by considering the legislative process as a whole. It is not solely a matter of compelling a first chamber to hasten slowly. It is also a matter of how slowly and maturely the lower chamber has in the first instance been forced to proceed. In this connection an English authority on constitutional law has said:

This is an aspect of the case which is worth dwelling upon for it goes far to limit the application of the theory that Upper Houses are a check upon hasty legislation. That theory has found expression in the writings of all apologists for a dual legislature-Montesquieu, Hamilton, Story, Tocqueville, Laboulaye, and Esmein. Now, it is a curious fact-not, I believe, hitherto remarked upon-that every one of these writers begins with the assumption that the executive and the legislature are separatean assumption which was, and is, true, or approximately true, of the countries with which they were most concerned. They assume that the Lower House has an unrestricted initiative in legislation, independently of the Ministry, and that it is the Ministry, quite as much as the people, which required to be protected against the Lower House.

An unrestricted initiative calls for an unrestricted veto, and a chamber which, without the sense of collective responsibility possessed by a Cabinet, without its continuity of programme, its trained draughtsmanship, its Treasury experts, can initiate legislation and carry it through-as, for example, the Lower Houses in France and America do-must be subject to an Upper Chamber which may supply these defects.

Test of argument for a second chamber

The English process of legislation 
But with us this unrestricted initiative does not exist, because our executive and legislature are not separate in fact whatever they may be in law. There is what I may call a prior veto upon the legislation of the House of Commons in the responsibility of the Cabinet for legislation and its consequent control of the time of the House, and, believe me, that veto is no inconsiderable check upon the kind of hasty legislation which the Upper Chambers of foreign countries are designed to control. A Government Bill is the product of many trained minds: the Parliamentary draughtsman sees that it is dovetailed into the body of existing statute law; the Treasury are called in to consider what charges upon the national revenue it may involve; the departments are consulted to advise what administrative duties it may throw upon them. ${ }^{1}$

Law-making by ministries

In continental countries, moreover, ministries have wide powers of collateral legislation which are seldom fully disclosed in the provisions of written constitutions. This tradition will doubtless be continued by the governments of the succession states. In Prussia, a Ministry unable to secure the enactment of a statute could usually reach the same end by an ordinance. ${ }^{2}$ The notorious Article 14 of the Austrian constitution ${ }^{3}$ gave this power explicitly; but it was a power that was derived almost as effectively by implication from other constitutions. In France, if the Senate is troublesome, the Ministry can frequently resort to a decree which can be challenged only by an administrative tribunal. What Professor Dicey has called the "rule of law" is not without its importance in connection with the problem of a second chamber. If it is unable to fall back upon administrative legislation, a ministry is

\footnotetext{
'J. H. Morgan, The Place of a Second Chamber in the Constitution, pp. 9-10 (London, 1910). Professor Morgan points out that this control is a development of the nineteenth century and that the English constitution copied by foreign countries is that of the eighteenth century. Under this earlier constitution the Lords as frequently supported the Ministry as opposed it. The Ministry could carry on the government independently of the Commons by a civil service which was a fixed, not an annual, charge. And most of the legislation was private bill legislation and not public legislation.
}

${ }^{2}$ Willoughby and Rogers, op. cit., p. 363.

3For the text see ibid., p. 377. The provision is copied in the Japanese constitution. 
more apt to act with reference to possible support or opposition from the upper house. Such an arrangement is not conducive to responsible government. As Professor Morgan has said:

A strong Upper House, in fact, everywhere means either a weak or a subservient executive. The exceptions to this rule are apparent rather than real. In France, the executive, although, as we have seen, possessed of considerable powers of independent legislation, is singularly weak in the face of the Chamber of Deputies, which, contrary to all English precedent, exercises an initiative in finance independently of the executive. The deputies can, in fact, turn the Cabinet's Finance Bills, like any other Bill, inside out. Not infrequently, therefore, the Cabinet looks to the Senate to support it against the Chamber of Deputies by restoring appropriations and taxes which the latter has omitted or reduced. A very similar condition of affairs prevailed at one time in Prussia. In the German Empire the Upper Chamber not only supports the executive, it is identical with it; so much so, indeed, that Bismarck always treated the demand of the German Liberals for a Cabinet responsible to the Reichstag as absolutely incompatible with the continued existence of the Upper House. If we turn to the English colonies, we shall find that Upper Houses are only strong in proportion as Cabinets are weak-the English tradition, now operative for something like fifty years, that a Government which cannot command a majority or secure the passage of its egislation, may dissolve, has not equal force.

\section{And Professor Morgan summarizes his conclusion as} follows:

Whereas in our own country the Government is dependent on the Lower House of the Legislature (the House of Commons), in foreign countries it is more often dependent on the Upper House, in so far as it is dependent on the legislature at all; and that, therefore, the large powers accorded to the Upper House in those countries are more often used to support the Government of the day than to oppose it. Now, with us, exactly the reverse is the case, and the problem which confronts us is that of an Upper House able, willing, and determined to bring the Government of the day to a standstill. In that respect our problem is unique, and the pretensions of our Upper House are both higher and more dangerous than those advanced by any other country living under a constitutional system. ${ }^{1}$

\footnotetext{
'Morgan, op. cit., pp. 14-15.
}

Strong second chamber makes weak ministry

Unique position of House of Lords 
Relation of problem of cabinet dominance

The English Cabinet is the most powerful and independent responsible Ministry in the world. It has been able to exert a very complete control over the House of Commons. Not the least of its levers has been the possibility that it might order a dissolution. The danger of a strong second chamber in England is that the power of dissolution might be transferred in whole or in part from the Cabinet to the Lords. That would destroy the balance of the constitution. There may well be strong arguments in favor of abolishing a fairly uncontrolled cabinet dictatorship, but this may be accomplished by measures short of the creation of a strong second chamber. Cabinet dominance, with the ever-present possibility of emergency action by the House of Commons, has much to commend it in comparison with the possibility of a powerfully reinvigorated upper chamber.

The manner in which the bicameral arrangements of the new constitutions will work is, of course, highly conjectural. ${ }^{1}$ Almost without exception, as has been said, the idea of a second chamber equal in strength to the lower, has found little favor. Every effort has been made to avoid the evils indicated in Benjamin Franklin's description of a bicameral legislature: "It is a cart with a horse hitched to each end and both pulling in opposite directions." But how effectively the cart will be pulled and in what direction remains to be seen.

\footnotetext{
1Professor Morgan ventured to prophesy concerning the workings of the Parliament Act. "I think," he said, "that it will enormously increase the legislative activity of the House of Lords; that, if conscientiously worked, it will give it a prestige of a more practical and less superstitious kind than it has ever enjoyed before." The Lords will be able to transform a Bill and send it back, whereas, the Commons, by the terms of the Parliament Act, only repass the same measure. "During the whole of the statutory two years, the House of Lords will be the centre and focus of all the agitation in the country against the particular Bill, the Areopagus to which every interest affected will look for consideration of its grievance." $O p$. cit., pp. 21-22.

The adjournment of politics during the war and the abandonment of party for coalition government prevent any estimate of the correctness of Professor Morgan's prophecy. The same reasoning would suggest that in the succession states the second chambers, uninfluenced by the necessity of compromise in order to reach an agreement, will be active in amending bills and shifting the responsibility to the lower house or the executive.
} 


\section{CHAPTER IV \\ SEGMENTATION AND FEDERATION}

THE segmentation of Empires and the decisions of the Peace Conference created a number of new small states. This reversal of the apparent tendency of political units to coalesce in great composite organizations is probably of greatest importance in international matters. It is fairly obvious that the fewer the members of the community of states, the fewer will be the possibilities of friction. International law depends for its validity upon the agreement, tacit or otherwise, of sovereign states. Its possibility for growth is lessened by an increase in the number of states whose agreement is necessary. Divide et impera is not a maxim appropriate to the end of world organization. There is, indeed, something of inconsistency between increasing the membership of the international community and at the same time promoting a League of Nations and diplomacy by conference. Treitschke objected to small states on the ground that "weakness is the most reprehensible and the most contemptible" of political sins; but apart from this callous count in the indictment, serious objections may be raised. Belgium and Serbia are never-to-be-forgotten examples of the opportunities that the small states offer for aggression. Economic exploitation is more insidious, more frequent, and in many cases just as disastrous as avowed political conquest. The new states in Europe will be politically and economically jealous of one another. ${ }^{1}$ For economic purposes

${ }^{1 " N o w}$ that they [the little nations] have achieved great success, dazzling success, almost blinding success, there is a real danger of their emulating the faults of great countries. . . The spirit of expansion is beginning to possess

International effects of numerous small states

Economic exploitation 
Pettiness of civic life
Value of small states larger units would be advisable: tariff walls could be raised and the integration of rich and poor sections would mean little loss to the former and much advantage to the latter.

"In a small state," moreover, as one very sympathetic eritic has summarized the case, "civic life must necessarily be petty, humble, unambitious. The game of politics must center around small issues, and thus circumscribed in scope, loses the ethical value of scale." A small state "can never be a source of that triumphant pride and hope which lifts citizenship up to the plane of heroism." Sooner or later the small states must go. "They will be absorbed in larger political aggregates. They will follow the line of historical development which has created the large modern states of Europe out of a mosaic of tiny and warring fiefs. And nobody will regret their demise, least of all the citizens themselves." It is even contended "that patriotism in its fullest sense is only possible to large nations. Great states march on, little states mark time. . . Guided by the hand of God, the mighty organs which are the chosen vessels of the highest culture upon earth take up, one after another in due sequence, each item of their sacred and providential programme." 1

On the other hand, it must be recognized that small states have distinet values. The almost fulsome admiration which was given them at the outbreak of the war was due to a very natural sentiment against the furious despoilment of Belgium and Serbia, and to the necessity of presenting an alternative to the ruthlessness of the Prussian political philosophy that contemned them. Per-

them. It is the most fatal error that any people, great or small, can possibly make. Their strength to-day and their strength for all time is in serving the liberty of their own race." Mr. Lloyd George, Address at the Welsh National Festival Dinner (March 3, 1919). Two years later, with particular reference to Poland, Mr. Lloyd George remonstrated with the children of the Peace Treaty for breaking up the crockery.

'H. A. L. Fisher, The Value of Small States, pp. 4-5. (Cxford, 1914). 
haps also the judgment of students is still influenced by the glorious although temporary brillianee of the ancient city-states and by the fact that three small communities-Holland, Switzerland, and Scotland-saved the principle of self-government from ultimate denial. Indeed the view has been expressed that "almost everything which is most precious in our civilization has come from small states, the Old Testament, the Homeric poems, the Attic and the Elizabethan drama, the art of the Italian Renaissance, the common law of England. Nobody needs to be told what humanity owes to Athens, Florence, Geneva, or Weimar. The world's debt to any one of these small states far exceeds all that has issued from the militant monarchies of Louis XIV, of Napoleon, of the present Emperor of Germany."

Even so, from the selfish viewpoint of the student of government, the creation of new political entities is to be welcomed. The more democracies there are at work, the more materials he will have for a study of different phases of popular government. There may be, as Lord Bryce says, most important "results within the next thirty years of setting up democracies in countries that have heretofore formed part of the Russian and AustroHungarian monarchies; or (to take a still more startling case) of trying the experiment of popular government in India, in China, in Russia, in Egypt, in Persia, in the Philippine Islands. If any of the bold plans of social reconstruction now in the air are attempted in practice

'Fisher, op. cit., p. 9. There is a well-known passage in which Aristotle gives his opinion of the ideal state. He is much concerned about the question of size. "For law is order, and good law is good order; but a very great multitude cannot be orderly: to introduce order into the unlimited is the work of a divine powerof such a power as holds together the universe. . . . To the size of states there is a limit, as there is to other things, plants, animals, implements; for none of these retain their natural power when they are too large or too small, but they either wholly lose their nature, or are spoiled." When a state is composed of too many, it is "almost incapable of constitutional government. For who can be the general of such a vast multitude, or who the herald, unless he have the voice of a Stentor?" Politics, VII, 4 (Jowett's translation).

Sources for study of popular government 
they will apply new tests to democratic principles and inevitably modify their working."'

Moreover, small states have the same value that federal states have in providing opportunities for political experiment; and, as will be seen later,the new states of Europe, in their constitutional arrangements, electoral devices, and canons of social justice, have not been content to follow beaten paths; they have attempted invention. The point is well stated by the chief defender of the small states:

Laboratories for social experiments

Indeed, one of the advantages flowing from the existence of smaller states consists in the fact that they serve as convenient laboratories for social experiment-a point likely to be appreciated in America, in view of the great mass of material for the comparative study of social and industrial expedients which is provided by the enterprise of the American state legislatures. Such experiments as woman suffrage, or as the state prohibition of the public sale of alcoholic drink, or as a thoroughgoing application of the reformatory theory of punishment, would never be seriously discussed in large, old, and settled communities, were it not for the fact that they have been tried upon a smaller scale by the more adventurous legislatures of the New World. Man is an imitative animal, and a study of such an organ as the Journal of Comparative Legislation exhibits the increasing uniformity of the problems which confront the legisla-

1Modern Democracies, Vol. I, p. x. Lord Bryce's opinions as to the value of small states underwent some changes. In his book on The Holy Roman Empire he was an enthusiastic champion of the big-state movement; but in 1905 he lamented the fact that "the most conspicuous feature in the evolution of the modern world has been the effacement of the smaller and the growth of the larger nations and nationalities" with the result that "local patriotism, with all that diversity and play of individuality which local patriotism has evolved, withers silently away." Quoted by J. A. R. Marriott, The European Commonwealth, p. 145 (Oxford, 1918). In Modern Democracies, Lord Bryce said: "It was in small communities that Democracy first arose: it was from them that the theories of its first literary prophets and apostles were derived: it is in them that the way in which the real will of the people tells upon the working of government can best be studied, because most of the questions which come before the people are within their own knowledge. The industrial and commercial forces which draw men together into large aggregations seem to forbid the hope that small self-governing units may reappear within any period to which we can look forward. Yet who can tell what may come to pass in the course of countless years? War and the fear of war were the chief causes which destroyed the little states. If the fear of war could be eliminated there might be some chance of their return." Vol. II, pp. 444-445. 
tor, and the increasing monotony of the solutions which he finds to meet them. All over the world industrial, educational, penal legislation tends to conform to type. And within limits the tendency is the necessary and wholesome consequence of the unifying influence of modern industrial conditions. But our enlarged facilities for imitation present obvious dangers, and among them the fatal temptation to borrow a ready-made uniform which does not fit. Small states may fall into this pitfall as well as big ones, but at least their continued existence presents some guarantee for diversity of life and intellectual adventure in a world steadily becoming more monotonously drab in its outer garment of economic circumstance. ${ }^{1}$

Manifestly, however, the principal problem of small states arises from this same "outer garment of economic circumstance," no matter how drab may be its appearance. In the modern world small states are seldom self-sufficient economically. Industrial Czechoslovakia and Austria have need of agricultural Rumania, Jugoslavia, and even Hungary. Units of transportation and communication are embarrassed and impeded by the multiplication of such artificialities as state boundary lines. Countries having no access to the sea are grievously handicapped in the struggle for material prosperity. And however contemptuous one may be toward a policy of materialism that is pursued as an end in itself, one must recognize that some degree of material prosperity is indispensable to a realization of the "good life" in almost any form.

In his essay on "The Action of Centripetal and Centrifugal Forces on Political Constitutions" Lord Bryce enumerated a number of factors that draw men or groups of men together in an organized community and keep them in union. Among the most important of these factors he mentioned trade, a common law and system of courts, religion, and a system of education that inculcates common ideas and aspirations. ${ }^{2}$ The absence of some of these factors in certain of the pre-war states of Europe

\footnotetext{
'Fisher, The Value of Small States, pp. 17-18.
}

'Bryce, Studics in History and Jurisprudence, p. 216 (New York, 1901).

Economic problems of small states

Centripetal and centrifugal forces 
Formation of the Little Entente

Its future development

unquestionably operated centrifugally. The existence of others, and especially of the economic factor, will undoubtedly serve to draw some of the small states into a closer union than their complete independence implies.

Already, for example, the Petite Entente of Czechoslovakia, Jugoslavia, and Rumania ${ }^{1}$ appears to have emerged into "something closely resembling a Great Power.", "So far from following any aggressive aims, the Little Entente exists to preserve peace on a basis of the new territorial status quo and the sanctity of treaties. It exists as a check upon Hungary's military and political ambitions, and is resolved to prove to her by its members' solidarity the utter hopelessness of recovering her lost provinces. It regards the House of Hapsburg and Magyar monarchism as identified with reaction and subversion. - . Each of its members asks nothing better than to continue in close accord with the Western nations, without whom its unity and independence could not have been achieved. But not even from them is any one of the three prepared to accept dictation in matters such as Hungary's frontiers or the régime of the Danube, which they regard as vital to their own development. They are bent upon economic consolidation and freer mutal intercourse, and intend to provide the proof that the break-up of Austria-Hungary does not involve anarchy or Balkanization."

It is impossible to say whether the Little Entente will ever grow into a true and effective confederation of the small states of central Europe. Austria was drawn partially into the group by the Treaty of Lana which was

\footnotetext{
${ }^{1}$ The Little Entente rests upon a series of bilateral agreements. The agreement between Czechoslovakia and Jugoslavia was signed August 14, 1920; that between Czechoslovakia and Rumania, April 23, 1921; and that between Jugoslavia and Rumania, June 7, 1921.

'D. Thompson and M. W. Fodor, "The Menace of the Little Entente," The New Republic, April 19, 1922.
}

${ }^{8} \mathrm{R}$. W. Seton-Watson, "The Little Entente," The New Europe, October 14, 1920. 
concluded with Czechoslovakia early in 1922.1 And Poland was drawn in to the extent of agreeing to stand with the Little Entente "both politically and economically" at the Genoa Conference in the spring of 1922. But Mr. Beneš, Prime Minister of Czechoslovakia and foremost spirit of the Entente, has been quoted as being "opposed to either a political or economic federation of these states" or even to a customs union or a free trade agreement; he favors only "the consummation of political and economic treaties between state and state, such as the one just concluded between Czechoslovakia and Austria."' Certainly there are many centrifugal forces that will operate against the possible transformation of the Little Entente into a close confederation.

There have been indications also that the Baltic States desire to modify their separatist status by acting jointly in respect to certain matters of common concern. Thus in March, 1922, a treaty was signed between Finland, Esthonia, Latvia, and Poland on the basis of "the community of their mutual political and economic interests." The treaty provided for arbitration of disputes between the signatory states, the negotiation of administrative and economic agreements, the protection of minorities, a "benevolent attitude" by the other states if one of them is attacked, and immediate consultation in such circumstances "as to measures to be undertaken."

Whatever may be the ultimate result of such arrangements as the Little Entente and the Baltic States' Treaty, they at least signify the early recognition of a necessity for striking some kind of compromise between nationalistic aspirations for complete independence and the sternly

\footnotetext{
${ }^{1}$ Austria agreed to execute the Treaties of St. Germain and Trianon to the full extent, to observe neutrality in case Czechoslovakia were attacked, and to prevent anti-Czech irredentist organizations on Austrian territory.
}

'Interview in The Manchester Guardian Weekly. March 31, 1922.

3'“The Baltic States' Treaty of Warsaw," Current History, June, 1922, p. 470.

The Baltic

States'

Treaty of

1922 
practical considerations that urge concerted action in some matters of common concern.

The federal idea in Germany and Austria

Prussian preponderance in German federalism
Of the European states engaged in the World War the German Empire was the only one with a federal system of government. The Austro-Hungarian Monarchy operated under a unique "dual" system that was far from being federal in character. ${ }^{1}$ Indeed federalism had been the high ambition of the non-German and non-Hungarian nationalities of Austria-Hungary when the dual scheme was agreed upon between the Germans of Austria and the Magyars of Hungary in 1867; and toward this ultimate goal some of these "subject" nationalities had never ceased to aspire. It is a curious though not inexplicable fact that in the gray twilight of military defeat and disillusionment the federal idea waned in Germany, while in Austria, although the races that had formerly advocated federalism were now organized into new states, the federal idea gained great headway among a population that was almost exclusively German. ${ }^{2}$

The problem of federalism in the new Germany was inextricably interwoven with the problem of Prussia's preponderance in the old Empire. ${ }^{3}$ If federalism was to be preserved, how could this preponderance be weakened or destroyed? If a unitary state was to be created, how could Prussia, with four-sevenths of the population of the country, be prevented from controlling the entire policy of the Reich? These were the most difficult questions that the makers of the German constitution faced. They were debated at great length and with great passion. ${ }^{4}$ Naturally the lesser states held Prussia especially responsible for the catastrophe that had fallen upon them all.

${ }^{1}$ See below, pp. $241 \mathrm{ff}$.

'See below, pp. 254, 255.

${ }^{3}$ See below, pp. $213 \mathrm{ff}$.

${ }^{4}$ For a brief account of the controversy in the Constituent Assembly, and the proposals that were brought forward, see Brunet, The New German Constitution, Chapter II (New York, 1922). 
And naturally the Prussians clung with desperation to their post of ascendency. In the solution that was reached-if solution it can be called-the status of Prussia in the Reich was unquestionably changed; but it is impossible to say in advance of events whether her power was increased or diminished, or whether it was, after all, not fundamentally altered in degree.

The most obvious way to diminish the importance of Prussia in the federal system, if that was to be continued, was to dismember her and to establish certain new states within her old territory. There were the Rhenish provinces, for example, which had never been enamored of their absorption into Prussia and of their domination by the Prussian burcaucracy. There was Hanover, which had been annexed to Prussia by force in 1866 and which had never been completely Prussianized. There were the provinces of Upper Silesia and of East Prussia, the latter now separated from the body of the Reich by Poland and the Danzig corridor. The plebiscites which were to be held in parts of both of these provinces to determine whether they would or would not remain with Germany might be favorably influenced by a separation of the provinces from Prussia. Among the small states of central Germany there was a movement for amalgamation into a single state which would also claim a slice of Prussian territory.

In the Constitutent Assembly the deputies from the Rhineland strenuously urged that the Rhenish provinces be formed into a new western state of the Reich, which would embrace also a part of Westphalia and the territories of Oldenburg and Bremen. Indeed it was the Rhineland that figured chiefly in all of the discussions of Prussian dismemberment. While the Prussians presented many arguments in opposition to the creation of a Rhenish state within the Reich, perhaps the most powerful opposing influence was the danger of the development of a Rhenish

Possible ways of dismembering Prussia

Possibility of a Rhenish state 
No segmentation of

Prussia

by the constitution

Constitutional provisions

Difficulty of operating state outside the Reich. In spite of the Peace Conference, France was leaving little doubt as to her own welcome attitude toward such an eventuation. In fact, it may well be that it was France, unwittingly, rather than Prussia, wittingly, that prevented the carving up of the latter's territory within the Reich.

The decision was at length reached that no immediate segmentation of Prussia was to take place. The constitution itself made no changes in the boundaries of the states. Instead, provisions were made by which future changes might be effected. These provisions are somewhat complicated and must be read largely in the light of the problem of Prussia's relative size and power. ${ }^{1}$

"The alteration of state boundaries and the creation of new states within the Reich shall take place by virtue of national law modifying the constitution." But a "national law modifying the constitution" requires a two-thirds vote of the Reichstag; hence Prussia could readily block any proposal to alter her boundaries. Needless to say, however, "where the states directly affected consent, an ordinary law shall suffice," such law being enacted by an ordinary majority vote. But what if one of the statesPrussia, for instance-does not consent? In such case, an ordinary law may likewise serve the purpose, provided "the alteration of a boundary or the creation of a new state is demanded by the wishes of the population." But note the difficulty of making these wishes known. "Onethird of the residents of the territory to be separated who are qualified to vote for members of the Reichstag" must demand a referendum upon the proposal. Manifestly this is an almost prohibitively high proportion of the voters, especially in consideration of the huge electorate composed of both men and women. Moreover, the proposal must be ratified by an absolute majority of all the electors, in-

${ }^{1}$ Art. 18 of the constitution.

${ }^{2}$ Art. 76. 
cluding those who do not participate, and by three-fifths of those who do participate. ${ }^{1}$ It is perhaps not to be presumed that Prussia would interpose opposition to a popular demand so overwhelmingly expressed; but it ought to be noted that even in respect to "ordinary laws" Prussia, having a majority of the population of the Reich, will doubtless also have a majority of the members of the Reichstag, ${ }^{2}$ although not of the Bundesrat. ${ }^{3}$

Having had no experience in the working of democratic institutions, the framers of the German constitution may have been over-sanguine concerning the ease with which initiative petitions and popular referenda are operated. Whether from largeness of faith, however, or from cleverness of design, they have made the process of segmenting Prussia extraordinarily difficult of accomplishment. And even at this, lest anti-Prussianism should attempt to ride the waves of the new democracy immediately, it was provided that this difficult process could not be tried for two years after the constitution went into effect-that is, not until August 11, 1921. ${ }^{4}$ It was not until January, 1921, that the plebiscite required in a part of Upper Silesia by Article 88 of the Treaty of Versailles was set for March 20, 1921. Meantime, however, it was desirable to offer every available attraction to the Silesians. The Prussian-owned coal mines in the plebiscitary area were of immense importance to Germany. ${ }^{5}$ Possible transformation of the Prussian province of Upper Silesia ${ }^{\beta}$ into the member state of Upper Silesia

'For other details see Art. 18.

'Since under the electoral law the number of members of the Reichstag is not determined by apportionment on the basis of population, but depends upon the number of voters who participate in an election, it is impossible to say that Prussia will always have an absolute majority. See below, p. 99.

3.Art. 61.

Art. 167.

${ }^{3}$ Bowman, The New World, pp. 345, 346 (Yonkers, 1922).

'The province was created by a Prussian law of October 14, 1919. Preussichegesetzblatt, 1919, No. 169.

Constitu-

tional amendment for Upper Silesia
Largeness of faith or cleverness of design 
might have a favorable influence upon the vote. But the creation of this state prior to August 11, 1921, could apparently be effected only by a constitutional amendment. ${ }^{1}$ An amendment making possible the establishment of this state was adopted November 27, 1920. ${ }^{2}$

Results of Upper Silesian plebiscite

The result of the plebiscite was on the whole more favorable to Germany than to Poland; but differences of opinion arose among the members of the Inter-Allied Commission in respect to the allocation of territory to Germany and Poland respectively. In the end the matter was referred to a Commission of the League of Nations, and on October 12, 1921, the text of the award of the League was made public. In addition to fixing a boundary, the League proposed that for a provisional period of fifteen years the plebiscitary area should be placed under an "Upper Silesian Mixed Commission" composed of an equal number of Germans and Poles under a "neutral" presidency. $^{3}$ On May 14, 1922, during the Genoa Conference, an agreement was signed by Doctor Rathenau and M. Skirmunt, the German and Polish foreign ministers, which generally confirmed the decision and proposal of the Council of the League of Nations. In view of these complications arising out of the indecisive result of the plebiscite, and in view of the extensive award of territory that was made to Poland, it is improbable that the state of Upper Silesia, as provided by the constitutional amendment, will be established. What remains of Upper Silesia will doubtless as heretofore be administered as part of the Regierungsbezirtk Oppeln, a subdivision of the Prussian province of Silesia.

\footnotetext{
${ }^{1}$ Article 167 did not postpone the date of making changes in state boundaries by constitutional amendment or "where the states directly affected consent." But Upper Silesia was not a state and therefore could consent only by a referendum, the taking of which was postponed.
}

${ }^{2}$ Reichsgesetzblatt, 1920, No. 1987; see below, German constitution, Art 167.

${ }^{3}$ League of Nations Official Journal, 2d year, Nos. 10-12, December, 1921, pp. 1223-1232. 
Almost immediately after the revolution the two small states of Reuss (elder and younger lines) united; and a movement was started for creating a state of "Great Thuringia" to embrace eight of the small states of central Germany and an important segment of Prussian territory with the Prussian city of Erfurt as capital. Both Prussia and Erfurt interposed violent opposition, and the project as a whole was abandoned. The state of Thuringia was nevertheless formed by the union of seven states-SaxeWeimar, Saxe-Altenburg, Reuss (the two branches having previously united), Saxe-Gotha (not including Coburg), Schwarzburg-Rudolstadt, Schwarzburg-Sonderhausen, and Saxe-Meiningen. The consolidation of these states was effected by a "treaty." Their consent having thus been given, the state of Thuringia was recognized by an "ordinary law" of the Reich of April 30, 1920. Shortly after the war Coburg detached itself from the Duchy of Saxe-Coburg-Gotha without any legal sanction. On October 30,1919 , the question of whether this "irregular" state should unite with Bavaria or with the new state of Thuringia, then in the making, was overwhelmingly decided by the voters of Coburg in favor of union with Bavaria. ${ }^{1}$ On March 11, 1920, the Bavarian government consented, and the union was legalized by an ordinary law of the Reich of April 30, 1920.

The former German Empire consisted of twenty-five units exclusive of the Imperial Territory of Alsace-Lorraine. The Reich now consists of eighteen units; for counting Reuss as two states, seven of the old states merged into the new state of Thuringia, while an eighth state (SaxeCoburg-Gotha) disappeared partly into Thuringia and partly into Bavaria. In net result, therefore, the constitutional provisions for the alteration of state boundaries and entities have, for the present at least, left the huge territory of Prussia unaffected.

${ }^{1}$ This referendum was apparently extra-constitutional. 
American provision for admitting new states of federal government

The constitution of the United States provides that "new states may be admitted by the Congress into the Union; but no new state shall be formed or erected within the jurisdiction of any other state; nor any state be formed by the junction of two or more states, or parts of states, without the consent of the legislatures of the states concerned as well as of the Congress." With the single exception of West Virginia, which was admitted to the Union under unusual and irregular circumstances, the territory of no state has ever been affected under this provision. The clause has not been used except to admit states formed out of territory not included within the jurisdiction of any existing state. The corresponding clauses of the German constitution have already been pressed into service; but it remains to be seen whether the difficult machinery provided for the possible partition of the overshadowing state of Prussia can be and will be made to operate.

Federal government as distinguished from unitary government is usually defined as a system under which a division of powers is made between a central government on the one hand and local units of government on the other, which division of powers is made by the national constitution and may be altered only by amending the constitution. It might be argued that this definition and the distinction it attempts to make are more legalistic than realistic. It might be urged that under most federal systems there can be and usually is a gradual increase in the centralization of powers without formal amendment of the constitution, and that under most unitary systems the complete obliteration of all powers of local self-government would be unthinkable outside the realm of legal speculation. It may be readily admitted that the difference is merely one of degree; but it is one of very important degree both in fact and in law. 
The essential tests of federalism, it would seem, are two in number: first, the powers that are conferred upon or reserved to the local units must be of some genuine political significance; and second, these powers cannot be withdrawn from the local units at the unrestricted will of the central government. A system that leaves only a negligible dross of powers to the component states is a federal system only in name. A system under which the central government is empowered to extend its own competence at pleasure is not a federal but a unitary system. Judged by either of these tests, the new German system leaves doubt as to the reality of its federalism.

The legislative powers of the former imperial government were by no means inconsiderable; but the powers of the Reich have been enormously increased under the new constitution. As a French commentator has said, the centralizing tendency "has gone as far as possible without completely suppressing the reason for the existence of the states."' Indeed it is not certain that their raison d'être has not been suppressed. 'The constitution, like the old constitution, confers power upon the Reich in respect to three different groups of subjects. Over the first group ${ }^{2}$ the Reich is given exclusive control. Over the second group $^{3}$ it is given priority of jurisdiction, for the states may legislate only "as long as and in so far as the Reich does not make use of its powers of legislation." In respect to the third group 5 the Reich "may prescribe fundamental principles," leaving only matters of detail to the states. In one important field of economic legislation not only do the laws of the Reich take precedence over those of the states, but without legislating itself the Reich

Legislative centralization in Germany

${ }^{1}$ Brunet, op. cit., p. 62.

2Art. 6.

${ }^{8}$ Art. 7, 8, 9. Cf. Art. 4 of the old constitution.

Art. 12.

Arts. 10, 11. 
Little power left to the states

Increase of administrative centraiization may also veto the laws of any state. ${ }^{1}$ In the realm of finance the Reich may not only claim such sources of revenue as it requires, with "due consideration" for the "needs of the states," but may also determine the fundamental principles of state taxation and revenue. ${ }^{2}$

Reading this list of subjects in respect to which the Reich is vested with exclusive or potential control, one can but wonder what sphere of action will remain to the states if the Reich elects to exercise the full measure of its competence. Tendency toward centralization has been the experience under most federal systems of government. It will require heroic opposition on the part of the states of Germany to resist this tendency. As a German commentator has remarked: "According to the conclusions of the Constitutional Committee, a constitutional competence is secured to the states free from control by the Reich, only in so far as the constitution fixes this competence by special provision. In case of doubt, power belongs to the states solely under the legislation and supervision of the Reich." Therefore, he says, "We can understand it when the governments of states were not acquiescent in respect to this matter and when Saxony in her declaration and protest of April 16 [1919] spoke of the use of force by the states."'3

It should be noted also that there is under the new constitution a very considerable increase in the administrative powers of the central government. Under the Empire nearly all laws including imperial laws were executed by the states and not by imperial officials. To an extent this is still true-indeed the largest sphere of competence that is left to the states appears to be administrative. But in the realm of its exclusive powers the Reich also has a large administrative competence of its own. Moreover,

${ }^{1}$ Art. 12.

${ }^{2}$ Art. 11.

${ }^{3}$ Erwin Jacobi, Einheitsstaat oder Bundesstaat, p. 10 (Leipzig, 1919). 
"in the entire sphere of possible legislation, the Reich now enjoys by constitutional grant also the power of supervision over the administration of the states, so that the Reich can exercise this supervision where it wills, unless perhaps a line is drawn by special and exceptional provisions of the constitution. Moreover, the means of supervision are strengthened; a commissioner of the Reich may be sent to the government of the state, and the Reich may, upon the failure of the central officers of the state, forward instructions direct to the intermediate and subordinate officers."

Finally, of course, if the Reich is not content with its immense grant of powers, there remains the possibility of amending the constitution. Under the old constitution the Bundesrat represented the state governments, and the provision that fourteen votes in the Bundesrat were sufficient to defeat a proposed amendment to the constitution operated, not only to safeguard the paramountcy of Prussia, but also to protect the small states against Prussian encroachment by the route of constitutional amendment. It is quite otherwise in the new constitution. An amendment requires a two-thirds vote in the Reichstag and the Reichsrat; but the former may by the same extraordinary majority adopt an amendment over the veto of the latter, in which case the Reichsrat may only demand a referendum. ${ }^{2}$ Moreover, the new Reichsrat is scarcely in any sense a counterpart of the old powerful Bundesrat which it nominally replaces. At the very least, then, it may be said that the German constitution may be amended as easily as a presidential veto may be overridden by the American Congress. But if Congress could add to its powers by such a process, only a high and unfamiliar sense of constitutional morality could delay the progress of the federal system in the United States toward the institutional scrap-heap.

'Jacobi, op. cit., pp. 9, 10.

${ }^{2}$ Art. 76.

Central powers may be increased by amendment

The legislature may amend the constitution 
Prussia makes question of federalism important

In one aspect of the matter, it may be, as Hugo Preuss has said, that "whether the German Republic should now be called a federation of States (Bundesstaat) with strong national central authority, or a unified State(Einheitsstaat) with strong territorial decentralization, is hardly more than a theoretical controversy about terminology."' But the question of the position of Prussia is inextricably bound up in the question of "Einheitsstaat oder Bundesstaat"; and until the rôle and the competence of Prussia in the new scheme of things are fully comprehended, neither the Germans themselves nor the rest of the world will be satisfied with this cavalier dismissal of the matter as "a theoretical controversy about terminology." Brunet says that "nearly all the German jurists have attempted to answer this question and are almost equally divided in the answer."'2 Unquestionably some of their arguments are directed to points of no interest or importance whatever. ${ }^{3}$ A federal system is not changed into a unitary system by rechristening the units Länder in lieu of Staaten. Federalism is a matter of the location of power and of nothing else. What is the power of Prussia in the new German scheme? In the words of a professor of law in the University of Leipsig, it is somewhat as follows:

But the neich in relation to Prussia finds itself in the situation here described. A Prussia, comprising more than four-sevenths of the Reich in area as well as in number of inhabitants, together

${ }^{1}$ The Encyclopadia Britannica, Vol. XXXI, p. 251 (London and New York, 1922). In the article on "Germany" the subdivision entitled "The Republican Constitution" was written by Dr. Preuss, who was chiefly responsible for drafting the constitution.

${ }^{2}$ Brunet, The New Constitution of Germany, p. 70 (New York, 1922). He cites as holding the view that Germany has become a unitary state: Giese, Die Reichsverfassung, vom 11. August 1919, p. 65; Jacobi, Einheitsstaat oder Bundesstaat, p. 6, et seq.; Poetsch, Handausgabe der Reichsverfassung, p. 25, et seq.; Wenzel, Festgabe für Bergbohn, 1919, p. 159, et seq. He cites as taking the opposite view: Stier-Somblo, Reichsverfassung, p. 79 et seq.; Walter Jellinek, Revolution und Reichsverfassung, in Jahrbuch des öffentlichen Rechts, p. 81; Arndt, Reichsverfassung, 1919, p. 35.

${ }^{3}$ Brunet, op. cit., pp. 70, 71 . 
with Prussian particularism which is incontestably strongly developed and remains in full vigor, makes of the unresisting German unitary state simply an extended Prussia. Prussia runs no risk when for the event of a unified transformation of the Reich, she places at its disposal her power over customs and railroads. For in reality the "merging of Prussian administration into the administration of the Reich" can for the present only lead to a transformation of the administration of the Reich into Prussian administration.

But in connection with this stroke only two possibilities present themselves for the event of a transformation of Germany into a unitary state: Either Prussia in her hitherto existing form will take possession of the state, in which case one must be conscious of this, that the German unitary republic in reality means a Prussian unitary republic, within which the non-Prussian districts in all questions to be decided must follow the Prussian will. Or-if one would avoid this Prussian unitary state and will at least make an effort to erect a unitary state with a so-tospeak neutral central will-then the end of Prussia is a preliminary condition, whether this be accomplished in the way of a self-undertaken decomposition or of a destruction decreed by the Reich.

Both the proposal of Preuss and the proposal of the Constitutional Committee counted upon such a dissolution of Prussia and provided a legal route toward this end; in doing so they thought first of all of a decomposition from within, but the Constitutional Committee also opened up the possibility of destruction. At all events it must be thus apparent that not the idea of an extended Prussia but the idea of a unitary Reich over Prussia would be realized. On the contrary the proposal in respect to the ministry permitted no change in its permanency by Prussia, certainly not in the interest of a Reich governed by a unitary Prussia but in behalf of a federal state.

If we continue for the present with the unitary state, so is the contrast between a destruction of Prussia and her decomposition from within not so great as at first appears. For in connection with a partition of Prussia by the Reich the determination by a law of the Reich is not conclusive. Always the question still arises whether the Reich is also competent to give ultimate effect to its order by force. And once more the simple fact is of weight that the Reich is powerless in the face of a closed Prussia. Only when within Prussia great districts fall away from her can the Reich partition Prussia. Moreover, the much discussed destruction of Prussia is possible only under the hypothesis of an internal disintegration. ${ }^{1}$

\footnotetext{
1Jacobi, Einheitsstaat oder Bundesstaat, pp. 27-29.
} 
Prussia is still above the Reich
The Austrian Bund

Prussia has lost the tremendous asset of having a King who was ex officio German Emperor and who appointed, usually in one and the same person, the powerful Imperial Chancellor and the powerful Minister President of Prussia. ${ }^{1}$ She has lost certain specified vetoes ${ }^{2}$ and privileges, as well as a leadership derived from her dominating influence in the most powerful organ of the Empire, the Bundesrat, now sadly reduced to the status of a gesturing Reichsrat. Even in this emasculated upper chamber she has been compelled to share her representation with her provinces. $^{3}$ But these losses cannot gloss the fact that Prussia, with four-sevenths of the population of Germany, can elect the President of the Reich and control a majority of the seats in the Reichstag. "Prussia is still above the Reich."

The union of Austria with Germany was contemplated by both the German ${ }^{4}$ and the Austrian ${ }^{5}$ constitutions but was prohibited by the Treaty of Versailles. ${ }^{6}$ Even if Austria, with a population of more than six millions, had been permitted to join Germany, whether as one state or as several states, Prussia would still have had a substantial majority of the population of the Reich. ${ }^{7}$ Needless to say, however, her relative strength would have been somewhat decreased.

The federal character of the Austrian Republic is emphasized throughout the constitution by the prodigal use

\footnotetext{
${ }^{1}$ See below, p. 213.

${ }^{2}$ Arts. $5,11,35$, and 37 of the old constitution.

${ }^{3}$ Art. 63.

Art. 61.

'See below, p. 255 .
}

"Article 80 reads: "Germany acknowledges and will respect strictly the independence of Austria, within the frontiers which may be fixed in a Treaty between that State and the Principal Allied and Associated Powers; she agrees that this indepeudence shall be inalienable, except with the consent of the Council of the League of Nations."

${ }^{7}$ According to the 1919 census there were $60,837,579$ people in the German Reich. Of these $37,665,013$ (more than four-sevenths, but slightly less than three-fifths) were in Prussia. Under the census of 1920 the population of Austria was approximately $6,711,859$. 
of the word Bund. It is not a Republik or a Reich but a Bundesstaat that recurs again and again in the Bundesverfassungsgesetz. It is, nevertheless, no difficult matter to comprehend the thin essence of the federalism that is provided by this prolix and circumlocutional instrument of government. The Union consists of only eight component states, ${ }^{1}$ but in the problem of the state of Lower Austria there is reproduced in miniature a situation somewhat similar to that of Prussia in Germany. Lower Austria contains about half of the population of the country. No doubt this accounts in large measure for the curious and complicated arrangements of the constitution in respect to the state of Lower Austria and the city of Vienna. ${ }^{2}$ For certain purposes these two divisions of Lower Austria are regarded as separate states, and a kind of "dualism" between them is set up within the constitution. ${ }^{3}$

In matters of legislation the powers of the central government in Austria appear to be even more comprehensive than those of the German Reich. As in the German constitution there are three groups of subjects, but the basis of division is somewhat different; there is, for example, no group of subjects over which the states may legislate until the central government elects to occupy its field of competence. Over the first group the Federal State has both legislative and executive control. ${ }^{4}$ Over the second and much less important group ${ }^{5}$ it has a legis-

1The constitution makes provision for the state of Burgenland, or German West Hungary, when that territory, which was assigned to Austria, shall have been completely handed over by Hungary. This constitutes the eighth state.

${ }^{2}$ Arts. 3, 34, 108-114.

"One would have supposed that the experience with "dualism" under the old Monarchy would have been sufficient to cause an avoidance of the principle; although of course the dualism between Lower Austria and Vienna is of a quite different variety.

4Art. 10. See also Art. 102 in re the administrative competence of the federal government.

'Art. 11.

Lower

Austria

comparable

to Prussia

Legislative and administrative centralization in Austria 
Federal

power of

veto and

dissolution

Austrian

federalism attenuated

Reason for centralization in Czechoslovakia

lative competence that is apparently exclusive; but "the states have the power of execution," which is nevertheless subject to federal supervision. ${ }^{1}$ Over the third group it has no power of execution and has the power to legislate only as to "fundamental principles."' The Federal State has practically complete control over the sources of national, state, and local revenue, ${ }^{3}$ while the division of competence in respect to education was left for later determination by a federal constitutional law. ${ }^{4}$ Residuary powers belong to the states; but it is difficult to imagine any power of importance that is not covered by the constitutional enumeration in favor of the Federal State. Even within the manifestly restricted field of state legislative competence, the Federal Ministry may impose a suspensory veto upon any state law; ${ }^{6}$ it may even bring about the dissolution of a state Landtag. Moreover, there are in the federal constitution a great many details regulating the organization not only of the state governments but also of the municipal governments.

It is difficult to assess a governmental system from the naked language of its fundamental law. But judged by other federal systems Austrian federalism appears to be highly attenuated. It is an idea rather than a fact, an impression rather than a reality - an impression created chiefly by repetitious reference to the Bund.

Because of their composite character and diversity of nationalities the introduction of federalism into the new states of Czechoslovakia and Jugoslavia would in many respects have been logical and natural. In Czechoslovakia there are five nationalities. Of the nearly fourteen million inhabitants, the Czechs (seven million) and the Slovaks (two and a half million) constitute about 65 per cent. There are nearly four million Germans, nearly seven hundred thousand Magyars, and six hundred thousand

${ }^{1}$ Art. 15. See also Art. 16.

AArt. 14.
S.Art. 15.
${ }^{2}$ Art. 12.

-Art. 98.
3.Art. 13.

${ }^{7}$ Art. 100. 
Ruthenians. ${ }^{1}$ These several nationalities are so distributed that, if a federal system were established with large local autonomy in the hands of the component units, the Czechoslovaks would find it difficult if not impossible to control the governments of some of these units. Silesia, for example, would doubtless be controlled by the Germans and Ruthenia by the Ruthenians, while in Slovakia the Slovak majority over the combined Magyars, Germans, and Ruthenians is so small that their control would be precarious. $^{2}$ It was because of this fact that federalism was not seriously considered by the Czechs and Slovaks. Manifestly they could dominate the political situation much more easily under a unitary system of government.

In Jugoslavia the issue between federalism, or decentralization, and unitarism, or centralization, was hotly fought. This was as might have been expected; for Jugoslavia Composition of Jugoslavia was formed of the independent Kingdoms of Serbia and Montenegro; of Croatia-Slavonia, which had enjoyed a considerable measure of autonomy under Hungary; of Bosnia-Herzegovina, which since 1910 had had a measure of autonomy under the joint administration of Austria and Hungary; of the Austrian province of Dalmatia and parts of the Austrian provinces of Carniola, Carinthia, Styria, and Istria (these parts constituting Slovenia); and of parts of Banat, Bačka, and Baranja, which had been integrated with Hungary proper. In view of the difference of political tradition in these several units and of diversity of sub-race, language, and religion, a federal system would

\footnotetext{
1'The figures given by Bowman, The New World, p. 231 (New York, 1922), do not entirely agree with those given by Masaryk in his article on "Czechoslovakia" in The Encyclopadia Britannica, Vol. XXX, p. 785 (London and New York, 1922).

${ }^{2 \times}$ Only 60 per cent. of the people of this district are Slovaks; a quarter are Magyars; 8 per cent. are Germans, and 7 per cent. are Ruthenians. The total population is about $3,000,000$. Therefore, in any local Slovak parliament there would be a bare majority of Slovak members. In a crisis involving the Czechs, Slovakia might lean toward Hungary in a way that would imperil the existence of Czechosiovakia." Bowman, op. cit., p. 24.
} 
Jugoslavia or a "Great Serbia"
Idea of

British

imperial federation dead

"Devolution" in the United Kingdom seem to have been highly appropriate. ${ }^{1}$ A genuine Jugoslav program called for a federation; but the program of a "Great Serbia" called for centralization. In the end the principle of centralization triumphed; but the constitution that embodied it was accepted by the Croats and Slovenes not with grace but apparently because any constitution was better than none. It was only in the official designation of the new state as the "Kingdom of the Serbs, Croats, and Slovenes" that their "separateness" found recognition.

No discussion of the recent development of federalism in Europe would be complete without some mention of the situation in Great Britain. For a quarter of a century or more there has been considerable discussion of the matter of imperial federation, looking to the establishment of more satisfactory relations between the self-governing Dominions and the mother country. But imperial federation is no longer a subject of practical politics in the British Empire. To any possible application of the federal idea the Dominions appear to prefer their present indefinite status, which nets them complete independence in nearly all but name. A British imperial constitution is probably wholly out of the question. ${ }^{2}$

As applied, however, to the United Kingdom itself, the agitation for federalism under the designation of "devolution" is by no means a dead issue. And the agitation rests not so much upon a demand for self-government among the units of the Kingdom as upon the practical necessity of bringing some measure of relief to an over-

1"The total number of inhabitants is about $12,000,000$, divided as follows: Serbs, 6,000,000; Croats, 2,500,000; Slovenes, 1,000,000; Macedonian Slavs, 550,000; Magyars, 450,000; Albanians, 250,000; Moslem Serbs, 625,000; Rumanians, 150,000; Germans, 450,000; others, 175,000." Bowman, op. cit., p. 253.

${ }^{2}$ For a discussion of some of the schemes for imperial federation see Dicey, The Law of the Constitution, Introduction (8th ed., London, 1915); Duncan Hall, The British Commonuealth of Nations (London, 1920); and Pollard, The Evolution of Parliament. 
burdened Parliament and Cabinet. The Parliament of the United Kingdom acts in four more or less distinct capacities: first, as a local legislature for the separate interests of England and Wales, of Scotland, and formerly of Ireland; second, as a national legislature for the interests of the United Kingdom as a whole; third, as an imperial legislature that is peculiarly responsible for the partially self-governing dependencies, crown colonies, and protectorates; and fourth, as the "single, sole, and sovereign authority finally responsible for the control and protection of the interests of the British Empire as a whole and in all its parts." In these several capacities the Parliament of the United Kingdom is responsible directly or indirectly for the peace, order, and good government of a quarter of the total population of the earth. The burden upon it has of recent years become almost intolerable. Imperial interests have grown in number and complexity. The internal legislative and administrative problems of the people of the British Isles, like the similar problems of most other peoples, have likewise become more numerous and more complicated. Merely because of the ever-increasing concentration of business many persons have thought that some measure of decentralization was not only desirable but also indispensable. To this end, and wholly apart from the unique and difficult Irish problem, proposals have been made for a devolution of some part of the authority of the English Parliament to local legislatures created for England, Scotland, and Wales. ${ }^{2}$

\footnotetext{
MacDonald, The Case for Federal Devolution, p. 8 (London, 1920).

${ }^{2} \mathrm{Mr}$. MacDonald lists a number of effects that congestion has on the English parliamentary system. (1) Closure of debates is necessary, but the rules in force can be used to override the rights of minorities, and "to accept them as permanent parts of the procedure of the House must inevitably tend to aggrandize the power of governments and to diminish in a corresponding degree the power of control by the House over them." (2) Legislation by reference is a device that is successfully used in order to save time; but it makes the law more difficult to understand and adds greatly to the cost of litigation. (3) The withdrawal of bills from the consideration of the House as a whole and their reference to committees results in a saving of time; but the practice divides the
}

Parliament overburdened 
Conference on "Devolution"

The Speaker's plan

In October, 1919, the Prime Minister appointed a Conference on Devolution, which was presided over by the Speaker of the House of Commons. This action was taken in response to a resolution passed by the House of Commons by a large vote on June 4, 1919.1 The Conference was unable to reach an agreement but made a report in April, 1920. Two schemes were proposed, one by the Speaker and the other by Mr. Murray MacDonald, a member of the Conference. ${ }^{2}$ The Speaker's plan favored the experimental establishment of a subordinate legislature for each of the three national units of Great BritainEngland, Scotland, and Wales. These subordinate legislatures, called Crown Councils, would be composed of two chambers, a council of commons and a council of peers. Each council of commons would be made up of the

responsibility of the House of Commons and has many other objections. (See also Willoughby and Rogers, op. cit., p. 249.) (4) "The rapidly growing and still more injurious practice of referring difficult and controversial points of legislation from parliament as a whole to public departments to be dealt with by them through orders in council, provisional orders, and departmental committees" furnisbes one explanation of the outcry against the increasing bureaucracy of administrative departments. (For an interesting discussion of the nature and consequences of this administrative legislation see C. T. Carr, Delegated Legislation [Cambridge, 1921]). (5) Moreover congestion is not without importance in respect to Cabinet responsibility. "The work of the Cabinet, and particularly the legislative and more onerous side of it, has branched out in so many and such different directions that no single member of it can possibly make himself acquainted with or responsible for it all. It is notorious that, in consequence of this, collective responsibility of the Cabinet for the proposals it submits to Parliament has ceased to be a reality and become a mere form." MacDonald, op. cit., pp. 17-30.

It was resolved: "That, with a view to enabling the Imperial Parliament to devote more attention to the general interests of the United Kingdom and, in collaboration with the other Governments of the Empire, to matters of common Imperial concern, this House is of opinion that the time has come for the creation of subordinate Legislatures within the United Kingdom, and that to this end the Government, without prejudice to any proposals it may have to make with regard to Ireland, should forthwith appoint a Parliamentary body to consider and report-

“(1) upon a measure of Federal Devolution applicable to England, Scotland, and Ireland, defined in its general outlines by existing differences in law and administration between the three countries;

"(2) upon the extent to which these differences are applicable to Welsh conditions and requirements; and

"(3) upon the financial aspects and requirements of the measure."

"See Conference on Devolution: Letter to Mr. Speaker from the Prime Minister (with Appendices). Cmd. 692, 1920. 
members of the House of Commons elected from the area of its jurisdiction. Each council of peers would consist of peers nominated by the committee of selection of the House of Lords, and its membership would be limited to half that of the council of commons. Sessions would be held in the autumn, it being assumed that Parliament would continue its practice of sitting during the spring and summer months.

The alternative scheme framed by Mr. MacDonald differed from the Speaker's scheme in the important particular of proposing the permanent establishment of subordinate parliaments separately elected. The question of whether these legislatures should be bicameral or unicameral was left to the determination of the Government; but it was urged that if the decision of the Government favored the bicameral system, the recommendations of the Bryce Conference should be followed in the matter of the composition and the powers of the second chambers. ${ }^{1}$ In respect to the "devolution" of powers, which of course amounted to a division of powers between the British Parliament and the local legislatures, the proposals were substantially identical.2 The division would be somewhat different from that of any other federal system; but, apart from the fact that it would be subject to alteration at the

\footnotetext{
ISee above, pp. 45 ff; ; below, Appendix V.

${ }^{2} \mathrm{On}$ the local legislatures, it was proposed to devolve powers over the following matters:

(1) internal commercial undertakings, professions, and societies (advertisements, amusement places and theatres, auctioneers, building societies and loan societies, licensing [liquor], markets and fairs); (z) order and good government (cruelty to animals, betting and gaming, charities and charitable trust acts, inebriates, police other than Metropolitan Police, poor law and vagrancy, prisons, reformatories); (3) ecclesiastical matters (burial law, and matters affecting religious denominations); (4) agriculture and land (commons and enclosures, game laws, drainage, improvements, settled land acts, distress and tenure); (5) judiciary and minor legal matters (coroners, county courts, minor criminal offences [procedure, definition, and punishment], law of inheritance, intestates' estates, conveyancing and registration of land, minor torts, trustees, guardians, and wards); (6) education-primary, secondary, and university (except Oxford, Cambridge, and London); (7) local government and municipal undertakings (county council and municipal bills, fire brigades, local legislation - private bills, gas, water, and electricity undertakings - municipal government,
}

Mr. MacDonald's plan 


\section{will of the central government, it would be none the less intrinsically federal in character.}

including local franchises); (8) public health (preventive measures, contagious diseases, hospitals, housing, national health insurance, lunacy and mental deficiency).

To the United Kingdom it was proposed specifically to reserve control over the following matters:

(1) the Crown and matters relating thereto (succession to the Crown, regency, civil list, Crown properties, treasure trove); (2) peace and war; (3) navy, army, and air services; (4) foreign affairs and extradition; (5) dominions, colonies, and overseas possessions; (6) dignities and titles; (7) treason and alienage; (8) postal, telegraph, and telephone services; (9) submarine cables; (10) wireless telegraphy; (11) aerial navigation; (12) lighthouses, buoys, and beacons; (13) currency, coinage, legal tender, weights and measures; (14) trade marks, patents, and copyrights; (15) regulation of trade, banking, and commercial law (law of agency, banking, census of production, internal commerce, company law, bills of exchange and negotiable instruments, insurance companies, sale of poisons, bankruptcy, bills of sale, sale of goods, shipping and pilotage, quarantine); (16) fisheries, forestry, and certain agricultural services (forestry commission, ordnance survey, import and diseases of animals, inland and sea fisheries, wild birds' protection; (17) industrial legislation (employers' liability and workmen's compensation, factories and workshops, industrial disputes, regulation of hours and wages, truck acts, law of master and servant, unemployment insurance, mines and quarries, trades unions, friendly societies, old age pensions, development commission); (18) railways and canals; (19) registration and census; (20) food regulations; (21) marriage and divorce; (22) vivisection; (23) major criminal offences (procedure, definition, and punishment); (24) major civil torts; (25) university education at Oxford, Cambridge, and at London; (26) Metropolitan Police.

It was proposed that power over the following matters be exercised partly by the United Kingdom Parliament and partly by local legislatures:

(1) corrupt practices; (2) explosives; (3) harbours; (4) acquisition of land for public purposes; (5) transport (roads and highways).

It was proposed that all other matters not expressly enumerated in these lists should be reserved to the United Kingdom Parliament. 


\section{CHAPTER V}

\section{PROPORTIONAL REPRESENTATION}

IN ONE respect all of the new constitutions agree: they provide for the application of the principle of proportional representation. It is possible that this was in part the result of the provisions of the special peace treaties for the protection of the minorities. ${ }^{1}$ These treaties, however,

Progress of proportional representation since the war contained no mention of such matters as suffrage and representation; they were aimed not so much at securing political rights as at guaranteeing civil, religious, racial, linguistic, and educational rights. They sought equality before the law rather than equality at the polls. ${ }^{2}$ Moreover, the so-called minorities treaties could not account

${ }^{1 "}$ Among the achievements of the Conference a not unimportant place must be assigned to a series of separate treaties which were attached to, but distinct from, the main Treaties of Peace with Germany and the other enemy States. The parties to them were, on the one side, the Principal Allied and Associated Powers, viz., America, the British Empire, France, Italy, Japan; on the other side, Poland. Czecho-Slovakia, the Serb-Croat-Slovene State, Rumania, and Greece. These treaties provide for the protection of racial, linguistic, or religious minorities included within the boundaries of the specified States; they also contain provisions for certain general principles affecting commerce and intercourse, and were so drafted as to include a formal confirmation of the recognition of Poland and Czecho-Slovakia as sovereign States. Almost identical are certain provisions which have been introduced into the Treaties of Peace with Austria, Hungary, Bulgaria, and Turkey." Temperley, Ed., A History of the Peace Conference of Paris, Vol. V, p. 112 (London, 1921). Chapter II of this Volume contains an excellent account of the origin and purport of these treaties.

2"To sum up: the principle on which the Treaty [with Poland, which was the model for all the minorities treaties] is based is not that there is any right to impose upon an existing State any principle of government, however admirable, nor does it lay down as a general principle that it is incumbent upon any State to admit to the full rights of citizenship all inhabitants of its territories or determine the principles on which nationalization shall be allowed. It is much more limited. What the Great Powers do is in the act of assigning new territories to an already existing State, or constituting a new State, to lay down conditions on which they transfer the territories to such State. These conditions are that all bona fide inhabitants of the territories in question shall receive full rights of citizenship and that in the future no distinction shall be made between citizens in consequence of difference of race, religion, or language." Ibid., Vol. V, p. 143. 
Rapid spread in Europe

Results of majority or plurality elections

for the fact that during or since the war a number of the other states of Europe have adopted or extended schemes of proportional representation under their old constitutions. Indeed, it is little short of remarkable that this plan of electing representative assemblies, having made only a modicum of progress throughout the sixty or more years of its agitation, should suddenly have been widely accepted in Europe almost without disputation. Apart from certain local elections, it was, prior to the opening of the war, applied to the election of one or both houses of the national legislature only in Denmark (partial), Belgium, Sweden, ${ }^{1}$ Bulgaria, ${ }^{2}$ Serbia, and Portugal,, ${ }^{3}$ and to the election of the lower chamber in the Grand-Duchy of Finland. During the war it was extended in Denmark and adopted in Holland. Since the war it has been further extended in Denmark and adopted in Germany, France (modified), Italy, Czechoslovakia, Austria, Jugoslavia, Switzerland, Poland, Danzig, Esthonia, and Greece.

The disproportionalities of result that obtain under the usual system of electing one or several representatives from a geographical district by majority or plurality vote are so well known as to require no recital here. ${ }^{4}$ They are

1For a description of the Swedish system, not outlined in this chapter, see Humphreys, Proportional Representation, Appendix III (London, 1911); E. von Heidenstam, "System of Proportional Representation," in Historical and Statistical II andbook, published by order of the Swedish Government, 2d. English ed, 1914 (J. Guinchard, Ed.).

${ }^{2}$ An electoral law of 1909 introduced proportional representation into Bulgaria for departmental and municipal elections. In 1911 the national constitution was revised, and an experiment in proportional representation was inaugurated in the two departments of Trnvo and Philippopli. This was extended to all elections by a law of March 8, 1912. For a description of the simple list system adopted, see Blätter für Wirtschaft- und Social politik (Switzerland, 1914); W. S. Munroe, Bulgaria and Her People, pp. 194-197.

${ }^{3}$ Minority representation by the plan of limited voting was adopted in Portugal by a law of August 8,1901. When Portugal became a republic in 1911, this system, as applied to the lower chamber of the legislature, was retained for some of the districts, and proportional representation following the Belgian system (see below, pp. $92 \mathrm{ff}$.) was applied to the four largest constituencies- two each in Lisbon and Oporto. Senators are elected by a plan of limited voting.

4For illustrations, see Humphreys, Proportional Representation, Chapter II (London, 1911); Willoughby and Rogers, op. cit., Chapter XV. 
a matter of common knowledge, bcing in fact merely a matter of common fractions. Over-representation or under-representation in proportion to the party vote is more usual than otherwise. Occasionally an actual minority wins a majority of the seats. Indeed, the possibilities of vagarious results are almost limitless. Moreover, wholly apart from such results, it is perfectly manifest that even where a balance of inequalities as among districts operates to secure for a party its approximate share of the total number of seats, the voters of the party in districts that it fails to carry have no representative in the assembly for whom they themselves have voted. On the contrary, their entire district is in theory represented by a member or members of some opposing party. Above all, however, if political parties mean anything of value, they imply a grouping of the voters on the basis of opinions and beliefs. But the obvious fact is that a grouping of the people for purposes of representation on the basis of their places of residence results only to a limited extent, if at all, in grouping them with reference to their opinions and beliefs.

In view of the complexity of human nature and of human society, no doubt every scheme of representation involves something of artificiality. Inevitably it smacks more of device than of principle. But upon the commonly accepted hypotheses of politics, the logic of proportional representation is fairly unavoidable. It is usually assumed, for example, that the voters of a country are divided (or would divide if they were given adequate opportunity) into two or more relatively permanent groups each united by a common set of political beliefs and opinions, or upon a definite program of political action, or upon both opinions and program. ${ }^{1}$ It is for the most

"'Democracy really means nothing more nor less than the rule of the whole people expressing their sovereign will by their votes." Bryce, Modern Democracies, Vol. I, p. viii (New York, 1921). In this definition there is a clear assumption of a free and rational "will."

Common assumptions of politics
Faults of geographical district groups 
Assumptions

do not correspond to facts

part assumed, moreover, that in the formation and activities of these groups the voters act in purely voluntary and rational fashion. And it is further assumed that the purpose of representative government is to reflect the opinions and effectuate the program of a majority of the voters. ${ }^{1}$ If happily an absolute majority form themselves into a single-minded political group, this task ought to be relatively simple; but if the people divide into a number of more or less irreconcilable and contending groups, the task of compromise in the matter of belief, opinion, and program is obviously more difficult.

These are some of the basic assumptions of politics in modern democracies. A complete consideration of their relation to facts would necessitate a detailed discussion of the origin, the purposes, and the operative methods of political parties. Such a discussion is impossible here. It is sufficient to say, perhaps, that in consideration of the number and complexity of the problems of modern government, it is open to question whether the people of any sizeable country do or can divide themselves on the basis of common opinions into two or three, or for that matter any small number, of more or less permanent and cohering groups. If they are to reach practical problems, group programs must of necessity be somewhat elaborate in character, and their very elaboration will of like necessity weaken the foundation of common opinions upon which the group presumably rests. It may be argued, indeed, that the complex character of modern life, with its rapidly changing and diversified needs and interests, offers no useful place for the large and permanent political party. Certain it is that a union of members upon the basis of genuine beliefs and a fairly stated program of action is by no means a universal characteristic

\footnotetext{
"But see the distinction that is sometimes drawn between "delegative" and "representative" government. Ireland, Democracy and the Human Equation (New York, 1921).
} 
of political parties. The more rigid the principles and the program of a party and the sharper its discipline, the more apt is the party to split upon the rocks of dissension as its numbers increase. The larger the party, the more necessary it is that it should have loose principles, a vague program, and lax discipline. This means that it represents in less degree any genuine division of the voters. Thus it happens that the range and intricateness of the problems of modern government play into the hands of party leaders who naturally desire to increase the party membership. The result is attenuation of program and purpose, with a consequent weakening of the foundation of common opinion upon which the group in theory rests. In order to bolster up this crumbling foundation resort is had to the agency of organization. Party becomes an end rather than a means. The group must be preserved whether or not it has sufficient intellectual vitality and purpose to warrant preservation. In consequence it is sometimes difficult to say whether this or that group is held together chiefly by common opinions or by party organization and activity.

Lord Bryce was not alone in thinking that party organization "has rendered some services, but far greater disservices," that "it is possibly the source of more evil than good."' Another distinguished commentator, Mr. Ostrogorski, has expressed the opinion that the day has passed when large and permanent political parties can perform any useful rôle in democracies. Arguing for their abolition and for the substitution of a scheme of impermanent, single-issue organizations, he says:

Party as a wholesale contractor for the numerous and varied problems, present and to come, should give place to special organizations, limited to particular objects and forming and reforming spontaneously, so to speak, according to the changing problems of life and the play of opinion brought about thereby.

Weakening the theoretical foundation of parties

Substitute of organization

Ostrogorski opposes permanent parties

\footnotetext{
1Modern Democracies, Vol. II, p. 453 (New York, 1921).
} 
Citizens who part company on one question would join forces on another.

The basic conditions for the corruption and tyranny engendered by the present party régime will disappear with their material foundation, which is permanence of organization, and their moral foundation, which is the conforming habit of the party adherents. The temporary and special character of the parties created on the new method will not permit of the enrollment and maintenance of those standing armies with whose help power was won and exploited. On the other hand, party "regularity" will no longer have an object: permanent homage is not to be paid to what is transitory. No longer able to rely on sentimental devotion to its name and style, party will have, in spite of itself, so to speak, to rest on the adhesion of minds and consciences to something well defined, to a clearly specified cause identified with a public interest. Enlisted in the exclusive service of that cause, party organization will revert to its function of means and will cease to be an end; formerly a tyrannical master, it will have to become a docile servant. The problem contained in these propositions is certainly a most serious and complex one and requires thorough scrutiny. ${ }^{1}$

But permanent parties exist

But whatever may be thought of the wisdom or unwisdom, the effectiveness or ineffectiveness, of permanent political parties, they nevertheless exist and must be reckoned with in every democratic country. The twoparty system, however unreasonable and illogical it may be in some of its aspects, has unquestionable advantages over a multiple party system in point of simplicity, responsibility, and efficiency. It has been urged against proportional representation that it would tend to break up such a system; and probably there is considerable justification for the fear that it would do so. But to oppose proportional representation on such ground is to exalt expediency over principle. It is to admit that the twoparty system perdures, not because the voters desire to divide into no more than two groups, but because they are offered no ready avenue of escape from such division. It

\footnotetext{
'Ostrogorski, Democracy and the Party System, pp. 441, 442 (New York, 1910). For a more elaborate discussion of this whole topic see his larger work Democracy and the Organization of Political Parties, Vol. II, pp. 651-695.
} 
is to confess that, contrary to all demagogic profession, the cohering agency of these groups is not so much common political opinions as it is something else-a combination no doubt of tradition, of system, of organization, of size, of legal status, of civic indifference, and above all perhaps of shrewdness on the part of party managers in not balking active and widespread public opinion too boldly or too long and in keeping the two parties somewhat apart on public questions but not too far apart.

Most of the states of Europe, new or old, did not have to consider the possible effect of proportional representation upon the two-party system. Such a system was unknown. In practically every country the voters were already divided actually or potentially into three or more groups. From Right to Left there ranged a series of minority parties, with the resulting necessity of securing majority action in the legislative body only by the unstable bloc, or coalition, of two or more of them. Government by coalition being inevitable, the introduction of proportional representation was inexorably logical. Moreover, the Socialist parties had long advocated the system; and, by and large, the Socialists of varying hues were in nearly every state the most important minority.

Innumerable schemes have been devised for accomplishing the purposes of proportional representation. ${ }^{1}$ But none of the new constitutions goes further than to require that elections shall be held according to the principle of proportional representation. Not even in broad outline do they prescribe any specific plan. The general scheme as well as its details are left to be supplied by electoral law. In view of the fact, however, that the several schemes constitute integral and important parts of the actual

Constitutions establish principle of proportional representation

\footnotetext{
${ }^{2}$ For a discussion of some of them see Humphreys, op. cit.; Commons, Proportional Representation (New York, 1912); Williams, The Reform of Political Representation (London, 1918).
}

The twoparty system

Multiple parties in European states 
The

Danish system

Recent extension in Denmark

working plans of government, and that they cannot be studied from the constitutions themselves, it seems advisable, even at the necessity of some tedious detail, to describe as briefly as possible one or two of the old and a number of the new schemes that have been adopted.

The Danish system deserves mention, not only because in its full application it is a very recent development, but also because it was in Denmark in 1855 that the earliest scheme of proportional representation was actually launched. It was first applied to the popular election of the single-chambered Parliament (Rigsraad) of the Kingdom of Denmark, Slesvig, and Holstein. But such wholehearted application of the plan was shortlived. When Slesvig and Holstein were lost to Prussia and Austria, the Danish constitution of 1863 , as well as that of 1867 , retained proportional representation only for the indirect election of the upper chamber (Landsting). Electoral colleges were chosen in each constituency by the usual majority method; and these colleges used proportional representation (by the single transferable vote) in electing the members.

In this limited form proportional representation remained static in Denmark for more than half a century. At length, in 1908, it was extended to municipal elections. And in 1915 it was adopted in diluted form from the election of members of the lower house (Folketing) of Parliament; but the scheme was a hybrid-a mongrel compromise with the system of single member constituencies. ${ }^{1}$ Employed in the parliamentary election of April 22, 1918, it disclosed serious disadvantages. In the spring of 1920 electoral reform was still on the tapis in Denmark when a ministerial crisis arose over the Slesvig question and a new parliamentary election was ordered. But the Socialists

\footnotetext{
1The 24 Copenhagen members were elected by proportional representation; 93 members were elected in single member districts; and 23 additional seats were distributed so as to secure more approximate proportionality.
} 
refused to participate in another election under the law of 1915, which they claimed would force them into unwelcome alliance with the Radicals. Through the medium of a general strike they succeeded in compelling the formation of a "business ministry" which undertook to carry a new election law through the old parliament. Only a few days were given to considering the law of April 11, 1920; but in spite of this haste and of the turbulence of the period it appears to be a fairly well-conceived scheme. ${ }^{1}$

Apart from the Faroes, which return one member, Denmark (including Slesvig) is divided into 23 electoral areas (3 Copenhagen and 20 county areas), and these areas are divided into 117 nominating districts. Each area returns primarily one member for each of its nominating districts. There are 31 additional seats for distribution to the several parties, ${ }^{2}$ making a total of 149 members. The names of the nominees are placed upon the ballot in party lists. In each nominating district the name of the party nominee from the district is placed first in the list and is printed in heavy type. The other names follow either in an order determined by the party managers or in alphabetical order. 'The voter may cast his ballot for the party list as it stands, or he may mark the name of a particular candidate, which operates to cast his vote for the list as well as to indicate his first preference. To this extent, therefore, the voters may alter the order of prefer-

\footnotetext{
1For a description of the law and some comments on its operation at the elections of April, July, and September, 1920, see Zeuthen, "Denmark-A Complete Victory for P. R.," Representation, No. 38, December, 1920, pp. $168 \mathrm{ff}$.

'The Chief Electoral Officer "first divides 148 seats (i.e., 'ordinary' and 31 'additional' seats) among the parties in strict proportion to their vote-totals for the whole country. The difference between the proportionate share as calculated and the number of 'ordinary' seats already gained gives the number of 'additional' seats for any party. The distribution is subject to the further condition that six must fall to the region of the capital, ten to the Islands, and fifteen to Jutland. The Chief Electoral Officer determines according to a prescribed method the number of additional seats each party shall hold in each of the three regions mentioned, and further allots the addition-seats obtained by each party to the P. R. area in which the party has the highest proportion of unrepresented votes." Ibid., p. 177.
}

Danish law of 1920 
ence determined by the party managers ${ }^{1}$ as well repudiate the first-place position given to the local nominee. The distribution of seats to the several parties within each electoral area is made in accordance with the so-called d'Hondt system, ${ }^{2}$ which, as will appear, is also used in many other

Results of 1920 election

The

Belgian system

countries of Europe. In the clection which was held on April 26, 1920, the following results wcre obtained: The Liberals, with 350,407 votes, secured 48 seats; the Socialists, with 299,892 votes, 42 seats; the Conservatives, with 201,031 votes, 28 seats; the Radicals, with 122,144 votes, 17 seats; the Trade Party (Conservatives), with 29,279 votes, 4 seats. $^{3}$ The proportionality was almost exact.

The Danish scheme of 1920 was in many of its essentials modeled after that of Belgium. Indeed, it seems worth

iBy an amendment of June 28, 1920, a party in any county area may decide not to declare any order of precedence, in which case the elected candidates of the party are those who receive the largest number of individual votes.

2This system is illustrated by Humphreys, op. cit., pp. 178, 179, as follows: "Iet it be assumed that three lists have been presented; that they have obtained $8,000,7,500$, and 4,500 votes respectively, and that there are five vacancics to be filled. The total number of votes for each list is divided successively by the numbers $1,2,3$, and so on, and the resulting numbers are arranged thus:

$\begin{array}{ccc}\text { List No. } 1 . & \text { List No. } 2 . & \text { List No. } 3 . \\ 8,000 & 7,500 & 4,500 \\ 4,000 & 3,750 & 2,250 \\ 2,666 & 2,500 & 1,500\end{array}$

"The five highest numbers (five being the number of vacancies to be filled) are then arranged in order of magnitude as follows:
8,000
7,500
4,500
4,000
3,750

"The lowest of these numbers, 3,750, is called the 'common divisor' or the 'electoral quotient,' and forms the basis for the allotment of seats. The number of votes obtained by each of the lists is divided by the 'common divisor' thus:

$$
\begin{aligned}
& 8,000 \text { divided by } 3,750=2 \text { with a remainder of } 500 \\
& 7,500 \text { “ } 3,750=2 \\
& 4,500 \quad \text { “ } 3,750=1 \text { with a remainder of } 750
\end{aligned}
$$

"The first list contains the 'electoral quotient' twice, and the second twice, and the third once, and the five seats are allotted accordingly. Each party obtains one representative for every quota of voters which it can rally to its support, all fractions of 'quotas' being disregarded."

'Figures taken from Representation, No. 36, May, 1920. 
while to outline the Belgian plan in brief detail in view of the fact that it is the oldest thoroughgoing system in Europe and in some respects may be regarded as the parent of many of the other systems.

Proportional representation was applied to the Belgian House of Representatives and part of the Senate by an electoral law of December 29, 1899. Although this law has been amended a number of times since that date, the latest revision being that of $1919,{ }^{1}$ and although the principle of proportional representation was not written into the constitution until the revision of 1921, the original plan has not been altered in any important particular. ${ }^{2}$ The country is divided into nine provinces; in each of these 3 or more Senators are elected by the provincial councils by a plan of proportional representation. The provinces are divided into arrondissements; and another group of Senators are popularly elected, in varying numbers, either from single arrondissements or from two arrondissements joined for this purpose. A third group are elected by these two groups, proportional representation being also used here. All the Representatives are elected by the voters of the several arrondissements, the number varying from 3 to 26 .

In the popular elections candidates are nominated in lists, the order being determined by the party or group that makes the nomination. The elector casts his vote either for a list as such (vote de liste), which means that he also approves of the preferences indicated by the order of names, or for a single candidate on a list (vote nominatif),

In operation since 1899
Distribution and assignment of seats

'Dispositions du code élcctoral modifiées et complétées par les lois du 9 Mai et des 17 et 22 Octobre 1919.

${ }^{2}$ For discussions of the Belgian scheme see Georges Lachapelle, La representation proportionnelle en France et en Belgique (1911); T. Petitjean, La representation proportionnelle devant les chambres françaises (1915); F. Goblet d'Alviella, La représentation proportionnelie en Belgique; La représentation proportionnelle intégrale (1910); Barriéty, La représentation proportionelle en Belgique (1906); Dubois, La représentation proportionnelle soumise à l'experience belge (1906); Humphreys, op. cit., Chapter VIII and passim. 
Results of the Belgian system

which means that he votes for the entire list but that his first preference is for a candidate who has not been given first place on the list. The party vote is obtained by adding the ballots cast for the list and the ballots marked for any candidate of the list. The distribution of seats is made according to the d'Hondt system, which originated in Belgium. The assignment of seats to the candidates is made with reference to the order of names upon the list as well as with reference to the individual votes polled by the several candidates. ${ }^{1}$ Provision is also made for the election at the same time and in the same manner of substitutes (suppléants). In the event of a vacancy in the office of a Representative or Senator during his term, his place is taken by the first substitute on his party list in his election unit.

This thoroughgoing Belgian scheme of proportional representation has had longer trial than any other in Europe. On the whole it has had salutary results, not the least of which was to lessen the sharp and somewhat bitter division of the Flemish and Walloon districts between the Catholic and the Liberal parties. It is not without its flaws and its critics. Owing to the fact that many of the election units are small (returning only two,

${ }^{1}$ Taking the same example as that given above (page 92, note 2 ), Humphreys says: "Assume that List No. 1 consists of three candidates, A, B, and C, arranged in the order named. and that the 8,000 supporters of the list have given their votes as follows:

$$
\begin{aligned}
& \text { Votes at the head of the List . . . . . . . 4,000 } \\
& \text { Preferential votes for A . . . . . . . . } 500 \\
& \text { " “ “ } \\
& \text { " " " C. . . . . . . } 3,000 \\
& \text { Total . . . . } \overline{8,000}
\end{aligned}
$$

"Candidate A, being the first in order on the list, has the first claim on the votes recorded for the list. The electoral quotient is 3,750 , and A's total 500 is raised to this number by the addition of 3,250 votes taken from those recorded for the list. This secures his election, and there remain 750 list votes which are attributed to candidate $B$, this candidate being second in order on the list. $B$, however, also had 500 votes recorded against his name, and his total poll therefore amounts to 1,250. But candidate $\mathrm{C}$ has obtained 3,000 votes, all recorded for himself personally, and as this total exceeds B's total of 1,250, C would be declared elected." Humphreys, op. cit., p. 181. 
three, or four members), and to the fact that no attention is paid to surpluses, there being no provision for a final national distribution of seats based on compounded surpluses, representation is seldom if ever exactly proportional to the vote. The limited power that is given to the voter in the matter of expressing his preferences among candidates has unquestionably played into the hands of the party machines; the actual choice of candidates almost invariably follows the predetermined choice of party managers as represented in the order of names upon the ballot. While interest in politics has been increased, party discipline has also been quickened.

But proportional representation is gaining, not losing, in Belgium. In 1895 it was applied in diluted form to communal elections. By a law of February 19, 1921, adopted almost unanimously, it was applied in full vigor to these as well as to provincial elections. ${ }^{1}$ The local election scheme, however, differs in some respects from the national plan, especially in that the elector may vote for as many candidates as there are offices to be filled and may "split" his ticket. ${ }^{2}$

${ }^{1}$ "Proportional representation is applied in Belgium to-day to the election of all our political assemblies - the two chambers of our parliament (Senate and House of Representatives), our provincial councils, and our communal councils. . . It is only in connection with the naming of the executive committees in the provinces (députations permanentes) and in the communes (collège des échevins) that the Belgian Parliament hesitated to apply P. R." Léon Dupriez, "P. R. in Belgium," Proportional Representation Revierc, January, 1922, p. 17.

${ }_{2}$ “The law of February 19, 1921, established a new system which differs from that which was in force during the operation of the law of September 12, 1895, and from that which the Electoral Code has provided for legislative elections.

"In principle, the elector may vote for as many candidates as there are seats to be conferred.

"He may vote for all the candidates of one list accepting the order in which the candidates are written upon the ballot. In this case, he votes in the space at the head of that list.

"He may vote for one or for several of the candidates of a single list. In this case, he votes in the spaces which are found at the side of the names of the candidates.

"He may 'split his ticket" (panacher), that is to say, vote for candidates of different lists (for as many as there are seats to he filled). In this case, he marks his vote at the side of the names of candidates that he intends to favor." Delcroix, Guide pratique pour les élections communales, p. 28 (Brussels, 1921).

Recent extension in Belgium 
The

Finnish system

"Compacts" of lists

Proportional representation was made applicable to the Diet, or Landtag, of the Grand-Duchy of Finland by an electoral law of July 20, 1906, which was enacted in conjunction with the organic law of the Landtag of the same date. ${ }^{1}$ The constitution of the Republie of Finland, of July 17, 1919, did not in any respect change the system that had previously been in force. The single chambered legislature (in Finnish, Eduskunta; in Swedish, Riksdag) consists of 200 members elected in $\mathbf{1 6}$ districts. 'The district of Lapland has only one member; the other districts return from 6 to 23 members each, the average being 13 . Although the districts are large, no list may contain more than three names; and the voter may vote for only one list, although he may change the order in which the names have been presented by the party managers. Manifestly a sizeable party in a district returning 13 or 17 or 27 members could not reasonably be restricted to the nomination of three candidates. Permission is therefore given to combine these lists of three names into groups known as "compacts." In other words, the party puts up a series of lists, containing in all at least as many candidates as it can hope to elect in the district. The idea seems to be, not only that small groups of voters, perhaps united upon a transitory issue or a matter of local or specific interest, may nominate a list unaffiliated with any regular party, but also that there may be a degree of mobility and of consideration of local or special interests within the party ranks. But in view of the fact that a name may be placed in any number of lists whether within or without a particular compact (although the voter may not vote in more than one list and although no compact may contain more different names than there are seats to be filled), it is needless to say that this flexibility lends itself more readily to party manipulation than to the encouragement of

\footnotetext{
1 For a brief account of events which led up to these enactments, see below, Chapter XIX.
} 
independent or insurgent candidacies. An unpopular candidate fitted into a number of lists headed by popular candidates may easily be carried to victory. For the voter casts his ballot, not only specifically for the three candidates (usually in the named order, although he may change the order), but incidentally also for the entire compact.

The method of counting the vote and of distributing seats is almost as complicated to describe as it is to accomplish. ${ }^{1}$ The details cannot be set forth here. ${ }^{2}$ Suffice it to say that there is one calculation to determine the order of the candidates within the list, another to determine the order of candidates within the compact, and a third to determine the order of candidates within the district, which in effect determines the distribution of seats. "In its internal party arrangement," says Mr. Humphreys, "the Finnish system shows boldness, originality, and, it must be added, no little complexity of procedure." But, he adds, it "gives a greater freedom to the elector than the Belgian system."

The Constituent Assembly that drafted the new German constitution was elected on January 19, 1919, under a system of proportional representation. ${ }^{3}$ According to a "Cabinet" decree of November 30, 1918, the several

Complicated method of counting

The German system of 1919

1The results of elections are not usually announced for two or three weeks.

${ }^{2}$ For a full description see Humphreys, op. cit., pp. 314 ff.; J. Deck and G. von Wendt, "La représentation proportionnelle et la récente loi électoral de grandduché de Finland," Cahiers ae la Quinzaine (Paris), 9 serie, 4 au 7 cahier, cinquième cahier de la neuvième série. See also British Blue Book, Report of the Royal Commission Appointed to Enquire into Electoral Systems, 1910.

'Proportional representation was not wholly unknown in Germany before the revolution. It was applied to the election of certain members of the lower house in Wurttemberg by a law of July 16,1906, and to the election of the unpaid members of municipal councils in cities of over 10,000 inhabitants by the Wurttemberg municipal code of July 28,1906 . In the same year it was applied to the election of 152 of the 160 members of the lower house of the legislature in the free city of Hamburg. In 1908 proportional representation was introduced in Bavaria as applied to municipal councilors. It was likewise applied to municipal councils in Oldenburg in 1907 (where, however, it was optional), and in Baden in 1910. In 1913 a proposal to use proportional representation in electing members of the Imperial Reichstag was defeated in that body by only one vote. In February, 1918, as an act of death-bed repentance, the Bundesrat approved and forwarded to the Reichstag a bill increasing the size of the 
parties were empowered to nominate by petition in each electoral district or circumscription a number of candidates not to exceed the number of delegates assigned to the district. ${ }^{1}$ The names of the candidates, arranged in the order determined by the nominating party, appeared upon the ballot in their respective groups or lists. The voter cast his ballot primarily for a party list. The count and distribution of seats followed the d'Hondt system.

Unsatisfactory results

The Ministry's proposals of 1920

In its operation at the election this plan of proportional representation did not give complete satisfaction. Chief objection was raised to the matter of combinations of lists, which operated to the disadvantage of the parties of no compromise. It was demonstrated also, as the Belgian scheme had disclosed, ${ }^{2}$ that the d'Hondt method, taking no account whatever of "remainders," worked to the advantage of the larger parties. In addition to this it was urged that the circumscriptions, or election districts, returning an average of eleven deputies each, were far too large. ${ }^{3}$

In January, 1920, the Ministry put forward for discussion three different proposals for an application of what came to be known in Germany as the Baden system of proportional representation. Article 22 of the new Baden constitution provided that "each party or group of electors shall have one deputy for each 10,000 votes cast for its list of candidates. The votes remaining unused in each circumscription shall be totaled for the entire country and distributed in accordance with the foregoing principle.

Reichstag and providing for proportional representation in the election of 80 members from 26 electoral districts. The bill was adopted by the Reichstag but never went into effect.

1For the text of the decree and some particulars in respect to the election, see Representation, No. 33, March, 1919.

${ }^{2}$ Humphreys, op. cit., pp. $188 \mathrm{ff}$.

${ }^{3}$ For a discussion of these criticisms, as well as of the projects proposed by the Ministry and the scheme finally adopted, see Brunet, The New German Constitution, pp. $103 \mathrm{ff}$. (New York, 1922). 
Every remainder of more than 7,500 votes shall be given one seat."

It is unnecessary to discuss in detail the differences contained in the three proposals of the Ministry. As a result of the attempted coup d'état of the militarists in March, 1920, a ministerial crisis arose which precipitated the election of a new Reichstag on June 6. The electoral system had to be reformed immediately, if at all. The imminence of the election, if nothing else, made it unwise to undertake the redistricting that was involved in the Ministry's proposals. The scheme that was adopted, therefore, was not identical with any of them.

The German system may be described as an "automatic" system. The number of members of the Reichstag and the number of members per district are fixed neither by the constitution nor by statute. They depend upon the number of votes that are cast, one deputy being assigned for every 60,000 votes cast for a list. The total number of members, therefore, and the number from each district are determined after the fact of the election. The several parties nominate lists for each of the 35 circumscriptions into which the territory of the Reich is divided. If the parties desire to do so, they may associate their lists in neighboring circumscriptions into a "union" of circumscriptions; 17 of these unions of circumscriptions are established by law. In case a party associates its lists in one of these unions, a first distribution of seats is made upon the basis of the circumscription vote in the ratio of one to 60,000 votes. Thereafter the surplus, or fractional, votes in the several circumscriptions of the union are added together to make a union total for each party; and for every 60,000 votes in this total the party is given an

1These "unions" are quite different from the Finnish "compacts"; for in Gcrmany the party is not limited to the nomination of three names upon a list, but many nominate a full set of candidates. Moreover, the "union" is a union of election districts, whereas the Finnish "compacts" are unions within one election district.

The "automatic" system adopted

Circumscription "unions" 
additional seat. There is, however, no separate list of candidates for such unions; the seats are assigned in order to the next candidates on the circumscription list that furnishes the largest number of surplus votes. Finally

National list

Provisions against "freak" parties each party must associate its circumscription lists with a national list nominated by the central managers of the party. Surplus votes from the several unions are then totaled for the entire country, and seats are assigned in the same ratio to this national party list. If the party has not created circumscription unions of its lists, the surplus votes go direct from the circumscriptions to make up the national total.

Two qualifications to the above-mentioned rules must be noted. If a party has united its circumscription lists, such unions are of no avail unless at least one-half of the quota of 60,000 votes has been polled in at least one single constituency. This is true even though the total of the party's surplus votes for the several circumscriptions of the union is more than 60,000 . The manifest object of this provision is to put weak and scattered parties at a disadvantage; it is to discourage the formation of "freak" parties. The second qualification of the general rule is that no party may elect from its national list a larger number of members than it has elected from its circumscription lists. Here again the result is to prejudice a party of inconsequence. But the primary purpose of the provision is to prevent a party from being represented in major part by candidates who are the choice of the national party machine rather than by those who are nominated and voted for locally. The introduction of the intermediate unions between the circumscription lists and the national list was likewise directed to the end of weakening the central party control. ${ }^{1}$

\footnotetext{
1" In trying to apportion the votes cast by the electors for the National Assembly according to the mechanism provided by Project A [one of the projects of the Ministry which provided for no unions of circumscription lists], it was seen
} 
In the election of June 6,1920 , the Communist party suffered from both of these "penalties." They polled $4,381,000$ votes, which was seven times the quota; but they secured only two seats, partly because their unions were of no avail, and partly because, having secured a seat in only one eircumseription, they could be allotted only one seat from their national list. On the other hand, the vote of the larger partics was very accurately reflected in the number of seats they obtained. The Social Democrats polled 21.6 per cent. of the votes and secured 22.2 per cent. of the seats. The German Democratic party polled 8.5 per cent. of the votes and secured exactly the same percentage of seats. The German National People's party polled 13.9 per eent. of the votes and obtained 14.1 per cent. of the seats. The Independent Socialists, with 18.8 per cent. of the votes, filled 19.1 per cent. of the seats. ${ }^{1}$

It must be recognized, of course, that this German system places immense power over the personnel and the relative chances of candidates in the hands of the party organizations-far greater power, for example, than does the Belgian system. The voter can express no preferences whatever; he must take the candidates in the order in which they are presented to him. Moreover, a number of seats are assigned from a national list that is not presented to the voters at all. On the other hand, this national list not only assists toward exactitude in the matter of proportionalities (by compounding surpluses from all over the country) but also makes it possible for parties to assure the election of leaders who might otherwise be defeated in particular circumscriptions. Like most expedients of politics it has both advantages and disadvantages.

that 18 per cent. of the members of the Reichstag, that is nearly one-fifth, would be elected on the ticket for the Reich, and it was estimated that such a result in the elections of future Reichstags would be but little compatible with the constitutional principle of the direct vote. It was decided in rejecting "group-ofdistrict tickets' to create, nevertheless, groups of districts." Brunet, op. cit., p. 108.

Effect of national lists

1For an analysis of the vote, see Representation, No. 37, August, 1920. 
Proportional representation in the

German

states

The Italian system of 1919

Method of voting
The German constitution prescribes that the principles of proportional representation shall be applied, not only in the election of members of the Reichstag, but also in the election of members of the state Landtags. ${ }^{1}$ The states, therefore, have no option in the matter. The Prussian electoral law of December 3, 1920, establishes a scheme of elections that is practically identical with that of the Reich. ${ }^{2}$ The main principles of the system have been applied also to the election of the municipal council of Greater Berlin, although in these municipal elections no provision is made for the grouping of wards into unions.

By a law of June 30,1912, manhood suffrage was introduced in Italy, the number of electors being increased from three and a half to more than eight and a half millions. By a law of August 15, 1919, proportional representation was applied to the election of the 508 members of the Chamber of Deputies. ${ }^{3} \quad$ The Italian scheme provides for the election of not less than ten deputies from each election district, the districts being formed of provinces or groups of provinces. The largest districts are Milan, Turin, and Naples, returning respectively 20,19 , and 17 deputies. Lists of candidates are nominated by from 300 to 500 electors; a list may contain fewer but not a greater number of names than there are seats to be filled. The voter is given a ballot which, prepared by the nominating party, contains in a circle printed on each side the party emblem but the names of no candidates whatever. Instead of names there are a few dotted lines, in number equal roughly to one-fifth of the members to be chosen from the district. Upon these, if he can write, and if he happens to know and

1Art. 17. See also the Prussian constitution, Article 33.

${ }^{2}$ Preussische Gesetzsammlung, 1920, pp. 559 ff.

'In November, 1918, a bill of Deputy Camera proposing the introduction of the scrutin de liste in place of the single member constituencies was referred to a parliamentary committee. This led to an elaborate report on the whole subject of proportional representation and the presentation of a bill on the subject. Camera dei Deputati. No. 1065-A. Relazione della Commissione Sulla proposta di legge d'iniziativa del deputato Camera. March 8, 1919. 
to remember the nominees of his party, the voter may inscribe, in the order of his preference, as many names as there are lines; and having done this on one side of the ballot, he must repeat the process on the other side. Otherwise, without marking the ballot at all, the voter may deposit the ballot of his party and thereby cast his vote for the list, which is actually before him only in the form of an emblem; he thus records himself as being in favor of the order in which the names have been officially nominated.

More than half of the voters of Italy are illiterate. One Panachage can readily understand, therefore, the mechanism of a ballot that requires no marking. It is more difficult to understand, however, why the literate voter should be put to the maximum of difficulty to express his preferences among the candidates; he must not only commit the names to memory or personal memorandum, but he must also write them down twice on the ballot. The law also permits a kind of panachage. If the voter does not express preferences by writing the names of candidates of his own party, and if his party has not nominated a full ticket, he may write on the dotted lines the names of candidates of another party to a number equal to the difference between the number of members to be elected and the number of candidates that his own party has nominated. In this case, therefore, the voter must remember, not only names, but also the number of vacant places upon his party list.

In determining the number of votes that go to the party list, all of the ballots containing the party emblem are first counted. To these are added the "additional votes" resulting from panachages, these additional votes being determined by dividing the number of them by the number of seats to be filled. ${ }^{1}$ Needless to say, perhaps,

IIf, for example, ten members are to be chosen, and if a voter of party $\mathrm{A}$ writes the name of a candidate of party B upon his ballot (party A not having nominated a full ticket), his ballot is counted as a whole vote for party $\mathrm{A}$ and as a onetenth vote for party $B$.

The count 
Assignments of seats

Results in 1919 election

the number of these additional votes will probably not often be sufficient to affect net results. The distribution of seats among the parties is thereupon made by applying the d'Hondt rule.

The determination of the order of election is strikingly different from that which prevails under the Belgian system. To the first name is not given the number of list votes that are necessary to make up the quota. On the contrary, the entire list vote is given to every candidate. To this is added his preference votes and his "additional" votes. It is these latter, therefore, that determine the order in which candidates are declared elected to the seats which the party has won. Relatively speaking, the number of preferential and additional votes will probably be small; at least, this was the result in the election of November, 1919. Certain it is that the order of election will always be determined by the literate element of the voters; for preferential and additional votes can be cast only by the writing of names on both sides of the ballot.

It has been said of the election in 1919, which was the first election held under proportional representation and the second under the manhood suffrage law of 1912: "The outstanding feature is the large increase in the Socialist representation. . . The contrast . . . between North and South has been mitigated and reduced to a correspondence with realities. Of the deputies who served in the last Chamber only 305 presented themselves for election, and of these one-third were defeated. Thus a large quantity of fresh blood has been infused into the Chamber. On the whole, the Italian Parliament is now much more representative of all the interests and phases of national life than it has ever been before."1

\footnotetext{
"Italy-The First General Election under P. R.-Just and Inclusive Representation Secured," Representation, No. 35, January, 1920, pp. 20 ff. In this article the working of the system is described, and the text of the law is given.
} 
In France proposals to substitute the scrutin de liste for the scrutin d'arrondissement and to apply a plan of proportional representation to the election of members of the Chamber of Deputies have been agitated for many years. ${ }^{1}$ But down to 1919 the Senate was unswerving in its opposition to every such proposal. In the immediate aftermath of the war, however, electoral reform was taken up by the French Parliament, and on July 12, 1919, a new electoral law was enacted. ${ }^{2}$ This law is a bungling makeshift, a product of compromise between irreconcilable ideas, "un mélange incohérent," as the Journal des Débats expressed it. 'The feature of proportional representation is so emasculated as to be scarcely recognizable. It can operate under certain circumstances; but at best the scheme is curiously inapt, inequitable, and illogical.

The department has been substituted for the arrondissement as the election district; ${ }^{3}$ each department returns one deputy for every 75,000 inhabitants and an additional deputy for a majority fraction of that number; but in no case may a department return less than three deputies. ${ }^{4}$ The departments vary widely in this matter; some departments return only the minimum, but the department of the Nord elected 23 deputies in 1919. Nominations are made in lists which may vary in names from one to the number of seats to be filled. But the voter does not cast his ballot for a list as such, either by one mark that signifies his adherence to the list, or by marking one name on the list and thus implying a list adherence. On the contrary, he votes

\footnotetext{
'Sait, Government and Politics of France, pp. $146 \mathrm{ff}$. (Yonkers, 1920).

${ }^{2}$ The text of the law see below, Appendix II. 3The law permits a division of populous departments into districts returning
not less than three deputies each.

4For the election of 1919 the existing apportionment of seats among departments was retained. With the 24 seats assigned to the 3 departments in AlsaceLorraine, the total number was 626 .
}

The French system of 1919

"Un mélange incohérent"

Method of voting 
Election

by majority vote
When proportional representation operates for specific candidates; and he has as many votes as there are seats to be filled, though he need not exercise his full rights in this regard. He is not restricted to voting for names in any one list but may "split the ticket" (panachage).

The number of voters in the district is determined by the number of ballots cast. Any candidate who receives a vote on an absolute majority of these ballots is declared elected. In other words, it is quite possible for a bare majority party to nominate a full ticket, to urge its electors to vote for every name on the ticket, and thus to secure the election of its entire delegation by a simple majority vote for each of its candidates. In the election of November, 1919, this is precisely what happened in a large number of departments; for in many instances the parties of the Right and Center coalesced in order to create a more or less fictitious absolute majority against the extreme Socialists. ${ }^{1}$ This is not proportional representation at all; it is the old familiar block system in the multiple member district. Its result-exactly the reverse of the Italian result-was to decrease the representation of the Socialists, although their relative strength among the voters showed considerable increase.

The proportional feature of the law comes into play only if the number of deputies to which the department is entitled are not elected by absolute majority votes. In such case an electoral quotient is obtained by dividing the number of ballots by the number of seats; and a list average is obtained for each list by adding the number of votes polled for the several candidates of the list and dividing the total by the number of candidates. In other words, the theory is that the average number of votes per

\footnotetext{
IIn consequence, "the Unified Socialists polled 1,700,000 votes, or roughly one-quarter, and have won 70 seats, about one-ninth. In 1914 the party polled $1,100,000$ votes, or about one-sixth, and obtained over one hundred seats." Representation, No. 35, January, 1920, p. 35.
} 
candidate is approximately the number of voters supporting the list. A primary distribution of seats to the several lists is then made by determining how many times the electoral quotient is contained in the list average, fractions being ignored. A secondary distribution, if necessary, is made by awarding all the remaining seats to the list having the highest average vote. Within the lists the seats are allotted to the candidates in the order of their respective number of votes.

It is doubtless unnecessary to point out not only that this scheme does not secure anything approaching exact proportionality but also that the secondary distribution of seats greatly favors the largest party in the district. Moreover, the assignment of seats to candidates in the order of their votes is an almost chance arrangement, if indeed it does not lend itself to the worst kind of political chicanery. In most instances the candidates on any list will receive nearly equal votes. Unpremeditated differences may result from carelessness on the part of some voters, from the occasional splitting of tickets, especially by the voters of a party that has not nominated a full ticket, and from the isolated likes and dislikes of individuals. But it is easy to see that, where it can be assumed that the candidates of any list will be very nearly on a par as to votes, a relatively insignificant number of voters, whether within or without the party, can by concerted action wield an enormous and wholly unjustified influence for or against a particular candidate. On the other hand, a voter of this or that party can indicate a preference for this or that candidate of his party only at the expense of his vote for the list as such; he must "scratch" other names and thus lower the list average in order to express a preference.

It can scarcely be believed that this muddled electoral system will remain long unaltered in France. It is A muddled system

Faults in method of assigning seats neither one thing nor another. In quieter times it is 
The Czeclioslovak system of 1920
National lists certain to invoke constant hostility-and not without reason.

In Czechoslovakia proportional representation was provided for by a law of February 29, 1920. There are 23 parliamentary constituencies each of which returns from 6 to 45 members of the lower house of the legislature. The parties nominate lists of candidates, the several lists being printed upon separate but uniform ballots. The voter has no opportunity but to vote a straight party ticket; it is the system of the "strictly binding lists"; and the order of precedence of the candidates is fixed by the nominating party. Even if one or all of the names are "scratched" the ballot is nevertheless counted for the entire list as it stood. The sum of all the valid ballots of all of the parties is divided by the number of seats assigned to the district. This "electoral number" or quotient is then divided into the sum of the ballots of each party; and the parties are allotted seats in accordance with the resulting numbers. Thereafter the surpluses of all the parties from all of the constituencies are added together to make a grand total of surplus votes for the entire country. ${ }^{1}$ This total is divided by the number of seats that remain unallotted and to this quotient one is added. This number is the "electoral number" or quotient for the second scrutin. It is divided into the total surplus votes of each of the parties, and seats are allotted accordingly. The candidates to whom these seats are given are taken from lists which have been drawn up by the several parties after the first allotment of seats in the constituencies, which lists consist exclusively of names of candidates who have unsuccessfully stood for election in the constituencies. The order in which they are presented on the list is a matter determined wholly by the party managers. If there

\footnotetext{
1The surplus votes of a party which has not obtained 20,000 votes (or the electoral number, if that is less than 20,000 ) in at least one constituency are not included in this total.
} 
still remain seats to be filled, these are assigned to the parties having the largest numbers of unused fractional votes.

The members of the Senate in Czechoslovalia are elected in precisely the same manner. There are, however, only 13 senatorial constituencies, these being composed in general of two deputy constituencies. They severally return from 4 to 23 senators.

This system of proportional representation is notable for its simplicity. ${ }^{1}$ Moreover, it will probably result in obtaining almost exact proportionality. It may be chiefly criticized no doubt because of the very great power that it vests in the party machines. The voter is not only put into a strait-jacket of party control of nominations and of party regularity in voting, but he is also, as in Belgium and more recently in Holland, compelled to vote no matter how much he may object to the alternatives that are proffered. The first election under the system was held in 1920-April 18 for the Chamber of Deputies and April 25 for the Senate. The principal parties that participated were the National Democrats, Agrarian, Popular (Conservative and Catholic), and the Socialists. ${ }^{2}$

In Switzerland proportional representation was first introduced in the canton of Ticino in 1891, where it was made applicable to practically all elections within the canton. Gradually the system was adopted in numerous other cantons for cantonal and municipal elections. ${ }^{3}$ In 1900 and again in 1910 amendments proposing to apply proportional representation to elections to the National Assembly, the lower house of the central legislature, were defeated at the polls. Vote on a similar amendment,

\footnotetext{
'The details of the system are briefly described by V. Joachim in an introduction to The Constitution of the Czechoslovak Republic (Édition de la Société l'Effort de la Tchécoslovaquie, Prague, 1920).
}

${ }^{2}$ Representation, No. 36, May, 1920.

It is now found in 18 of the 22 cantons.

Encourages party control

The Swiss system of 1919 
"Cumul officiel"

"Cumul privé"

proposed by initiative petition for a referendum in 1914, was deferred by reason of the war until October 13, 1918, when it was adopted by an overwhelming majority. Only the principle was written into the constitution; the specific plan was elaborated by a law of February 14, 1919. The first election under the system was, by a transitional constitutional amendment, advanced from 1920 to October 26, 1919.

By the new law the 25 cantons and half-cantons are made the election units, returning from 1 to 16 members each-Vaud 16, Geneva 8, Neuchâtel and Fribourg 7 each, Valais 6, and so on. Nomination is by lists bearing party designations, which lists may contain a full ticket of nominees or a less number of names. A single name may be given two places, but not more than two, upon a list (cumul officiel). ${ }^{1} \quad$ Separate ballots are printed for each party list. ${ }^{2}$

The voter may deposit an unaltered ballot; he may "scratch" (biffer) one or more names upon his party ballot; he may substitute for scratched names, or he may complete an incomplete list, by writing on his ballot the names of candidates of other parties (panachage); or finally, he may cumulate two votes (but not more than two) for one or more candidates by writing the names of such candidates a second time upon the ballot (cumul

'The reasons for this provision have been explained as follows:

"First. It was desired to institute a corrective for panachage; it was feared that some individuals would be given the word to 'scratch' certain candidates of their party and thus run them ashore; it was feared also that some electors of party A would 'split' their votes in favor of the weaker candidates of party $B$ and that the latter would thus be placed in first rank on the B list to the detriment of the leaders of the party. These manœuvres might result in the election of candidates little known or of little value and in ousting the party leaders.

"Second. It was desired also that a party-or rather the group of electors who prepare the list-should be able to indicate which of its candidates it preferred and desired to see elected in any case.

"Third. Finally it is in the interest of small parties to have in their lists as few blank lines as possible." Krafft et Leresche, L'élection et le renouvellement du Conseil National d'après le système proportionnel, p. 9 (Lausanne, 1919).

${ }^{2}$ Blank ballots are also provided; but the use of these and their effect upon the count need not be described. 
privé). ${ }^{1} \quad$ The total votes of the several parties, upon which the distribution of seats depends, consist of two distinct kinds of votes. In the first place, one vote is counted for the party for every vote given to any candidate of the party, whether on the party ballot or on the ballot of some other party by panachage (suffrages nominatifs). In the second place, what are known as complementary votes are accredited to the parties (suffrages complémentaires). These are the number of votes that are necessary to complete a full list on each ballot, whether because the party has not nominated a full ticket, or because the voter has scratched names without substituting others, or because he has written in the names of persons who have not been nominated by any party. ${ }^{2}$ The electoral quotient is determined by dividing the total votes (nominatifs and complementaires) of all the parties by one more than the

Allotment of seats to parties number of seats to be filled. ${ }^{3}$ The several parties are then

'The cumul prive "enlarges the freedom of the voter"; but it has been denounced as "favoring the manœuvres of a small coterie within a party." "This objection loses much of its force because of the permission granted to the parties to "cumulate" upon the printed list the candidates whom the party prefers." Krafft et Leresche, op. cit., p. 18.

"'The system of complementary votes, already in force in the laws of Geneva and Neuchatel, was introduced in order not to do injury to small parties. Suppose that in an arrondissement there are 8 deputies to be elected and that there are two parties, party $A$ having 5,000 adherents and party $B$ having 10,000 . Party A nominates 4 candidates and party B 8. Party A obtains $5,000 \times 4=$ 20,000 nominative votes, and party $B, 10,000 \times 8=80,000$. If party $A$ could not have the additional benefit of complementary votes, party $\mathrm{B}$, having four times as many votes, would have four times as many representatives, although it counted only twice as many electors as party $\mathbf{A}$. This injustice could have been corrected in three ways other than that adopted by the law: (1) by permitting unlimited cumulation (the parties would thus always have the possibility of presenting complete lists); ( 2 ) by distributing the seats according to the number of lists drawn from the ballot box (system of competition between list votes [concurrence des suffrages de listes] used in the cantons of Soleure, SaintGall, Zoug, Lucerne, and in the canton of Valais for communal elections); (3) by dividing the number of votes of a party by the number of names that it carries upon its list. For various reasons, which we cannot consider summarizing here, these three systems were rejected." Krafft et Leresche, op. cit., p. 19, n. 2.

${ }^{3}$ Naturally the result is a large figure; it does not at all correspond to the quotients or quotas under systems which count each party ballot as giving only one party or list vote. For in Switzerland each elector, generally speaking, is regarded as having cast for one or more parties a number of votes equal to the number of deputies to be elected from the canton. 
Assignments of seats to candidates

Results of 1919 election

allotted as many seats as the electoral quotient is contained in their respective totals. If after this allotment some seats remain to be filled, the plan is followed of redividing the total of each party by one more than the number of seats that have already been allotted to the party; and the remaining seats are assigned to the several parties in the order of the resulting quotients (quotients définitifs). ${ }^{1}$

The candidates are assigned to seats in accordance with the numbers of their individual votes. ${ }^{2}$ The differences between the votes of candidates of the same party will result from the cumul officiel, from the cumul prive, from the scratching of names without substitution, and from panachage. The differences will be large or small in accordance with the extent to which these several practices are followed. It is at least possible, however, that they may be determined by the action of relatively small groups of voters.

It was said of the election in October, 1919: "Proportional Representation has made it possible for it [the Socialist group] to obtain the number of seats to which the number of its adherents entitles it. One may regret that the number of its adherents is so high. One may deplore particularly that a crowd of functionaries who are not at all Bolshevist voted for the most extreme Left. But one ought not to regret that a party obtains the

\footnotetext{
1This seems to be merely a complicated way of awarding the seats to the parties having the highest surpluses after the first distribution. It is known as the Hagenbach-Bischoff rule. As Mr. Humphreys has shown, its results are identical with results under the d'Hondt rule. $O p$. cit., Appendix XI.

${ }^{2}$ Where large complementary votes have been added to the nominative votes the total vote of even the leading candidate will naturally be much smaller than the electoral quotient; for complementary votes do not count for any specific candidates. A candidate whose name has been printed twice upon the ballot by the nominating party is not declared elected unless he has received a number of votes equal to the average vote of his party candidates. In other words, the voters may by generous scratching of such a candidate defeat the effort of the party managers to guarantee his election; but to that extent they also lower the party total. A candidate whose name has been printed only once upon the ballot cannot be assigned a seat unless he receives at least one-half of the average vote of the party candidates.
} 
representation to which it has a right according to its numerical force. By securing an equitable parliamentary representation the Socialists lose all pretext to have recourse to unconstitutional action."'1

In the spring of 1922 , while the constituent assembly of Poland was still acting as a provisional parliament, an electoral law for the permanent Parliament was brought to its third reading. ${ }^{2}$ This bill proposed that the 408 deputies of the lower chamber (Sejm) should be elected in 69 electoral districts returning from 4 to 16 members each -an average of 6 deputies per district. Nominations are made by district lists; and after the determination of the electoral quotient and the allotment of seats in the districts, the surpluses for each party are added to make a party total for the entire country. Seats are thereafter allotted to the several parties from their national lists. ${ }^{3}$

1Journal de Genère, October 28, 1919; quoted in Representation, No. 36, May, 1920. The election results were as follows:

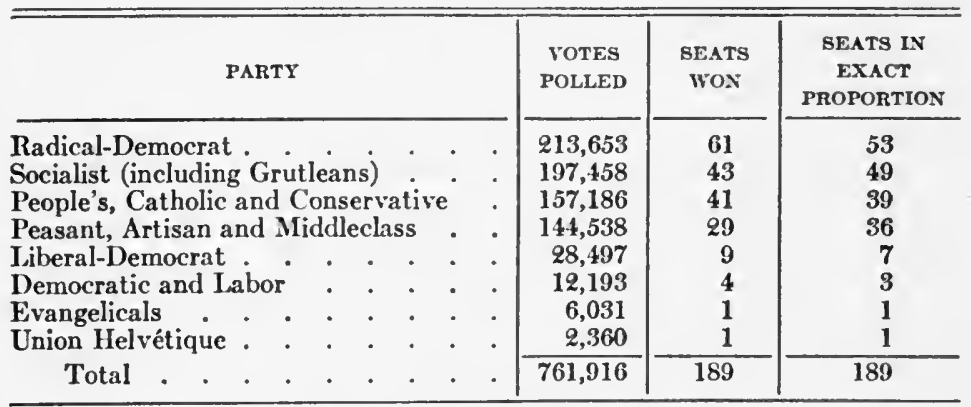

2This proposed law is briefly outlined in Weekly Ners Release Issued by the Polish Bureau of Information, May 31, 1922 (New York). It was merely a proposal of law and therefore may have been changed in some particulars before final cnactment.

${ }^{3}$ From the only summary of the law that is available at this early writing it does not appear: (1) whether the voter is limited to voting a straight ticket or may mark preferences; $(z)$ whether the d'Hondt or some other rule is applied; (3) how the district quotient is ascertained; (4) how the national quotient is ascertained; (5) whether the national lists are prepared before election or are made up of candidates not elected in the districts; (6) no: how the final seats are allotted in sase some seats remain unfilled after applying the national quoticnt. 
It is provided, however, in order to discourage parties of little consequence, that no party may be assigned a seat from its national list unless it has secured one or more deputies in at least three districts. This provision is of special importance in Poland because of the large number of miniature parties that exist. It will no doubt operate to force some of them out of existence or into affiliation with stronger groups. ${ }^{1}$

The 102 members of the Senate are elected by a similar system of proportional representation in the 17 voyvodships into which Poland is divided, each voyvodship returning a number proportionate to its population. By the constitution, however, the electorate for the Senate is smaller than for the lower chamber, for the age requirement is thirty years instead of twenty-one. ${ }^{2}$

Proportional representation in other European states

Proportional representation was adopted in Norway in 1919, and the first parliament (Storting) was elected under it in October, 1921. In 1917 the principle was by amendment of the constitution applied to the Holland Chamber of Deputies, ${ }^{3}$ though not to the Senate, ${ }^{4}$ and the principle was elaborated by an electoral law promulgated in November, 1917. In Austria the constituent assembly which met on March 4, 1919, was elected by proportional representation, and the requirement of the constitution to this end was met by electoral laws of July 20, 1920.5 The Jugoslavian electoral law of September 3, 1920, provided a list system of proportional representation with a unique

\footnotetext{
IIn the constituent assembly there were fifteen parties; but eight of them constituted nine-tenths of the membership, and these eight fell into four principal groups.

${ }^{2}$ Art. 12, sec. 2; Art. 36, sec. 2.

${ }^{3}$ Constitution of Holland, Art. 143.

"The 50 Senators are elected from the 11 provincial states in numbers ranging from 2 to 10 . One-third of them are elected every three years. Under this system it would have been impracticable to apply proportional representation to the election of Senators in most of the states.
}

SStaatsgesetzblatt, 1920, Nos. 317, 351. 
plan of casting ballots. ${ }^{1}$ The Esthonian and Danzig systems embody no unusual features. The short-lived Russian constituent assembly, which was elected under the Kerensky Government in November, 1917, was chosen by a scheme of proportional representation closely following the Belgian plan; ${ }^{2}$ but proportional representation finds no place in the Soviet constitution.

It seems unnecessary to outline here each of these several systems in detail. Like the systems sketched above, each has its own peculiarities; but none of them contains any feature of importance that is not found in one or more of the plans already described. These serve to illustrate practically all of the principles involved as well as most of the striking differences of mechanism.

The principle of proportional representation is manifestly no longer a political issue in most of the ccuntries of Europe; it is an accepted phenomenon of the new era. Doubtless the several schemes will be revamped from time The principle no longer an issue to time as weaknesses and injustices are disclosed. But the principle itself is not likely to be abandoned. What its actual fruits may be only the future can reveal. Wise or unwise, reasonable or unreasonable, it will, of course, be no panacea for the desperate illness of Europe. Indeed, for peoples who are tyros in the high art of selfgovernment, it has, despite its logic, some obvious disadvantages; for as Lord Morley has remarked: "But this is not to say that the State will be fortified in its tasks by special electoral devices with a scent of algebra and decimals about them. These are not easily intelligible

\footnotetext{
1"In each polling-booth there are placed voting-urns on which are posted the names and possibly some pictorial designation of the party lists. Each elector on his arrival is handed by the returning officer an electoral token sufficiently small to be completely concealed in a closed hand. The voter proceeds to the urns and inserts his hand in each in turn, dropping the token in the urn of his own party." Representation, No. 38, December, 1920, p. 182.
}

${ }^{2}$ There were 73 electoral districts returning varying numbers of delegates. The largest district returned 36 . The total number was 730 . 


\section{NEW CONSTITUTIONS OF EUROPE}

either in principle or working to plain men; they are more likely to irritate than to appease, to throw grit instead of oil among the huge rolling shafts and grinding wheels of public government."'

1Morley, On Politics and History, pp. 197, 198 (New York, 1914). 


\section{CHAPTER VI \\ FUNCTIONAL REPRESENTATION}

Functional, occupational, interest, or class representation-by whatever name it is called-is by no means a modern idea. Indeed modern systems of representation in Europe were in most instances evolved out of the representation of three or more distinct classes or estatesthe nobility, the clergy, and the commons, for instancewhich estates were, at least originally, usually represented in separate bodies. Survivals of this kind of representation were found in a number of the upper chambers of Europe before 1918 and are still found in the English House of Lords and to a less degree in such a second chamber as the Italian Senate. ${ }^{1}$ Needless to say also the ownership of property as a qualification for suffrage and for office-holding has played an important rôle in the history of representation, the most significant modern instance having been in Prussia under the famous threeclass system of voting. ${ }^{2}$ Prior to 1907 members of the Austrian lower house (Abgeordnetenhaus) were chosen by five elasses of voters, at least two of which-the chambers of commerce and the great landowners ${ }^{3}$ - could very properly be said to have been "functionally" represented. Other instances might be cited, but these are sufficient to demonstrate the venerable eharacter of the general idea of funetional representation. ${ }^{4}$

1Art. 33.

'See below, p. 214.

${ }^{3}$ The other classes werc the cities, the rural communes, and a general class. See below, p. 249.

${ }^{4}$ For an interesting discussion of the subject, see Beard, The Economic Basis of Politics, pp. $46 \mathrm{ff}$. (New York, 1922).

Functional representation an old idea 
Theoretical proposals

Benoist

Duguit

G.D.H. Cole

The Webbs

With the advent of the modern industrial era functional representation of a somewhat different kind has been proposed by many political writers. For the most part, however, their proposals have been vaguely theoretical. They have not often specified and defined the groups to which representation should be given; nor have they attempted the even more difficult task of allotting representation to the several groups they have in mind. Among the numerous French writers upon this subject $\mathbf{M}$. Benoist worked out a unique scheme of functional representation combined with proportional representation; ${ }^{1}$ while $\mathbf{M}$. Duguit has proposed that representation be established in one chamber of the legislature on the usual basis of numbers of individuals in geographical districts, and in a second chamber on the basis of functional groups. ${ }^{2}$ Among English writers, Mr. G. D. H. Cole would divide economic and political power among a number of functional associations independent of one another within their respective spheres, and at the top he would have a "joint council or congress of the supreme bodies representing each of the main functions in society." But this council would not be a vocational second chamber; it would be a "democratic Supreme Court of Functional Equity" to decide questions of dispute between the state, exercising power over political questions, and the various vocational associations, exercising power over vocational questions. ${ }^{3}$ On the other hand, while Sidney and Beatrice Webb propose a "political parliament" and a "social parliament," each supreme within its sphere, they do not contemplate that either one of these parliaments shall be

\footnotetext{
'Charles Benoist, La crise de l'état moderne, de l'organisation du suffrage universel (Paris, 1898).

2Duguit, Traité de droit constitutionnel, pp. 506-512 (Paris, 2d ed., 1921); "La représentation syndicale au Parlement," Rerue politique et parlementaire, July, 1911.
}

${ }^{3}$ Cole, Social Theory, Chapter VIII (New York, 1920). 
constituted upon any principle of functional representation. ${ }^{1}$

The various indefinite schemes of functional representation that have been put forward cannot be discussed here. Suffice it to say that the general idea of having people represented in a legislative body upon the basis of their functional, occupational, or other group associations is easy enough to understand however difficult it may be to elaborate a satisfactory scheme for such representation. The specification of the groups to be represented, the probable necessity of reorganizing existing groups with reference to purposes of representation, the allotment of representation to the several groups on the basis of relative importance, the question of plural voting by the individual who belongs to more than one group, the determination of whether there should be a single assembly in which all "functions" were represented or many functional assemblies coördinated in some fashion-all of these would be problems of no ready solution. On the subject of functional representation it is less difficult to philosophize than to specifize.

Meantime, however, it has remained for Germany to make a first halting step in the direction of a new kind of functional representation. It is elsewhere pointed out that with the advent of the revolution in November, 1918, Origin of German Council system there arose all over Germany organizations of Soldiers and Workers Councils, ${ }^{2}$ and that a Congress of these Councils met in Berlin in December, 1918, and again in April, 1919. In this spontaneous system of Councils there was naturally an enormous amount of confusion and irregularity. Potentially and actually, however, they were

\footnotetext{
'Sidney and Beatrice Webb, A Constitution for the Socialist Commonvealth of Great Britain (Iondon, 1920).

2See below, pp. $170 \mathrm{ff}$. The groundwork had been laid for these organizations by the National Patriotic Service Law, introduced in December, 1916, which, as a concession to the demands of labor. provided for the establishment of Committees of Workers in all sizeable factories. See Temperley, Ed., A History of the Peace Conference of Paris, Vol. II, p. 455 (Iondon, 1920).
}

Difficulties of working out a plan 
Councils

"anchored"

in the

constitution

Article 165

a constitu-

tional

landmark

none the less a powerful agency. In fact, even after the die had been cast in favor of convoking a constituent assembly, and after the assembly had come together in February, 1919, the Council system was so strongly intrenched that the Provisional Cabinet, resting upon the politically elected assembly, was in no position to ignore it. Adopting at first an attitude of opposition to the Councils, the Government was in the end compelled by strike and threat to modify its stand and to find a place within the constitutional edifice for a legally recognized system of Councils. Needless to say this outcome was far from satisfying the demands of the Independent Socialists and communists, who had hoped to realize a thoroughgoing soviet system. ${ }^{1}$

Difficult as it may be to forecast its ultimate effect, Article 165 of the new German constitution unquestionably marks an important landmark in modern constitutional development. To be sure it is for the most part extremely vague in purport; it is manifestly a compromise that deliberately leaves not only all details but also many matters of principle wholly undetermined. It is nevertheless fundamentally significant both economically and politically. In the realm of economics it piously invokes the principle of coöperation "on an equal footing" between employers and employees "in the regulation of salaries and working conditions, as well as in the entire field of the economic development of the forces of production." But it provides no specific means whatever by

1As one sympathizer with the radicals remarked: "At the same time, schemes are being continually put forward by the less reactionary elements for drawing the teeth of the [Council] movement by 'diddling' concessions. Among such may be counted the clauses 'anchoring' the Councils in the Constitution. The word itself shows how rapidly the German politicians are picking up the devices of parliamentary democracy. Again and again, on the platform and in the Press, the workmen are assured that all is well with the Councils because they are 'anchored' in the Constitution. What the workmen want is not to see them 'anchored' so much as under way; but it is creditable diddling is that catchword, 'anchored in the Constitution." "Young, The New Germany, p. 184 (New York, 1920). 
which this millennium of coöperation inter pares is to be effected. "For the purpose of looking after their economic and social interests," it calls for the establishment of three grades of Workers Councils - for factories, for districts, and for the Reich. And "for the purpose of performing economic functions and for coöperation in the execution of the laws of socialization," it calls for two grades of Economic Councils-for districts and for the Reich. These latter Councils are apparently to include respectively the District and the Reich Workers Councils, as well as representatives of employers and other groups, and are to be "constituted so that all important economic groups shall be represented therein proportionately to their economic and social importance." Thus does the constitution pass along the quicksandy question of relativity of importance among groups.

Manifestly such nebulous provisions as these do not reach a goal; they do little more than point a direction. Their vitality depends wholly upon the manner in which these several Councils are constituted and the specific powers with which they are endowed. From the economic point of view it is difficult to say which of these proposed Councils will prove to be the most important. But from the political and constitutional point of view it is certain that the Economic Council of the Reich is of chief significance. For this is the only one of the councils that is vested with any specific power. "Before proposing drafts of politico-social and politico-economic bills of fundamental importance," the Ministry must submit such bills to this Council. Moreover, the Council may itself propose bills and may submit them to and defend them before the Reichstag even over the protest of the Ministry. Here indeed is a power of some essence. An economic parliament, a chamber constituted on the basis of functional representation, is vested with the power to initiate and the right to be consulted upon social and economic

Economic Council of chief political significance 
legislation. It is not a third chamber standing alongside the Reichstag and the Reichsrat; for it has no power either to enact or to veto; it can only advise and propose. Speaking before the constituent assembly former Under Secretary of State von Delbriuck said: "We are on the eve of a period in which the Reichstag and the Reichsrat will be considered as one side of the balance and the Economic Council as the other. Behold in this a wholly new political evolution. There will come a day when the Economic Council will seek to become the heir of the Reichsrat and to take its place."' Such a development

Possibilities of Economic Council of the Reich

Legislation under Article 165 is surely within the range of possibility. Indeed it is conceivable that by the quality of its personnel and its political sagacity the Economic Council may sow in public confidence and esteem that it may not only seek to take the place of the somewhat emasculated Reichsrat, but may also actually rival or dominate the Reichstag. Judged, however, in the light of the history of advisory councils, this is not a probable development unless the character and worth of the Economic Council should lead to a constitutional amendment vesting it with larger powers. It remains to be seen, then, whether a body representing all important economic groups in proportion to "somebody's" view of their economic and social importance will spend its energy in internal dissensions arising out of conflicts of interest or will by concert of action exert a powerful constructive influence. ${ }^{2}$

It is naturally of interest to inquire how the requirements of Article 165 have been met. As yet no attempt has been made to establish the complete system of Councils for which the constitution makes provision. Only two steps have been taken: the creation of Factory Workers Councils and the setting up of a Provisional Economic Council of the Reich. Even in the enactment of these

${ }^{1}$ Quoted in Brunet, The Nero German Constitution, p. 268 (New York, 1922).

'See below, pp. 131, 132. 
two laws tremendous difficulties were encountered and much opposition was aroused.

Almost immediately after the promulgation of the constitution a bill was introduced into the constituent assembly for the establishment of the Factory Workers Councils. As finally enacted on January 18, 1920 (effective February 4), this law was an elaborate measure set forth in 106 articles. ${ }^{1}$ It can be only briefly summarized here. ${ }^{2}$ The organization of the Factory Workers Councils, sometimes referred to simply as Works Councils, ${ }^{3}$ has been described as follows:

There is first of all the "Factory Workers Council," properly so-called, which exists in every industrial or commercial unit and in all the public and private administrations where there are at least twenty workers.

The wage-worker members of the Factory Workers Council constitute a "Workers Council" and the salaried employê members make up an "Employê Council." If the Factory Workers Council has more than nine members it elects according to the principles of proportional representation a "Factory Committee" of five members. If the Factory Workers Council comprises both representatives of workers and of employês, each of these two groups must be represented in the Factory Committee.

A "General Factory Workers Council" must be created for enterprises of the same kind situated in the same locality or in adjoining localities and belonging to the same owners, if the Factory Workers Council in each plant so decide. This organization may either remain in juxtaposition with the Factory Workers Councils of the different plants, or it may replace them. In that case it functions as a common Factory Workers Council.

A "shop chairman" must be elected in the place of a Factory Workers Council in establishments employing less than twenty workers, of whom at least five must be electors.

There is finally a "Factory Assembly" composed of all the regular employes of the factory. It is convened by the presi-

'Deutsche Nationalversammlung, 1920, No. 2028.

"See "German Works Council Law," Monthly Labor Revieu, May, 1920, pp. $172 \mathrm{ff}$.; "Problems of Labor and Industry in Germany," Special Report Number 15, National Industrial Conference Board, September, 1920, pp. $30 \mathrm{ff}$.

${ }^{3}$ The constitution uses Betriebsarbeiterrat: the law uses Betricbsrat, which is divided into an Arbeiterrat and an Angestellienrat.

Organization of Councils
The Factory

Workers

Councils

Law, 1920

\section{Councils}


dent of the Factory Council. He must convoke it if the employer or at least one-quarter of the workers demand it. ${ }^{1}$

Powers mostly advisory

In spite of this elaborate organization the powers of the Factory Workers Councils are almost wholly advisory. ${ }^{2}$ They may support with advice, coöperate, invoke conciliation, carry out awards that have been accepted, agree with the employer, promote harmony, receive complaints, support the factory inspectors; but they are not vested with any legal power to render and enforce decisions or otherwise to participate in any effective way in the actual management of the business against the will of the employer. It is true that in enterprises that are managed by a board of directors a Factory Workers Council may designate one or two of its members to sit on this board;

'Brunet, op. cit., pp. 250, 251.

${ }^{2}$ The law assigns to them the following duties:

"1. In establishments with economic (commercial or industrial) aims, to support the management with advice in order to assist it to bring the establishment to the highest possible state of efficiency.

" 2 . To coöperate in the introduction of new labor methods.

"3. To safeguard the establishment from violent disturbances, and, without prejudice to the rights of economic organizations of manual workers and salaricd employees, to invoke the conciliation committee or some other conciliation or arbitration board agreed upon in case of disputes between the works council, the workers, or a part of the workers, and the employer which cannot be settled by agreement.

"4. To see to it that awards made by a conciliation or arbitration board in matters concerning the entire establishment and accepted by the intcrested parties be carried out.

"5. To fix, in agreement with the employer, general shop regulations and any modifications of the same within the terms of collective agreements then in force.

" 6 . To promote harmony among the workers and between them and the employer and to safeguard the workers' right of combination.

“7. To receive complaints of the workers' and salaried employees' council and to dispose of them in agreement with the employer.

"8. To take measures to combat danger to health and accidents in the establishment; support the factory inspectors and other officials in the task of combating these dangers by information, advice, and calling them in when necessary, and by supervising the carrying out of the orders of the industrial authoritics and of the provisions for the prevention of accidents.

"9. To take part in the administration of pension funds, company-owned workmen's dwellings, and other welfare institutions of the establishment." "German Works Council Law," Monthly Labor Review, May, 1920, p. 178.

The powers of the "Workers Council" and of the "Employe Council" into which the Factory Workers Council is divided, are as applied to their respective groups practically identical with the powers of the Factory Workers Council with respect to both groups. 
but these members constitute a negligible minority. It is true also that the Council may demand the wage sheet and a quarterly report on the condition and output of the plant, and that in sizeable establishments it may request an annual balance sheet and the profit and loss account; but it is given no general access to the books of the enterprise, and even the meager information that it may demand must be held in strictest confidence. In the matter of hiring and firing the Councils are vested with the power to entertain appeals only in certain limited cases of dismissal, to "negotiate" with the employer, and in the event of disagreement to pass the matter on to an arbitration board.

It must not be thought that the system of Factory Workers Councils was proposed or accepted as a substitute for the more powerful organizations of the trade-unions. At the outset, in fact, the trade-unions had bitterly opposed the establishment of a council system; for in November and December, 1918, they had concluded with the big associations of employers highly satisfactory agreements for the establishment of "labor partnerships" (Arbeitsgemeinschaften) composed of equal numbers of workers and employers. ${ }^{1}$ In the end, however, they were compelled by the radical elements to accept the proposal for Councils; and they agreed to assist the Factory Workers Councils on condition that the Councils operated in accord with the unions. The law creating the Councils expressly provides that "the right of the economic organizations of workers and of employees to represent the interests of their members is in no way prejudiced by the provisions of this law." By a number of other provisions, moreover, it is fairly implied that the Councils are to coöperate with and be in supplement of the trade-unions. Although the law does not mark a sharp line of functional distinction between the two, it was almost certain that the success

1Brunet, op. cit., pp. 238-244. 


\section{NEW CONSTITUTIONS OF EUROPE}

Similiarity

of functions

of the Factory Workers Councils would depend in large measure upon the extent to which they coöperated with and depended upon the older, larger, more resourceful, and more powerful trade-unions. An isolated Factory Council could not possibly develop the strength of a national organization. Moreover, the growth of the tradeunions in Germany since the close of the World Warhas been almost incredible. ${ }^{1}$ On the other hand, the radicals maintain that there is an essential difference of purpose between the trade-union and the Council; the former's mission is to promote the interests of labor under a capitalistic régime; the mission of the latter is to prepare the working class to take over the whole function of production. It is simply a fact, however, that there is not the most remote hint of this larger mission in the law itself.

Elections of members of the Factory Workers Councils took place in April and May, 1920. Basing its opinions upon the reports of the German factory inspection service, the United States Bureau of Labor Statistics, making due allowance for the brief period of ten months' operation of the law, reaches the following conclusions in respect to its effectiveness:

Results of operation of Councils
1. The works council law . . . was a compromise product of the coalition parties of that time. The principle of the right of co-management was almost entirely surrendered by this compromise. The compromise character of the law had the particular result that, from a technical legal standpoint, it was interpreted inaccurately and ambiguously. If one studies the commentaries on the law which have been written by jurists and by representatives of the employers and of the workers they are found to lack uniformity. The elastic interpretations of the law since it has been put to practical use betray this lack of uniformity even more than the commentaries. It is, therefore, but natural that during the first ten months of

\footnotetext{
1"Viewed in the large, it may be said that the number of employees in Germany, whether manual or clerical workers, who are not organized is smali. Only here and there one finds a workman who is not a member of a labor organization." "Problems of Labor and Industry in Germany," Special Report Number 15, National Industrial Conference Board, September, 1920, p. 8.
} 
the operation of the works councils the workers in many instances attempted to exceed the rights granted them by the law, while, on the other hand, many employers endeavored to withhold from the workers even those rights to which the latter were entitled. Thus these ten months have been spent to a large extent in conflicts over the interpretation of the law and in efforts of the political parties to secure control of the works councils.

2. The comparatively large number of disputes that have arisen out of the operation of the works council law have nearly always been settled amicably through the intervention of the factory inspectors.

3. The most outstanding fact revealed by experiences from the first year's operation of the councils is that in disputes between employers and councils both sides, as a rule, do not act on their own initiative but are generally guided by their respective organizations. This accounts for the fact that many disputes were initiated as mere test cases and were fought out through both tribunals of appeal permitted under the law.

4. The works councils, and still more the workers councils [i. e., the councils of manual workers as distinguished from the councils of salaried or clerical employees], are entirely controlled by the trade-unions. In view of the phenomenal development of the trade-union movement in Germany since the end of the war-the unorganized workers now form only a small minority in nearly all establishments-this seems but the natural outcome. It often leads, however, to attempts on the part of the works councils to discriminate against the unorganized workers and to force them into joining an organization. Friction has often arisen among council members themselves when they belonged to rival labor organizations.

5. The councils so far elected are mostly composed of younger workers with pronounced radical tendencies. The older and more conservative workers either are not being considered in the nominations or refuse election. The office of council member seems to be no sinecure and is little sought after. The duty of mediation puts the council members, and especially the chairman of the council, in a rather difficult position. If the council in its dealings with the employer upholds the interests of the workers only, there is continuous friction with the employer, and if it observes a more moderate attitude, it is accused by the working force of subserviency to the employer's interests. This has led many councils to resign in a body.

6. So far the councils have failed to take seriously one of their principal duties, that of "supporting the management with advice in order to assist in bringing the establishment to the highest possible state of efficiency.

Control by tradeunions 
7. All reports agree in one point, namely, that the smooth operation of works councils depends largely on their make-up.

A great deal depends also upon the intellectual and technical fitness of the council members for their office. The trade-unions seem to be fully aware of this fact and have established training courses for council members in all industrial centers.

8. Works councils have operated most satisfactorily in establishments in which, from the beginning, both sides showed good will and an honest desire for successful coöperation.

9. There seems to be little need for works councils in small establishments.

10. The majority of employers are adapting themselves to the new institution, and facilitate the operation of the councils by providing them with office rooms, clerical help, telephones, etc., and by exempting a reasonable number of the council members from productive work.

11. Women workers show scant interest in works councils.

12. All works councils are supporting the factory inspection service to the best of their ability in combating health and accident hazards. ${ }^{1}$

Law of

1920 for

Provisional

Economic

Council

At no time apparently has the Government been prepared to bring forward a comprehensive proposal for the entire system of Councils mentioned in the constitution. Having provided for the lowest order of Councils-the Factory Workers, or Works, Councils-it turned its attention to the highest Council, the Economic Council of the Reich. It was difficult if not impossible, however, to create this Council in constitutional form without also creating at least the Workers Council of the Reich; for Article 165 evidently contemplates that members of the central Workers Council should unite with representatives of other economic interests to form the central Economic Council. It was therefore decided to establish a Provisional Economic Council of the Reich. A law to this end was enacted in May, 1920, and the Provisional Economic

\footnotetext{
1"Factory Inspectors' Reports on Operation of German Works Councils," Monthly Labor Review, February, 1922, pp. 10-12.
} 
Council met for the first time on the thirtieth of June following. ${ }^{1}$

As might have been expected extraordinary difficulty was encountered in allotting representation to various interests "proportionately to their economic and social importance." It was finally determined that of the 326 members, representation should be distributed as follows:

Apportionment of representation

68 representatives of agriculture and forestry

68 representatives of general industry

44 representatives of commerce, banking, and insurance

36 representatives of small business and small industries (handicrafts)

34 representatives of transport services (water and railway transport and postal service)

6 representatives of market industries and fisheries

30 representatives of consumers (municipalities, consumers associations, and organizations of women)

16 representatives of civil servants and the professions

24 representatives named by the government

Most of these divisions comprise enterprises or services in which there are employers and employees; in such divisions it is expressly provided that there shall be parity of representation between the two. So far as the election or appointment of labor representation is concerned, use was of necessity made of the trade-union organizations. Greater difficulty was encountered in determining the mode of choosing the representatives of employers and property owners. A complicated compromise was finally reached by which some of these representatives were chosen with reference to the national associations of employers organized on the basis of specific industries, while others were chosen with reference to the local or regional organization of employers in chambers of commerce and similar associations. For the purpose of actually naming

${ }^{1}$ The original project of the law is outlined in "Problems of Labor and Industry in Germany," Special Report Number 15, National Industrial Conference Board, September, 1920, pp. 33 ff. As finally enacted the law is best described by Brunet, op. cit., pp. $263 \mathrm{ff}$.

Parity of employers and employees 
Representatives of general industry as illustration

the delegates, power was in many instances vested in Arbeitsgemeinschaften, or "labor partnerships," consisting of equal numbers of representatives of trade-unions and of associations of employers. For example, of the 68 representatives of general industry, 48 represent national trade groups. Of these 48, 21 employers and 21 employees were designated with due regard for specific industries, by the central or national Arbeitsgemeinschaft of all the employers and employees of Germany; 2 employers and 2 employees were named by the Coal Council of the Reich (Reichskohlenrat), consisting of both employers and employees; and 1 employer and 1 employee were named by the similarly constituted Potash Council. Of these same 68 representatives of general industry, the remaining 20 represent regional groups; 10 of these are employers chosen by the national Chamber of Commerce from among local chambers of commerce in regions not otherwise adequately represented, and $\mathbf{1 0}$ are employees chosen by the tradeunion members of the central Arbeitsgemeinschaft from regions similarly unrepresented.

Whether the basis of representation in the permanent Economic Council of Reich, which is yet to be established, will be identical with or similar to the basis provided for this Provisional Council has not been determined. If a similar basis is adopted, it would seem that, according to the literal terms of Article 165, the Workers Council of the Reich would of necessity consist of the labor members of the Economic Council. On the other hand, it would in many ways seem appropriate that the three grades of Workers Councils (Factory, District, and Reich) should be constituted in some hierarchical relationship to one another.

Functions

of

Provisional

Economic

Council
This Provisional Economic Council is regarded primarily as a kind of "constituent assembly" convoked for the purpose of proposing a "constitution" for the several councils (except the Factory Workers Councils already 
established) required by the constitution. This appears to be its main task. Meantime, however, it is to a considerable extent performing the functions of a permanent Economic Council. Certain bills of a socio-economic or politico-economic character have been submitted to it by the Ministry. ${ }^{1}$ For example, a bill for the organization of employment information bureaus and a bill for the establishment of a system of arbitration for the settlement of industrial disputes were vigorously debated both in the committees and the plenary sessions of the Provisional Economic Council. In December, 1921, those bills were adopted in such form that a majority of the trade-union delegates voted against them. It is interesting to note that there appears to be more solidarity among the employer group than among the labor group; the latter tends more frequently to split into smaller groups representing various shades of radical opinion. Even so the line between employer representative and employee representative is fairly drawn, with the result that the balance of power lies with the $\mathbf{2 4}$ appointees of the government, who are likely to reflect the views of the government. It was this fact no doubt that led the organ of the General

\footnotetext{
'The Korrespondenzblatt des Allgemeinen Deutschen Geverkschaftsbundes of April 8, 15, and 22, 1922, contains long articles on the results of bills considered by the Provisional Economic Council of the Reich. One of the first bills considered by its socio-political committee was concerned with the hours of labor for industrial workers. This bill was referred to a sub-committee (Arbeitsausschuss) which attempted to consider the whole question of labor conditions in industry. The employer members thereupon absented themselves from the meetings of the sub-committee, and the matter was referred back to the socio-political committee, which passed a resolution restricting the scope of the sub-committee's inquiry. Thereupon the labor members absented themselves, and the matter again went to the socio-political committee, which finally referred it to a committee of 14 experts. Other matters considered by the socio-political committee have been the status of house-servants and social insurance. On January 19 and 20,1922, the finance committee considered tariff questions; and on February $4-7$, the Council itself discussed export duties. On March 15-24, it considered the matter of duties on ink and paper with reference to the needs of the German press. On March 8, the politico-economic committee had under consideration the agenda of the Genoa Conference. On March 22, the reparation committee considered the problem arising out of the Wiesbaden agreement on reparations. This brief review serves to illustrate the kind of questions that are being brought to the attention of the Provisional Fconomic Council of the Reich.
}

Balance of power is with government appointees 
Little progress with

District Economic Councils

Federation of German Trade-Unions to declare after the vote on the above-mentioned bills: "The Economic Council of the Reich is not a favorable ground for the free tradeunions to realize their fundamental principles. The employers have more opportunity for doing so, but they also are kept in check by their class politics. Thus it remains for the Government to make the final decision. The Economic Parliament has of its own accord ruled itself out." Ever since the opening of the Provisional Economic Council its committee on constitution has been endeavoring to outline a plan of organization for the District Economic Councils. Great difficulties have been encountered. The trade-unions demand the abolition of chambers of commerce and other existing associations of cmployers, and the election by some plan of proportional representation of District Workers Councils and of District Employers Councils which together and in equal numbers would form the District Economic Councils. The employers as well as the Government are opposed to the abolition of the existing employers organizations. Down to January, 1922, the committee on constitution had not reached any decision on this matter; nor had they settled the question of the powers of District Councils or the question whether they should be organized according to industries, or existing political divisions, or newly created geographical districts, or some other criterion. ${ }^{2}$

\footnotetext{
${ }^{1}$ Korrespondenzblatt des Allgemeincn Deutschen Gewerkschaftsbundes, December $17,1921$.

${ }^{2}$ In the Korrespondenzblatt des Allgemeinen Deutschen Geverkschaftsbundes of February 4, 1922, there is reprinted from Afa, the organ of the Allgemeine Freie Angestelltenbund, an article entitled: "What is becoming of the District Economic Councils?" The author, Herr Aufhäuser, is a trade-union member of the committee on constitution of the Provisional Economic Council of the Reich. He contends that the continued existence of chambers of commerce and employers' associations without any organic connection with the District Economic Councils would reduce the latter to impotence. On the other hand, unless some substitute based on economic conditions and not on constitutional paragraphs can be found, these existing units cannot be abolished. The important task is to create local economic councils, but the big capitalists are absolutely opposed to this. They will not admit the workers into their cham-
} 
Although the matter is wholly outside the sphere of the constitution, no discussion of the functional representation of labor in Germany would be complete without reference to the important events that followed the short-lived military coup de main of March, 1920, which was effected under the leadership of von Kapp and von Luittwitz. Taken by surprise and deprived of the support of the troops upon whom they had counted, the Government fled from Berlin and, together with members of the political parties which had supported it, issued a proslamation calling for a general strike. The strike immediately broke the back of the monarchist insurrection; but the radicals were quick to take advantage of the chaotic situation that ensued. Before they would call off the strike or permit a restitution of the old Government, the trade-unions forced the Government to sign an agreement recognizing: (1) their right to dictate future Cabinet appointments both in the Reich and in Prussia; (2) their right to have a decisive voice in the formulation of economic and sociopolitical legislation; and (3) their right to approve a reform of the administration "on a democratic basis." 1

bers or give them a direct share in the management of industry. In this connection it should be remembered what a powerful influence the chambers of commerce exert upon the Reichsrat, which is continually curbing both the Reichstag and the Economic Council of the Reich. "It is not too much to say that the value of all the council organizations stands or falls with this: whether it will be possible to reorganize the employers' chambers into true economic chambers in which the workers will have equal rights."

'The terms of the agreement between the Government and the trade-unions were as follows:

"1. That in the approaching creation of new Governments in the nation and in Prussia, the question of personnel be solved by the several parties after agreement with those trade-union organizations of manual workers, clerical employees, and officials who had taken part in the general strike; and that these organizations, with due regard for the rights of the reprcsentatives of the people, be accorded a deeisive voice in the formulation of economic and socio-political legislation.

"2. Immediate disarmament and punishment of all those who had participated in the overthrow of the Constitutional Government and also of all those officeholders who had placed themselves at the disposal of the unlawful Government.

"3. Thorough house-clcaning of all public administrative offices and of the managements in industrial establishments of all persons who had taken part in 


\section{NEW CONSTITUTIONS OF EUROPE}

Significance of agreement

The recognition of such far-reaching claims was, of course, nothing short of revolutionary. Only time can tell whether this documentary contract between the tradeunions and the Government of the day must be regarded as the ephemeral product of a turbulent period, binding upon no Government of the future because it is no part of the fundamental law of Germany; or whether it will take its place as among the world's famous charters of rights-a charter indeed that might prove to be far more important

the counter-revolution, particularly of those who had held leading positions and the substitution for them of trustworthy leaders; reinstatement of all representatives of organizations who have been disciplined for industrial or political reasons.

" 4 . The promptest carrying out of administrative reform on a democratic basis with the approval of the trade-union organizations of manual workers, clerical employees, and officials.

" 5 . Immediate extension of existing social legislation and the enactment of new laws which would guarantee complete economic and social equality to manual workers, clerical employees, and officials; immediate enactment of a liberal civil service law.

"6. Immediate beginning of the socialization of those branches of economic activity which are ripe for it on a basis of the recommendations of the Commission on Socialization; convening of the Commission on Socialization; Government ownership of the Coal Syndicate and the Potash Syndicate.

"7. Effective control and, if necessary, seizure of available articles of food and the severest repression of extortionate charges and profiteering in cities and in rural regions; assurance of the fulfilment of promises of delivery through the establishment of delivery organizations and penalty of severe punishment for malicious violation of these promises.

"8. Disbandment of all associations of counter-revolutionary troops that were unfaithful to the Constitution and the substitution for them of military organizations formed from among that body of trustworthy Republican population, particularly from organized manual workers, clerical employees, and officials without discrimination against any class. In this reorganization, the well-earned legal claims of those troops and Security Guards who remained loyal shall not be disturbed.

"9. Withdrawal from the Government of Noske, Minister of Defense, and of Heine, who have already handed in their resignations."

In connection with this agreement, the German General Federation of TradeUnions, the Industrial League of Free Unions of Clerical Employees, and the Federation of Government Employees issued the following proclamation:

"The Conference of representatives of those organizations of manual workers, clerical employees, and employees in the public service, who participated in the general strike, announces that although it is not entirely satisfied with the terms of the agreement arrived at in its negotiations with the representatives of the political parties in the Government, it nevertheless approves these and hereby declares the general strike terminated as of this day.-Berlin, March 20, $1920-7.05$ A.M." "Problems of Labor and Industry in Germany," Special Report Number 15, National Industrial Conference Board, September, 1920, pp. 45-47. The general strike was not in fact called off until March 23, after further negotiations and agreement with the Independent Socialists. 
than the constitution itself. Certain it is that, if for all time to come the trade-unions of Germany are to have the right to make and unmake ministries and to have a decisive voice in the formulation of all important legislative policies, functional representation of labor has arrived in Germany full grown and full panoplied.

Although the Austrian constitution contains no provision on the subject, it is nevertheless of interest to note that a Workers Chamber (Arbeiterkammer) has been set up in each of the Austrian states by national law. ${ }^{1}$ 'These Chambers, varying in size from state to state, consist of representatives of (1) manual workers and of (2) clerical employees in private industry, and of (3) manual workers and of (4) clerical employees in certain public services. ${ }^{2}$ The functions of these Chambers are almost wholly economic. The mere fact, however, that they are involuntary creatures of the law cannot fail to give them a measure of political signification.

Finally, attention must be directed to the brief pronouncements of three other constitutions. "For the framing of social and economic legislation the economic council is created" in Jugoslavia." In Poland "a special statute will create . . . economic self-government" and a "Supreme Economic Council of the Republic" to collaborate "with state authorities, in directing economic life and in the field of legislative proposals." In Danzig bills may be introduced into the legislature "by legally constituted bodies representing the various professions and trades"; and "bills dealing with economic and social questions shall be submitted to these bodies for their approval."5 Thus in Europe is functional representation casting its portentous shadow before it.

\footnotetext{
${ }^{1}$ Laws of February 26, 1920, and of October 1, 1920; Staatsgeselzblatt, 1920 , Nos. 100, 469.

${ }^{2}$ Wahlordnung der Kammern für Arbeiter und Angestellte, Bundesgesetzblatt für die Republik Österreich, 1920, p. 27.

${ }^{3}$ Art. 44.

Art. 68.

Art. 45; see also Art. 114.
}

Workers

Chambers

in Austria

Economic

Councils in other States 


\section{CHAPTER VII \\ DEMOCRATS AND DIPLOMATS}

Secret

diplomacy and the World War

Problem of legislative control of diplomacy

IN His Modern Democracies, Lord Bryce declared that "the adjustment of relations between the Executive and Legislature in the conduct of foreign affairs has been one of the most difficult and indeed insoluble problems of practical politics."' It is a problem to which, during the last few years, much attention has been devoted. If it is not true, as has frequently been argued, that autocratic methcds of diplomacy were responsible for Europe's plunge into war, ${ }^{2}$ it is certain that statesmen had made commitments concerning which great self-governing peoples were ignorant; and it is arguable that greater publicity and more effective parliamentary control might have served at least to delay the cataclysm. ${ }^{3}$ Naturally enough, therefore, the problem of adjusting the relations between the executive and legislature in the management of foreign affairs has been of particular interest to the framers of the new constitutions of Europe. Recently also it has been discussed in England, France, Italy, Norway, Sweden, and Switzerland. If the solution is not evident, it is at least certain that the extinction of monarchical control over foreign affairs, which in varying degrees existed in Russia, Germany, and Austria-Hungary, has been an immense gain. The new instruments of government all attempt to provide a measure of parliamentary supervision, either

${ }^{1}$ Vol. II, p. 74 n.

'See, for example, E. D. Morel, Ten Years of Secret Diplomacy (London, 1915); A. Ponsonby, Democracy and Diplomacy (London, 1915); F. Neilson, How Diplomats Make War (New York, 1915).

${ }^{3}$ Lord Loreburn, How the War Came (London, 1920). 
through a requirement that treaties nust be ratified by the legislature in order to be binding, or through the agency of a standing committee of foreign affairs. Agreements need not be openly arrived at, and secret treaties there still are, even though the League of Nations Covenant requires that, to be valid, international undertakings must be registered with the League's secretariat. But dynastic control is gone; ${ }^{1}$ the right of democracies to control their foreign relations is rarely challenged in principle; and constitutional changes have limited the exclusive competence of the executive.

The problem of the popular control of diplomacy is of very recent origin. ${ }^{2}$ Indeed, it may almost be said that with regard to foreign policy our systems of government

Recent origin of the problem are primitive. ${ }^{3}$ Law-making bodies have been democratized; in formulating and effectuating internal policies representatives attempt, at least in theory, to consult and to follow the wishes of the people. In foreign affairs, however, either through indifference, or perhaps

1The stability of the dynastic system in Europe "rested very largely upon the maintenance of peace. It was the failure to understand this on the part of the German and Bulgarian rulers in particular that has now brought all monarchy to the question. . . . In the days when Queen Victoria was the grandmother of Europe this was a plausible argument. King, Czar and Emperor, or Emperor and Emperor would meet. It was understood that these meetings were the lubrication of European affairs. The monarchs married largely, conspicuously, and very expensively for our good. Royal funerals, marriages, christenings, coronations, and jubilees interrupted traffic and stimulated trade cverywhere. They seemed to give a raison d'être for mankind. It is the Emperor William and the Czar Ferdinand who have betrayed not only humanity but their own strange caste by shattering all these pleasant illusions. The wisdom of Kant is justified, and we know now that Kings cause wars. It needed the shock of the great war to bring home the wisdom of that old Scotchman of Königsberg to the mind of the ordinary man." H. G. Wells, "The Future of Monarchy," The New Republic, May 19, 1917.

${ }^{2}$ With regard to diplomacy, "democracy enters on a province alien to its true character. Diplomacy demands secrecy and the concession of large discretionary powers to its agents. Democracy demands the discussion of every important compact, even of the step leading to such compact, by the people's Chamber. Here is the Achilles' heel of popular government, and autocrats have ever aimed their deadliest shafts at this vulnerable point." J. Holland Rose, The Rise and Grouth of Democracy in Great Britain, p. 237 (Chicago, 1898).

${ }^{3}$ C. D. Burns, International Politics, p. 120 (London, 1920). For an elaborate discussion, see Barthélemy, Democratie et politique étrangère, Chapter I (Paris, 1917). 


\section{8 \\ NEW CONSTITUTIONS OF EUROPE}

American practice

Common Sense in Foreign Policy

through conviction of their lack of special competence, the people have suffered the executive to exercise a wide and largely uncontrolled discretion. In the American experiment it was assumed that there would be no exception to the matters entrusted to the democracy; the constitution provided for the senatorial ratification of treaties. By many this arrangement was considered of doubtful wisdom. ${ }^{1}$ It antedated by a century the development of any popular control in England. For, although the revolution of 1688 may have established the principle that all political power comes from the people, it was not until very recent times that the direction of international policy was taken out of the hands of the monarch, to whom by curious tradition it was said to belong.

In 1913 there was published in England a remarkable little book called Common Sense in Foreign Policy. The author was Sir Harry Johnston, an experienced and able colonial servant. He surveyed the existing questions of world politics, and ventured predictions to which the war of the next year gave striking confirmation. If his modest little book had been published in 1886, Sir Harry remarked, it "would have savored of indiscretion or impertinence."

\footnotetext{
1This attitude, for example, was well expressed by De Tocqueville:

"As for myself, I do not hesitate to say that it is especially in the conduct of their foreign relations that democracies appear to me decidedly inferior to other governments. Experience, instruction, and habit almost always succeed in creating in a demociacy a homely species of practical wisdom, and that science of the petty occurrences of life which is called good sense. Good sense may suffice to direct the ordinary course of society; and amongst a people whose education is completed, the advantages of democratic liberty in the internal affairs of the country may more than compensate for the evils inherent in a democratic government. But it is not always so in the relations with foreign nations.

"Foreign politics demand scarcely any of those qualities which are peculiar to a democracy; they require, on the contrary, the perfect use of almost all those in which it is deficient. . . . A democracy can only with great difficulty regulate the details of an important undertaking, persevere in a fixed design, and work out its execution in spite of serious obstacles. It cannot combine its measures with secrecy, or await their consequences with patience." The natural defects of aristocracy do not injure the direction of external affairs. "The capital fault of which aristocracies may be accused is, that they work for themselves, and not for the people. In foreign politics, it is rare for the interest of the aristocracy to be distinct from that of the people." Democracy in America, Chapter XIII.
} 
In those days, a country's relations with its neighbors or with distant lands were dealt with almost exclusively by the head of the State-Emperor, King, or President-acting with the more-or-less dependent Minister-of-State, who was no representative of the masses, but the employe of the Monarch. Events were prepared and sprung on a submissive, a confident, or a stupid people. The public Press criticized, more often applauded, but had at most to deal with a fait accompli and make the best of it. Occasionally, in our own land, a statesman, out of office and discontented, went round the great provincial towns agitating against the trend of British foreign policyperhaps wisely, perhaps unfairly, we do not yet know-and scored a slight success. But once in office, his Cabinet fell in by degrees with the views of the Sovereign and the permanent officials (after the fifties of the last century these public servants were a factor of ever-growing importance); and, as before, the foreign policy of the Empire was shaped by a small camarilla consisting of the Sovereign, two Cabinet Ministers, the permanent Under-Secretary of State for Foreign Affairs, and perhaps one representative of la plus haute finance. ${ }^{1}$

The Times was the only English newspaper that had any independent sources of information about foreign affairs and its connection with successive governments was very close. ${ }^{2}$ Practically its only attempt at opposition was with regard to the policy of Gladstone. Foreign policy was still "the natural employment of courts and monarchies."’3

That theory prevailed on the continent until the conclusion of the war. Russia was the extreme example. The Czar was supreme; management of foreign policy was his prerogative. He declared war, decided on peace, and concluded treaties. The right of interpellation and debate in the Douma was so limited as to be valueless; the Minister for Foreign Affairs could make a statement only with the express permission of the Emperor. In Germany, the Reichstag did possess some slight authority, and upon occasions like that of the Daily Telegraph interview

'Johnston, Common Sense in Foreign Policy, pp. 1-2.

'See Sir Edward Cook, Delane of The Times (London, 1916).

${ }^{3}$ H. G. Wells, The Outline of History, Vol. II, p. 216 (New York, 1920).

Press
influence

Press
influence

Continental practice

English

practice

in 1886 
Queen

Victoria in foreign affairs it was able to exert some influence; but the powers of the Emperor were great. ${ }^{1}$ His correspondence with the Czar ${ }^{2}$ and his annotations on the Kautsky documents are not mere illustrations of Hohenzollern idiosyncrasies; they are also significant in a constitutional sense. ${ }^{3}$ In continental countries with eabinet responsibility, the constitutions did not require certain treaties to be laid before the legislature, and the executive had in consequence large discretion. ${ }^{4}$ With the disappearance of kings all this has been changed. Japan is now the only great power in which there is not even a pretence of popular control. ${ }^{5}$

In England, as Sir Harry Johnston said, not until recently has Parliament asserted much control; but the prineipal problem has been with regard to the constitutional rather than the titular executive. The Cabinet, that is to say, rather than the Crown, has possessed the power, and the question has been as to the measure of parliamentary control. Nevertheless, even in recent years the royal authority has been far from negligible. Mr. Strachey's incomparable biography by no means tells the whole story of the influence exerted by Queen Victoria with the able assistance of her husband, who was also, as he told the Duke of Wellington in 1850, her "private secretary, her permanent minister, and her sole confidential adviser in politics."'6

'D. P. Myers, in his Notes on the Control of Foreign Relations (Central Organization for a Durable Peace, 1917) magnifies this parliamentary control.

${ }^{2}$ N. F. Grant (ed.), The Kaiser's Letters to the Tsar: The Willy-Nicky Correspondence (London, 1920).

3" Who authorized him to do this?" was the note when the German ambassador urged moderation on Austria. "The Serbs must be finished as soon as possible." "Serbia's national dignity does not exist," the Kaiser wrote on a dispatch from Lichnowsky. "The question has nothing to do with Grey; it is his Majesty Francis Joseph's affair. What gigantic British impudence!" Karl Kautsky, Comment s'est déclenchée la guerre mondiale, pp. 53, 131 (Paris, 1921).

${ }^{4}$ See President Poincaré's book Les origines de la guerre (Paris, 1921) which discusses his own share in the Anglo-French agreements; see also his How France Is Governed, p. $165 \mathrm{ff}$. (New York, 1914).

'See Willoughby and Rogers, op. cit. pp. $375 \mathrm{ff}$.

'Martin, Life of the Prince Consort, Vol. II, pp. 259, 260. "A foreign Baron (Stockmar) controlled a foreign Prince, and the foreign Prince controlled the 
During the reign of Victoria the most important constitutional incident was the difference of opinion between the Queen and Lord Palmerston. In that struggle (1851) "all the weight of experience was on Palmerston's side, and their victory over him was the victory of anti-liberal principles in foreign policy. And it was won at the expense of the nation by the Court's successful assertion of its claim to a dominant control over foreign affairs. Of the Parliament that was behind the Minister or of the public that was behind Parliament there is no evidence derivable from the Royal correspondence that the Court took the smallest account. Foreign policy came to be considered as a matter to be solely or mainly directed by the Crown, and if the Crown and the country took divergent views it was the views of the Crown that had the right to prevail." It was the Crown that asserted "the unfettered right to approve or disapprove the choice of a Minister for the office."1

The right to offer advice became the right to withhold consent, or at least to force ministerial concessions. Thus the Queen wrote to Lord Clarendon on July 24, 1855: "Having read the whole of these documents, she confesses that she requires some explanation as to the advantages which are to arise to England from the proposed treaty, before she can come to any decision about it." 2 Again, the English Ambassador at Paris was told that "the Queen cannot understand how Lord Cowley can propose anything so indefensible in a moral point of view." 3

It matters not that the influence of the Crown was beneficial and in some cases imposed very wise restraints on ministerial action. From the standpoint of the conCrown of England. And the Crown itself was creeping forward ominously; and when, from under its shadow, the Baron and the Prince had frowned, a great Minister, beloved of the people, had fallen. Where was all this to end?" Strachey, Queen Victoria, p. 251 (New York, 1920).

'J. A. Farrar, The Monarchy in Politics, pp. 228-229 (New York, 1917).

:Letters of Qucen Victoria, Vol. III, p. 169; Farrar, op. cit., p. 194.

${ }^{3}$ Letters of Queen Victoria, Vol. III, p. 435.

Foreign policy determined by the

Crown

Illustrations 


\section{NEW CONSTITUTIONS OF EUROPE}

stitution, the problem was serious. The sovereign, who was a Queen, wove the threads of England's foreign policy. In 1874, for example, Victoria planned to go to Balmoral two days before the departure from Isondon of the Czar who was in England for the marriage of his daughter to the Duke of Edinburgh. When it was pointed out to her Majesty that this would be gravely impolite and that serious consequences might ensue, she remained adamant; her plans could not be changed. ${ }^{1}$ Lord Derby, Lord Salisbury, even the Prince of Wales, could not dissuade her; but Disraeli succeeded. "Salisbury," he wrote, "says that I have saved an Afghan War, and Derby compliments me on my unrivalled triumph." The delay was made, the Queen confessed, "for Disraeli's sake and as a return for his great kindness." "The blandishments used were extra-constitutional, but the whole theory of the

Conflict of control between Crown and Parliament English constitution is that the checks on the Crown should be definite and effective; that nothing should depend upon the finesse of the statesman who happens to be Prime Minister. ${ }^{3}$ The Sovereign had claimed and had succeeded in securing a control of diplomacy far greater than foreign ministers had allowed the three preceding kings, and the struggle was not without its effect on the share that Parliament could assert in the conduct of foreign relations. The result was "that successive Foreign Ministers found themselves confronted with two responsible ties, of which that to the Crown tended to override that to Parliament, and to bring about that impotence of Parliament over foreign policy which has now reached the stage of complete paralysis. Now for better, now for worse, a dual and often conflicting control was set up,

\footnotetext{
'Strachey, op. cit., p. 357.

${ }^{2}$ Monypenny and Buckle, The Life of Benjamin Disraeli, Vol. V, p. 415 (New York, 1920).

"In 1877 Victoria told Disraeli that "if England is to kiss Russia's feet," the Queen "would lay down her Crown." The Queen would be "so humiliated that she thinks she would abdicate at once. Be bold." Strachey, op. cit., p. 363.
} 
and whilst in domestic affairs the Court bowed, however reluctantly, to the Cabinet, in foreign affairs its claim to a concurrent or even dominant power was the main political result of the Queen's reign."1

In politics the play of chance has effects which are sometimes overlooked. ${ }^{2}$ Queen Victoria's widowhood was an accident that prevented further accretions of royal power. Gladstone's friendship was also a restraining influence. He viewed with disfavor the concessions that Disraeli had made, and he was none the less alarmed because tactful flattery and not constitutional right was Disraeli's resource. That the sovereign should be told what transpired in cabinet meetings seemed to Gladstone particularly dangerous. ${ }^{3}$ During his long premiership, therefore, the constitutional executive asserted more and more independence. Then came another accident.

Mr. Strachey's picture of Victoria's son, a mature Prince of Wales, late for dinner, nervously delaying the moment of receiving his mother's reproof, does not forecast a king who would take a prominent, independent part in European politics and who would raise more serious constitutional questions than had been before England in a century. ${ }^{4}$ Yet that was the case. Victoria's influence was always exerted through her ministers, but Edward VII worked directly. He was known as "the great international statesman" and "the European peacemaker." There was no precedent for this practice before the foreign secretaryship of Lord Lansdowne. The King made several visits, unattended by any member of the Cabinet,

'Farrar, The Monarchy in Politics, p. 192.

'See Willoughby and Rogers, op. cit., p. 9.

${ }^{3}$ See Monypenny and Buckle, op. cit., Vol. VI, p. 454; Morley, Life of Gladstone, Book XII, Chapter 5.

"Strachey, op. cit., p. 387. "What, indeed," wrote Hallam, "might be affected by a king at once able, active, popular and ambitious, should such ever unfort unately appear in this country, it is not easy to predict; certainly his reign would be dangerous on one side or other to the present balance of the Constitution." Constitutional History of England, Vol. III, p. 297.

Influence of Edward VII
The play of chance 


\title{
144 NEW CONSTITUTIONS OF EUROPE
}

to the King of Italy, the Emperor of Germany, the President of the French Republic, and the Czar of Russia. ${ }^{1}$

Question of constitutionality $\mathrm{He}$ carried on a correspondence with the heads of foreign powers without the interference of the Secretary of State for Foreign Affairs. A generation before, this would have been unconstitutional; to-day it would be equally so. ${ }^{2}$ The facts concerning it did not come to light until recently; and the future historian will have to determine

\begin{abstract}
1An experienced and well-informed observer wrote in 1908: "All the diplomacy is done by Hardinge and the King, while Grey is their mouth-piece in the House of Commons, having a fine presence and an impressive manner with a wonderfully fine speaking voice." Wilfred Scawen Blunt, My Diaries, Vol. II, pp. 204-285 (New York, 1921). Upon the death of the King the same diarist wrote: Edward VII "knew Europe well, and exactly what foreigners thought of England. The knowledge was of use to him and to our Foreign Office, especially under such insular Secretaries of State as Arthur Balfour and Edward Grey. . . He stopped the Boer War, knowing how unpopular it was making England on the Continent and everywhere, and how much we were becoming despised for our childish attempts at subduing this sturdy little people.

The Anglo-Russian treaty he did off his own bat with Hardinge, Sir Edward Grey looking on. His only notable failure was in the affair of Bosnia, and people in England knew too little of the conditions to understand how great a failure it was. Also, he never succeeded in making friends with his nephew Wilhelm, and I fancy they hated each other to the end." Ibid., Vol. II, p. 308.
\end{abstract}

${ }^{2}$ The practice was correctly stated by Mr. Todd in 1887: "At every interview between the sovereign and the minister of any foreign court, it was the duty of the secretary of state for foreign affairs to be present. Private communication between a king of England and foreign ministers is contrary to the spirit and practice of the British constitution.

"Moreover, it is not usual for the king of England to receive from other sovereigns letters upon public questions which do not pass through the hands of his ministers; and sometimes such letters have been returned, because copies were not sent (with the sealed letter) for the information of the minister. It is still more unusual and improper for the king to answer a letter from another sovereign without the advice of his minister, who, whether he advises or does not, is responsible if he knows of the letter being written." Parliamentary Government in England, Vol. I, pp. 83-84 (ed. Walpole). Mr. Todd cites the case of a letter to Queen Victoria from the King of Prussia, who requested his ambassador to deliver it at a private audience. Prince Albert detected the irregularity and the letter was read in the presence of the Foreign Secretary.

'See the three letters of Sir Sidney Lee (the King's biographer) in the Iondon Times, July 21, 22, and 23, 1921. Lord Esher scouted the idea that the King had taken any independent action. "The popular idea, outside the British Isles, that King Edward moulded the Foreign policy of this country is of course pure illusion. . . He always recognized that to initiate the policy of Great Britain was the business of ministers for the time being, and his function was to criticize or approve it, and finally to support it with all his powers. . . . The Foreign policy of the Ministry of the day was in his eyes-as under a constitutional government it must be assumed to be-the policy of the nation, and therefore the settled policy of the Sovereign." Lord Esher, The Influence of King Edward and Other Essays, pp. 50-51 (London, 1915). 
whether Edward's work, for the moment successful in preserving peace, was, on the whole, for the best; or whether England should not have avoided such definite Doubtful results of his policy commitments toward Russia and France. Both Conservative and Liberal Cabinets, however, consented to tlie King's taking the initiative, the theory being that there was no encroachment on ministerial responsibility, since ministers were open to reject the King's suggestions. But, as a recent critic has pointed out:

The action of the Sovereign on his own initiative in foreign affairs, so long as a system of secret diplomacy prevails, must render it a matter of uncertainty whether the Cabinet, who can only follow the suggestions of the Sovereign by making them their own, are adopting a line of action consonant with their own views, or a policy against their own inclination, but pressed on them owing to a situation created by the independent action of an irresponsible Sovereign. Interviews of the Sovereign with foreign Ministers and the heads of foreign States, unaccompanied with a responsible Cabinet Minister, and letters written by the Sovereign to these personages on his own initiative, unread and unrevised by responsible Ministers-in fact independent action in foreign affairs by the Sovereign-must invariably, under a system of secret diplomacy, have the character of initiating and formulating a policy in such a way as directly or indirectly to influence Ministers of the Crown far more powerfully than was probably intended. Independent action on the part of the Sovereign, while it may or may not be an "encroachment" on Ministerial responsibility, must be a potent factor in the moulding of Ministerial policy - and as such is contrary to the theory and the practice of the Constitution, however beneficial its results in some cases may be.?

'J. G. Swift MacNeill, "Foreign Policy and Royal Influence," Fortnightly Review, December, 1921. Concerning the future, Mr. MacNeill says: "The Great War has made intelligent participation by the people in the foreign policy of the Government of this country absolutely unavoidable. In every step of foreign policy they must be henceforth fully informed and consulted and obeyed. Viscount Bryce wrote in 1886: "The day may come when in England the question of limiting the, at present, all but unlimited discretion of the Executive in foreign affairs will have to be dealt with.' That day has now come. Its coming has been manifested by the full and free communication to the people of these countries of the foreign policy of the Government, which is subject to their revision and control. A Cabinet which no longer can control a foreign policy itself cannot give the control of that policy to a Sovereign. The control of forcign policy asserted since the war by the people would alone prevail to render cont rol of that policy by a Sovereign an impossibility."

Uncertainty of responsibility 
Variableness in the role of the Crown

Bagehot's view

It seems certain that, with respect to foreign policy, George V has had much less concern than his father, ${ }^{1}$ although there will probably be disclosures that the Crown played a not inconsiderable part in the Balkan and Russian diplomacy of the war. This problem of royal influence is an excellent illustration of the peculiarly flexible character of the English constitution. In Lord Courtney's words: "The special and almost unique characteristic of the Constitution is that it is subject to constant and continuing growth and change. It is a living organism absorbing new facts and transforming itself. Its changes are sometimes considerable, even violent, and then for long periods the movement is almost imperceptible, although it is quickly realized when we compare the outcome presented at different points of time. The Constitution of to-day is different from what it was fifty years since and fifty years hence it will certainly be different from what it is to-day."'?

For more than a half century the control of diplomacy has been discussed in England. Bagehot expressed the opinion that "treaties are quite as important as most laws and to require the elaborate assent of representative assemblies to every word of the law and not to consult them even as to the essence of the treaty is prima facie ludicrous." If it was argued, he said, that the whole truth could not be told as to treaties, his answer would be that the whole truth could not be told as to laws; for all important laws affected vested interests which had to be treated just as delicately and with as much manipulation of language as the feelings of any foreign country. ${ }^{3}$

1"Nobody in England has now any fear of interference on the part of the Crown, for the conduct both of the last sovereign, Edward VII, and of the present sovereign is understood to have been irreproachably constitutional in every respect, and has never elicited popular criticism." Lord Bryce, "The Life of Disraeli, V, VI," American Historical Review, Vol. XXVI, p. 682 (July, 1921).

${ }^{2}$ The Working Constitution of the United Kingdom and Its Outgrouth, p. 9 (New York, 1901).

'The English Constitution, pp. 35-42 (2nd American ed.). 
The instruments of control over foreign affairs by Parliament have for the most part been indirect-the general responsibility of the cabinet, the control of the purse, the debate on the Foreign Office vote, and questions addressed to the Secretary of State for Foreign Affairs. None of these has been very effective. The Cabinet now dominates the Commons. To deny supplies is a dangerous weapon for the legislature to use. Sessions have passed without a debate on the Foreign Office vote. ${ }^{1}$ And if they have not sacrificed their veracity, ministers have at least been exceedingly skilful in answering questions. 'Thus, before the war the "obligations of honor" toward France were inquired about several times in the House of Commons, but the extent of England's commitments was not disclosed.2

A parliamentary committee on foreign affairs has been proposed a number of times. ${ }^{3}$ More than once Parliament has discussed the advisability of subjecting all treaties to legislative ratification; on one occasion a motion to this effect failed by only four votes. ${ }^{4}$ After the conclusion of the Peace Conference the Prime Minister did introduce "a bill for carrying into effect the Treaty of Peace between His Majesty and certain other Powers." Unquestionably this created a momentous precedent of genuine constitutional significance. Was this a recognition of the right of Parliament to control foreign policy; or was the practice resorted to more by grace of the executive than because of any positive demand on the part of the House of Commons? The proposed Anglo-American

Peace

Treaty submitted to Parliament

Commons not consulted apart from treaties

1Ponsonby, Democracy and Diplomacy, p. 50.

:See Parliamentary Questions, March 24, 1913; June 11, 1914; and Lord Loreburn, How the War Came, p. 10 .

${ }^{3}$ For references to the debates see Heatley, Diplomacy and the Study of International Relations, p. 265; and Willoughby and Rogers, op. cit., p. 250.

4March 19, 1886. In the debate Mr. Gladstone said: "The present system cannot possibly be defended as an ideal system," but he protested that executive and legislative functions should not be mixed up and that the House of Commons in its legislative capacity could not take upon itself executive duties. 
Instance

of the Mesopotamian Mandate

guarantee to France contained a specific clause that it should not become binding without parliamentary approval; but that was probably an evidence of the desire of Mr. Lloyd George to avoid responsibility rather than a recognition of Parliament's constitutional right. Since the Peace Conference, furthermore, it is notorious that England's foreign policy has been conducted, apart from the making of treaties, with slight consultation with the House of Commons.

One interesting illustration of this was furnished in February, 1921, when the government was asked for a copy of the Mesopotamian Mandate. Mr. Bonar Law, the then leader of the Government in the House of Commons, laid down the startling proposition, not only that the Mandate must be submitted to the League of Nations first, but also that thereafter there was no power in the Commons to revoke it even in the matter of financial responsibility. This meant that the English Parliament might, without its knowledge, be committed to foreign adventures of very serious consequences and entailing material expenditures; the House of Commons could do nothing except express a lack of confidence in the ministry after the fact. Immediately there was an outcry in the press and in Parliament. On February 23 the Government reconsidered its extreme position. Mr. Bonar Law said: "We shall circulate the terms of the mandates, which have already been submitted to the League of $\mathrm{Na}$ tions, to the House. I may add, however, that in our view this is very similar to the negotiation of a treaty which must be carried out by the Government of the day. But of course, as in the case of a treaty, Parliament would have the right to refuse to adopt it."1 With that state-

'See letters to the London Times, February 23, February 24, March 22, 1921, and the debate in the House of Lords, March 14, 1921. A letter of Sir Eric Drummond, Secretary General of the League of Nations, announced that it was no concern of the League "whether or not the terms of the mandate were discussed by the legislature of the mandatory power before submission to the Council." The London Times (weekly ed.), April 15, 1921. 
ment of existing constitutional practice Parliament was apparently content. ${ }^{1}$

In Italy Signor Giolitti proposed to amend the constitution so as to require treaties to be approved by Parliament. His bill provided that "treaties and international understandings, whatever their subject and their character, are only valid after they have been approved by Parliament. The government of the King can only declare war with the approval of the two chambers." In urging his bill Signor Giolitti said that "foreign policy should be subject to the widest and freest possible discussions in Parliament and the people ought to feel assured that it be directed above all things to the ends of peace and constructive work"; but Signor Giolitti went out of office before his bill could be passed at the session of $1921 .^{2}$

Parliamentary control in Norway is more a matter of custom than of constitutional provision. No Norwegian Government can now venture to make any treaty or other agreement with foreign powers, whether dealing with military, commercial, or other relations, without first submitting such treaties or agreements to Parliament for its sanction. The usual procedure is for a special parliamentary committee to be set up for the purpose of examining the so-called secret protocols of the Government. These protocols disclóse the decisions made by the Cabinet concerning military matters and secret diplomatic affairs. The committee reports to Parliament how the subjects dealt with have been handled by the Government and approves or

${ }^{1 "}$ "The contention of Lord Loreburn, that "we are not a self-governing nation in foreign affairs' is truer to-day than it ever was. There is no real parliamentary control; 'the idea of a Foreign Affairs Committee in the House, such as most foreign Chambers possess, has been allowed to drop, and any real reform of the diplomatic service is as far off as ever. Facts such as these explain the function of the "Council of Action"; the underlying notion was sound, though the procedure was a defiance of sound constitutional practice. Foreign politics are pre-eminently a field in which neglect exacts bitter punishment, and we could have wished that it was still possible to play the mosquito to a deadened public opinion." "A Farewell Survey," The New Europe, October 28, 1920.

'E. D. Morel, "Giolitti's Bill to Abolish Secret Diplomacy," Foreign Affairs, January, 1921. Norwegian
practice Norwegian
practice

Giolitti's proposal in Italy 
Swedish practice

French Commission on Foreign Affairs

Control of foreign affairs in the new governments

criticizes the Government's acts. It may thus be said that "Parliament is in due course made acquainted with all the decisions of the Government in regard to foreign affairs, and it is of course true that the mere existence of this post control has a certain preventive effect because the Government must always be prepared to answer for all its acts of Parliament."'1

A similar commission is provided in Sweden to confer with the King as frequently as he summons it; but it is not a parliamentary committee in the ordinary sense since it operates only in consultation with the Government and does not report to the chamber. In practice, members of the committee, when not bound by a pledge of secrecy, are free to communicate with their friends in the parliamentary parties; but this, as is obvious, is a rather meagre concession to complete parliamentary supervision. ${ }^{2}$

The model for these legislative committees is the French Commission on Foreign Affairs. This commission may summon before it any persons whose vote may be of a nature to guide it in its deliberations and may request a minister himself to appear and explain his policies. While secret treaties in France are not unknown, it is probably correct to say that this commission exercises a more constant and effective supervision over the executive than is exercised by the parliamentary body in any other country. ${ }^{3}$

The new constitutions follow the model of France. Certain classes of treaties are enumerated that require legislative ratification; inferentially other treaties may be concluded by the executive. War and peace may be declared only by the legislature. In most of these constitu-

\footnotetext{
'Oscar Pedersen, "Foreign Policy Control in Norway," Foreign Affairs, December, 1921.

'Axel Brusewitz, "Parliamentary Control of Foreign Affairs in Sweden," Foreign Affairs, January, 1922.

${ }^{3}$ See Barthélemy, Democrat et politique Etrangère, pp. $130 \mathrm{ff}$. and $322 \mathrm{ff}$. (Paris, 1917.)
} 
tions no provision is made for a commission of foreign affairs similar to the French, although presumably such commissions may be established under the standing orders of the parliaments without express constitutional authorization. It is probable, also, that the legislative committees which operate during parliamentary ${ }^{1}$ recesses will have some competence with regard to foreign affairs. In Germany, however, a commission is created on the French plan which may sit whether the Reichstag is in session or not. There will thus be two legislative agencies empowered to supervise the executive when the full parliament is not meeting. In the Weimar constituent assembly, serious objections were raised to this proposal of a commission on foreign affairs. It was urged that the commission would evidence distrust of the government, and that, acting as an organ of surveillance, it would embarrass the conduct of foreign relations. The principal answer to these arguments was that there had been no unfavorable results in countries which used the commission system. ${ }^{2}$

It is interesting to note that even though the new constitutions contain liberal provisions for the initiative and referendum they make no attempt to bring foreign affairs within the scope of direct government. Indeed, the Esthonian constitution-perhaps the most extreme in this respect-specifically excludes foreign affairs from the operation of the referendum. Until a recent Swiss constitutional amendment the referendum on treaties had never been incorporated in any constitution except the French constitution of $1793 .^{3}$ In April, 1913, the proposal

\footnotetext{
'See above, p. 34.

'Brunet, The New German Constitution, p. 151. M. Brunet suggests that the principal function of the commission may be to serve as an organ which will "bring the influence of politically experienced personalities of the Reichstag to bear on the professional agencies of the diplomatic service."

${ }^{3}$ Art. 50 required declarations of war, treaties of peace, alliance, and commerce to be proposed, discussed, and promulgated like laws, and for laws this constitution provided an optional referendum. Fsmein, Éléments du droit constitutionnel, pp. 356-699 (Paris, 1909, 5th ed.).
}

Legislative Committees

Swiss referendum on treaties 
Swiss referendum on joining the League of Nations

was made by the initiative to add to Article 89 of the Swiss constitution the following clause: "International treaties concluded for an indeterminate period or for more than fifteen years are likewise submitted to the people for adoption or rejection if the demand is made by thirty thousand active citizens or by eight cantons." The chambers had recently accepted an unpopular treaty and its opponents suggested this expedient of a referendum to control foreign policy in the future.

The vote on the proposal, postponed on account of the war, was not held until January, 1921. The measure carried by a large majority $(388,365$ to 158,688$)$, every canton being in favor of it except Uri and Thurgau. ${ }^{1}$ There was a referendum in Switzerland on the proposition of joining the League of Nations, May 16, 1920. Seventysix per cent of the electorate voted, a very high percentage, 415,819 being in favor and 323,225 being against. Eleven and one-half cantons voted for, and ten and one-half against, the proposal. A change of ninety-four popular votes in Appenzell Exterior would have tied the canton vote and resulted in defeat of the proposal. ${ }^{2}$ This constitutional amendment came after a long agitation for direct control in foreign affairs and after much discussion of the present complicated situation with regard to treaty ratification in Switzerland. ${ }^{3}$ The amendment as adopted would seem to have all the vices and none of the merits of a plebiscite in foreign affairs. That is to say, it is sub-

\footnotetext{
'Brooks, "Swiss Treaty Initiative," American Political Science Review, August, 1921.

"Brooks, "Swiss Referendum on the League of Nations," American Political Science Review, August, 1920.

'The problem is ably discussed by M. Edouard Georg, Le contrôle du peuple sur la politique extérieure (Geneva, 1916). He gives a detailed and careful analysis of the cantonal referenda in the rare cases in which treaties are concluded between the cantons and foreign nations and in cases of inter-cantonal concordats. There is also an interesting discussion of the Landsgemeinden and a full analysis of questions arising when treaties involve changes in laws and the plea of urgency is made as to decrees putting treaties into effect and thus avoiding a referendum.
} 
ject to all the objections that questions of diplomacy are too difficult, that they require too immediate action, and that their bilateral character would cause too many difficulties with other states to allow them to be subject to popular vote. On the other hand, a good many of the controversies in Switzerland had concerned commercial treaties modifying customs regulations; by this amendProbable results in ment commercial treaties would not be directly involved since their life is brief. The result of the constitutional change will probably be to persuade the Government to put a time limit of less than fifteen years on all its international agreements-a result which, generally speaking, will no doubt be beneficial. ${ }^{1}$

'John Stuart Mill, "Treaty Obligations," Fortnightly Review, Vol. VIII, p. 715 (N.S., 1870).

M. Georg advocates a commission of foreign affairs for Switzerland. He cites a proposal to have such a commission extra-parliamentary, Switzerland already having twenty such bodies, some with administrative and some with only consultative authority. The suggestion was that the commission be composed of professors of international law, retired diplomats and economists, and composed thus "of men whose career has put them in touch with the international interests of the country; it could give valuable advice to the Federal Council and the political department." Such a commission, however, would have incomplete powers, for it could only advise, and the author, therefore, inclines to a parliamentary body. Like most foreign observers he assigns a too important role in the formulation of policy to the American Senate Committee on Foreign Affairs. A parliamentary committee in Switzerland would have two important advantages: "it would permit deputies who were particularly competent in the matter of foreign politics to express their opinions with full knowledge, and it would establish a very effective liaison between the chambers and the executive authority." (P. 234.) M. Georg, however, advocates the commission as an alternative to the referendum, if it is thought necessary to add to the numerous existing guarantees another restriction on the competence of the Federal Council in foreign policy. Le contrôle du peuple sur la politique extérieure. 


\section{CHAPTER VIII \\ INDIVIDUALISM AND SOCIALISM}

The

American concept of a constitution

A constitution is a body of rules or maxims defining the scope of public authority and determining the manner of its exercise; but except in this elementary respect, the American and European conceptions of constitutional law are not in agreement. ${ }^{1}$ In the United States, the federal and state constitutions are written documents. It is not easy to change them. Amendments require greater formality, more mature deliberation, and greater unanimity than is the case with ordinary laws. They may not be enacted by Congress or the state legislatures alone. American constitutions, moreover, are intended to protect the citizen against unconstitutional action by the executive or legislature. These branches of the government have only a limited competence and in the exercise of such powers as they have, they may not encroach on the sphere of individual liberty that the constitution guarantees to private persons. These limitations and rights are enforced by the courts. The American judiciary is the arbiter between the powers of the executive and legislature on the one hand and the rights and immunities of private persons on the other. Judicial supremacy is the keystone of the American political system.

\footnotetext{
1"There is between constitutional and ordinary laws a difference in degree. Constitutional laws, by reason of their importance, are superior to ordinary laws. They have for their end the organization of the state, the regulation of the political form of the government; all the organs of the state are created by them and they cannot be violated, any more by the organ to which is entrusted the exercise of the legislative function than by the other organs. Laws cannot transgress constitutional dispositions; they are absolutely dependent on the fundamental and superior law of the constitution." Jean Gajac, De la distinction des lois constitutionelles et des lois ordinaires, p. 3 (Bordeaux, 1903). But this injunction against transgression is moral not legal.
} 
These distinctively American elements of a constitution are incorporated only to a very limited extent in the charters that have been adopted by the new states of Europe. This is the case in spite of the fact that the "founding fathers" in Europe had the American constitution before them. They apparently preferred the European model. The new constitutions define the scope of public authority and determine the manner of its exercise; but they may be changed by the legislature alone, and there is for the most part no application of the doctrine of judicial supremacy - the courts may not refuse to give effect to laws on the ground that they are contrary to the constitution.

All of the new constitutions are, of course, definite written documents. ${ }^{1}$ Some lacunce are apparent and some obscurities will doubtless cause difficulty, but the attempt has been made to meet all probable contingencies. Documentary constitutions were inevitable. In Europe the Hungarian common-law constitution (so similar to that of England) stood alone; of the succession states of the Austro-Hungarian Monarchy only Hungary could make use of it in order to graft governmental usages upon an accustomed system. The other new states had to create their political institutions.

'Though the republicans (England, 1647) "rejected the common law, and regarded Magna Charta as 'a beggarly thing'-Cromwell himself only insisting on 'Somewhat like a Magna Charta'- the pretensions of a virtually non-representative legislature had brought home to them the necessity of a check for it. The royalists could regard the old fundamental law as such a check. That alternative was not open to the republicans. It was a double-edged weapon. The principles of the common law were as destructive of their own theories as they were of parliamentary sovereignty. A check on that sovereignty must be found, however, and the idea of a fundamental law supplied it. If an ancient fundamental law - if Magna Charta - could curb the King or the Parliament, why could not a new document be drawn embodying their own principles and free from the encumbrance of the old law, which should be binding upon and unalterable by the legislative power? Such a notion received the assent of the more extreme republicans because it restricted Parliament; it was favored by the more conservative, as Cromwell, because it offered a protection against the too sudden and sweeping changes which the radicals were clamoring for. And so we have the trial of a new thing in English history - the written constitution." C. H. McIlwain, The High Court of Parliament and Its Supremacy, pp. 91-92 (New Haven, 1910).

Not adopted by the new states

Written constitutions were inevitable 
Advantage of written constitutions

Conditions necessary for flexible constitutions

For peoples unused to self-government a documentary constitution has the advantage of being more workable than a system that makes custom and political morality more important than rule. Moreover, a documentary constitution "appears to the people as the immediate outcome of their power, the visible image of their sovereignty. It is commended by a simplicity which contrasts favorably with the obscure technicalities of an old common law constitution." The taste of the multitude is for "ideas level with their comprehension, sentiments which need no subtlety to be appreciated, propositions which can be expressed in unmistakable positives and negatives." These considerations have not been without importance in the new states of Europe.

Flexible constitutions, Lord Bryce pointed out, have an affinity for an aristocratic form of government; "there is a sort of natural attraction between an aristocracy and an undefined and elastic form of government." It needs knowledge and skill to work a flexible constitution successfully; one of three conditions is necessary:

Either (1) the supremacy must remain in the hands of a politically educated and politically upright minority, or (2) the bulk of the people must be continuously and not fitfully interested in and familiar with politics, or (3) the bulk of the people, though legally supreme, must remain content, while prescribing certain general principles, to let the trained minority manage the details of the business of governing. Of these conditions the first has disappeared from nearly all civilized countries. The second has always been rare, and in large industrial countries is at present unattainable. The best chance of success is therefore to be found in the presence of the third; but it needs to be accom-

\footnotetext{
'Bryce, "Flexible and Rigid Constitutions," Studies in History and Jurisprudence, p. 200 (New York, 1901). Lord Bryce said that "rigid" constitutions are those which could not be changed by the ordinary legislative authority, while "flexible" constitutions are those which are always undergoing some change, however slight, in the course of ordinary legislation. The essay is highly suggestive but the distinction is not clearly marked. France's constitution, for example, is certainly flexible if compared with the American, even though it may not be amended by the ordinary legislative processes, and legislation (like the electoral law of 1919) may be passed which, though not part of the constitution, is really a fundamental change in the governmental machinery.
} 
panied by a tone and taste and sense of public honor among the people which will recoil from the mere demagogue. ${ }^{1}$

None of these conditions is to be found in the new states of Europe; and while their constitutions are not flexible in the sense of Lord Bryce's classification, they are not sufficiently above the plane of ordinary legislation to avoid the dangers that a flexible constitution invites. ${ }^{2}$ They are sufficiently elastic to enable revolutions to be met half way, although the danger is that this elasticity, by the very facility for change that it permits, may lead perhaps to a hasty misuse of power.

Furthermore, it is only in the course of time, if at all, that these new documents will come to possess an element of sacrosanctness. "A constitution which has come down in the form of a mass of laws, precedents, and customs is not only more mysterious, and therefore more august, to the minds of the ordinary citizens than one they can read in a document, but is not felt by them to lie at their mercy and to live only by their pleasure. A constitution embodied in a document which they have seen drafted, and have enacted by their votes, has no element of antiquity or mystery. It issues from the sovereignty of the people, it reminds them of their sovereignty, it suggests to them nothing more exalted. Perhaps it has been the work of one party in the state; and if that party becomes discredited, it may share the discredit. . . . The fact that an old constitution represents a long course of progressive development, or, to use a somewhat vulgarized term, of

${ }^{1}$ Bryce $o p$. cit., pp. 160-161.

2The Czechoslovak constitution may be amended by the legislative body against the wishes of the upper chamber, a referendum (permissible in the case of ordinary laws) being specifically forbidden. Nevertheless, one writer says:

"The National Assembly, having the choice between a rigid and a flexible system of constitution, adopted the first because of the very bad experience under the Hapsburg rule, when the constitution was often and arbitrarily changed, and so had no opportunity to become established in the respect of the people." Dedek, "The Constitution of Czechoslovakia," Journal of Comparative Legislation and International Law, Third Series, Vol. III, p. 115 (January. 1921).

Not found

in the

new states

Advantages of "customary" constitutions 


\section{8} NEW CONSTITUTIONS OF EUROPE

Bills of rights

Lack of judicial supremacy

evolution, gives it some claim on the respect of imaginative or philosophical minds. These sources of moral strength have been found sufficient in many countries to secure an enduring life for political institutions which the people, or a legislative body, had it in their power to change, and which, in some instances, ought to have been replaced by other institutions more suited to their altered environment.",

All of the new constitutions have elaborate bills of rights. This is perhaps the principal feature drawn from the American constitutional system. But an inspection of the clauses will show that guarantees given by one hand are often taken away by the other. Freedom of the press shall be assured-unless limited by law; private property shall not be taken for public use without the payment of compensation-unless otherwise determined by law. The guarantees are hortatory rather than mandatory; they safeguard the citizen against arbitrary executive action, but for the most part the legislative power is apparently not limited by the bills of rights. Moreover, even if it were limited, the legislature itself would be judge of the scope of the limitations. For the American doctrine of judicial supremacy found little favor. An attenuated bicameral theory, with the upper chambers being given only suspensory vetoes, is not particularly hospitable to the creation of what is in some respects a third legislative chamber-a court with power to declare statutes unconstitutional. The popular representative body is not overborne by a revisory chamber or by the judiciary. Executive orders do have to run the judicial gauntlet and "the rule of law" is thus partly assured; but in the case of legislative acts the courts are limited to declaring whether they have been properly passed and promulgated. Some of the clauses of the constitutions dealing with this matter are vague, but it would seem that only the Czecho-

\footnotetext{
${ }^{1}$ Bryce, op. cit., p. 143.
} 
slovak $^{1}$ and Austrian constitutions provide for any considerable measure of judicial review. ${ }^{2}$

The new constitutions show at a glance that they permit -indeed invite - more extensive measures of socialization than have been hitherto resorted to by any constitutional government-agrarian reform, land nationalization, state-managed coal mines, bread subsidies, unemployment doles. Even though they have decided against the communist philosophy and organization of Russia, the new states provide, almost as a matter of course, for action which in the United States would be denounced as "Bolshevistic." To describe the various experiments in legislation and administration would take us too far afield, but one general consideration deserves mention.

The political philosophy of nationalization has many severe and acute critics. Little attention has been paid, however, to the fact that the experiences of the war and the provisions of the treaty settlements have greatly encouraged socialistic enterprises. The individualist may argue that nationalization is the worst possible system from the point of view of efficiency; he may say, with much truth, that the methods that were used to win the war

\footnotetext{
${ }^{1}$ A commentator on the Czechoslovak constitution has pointed out "that the charter of the Constitution is placed in its entirety under the special and effective protection of a Constitutional Court. It is intended that the Charter of the Constitution be the foundation stone of the whole life of the State, the fountain of the rights of all citizens. An ordinary law may not conflict with the Constitution without becoming null and void. The judgment of the Constitutional Court declaring a law invalid causes it or its defective part to lose its binding force for the future. This institution likewise serves as a protection of the rights of minorities whether racial or religious." Hoetzl, The Constitution of the Czechoslovak Republic, p. 15 (Prague, 1920). Article 102 of the constitution, however, declares that "in the case of a law they [the judges] can only enquire as to whether it was properly promulgated." Article 1 declares that "enactments which are in conflict with the Constitutional Charter or with laws which may supplement or amend it are invalid." The Act of March 9, 1920, establishing the Constitutional Court declares that "laws promulgated either by the National Assembly or by the Diet of Russinia, which are in conflict with the Charter of the Constitution or with laws amending or supplementing it, are invalid."
}

${ }^{2}$ See the complicated provisions of Arts. 89, 138, 139, 140,144, of the Austrian constitution as to judicial review. See also Art. 13 of the German constitution.

New constitutions invite socialization

Effects of the war, on nationalization 
Effect of the war on private property

In England

would never be tolerated in times of peace. The fact remains, nevertheless, that when the need of the state was greatest it resorted to these much-decried methods of control; England, France, and the United States became socialist countries by popular consent. They will never be able to restore the individualistic economy that prevailed before the war; and no doubt the tendency will be to resort to similar emergency expedients when the menace is not a foreign enemy but a wasteful economic system. From a moral standpoint, moreover, the war presented the institution of private property in a new light. Conscription had more than military importance. It may be argued that if the life of the citizen belongs to the state in its time of need, then surely his property does also. As an English writer has said: "The communist state which says to the citizen, "You must work and surrender your private property or you will have no vote,' asks, after all, somewhat less that the bourgeois military state which says to the conscript, 'Fight and give your person to the state or we will kill you.' For great masses of the British working classes conscription answered the ethical problem involved in the confiscation of capital. The Eighth Commandment no longer stands in the way."1

In the new states
If this be true of England, the Eighth Commandment stands even less in the way of the peoples of the succession states; for their need is greater, their sacrifices have been more material, and the prospects of a good life on the basis of the pre-war individualist economy are almost entirely illusory. They are too sanguine that economic miracles like those performed during the war are possible in times of peace; but their philosophy was derived, in part at least, from the examples of states which now incline toward the other extreme in the relation of politics to economics and in which the continuance of the war-time methods of control is bitterly denounced.

${ }^{1}$ Norman Angell, The Fruits of Victory, p. 73 (London, 1921). 
If, furthermore, it has scemed justifiable and proper for states to pay their internal war debts in irredeemable paper or by the making of huge drafts upon large private incomes, why, it is asked, may not a state find money in the same way for its social experiments? Protection of a citizenry against poverty may be as high a purpose as protection against a foreign enemy. Before the war the future legal status of private property was a matter for interesting theoretical speculation; it is now a subject of practical politics; it is perhaps the chief problem of European statecraft. 'This fact, which can be considered as almost entirely independent of the challenge of the Russian Revolution, is nowhere revealed more fully than in the fundamental laws of the political children of the Peace treaties.

Another fact to which inadequate attention has been paid is that the Peace treaties themselves prevent a return to the pre-war economy and cause a continuance of state control. They make a large measure of national tutelage compulsory in the enemy states; and if the terms of the treaties are carried out, this will be true for a generation. The treaties provide for the wholesale confiscation of the private property of enemy nationals in allied countries and in territories taken from Germany, ${ }^{1}$ and in case of default by Germany on her reparation payments, balances due Germany on private accounts need not be paid over. The barrier that this provision would raise to trade was so obvious that the British Government sought to

\footnotetext{
${ }^{1}$ As conservative an organ as the Quarterly Review deals with this clause in severe fashion: "We are justified in regarding this policy with the utmost apprehension, not only because of its injustice, but also because it is likely to form precedents of a most mischievous character in the future. If, it will be said, the Allied Governments ended their great war for justice and right by contiscating private property and ruining those unfortunate individuals who happened to have investments outside their own country, how can private wealth at home complain if a Labor Government proposes to confiscate private property in any business which it thinks suitable for 'nationalization'? Under another provision the Reparation Commission is actually allowed to demand the surrender of German properties and German enterprises in neutral countries. This will be found in Article 235, which introduces a quite novel principle in the collection of indemnities." "Economics of the Peace," Quarterly Revieu, April, 1920.
}

Future of private property

Peace treaties encourage national control of industry 


\section{I\% NET CONSTITTIONS OF EUROPE}

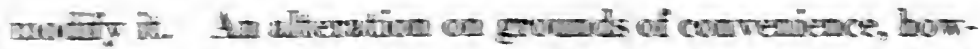

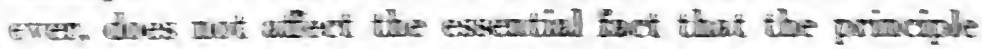

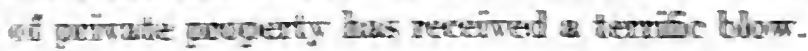

c Gerangr

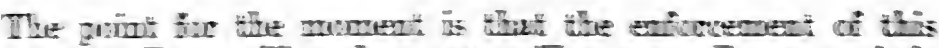

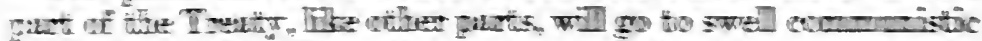

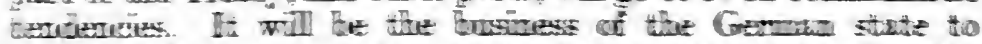

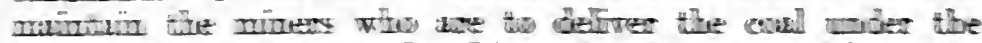

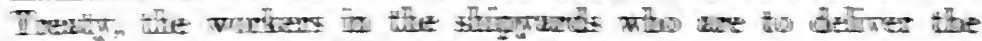
Trth

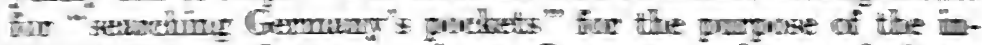

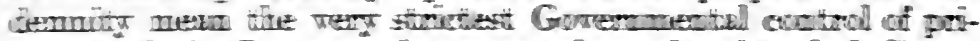

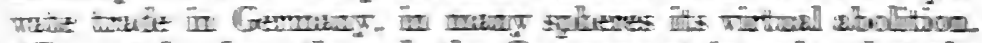

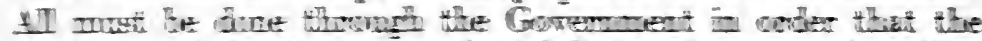

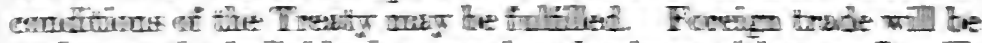

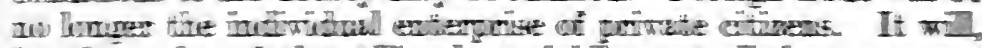

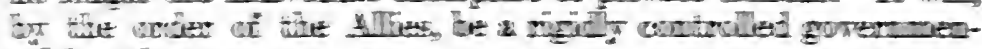

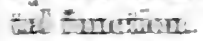

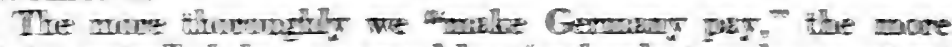

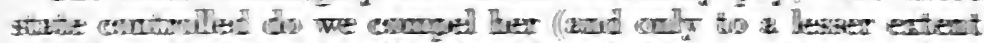

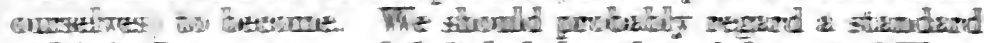

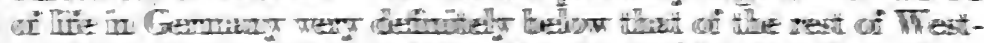

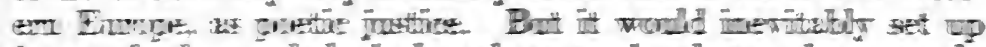

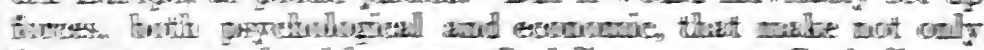

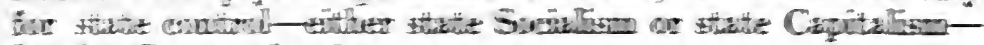

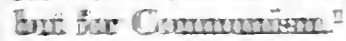

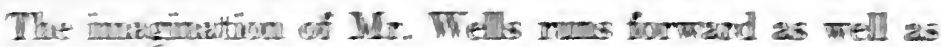

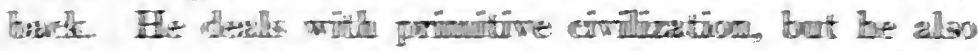

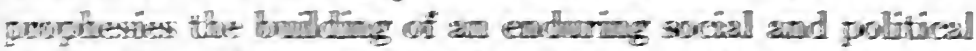

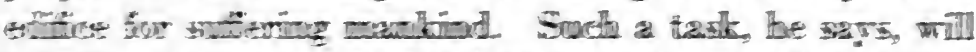

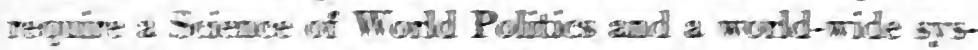

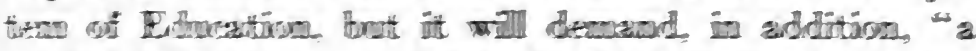

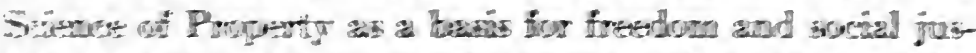

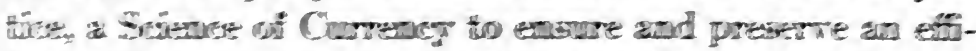

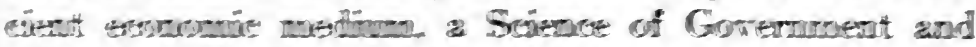

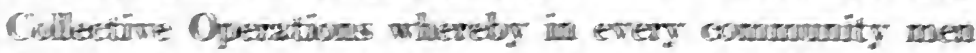

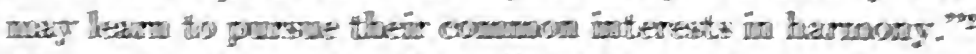

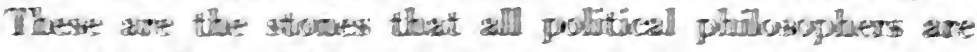

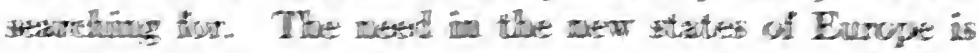

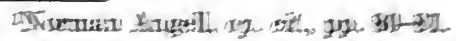

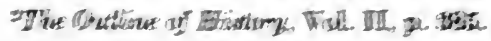




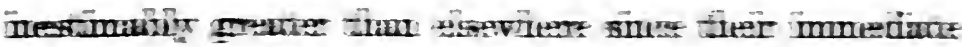

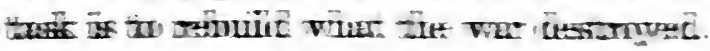

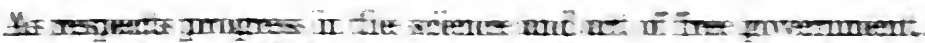

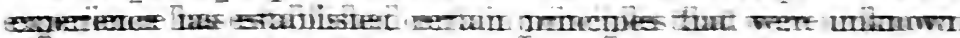

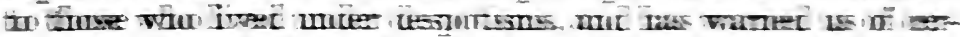

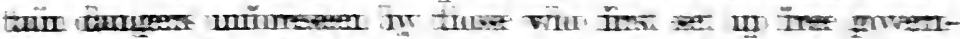

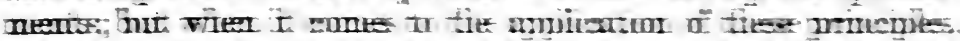

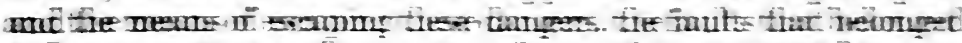

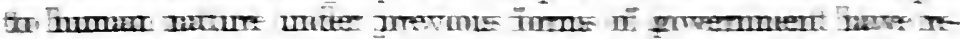

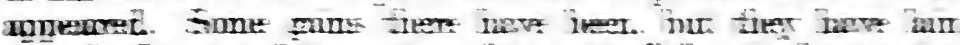

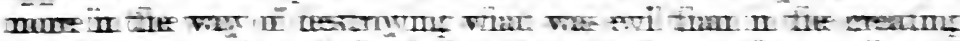

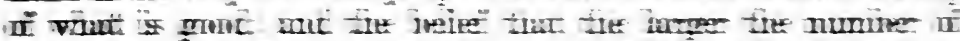

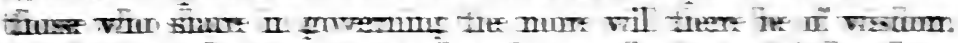

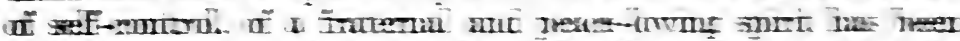

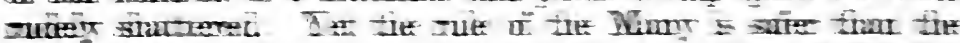

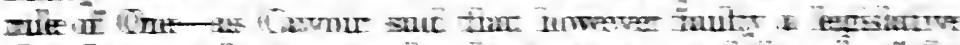

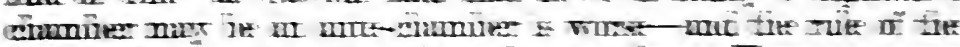

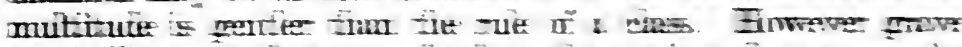

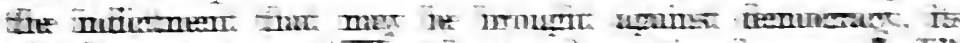

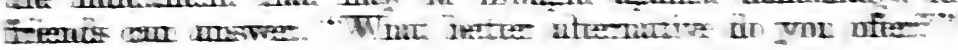

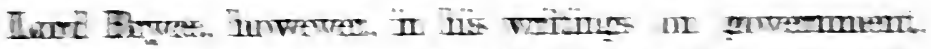

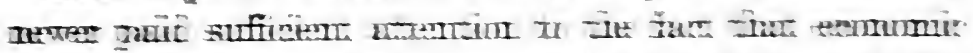

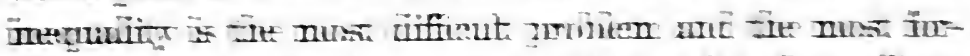

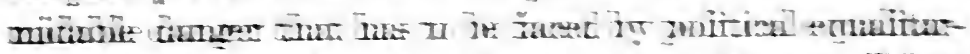

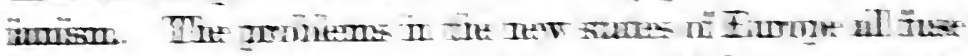

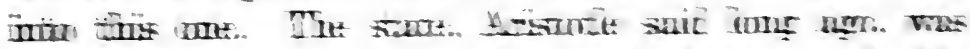

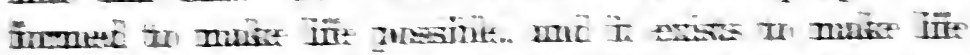

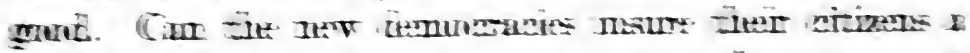

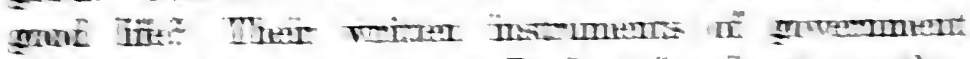

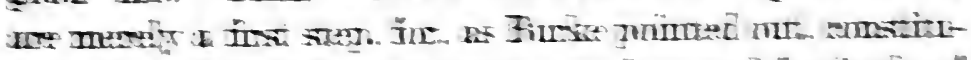

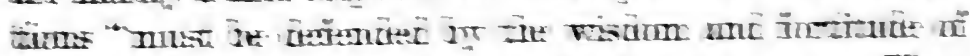

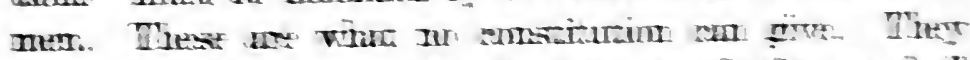

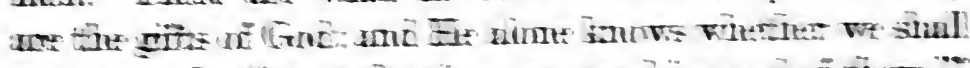

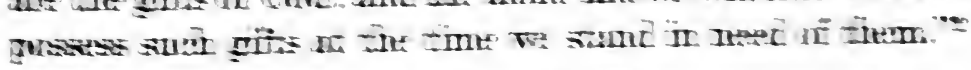

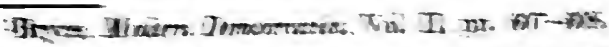

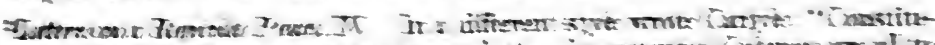

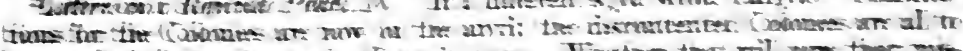

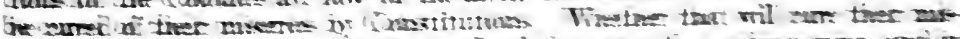

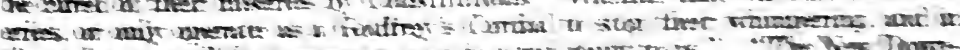

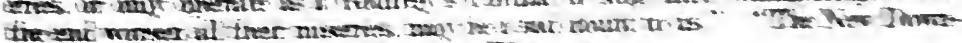

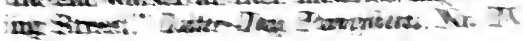

ion inge co verer एक्य

Timiantion ar wher एक्षयाम$\operatorname{trosex} 200$ $\rightarrow$ anist 


\section{NEW CONSTITUTIONS OF EUROPE}

The new states of Europe are putting their trust in parliamentary government, geographical representation. and decision by majorities. One may wonder how nearly Gladstone was right when, with fine disregard of the examples of his own political career and the tenets of his philosophy, he said: "It is not by the state that man can be regenerated and the terrible woes of this darkened world effectually dealt with." 


\section{PART II}

THE NEW CONS'TITU'TIONS OF EUROPE 



\section{CHAPTER IX}

\section{GERMANY}

\section{HISTORICAL NOTE}

From 1815 to 1866 the numerous German states, including Austria, were held together in an extremely loose confederation - a creation of the Congress of Vienna. In the latter year an open rupture between Prussia and Austria, the two leading states of the Union, led to a dissolution of the confederation. Civil war eventuated in a quick victory for the Prussian arms. The so-called August Treaty that followed bound Prussia and the North German States in an offensive and defensive alliance and provided for the establishment within one year of a federal union along lines proposed by. Bismarck. By October, 1866, twenty-two states had signed this treaty, including a few small states that had fought on the side of Austria.

In December, 1866, diplomatic representatives appointed by the kings and princes of the several states met in Berlin; and early in February, 1867, this assembly agreed upon a proposed constitution for the Union. Later in the same month an assembly of delegates, elected by manhood suffrage and secret ballot, ratified, after making some amendments, the constitution thus prepared for their consideration. $^{1}$ Thereafter the constitution was sub-

${ }^{1}$ Concerning the principle of manhood suffrage by which delegates to this ratifying convention were elected, Bismarck, the originator of the scheme, had this to say in later years:

"Looking to the necessity, in a fight against an overwhelming foreign power, of being able, in extreme need, to use even revolutionary means, I had had no hesitation whatever in throwing into the frying pan, by means of the circular dispatch of June 10, 1866 [which dispatch contained the first draft of the proposed constitution], the most powerful ingredient known at that time to libertyIts constitution

of 1867

Formation of the North German Confederation 
mitted to the governments of the several states and ratified by them in accordance with the procedure required for amending the constitutions of their respective states. Concerning the rôle that was actually performed by this "democratic" convention the most distinguished commentator on the constitutional law of Germany has said:

Rôle of the "popular" convention

The Parliament (or popular convention) was not one of the "parties" to the constitution, but only a means of coming to some sort of agreement over the constitution. It had no legal powers, but simply a political duty. It was meant to balance the divergent views and particularistic tendencies of the several Governments, and its consent should serve as a guarantee that the constitution, as agreed upon, should correspond to the political views and desires of the people, to public opinion. The "agreement" between the Governments and the Parliament was a harmonizing of the views as to what sort of a constitution should be given to the Bund, and the result of that "agreement" was not to impart validity to a constitution, but to produce the draft of a constitution. ${ }^{1}$

There was, indeed, never the slightest pretense in German political philosophy that the North German constitution of 1867, which to all intents and purposes became the constitution of the Empire, actually emanated from the people who were to be governed under it. Despite the fact that in turbulent times it was given intermediary ratification by a "popular" assembly, it was drafted by the autocracy of Prussia and was given its ultimate sanction by the autocracies of the several uniting states. In the history of American institutions no assemblage stands out so conspicuously as the convention that drafted the American constitution of 1787; in the history of German institutions no assembly has been given slighter considera-

mongers, namely universal suffrage, so as to frighten off foreign monarchies from trying to stick a finger in our national omelette. I never doubted that the German people would be strong and clever enough to free themselves from the existing suffrage as soon as they realized that it was a harmful institution. If it cannot, then my saying that Germany can ride when once it has got into the saddle was erroneous." Bismarck, The Man and Statesman [Autobiography] Vol. II, p. 65 (New York, 1899).

ILaband, Das Staatsrecht des Deutschen Reiches, Vol. I, p. 23 (Hamburg, 1883). 
tion than that which in March-April, 1867, interposed for a brief moment between the autocracy that drafted and the autocracies that gave validity to the fundamental law of the inchoate Empire.

The constitution of the North German Confederation became effective on July 1, 1867. It made prophetic provision for the ultimate inclusion of the South German States in the Union. The swollen prestige of Prussia in consequence of her victory over France in 1870 brought these states to terms. In November of that year Bavaria, Württemberg, Baden, and Hesse entered into treaties with the Confederation which resulted in their incorporation into the Union and in the substitution of Empire for Confederation (Bund). Strictly speaking, the German Fmpire came into being on January 1, 1871; but the constitution of the Empire was a codification of the constitution of the North German Confederation of 1867 and of the treaties of November, 1870, between the Confederation and the several South German States. On April 16, 1871, this codified constitution was published as an "imperial law." Under this instrument, amended from time to time in certain unimportant respeets, Germany was governed until the end of the World War in 1918.

In 1914 it was "military, not political, opinion in Germany" which "decided that war was, if not desirable, at least inevitable." It was the military strategist who usurped the function of the diplomatist-politician. And during the course of the war nothing was more evident in Germany than the steadily increasing ascendancy of the military authorities over the political in every field of governmental activity. Quite apart, therefore, from the pressure of external propaganda against the autocratic form of the imperial government, the military collapse of Germany was in a very real sense also a political and institutional collapse.

${ }^{1}$ Munroe Smith, Militarism and Statecraft, p. 115 (New York, 1918). 
Revolution

of

November, 1918

Workers and

Soldiers

Councils

The Empire came to an end with a bloodless revolution. ${ }^{1}$ The body politic appeared to be more stunned than torn. On November 9, 1918, the Kaiser's abdication was announced; and Scheidemann, acting for the Social Democratic party, proclaimed Germany a Republic. Prince Max von Baden resigned as Chancellor and himself named the Social Democrat, Friedrich Ebert, to succeed him. The Social Democrats and the Independent Socialists (the latter a radical offshoot of the Social Democrats, dating from 1916) agreed through their leaders to appoint a provisional "Cabinet" composed of three members of each party. $^{2}$ It was this government, wholly irregular in origin, that signed the Armistice on November 11, 1918. The monarchists were as quiescent as were the proletarians. Even with a huge army returning home under shattered discipline there was practically no violence. Nor was there any break in public services; the vast army of civil servants continued to function at the orders of the new government.

But in spite of the comparative "regularity" of this irregular provisional government, potential political power in Germany had none the less passed into other hands. Almost over night Workers and Soldiers Councils had sprung into being all over the country. ${ }^{3}$ The coalition Socialist Government had been formed only with the consent of the "Executive Council" of the Berlin District. Moreover, the Independent Socialists had entered into this coalition upon the express condition that the Government would recognize the authority of the Workers and

\footnotetext{
1For a more detailed account of the events of the revolution, see Temperley, Ed., A History of the Peace Conference of Paris, Vol. I, Ch. II; Vol. II, Ch. VII (London, 1920).

${ }^{2}$ Ebert, Scheidemann, and Lansberg were the Social Democrats and Haase, Dittman, and Barth were the Independent Socialists.

${ }^{3}$ The way had been prepared by the National Patriotic Service Law, introduced in December, 1916, which as a concession to labor provided for the establishment of Committees of Workers in all sizeable factories. See Temperley, Ed., op. cit., Vol. II, p. 455.
} 
Soldiers Councils. Representatives of these Councils supervised all departmental activities of the Government and countersigned official documents.

Faithful to the Erfurt Programme of 1892, the Social Democrats declared themselves in favor of summoning a constituent assembly vested with constitution-making power. The Independents were for a time hesitant about this proposal. They appeared to be in favor of a soviet system; but at the same time they appeared to be not wholly opposed to a parliamentary system. The Communists, led by Karl Liebknecht and Rosa Luxemburg, were in unqualified opposition. Strangely enough, moreover, they found in this opposition a measure of support from the extreme Monarchists. Many of these appeared to reject the prospect of a parliamentary democracy that would sign a treaty imposed by the victors, and to welcome, as more promising, a Bolshevistic régime, with its probably infectious consequences in the countries of the Allies and its incapacity to comply with many probable terms of the treaty.

On November 19 the Executive Committee of the Workers and Soldiers Councils, unable to agree on the question of a constituent assembly, issued a call for a

Congress of Workers

Councils Congress of all such councils in Germany. In the month that followed there was feverish political agitation. On this question of a constituent assembly hung the issue of soviet or parliamentary government. The Congress assembled on December 16 and two days later voted overwhelmingly in favor of calling a constituent assembly. The Independent Socialists withdrew in protest; and shortly thereafter the three Independents resigned from the "Cabinet." They were replaced by three Social Democrats.

The Congress of Councils also elected a Central Council and vested it with power to ratify appointments to German and Prussian Cabinet posts, as well as with power to

Opposition to a constituent assembly
The

Central Council 
Failure of Spartacists

The constituent assembly of 1919 veto provisional laws. In a sense it may be said that the Congress of the Councils was the potential legislature and the Central Council was the potential executive of the revolution. But political action was in form taken by the "Cabinet" or so-called "People's Commissioners."

In December, 1918, and January, 1919, the revolution burst into violence. The Communists or Spartacists, considerably augmented by Independent Socialists, sought by force to capture the Government and to prevent the election of a constituent assembly. The Cabinet, duly authorized by the Central Council, interposed armed resistance, not only in Berlin, but also in other cities where the conditions of the capital were being reproduced. With the assassination of Liebknecht and Rosa Luxemburg on January 15 the proletarian effort collapsed in débâcle. It was a curious though not inexplicable aspect of the German revolution that such violence as it produced was not directed against the late rulers - the aristocrats, monarchists, militarists, and junkers. These were bystanders, mere onlookers, at the short-lived drama of armed conflict between the extreme radicals and the long contemned bourgeoisie, who now for the first time held the reins of power in trembling and untried hands.

The date of the election of the constituent assembly was January 19, 1919. The conditions of election were fixed by a "Cabinet" decree of November 30, 1918. The suffrage was made "universal, equal, direct, and secret." It was extended to women as well as to men, and twenty years was fixed as the age requirement. Provision was made for a registration of voters; and a system of proportional representation was established under which from six to sixteen delegates were to be elected in each of thirtyeight districts. ${ }^{1}$ Originally the decree called for four hundred and thirty-three delegates, but subsequent events reduced the number to four hundred and twenty-one. In

'See above, pp. $97 \mathrm{ff}$. 
the campaign most of the old political parties were rechristened with names appropriate to the changed order. The voters went to the polls in enormous numbers; more than thirty million votes were cast. The results of the election showed clearly that the advocates of parliamentary government had completely triumphed over the extremists of the Left. ${ }^{1}$ The assembly could not boast a large leaven of political experience; for of the delegates elected only forty-five had served in the dissolved Reichstag. Thirty-six of the delegates were women.

"By this election," writes a German commentator, "the German people seized the sovereignty that had hitherto been recognized as belonging to those who possessed political power, and for the first time actually exercised the power of the state. All the declarations of the former dictatorial masters to the effect that the new Germany should be erected upon a democratic foundation and that the political power of the Empire should also rest with the German people, were meaningless so long as the people did not by their own action make use of their right. The actual management of the organs of state is what primarily proves that the people have the will to exercise the power that is proposed to be vested in them and demonstrates the existence of an established form of state.",

The assembly came together on February 6, 1919. "Professedly to steep it in the sedative atmosphere of the old pre-Prussian 'kultur' of the philosophers and poets and practically to withdraw it from the too-stimulating atmosphere of Berlin,"' Weimar was chosen as the place

\footnotetext{
IThe election results were as follows: Social Democrats, 163; Christian Peoples party (old Center or Catholic Federal), 92; German Democratic party (old Progressives and Radical Liberals), 75; German National Peoples party (old Conservatives), 42; Independent Socialists, 22; German Peoples party (old National Liberals), 21; small peasant parties, 6. Total, 421. There are some slight variations in these figures in different reports of the election.
}

${ }^{2}$ F. Giese, Die Verfassung des Deutschen Reiches, rom 11. August 1919, 3d. ed. pp. 19, 20 (Berlin, 1921).

'Young, The New Germany, pp. 323-34 (New York, 1120).

Significance of election of assembly

A "constitutional" provisional government 


\section{4}

NEW CONSTITUTIONS OF EUROPE

of meeting. Four days after the opening of the assembly an act was passed which established a provisional form of government. In many respects this act foreshadowed the provisions of the permanent constitution. Its details need not be elaborated. Suffice it to say that the assembly itself was to exercise provisional legislative power. Provision was made for a President and for a Chancellor at the head of a Ministry responsible to the assembly. But the power of the Ministry to initiate legislative proposals was made subject to the advice of a Committee of the States. On February 12 a coalition was affected in the assembly between the Social Democrats, the Christian Peoples party (the Catholic Center), and the Democratic party (the Progressives and Left Wing Liberals). Ebert was elected provisional President and Scheidemann became Chancellor. Under this system a legislative program of considerable importance was put through while the permanent constitution was in process of being completed.

Action of Workers Councils

This "constitutional" provisional government came into existence almost immediately after the assembly met; but the organization of Workers Councils did not in consequence cease to exist. In this situation, therefore, there was large opportunity for embarrassment and friction. There was indeed the possibility that the Councils might yet assert a claim of superiority over the assembly. On February 11 the Central Council, which had been set up in December, formally turned over to the assembly the powers which it had received from the Congress of Workers Councils. But insistent pressure by the Independents, and especially by the Berlin Executive Council, led to the call of a second general Congress. On April 5 this Congress passed a "self-denying" resolution by which the way was cleared for the work of the assembly and the establishment of parliamentary government under a permanent constitution.

Dr. Hugo Preuss, Minister of the Interior in the 
Scheidemann Cabinet, was chiefly responsible for the constitution. His draft of the provisional constitution, which had received the approval of a conference of state representatives prior to the meeting of the assembly, was the basic proposal out of which the constitution was evolved.

Convoked for the primary purpose of making a constitution, the assembly was nevertheless compelled to give attention to many other important matters. Critical services of the government had to be carried on. Pressing laws had to be enacted. Recrudescent uprisings of Communists and Spartacists had to be suppressed. And above all, peace had to be made. It was in such distracting circumstances that the German constitution of 1919 was patterned and moulded. On July 31 , it was finally adopted by a vote of two hundred and sixty-two to seventyfive, the opposition coming from the extreme Right and the extreme Left. On August 11, it was promulgated and published. It went into effect immediately; for by its own terms the constituent assembly was to operate temporarily in place of the Reichstag, and the provisional President in place of a President elected by popular vote. ${ }^{1}$ The first Reichstag was elected on June 6, 1920; but

\footnotetext{
1The translation which follows was made especially for this volume. Other English versions are to be found in Young, The Nero Germany, Appendix; The International Review, November and December, 1919; and Temperley, Ed., A History of the Peace Conference of Paris, Vol. III, p. 347 (London, 1920). There is also a translation by Professors William Bennett Munro and Arthur Norman Holcombe which appeared in League of Nations, Vol. II, No. 6 (World Peace Foundation, December, 1919). This translation is used in the English version of Brunet, La constitution allemande du 11 Aout, 1919, with the result that there is some confusion of terms between the constitution and the text. The French translation of the constitution, by $\mathbf{M}$. Brunet, is an excellent piece of work.

M. Brunet's book, translated by Joseph Gollomb under the title The New German Constitution (New York, 1922) is to date the most valuable work dealing with the constitution. An interesting summary is J. W. Gordon, "The New German Constitution," Quarterly Revieu, January, 1921. See also the references in Willoughby and Rogers, An Introduction to the Problem of Government, p. 375 .

A great many volumes dealing with the constitution have appeared in Germany. Two of these are now in their third editions and have elaborate bibliographical notes: Giese, Die Verfassung des Deutschen Reiches tom 11. August
}

Hugo

Preuss

The constitution of 1919 
three years after the promulgation of the constitution no date had been set for the election of a President by the people.

\section{CONSTITUTION OF THE GERMAN REICH ${ }^{1}$ OF AUGUST 11, 1919}

The German people united in every respect and inspired by the determination to restore and confirm the Reich in liberty and justice, to serve peace at home and peace abroad, and to further social progress, has given itself this constitution.

\section{CHAPTER I}

\section{THE REICH: ITS ORGANIZATION AND FUNCTIONS}

\section{SECTION I \\ The Reich and the States ${ }^{2}$}

Article 1. The German Reich is a Republic.

The political power emanates from the people.

Art. 2. The territory of the Reich consists of the territories of the German states. Other territories may be incorporated in the Reich by a national law, if their populations so desire by virtue of the right of self-determination.

Art. 3. The national colors are black-red-gold. The commercial flag is black-white-red with the national colors in the upper inside corner.

1919 (Berlin, 1920) and Poetzsch, Handausgabe der Reichsterfassung vom 11. August 1919 (Berlin, 1921). The last named volume contains a summary of recent legislation which will not be without influence on parliamentary practice. A volume contrasting the new constitution with the old is Navaisky, Die Grunddanken der Reichsverfassung (Munich, 1920).

${ }^{1}$ We do not translate "Reich." The most literal English equivalent is "Empire" which has a connotation that the framers of the constitution have sought to avoid. In other English versions "Reich" has been translated "Realm" and "Commonwealth." Obviously neither of these terms is wholly satisfactory.

"The German word is "Länder," literally countries, regions, or territories. It has been used deliberately instead of "Staaten", apparently to signify the changed status of the separate units under the new constitution. (See above, pp. $62 \mathrm{ff}$.) The word "states" for the members of the Reich is therefore slightly misleading; but it has been used because any literal translation has too vague a connotation, and because no other term seemed more appropriate. It is of some significance, moreover, that the constitutions of Prussia and the other units use the word "Staat"-for example, Verfassung des Friestaats Preussen. Throughout the German constitution "Staat" is occasionally used in a generic sense. 
Art. 4. The universally recognized rules of international law are accepted as integral and obligatory parts of the law of the German Reich.

Art 5. Political power shall be exercised, in matters pertaining to the Reich, through the organs of the Reich on the basis of the national constitution, and, in matters pertaining to the states, through the organs of the states on the basis of the constitutions of the states.

Art. 6. The Reich shall have the exclusive power of legislation in respect to:

(1) Foreign relations.

(2) Colonies.

(3) Citizenship, freedom of movement, immigration and emigratıon, extradition.

(4) National defence.

(5) Currency.

(6) Customs, including uniformity in customs and commercial districts and the free transit of goods.

(7) Posts and telegraphs, including telephones.

Art. 7. The Reich shall have power of legislation in respect to:

(1) Civil law.

(2) Criminal law.

(3) Judicial procedure, including the execution of justice; as well as official assistance by one public authority to another.

(4) Passports and police supervision of aliens.

(5) Poor relief and vagrancy.

(6) The press, the right of association, the right of assembly.

(7) Problems of population, and protection of maternity, infancy, childhood, and adolescence.

(8) Public health, veterinary regulations, and protection of plants against disease or injury.

(9) The right to work, insurance and protection of workers and other employees, and employment exchanges.

(10) The organization of professional associations extending over the Reich.

(11) The care of discharged soldiers and their dependents.

(12) The law of expropriation.

(13) Socialization of natural resources and of economic undertakings, as well as the manufacture, production, distribution, and price-fixing of economic goods destined for public use. 


\section{NEW CONSTITUTIONS OF EUROPE}

(14) Commerce, weights and measures, the issue of paper money, banking, and stock and produce exchanges.

(15) Commerce in foodstuffs and food luxuries, as well as in commodities of daily use.

(16) Industry and mining.

(17) Insurance.

(18) Maritime commerce, deep sea and coast fisheries.

(19) Railways, internal navigation, motor traffic by land, sea, and air, and the construction of roads for general traffic and national defense.

(20) Theaters and cinematographs.

Art. 8. The Reich shall have in addition the power of legislation as to taxation and other revenues in so far as they are claimed in whole or in part for its purposes. If the Reich lays claim to taxes or other revenues which formerly belonged to the states, due consideration must be given to the protection of the financial needs of the states.

Art. 9. In so far as it is necessary to issue uniform regulations, the Reich shall have the power of legislation in respect to:

(1) Social welfare.

(2) Protection of public order and safety.

Art. 10. The Reich may by law prescribe fundamental principles with respect to:

(1) Rights and duties of religious associations.

(2) Education, including higher education and scientific libraries.

(3) Rights of officials of all public bodies.

(4) Land titles, land distribution, land colonization and homesteads, entail, housing, and distribution of the population.

(5) Disposition of the dead.

Art. 11. In so far as is necessary the Reich may by law prescribe fundamental principles with respect to the imposition and collection of state taxes in order to safeguard important commercial interests, or in order to prevent:

(1) Prejudice to the national revenues or the commercial relations of the Reich.

(2) Double taxation.

(3) Levies on public communications or institutions which are excessive or which interfere with communication.

(4) Discriminatory taxes upon imported goods as against. domestic products in interstate or local commerce.

(5) Export premiums. 
Art. 12. As long as, and in so far as, the Reich does not make use of its powers of legislation, the states shall retain the power of legislation. This does not apply to the power of legislation which belongs exclusively to the Reich.

The National Ministry shall have the right to veto laws of the states which relate to matters covered by Article 7, subsection 13, in so far as the welfare of the people of the Reich is thereby affected.

Art. 13. National laws are superior to the laws of the states.

Should any doubt or difference of opinion arise as to whether a state regulation is compatible with a law of the Reich, the competent national or state authority may request a decision from a superior judicial court of the Reich in accordance with the more specific requirements of a national law.

Art. 14. National laws shall be executed by the authorities of the states in so far as the national laws do not otherwise provide.

Art. 15. The National Ministry shall have the right to supervise those matters in respect to which it has the power of legislation.

In so far as national laws are to be executed by the authorities of the states the National Ministry may lay down general directions. The National Ministry shall have power to send commissioners to the Central authorities of the states, and with their concurrence to subordinate authorities, in order to supervise the execution of the national laws.

It is the duty of the state ministries to remedy, on the request of the National Ministry, deficiencies which may have appeared in the course of the execution of national laws. In case of dispute, both the National Ministry and the state ministries may request a decision from the Supreme Judicial Court (Staatsgerichtshof), provided another court is not prescribed by national law.

Art. 16. Officials charged with the direct administration of national affairs in any state shall, as a rule, be citizens of that state. Officials, employees, and workers of the national administration shall, at their request, be employed within their home districts, in so far as this is possible, and in so far as may be consistent with the requirements of the service and of their training.

Art. 17. Every state must have a republican constitution (freistaatliche Verfassung). The representative body must be 
elected by universal, equal, direct, and secret suffrage of all German citizens of either sex, according to the principles of proportional representation. The state ministry must have the confidence of the representative body.

The principles applicable to elections to the representative body shall apply also to elections to municipal bodies. Nevertheless, by a state law the right of suffrage may be made to depend upon residence within the municipality for a period not exceeding one year.

Art. 18. ${ }^{1}$ The division of the Reich into states shall serve the highest economic and cultural progress of the people, with due regard to the wishes of the population affected. The alteration of state boundaries and the creation of states within the Reich shall take place by virtue of national law modifying the constitution.

Where the states directly affected consent, an ordinary national law shall suffice.

An ordinary national law shall also suffice where one of the states affected does not consent, but where the alteration of a boundary or the creation of a new state is demanded by the wishes of the population and an overwhelming national interest requires it.

The wishes of the population shall be ascertained by a referendum. The National Ministry shall order such a referendum to take place upon demand of one-third of the residents of the territory to be separated who are qualified to vote for members of the Reichstag.

Three-fifths of the votes recorded, and at least a majority of the total number of electors, are necessary to effect any alteration of boundaries or the creation of a new state. Even for the separation of only a part of a Prussian governmental district or of a corresponding administrative district in any other state, the wishes of the population of the whole district affected must be ascertained. If there is no geographical connection between the portion to be separated and the whole district, a special national law may declare that the wishes of the population of the part to be separated shall be sufficient.

When the wishes of the population have been ascertained, the National Ministry shall submit an appropriate law to the Reichstag for its acceptance.

If a dispute arises on the occasion of a union or a separation

'See below, Art. 167. 
of territory in respect to property rights, it shall be decided by the Supreme Judicial Court of the Reich at the request of either party.

Art. 19. If constitutional controversies arise within a state, for the decision of which there is no competent court, or should controversies of a public nature arise between different states or between the Reich and a single state, the Supreme Judicial Court of the German Reich shail decide the controversy on the appeal of either of the contesting parties, if no other court of the Reich is competent. The President of the Reich shall execute the decision of the Supreme Judicial Court.

\section{SECTION II}

\section{The Reichistag}

Art. 20. The Reichstag shall be composed of the representatives of the German people.

Art. 21. The deputies shall be representatives of the entire people. They are subject only to their conscience and are not bound by instructions.

Art. 22. The deputies shall be elected by the universal, equal, direct and secret suffrage of all men and women over twenty years of age, according to the principles of proportional representation. Election day must be a Sunday or a public holiday. Detailed regulations shall be proscribed by a national electoral law.

Art. 23. The Reichstag shall be elected for a four-year term. A new election shall take place no later than sixty days after the expiration of its term.

The Reichstag shall assemble for its first meeting no later than the thirtieth day after election.

Art. 24. The Reichstag shall assemble on the first Wednesday of November in every year at the seat of the National Ministry. The President of the Reichstag must call it together at an earlier date if the President of the Reich or at least onethird of the deputies of the Reichstag demand it.

The Reichstag shall determine the date of the close of its session and the date of its re-assembly.

Art. 25. The President of the Reich may dissolve the Reichstag, but only once for the same cause.

A new election must be held no later than the sixtieth day after the dissolution. 


\section{2}

\section{NEW CONSTITUTIONS OF EUROPE}

Art. 26. The Reichstag shall choose its own President, its Vice-Presidents, and its Secretaries. It shall determine its own rules of procedure.

Art. 27. Between two sessions or between legislative terms the President and Vice-Presidents of the last session shall carry on its business.

Art. 28. The President shall exercise powers of discipline and police within the Reichstag building. The administration of the building is under his control; he has control over the income and expenditures for the building within the limits laid down by the national budget, and he represents the Reich in all legal business and legal actions involved in his administration of the building.

Art. 29. The sittings of the Reichstag shall be public. On the demand of fifty deputies the public may be excluded by a two-thirds majority vote.

Art. 30. True and accurate reports of the proceedings at the public sittings of the Reichstag, or of a Landtag, or of their committees are privileged matters.

Art. 31. A tribunal to examine election returns shall be instituted by the Reichstag. It shall also decide whether a deputy has lost his seat.

The tribunal to examine election returns shall be composed of members of the Reichstag elected by the Reichstag for the legislative term, and, in addition, of members of the Supreme Administrative Court (Reichsverwaltungsgericht) whom the President of the Reich shall appoint on nomination of the presidency of that Court.

The tribunal to examine election returns shall pronounce judgment on the basis of public and oral sittings by a quorum of three members of the Reichstag and two judicial members.

Proceedings apart from the sittings of the tribunal to examine election returns shall be conducted by a commissioner of the Reich appointed by the President of the Reich. In other respects, procedure shall be regulated by the tribunal to examine election returns.

Art. 32. A resolution of the Reichstag requires a simple majority of the votes cast, except as the constitution requires another majority. The rules of procedure of the Reichstag may permit exceptions in the case of elections held by it.

The quorum shall be determined by the rules of procedure.

Art. 33. The Reichstag and the committees of the Reichstag 
may demand the presence of the Chancellor and of every minister.

The Chancellor, the ministers, and their deputies shall have access to the sittings of the Reichstag and of its committees. The states shall be privileged to send authorized agents to these sittings who shall submit the views of their ministries upon matters under discussion. On demand, the representatives of the state governments must be heard during the deliberations; and the representatives of the National Ministry must also be heard regardless of the order of the day.

They shall be subject to the rulings of the presiding officer.

Art. 34. The Reichstag shall have the right to, and upon the proposal of one-fifth of its members must, set up committees of investigation. These committees shall in public sitting inquire into such evidence as they or the petitioners consider necessary. The public may be excluded from sittings of a committee of investigation by a two-thirds majority vote. The rules of procedure shall regulate the business of the committee and determine the number of its members.

The courts and administrative authorities are required to submit evidence requested by these committees; upon their demand the records of the authorities shall be laid before them.

The provisions of the criminal code shall apply, as far as may be, to the inquiries of committees and of the authorities assisting them; nevertheless, the secrecy of the postal, telegraph, and telephone services shall remain unaffected.

Art. 35. The Reichstag shall appoint a standing committee on foreign affairs which may act between sessions of the Reichstag and after the end of the legislative term, or between the dissolution of the Reichstag and the convening of a new Reichstag. The sittings of this committee shall not be public, unless the committee itself decides by a two-thirds majority vote to admit the public.

The Reichstag shall further appoint a standing committee for the protection of the rights of the representative body over against the National Ministry, for the period between sessions and after the end of a legislative term.

These committees shall have the powers of committees of investigation.

Art. 36. No member of the Reichstag or of a Landtag may at any time be subjected to judicial or administrative prosecution, or otherwise held responsible outside the sittings, by 


\section{NEW CONSTITUTIONS OF EUROPE}

reason of his vote or by reason of any utterances made in his official capacity.

Art. 37. No member of the Reichstag or of a Landtag may, without the consent of the house of which he is a member, be subjected to investigation or arrest during the session for a penal offense unless he is apprehended in the commission of the act, or at latest in the course of the following day.

Consent is similarly required for every other restriction of personal liberty which obstructs a deputy in the exercise of his office.

Every criminal proceeding against a member of the Reichstag or of a Landtag and every arrest or other restriction on his personal liberty shall, on demand of the house to which the deputy belongs, be deferred for the duration of the session.

Art. 38. The members of the Reichstag and of the Landtags have the right to refuse to give evidence as to persons who have made communications to them in their capacity as deputies, and to whom they have given information in the exercise of their office, as well as in respect to the facts themselves. With regard also to the seizure of documents their position is identical with that of persons who have the legal right to refuse to give evidence.

A search or seizure may not take place within the rooms of the Reichstag or of a Landtag except with the consent of its President.

Art. 39. Public officials or members of the military forces shall not require leave in order to exercise their functions as members of the Reichstag or of a Landtag.

If they seek election to these bodies, leave necessary to carry on their campaign shall be granted to them.

Art. 40. The members of the Reichstag shall have the right of free transportation on all German railways as well as compensation provided by national law.

\section{SECTION III}

The President of the Reicil and the National Ministry

Art. 41. The President of the Reich shall be elected by the whole German people.

Every German who has completed his thirty-fifth year is eligible. Detailed regulations shall be prescribed by a national law. 
Art. 42. The President of the Reich shall take the following oath on assuming office-

I swear that I will devote my energy to the good of the German people, that I will advance the people's interests, will protect the people from injury, will maintain the constitution and the laws, will fulfill my duties conscientiously, and will exercise justice toward all.

The addition of a religious oath is permissible.

Art. 43. The term of office of the President shall be seven years. Reëlection is permissible.

Before the expiration of his term the President of the Reich may be removed from office by popular vote on resolution of the Reichstag. The resolution of the Reichstag requires a twothirds majority vote. By such resolution the President is suspended from further exercise of his functions. If the popular vote fails to remove the President such vote shall be regarded as a new election of the President and a dissolution of the Reiclistag shall follow.

The President of the Reich may not be subjected to criminal prosecution without the consent of the Reichstag.

Art. 44. The President of the Reich may not at the same time be a member of the Reichstag.

Art. 45. The President of the Reich represents the Reich in international relations. In the name of the Reich he makes alliances and other treaties with foreign powers. He accredits and receives diplomatic representatives.

Declaration of war and conclusion of peace shall be made by national law.

Alliances and treaties with foreign states which relate to subjects of national legislation require the consent of the Reichstag.

Art. 46. The President of the Reich shall appoint and remove national officials and military officers of the Reich, except as otherwise provided by law. He may permit other authorities to exercise the powers of appointment and removal.

Art. 47. The President of the Reich shall have supreme command over the entire military forces of the Reich.

Art. 48. If a state fails to carry out the duties imposed upon it by the national constitution or national laws, the President of the Reich may compel performance with the aid of armed force.

If public safety and order be seriously disturbed or threatened within the German Reich, the President of the Reich may take the necessary measures to restore public safety and order; if 
necessary, with the aid of armed force. For this purpose he may temporarily suspend in whole or in part the fundamental rights enumerated in Articles 114, 115, 117, 118, 123, 124 and 153.

The President of the Reich must immediately communicate to the Reichstag all measures taken by virtue of Paragraph 1 or Paragraph 2 of this Article. On demand of the Reichstag these measures must be abrogated.

If there be danger in delay, the state ministry may, for its own territory, take such temporary measures as are indicated in Paragraph 2. On demand by the President of the Reich or by the Reichstag such measures shall be abrogated.

Detailed regulations shall be prescribed by a national law.

Art. 49. The President of the Reich shall exercise the pardoning power for the Reich. For national amnesties a national law is necessary.

Art. 50. All orders and decrees of the President of the Reich, including those concerning the armed force, require for their validity the counter-signature of the Chancellor or of the competent national minister. Responsibility is accepted by the act of counter-signature.

Art. 51. In case of disability the President of the Reich shall be represented first of all by the Chancellor. If the disability will presumably continue for a longer time, the matter of a substitute shall be determined by national law.

In case of a premature vacancy in the presidency, the same course shall be followed until a new election has been held.

Art. 52. The National Ministry shall consist of the Chancellor and the national ministers.

Art. 53. The Chancellor and, upon his recommendation, the national ministers shall be appointed and removed by the President of the Reich.

Art. 54. The Chancellor and national ministers must have the confidence of the Reichstag for the exercise of their offices. Any one of them must resign if the Reichstag withdraws its confidence by express resolution.

Art. 55. The Chancellor shall preside over the National Ministry, and shall conduct its business according to rules of procedure which shall be determined by the National Ministry and approved by the President of the Reich.

Art. 56. The Chancellor shall lay down the general course of policy and shall be responsible therefor to the Reichstag. 
In accordance with this general policy each national minister shall independently conduct the branch of administration intrusted to him, and shall be under personal responsibility to the Reichstag.

Art. 57. National ministers shall submit to the National Ministry for consideration and decision all legislative proposals and all matters for which the constitution or the laws require such submission, as well as differences of opinion on questions which concern the sphere of action of more than one national minister.

Art. 58. The National Ministry shall reach its decisions by majority vote. In case of a tie the vote of the presiding officer shall decide.

Art. 59. The Reichstag shall have power to bring before the Supreme Judicial Court impeachment procecdings against the President of the Reich, the Chancellor, and the national ministers, for a wrongful violation of the constitution or a national law. The bill of impeachment must be signed by at least one hundred members of the Reichstag and requires the approval of the majority necessary for constitutional amendments. Detailed regulations for the Supreme Judicial Court shall be prescribed by a national law.

\section{SECTION IV}

\section{The ReichsRat}

Art. 60. A Reichsrat shall be established to represent the German states in national legislation and administration.

Art. 61. Each state shall have at least one vote in the Reichsrat. The larger states shall have one vote for each million of inhabitants. Any fraction which is equal at least to the total number of the inhabitants of the smallest state shall be counted as a million. No state may have a representation of more than two-fifths of the members.

German-Austria, after union with the German Reich, shall be represented in the Reichsrat by votes corresponding in number to its population. Meanwhile the representatives of GermanAustria shall have a deliberative voice. ${ }^{1}$

'Stricken out at the demand of the Supreme Council of the Allied and Associated Powers. The Supreme Council addressed the following demand to Germany on September 2, 1919:

"The Allied and Associated Powers have examined the German Constitution of August 11, 1919. They observe that the provisions of the second paragraph 


\section{The representatives shall be reapportioned by the Reichsrat} after each general census.

Art. 62. No state may have more than one vote in committees appointed by the Reichsrat from its own membership.

Art. 63. The states shall be represented in the Reichsrat by members of their ministries. But one-half of the Prussian representatives shall be appointed, in accordance with a state

of Article 61 constitute a formal violation of Article 80 of the Treaty of Peace signed at Versailles on June 28, 1919. This violation is twofold.

" 1 . Article 61 by stipulating for the admission of Austria to the Reichsrat assimilates that Republic to the German States composing the German Empire -an assimilation which is incompatible with respect to the independence of Austria,

" $\%$. By admitting and providing for the participation of Austria in the Council of the Empire Article 61 creates a political tie and a common political action between Germany and Austria in absolute opposition to the independence of the latter.

"In consequence the Allied and Associated Powers, after reminding the German Government that Article 178 of the German Constitution declares that 'the provisions of the Treaty of Versailles can not be affected by the Constitution,' invite the German Government to take the necessary measures to efface without delay this violation by declaring Article 61, Paragraph 2, to be null and void.

"Without prejudice to subsequent measures in case of refusal, and in virtue of the Treaty of Peace (and in particular Article 29), the Allied and Associated Powers inform the German Government that this violation of its engagements on an essential point will compel them, if satisfaction is not given to their just demand within 15 days from the date of the present note, immediately to order the extension of their occupation on the right bank of the Rhine."

Article 29 of the Treaty of Peace refers to Map No. 1 which shows the boundaries of Germany and provides that the text of Articles 27 and 28 will be final as to those boundaries. Article 80 reads as follows:

"Germany acknowledges and will respect strictly the independence of Austria, within the frontiers which may be fixed in a Treaty between that State and the Principal Allied and Associated Powers; she agrees that this independence shall be inalienable, except with the consent of the Council of the Ieague of Nations."

A diplomatic act was signed at Paris on September 22, 1919, by the representatives of the Principal Allied and Associated Powers and Germany in the following terms:

"The undersigned, duly authorized and acting in the name of the German Government, recognizes and declares that all the provisions of the German Constitution of August 11, 1919, which are in contradiction of the terms of the Treaty of Peace signed at Versailles on June 28, 1919, are null.

"The German Government declares and recognizes that in consequence Paragraph 2 of Article 61 of the said Constitution is null, and that in particular the admission of Austrian representatives to the Reichstag could only take place in the event of the consent of the Council of the League of Nations to a corresponding modification of Austria's international situation.

"The present declaration shall be approved by the competent German legislative authority, within the fortnight following the entry into force of the Peace Treaty.

"Given at Versailles, September 22, 1919, in the presence of the undersigned representatives of the Principal Allied and Associated Powers."

Cf. below, Article 178. 
law, from among the Prussian provincial administrative authorities.

The states may send to the Reichsrat as many representatives as they have votes.

Art. 64. Upon demand of one-third of its members the Reichsrat must be convened by the National Ministry.

Art. 65. A member of the National Ministry shall preside over the Reichsrat and over its committees. The members of the National Ministry have the right to, and upon demand must, take part in the proceedings of the Reichsrat and its committees. On their demand they must be heard at any time during the deliberations.

Art. 66. The National Ministry, as well as every member of the Reichsrat, may initiate proposals in the Reichsrat.

The Reichsrat shall determine its order of business by rules of procedure.

The plenary sessions of the Reichsrat shall be public. According to the rules of procedure the public may be excluded during the discussion of certain matters.

Decisions shall be reached by simple majority vote.

Art. 67. The Reichsrat shall be kept informed by the national departments concerning the conduct of national business. In deliberations upon important matters the appropriate committees of the Reichsrat shall be consulted by the national departments.

\section{SECTION $\mathrm{v}$}

\section{National Legislation}

Art. 68. Bills shall be introduced by the National Ministry, or by members of the Reichstag.

National laws shall be enacted by the Reichstag.

Art. 69. The initiation of bills by the National Ministry shall require the consent of the Reichsrat. If the National Ministry and the Reichsrat fail to agree, the National Ministry may, nevertheless, introduce the bill, but must present therewith the dissenting opinion of the Reichsrat.

If the Reichsrat passes a bill to which the National Ministry fails to assent, the Ministry must introduce such bill in the Reichstag accompanied by an expression of its views.

Art. 70. The President of the Reich shall proclaim the laws constitutionally enacted, and shall publish them within a month in the National Law Gazette. 
Art. 71. National laws, unless otherwise provided, shall be effective on the fourteenth day after the day of publication in the National Law Gazette in the capital of the Reich.

Art. 72. Publication of a national law shall be deferred for two months on request of one-third of the members of the Reichstag. Laws which the Reichstag and the Reichsrat declare to be urgent may be published by the President of the Reich regardless of this request.

Art. 73. A law passed by the Reichstag shall, before its publication, be subject to a referendum if the President of the Reich, within a month, so decides.

A law, the publication of which has been deferred on the request of one-third of the members of the Reichstag shall be subject to a referendum upon the request of one-twentieth of the qualified voters.

A referendum shall also take place, if one-tenth of the qualified voters petition for the submission of a proposed law. Such petition must be based on a fully elaborated bill. The bill shall be submitted to the Reichstag by the Ministry accompanied by an expression of its views. The referendum shall not take place if the bill petitioned for is accepted by the Reichstag without amendment.

Only the President of the Reich may order a referendum concerning the budget, tax laws, and salary regulations.

Detailed regulations in respect to the referendum and initiative shall be prescribed by a national law.

Art. 74. Laws enacted by the Reichstag shall be subject to veto by the Reichsrat.

The veto must be communicated to the National Ministry within two weeks after the final vote in the Reichstag, and within two additional weeks must be supported by reasons.

In case of veto the law must be presented to the Reichstag for reconsideration. If no agreement upon the matter is reached between the Reichstag and the Reichsrat, the President of the Reich may within three months submit the matter in dispute to a referendum. If the President fails to exercise this right, the law shall be considered as of no effect. If the Reichstag overrules the veto of the Reichsrat by a two-thirds majority vote, the President shall within three months publish the law in the form adopted by the Reichstag or shall order a referendum.

Art. 75. A resolution of the Reichstag shall not be annulled 
unless a majority of the qualified voters participate in the election.

Art. 76. The constitution may be amended by legislative action. However, resolutions of the Reichstag for amendment of the constitution are valid only if two-thirds of the legal members are present and if two-thirds of those present give their assent. Moreover, resolutions of the Reichsrat for amendment of the constitution require a two-thirds majority of all the votes cast. If by popular petition a constitutional amendment is to be submitted to a referendum, it must be approved by a majority of the qualified voters.

If the Reichstag adopts a constitutional amendinent over the veto of the Reichsrat, the President of the Reich shall not publish this law if the Reichsrat within two weeks demands a referendum.

Art. 77. Except as otherwise provided by law; the National Ministry shall issue such general administrative regulations as are necessary for the execution of national laws. The National Ministry requires for this purpose the approval of the Reichsrat in cases in which the execution of national laws rests with the authorities of the states.

\section{SECTION VI}

\section{National Administration}

Art. 78. The conduct of relations with foreign states is exclusively the function of the Reich.

The states may make treaties with foreign states on matters which fall within the legislative competence of the states; but such treaties require the approval of the Reich.

Agreements with foreign states concerning the alteration of the national boundaries shall be concluded by the Reich with the consent of the state affected. Changes of boundaries may be effected only by a national law exeept in case of a simple adjustment of the boundaries of uninhabited districts.

In order to safeguard the representation of interests which arise in particular states from their special economic relations with, or their geographical contiguity to, foreign states, the Reich shall take the necessary measures and make the necessary arrangements in agreement with the states affected.

Art. 79. National defense is a function of the Reich. The organization of the armed forces of the German people shall 
be regulated in a uniform manner by a national law with due regard to the special regional peculiarities of the population.

Art. 80. Colonial affairs are within the exclusive jurisdiction of the Reich.

Art. 81. All German merchant ships shall form a single commercial fleet.

Art. 82. Germany forms a single customs and commerce zone surrounded by a common customs boundary.

The customs boundary coincides with the political boundary. On the seacoast the shore of the mainland and of the islands belonging to the national territory shall form the customs boundary. Changes may be made in the line of the customs boundary on the sea coasts and other waters.

Foreign territories or parts of territories may by treaties or agreements be included within the customs boundary.

Under special conditions, portions of territory may be excluded from the customs zone. In the case of free ports such exclusion may be terminated only by a constitutional amendment.

Territories excluded from the customs may be joined to a foreign customs zone by treaties or agreements.

All natural products as well as manufactured articles and works of art which are subjects of free commerce in the Reich may be carried across the boundaries of the states for import, export, or through traffic. Exceptions may be made by a national law.

Art. 83. Customs and consumption taxes shall be administered by national authorities.

In the administration of national taxes by national authorities, arrangements shall be made which will permit the states to safeguard special state interests in respect to agriculture, commerce, trade, and industry.

Art. 84. The Reich shall by law regulate:

(1) The organization of the tax administration of the states, so far as the uniform and impartial execution of national tax laws requires.

(2) The organization and powers of the authorities empowered to supervise the execution of the national tax laws.

(3) Accounting with the states.

(4) The reimbursement of administrative expenses incurred in the execution of the national tax laws.

Art. 85. All revenues and appropriations of the Reich must for each fiscal year be estimated and incorporated in the budget. 
The budget shall be adopted by law before the beginning of the fiscal year.

The appropriations shall as a rule be voted for one year. In special cases they may be voted for a longer period. Except in such cases the national budget law shall not contain provisions which run beyond the fiscal year or which do not relate to the revenues and appropriations of the Reich or to their administration.

The Reichstag may not, without the consent of the Reichsrat, increase appropriations or insert new items in the draft of the budget.

The consent of the Reichsrat may be dispensed with in accordance with the provisions of Article 74 .

Art. 86. In the succeeding fiscal year, the minister of national finance shall account to the Reichsrat and the Reichstag for the disposition of all national revenue so as to discharge the responsibility of the National Ministry. The audit shall be regulated by national law.

Art. 87. Funds may be procured on credit only for extraordinary needs and as a rule only for expenditures for productive works. Such a procurement as well as the assumption of any liability by the Reich may be undertaken only by authority of a national law.

Art. 88. Posts and telegraphs, including telephones, are exclusively in the hands of the Reich.

Postage stamps shall be uniform throughout the entire Reich.

The National Ministry shall, with the consent of the Reichsrat, issue regulations prescribing the conditions and rates for the use of the services of communication. With the consent of the Reichsrat it may delegate this function to the national minister of posts.

The National Ministry shall, with the consent of the Reichsrat, establish an advisory council to consult and coöperate in matters pertaining to the posts, telegraphs, telephones, and rates.

Treaties with foreign states in respect to communication may be made only by the Reich. ${ }^{1}$

Art. 89. It shall be the duty of the Reich to acquire as its own property all railroads serving as means of general communication and to administer them as a uniform system of transportation.

\footnotetext{
${ }^{1}$ See Article 170.
} 
The rights of the states to acquire private railways shall be transferred to the Reich on its demand.

Art. 90. With the taking over of the railways, the Reich shall acquire the right of expropriation and the public sovereign rights pertaining to the railway system. In respect to the scope of these rights the Supreme Judicial Court shall decide in case of dispute.

Art. 91. The National Ministry shall, with the consent of the Reichsrat, issue regulations concerning the construction, operation, and traffic of the railways. With the consent of the Reichsrat it may delegate this function to the competent national minister.

Art. 92. The national railway system, notwithstanding the inclusion of its budget and its accounts in the general budget and general accounts, shall be administered as an autonomous economic enterprise, responsible for its own expenditures including interest and amortization of the railroad debt and the accumulation of a railroad reserve fund. The amount of this amortization and of the reserve fund, as well as the purposes for which the reserve fund shall be used, shall be regulated by special law.

Art. 93. The National Ministry shall, with the consent of the Reichsrat, establish advisory councils for the national railway system to consult and coöperate in matters pertaining to railway traffic and rates.

Art. 94. When the Reich has taken over the railways serving as means of general communication within a particular district, new railways serving as means of general communication may be constructed within such district only by the Reich or with its consent. If the construction of new national railway lines or the alteration of existing lines touches upon the sphere of the police authority of a state, the national railway administration shall, before reaching a decision, give a hearing to the state authorities.

Where the Reich has not acquired railroads as a part of its administration, it may, by virtue of a national law and even against the objection of the states whose territory is crossed, but without prejudice to the sovereign rights of the states, construct on its own account such railways as are deemed necessary for general communication or national defense, or may confer upon others the power to construct, together with a grant of the right of expropriation in case of necessity. 
Every railway administration must consent to connection with other railroads at the latter's expense.

Art. 95. Railways of general communication which are not administered by the Reich, are subject to supervision by the Reich.

Railways subject to the supervision of the Reich shall be constructed and equipped according to uniform standards established by the Reich. They must be maintained in safe working order and must be extended to meet traffic requirements. Passenger and freight service shall be furnished and developed according to needs.

In connection with the supervision of matters pertaining to rates, effort shall be made to secure uniform and low railway rates.

Art. 96. All railways, including those not serving as means of general communication, must comply with the requirements of the Reich for the use of the railways for purposes of national defense.

Art. 97. It shall be the duty of the Reich to acquire as its own property and to administer waterways serving as means of general communication.

After such acquisition, waterways serving as means of general communication may be constructed or extended only by the Reich or with its consent.

In the administration, extension, or new construction of waterways the requirements of agriculture and of water supply shall be safeguarded in coöperation with the states. Consideration must also be given to the promotion of these interests.

Every waterways administration shall consent to connection with other inland waterways at the expense of the entrepreneur. The same obligation shall apply to the construction of a connection between inland waterways and railways.

In the acquisition of waterways the Reich acquires the right of expropriation and the rate-making power as well as police authority over water courses and navigation.

The projects of river improvement associations in respect to the extension of natural waterways in the basins of the Rhine, the Weser, and the Elbe shall be taken over by the Reich.

Art. 98. In accordance with detailed regulations of the National Ministry, advisory councils along the national waterways shall, with the consent of the Reichsrat, be establishcd to coöperate in matters pertaining to waterways. 
Art. 99. On national waterways charges may be made only for such construction, improvements, and other public works as are intended for the facilitation of traffic. They must not exceed, in the case of state or municipal works, the costs incurred for construction and maintenance. Construction and maintenance costs for public works which are not intended exclusively for the facilitation of traffic but also for the premotion of other ends may be defrayed only in a proportionate ratio by navigation charges. Interest and sinking-fund charges for the capital expended shall be regarded as construction costs.

The provisions of the preceding paragraph shall apply to charges levied for artificial waterways as well as for public works in connection therewith and in harbors.

In respect to inland navigation, the total cost of a waterway, a river basin, or a system of waterways may be taken as the basis for computing navigation charges.

These provisions shall also apply to timber-rafting on navigable waterways.

The Reich alone may levy on foreign ships and their cargoes other or higher charges than on German ships and their cargoes.

For the procurement of funds for the maintenance and extension of the German system of waterways, the Reich may also by law levy contributions on shipping interests in other ways.

Art. 100. In order to cover the costs of maintenance and construction of inland waterways, any person who profits from the construction of dams otherwise than by navigation may by national law be called upon to contribute, if more than one state shares in, or if the Reich bears, the cost of the work.

Art. 101. It shall be the duty of the Reich to acquire as its own property and to administer all aids to navigation, in particular lighthouses, lightships, buoys, floats, and beacons. After such acquisition, aids to navigation may be constructed or extended only by the Reich or with its consent.

\section{SECTION VII}

Administration of Justice

Art. 102. Judges are independent and responsible only to the law.

Art. 103. Ordinary jurisdiction shall be exercised by the national court and by the state courts.

Art. 104. Judges of ordinary jurisdiction shall be appointed 
for life. Against their will they may be temporarily or permanently removed from office or transferred to another position or retired only by a judicial decision and only for reasons and according to forms prescribed by law. Legislation may fix age limits at which judges may be retired.

Temporary removal from office which may take place according to law shall not be affected by this provision.

In case of a change in the organization of the courts or of their judicial districts, the state judicial administration may provide for involuntary transfers to another court or for removals from office, but only with the payment of full salary.

These provisions shall not apply to commerce judges, petty magistrates, or jurors.

Art. 105. Extraordinary courts are prohibited. No one may be withdrawn from the jurisdiction of his legally established court. Provisions of law relating to military courts and courts-martial are not hereby affected. Military courts of honor are abolished.

Art. 106. Military jurisdiction is abolished except in time of war and on board war vessels. Detailed regulations shall be prescribed by national law.

Art. 107. There shall be administrative courts in the Reich and in the states, as provided by law, for the protection of individuals against ordinances and decrees of the administrative authorities.

Art. 108. A Supreme Judicial Court shall be established for the German Reich in accordance with a national law.

\section{CHAPTER II}

\section{FUNDAMENTAL RIGHTS AND DUTIES OF GERMLNS}

\section{SECTION I}

\section{The Individual}

Art. 109. All Germans are equal before the law.

Men and women have in principle the same civil rights and duties.

Privileges or discriminations in public law based upon birth or rank are abolished. Titles of nobility are regarded only as part of a name and may no longer be conferred. 
Titles may be conferred only if they designate an office or a profession; academic rank is not hereby affected.

The state (Staat) may not confer orders and decorations.

No German may accept titles or orders from a foreign government.

Art. 110. Citizenship in the Reich and in the states shall be acquired and lost in accordance with the provisions of a national law.

Every citizen of a state is at the same time a citizen of the Reich.

Every German shall have in every state of the Reich equal rights and duties with the citizens of that state.

Art. 111. All Germans shall enjoy freedom of movement throughout the whole Reich. Everyone shall have the right to sojourn and settle in any place he pleases, to acquire property, and to carry on any gainful occupation. Restrictions require a national law.

Art. 112. Every German has the right to emigrate to nonGerman countries. Emigration may be restricted only by a national law.

All German citizens within and without the boundaries of the Reich have the right of protection by the Reich against foreign countries.

No German may be extradited for prosecution or punishment by a foreign government.

Art. 113. The foreign language parts of the population of the Reich may not be interfered with by legislative or administrative action in their free racial development, especially in the use of their mother tongue in education, as well as in the communal administration and the administration of justice.

Art. 114. Liberty of the person is inviolable. A restriction upon, or deprivation of, personal liberty, may not be imposed by public authority except by law.

Persons who have been deprived of their liberty must be informed no later than the following day by what authority, and upon what grounds, the deprivation of liberty was ordered; without delay they shall have the opportunity to lodge objections against such deprivation of liberty.

Art. 115. The dwelling of every German is his sanctuary and is inviolable. Exceptions may be imposed only by authority of law. 
Art. 116. An act may be punishable only if the penalty was fixed by law before the act was committed.

Art. 117. Secrecy of postal, telegraphic, and telephonic communication is inviolable. Exceptions may be permitted only by a national law.

Art. 118. Every German has the right within the limits of the general laws, to express his opinion orally, in writing, in print, pictorially, or in any other way. No circumstance arising out of his work or employment shall hinder him in the exercise of this right, and no one shall discriminate against him if he makes use of such right.

No censorship shall be established, but exceptional provisions may be made by law for cinematographs. Moreover, legal measures are permissible for the suppression of indecent and obscene literature, as well as for the protection of youth at public plays and exhibitions.

\section{SECTION II}

\section{Community Life}

Art. 119. Marriage, as the foundation of family life and of the preservation and increase of the nation, stands under the special protection of the constitution. It shall rest upon the equality of rights of both sexes.

It shall be the duty of the state (Staat) and of the municipalities to maintain the purity, health, and social welfare of the family. Families of many children shall have the right to compensatory public assistance.

Maternity shall have the right to the protection and public assistance of the state.

Art. 120. The education of their children for physical, intellectual, and social efficiency is the highest duty and natural right of parents, whose activities shall be supervised by the political community.

Art. 121. Illegitimate children shall be given by law the same opportunities for their physical, intellectual, and social development as legitimate children.

Art. 122. Youth shall be protected against exploitation as well as against moral, spiritual, or physical neglect. The state (Staat) and the municipalities shall make the necessary provisions.

Protective measures by way of compulsion may be instituted only by authority of law. 
Art. 123. All Germans have the right to assemble peaceably and unarmed without notice or special permission.

By national law notice may be required for meetings in the open air, and they may be prohibited in case of immediate danger to the public safety.

Art. 124. All Germans have the right to form societies or associations for purposes not prohibited by the criminal code. This right may not be limited by preventive regulations. The same provision applies to religious societies and associations.

Every association has the right to incorporate according to the provisions of the civil code. Such right may not be denied to an association on the ground that its purpose is political, social, or religious.

Art. 125. Freedom and secrecy of voting are guaranteed. Details shall be prescribed by the election laws.

Art. 126. Every German has the right to address in writing petitions or complaints to the competent authorities or to representative bodies. This right may be exercised by individuals as well as by groups.

Art. 127. Municipalities and groups of municipalities have the right of local autonomy within the limitations of the laws.

Art. 128. All citizens without discrimination shall be eligible for public office in accordance with the laws and their capacities and merits.

All exceptional provisions in respect to female officials shall be abolished.

The principles governing official relationships shall be regulated by national law.

Art. 129. Officials shall be appointed for life except as otherwise provided by law. Pensions and provision for surviving dependents shall be regulated by law. Duly acquired rights of officials shall be inviolable. Lawful salary claims of officials may be established by legal process.

Officials may be temporarily removed from office, provisionally or permanently retired, or transferred to another position at a smaller salary, only for reasons and according to forms provided by law.

In case of disciplinary punishment a mode of redress and the opportunity for reconsideration shall be open.

Entries upon the service records of an official of facts unfavorable to him shall be taken into consideration only after he 
has been given an opportunity to be heard in respect to them. Officials shall have a right to inspect their service records.

The inviolability of duly acquired rights and the right of resort to legal process for lawful salary claims are especially guaranteed to professional soldiers. Their status shall in other respects be regulated by national law.

Art. 130. Officials are servants of the whole community and not of a party.

All officials shall be guaranteed freedom of political opinion and freedom of association.

Officials shall receive special official representation according to detailed provisions of national law.

Art. 131. If an official in the exercise of the public authority vested in him be guilty of a breach of his official duty toward a third party, responsibility therefor shall attach primarily to the state or to the public body in whose service the official is. The right of redress against the officer is reserved. The ordinary legal process shall not be denied.

The competent legislative authority shall make detailed regulations.

Art. 132. It is the duty of every German, in accordance with the laws, to accept honorary office.

Art. 133. It is the duty of all citizens in accordance with the laws, to perform personal service for the state (Staat) and the municipalities.

Military duty shall be regulated in accordance with the provisions of the laws of national defense. These laws shall determine also to what extent certain fundamental rights may be denied to members of the armed forces in order to assure the performance of their duties and the maintenance of discipline.

Art. 134. All citizens without discrimination shall in proportion to their means contribute to all public burdens in accordance with the laws.

\section{SECTION III}

\section{Religion and Religious Associations}

Art. 135. All inhabitants of the Reich shall enjoy complete liberty of belief and conscience. The peaceful exercise of religious worship shall be guaranteed by the constitution and is under the protection of the state (Staat). General legislation shall not be affected by this provision. 
Art. 136. Civil and political rights and duties shall be neither conditioned upon, nor restricted by, the exercise of religious freedom.

The enjoyment of civil and political rights as well as eligibility to public office shall be independent of religious belief.

No one shall be compelled to disclose his religious convictions. The authorities have the right to inquire into a person's membership in a religious association only in so far as rights and duties are dependent thereon, or in so far as may be required by a legally instituted census.

No one may be compelled to be present at any religious act or ceremony or to take part in religious exercises or to use any form of religious oath.

Art. 137. There is no state church (Staatskirche).

Freedom of assembly in religious association is guaranteed. No restriction shall be placed upon the union of religious associations within the territory of the Reich.

Every religious association shall direct and administer its affairs without interference, within the limitations of the law applicable to all. It shall fill its own offices without assistance from the state (Staat) or local authorities.

Religious associations have the right to incorporate according to the general provisions of the civil code.

Religious associations shall, to the extent that they were formerly, remain public corporations. The same rights may be accorded to other religious associations if, by their constitution and the number of their members, they give assurance of permanence. If several of these public corporate religious associations combine in a union, this union shall also be a public corporation.

Religious associations which are public corporations are entitled to levy taxes on the basis of the civil tax lists in accordance with provisions of the laws of the states.

Societies which aim at mutual cultivation of a Weltanschainung shall be in a status similar to that of religious associations.

So far as the execution of these provisions requires further regulation, it shall be provided by legislation of the states.

Art. 138. Public grants to religious associations by law, contract, or special legal title may be redeemed by legislation of the states. The general principles for this shall be established by the Reich.

The property and other rights of religious associations and 
religious unions in their cultural, educational, and social welfare institutions, foundations, and other funds shall be guaranteed.

Art. 139. Sundays and holidays recognized by the state (Staat) remain protected by law as days of rest and spiritual uplift.

Art. 140. Necessary free time shall be accorded to the members of the armed forces for the fulfilment of their religious duties.

Art. 141. So far as there is need for divine worship and spiritual ministration in the army, hospitals, penal establishments, or other public institutions, religious associations shall be admitted for the performance of religious offices without the exercise of any compulsion.

\section{SECTION IV}

\section{Education and Schools}

Art. 142. Art, science, and instruction in them are free. The state (Staat) guarantees their protection and participates in their promotion.

Art. 143. The education of youth shall be provided for through public institutions. The Reich, the states, and the municipalities shall coöperate in their organization.

The training of teachers shall be uniformly regulated for the Reich according to the principles which apply generally to higher education.

The teachers in public schools shall have the rights and duties of state officials.

Art. 144. The entire school system shall be under the supervision of the state; the latter may cause the municipalities to participate therein. The supervision of schools shall be carried on by officials mainly occupied with this duty and technically trained.

Art. 145. Compulsory education shall be universal. For this purpose the elementary school with at least eight school years, followed by the continuation school up to the completion of the eighteenth year, shall serve primarily. Instruction and school supplies shall be free in elementary and continuation schools.

Art. 146. The public school system shall be organized according to a general plan. The intermediate and higher school 
system shall be developed on the basis of an elementary school common to all. This development shall be governed by the varying requirements of vocations; and the admission of a child to a particular school shall be governed by his ability and aptitude and not by the economic and social position or the religious belief of his parents.

Nevertheless, within the municipalities, upon the request of those persons having the right to education, elementary schools of their own religious belief or of their Weltanschauung shall be established, provided that an organized school system in the sense of Paragraph 1 is not thereby interfered with. The wishes of those persons having the right to education shall be considered so far as possible. Detailed regulations shall be prescribed by state legislation on the basis of a national law.

To enable those in poor circumstances to attend secondary and higher schools, the Reich, the states, and the municipalities shall provide public funds, especially educational allowances for the parents of children who are considered qualified for further education in intermediate and higher schools until the completion of such education.

Art. 147. Private schools as a substitute for public schools shall require the approval of the state (Staat) and shall be subject to the laws of the states (Länder). Such approval shall be granted if the standard of the private schools in their curricula and equipment, as well as in the scientific training of their teachers, does not fall below that of the public schools, and if no discrimination against pupils on account of the economic standing of their parents is fostered. Such approval shall be denied if the economic and legal status of the teachers is not sufficiently safeguarded.

Private elementary schools shall be established only if, for a minority of those persons having a right to education whose wishes must be taken into consideration according to Article 146, Paragraph 2, there is in the municipality no public elementary school of their religious belief or of their Weltanschauung, or if the educational administration recognizes a special pedagogical interest.

Private preparatory schools are abolished.

The existing laws shall continue in force for private schools which do not serve as substitutes for public schools.

Art. 148. In all schools effort shall be made to develop moral education, civic sentiments, and personal and vocational eff- 
ciency in the spirit of the German national character and of international conciliation.

In the instruction in the public schools care shall be taken not to offend the sensibilities of those of contrary opinions.

Civic education and manual training shall be part of the curricula of the schools. Every pupil shall at the end of his obligatory schooling receive a copy of the constitution.

The Reich, the states, and the municipalities shall foster popular education, including people's institutes.

Art. 149. Religious instruction shall be part of the regular school curriculum with the exception of non-sectarian (secular) schools. Such instruction shall be regulated by the school laws. Religious instruction shall be given in harmony with the fundamental principles of the religious association concerned without prejudice to the right of supervision by the state (Staat).

Teachers shall give religious instruction and conduct church ceremonies only upon a declaration of their willingness to do so; participation in religious instruction and in church celebrations and acts shall depend upon a declaration of willingness by those who control the religious education of the child.

Theological faculties in institutions of higher learning shall be maintained.

Art. 150. Artistic, historical, and natural monuments as well as landscapes enjoy the protection and care of the state (Staat).

It shall be the duty of the Reich to prevent the removal of German artistic treasures to foreign countries.

\section{SECTION v}

Economic Life

Art. 151. The organization of economic life must conform to the principles of justice to the end that all may be guaranteed a decent standard of living. Within these limits the economic liberty of the individual shall be assured.

Legal compulsion is permissible only to safeguard threatened rights or to serve the purpose of promoting an overwhelming public interest.

Freedom of commerce and industry shall be guaranteed by national laws.

Art. 152. In economic transactions freedom of contract shall prevail in accordance with the law. 
Usury is prohibited. Legal transactions which are contrary to public policy are null and void.

Art. 153. Property shall be guaranteed by the constitution. Its nature and limits shall be prescribed by law.

Expropriation shall take place only for the general good and only on the basis of law. It shall be accompanied by payment of just compensation unless otherwise provided by national law. In case of dispute over the amount of compensation recourse to the ordinary courts shall be permitted, unless otherwise provided by national law. Expropriation by the Reich over against the states, municipalities, and associations serving the public welfare may take place only upon the payment of compensation.

Property imposes obligations. Its use by its owner shall at the same time serve the public good.

Art. 154. The right of inheritance shall be guaranteed according to the provisions of the civil code.

The share of the state in estates shall be determined by law.

Art. 155. The distribution and use of the soil shall be controlled by the state in such a manner as to prevent abuse and to promote the object of assuring to every German a healthful habitation and to all German families, especially those with many children, homesteads for living and working that are suitable to their needs. Discharged soldiers shall receive special consideration in the homestead law that is to be drafted.

Landed property the acquisition of which is necessary for the satisfaction of the demand for dwellings, for the promotion of colonization and reclamation, or for the improvement of agriculture may be expropriated. Entailments shall be abolished.

The cultivation and use of the soil shall be the duty of its owner toward the community. An increase in the value of land which accrues without the application of labor or capital to the property shall inure to the benefit of all.

All natural resources of the soil and all economically useful forces of nature shall be under the supervision of the state (Staat). Private royalties shall by law be transferred to the state (Staat).

Art. 156. The Reich may by law, without prejudicing the right of compensation, and with due application of the provisions in force with regard to expropriation, transfer to public ownership private economic enterprises suitable for socialization. The Reich itself may participate or may cause the states or municipalities to share in the management of economic enter- 
prises and associations, or may in any other manner assure to itself a determining influence therein.

Moreover, in case of pressing need, the Reich may, in the interest of collectivism, combine by law, on a basis of administrative autonomy, economic enterprises and associations, in order to secure the coöperation of all human elements of production, to give to employers and employees a share in management, and to regulate the manufacture, production, distribution, use, and prices, as well as the import and export, of economic goods upon collectivist principles.

Producing and consuming coöperative societies, or associations thereof, shall upon their request be brought into the collectivist system with due regard for their constitution and peculiarities.

Art. 157. Labor shall be under the special protection of the Reich.

The Reich shall adopt a uniform labor code.

Art. 158. Intellectual labor, rights of authors, inventors, and artists shall enjoy the protection and care of the Reich.

Recognition of, and protection for, the products of German intellect, art, and technical science shall also be secured in foreign countries by international agreements.

Art. 159. For the defense and amelioration of conditions of labor and of economic life, freedom of association is guaranteed to everyone and to all professions. All agreements and provisions which attempt to limit this freedom or seek to hinder its exercise are illegal.

Art. 160. Any person who stands in a service or work relationship as employee or worker shall have the right to such free time as is necessary for the exercise of his civic rights and, in so far as the business in which he is engaged is not thereby seriously interfered with, for the performance of the public honorary official duties assigned to him. The extent to which his claim to compensation shall be recognized will be determined by law.

Art. 161. The Reich shall, with the controlling participation of the insured, establish a comprehensive scheme of insurance for the conservation of health and of the capacity to work, for the protection of maternity, and for the amelioration of the economic consequences of old age, infirmity, and the changing circumstances of life.

Art. 162. The Reich shall endeavor to secure international regulation of the legal status of workers to the end that the en- 
tire working class of the world may enjoy a universal minimum of social rights.

Art. 163. Every German shall, without prejudice to his personal freedom, be under the moral duty to use his intellectual and physical capacity as may be demanded by the general welfare.

Every German shall be given an opportunity to gain a living by productive work. In so far as a suitable occupation cannot be found for him, provision shall be made for his necessary maintenance. Detailed regulations shall be prescribed by special national laws.

Art. 164. The independent middle class in agriculture, industry, and commerce shall be benefited by legislation and administration and shall be protected against exploitation and oppression.

Art. 165. Workers and employees shall be called upon to coöperate in common with employers, and on an equal footing, in the regulation of salaries and working conditions, as well as in the entire field of the economic development of the forces of production. The organizations on both sides and their agreements shall be recognized.

Workers and employees shall, for the purpose of looking after their economic and social interests, be given legal representation in Factory Workers Councils, as well as in District Workers Councils organized on the basis of economic areas and in a Workers Council of the Reich.

District Workers Councils and the Workers Council of the Reich shall meet with the representatives of employers and other interested population groups as District Economic Councils and as an Economic Council of the Reich (Reichswirtschaftsrat) for the purpose of performing economic functions and for coöperation in the execution of the laws of socialization. District Economic Councils and the Economic Council of the Reich shall be constituted so that all important economic groups shall be represented therein proportionately to their economic and social importance.

The National Ministry shall, before proposing drafts of politico-social and politico-economic bills of fundamental importance, submit them to the Economic Council of the Reich for consideration. The Economic Council of the Reich shall itself have the right to initiate drafts of such bills. If the National Ministry fails to assent, it shall nevertheless present the 
draft to the Reichstag accompanied by an expression of its views. The Economic Council of the Reich may designate one of its members to appear before the Reichstag in behalf of the proposal.

Powers of control and administration may be conferred upon Workers and Economic Councils within the spheres assigned to them.

The regulation of the development and functions of Workers and Economic Councils, as well as their relations with other administratively autonomous social bodies shall be exclusively a matter for the Reich.

\section{TRANSITIONAL AND CONCLUDING PROVISIONS}

Art. 166. Until the establishment of the Supreme Administrative Court, the Supreme Judicial Court shall take its place in the organization of the tribunal to examine election returns.

Art. 167. The provisions of Article 18, Paragraphs 3 to 6, shall not be effective until two years after the promulgation of the constitution of the Reich.

Within two months after the German authorities have again taken over the administration of the previously occupied territory, a referendum according to Article 18, Paragraph 4, Sentence 1, and Paragraph 5 shall take place in the Prussian province of Upper Silesia in order to ascertain whether a state of Upper Silesia shall be formed.

If the referendum results affirmatively, the state shall forthwith be established without the necessity of an additional national law. Thereupon the following provisions shall be in force:

(1) Within three months after the official result of the referendum is determined, a state assembly shall be elected which shall be convened for the establishment of the state ministry and the drafting of the state constitution. The President of the Reich shall issue a writ of election according to the provisions of the national election law and he shall fix the election day.

(2) The President of the Reich, in coöperation with the state assembly of Upper Silesia, shall declare when the state shall be considered established.

(3) The following shall be citizens of Upper Silesia:

(a) All adult citizens of the Reich who on the date of the 
establishment of the state of Upper Silesia (No. 2) had within its territory their permanent abode or their domicile shall be citizens from that date;

(b) Other adult Prussian citizens who were born within the territory of the province of Upper Silesia and who within one year after the establishment of the state (No. 2) declare that they desire to be citizens of Upper Silesia shall be citizens on the date of the filing of such declaration;

(c) All citizens of the Reich who by birth, legitimation, or marriage follow the citizenship of any person specified in (a) or (b). ${ }^{1}$

Art. 168. Until the promulgation of the state law provided for by Article 63, but no later than July 1, 1921, ${ }^{2}$ all Prussian votes in the Reichsrat may be exercised by members of its ministry.

Art. 169. The National Ministry shall determine the time at which Article 83, Paragraph 1, shall go into effect.

During a reasonable transition period, the collection and administration of customs and consumption taxes may be left to the states at their request.

Art. 170. The postal and telegraph services of Bavaria and Wuirttemberg shall be taken over by the Reich not later than April 1, 1921.

If no agreement upon the conditions of transfer is reached by October 1, 1920, the Supreme Judicial Court shall decide.

Until the transfer, the existing rights and duties of Bavaria and Württemberg shall remain in force. Postal and telegraph communication with neighboring foreign countries shall, however, be exclusively regulated by the Reich.

Art. 171. State railways, waterways, and maritime signals shall be taken over by the Reich no later than April 1, 1921.

If no agreement upon the conditions of the transfer is reached by October 1, 1920, the Supreme Judicial Court shall decide.

\footnotetext{
1Paragraph 1 of this Article was in the original constitution. The other paragraphs were added by an amendment adopted November 27, 1920. Reichsgesetzblatt, 1920, No. 1987.

By Paragraph 1 no referendum could be had upon a change of the boundaries of a state or the creation of a new state for a period of two years after the adoption of the constitution, i. e., not until August 11, 1921. For a discussion of this amendment, see above pp. $65 \mathrm{ff}$.

${ }^{2}$ Originally this clause read "Within the period of one year." Prussia was unable to comply with the requirement of Article 63. By a constitutional amendment of August 6,1920 (Reichsgesetzblatt, 1920, No. 1565) the time was extended to July 1,1921 .
} 
Art. 172. Until the national law concerning the Supreme Judicial Court (Staatsgerichtshof) goes into effect its functions shall be exercised by a Senate of seven members, four of whom shall be elected by the Reichstag and three by the National Court (Reichsgericht) from among its own members. It shall regulate its own procedure.

Art. 173. Until the promulgation of a national law provided for by Article 138, existing public grants to religious associations based on law, contract, or special legal title shall remain in force.

Art. 174. Until the promulgation of a national law provided for in Article 146, Paragraph 2, the existing legal status shall continue. The law shall give special consideration to parts of the Reich in which schools legally exist that are not divided according to religious beliefs.

Art. 175. The provision of Article 109 shall not be applicable to orders and decorations which may be awarded for services during the years of the war, 1914-1919.

Art. 176. All public officials and members of the armed forces shall take oath to support this constitution. Detailed regulations shall be prescribed by an ordinance of the President of the Reich.

Art. 177. Wherever in existing laws provision is made for the taking of an oath by the use of a religious formula the oath shall also be valid when taken in the following manner: the person taking the oath, omitting the religious formula, shall declare: "I swear." In other respects the content of the oath provided for in the laws shall remain unaffected.

Art. 178. The constitution of the German Reich of April 16,1871 , and the law relating to the provisional powers of the Reich of February 10, 1919, are hereby annulled.

The other laws and ordinances of the Reich shall remain in force in so far as they are not in conflict with this constitution. The provisions of the Treaty of Peace signed at Versailles on June 28, 1919, shall not be affected by this constitution. In consideration of the negotiations for the possession of the Island of Heligoland, deviation may be made from the provision of Article 17, Paragraph 2, in favor of its indigenous population. ${ }^{1}$

Orders legally issued by public authorities on the basis of previous laws shall remain in force until annulled by subsequent order or legislative action.

'This sentence was added by a constitutional amendment of August 6, 1920. Rrichsgesetzblatt, 1920, No. 1566. 


\section{NEW CONSTITUTIONS OF EUROPE}

Art. 179. In so far as reference is made in laws or ordinances to regulations and adjustments which are repealed by this constitution, the corresponding regulations and adjustments of this constitution shall be substituted therefor. Specifically the Reichstag shall take the place of the Constituent Assembly, the Reichsrat shall take the place of the Committee of the States, and the President of the Reich elected by virtue of this constitution shall take the place of the President of the Reich elected by virtue of the law relating to the provisional powers of the Reich.

The power vested in the Committee of the States, according to previous regulations, to enact ordinances shall be taken over by the National Ministry; for the enactment of ordinances the National Ministry requires the consent of the Reichsrat in accordance with the provisions of this constitution.

Art. 180. Until the first Reichstag convenes the Constituent Assembly shall function as the Reichstag. Until the first President of the Reich assumes office, the President of the Reich elected by virtue of the law relating to the provisional powers of the Reich shall exercise the functions of the office.

Art. 181. The German people has, through its Constituent Assembly, determined upon and decreed this constitution. It shall go into effect on the day of its publication.

Schwarzburg, August 11, 1919

The President of the Reich

EBERT

The National Ministry

BAUER

Erzberger

Noske

HermanN Müller

SCHMIDT

SCHLICKE

Dr. MAYer

Dr. Bell

Dr. David

Giesberts 


\section{CHAPTER $\mathrm{X}$ PRUSSIA}

\section{HISTORICAL NOTE}

IT was Prussia that created the North German Confederation in 1866 and the German Empire in 1871. Her obstacle at the time was state particularism. Her instruments were war, intimidation, and a modicum of Bismarckian diplomacy. Once the union was effected her paramountcy in the Empire was never seriously in danger. Hers was three-fifths of the population. Changes in the imperial constitution could be made and other important legislation enacted only with her consent. In fact, little was done without her consent; and practically all things were done at her behest. For the King of Prussia was German Emperor because he was King of Prussia. Herein lay one cornerstone of Prussian political supremacy. As a result, except for a negligible period of time, the Prime Minister of Prussia (President of the Council of Ministers) and the Chancellor of the Empire were always one and the same person. Moreover, this powerful dual officer was always a Prussian, with the exception of Prince Hohenlohe (1894-1900), a Bavarian pre-Empire imperialist, and of Count von Hertling of Bavaria and of Prince Max von Baden, to whom the Emperor turned in something of desperation toward the end of the war.

Federalism it was that the Empire enjoyed; but it was federalism under the hegemony of a single dominant state. ${ }^{1}$

1See above, pp. 62-68; 72-74.

Prussia's position in the German Empire 
Constitution of 1850

The revolution of November, 1918
And the material prosperity that accrued to the Empire, not to mention the Prussianization of the imperial army, served inevitably to enhance this dominance. Prussian supremacy was the most striking characteristic of German federalism as compared with the other federal systems of the world.

When Prussia led the other German states into imperial union, she herself was operating under her constitution of January 31, 1850. Under this instrument she continued to operate. Not a single change of importance was made prior to the opening of the war. Especially was the reactionary three-class system of voting preserved in the face of frequently voiced criticism and denunciation. It was a stalwart bulwark against the possible transformation of democracy from vocal aspiration into reality. It is true that after three years of war (July 11, 1917) an imperial rescript promised the abolition of the three-class system and the introduction of equality of suffrage for the next elections. But the promise came too late. Constitutional reform in Prussia, as in the Empire, was to arrive by the avenue of military defeat.

In November, 1918, the imperial government collapsed. The revolution in the Empire was accompanied by more or less distinct revolutions in each of the several states. Because of her position in the Empire the revolution in Prussia was practically identical with the revolution in the Empire. The flight of the German Emperor was also the flight of the Prussian King. There was established in Berlin not only a provisional government of the Empire but also a provisional government of Prussia. For several months these governments weathered the storms of revolution. In January, 1919, the Prussian provisional government called for the election of a constituent assembly. The election of delegates was held on January 26, 1919, under the system of proportional representation provided by the Decree of November 30, 1918, which regulated 
elections to membership in the constituent assembly of the Reich. ${ }^{1}$

The Prussian constituent assembly came together on March 5. On March 20 the assembly enacted a law setting up a provisional government. Complete power was reserved to the assembly itself, but for the exercise of executive power ministers were provided, each minister being directly responsible to the assembly.

Most of the German states proceeded quickly to draft new constitutions establishing permanent governments on a new legal basis. Some of them antedated the proclamation of the Constitution of the German Reich on August 11, 1919. In one or two instances, as in Bavaria and Wiirttemberg, these hurriedly drafted constitutions had to be remade in the republican form required by the national fundamental law.

Almost of necessity, however, the Prussian constituent assembly made haste slowly. It was well-nigh impossible to establish a permanent government for Prussia until her position in the realm had been predetermined. The South Germans, the party of the Center, and many of the Socialists were strongly opposed, although for very different reasons, to a continuation of the Prussian hegemony. ${ }^{2}$ On the one hand, however, was the necessity for German unity-a close union of the several states. On the other hand was the ineluctable fact of the preponderating Prussian population. How could the union of states be preserved while the paramountcy of Prussia was weakened or destroyed? Out of this dilemma arose the agitation for a segmentation of Prussia and the exaltation of some of her provinces to the status of states of the Reich.

\footnotetext{
'Supra, p. 172. The election results were as follows: Social Democrats, 145; Christian People's Party (old Center or Catholic Federal), 94; German Democratic Party (old Progressives and Radical Liberals), 66; German National People's Party (old Conservatives), 50; Independent Socialists, 24; German People's Party (old National Liberals), 21; Hanoverians, 2. Total 402.
}

¿Paul Matter, "Ia constitution prussienne et les élections du 20 février 1921," Revue des sciences politiques, Vol. 44, No. 2, April-June, 1921, p. 185.

Constituent assembly elected

Assembly worked slowly 
Decentralization in the Reich and in Prussia

Difficulties of the assembly
Everybody must have realized, however, that the dismemberment of Prussia within the Reich would operate in the direction of German weakness, unless a unitary state, which would be controlled by the preponderant Prussian population, were substituted for the federal system. An all-powerful Prussia had been the strength of a powerful Empire; a united Prussia must still be the strength of a federated Germany. The national constitution of Weimar probably settled the unity of Prussia so far as the national federation was concerned. In respect to matters of strictly state concern it was still possible to introduce into the constitution of Prussia as large an amount of decentralization as seemed to be desirable. But the powers of the central government of the realm were so large that this element of decentralization, even if established, could not be of enormous importance in national politics. The national constitution did not alter Prussia as a unit; of necessity, therefore, there had to be a strong central government in Prussia for national purposes. Her relations with the central government Prussia could not devolve upon her provinces.

Even after the integrity of Prussia in the Reich had been fairly determined by the national constitution, the constituent assembly found it no easy matter to draft a form of government adjusted to the new situation 'and acceptable to the various conflicting opinions. A definite draft of a constitution was not presented to the assembly until February 25, 1920. This was the proposal of the Social Democrats comprising the largest single group in the assembly. A special commission was appointed to consider the proposal. Certain changes were made, especially in the direction of increasing the powers of the Staatsrat. The chief difficulty was encountered in respect to the matter of provincial autonomy - a matter which was in the end left largely unsettled. Apparently the only concessions to provincial autonomy are the provision that the mem- 
bers of the Staatsrat, a quasi second chamber, shall be elected by the provincial diets, and the vague and uncertain direction that the provinces and communes shall enjoy self-government and that their powers of selfgovernment may be increased by law. In October the commission made its report and in November the assembly adopted the constitution by a vote of 280 to 60 . The

Constitution of 1920

promulgated constitution was promulgated November 30, 1920, two years after the revolution and fifteen months subsequent to the promulgation of the constitution of the Reich. ${ }^{1}$ The first election under the constitution was held February 20, 1921.

\section{CONSTITUTION OF THE FREE STATE OF PRUSSIA OF NOVEMBER 30,1920}

The Prussian people by its Constituent Assembly gives itself the following constitution, which is hereby promulgated:

\section{SECTION I \\ The State}

Article 1. (1) Prussia is a republic and a member of the German Reich.

(2) The consent of Prussia, required by the constitution of the Reich for territorial alterations, shall be given by law.

(3) The Prussian colors are black and white.

(4) The language used in public business and negotiations shall be German.

\section{SECTION II \\ The Powers of the State}

Art. 2. The sovereignty of the state resides in the whole people.

Art. 3. In accordance with the provisions of this constitution and of the constitution of the Reich, the people shall express

1The following translation was made for this volume from the German text in Preussische Gesetzsammlung, 1920, No. 54. A French version, by M. Robert Redslob, which is not wholly accurate, is to be found in Rerue du droit public et de la science politique, Vol. 38, No. 2, April-May-June, 1921, p. 196. 
their will directly through popular suffrage (popular initiative, popular referendum, and popular election) and indirectly through the agencies established by the constitution.

Art. 4. (1) All German citizens, men and women, over twenty years of age, who are domiciled in Prussia, are qualified to vote.

(2) The right to vote shall be universal and equal and shall be exercised secretly and directly. Election day must be a Sunday or a public holiday.

(3) Detailed regulations shall be prescribed by law.

Art. 5. The following persons shall be denied the right to vote:

(a) those who are under interdiction or who have been placed under temporary guardianship or are under tutelage by reason of mental incapacity;

(b) those who do not possess civil rights.

Art. 6. (1) Popular initiative may be used for:

(a) constitutional amendments;

(b) enactment, amendment, or repeal of laws;

(c) dissolution of the Landtag.

(2) Initiative proposals must be addressed to the Ministry of State and shall immediately be submitted by the latter to the Landtag with a statement of the Ministry's views. A complete draft of law must be the basis of an initiative proposal in cases (a) and (b). The initiative proposal shall be valid only if it is supported in case (b) by one-twentieth and in cases (a) and (c) by one-fifth of the qualified voters.

(3) An initiative proposal shall not be admissible concerning questions of finance, tax laws, and salary regulations.

(4) A popular referendum shall be held upon an initiative proposal and in such other cases as are provided for in the constitution; it shall be valid only if a majority of the qualified voters participate therein.

(5) A popular referendum shall not be held if the Landtag has adopted the initiative proposal.

(6) Proposals for amendment of the constitution, or for a dissolution of the Landtag require for acceptance the consent of a majority of all qualified voters. In other cases a simple majority of the valid votes polled shall determine. The vote may be only by "yes" or "no."

(7) The procedure of popular initiative and popular referendum shall be regulated by law. 
Art. 7. The Ministry of State shall be the supreme executive and directing authority of the state.

Art. 8. (1) The judicial power shall be exercised by independent courts, subject only to law.

(2) Judgments shall be rendered and executed in the name of the people.

\section{SECTION III}

\section{The Landtag}

Art. 9. (1) The Landtag shall consist of deputies of the Prussian people. The deputies shall be representatives of the entire people and shall be elected by them according to the principles of proportional representation.

(2) Qualified voters who are twenty-five years of age are eligible for election.

Art. 10. The deputies shall vote according to their independent convictions, with consideration only for the public welfare; they shall not be bound by orders or instructions.

Art. 11. (1) Officials, employees, and workers of the state and of public corporations shall not be required to obtain leave to sit as deputies.

(2) If they seek election to the Landtag, lcave necessary to carry on their campaign shall be granted to them.

(3) Payments of their salaries or wages shall be continued.

(4) The above mentioned provisions shall not affect the rights conferred upon religious associations by Article 137 of the constitution of the Reich.

Art. 12. (1) The validity of elections shall be verified by a tribunal to examine election returns constituted by the Landtag for this purpose. It shall also decide whether a deputy has lost his seat.

(2) The tribunal to examine election returns shall consist of members of the Landtag, elected by the.Landtag for the legislative term, and, in addition, of members of the Superior Administrative Court (Oberverwaltungsgericht) appointed by the presidency of this Court for the same period.

(3) The tribunal to examine election returns shall pronounce judgment upon the basis of public and oral sittings by a quorum of three members of the Landtag and two judicial members.

(4) Proceedings apart from the sittings of the tribunal to examine election returns shall be conducted by one of the 
members appointed from the Superior Administrative Court, who shall not belong to the above named tribunal to examine election returns.

(5) Detailed regulations shall be prescribed by law.

Art. 13. The Landtag shall be elected for a four-year term. A new election shall take place before the expiration of this period.

Art. 14. (1) A dissolution of the Landtag may take place upon its own motion or by the action of a committee consisting of the Minister President and of the Presidents of the Landtag and of the Staatsrat, or by popular referendum. A popular referendum [on a question of dissolution] may also be had by resolution of the Staatsrat.

(2) The dissolution of the Landtag upon its own motion shall require the consent of a majority of all the legal members.

Art. 15. A new election must be held within sixty days after a dissolution of the Landtag.

Art. 16. In case of a dissolution of the Landtag the legislative term of the new Landtag shall begin on the day of the new election; in all other cases it shall begin with the expiration of the legislative term of the old Landtag.

Art. 17. (1) The Landtag shall meet at the seat of the Ministry of State.

(2) After each new election the Landtag shall assemble for its first session thirty days after the beginning of its legislative term, unless the Ministry of State convokes it at an earlier date.

(3) Thereafter the Landtag shall meet on the second Tuesday in November of each year. The President of the Landtag must call an earlier meeting, if the Ministry of State or not less than one-fifth of the members of the Landtag demand it.

(4) The Landtag shall determine the day of its adjournment and the day of its reassembly.

Art. 18. The Landtag shall elect its own President, its VicePresidents, and its other officers.

Art. 19. Between two sessions, as well as prior to the convening of a newly elected Landtag, the President and VicePresidents of the last session shall carry on its business.

Art. 20. The President shall administer all the business affairs of the Landtag within the limits laid down by the state budget law and with the powers of a minister of state. It shall be his duty to supervise the work of all officials and employees 
of the Landtag, to engage and dismiss all paid employees, and also, in conjunction with the other officers of the Landtag, to appoint and dismiss the civil service officials of the Landtag. He shall represent the state in all legal business and legal actions involved in his administration. He shall exercise powers of discipline and police within the Landtag building.

Art. 21. (1) There shall be a quorum of the Landtag when a majority of the legal membership are present.

(2) The rules of procedure of the Landtag may permit exceptions in the case of elections held by it.

Art. 22. (1) Resolutions of the Landtag require a simple majority of votes.

(2) Exceptions to this rule may be prescribed by law, and in the case of elections by the standing orders.

Art. 23. Plenary sessions of the Landtag shall be public. Upon the request of fifty deputies, the Landtag may by a twothirds majority vote exclude the public for the consideration of special matters on the calendar. Such request shall be dealt with in secret session.

Art. 24. The Landtag and each of its committees may demand the presence of every minister. The ministers and their deputies shall have access to the sittings of the Landtag and of its committees. They may speak in the Landtag at any time regardless of the order of the day. They are subject to the rulings of the presiding officer.

Art. 25. (1) The Landtag shall have the right to, and upon the proposal of one-fifth of its members must, set up committees of investigation. These committees shall in public sitting inquire into such evidence as they or the petitioners consider necessary. The public may be excluded by a two-thirds majority vote. The rules of procedure shall regulate their business and determine the number of their members.

(2) The courts and administrative authorities are required to submit evidence requested by these committees; upon their demand the records of the authorities shall be laid before them.

(3) The provisions of the criminal code shall apply, as far as may be, to the inquiries of committees and of the authorities assisting them; nevertheless, the secrecy of the postal, telegraph and telephone services shall remain unaffected.

Art. 26. The Landtag shall appoint a standing committee for the protection of the rights of the representative body over 
against the Ministry of State, for the period between sessions, and between the expiration of a legislative term or a dissolution of the Landtag and the convening of a new Landtag. This committee shall have the powers of a committee of investigation. Its composition shall be regulated by the rules of procedure.

Art. 27. The Landtag may transmit memorials, addressed to it, to the Ministry of State and may demand from the Ministry information concerning petitions and remonstrances that are filed with it.

Art. 28. (1) Members of the Landtag shall have the right of free transportation on all German railways included within the former Prussian-Hessian railroad system, as well as the right to compensation. In addition to this the President [of the Landtag] shall receive an allowance for official expenses during his term of office.

(2) Refusal of compensation shall not be permitted.

(3) Detailed regulations shall be prescribed by law.

Art. 29. (1) The Landtag shall have legislative authority within the limits prescribed by the constitution; it shall approve the budget of revenues and expenditures; it shall determine the principles according to which state affairs shall be administered, and shall supervise their execution. State treaties (Staatsverträge) require the consent of the Landtag if such treaties relate to matters within the scope of its legislative power.

(2) The Landtag shall determine its own rules of procedure within the limits of this constitution.

Art. 30. A resolution by the Landtag to amend the constitution shall be valid only if at least two-thirds of the legal members are present and at least two-thirds of those present consent.

\section{SECTION IV}

\section{The Staatsrat}

Art. 31. A Staatsrat shall be established to represent the provinces in the legislation and administration of the state.

Art. 32. (1) The Staatsrat shall be composed of representatives of the provinces. The following are recognized as provinces: East Prussia, Brandenburg, City of Berlin, Pomerania, the Posen-West-Prussian Mark, Lower Silesia, Upper Silesia,

\footnotetext{
${ }^{1}$ See Article 167 of the constitution of the German Reich, and note; see also above, pp. 65,66 .
} 
Saxony, Schleswig-Holstein, Hanover, Westphalia, the Rhine Province, and Hessen-Nassau.

(2) For each 500,000 inhabitants a province shall be entitled to one representative, but each province shall have at least three representatives in the Staatsrat. A fraction of more than 250,000 inhabitants shall be counted as equal to 500,000 inhabitants.

(3) In addition, the Hohenzollern Territories shall have one representative.

(4) The number of representatives from the provinces shall be re-determined by the Ministry of State after each general census and after any alterations of the territory of the provinces.

Art. 33. (1) The members of the Staatsrat and their deputies shall be elected by the provincial diets (in Berlin by the municipal council, in the Hohenzollern Territories and in the Posen-West-Prussian Mark by the communal diets). In the Hohenzollern Territories election shall be by majority vote; in all other cases according to the principles of proportional representation. All qualified voters over twenty-five years of age who have been domiciled in the province for one year shall be eligible for election.

(2) No person may be a member of the Landtag and the Staatsrat at the same time. Deputies to the Landtag must resign therefrom upon acceptance of election to the Staatsrat. Members of the Staatsrat must resign therefrom upon acceptance of election to the Landtag.

(3) Members of the Staatsrat shall exercise the functions of their office until their successors have qualified.

(4) A new election of members of the Staatsrat shall take place immediately after a new election of any provincial diet (municipal council, communal diet).

Art. 34. The members of the Staatsrat shall vote according to their independent convictions, with consideration only for the public welfare; they shall not be bound by orders or instructions.

Art. 35. No member of the Staatsrat may at any time be subjected to judicial or administrative prosecution, or be otherwise held responsible outside of the sittings by reason of his vote or by reason of any utterances made in his official capacity.

Art. 36. (1) Officials, employees, and workers of the state and of public corporations shall not require leave in order to exercise their functions as members of the Staatsrat.

(2) Payments of their salaries and wages shall be continued. 
Art. 37. The Staatsrat shall elect its presiding officer and its secretaries and their deputies, and shall regulate its order of business by rules of procedure.

Art. 38. (1) The Staatsrat shall be convened for the first time by the Ministry of State. Thereafter it shall convene upon the call of its presiding officer as often as its business requires. The presiding officer shall convene the Staatsrat if one-fifth of its members or all the representatives of one province or the Ministry of State demand it.

(2) There shall be a quorum of the Staatsrat when a majority of its legal members are present. In case of voting a simple majority of the votes cast shall decide.

(3) For resolutions of the Staatsrat relating to Article 14, and Article 42, Paragraph 1, there must be a recorded vote.

Art. 39. (1) Plenary sessions of the Staatsrat shall be public. The Staatsrat may by a two-thirds majority vote exclude the public for the consideration of special matters on the calendar. A request to exclude the public shall be dealt with in secret session.

(2) The provisions of Article 24 shall apply.

Art. 40. (1) The Staatsrat shall be kept informed by the Ministry of State with regard to the conduct of public business.

(2) Before their introduction bills must be submitted by the Ministry of State to the Staatsrat for examination and criticism. The Staatsrat may communicate its dissenting opinion in writing to the Landtag.

(3) The Staatsrat may submit bills to the Landtag through the Ministry of State.

(4) The Ministry of State must consult the Staatsrat or a competent committee thereof, before issuing decrees for the execution of laws of the Reich and of the state or before issuing general administrative ordinances.

Art. 41. The members of the Staatsrat shall receive such compensation for travel and official expenses as may be fixed by law. Refusal thereof shall not be permitted.

Art. 42. (1) Laws enacted by the Landtag shall be subject to veto by the Staatsrat.

(2) The veto must be communicated to the Ministry of State within two weeks after the final vote in the Landtag and within two additional weeks must be supported by reasons.

(3) In case of veto the law must be presented to the Landtag for reconsideration. If the Landtag reaffirms its original resolu- 
tion by a two-thirds majority vote, this resolution shall be final. If, however, in the reconsideration by the Landtag only a simple majority vote is obtained for the original resolution, the resolution shall be invalid, unless it be approved by a popular referendum initiated by the Landtag.

(4) The approval of the Staatsrat is necessary if the Landtag desires to vote expenditures which are in excess of the amounts proposed or approved by the Ministry of State. If the Staatsrat refuses consent, the resolution of the Landtag shall be valid only in so far as it agrees with the proposal or approval of the Ministry of State. A popular referendum shall not be applicable in such circumstances.

Art. 43. Detailed regulations shall be prescribed by law.

\section{SECTION $\mathrm{v}$ \\ The Ministry of State}

Art. 44. The Ministry of State shall consist of the Minister President and the ministers of state.

Art. 45. The Landtag shall elect the Minister President without debate. The Minister President shall appoint the other ministers of state.

Art. 46. The Minister President shall determine the general principles of governmental policy and shall be responsible for them to the Landtag. Within these principles each minister of state shall independently carry on the branch of administration entrusted to him, and shall himself be responsible to the Landtag.

Art. 47. (1) The Minister President shall be chairman of the Ministry of State and shall conduct its business.

(2) The Ministry of State shall determine the jurisdiction of each minister of state in so far as this has not been regulated by legislative enactment. Such determinations shall be immediately submitted to the Landtag and must be altered or repealed at the request of the Landtag.

(3) Differences of opinion in respect to matters pertaining to the scope of the authority of the several ministers of state must be submitted to the Ministry of State for consideration and decision.

Art. 48. The ministers of state shall be entitled to remuneration. Pensions and provision for dependent survivors shall be determined by special law. 
Art. 49. The Ministry of State shall represent the state in external affairs.

Art. 50. The Ministry of State shall pass on bills which shall be presented to the Landtag.

Art. 51. The Ministry of State shall issue ordinances for the execution of the laws in so far as this duty is not imposed upon individual ministers of state by law.

Art. 52. The Ministry of State shall appoint all officials who are directly under its jurisdiction.

Art. 53. The Ministry of State shall appoint delegates to the Reichsrat except when they are appointed by the provincial administrations as provided for by Article 63 of the constitution of the Reich.

Art. 54. (1) The Ministry of State shall exercise the pardoning power in the name of the people.

(2) In the case of a minister who has been condemned for malfeasance in office this power may be exercised only at the instance of the Landtag.

(3) General amnesties or discontinuance of prosecutions in special classes of criminal cases, or in a single pending criminal case, may take place only upon the basis of a law.

Art. 55. If the maintenance of public safety or the meeting of an unusual emergency urgently requires it, the Ministry of State may, when the Landtag is not in session, in conjunction with the standing committee provided for in Article 26, issue ordinances not in conflict with this constitution, which shall have the force of laws. Such ordinances must be submitted to the Landtag for approval at its next session. If approval is refused, the ordinance must be immediately declared void by publication in the Law Gazette.

Art. 56. The ministers of state, upon their induction into office, shall take an oath to perform their duties impartially and for the public welfare, and in accordance with the constitution and the laws.

Art. 57. (1) The Ministry of State as such and each individual minister of state must possess, in order to retain office, the confidence of the people, which is expressed through the Landtag. The Landtag may withdraw its confidence in the Ministry of State or in an individual state minister by express resolution. Such resolution shall not be valid if a popular referendum to dissolve the Landtag is legally invoked. 
(2) A petition which initiates such a resolution must be signed by at least thirty deputies.

(3) Such petition shall be voted upon no earlier than the second day after its consideration. It must be acted upon within fourteen days after its introduction.

(4) A recorded vote must be taken on a question of lack of confidence.

(5) A resolution of lack of confidence shall be valid only if approval is given by at least one-half of the total membership of the Landtag at the time.

(6) If the resolution is passed, the ministers affected thereby must resign, but the Minister President must resign only if he does not avail himself of his privilege of requesting a dissolution of the Landtag or if such request is denied by the committee. ${ }^{1}$

(7) These provisions shall apply also in case the Ministry of State as a whole or an individual minister demands a vote of confidence.

Art. 58. (1) The Landtag shall have the right to bring an action before the State Supreme Court (Staatsgerichtshof) against any minister for having wilfully violated the constitution or the laws. The bill to initiate such an action must be signed by at least one hundred members of the Landtag and shall require the consent of such a majority as has been designated for changes in the constitution.

(2) The composition of the State Supreme Court, its procedure, and the decisions to be rendered by it shall be regulated by law.

Art. 59. (1) Any state minister may resign his office at any time.

(2) In the event of a resignation of the entire Ministry of State, the resigning ministers shall carry on current business until it is taken over by the new ministers.

\section{SECTION VI}

\section{LEgisLATION}

Art. 60. The Ministry of State shall publish in the Prussian Law Gazette laws constitutionally enacted and state treaties approved by the Landtag.

Art. 61. (1) A law shall be binding when it has been constitutionally enacted and has been published by the Ministry of

\footnotetext{
'See Article 14, Clause 1.
} 
State in the form prescribed. The publication shall indicate whether the law was enacted by the Landtag or by a popular referendum. Article 13 of the constitution of the Reich shall not be affected hereby.

(2) If the law does not otherwise specify it shall go into effect on the fourteenth day after its publication in the Law Gazette.

(3) The laws must be published within a month.

Art. 62. Bills which are rejected by the Landtag shall not be introduced again during the session, unless a valid popular initiative so demands.

\section{SECTION VII}

\section{Finance}

Art. 63. (1) The Landtag shall vote the necessary current funds to meet the needs of the state.

(2) All revenues and appropriations of the state must for each fiscal year be estimated and incorporated in the budget. The budget must be adopted by law before the beginning of the fiscal year.

(3) The appropriations shall as a rule be voted for one year; in special cases they may be voted for a longer period. Except in such cases the budget law shall not contain provisions which run beyond the current fiscal year or which do not relate to the revenues and appropriations of the state or to their administration.

Art. 64. If before the end of a fiscal year the budget for the following year has not been determined by law, the Ministry of State shall be empowered until a budget goes into effect:

(a) to make all expenditures which are necessary in order:

(i) to maintain legally existing institutions and to execute legally adopted measures,

(ii) to fulfill the lawful obligations of the state,

(iii) to continue building operations, contracts, and other undertakings for which appropriations have already been granted in the budget of a previous year, as well as to continue under the same conditions subsidies for building operations, contracts, and other undertakings.

(b) to issue, for periods of three months, treasury notes to the amount of one-fourth of the total of the previous budget, in so far as revenues derived by 
special laws from taxes, duties, and other sources do not cover the expenditures under clause (a).

Art. 65. Funds may be procured upon credit only for extraordinary needs and as a rule only for expenditures for productive works. Such a procurement as well as the assumption of any liability by the state may be undertaken only by authority of a law.

Art. 66. Resolutions of the Landtag which authorize additional expenditures apart from the budget or which will result in such additional expenditure in the future must at the same time specify how such additional expenditures shall be met.

Art. 67. (1) Expenditures in excess of amounts granted by, or not included in, the budget must be approved by the Landtag within the next fiscal year.

(2) Expenditures in excess of amounts granted by, or not included in, the budget require the approval of the Minister of Finance. Such consent shall be given only in case of an unforeseen and unavoidable emergency.

Art. 68. The budget accounts shall be examined and approved by the Superior Board of Audit. The general budget accounts of each year and a schedule of state debts shall be submitted to the Landtag with a statement from the Superior Board of Audit, which shall operate to discharge the Minister of Finance from responsibility.

Art. 69. Notwithstanding the provisions of Articles 63-68 the financial management of revenue-producing enterprises of the state may be regulated by law.

\section{SECTION VII}

\section{Local Autonomy}

Art. 70. Municipalities and groups of municipalities have the right of local autonomy in their affairs under the supervision of the state as may be determined by law.

Art. 71. (1) The state shall be divided into provinces.

(2) the division of the provinces into circles, cities, rural municipalities, and other groups of municipalities as well as the constitution, rights, and duties thereof shall be regulated by law.

Art. 72. (1) In accordance with the provisions of law and through their own agencies: 
(a) the provinces shall administer independently their own affairs, whether imposed upon them by law or voluntarily assumed by them (matters of local autonomy);

(b) the provinces shall, as executive agencies of the state, administer those state affairs which have been devolved upon them (delegated matters).

(2) The law may extend the sphere of matters of local autonomy assigned to the new provinces and may devolve delegated matters upon them.

Art. 73. The provincial diets may, by provincial legislation, permit, in addition to German, the use of another language:

(a) as a language of instruction for foreign language parts of the population, provided the protection of German minorities is safeguarded;

(b) as another official language in multiple language districts.

Art. 74. The fundamental principles applying to elections to the popular representative bodies shall apply also to elections to provincial, circle, and municipal representative bodies. Nevertheless, in the case of elections to municipal representative bodies, the election qualification may by law be made to depend upon a specified period of residence in the municipality.

Art. 75. (1) Officials, employees, and workers of the state and of public corporations shall not require leave in order to exercise their functions as members of a provincial, circle, or municipal representative body.

(2) Payment of their salaries and wages shall be continued.

\section{SECTION IX}

\section{Religious Associations}

Art. 76. (1) Any person who desires to withdraw from a public corporate religious association exercising civic functions shall make a declaration of withdrawal before a court or shall file a personal declaration duly sworn to. The tax liability of the person who withdraws shall not be extinguished before the end of the tax year in which the declaration of withdrawal is made.

(2) Detailed regulations shall be prescribed by law. 


\section{SECTION $\mathrm{x}$ \\ State Officials}

Art. 77. (1) Any citizen of the Reich, without regard to sex or previous occupation, may, if he possesses the qualification for the office, be appointed a state official.

(2) The necessary qualification for specific offices shall be prescribed by law.

Art. 78. Every state official must take an oath that he will discharge the duties of the office entrusted to him impartially and according to his best knowledge and ability, and that he will conscientiously uphold the constitution.

Art. 79. (1) State officials may not, against their will, be temporarily or permanently retired upon pension, or transferred to another position with a lower salary except under conditions and according to forms prescribed by law.

(2) Resort to legal process shall be permitted for the prosecution of the lawful salary claims of state officials and of their dependent survivors.

Art. 80. In addition the law of officers shall be determined by legislation in accordance with the law of the Reich.

\section{SECTION XI}

\section{-Transitional and Final Provisions}

Art. 81. (1) The constitution of January 31, 1850, and the law of March 20,1919, relating to the provisional organization of public powers in Prussia are hereby repealed.

(2) All other existing laws and ordinances not in conflict with the provisions of this constitution shall remain in force.

Art. 82. (1) The powers which according to previous laws, ordinances, and treaties were vested in the King are hereby transferred to the Ministry of State.

(2) The rights which pertained to the King as temporal head of the Established Church of Prussia shall be exercised by three ministers of the evangelical faith appointed by the Ministry of State, in so far as the evangelical churches have not by ecclesiastical laws, approved by state law, transferred such rights to church authorities.

(3) All other rights hitherto exercised by the King as against religious associations shall be regulated anew in accordance with Article 137 of the constitution of the Reich. 


\section{NEW CONSTITUTIONS OF EUROPE}

Art. 83. At the instance of any interested party an existing patronage shall be annulled as soon as lawful financial obligations shall have been cancelled. The procedure and the principles for the cancellation shall be prescribed by law.

Art. 84. Existing taxes and duties shall continue to be levied until altered or repealed.

Art. 85. Until the convening of the first Landtag the Constituent Assembly shall function as the Landtag.

Art. 86. Until the legislation provided for in Article 72 goes into effect, the Oberpräsidents, the Regierungspräsidents, and the presiding officers of the provincial education council and of the bureau of agriculture shall be appointed in agreement with the provincial committee.

Art. 87. Constitutional conflicts shall be decided by the State Supreme Court.

Art. 88. This constitution shall be in force from the date of its publication except for Articles 31-43, 72, and 86. These Articles shall not be in force until the provincial diets shall have been newly elected as provided by Article 74 .

Berlin, November 30, 1920

The Prussian Ministry of State

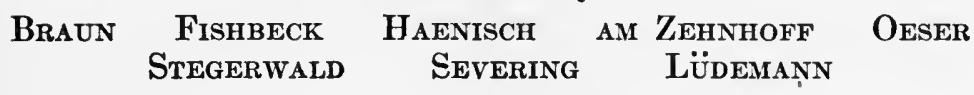




\section{CHAP'TER XI \\ BAVARIA, WÜRTTEMBERG, AND BADEN ${ }^{1}$}

AfTER the revolution of November, 1918, the states that had been members of the German Empire were faced with the problem of adopting new constitutions. In this matter, however, they could not proceed according to their own free will, for in Article 17 of the constitution of the Reich of August 11, 1919, certain basic provisions were laid down to which the constitutions of each of the federal states had to conform. It was, for example, necessary that the Government of each one of the states should at all times possess the confidence of the popular representative body. Furthermore, the states were prevailed upon to give up the idea of electing presidents, and it was also suggested that they should constitute their executives on the Swiss pattern. Their problem, therefore, was a new one; they had to combine a parliamentary system and a collegial or directorial system. The question arises whether a fusion of these two systems is possible unless one of them loses its essential characteristics. This question can best be answered by considering the solutions that are attempted by the constitutions of the different free states.

\section{The Government of Bavaria According to the Constitution of August 14, 1919}

Eight days before the elections to the constituent assembly on January 4, 1919, the provisional government

1This description of the governments of the German states is condensed from Adelheid Meuschel, "Die Regierungsbildung im Deutschen Reich und seinen Ländern nach den Vorschriften der gegenwärtig gültigen Verfassungen," Archiv des öffentlichen Rechts, Vol. XLI, pp. 32ff. (Tübingen, 1921).

The Reich and the State constitutions
Bavarian constituent assembly 


\section{4 NEW CONSTITUTIONS OF EUROPE}

Provisional fundamental law

Position of Ministry under provisional law issued a basic law which was to serve as a guide for the assembly when it proceeded to the drafting of a new constitution. ${ }^{1}$ This law, however, was vague on the question of the form of the government. In case of conflict between the Landtag and the Government, it was the idea that the people themselves should decide. The probable purpose of this provision was to allow the Government to have the support of the people on which to fall back in case of dispute with the Landtag. This provision, however, was not adopted.

The first meeting of the constituent assembly was interrupted by a popular outbreak on February 21. When it met again in March, 1919, a fundamental state law was adopted, which provided in Section 8 that the highest executive authority should be exercised by the entire Ministry. The presiding officer of the Ministry was to be elected by a majority vote of the assembly. The other ministers were to be chosen by him. Since it was necessary for the ministers to have the confidence of the assembly at all times, it was also necessary for the presiding officer to undertake the selection of his colleagues in consultation with the parties in the assembly.

It is therefore clear that the parties of the assembly were to exercise the controlling influence in the formation of the Government. Section 7 of the temporary fundamental state law provided that the final decision with regard to the formation of the Government should lie with the voting population, for the Ministry was given the right, in case of a resolution of the assembly that was contrary to the fundamental state law, to cause a referendum to be had with regard to the resolution. This referendum should at the same time decide as to the continued

\footnotetext{
${ }^{1}$ On October 30, 1919, the Free State of Coburg decided by an overwhelming majority to join the Free State of Bavaria and on March 11, 1920, the Bavarian Landtag unanimously adopted a bill for the union of the two States. See above, p. 67. Coburg had three representatives in the constituent assembly that drafted the Bavarian constitution.
} 
existence of the Ministry. 'This provision, however, did not secure a balance between the popular representative body and the Government itself, because the decision of the people could be had only in certain definitely prescribed eases, namely, if a resolution of the Landtag was in violation of the fundamental state law. The continued existence of the Ministry was in all other cases subject to the will of the assembly, which had constituted it and which could cause it to resign in case of a vote of lack of confidence. Accordingly, the temporary fundamental state law had not created a parliamentary system in its true form. The solution of this problem was reserved for the constitution.

A draft of the final constitution was presented to the assembly by the Government on May 28, 1919. It was referred to a committee which changed many details, but which did not touch the fundamentals of the draft. The final draft presented by the committee was accepted by the assembly without change and was promulgated on August 14, 1919, three days after the promulgation of the constitution of the Reich.

Section 58 of the constitution contains the provisions applying to the formation of the Government. The Ministry is appointed by the Landtag and thus derives its power from the representatives of the people. As in the provisional constitution, the Minister President is chosen by the Landtag on the basis of a majority vote. He in turn recommends a list of the other ministers to the Landtag and they are appointed by him with its consent. In case of a ministerial crisis the various parties of the Landtag hold a conference in order to determine which parties shall combine to form a parliamentary majority, and in order to nominate a Minister President and the personnel of the new ministry on the basis of the relative strength of the parties. In other words, the constitution provides

The constitution of 1919

The Ministry under the final constitution 
Modes of dissolution

The

Landtag dominates

Württemberg constituent assembly a definite machinery for the creation of coalition ministries, which subsequently are formally ratified by the Landtag.

Article 31 empowers the Landtag to dissolve itself. It seems improbable that the Landtag will use this method of appealing to the people in case of dispute with the Government, since it has express authority to substitute a new government for one with which it does not agree.

The final constitution does not permit the Ministry to appeal to the people for a decision by popular referendum in case of dispute with the Landtag. Section 40 of the first draft had provided for such action, but this privilege of the Government was later eliminated. The Landtag may dissolve itself, or it may be dissolved if one-fifth of the qualified voters so demand. This demand must be made on the basis of a vote in which at least one-half of the qualified voters have taken part, and at least twothirds of those who vote must be in favor of the dissolution. It is apparent that the power that has been placed in the hands of the people can be used only in very unusual cases. In truth, the Government itself is unable, under the new constitution, to defend its stand on any particular question. The most important factor is the Landtag, and on careful analysis one sees that the people themselves play only a minor part in the direction of the policies of the Government except in the matter of electing the Landtag.

The Government of Württemberg According to the Constitution of September 25, 1919

The revolutionary government of Wiirttemberg caused the election of a constituent assembly to be held on January 12, 1919. On April 26, 1919, a constitution was adopted by this assembly, but the promulgation of the constitution of the Reich in August made many changes 
necessary. On September 25, 1919, however, the final draft was approved and adopted. On the whole, the provisions relating to the formation of the Government are the same in this constitution as in the Bavarian constitution.

The constitution of Württemberg expressly provides (Article 27) that a new ministry shall be formed after each election of a Landtag. This provision would appear to be wholly unnecessary, or at best purely a formal matter, since the returns of the elections will automatically fix the status of the former ministry and its ability to remain in office. The probable intention of the article was to give an appearance of direet influence on the part of the voting population in the formation of the Ministry.

In Württemberg the Government has the right to invoke a popular referendum on the dissolution of the Landtag (Article 16). While they may eall on the people to Referendum on dissolution act as judges in case of dispute with the Landtag, the Ministry will scarcely take this step, for, if it be assumed that they have properly estimated the state of public opinion, and if the popular referendum decides for the dissolution of the Landtag, the new elections will bring a majority into the Landtag which will certainly differ from that majority which put the Government into office.

It is true, however, that the weapon that has been placed in the hands of the people to control the Landtag is worked out on a better plan than it is in Bavaria. Onefifth of the qualified voters may, according to this constitution, demand that a referendum be had with regard to the dissolution of the Landtag. But only a majority of those voting need be in favor of a dissolution. The result is that this constitution succeeds somewhat better in bringing about a balance between the authority of the Landtag and that of the Ministry. 


\section{8 NEW CONS'TITUTIONS OF EUROPE}

The Government of Baden According to the ConStitution of MARCH 21, 1919

It may be said that the changes that took place in Baden after the revolution were probably carried into effect with greater dispatch and with less opposition than in any other state of the Reich. The constitutional assembly met for the purpose of adopting a constitution in January, 1919; the draft was presented in March of the same year and was accepted and promulgated as early as April 13, 1919.

The Baden collegial executive

Control by Landtag

The provisions of the constitution of this state vary markedly from those of the constitutions of the states mentioned previously. Especially is this true of the formation of the Government as provided in Articles $52 \mathrm{ff}$. The constitution of Baden attempts, in so far as is possible, to follow the provisions laid down in the constitution of Switzerland. 'The parliamentary system that is imposed upon the states by Article 17 of the constitution of the Reich is followed in Baden only in so far as is absolutely necessary to conform with this national requirement.

The Ministry is a collegial executive. The ministers, seven in number according to a law of April 2, 1919, are elected in open meeting of the Landtag for their individual offices. Thereafter the Landtag elects the Minister President from among the ministers.

In the constitution of Baden the Landtag is vested with power to recall the entire Ministry or any member of it by a majority vote. A vote of lack of confidence in the Ministry is therefore not necessary to force the entire Ministry or members of it out of office. Manifestly this provision is only a change in form from the provisions mentioned in the previous constitutions, since a Ministry in order to remain in office must have the confidence of the Landtag which can at all times either vote it down or bring a direct vote of expulsion. Contrary to the custom 
in Switzerland, each member of the Ministry in Baden must be affiliated with some one of the parties represented in the Landtag; here also the formation of a Ministry is undertaken on the basis of the relative strength of the parties.

The formation of the Government may be influenced by the people every four years at the time of the general elections. Apart from this, provision is made that 80,000 voters may at any time demand a referendum upon the question of a dissolution of the Landtag. This must be carried out within one month; and if a majority of those voting express themselves in favor of dissolution it must be ordered by the Ministry. It is to be observed that 80,000 electors constitute only one-fifteenth of those eligible to vote. The fact that such a small number is necessary to initiate a demand for a popular referendum is noteworthy, because it gives the opposition parties a much better chance to carry out a threat of overthrowing the Government than in Bavaria and Wüttemberg where one-fifth of the qualified voters must initiate the demand for a referendum. The constitution as finally adopted does not give the Landtag the right to dissolve itself, nor does it permit the Ministry to dissolve it, the idea being that the Ministry is at all times subject to the Landtag. In other words, the Landtag, as an organ of popular will, is the central directing body; it elects and controls the Ministry. The Government is intentionally subordinated to the popular representative body. At best the people can be considered as factors only in the general elections after each legislative term; for at other times their potential power will rarely be brought into play.

It is, of course, impossible at this time to venture any detailed criticisms of the provisions of the constitutions of Conclusions impossible the German states. The new governments have been in

Control by voters over dissolution

Importance of Landtag 
240 NEW CONSTITUTIONS OF EUROPE

existence for a short time only. The formation of the Ministries and their responsibility to the Landtags raise what are probably the most important and the most interesting questions in connection with the constitutions; but the wisdom of the adjustments that have been made can be tested only by experience. 


\section{CHAPTER XII}

\section{AUSTRIA}

\section{HISTORICAL NOTE}

IT would require pages of historical recital to describe with approximate accuracy the origin of the political entity that was known from 1867 to 1918 as the AustroHungarian Monarchy. Suffice it to say that the period from 1859 to 1867 marked an epoch of importance in the politico-legal relations of the group of twenty-odd political units which, united under the absolutism of the Hapsburg dynasty, were generically known as the Austrian Empire. Of these political units, or provinces, Hungary was by far the largest; and it was Hungary's claim that the interests of Croatia, Slavonia, and Transylvania were, as against most of the other provinces, closely tied up with her own interests. Over against these Hungarian interests and aspirations were set those of a group of German controlled provinces in the west. The Italians in the southwest, the Czechs in Bohemia and Moravia to the northwest, and the Poles and Ruthenes in Galicia and Bukowina to the northeast, were by no means enamored of close union with the Germans; but they were also not drawn to the Hungarians.

When it became no longer possible to stem the tide of demand for an abolition of absolutism in favor of a constitutional system, the issue was squarely presented whether there should be a centralized system, which the Germans advocated; or a federal system, which would have met the wishes of the minor nationalities and especially of the Czechs and Poles; or a dual system, which the Hun-

Austrian affairs, 1859 to 1867

Centralization, dualism, or federalism 
The

Diploma of 1860

The Patent of 1861

Importance of the Patent

garians demanded, and which the Germans on the whole preferred to federalism. The steps which led up to the triumph of dualism in $\mathbf{1 8 6 7}$ may be briefly recounted.

In March, 1860, the Emperor called the first legislative assembly of the whole Empire. This assembly was in fact merely the old so-called Reichsrat of permanent officials, reinforced by certain life members and certain appointees of the Emperor. It was almost exclusively aristocratic. In October, 1860, an imperial Diploma was issued which was said to be "completed" but was actually superseded in February, 1861, by an imperial Patent establishing in effect a centralized form of government.

The Patent instituted a Reichsrath, composed of two Chambers. In the first, the Chamber of Lords, were represented, by right of succession or nomination, those who, by birth, position, or merit, belonged to the aristocracy. In the second, the Chamber of Deputies, sat 343 representatives, who were elected by the provincial Diets on the system of the representation of interests. Like the members of the Diet itself, they were divided into four Curio, namely, the great landowners, the Chambers of Commerce, the cities, and the rural districts. In each Curia a certain payment in taxes was the qualification for the franchise. The value of the vote varied considerably in the several Curice and provinces: some deputies were elected by two or three votes only, others by between ten and twelve thousand. In every case, the German provinces or districts were favored and the Slavs treated unfairly. Under the cloak of principle, all principle was ignored; for the sole object was to set up a Reichsrath which would not hamper the Government. Moreover, both in the Diets and in the Chamber of Deputies, everything was calculated to ensure a permanent majority of the great landowners, on whose unflinching devotion the Government reckoned in all circumstances. ${ }^{1}$

This constitution, or Patent, was never in full operation, for Hungary refused to send representatives to the Reichsrat, and after a brief trial the Czechs withdrew. The Patent was suspended in September, 1865. But the char-

${ }^{1}$ Cambridge Modern History, XII, pp. 178, 179 (London, 1910). 
acter of the parliament or Reichsrat which it established is of importance, for it was the Austrian "rump" of this Reichsrat which in 1867 agreed to the dualistic compromise with Hungary and enacted the constitution under which the Austrian part of the Dual Monarchy was governed down to 1918.

In the year 1866 occurred the seven weeks' war between Austria and Prussia. The swift and decisive defeat of Austria not only made possible the creation of the German Empire but also made it inevitable that Hungary would successfully assert a large measure of autonomy in a new constitutional system for the agglomeration of states known as Austria. Before the signing of the treaty of peace on August 20, 1866, negotiations were got under way between Deák and Count Andrássy, the Magyar leaders in Hungary, and Baron Beust, the Chancellor and Minister President of Austria.

The Hungarian scheme for dividing the Empire into two sections, under German and Magyar leadership respectively, had been completed just before the outbreak of hostilities. A commission of the Hungarian diet had

The Hungarian scheme of dualism perfected a proposal of organization for the conduct of affairs common to the two sections. This was the Hungarian program; and on the part of Hungary ratification by her own diet was sufficient to give the proposal legality. But there was no such unity of program among the numerous non-Hungarian provinces, and there was no 'single legislative body to act in their behalf. There were those who urged that a special Reichsrat be called, consisting of representatives elected by all of the diets (including that of Hungary) without distinction of curia. But it was certain that such an assembly would amend the Hungarian scheme in the direction of federalism. In the end the Emperor, by a Patent of January 1, 1867, ordered new elections of diets in a designated list of provinces and convoked a Reichsrat the lower house of which 
The "smaller" Reichsrat

The

Ausgleich of 1867

Character of the Dual Union consisted of members chosen by these provincial diets in accordance with the illiberal provisions of the constitution of 1861. Hungary, Croatia, Slavonia, and Transylvania were not called upon to send representatives to this Reichsrat. $^{1}$ The effect of this patent was to insure the success of dualism; for it gave legal recognition to a division of the Empire into two segments. The non-Hungarian segment was to be represented in this so-called "smaller" Reichsrat. By dissolving provincial diets and manipulating elections, this body was made safely German and therefore anti-federalist. The Hungarian part of the new Austro-Hungarian Monarchy naturally continued to be known under the ancient title of the Kingdom of Hungary. In popular usage both in and out of the Dual Monarchy the non-Hungarian part came to be called the Austrian Empire. $^{2}$

On May 29, 1867, the Ausgleich, or Compromise, founded upon the proposal of Hungary, was formally ratified by the Hungarian diet; but the Austrian "smaller" Reichsrat, which had just assembled, proposed certain amendments. Thereupon deputations of fifteen members from each of the parliaments met as a kind of conference committee. The proposals upon which they agreed were finally adopted, although not in identical forms, by both parliaments. The Austrian act bears the date of December 21, 1867.

The Union of Empire and Kingdom was unique. It was more than a mere personal union but less than a federation. Although there were only two units, it perhaps more nearly approximated a confederation founded upon a treaty. Apart from the three central organs of the Union, each of the units was completely autonomous. These central organs were the Crown, the so-called Dele-

${ }^{1}$ Reichs-Gesetz-Blatt für das Kaiserthum Oesterreich, 1867, p. 1.

${ }^{2}$ From 1867 the official designation for the Austrian part of the Dual Monarchy was simply "the Kingdoms and Lands represented in the Reichsrat." It was not until 1915 that the term "Austrian Empire" was officially adopted. 
gations, and the Ministers of Foreign Affairs, War, and Finance. For the most part the relations of the monarch were not with the Austro-Hungarian Monarchy but with Austria as Emperor and with Hungary as King. For the consideration of certain common affairs each parliament elected annually a Delegation of sixty members. These Delegations sat as separate houses, except in case of disagreement, and alternately in Vienna and Budapest. Save for approving appropriations and dealing with some matters relating to the common ministries, the Delegations enacted no laws. There was uniform legislation on a few important subjects, but it was not enacted by the Delegations. It consisted of identical or parallel laws enacted by each of the parliaments. Upon many subjects the laws of the two parts of the Monarchy were not in accord. It is needless to say that under these circumstances there could be no such thing as a central responsible ministry of the Dual Monarchy. Ministerial responsibility implies at least some measure of unity in the system of representative control. There was little or no unity in the coequal and often clashing Delegations; and there was still less unity in the coequal parliaments, each consisting of two approximately coequal chambers. The common ministers of Foreign Affairs, War, and Finance stood in a wholly anomalous and uncertain position between the EmperorKing on the one hand and the Deputations of two almost independent and internally discordant parliaments on the other.

The inexactitude of powers and responsibilities in this strange union was a more or less exact reflection of the racial and other elements of disharmony upon which the union rested. The scheme inevitably played into the hands of a powerful and autocratic bureaucracy. By and large, the influence of Hungary not only outweighed that of Austria but was also wholly out of proportion to her relative population or wealth. For the Magyars, though

Absence of ministerial responsibiiity

Results of the scheme 
in bare majority, dominated the other peoples of Hungary and were able to present a united political front and purpose that could not be matched in Austria by the efforts of the German-Austrians to dominate the Czechs and the Poles.

Economic interdependence

Austrian and Hungarian counter influences

The geography of Austria
It is true that, in addition to the magnet of dynasty, one far-reaching circumstance of cohesion existed; economically there was an immense amount of interdependence among the parts of the loosely knitted Dual Monarchy. ${ }^{1}$

Even so, in view of the fragile character of the organs of Union between Austria and Hungary, one might hazard the guess that the institutional history of the one could be written without much regard for that of the other. In fact, quite the reverse is true. Paradoxical as it may seem, the thin quality of the legal Union made the internal affairs of each part of the Dual Monarchy a matter of concern to the other part. Especially would it be impossible to describe the political or institutional life of the Austrian part of the Monarchy without consideration of the Hungarian influence. But whatever may be true of history, it is manifest that the institutional cord that joined the two grand divisions of the Monarchy could be severed without any serious shock to either of the bodies politic. In the dissolution of the Monarchy in 1918, this severance of course occurred. It is, therefore, not only possible but almost indispensable to consider the situation and the eventualities in the Austrian Empire apart from those in the Kingdom of Hungary.

It was Hungary that gave geographical compactness to the Dual Monarchy. The Kingdom fitted like a huge ball into the far-flung crescent of the Empire. This Austrian

" The political powers, then, which control respectively the Austrian and the Hungarian half of the Monarchy, have reckoned with the economic factor, and have both concluded that it is the determining force in their political destinies. They see that neither of them is economically strong enough to stand alone, and that the alternative to 'Dualism' is not independence, but the incorporation of each in another group or unit." Toynbee, Nationality and the War, p. 121 (New York, 1915). 
crescent was two thousand miles in length and only about one hundred miles in average width. ${ }^{1}$ With Hungary excluded, the geographical sprawl of political Austria was positively fantastic. Upon such a territory, carved out of the heart of Europe, it would have been difficult to hold even a homogeneous people in political integration. And the peoples of Austria were highly heterogeneous. According to the Austrian census of 1910 there was a total population in the seventeen provinees of $28,500,000 .^{2}$ Of these a little more than one-third were German, something more than one-fifth were Czechs, slightly more than onesixth were Poles, and about one-eighth were Ruthenians. The other included nationalities, in the order of their numbers, were Slovenes, Italians, Serbs, Croats, and Rumanians. About three-fifths of the Germans were concentrated in seven western provinces, ${ }^{3}$ in most of which they were in overwhelming majority; but they also constituted important minorities in the three provinces of the northwest. ${ }^{4}$ The Czechs were concentrated almost wholly in two of these northwestern provinces-Bohemia and Moravia-where they were in very substantial majority. Apart from constituting a sizeable minority in Silesia, the Poles were almost exclusively in the huge western province of Galicia, where they outnumbered the Ruthenians three to two. The Ruthenians and Rumanians had large and nearly equal minorities in Bukowina, at the eastern tip of the crescent. In the southwestern provinces bordering on Italy and the Adriatic, Germans, Italians, Slovenes, and Serbo-Croats intermingled in varying and bewildering combinations from province to province. ${ }^{5}$

\footnotetext{
${ }^{1}$ Bowman, The New World, p. 208 (New York, 1922).

'See table, ibid., p. 210.

${ }^{3}$ Lower Austria, Upper Austria, Salzburg, Styria, Carinthia, Vorarlberg, and Tyrol.

'Bohemia, Moravia, and Silesia.

'In the province of Tyrol the Germans were in majority, the Italians in the minority. In Styria and Carinthia the Slovenes had substantial minorities among strong German majorities. In Gorizia and Trieste the Italians and
}

The nationalities of Austria 
Dissentious political history

Austrian Constitution of 1857
Apart from the influence of dynasty and the degree of economic interdependence that assisted in holding all parts of the Dual Monarchy together, there was indeed an additional cohering circumstance in the Austrian part: the population of nearly every province was overwhelmingly Roman Catholic. But this was not sufficient to create unity in a state that embodied such an opulence of variety in the matter of nationalities and spread itself over a territory of such weird contour and dimensions. It is unnecessary to review here the dissentious political history of Austria during the years preceding the outbreak of the World War. Let it be said merely that the turbulence of her internal politics was sufficient to show that under any heavy strain the Austrian part of the Dual Monarchyto say nothing of the Hungarian unit-would crack and crumble into bits.

In 1918 Austria was operating under a written constitution. In essence this constitution was found in five fundamental laws adopted December 21, 1867, as part and parcel of the general arrangement which resulted in the Ausgleich with Hungary. The constitution was, therefore, the work of the "smaller" Reichsrat which the Emperor had convoked to deal with the circumstance of Hungarian disaffection. In both of its houses this "constituent assembly" was essentially aristocratic. The form of government that was established by this constitution need not be described in detail. It was in most respects identical with the centralized system which the Emperor had attempted to set up over the whole Monarchy by the Patent of 1861.

The Reichsrat that was created by the constitution was empowered to amend it by a two-thirds vote of each of the two chambers-the Herrenhaus and the Abgeord-

Slovenes divided honors. Carniola was occupied almost exclusively by Slovenes. Istria was divided almost equally between Italians and Serbo-Croats, neither having a majority. Dalmatia, the extreme southwestern tip of the crescent, belonged almost wholly to the Serbo-Croats. 
netenhaus. In this manner several important amendments were adopted. In 1873 the power of electing members of the Abgeordnetenhaus was taken from the provincial diets and vested in the voters organized into four classesthe great landowners, the cities, the chambers of commerce and industry, and the rural communes. Elections were thus made direct; but the old illiberal class system was preserved intact. In 1896 a fifth class of general voters was established; but this class was empowered to elect only about one-sixth of the whole number of deputies. In 1907, however, after prolonged agitation, an amendment was at length adopted which abolished the class system of representation and introduced approximate manhood suffrage. It also redistributed seats not only among the provinces but also among the races; for provisions were made in most instances that resulted in separate racial representations in the mixed provinces.

It was hoped that the liberalization of the suffrage would result in creating an assembly divided upon economic and social issues rather than upon lines of race and nationality. But this hope was not realized. Interest in nationality proved to be stronger than economic class interests. The last general election was held in June, 1911. The results were as follows: German Nationalists, 100; German Christian Socialists, 73; German Social Democrats, 49; United Bohemian Club (Czechs), 84; Bohemian Social Democrats (Czechs), 25; Poles, 70; Polish Social Democrats, 9; Ukraine Union (Ruthenians), 28; Croatio-Slavonian Club (Slovenes and Serbo-Croats), 27; Dalmatians (Serbo-Croats), 7; Uniolatina (Italians), 21; Independents, 23. ${ }^{1}$ Practically every party had its racial designation. Even the members of the Social Democratic party, which ran across national lines, were primarily Germans, Czechs, or Poles, and only secondarily Social Democrats.

Little can be related here concerning the manner in

'Figures from The Statesman's Yearbook, 1915, p. 681. 


\section{0 NEW CONSTITUTIONS OF EUROPE}

Difficulties for Austria in defeat or victory

War increased race antagonisms

National aspirations in 1917 which the shifting events of the World War operated with disrupting effect upon the nationalities embraced within the Austro-Hungarian Monarchy. ${ }^{1}$ At the outbreak of hostilities there was an unexpected loyal rally of the races around the Hapsburg dynasty. But it was certain from the outset that either victory or defeat would have farreaching practical consequences in the Dual Monarchy. In victory, for example, any possible disposition of Russian Poland (whether it was joined to the German Poland of Prussia, or to the Austrian Poland of Galicia, or was erected into a nominally independent kingdom) would create a serious political problem for Austria. The annexation of Serbia would be opposed by the Magyars of Hungary because they wanted no more Jugoslav territory. And needless to say Hungary would bitterly oppose any arrangement which joined her with Austria in subordination to a Mittel-Europa dominated by Germany. To the Austro-Hungarian victors would belong the embarrassments.

But apart from the embarrassments of possible victory, which more than once seemed imminent, there were numerous events that increased the antagonism of race toward race. German Austrians did not win the affection or confidence of the Poles and Ruthenes by the reception they gave to refugees from the Galician theatre of action. As the food shortage became more and more acute, the German Austrians furiously resented the internal " hunger blockade" established by Hungary, the principal food producer of the Monarchy. Ruthless suppression and imprisonment affected all the minor races adversely.

In most of the countries at war, parliaments took a back seat during the period of hostilities. But in Austria parliament disappeared entirely. Prorogued early in 1914, the Reichsrat was not convoked for more than three

${ }^{1}$ See Temperley, Ed., A History of the Peace Conference of Paris, Vol. IV, pp. 29-118, 462-484 (London, 1921). 
years. It was the outbreak of the Russian Revolution, which could not fail to make a profound impression in the Dual Monarchy, that led to its reassembly on May 30,1917 . At once the spokesmen of the subject races came forward with programs of national aspiration that struck at the very foundations of the state. Through the remaining months of 1917 and the first half of 1918 there were seething discussions and negotiations concerning the conditions of settlement. And the difficulties were only increased by the cession of Russian territories to the Central Powers under the Treaty of Brest-Litovsk of March 3, 1918. It is highly improbable, however, that any attempt to remake Austria-Hungary from within could ever have been successfully effected.

At different dates during the summer of 1918 France, Great Britain, and the United States recognized the belligerency or independence of the Czechoslovaks; and thereafter the Slav deputies in the Austrian Reichsrat openly defied the Government. In the event of Allied victory, the Jugoslavian, Italian, and Rumanian parts of Austria-Hungary were, by treaties and engagements, already negotiated to Serbia, Italy, and Rumania respectively. On September 29, 1918, Bulgaria signed an armistice with the Allies which was in effect complete surrender. This was the beginning of the end. At the opening of the Austrian Reichsrat thrce days later, Prime Minister Hussarek delivered a pathetically ludicrous address about "setting" the Austrian "house in order" and "considering and solving the problem of autonomy for the different nationalities." Mere autonomy within the Monarchy was now hopelessly anachronous. The Monarchy was doomed, as were its coequal parts, the Empire and the Kingdom.

On October 4, Germany, Austria-Hungary, and Turkey offered to negotiate peace upon the basis of President Wilson's "fourteen points" and subsequent addresses.

Recognition of Czechoslovakia, 1918

The Monarchy doomed 
President Wilson and the AustroHungarian Government

Disintegration

Creation of GermanAustria
On October 8, President Wilson asked the German Chancellor whether he was "speaking merely for the constituted authorities of the Empire." By wholly ignoring the Austro-Hungarian Government he clearly indicated that he regarded that government as incompetent to speak for its peoples. Thereupon a panicky attempt was made to create a coalition cabinet that would be somewhat representative of the various nationalities. But the Czechs and other nationalities refused to be led into such a trap. There were evidences also that Hungary was ready to scuttle the sinking Austrian ship in the hope of appearing herself in the guise of a submerged and oppressed nationality.

On October 16, an imperial manifesto proclaimed that "Austria, in accordance with the will of her nationalities, is to become a federal state in which every nationality within its territory forms its own commonwealth." On the same day Prime Minister Wekerle declared in the Hungarian parliament that the Union between Austria and Hungary would thereafter be only a personal union. But the Czechs and Jugoslavs in Austria replied with a declaration in favor of the settlement of their status by the general Peace Conference; while the Rumanians and Slovaks of Hungary denied the authority of the Hungarian Government to speak for them.

President Wilson's note of October 18, published in Austria three days later, in effect demanded as a condition for the negotiation of peace the independence of the Czechoslovaks and of the Jugoslavs. On the same day, October 18, the Czechoslovak National Council, sitting in Paris, declared the independence of Czechoslovakia and constituted itself the provisional government of the country. The German members of the Austrian Abgeordnetenhaus, realizing that the end was at hand, and ignoring both the Dual Monarchy and the Austrian Empire, constituted themselves a provisional national assembly 
to represent the German-Austrian people at the peace table.

The old Government still clung to the fast-fading shadow of existence. Thin meetings of the Reichsrat were occasionally held. The Hussarek Ministry in Austria gave way to a sort of post-mortem Ministry formed by Lammasch. Count Burian, Minister of Foreign Affairs of the Dual Monarchy, resigned, and Count Andrássy succeeded him upon the legally correct but factually absurd theory that "until the Act of 1867 is changed, nothing but a Common Ministry of Foreign Affairs is conceivable or possible." A well-nigh grotesque situation followed. For almost immediately Andrássy dispatched to Washington a note accepting for the Dual Monarchy the conditions of independence for Czechoslovakia and Jugoslavia. In other words, Austria-Hungary accepted conditions which were practically incompatible with the continuance of its own existence. Thereafter, not even legal objections could be raised against the revolutionary process of establishing independent governments in these sections of the defunct Monarchy. There might be, indeed, as there were, serious questions in respect to boundaries. But the existence of an Austrian state narrowly confined to territory occupied almost exclusively by German-Austrians was in fact determined by events external to the new state itself.

Under the census of January 31, 1920, the new Austria, geographically compact, has a population of between six and seven millions-approximately one-fourth of the population of the former crescent-shaped Austrian Empire. It embraces seven of the old provinces, from several of which, however, large or small sections were clipped in favor of neighboring states. ${ }^{1}$ About 3,000,000 GermanAustrians are included within these neighboring states.

\footnotetext{
1Lower Austria, Upper Austria, Salzburg, Tyrol, Vorarlberg, Styria, Carinthia.
}

The end of

Austria-

Hungary

The new

Austria 
The

Provisional

National

Assembly
The

constituent assembly of 1919
It embraces also an eighth state, Burgenland, or German West Hungary, carved out of territory formerly Hungarian.

When the Austrian Provisional National Assembly, consisting of the German members of the old Abgeordnetenhaus, met on October 30, it immediately adopted a provisional constitution establishing a republican form of government. ${ }^{1}$ It was, therefore, merely a tardy gesture when the Emperor on November 11 issued a proclamation renouncing his right to participate in Austrian affairs. The provisional constitution vested legislative and executive powers in the Provisional National Assembly and provided for the exercise of executive powers by a Staatsrat or committee of its own members. On this committee the three parties, Christian Socialists, German Nationalists, and Social Democrats, were proportionally represented. This Staatsrat, in turn, nominated the members of a Cabinet, who functioned as the heads of the several departments. The scope of powers of the Provisional National Assembly was, however, somewhat indefinite; for revolutionary assemblies growing out of the old diets of the provinces arose to contest the power of the central assembly. Moreover, the old complicated system of parallel imperial and provincial administration, which had been a source of continuous embarrassment and friction, gave way to a decentralized system in which administrative services, carried on by the several provinces, were subject to central control only in theory.

The provisional constitution made provision for the call of a constituent assembly to draft a permanent constitution. An electoral law was enacted which provided for the election of 225 delegates in 38 districts, on the basis

\footnotetext{
${ }^{1}$ For the text and a discussion of the resolution (Staatsgesetzblatt, 1918, No. 1), see Kelsen, Die Verfassungsgesetze der Republik Deutschösterreich, Part I, pp. 11-28. For the text and a discussion of the law of November 12, 1918, in respect to the form of the state and the government (Staatsgesetzblatt, 1918, No. 5), see ibid., Part I, pp. 29-40.
} 
of equal, secret, direct, and universal suffrage without distinction of sex, and according to the principles of proportional representation. ${ }^{1}$ 'The elections took place on February 16, 1919. No elections were held in certain territories which were claimed by Austria but were actually occupied by Czechoslovakia, Jugoslavia, and Italy. In consequence only 170 delegates were returned. Of these 72 were Social Democrats, 69 were Christian Socialists, 26 were German Nationalists, and 3 were scattered.

The constituent assembly met on March 4, 1919. Its first task was to make certain important alterations in the provisional constitution. ${ }^{2}$ The Staatsrat was abolished, and certain changes were made in the relations of the Cabinet to the assembly. But the most important change effected was in the direction of curbing the powers of the provisional governments of the provinces. While the permanent constitution was in the making, the constituent assembly also engaged in a considerable amount of lawmaking and otherwise carried on the affairs of government for a people living under appalling circumstances of near-starvation and general economic misery. At Easter and again in June there were outbursts of violence in Vienna. But for the most part the revolutionary passing from the old to the new order was pacific.

The Treaty of St. Germain (September 10, 1919) necessitated a redefinition of some of the frontiers of Austria, the substitution of the "Republic of Austria" for the name "German-Austria," and a repeal of the constitutional declaration: "German-Austria is a constituent part of the German Reich." The provisional constitution, as amended in important particulars by the constituent assembly, formed the basis upon which the assembly

\footnotetext{
1 For the text and a discussion of the laws relating to the constituent assembly (Staatsgesetzblatt, 1918, Nos. 114, 115) see Kelsen, op. cit., Part II, pp. 1-9, 10-191.

${ }^{2}$ For these laws and discussions thereof (Staatsgesetzblatt, 1919, Nos. 179, 180), see ibid., Part III, pp. 121-140, 141-160.
}

Changes in the provisional government

Changes required by Treaty of St. Germain 
The constitution of 1920

worked out the permanent constitution. The chief obstacle that was encountered was the application of the federal principle with due regard on the one hand for the imperative needs of centralization and on the other for the autonomous rights that were demanded by the states. ${ }^{1}$ Decentralization was the order of the day even within the strictly German parts of the disintegrated Empire.

The constituent assembly governed in Austria for more than eighteen months. The permanent constitution did not go into effect until October 1, 1920. Elections under the new constitution were held on October 17; and on December 8, the first President, Dr. Michael Hainisch, was elected by the joint assembly of the two houses. Thus was the new permanent government formally launched. ${ }^{2}$

\section{CONSTITUTION OF AUSTRIA}

Act of October 1, 1920, by which the Austrian Republic is established as a Federal State.

(Federal Constitutional Law)

The Constituent Assembly has resolved:

\section{CHAPTER I \\ General Provisions}

Article 1. Austria is a democratic republic. The will of the people is the foundation of its laws.

Art. 2. (1) Austria is a Federal State (Bundesstaat).

(2) The Federal State is composed of the autonomous states ${ }^{3}$ of Burgenland, Carinthia, Lower Austria (state of Lower Austria

\footnotetext{
'See above, pp. 62, $74 \mathrm{ff}$.
}

${ }^{2}$ The text of the constitution, which follows, is a translation of the original German text contained in Bundesgesetzblatt für die Republik Österreich, 1920, p. 1. It has been compared to some extent with an anonymous French translation found in Revue du droit public et de la science politique, Vol. 38, No. 2, AprilMay-June, 1921, p. 261. In the rendering of the English version presented herewith, the authors are under special obligation to Mr. Rüdiger Bilden.

${ }^{3}$ Länder is translated "states." See above, p. 176, note 2 . 
and city of Vienna), Upper Austria, Salzburg, Styria, Tyrol, and Vorarlberg.

Art. 3. (1) The territory of the Federal State consists of the territories of the Austrian states.

(2) Alteration of federal boundaries, affecting also the boundaries of a state, as well as alteration of state boundaries within the federal territory may take place-except as provided by peace treaties - only by concurrent constitutional laws of the Federal State and the state affected thereby.

(3) Separate provisions for the state of Lower Austria and the City of Vienna are included in the fourth chapter.

Art. 4. (1) The federal territory forms a uniform currency, economic, and customs zone.

(2) Customs zones or other restrictions on communications may not be established within the federal territory.

Art. 5. Vienna shall be the federal capital and the seat of the highest federal authorities.

Art. 6. (1) There shall be a state citizenship for each state. Domicile (Heimatrecht) in a municipal district (Gemeinde) of the state shall be a condition for state citizenship. The conditions for the acquisition and loss of state citizenship shall be the same in every state.

(2) Federal citizenship shall be acquired on the basis of state citizenship.

(3) Every Austrian citizen shall have in every state equal rights and duties with the citizens of that state.

Art. 7. (1) All Austrian citizens are equal before the law. Privileges, based upon birth, sex, rank, class, or religious belief are abolished.

(2) All public employees, including the members of the federal army, shall be guaranteed the unrestricted exercise of their political rights.

Art. 8. The official language of the Republic shall be German, without prejudice to the rights conceded by federal law to foreign-language minorities.

Art. 9. The universally recognized rules of international law are accepted as integral parts of the law of the Austrian Republic.

Art. 10. The Federal State shall have powers of legislation and execution in respect to the following matters:

(a) The federal constitution, especially elections to the Nationalrat, and popular suffrage by virtue of the federal constitution; jurisdiction in regard to the constitution. 
(b) Foreign relations, including political and commercial representation in relations with foreign countries, in particular the conclusion of all treaties, marking out of boundaries, traffic in goods and live stock with foreign countries, and customs.

(c) Regulation and supervision of entrance into and departure from the federal territory; immigration and emigration; passports, deportation, removal, expulsion, and extradition from or through the federal territory.

(d) Federal finance, especially taxes to be collected exclusively or in part for the federal treasury; monopolies.

(e) Currency; credit, produce, and stock exchanges; banking; weights and measures; standards and assaying.

(f) Civil law, including the law of economic associations; criminal law with the exception of administrative criminal law and administrative criminal procedure in matters which come within the autonomous jurisdiction of the states; administration of justice; administrative jurisdiction; copyright; the press; expropriation not pertaining to specific matters within the autonomous jurisdiction of the states; matters pertaining to public notaries, lawyers, and related professions.

(g) The right of association and the right of assembly.

(h) Commerce and industry; suppression of unfair competition; patents and protection of patterns, trademarks, and other commercial designations; matters pertaining to patent lawyers; engineering and consulting engineering; chambers of commerce, trade, and industry.

(i) Traffic by rail, water, and air; matters concerning roads declared by federal law to be federal highways on account of their importance in intercommunication; police authority over watercourses and navigation; posts, telegraphs, and telephones.

(j) Mining; regulation and maintenance of all waters used for navigation or rafting or suitable for such use, and of such waters as form a boundary with foreign countries or between states, or which flow through two or more states; construction and maintenance of those waterways which connect the inland with foreign countries or connect several states; general technical measures for adequate utilization of water power, exclusive of agricultural and small industrial plants: standardization and systematization of electrical establishments and plants, safety measures in this field; right of way for electric power transmission in so far as the transmission extends across 
the boundaries of two or more states; steam boilers and power engines; surveying.

(k) Labor law and protection of workers and other employees not engaged in agriculture or forestry; social insurance and contract insurance.

(l) Public health, exclusive of the disposal or burial of the dead, as well as of the municipal sanitation and life-saving service; but only sanitary supervision over hospitals and sanatoria, health resorts, and watering places; veterinary regulations; foodstuffs including food control.

(m) Scientific and technical archives and libraries; artistic and scientific collections and institutions; protection of monuments; matters pertaining to religion; census and other statistics not solely in the interest of one state; endowments and foundations not intended to serve the interest of only one state and not hitherto autonomously administered by the states.

(n) Federal police and federal gendarmerie.

(o) Military affairs; war indemnities and care of discharged soldiers and their dependents; such measures occasioned by or in consequence of a war as are necessary to safeguard the uniform administration of economic affairs, especially the supply of necessities to the population.

(p) Creation of federal authorities and other federal officers; law of the federal public service.

Art. 11. (1) The Federal State shall have the power of legislation, but the states shall have the power of execution in respect to the following matters:

(a) Citizenship and domiciliary rights (Heimatrecht), vital statistics, including registration and change of name; police supervision of aliens.

(b) Professional associations not included in Article 10, but exclusive of those pertaining to agriculture and forestry.

(c) Public agencies and private brokerages.

(d) Taxes not collected exclusively or partially for the federal treasury; provisions for the prevention of double taxation and other excessive levies; for the prevention of obstructions to foreign, interstate, or domestic traffic or economic relations; for the prevention of excessive levies on public communications or institutions, or levies which interfere with communication; and for the prevention of prejudice to federal finance. 
(e) Ammunition, projectiles, and explosives, not subject to monopoly, as well as the manufacture of arms; motor vehicles.

(f) Housing.

(g) Administrative procedure and administrative criminal procedure including execution, and the general provisions of administrative criminal law, even in matters in which the states have the power of legislation.

(2) Ordinances for the execution of the laws provided for in Paragraph 1 shall be issued by the Federal State, unless otherwise provided by such laws.

Art. 12. (1) The Federal State shall have the power of legislation as to fundamental principles, but the states shall have the power of supplementary legislation and the power of execution in respect to the following matters:

(a) Organization of administration in the states.

(b) Poor relief; problems of population; public sanatoria; protection of maternity, infancy, and adolescence; hospitals and sanatoria; health resorts and watering places.

(c) Institutions such as penitentiaries and workhouses, or institutions of a similar character for the protection of society against criminals, vagrants, and other dangerous persons; deportation and expulsion from one state to another.

(d) Public institutions for the extra-judicial adjustment of controversies.

(e) Labor law and protection of workers and other employees in agriculture and forestry.

(f) Land reform, including especially agrarian reform and recolonization.

(g) Forestry including pasturage, protection of plants against disease or injury.

(h) Electricity and water rights not included in Article 10.

(i) Building regulations (Bauwesen).

(j) Law of the public service concerning employees of the states performing official dutics.

(2) Final decision in matters pertaining to land reform (Paragraph 1, Clause F) shall be vested in a commission appointed by the Federal State and consisting of judges, administrative officials, and experts.

Art. 13. (1) The Federal State shall have powers of legislation and execution to determine what taxes shall belong to the 
Federal State, the states, or the municipal districts (Gemeinde); to determine the shares of the states or municipalities in the revenues of the Federal State; and to determine the contributions and allowances from the federal treasury for state or municipal expenditures.

(2) The states shall have power of legislation and execution to determine what state taxes shall be allocated to the municipal districts; to determine the shares of the municipal districts in the revenues of the states; and to determine the contributions and allowances from the treasuries of the states to the expenditures of the municipal districts.

Art. 14. A special federal constitutional law shall regulate the scope of action of the Federal State and the states in regard to schools, education, and popular instruction.

Art. 15. (1) In so far as a subject matter has not been specifically assigned by the federal constitution to the Federal State as to legislation or execution, it shall remain within the the autonomous sphere of action of the states.

(2) In so far as the power of legislation has been reserved to the Federal State only as to fundamental principles, the states shall have the power of supplementary legislation within the scope determined by federal law. Federal law may fix a period of time for the enactment of supplementary legislation which, without the consent of the Bundesrat, shall not be less than six months nor more than one year. If a state does not observe this period of time, the power of supplementary legislation for such state shall be transferred to the Federal State. With the enactment by the state of a supplementary law, the fcderal supplementary law shall cease to be in force.

(3) If an act of execution on the part of a state in the subjects covered by Articles 11 and 12 shall be effective for several states, such states shall take steps first to reach an agreement thereon. If they fail to agree, the power of performing such an act shall, on application of one of these states, be transferred to the competent federal minister. Detailed regulations may be prescribed by federal laws in accordance with Articles 11 and 12.

(4) The Federal State shall have the right to supervise the execution of the regulations issued by the Federal State in respect to such subjects as are reserved for legislation by the Federal State in accordance with Articles 11 and 12.

(5) The states shall be empowered within the scope of their 
legislative authority to issue all regulations necessary for enforcement, even in the province of criminal and civil law.

Art. 16. (1) The states shall be obliged to take whatever measures are necessary within their autonomous sphere of action for the execution of treaties; if a state does not comply with this obligation in due time the Federal States shall be vested with the power to take such measures, and especially to enact the necessary laws.

(2) Likewise, the Federal State, when carrying out treaties with foreign states, shall have the right of supervision even in regard to such matters as come within the autonomous sphere of action of the states. In this case the Federal State shall have the same rights over against the states as in matters of indirect federal administration.

Art. 17. (1) The provisions of Articles 10-15 in respect to the powers of legislation and execution shall in no way affect the status of the Federal State in the matter of its private rights.

(2) In all these legal relations the legislation of a state shall never affect the Federal State more disadvantageously than it affects the state itself.

Art. 18. (1) The entire public administration must be conducted in accordance with the laws.

(2) Within the limits of the laws every administrative authority may issue ordinances in its own sphere of action.

Art. 19. (1) The supreme executive authority of the Federal State shall be entrusted to commissioners of the people chosen by the assemblies of representatives of the people in the Federal State and in the states. The commissioners of the people shall be the Federal President, the federal ministers, the secretaries of state, and the members of the state governments.

(2) The transaction of business by the commissioners of the people shall be under the supervision of the assembly by which they are chosen.

(3) They may be called before the Supreme Constitutional Court (Verfassungsgerichtshof) to account for their actions and omissions, in so far as the federal constitution or the state constitutions provide.

Art. 20. Under the direction of the commissioners of the people, agencies elected for a certain period or appointed professional agencies shall conduct the federal or state administration in accordance with the laws. They shall be bound by the directions of the commissioners of the people, who are their 
superiors, and shall be responsible to them for the exercise of their office, unless the federal constitution or the state constitutions otherwise provide.

Art. 21. (1) The law of the public service, including the salary scale and the power of discipline over employees of the Federal State and of the states performing official tasks, shall be regulated by federal law according to uniform principles. (Article 10, Clause P, and Article 12, Clause J.) This law shall also contain provisions determining the extent to which representatives of employees may participate in the regulation of the rights and duties of such employees without prejudice to the supreme control of service on the part of the Federal State and the states.

(2) The federal commissioners of the people shall have the supreme control of service over employees of the Federal State; the state commissioners of the people shall have the supreme control of service over employees of the states.

(3) The appointment of employees of local or territorial municipalities who perform official tasks, and the law of the public service concerning such employees, shall be regulated in connection with the organization of the administration.

(4) Public employees shall always be guaranteed the possibility of an interchange of service between the Federal State, the states, and the municipalities. Change of service shall take place with the consent of the authorities authorized to exercise the supreme control of service. Special arrangements to facilitate interchange of service may be made by federal law.

(5) Titles of office for the agencies of the Federal State, the states, or the municipalities may be regulated in a uniform manner by federal law. They shall be protected by law.

Art. 22. All agencies of the Federal State, the states, or the municipalities must render mutual assistance to one another within scope of their lawful authority.

Art. 23. (1) All persons entrusted with functions of federal, state, or municipal administration, or with judicial functions, shall be liable for any injury inflicted on any third party through intentional or grossly negligent violation of the law in the exercise of their office. The Federal State, the states, or the municipalities shall be liable for violations of the law on the part of persons in their service.

(2) Detailed regulations shall be prescribed by federal law. 


\author{
CHAPTER II \\ Federal Legislation \\ A. The Nationalrat
}

Art. 24. The power of legislation of the Federal State shall be exercised by the Nationalrat, elected by the entire Austrian people, with the concurrence of the Bundesrat, elected by the Landtags.

Art. 25. (1) The seat of the Nationalrat shall be the federal capital, Vienna.

(2) For the duration of a period of extraordinary conditions, the Federal President, at the request of the Federal Ministry, may call the Nationalrat together in any other place in the federal territory.

Art. 26. (1) The Nationalrat shall be elected according to the principles of proportional representation by the equal, direct, secret, and personal suffrage of all Austrian men and women who are more than twenty years of age before the first of January of the year of the election.

(2) The federal territory shall be divided within the state boundaries into contiguous election districts. A number of deputies shall be allowed to the qualified voters of an election district (electoral body) in proportion to the number of citizens in the election districts; that is, the number of Austrian citizens who in accordance with the results of the last census had their domicile in the election districts. A division of the voters into other electoral bodies shall not be permissible.

(3) Election day must be a Sunday or other public holiday.

(4) Every qualified voter who is more than twenty-four years of age before the first of January of the year of the election, shall be eligible for election.

(5) Denial of the right to vote or to be elected may result only from a judicial conviction or decree.

Art. 27. (1) The Nationalrat shall be elected for a four-year term, computed from the day of its first meeting, but continuing to the day on which the new Nationalrat meets.

(2) The newly elected Nationalrat must be called together by the Federal President no later than the thirtieth day after the election. The election must be arranged by the Federal Ministry in such a manner as to enable the newly elected Nationalrat 
to meet on the day after the expiration of the four year term of the old Nationalrat.

Art. 28. The Nationalrat may be adjourned only by its own resolution. It shall reassemble at the call of its President. He must call the Nationalrat together immediately if at least onefourth of its members or if the Federal Ministry demands it.

Art. 29. Before the expiration of its term the Nationalrat may by simple law decree its own dissolution. In such case also its term shall last until the newly elected Nationalrat meets.

Art. 30. (1) The Nationalrat shall choose from among its own members its President and its Second and Third Presidents.

(2) The business of the Nationalrat shall be conducted in accordance with a special law and autonomous rules of procedure determined by the Nationalrat within the limits of this law. The law concerning the rules of procedure may be passed only in the presence of one-half of the members and by a majority of two-thirds of the votes cast.

Art. 31. A resolution of the Nationalrat requires the presence of at least one-third of the members and an absolute majority of the votes cast, unless the law regulating the rules of procedure otherwise provides.

Art. 32. (1) The sittings of the Nationalrat shall be public.

(2) On demand of the presiding officer or of one-fifth of the members present the public shall be excluded if the Nationalrat so resolves in executive session.

Art. 33. True and accurate reports of the proceedings at the public sittings of the Nationalrat or its committees are privileged matters.

\section{B. The Bundesrat}

Art. 34. (1) The Bundesrat shall represent the states in proportion to the number of citizens in the state in accordancc with the following provisions:

(2) The city of Vienna and the State of Lower Austria (Articles 108-114) shall be regarded as separate states in respect to representation and status in the Bundesrat.

(3) The state having the greatest number of citizens shall have twelve members; every other state shall be represented by a number of members determined by the ratio of its number of citizens to the aforementioned number of citizens, a fraction of more than one-half of the proportional number being counted 
as the full proportional number. Every state shall be entitled to at least three representatives. An alternate shall be chosen for each representative.

(4) The number of representatives from each state in accordance with the aforementioned provision shall be reapportioned by the Federal President after each general census.

Art. 35. (1) The members of the Bundesrat and their alternates shall be elected by the Landtags for the duration of their terms in accordance with the principles of proportional representation; at least one representative, however, must be assigned to the party which has obtained the second largest number of seats in the Landtag, or, in case several parties have obtained the same number of seats, to the party which polled the second largest number of votes at the last election to the Landtag. Equal claims of several parties shall be decided by lot.

(2) Members of the Bundesrat need not necessarily be members of the Landtag by which they are elected; they must, however, be eligible for election to that Landtag.

(3) After the expiration of the term of a Landtag or after its dissolution, the members of the Bundesrat elected by it shall exercise their functions until the election of members of the Bundesrat by the new Landtag has taken place.

(4) The provisions of this Article may be changed only if in the Bundesrat such change is made by resolution with an affirmative vote of a majority of the representatives of at least four states, provided that the majority necessary for any resolution concurs in this resolution.

Art. 36. (1) The presidency of the Bundesrat shall be held alternately by the states in alphabetical order for a period of six months.

(2) The ranking representative of the state entitled to the presidency shall act as presiding officer; substitutes shall be chosen in accordance with the rules of procedure of the Bundesrat.

(3) The Bundesrat shall be called together by its presiding officer at the seat of the Nationalrat. The presiding officer must call the Bundesrat together immediately if at least one-fourth of its members or if the Federal Ministry demands it.

Art. 37. (1) Except as otherwise provided in this law, a resolution of the Bundesrat requires the presence of at least onethird of the members and an absolute majority of the votes cast.

(2) The Bundesrat shall by resolution determine its own rules of procedure. This resolution requires the presence of at least 
one-half of the members and a majority of two-thirds of the votes cast.

(3) The sittings of the Bundesrat shall be public. The public may, however, be excluded by resolution in accordance with the provisions of the rules of procedure. The provisions of Article 33 shall apply also to the public sittings of the Bundesrat and its committees.

\section{The Bundesversammlung}

Art. 38. The Nationalrat and the Bundesrat shall assemble as the Bundesversammlung in a joint public sitting at the seat of the Nationalrat for the election of the Federal President and for administering his oath of office as well as for a resolution concerning a declaration of war.

Art. 39. (1) With the exception of the cases provided for by Article 63, Paragraph 2, Article 64, Paragraph 2, and Article 68, Paragraph 2, the Bundesversammlung shall be called together by the Federal President. The presidency shall be exercised alternately by the President of the Nationalrat and the presiding officer of the Bundesrat, for the first time by the latter.

(2) The rules of procedure of the Nationalrat shall be duly applied in the Bundesversammlung.

(3) The Nationalrat and the Bundesrat may in advance separately consider any matter subject to a vote of the Bundesversammlung.

(4) The provisions of Article 33 shall apply also to the sittings of the Bundesversammlung.

Art. 40. (1) The resolutions of the Bundesversammlung shall be authenticated by its presiding officer and countersigned by the Federal Chancellor.

(2) Official publication shall be the duty of the Federal Chancellor.

\section{Federal Legislative Procedure}

Art. 41. (1) Bills shall be submitted to the Nationalrat either as proposals of its members or as bills of the Federal Ministry. The Bundesrat may submit bills to the Nationalrat through the Federal Ministry.

(2) Every proposal signed by 200,000 qualified voters or by one-half of the qualified voters of each of three states (popular initiative) must be submitted by the Federal Ministry to the 
Nationalrat to be acted on in accordance with its rules of procedure. The initiative proposal must take the form of a bill.

Art. 42. (1) Every law enacted by the Nationalrat must be transmitted at once by its President to the Federal Chancellor, who must communicate it immediately to the Bundesrat.

(2) Except as otherwise provided by constitutional law, an enacted law may be authenticated and published only if the Bundesrat does not veto it. Such veto must be supported by reasons.

(3) This veto must be communicated in writing to the $\mathrm{Na}$ tionalrat through the medium of the Federal Chancellor within eight weeks after the law has reached the Bundesrat.

(4) If the Nationalrat in the presence of at least one-half of its members reaffirms its original resolution, the law must be authenticated and published. If the Bundesrat resolves not to veto the law, or if no valid veto, supported by reasons, has been interposed within the period of time precribed by Paragraph 3, the law must be authenticated and published.

(5) The Bundesrat may not veto resolutions of the Nationalrat in respect to a law concerning the rules of procedure of the Nationalrat, the dissolution of the Nationalrat, the grant of the federal budget estimates, the approval of the final budget accounts, the issue or conversion of federal loans, or the disposition of the federal property. Such laws enacted by the Nationalrat must be authenticated and published without further delay.

Art. 43. If the Nationalrat so resolves, or if a majority of the members of the Nationalrat so demands, every law enacted by the Nationalrat shall, before its authentication, be submitted by the Federal President to a referendum.

Art. 44. (1) Constitutional laws or constitutional provisions contained in ordinary laws may be enacted by the Nationalrat only in the presence of at least one-half of its members and by a majority of two-thirds of the votes cast. They must be specifically designated as such ("constitutional laws" or "constitutional provisions").

(2) A complete revision of the Federal Constitution must upon conclusion of the procedure prescribed in Article 42, but before authentication by the Federal President, be submitted to a referendum of the entire people of the Federal State; but an amendment need be so submitted only on demand of onethird of the members of the Nationalrat or the Bundesrat. 
Art. 45. (1) An absolute majority of the valid votes cast in the referendum shall decide.

(2) The result of the referendum must be officially announced.

Art. 46. (1) Detailed regulations in respect to the initiative and referendum shall be prescribed by federal law.

(2) Every citizen of the Federal State qualified to vote in the elections to the Nationalrat shall be qualified to participate in the initiative and the referendum.

(3) The Federal President shall make arrangements for the referendum.

Art. 47. (1) The signature of the Federal President shall certify that the federal laws have been constitutionally enacted.

(2) Presentation for certification shall take place through the Federal Chancellor.

(3) The certification must be countersigned by the Federal Chancellor and the competent federal ministers.

Art. 48. Federal laws and the treaties referred to in Article 50 shall be published in the form in which they are approved by the Nationalrat; federal laws based on a referendum shall be published in the form in which they are approved by the referendum.

Art. 49. (1) The federal laws and such treaties of state as are referred to in Article 50 must be published by the Federal Chancellor in the Federal Law Gazette. Unless otherwise explicitly provided, they shall become effective at the expiration of the day on which the number of the Federal Law Gazette containing the publication is issued and distributed; and unless otherwise explicitly provided, they shall apply to the entire federal territory.

(2) A special federal law shall regulate the publication of the Federal Law Gazette.

E. Participation of the Nationalrat and the Bundesrat in the Executive Power of the Federal State

Art. 50. (1) All political treaties, and all other treaties only in so far as they provide for an alteration of existing laws, shall require for their validity the consent of the Nationalrat.

(2) The provisions of Article 42, Paragraphs 1-4, and, in case of alteration of a constitutional law by a treaty, the provisions of Article 44, Paragraph 1, shall be duly applied to resolutions of the Nationalrat concerning the approval of treaties. 
Art. 51. The Federal Ministry must submit to the Nationalrat no later than eight weeks before the expiration of the current fiscal year estimates of the federal revenues and appropriations for the ensuing fiscal year.

Art. 52. The Nationalrat and the Bundesrat shall be authorized to examine the conduct of public business by the Federal Ministry, to question the members of the Federal Ministry on all matters relating to the execution of the laws, and to demand all pertinent information as well as to express by resolution their wishes in respect to the exercise of the executive power.

Art. 53. (1) The Nationalrat may by resolution set up committees of investigation.

(2) The courts and all other authorities shall be obliged to comply with the requests of these committees for evidence; upon their demand all public authorities shall lay their records before them.

(3) The procedure of the committees of investigation shall be regulated by the law concerning the rules of procedure of the Nationalrat.

Art. 54. The Nationalrat shall participate in fixing railroad, postal, telegraph, and telephone rates and prices of articles subject to monopoly, as well as salaries of persons permanently employed in the enterprises of the Federal State. The character of such participation shall be prescribed by federal constitutional law.

Art. 55. The Nationalrat shall itself share in the executive power of the Federal State in such cases as are specified by this law, as well as through the main committee elected from among its members in accordance with the principles of proportional representation. It shall be a special function of the main committee to participate in the choice of the Federal Ministry (Article 70). Moreover, certain ordinances of the Federal Ministry shall require the consent of the main committee, as may be prescribed by federal law.

\section{F. Status of the Members of the Nationalrat and the Bundesrat}

Art. 56. When acting in their official capacity the members of the Nationalrat or the Bundesrat shall not be bound by instructions.

Art. 57. (1) The members of the Nationalrat shall never be 
held responsible for any votes cast in their official capacity, and they shall be held responsible only by the Nationalrat for any utterances made in this capacity.

(2) No member of the Nationalrat may, without the consent of this body, be subjected to arrest or any other official prosecution for a penal offense unless he is apprehended in the act of committing a crime.

(3) In case of apprehension in the very act, the authorities must notify the President of the Nationalrat that the arrest has taken place.

(4) On demand of the Nationalrat the arrest must be cancelled or the entire prosecution must be deferred during the term of the Nationalrat.

(5) The immunities attaching to the agencies of the Nationalrat whose functions extend beyond the term of the $\mathrm{Na}$ tionalrat shall continue for the duration of their functions.

Art. 58. The members of the Bundesrat shall, during the entire term of their functions enjoy the immunity of members of the Landtag by which they are deputized.

Art. 59. (1) No person may be a member of the Nationalrat and the Bundesrat at the same time.

(2) Public officials, including members of the federal army, shall not require leave to exercise their functions as members of the Nationalrat or the Bundesrat. Should they seek election to the Nationalrat the time necessary therefor shall be granted to them. Detailed regulations shall be prescribed by the rules for the public service.

\section{CHAPTER III}

\section{The Executive Power of the Federal State}

\section{A. Administration}

\section{The Federal President}

Art. 60. (1) The Federal President shall be elected by the Bundesversammlung in accordance with Article 38 and by secret ballot.

(2) His term of office shall be four years. A reëlection for the term of office immediately following shall be permissible only once.

(3) Only a person who is qualified to vote in the elections to the Nationalrat and who is more than thirty-five years of age 
before the first of January of the year of the election may be elected Federal President.

(4) Members of reigning or formerly reigning families are not eligible.

(5) The person who receives a majority of all votes cast shall be elected. Balloting shall be repeated until an absolute majority is obtained for one person.

Art. 61. During his term of office the Federal President must not be a member of any general representative body or exercise any other profession.

Art. 62. On assuming office the Federal President shall before the Bundesversammlung take the following oath: "I swear that I will faithfully observe the constitution and all laws of the Republic and will fulfill my duty to the best of my knowledge and conscience."

Art. 63. (1) An official prosecution of the Federal President is permissible only if the Bundesversammlung assents to it.

(2) A bill for the prosecution of the Federal President shall be presented by the competent authority to the Nationalrat, which decides whether it shall be submitted to the Bundesversammlung. If the Nationalrat decides in the affirmative, the Federal Chancellor must call the Bundesversammlung together immediately.

Art. 64. (1) In case of disability on the part of the Federal President or in case of a vacancy in his office, the functions of the Federal President shall devolve upon the Federal Chancellor.

(2) In case of a vacancy in the Federal Presidency the Federal Chancellor must immediately call the Bundesversammlung together for the election of a new Federal President.

Art. 65. (1) The Federal President represents the Republic in international relations; he receives and accredits diplomatic representatives; he accepts the exequaturs of foreign consuls; he appoints the consular representatives of the Republic in foreign countries and concludes treaties.

(2) Moreover, in addition to the powers conferred upon him by other provisions of this constitution, he shall be empowered:

(a) To appoint all federal officials, including military officers and other federal functionaries, and to commission them.

(b) To create and confer professional titles.

(c) Specifically, to pardon persons convicted by final judgments of the courts, to mitigate or alter sentences pro- 
nounced by the courts, to remit the legal consequences of a conviction and to cancel convictions by pardon, to quash criminal proceedings in case of penal offenses to be officially prosecuted.

(d) To legitimatize illegitimate children on the petition of the parents.

(3) Moreover, special laws shall prescribe to what extent the Federal President shall be empowered to confer honorary rights, to grant extraordinary allowances and increases in salaries and pensions, to confer rights of appointment or confirmation, and to exercise other powers in matters concerning individuals.

Art. 66. (1) The Federal President may transfer to the competent members of the Federal Ministry the right conferred on him to appoint certain classes of federal employees.

(2) The Federal President may authorize the Federal Ministry or the competent members thereof to conclude certain categories of treaties which are not covered by the provisions of Article 50.

Art. 67. (1) Except as otherwise provided by the constitution, all official acts of the Federal President shall be performed upon the proposal of the Federal Ministry or of a federal minister empowered by it. The law shall prescribe to what extent the Federal Ministry or the competent federal minister shall be bound by proposals emanating from other sources.

(2) All official acts of the Federal President require for their validity the countersignature of the Federal Chancellor or the competent federal ministers.

Art 68. (1) In accordance with Article 142, the Federal President shall be responsible to the Bundesversammlung for the exercise of his office.

(2) Upon resolution of the Nationalrat or the Bundesrat the Federal Chancellor must call the Bundesversammlung together to decide upon this issue [of impeachment].

(3) A resolution of impeachment within the meaning of Article 142 shall require the presence of more than one-half of the members of each of the two representative bodies and a majority of two-thirds of the votes cast.

\section{The Federal Ministry}

Art. 69. (1) The highest administrative functions of the Federal State, unless conferred upon the Federal President, shall 
be entrusted to the Federal Chancellor, the Vice-Chancellor, and the other federal ministers. Together they form the Federal Ministry under the presidency of the Federal Chancellor.

(2) The Vice-Chancellor shall be empowered to represent the Federal Chancellor in the entire sphere of his authority.

Art. 70. (1) The Nationalrat shall elect the Federal Ministry by a recorded vote upon nomination by a main committee on the election of an entire Federal Ministry.

(2) Only persons eligible to the Nationalrat may be elected members of the Federal Ministry. The members of the Federal Ministry need not be members of the Nationalrat.

(3) If the Nationalrat is not in session the Federal Ministry shall be chosen provisionally by the main committee; as soon as the Nationalrat meets, the election must take place.

(4) The provisions of Paragraphs 1-3 shall be duly applied to the appointment of individual members of the Federal Ministry.

Art. 71. If the Federal Ministry resigns from office the Federal President must, until a new Federal Government has been formed, entrust the carrying on of the administration to members of the retiring Ministry or to high officials of the federal administration, and must authorize one of them to preside over the provisional Federal Ministry. This provision shall be duly applied if individual members of the Federal Ministry resign.

Art. 72. (1) Before assuming office the members of the Federal Ministry shall take an oath before the Federal President.

(2) The official commissions of the Federal Chancellor, the Vice-Chancellor and the other federal ministers shall be issued by the Federal President on the day on which they take the oath of office, and shall be countersigned by the newly commissioned Federal Chancellor.

(3) These provisions shall also be duly applied to the cases enumerated in Article 71.

Art. 73. In case of temporary disability of a federal minister the Federal President shall authorize a federal minister or a high official of the federal administrative to represent this minister. This representative shall be under the same responsibility as a federal minister (Article 76).

Art. 74. (1) If the Nationalrat by express resolution withdraws its confidence from the Federal Ministry, or from individual members of it, the Federal Ministry or the federal minister in question is thereby removed from office. 
(2) The presence of one-half of the members of the Nationalrat shall be required for a resolution of the Nationalrat by which confidence is withdrawn. On demand, however, of one-fifth of the members present, the vote must be postponed to the second week-day next following. A further postponement of the vote may take place only by resolution of the Nationalrat.

(3) The Federal Ministry or its individual members shall be relieved of office by the Federal President in cases prescribed by law or upon their request.

Art. 75. The members of the Federal Ministry as well as their deputies shall be authorized to participate in the deliberations of the Nationalrat, the Bundesrat, or the Bundesversammlung, as well as in the deliberations of the committees of these representative bodies; and, on special invitation, to participate in the deliberations of the main committee of the Nationalrat. At their request they must always be heard. The Nationalrat, the Bundesrat, or the Bundesversammlung as well as their committees may demand the presence of the members of the Federal Ministry.

Art. 76. (1) The members of the Federal Ministry (Articles 69 and 71) shall be responsible to the Nationalrat in accordance with Article 142.

(2) A resolution of impeachment in accordance with Article 142 shall require the presence of more than one-half of the members.

Art. 77. (1) The federal ministers and the officials subordinate to them shall be authorized to conduct the business of the federal administration.

(2) The number of the federal ministers, their scope of authority, and the organization of their officers shall be prescribed by federal law.

(3) The head of the federal chancellery shall be the Federal Chancellor and the head of each of the other federal offices shall be a federal minister.

(4) The Federal Chancellor or any other federal minister may in exceptional cases be placed in charge of two federal offices.

Art. 78. (1) In special cases federal ministers may be appointed without at the same time being commissioned to take charge of a federal office.

(2) Secretaries of state, who are chosen and relieved of office in the same manner as the federal ministers, shall be assigned 
to the federal ministers to assist them in their departmental and parliamentary duties.

(3) The secretary of state shall be subordinate to the federal minister and shall be bound by his instructions.

\section{Federal Army}

Art. 79. (1) The federal army shall be entrusted with the protection of the frontiers of the Republic.

(2) In so far as the lawful civil authorities require its coöperation, the army shall in general protect the constitutional institutions, as well as maintain order and safety within the realm, and shall give relief in cases of disasters due to natural forces and of accidents of unusual gravity.

Art. 80. (1) The Nationalrat shall have control over the army. In so far as immediate control is not reserved to the Nationalrat by the laws of national defence, the control shall be entrusted to the Federal Ministry, or to the competent federal minister, within the limits of the power conferred upon him by the Federal Ministry.

(2) The laws of national defence shall prescribe to what extent the authorities of the states or the municipalities may demand directly the coöperation of the federal army for the purposes mentioned in Article 79, Paragraph 2.

Art. 81. Federal law shall prescribe to what extent the states are to participate in recruiting, provisioning, and quartering the army and in granting subventions of other necessaries.

\section{B. The Administration of Justice}

Art. 82. (1) All jurisdiction emanates from the Federal State.

(2) Judgments and decrees shall be pronounced and executed in the name of the Republic.

Art. 83. (1) The constitution and jurisdiction of the courts shall be prescribed by federal law.

(2) No one may be withdrawn from the jurisdiction of his regularly established court.

(3) Extraordinary courts shall be permissible only in cases prescribed by the laws concerning the procedure in criminal matters.

Art. 84. Military jurisdiction shall be abolished except in time of war. 
Art. 85. Capital punishment in ordinary procedure shall be abolished.

Art. 86. (1) Except as otherwise provided by this law the judges shall be appointed upon nomination of the Federal Ministry by the Federal President, or by the competent federal minister, upon authorization of the Federal President. The Federal Ministry or the federal minister shall request the senates (Senate) provided for by the constitution of the courts to submit proposals for appointment.

(2) The proposal for appointment, submitted to the competent federal minister and forwarded by him to the Federal Ministry, shall comprise, if there be a sufficient number of applicants, at least three names, and, if more than one position is to be filled, at least twice as many names as there are judges to be appointed.

Art. 87. (1) Judges shall be independent in the exercise of their judicial functions.

(2) A judge shall be regarded as exercising his judicial functions when he conducts all judicial business entrusted to him by law or by assignment of business, with the exception of such matters of judicial administration as may not be discharged, in accordance with prescriptions of the law, through senates or commissions.

(3) Business shall be assigned in advance among the judges of a court for a term designated by the constitution of the courts. Any matter thus assigned to a judge may be removed from his jurisdiction by decree of the administration of justice only in case of his disability.

Art. 88. (1) An age limit shall be fixed by the constitution of the courts upon the attainment of which judges shall be permanently retired.

(2) In all other cases judges may be removed from office, or against their will transferred to another position or retired, only by a formal judicial decision and only in the cases and according to the forms prescribed by law. These provisions, however, shall not apply to transfers or retirements which become necessary through changes in the constitution of the courts. In such cases the law shall prescribe within what period of time judges may be transferred or retired without the formalities otherwise prescribed.

(3) Temporary removal of judges from office may take place only by decree of the president of the court or of the superior 
judicial authority with the simultaneous reference of the matter to the competent court.

Art. 89. (1) The courts shall not have power to examine into the validity of laws duly proclaimed.

(2) If a court, on the ground of its being illegal, questions whether an ordinance governs a case, it shall suspend the proceedings and submit an application to the Supreme Constitutional Court for its annulment.

Art. 90. (1) Hearings or proceedings in civil or criminal cases before the court authorized to pass judgment shall be oral and public. Exceptions may be prescribed by law.

(2) In criminal procedure the indictment process shall apply.

Art. 91. (1) The people shall participate in the rendering of judgments.

(2) In case of crimes punishable by severe penalties-which crimes shall be described by law-and in case of all political crimes and misdemeanors, the jury shall render the verdict as to the guilt of the accused person.

(3) In criminal procedure for other penal offences lay judges (Schöffen) shall participate in the rendering of judgments, if the penalty to be imposed exceeds a limit to be prescribed by law.

Art. 92. The Supreme Judicial Court in Vienna shall be the highest court of appeal in civil and criminal cases.

Art.93. Amnesties on account of legally criminal acts may be granted by federal law.

Art. 94. (1) The administration of justice shall be separated from the administration in every instance.

(2) If an administrative authority has to decide upon private claims, the party aggrieved by such decision shall be given a remedy against the other party by regular legal process, provided there is no legal provision to the contrary.

(3) In matters concerning land reform (Article 12, Paragraph 1, Clause F) the commissions consisting of judges, administrative officials, and experts shall have the exclusive right of decision.

\section{CHAPTER IV}

The Legislative and Executrve Power of the States

A. General Provisions

Art. 95. (1) The legislative power of the states shall be exercised by the Landtags. Their members shall be elected in 
accordance with the principle of proportional representation by the equal, direct, secret, and personal suffrage of all Austrian citizens of both sexes, who are qualified to vote according to the regulations for elections to the Landtags and who have their domicile in the state.

(2) In the regulations for elections to the Landtags limitations upon the right to vote or to be elected may not be more restricted than in the regulations for election to the Nationalrat.

(3) The voters shall exercise their suffrages in election districts, which must consist of contiguous territory. The number of deputies must be apportioned among the election districts on the basis of the number of their citizens. A division of the voters in other electoral bodies shall not be permissible.

Art. 96. (1) Members of the Landtags shall enjoy the same immunity as the members of the Nationalrat. The provisions of Article 57 shall be duly applied.

(2) The provisions of Articles 32 and 33 shall apply also to the sittings of the Landtags and their committees.

Art. 97. (1) A state law shall require for its validity enactment by the Landtag, authentication and countersignature in accordance with the provisions of the state constitution, and publication by the chief executive officer of the state (Landeshauptmann) in the State Law Gazette.

(2) In so far as a state law provides for the participation of the federal authorities in its execution, the consent of the Federal Ministry must be obtained for this participation. Before this consent is obtained, the law may not be published.

Art. 98. (1) All laws enacted by the Landtags must be communicated to the competent federal minister by the chief executive officer of the state immediately after their enactment by the Landtag and before their publication.

(2) Within eight weeks after the day on which the law enacted by a Landtag has been filed at the office of the competent federal minister, the Federal Ministry may interpose a veto, supported by reasons, on the ground that the enacted law endangers federal interests. In that event the enacted law may be published only if the Landtag in the presence of at least onehalf of its members reënacts the law.

(3) Before the expiration of the time allowed for interposing a veto, publication shall be permissible only with the express consent of the Federal Ministry.

Art. 99. (1) A state constitution, enacted by state law, may 
be amended by state law in so far as the federal constitution is not affected thereby.

(2) A state constitutional law may be enacted only in the presence of one-half of the members of the Landtag and by a majority of two-thirds of the votes cast.

Art. 100. (1) Every Landtag may be dissolved by the Federal President on the demand of the Federal Ministry and with the consent of the Bundesrat. The consenting vote of the Bundesrat requires the presence of one-half of the members and a majority of two-thirds of the votes cast. The representatives of the Landtag to be dissolved may not participate in the vote.

(2) In case of dissolution writs of election must, according to the provisions of the state constitution, be issued within three weeks. The newly elected Landtag must be called together within four weeks after the election.

Art. 101. (1) The executive power of each state shall be exercised by a state ministry to be elected by the Landtag.

(2) The members of the state ministry need not be members of the Landtag. However, only persons eligible to the Landtag may be elected members of the state ministry.

(3) A state ministry shall consist of the chief executive officer of the state, the necessary number of deputies, and other members.

(4) On assuming office the chief executive officer of the state shall take an oath before the Federal President to support the federal constitution, and likewise the other members of the state ministry shall take the same oath before the chief executive officer of the state.

Art. 102. (1) Within the states the executive power of the Federal State shall be exercised-in so far as no federal authorities exist (direct federal administration) - by the chief executive officer of the state and the state authorities subordinate to him (indirect federal administration).

(2) The following matters may be administered directly by federal authorities within their constitutional sphere of action:

Marking out of boundaries, traffic in goods and live stock with foreign countries, customs, federal finances, monopolies, measures, weights, standards and assaying, technical experiments, administration of justice, commerce and industry, patents, protection of patterns, trademarks, and other commercial designations, engineering and consulting engineering, traffic, 
federal highways, police authority over watercourses and navigation, posts, telegraphs and telephones, mining, regulation and maintenance of waters, construction and maintenance of waterways, hydrographic service, surveying, labor law, protection of workers and other employees, social insurance, protection of monuments, federal police, federal gendarmerie, military affairs, care of discharged soldiers and their dependents.

(3) The Federal State shall have power to commission the chief executive officer of the state with the executive power of the Federal State in the matters enumerated in Paragraph 2.

(4) The extension of federal administrative authority over matters other than those enumerated in Paragraph 2 may take place only with the consent of the states affected thereby.

(5) The federal law, mentioned in Article 120, Paragraph 1, shall prescribe to what extent the chief executive officers of the states may have authority over the federal police and the federal gendarmerie.

Art. 103. The chief executive officer of the state shall be bound by the directions of the Federal Ministry and the individual federal ministers in matters of indirect federal administration. Administrative appeal in such matters shall, unless otherwise expressly provided by federal law, extend to the competent federal ministers.

Art. 104. The provisions of Article 102 shall not be applied to agencies created to administer the business of the Federal State referred to in Article 17.

Art. 105. (1) The chief executive officer of the state shall represent the state. In matters of indirect federal administration he shall be responsible to the Federal Ministry in accordance with Article 142. This responsibility may be asserted notwithstanding any immunity.

(2) The members of the state ministry shall be responsible to the Landtag in accordance with Article 142.

(3) A resolution of impeachment in accordance with Article 142 shall require the presence of one-half of the members.

Art. 106. An administrative official, legally trained, shall be commissioned as Landesamtsdirektor to direct administrative services of the state government. He shall also be the assistant to the chief executive officer of the state in matters of indirect federal administration.

Art. 107. The states may reach agreements among themselves only concerning matters within their autonomous sphere 
of action and must communicate the same immediately to the Federal Ministry.

B. The Federal Capital Vienna, and the State of Lower Austria

Art. 108. (1) The Landtag of Lower Austria is divided into two curiæ (Kurien). The one curia (state curia) shall consist of the deputies elected by the state exclusive of Vienna. The election of the other curia (city curia) shall be regulated by the constitution of the federal capital, Vienna.

(2) The number of deputies must be divided between the two curiæ in proportion to the number of citizens.

Art. 109. The two curiæ shall meet as the Landtag of Lower Austria to exercise the power of legislation in all such matters pertaining to the formerly autonomous provincial administration as may be declared common to both by their common state constitution. Among such matters shall be particularly the common state constitution itself.

Art. 110. (1) In all matters not common to both, each of the two divisions of the state shall have the status of an autonomous state.

(2) In such matters the municipal council of the city of Vienna shall have for Vienna the status of a Landtag, and the state curia shall have for the state of Lower Austria the status of a Landtag. The provisions of Article 57 shall be applicable to members of the municipal council of Vienna.

Art. 111. (1) The constitutions of the two divisions of the state as well as the election of members to the Bundesrat (Article 35) shall not be among the matters common to both.

(2) Likewise, in so far as it is within the sphere of action of the states, the power of legislation in respect to taxes shall be exercised separately by the municipal council of Vienna and the Landtag (state curia).

(3) Their common state constitution shall regulate in what manner the expenses for matters common to both shall be met.

Art. 112. The general provisions of this chapter shall apply to both divisions of the state. In regard to Vienna the Buirgermeister elected by the municipal council shall have the same status as the chief executive officer of a state; the city senate (Stadtsenat) elected by the municipal council shall have the status of a state ministry; and the Magistratsdirektor shall have the status of a Landesamtsdirektor. 
Art. 113. (1) Matters common to both shall be administered by an administrative commission elected by the Landtag of Lower Austria from among its members in accordance with the principles of proportional representation.

(2) The Bürgermeister of the city of Vienna and the chief executive officer of the state of Lower Austria shall be members of the administrative commission and shall preside alternately.

Art. 114. A separate state of Vienna may be formed by concurrent laws of the municipal council of Vienna and the Landtag of the state of Lower Austria.

\section{The Municipalities (Gemeinden)}

Art. 115. General public administration in the states shall, in accordance with the following provisions, be organized on the basis of local self-government.

Art. 116. (1) Administrative districts and units of local self-government into which the states are divided shall be the local municipalities (Ortsgemeinden) and the district municipalities (Gebietsgemeinden).

(2) The local municipalities shall be subordinate to the district municipalities and the latter shall be subordinate to the states.

Art. 117. (1) Local municipalities of more than 20,000 inhabitants shall at their request be declared district municipalities. In such local municipalities district administration shall be consolidated with municipal administration.

(2) Cities heretofore governed under their own charters shall be district municipalities.

Art. 118. The local municipalities and district municipalities shall be also autonomous economic units. They shall have the right to own and acquire property of any description and to dispose thereof within the limits of federal and state law, to engage in economic enterprises, to prepare and carry out their independent budgets, and to collect taxes.

Art. 119. (1) The agencies of the local municipality shall be the local municipal council and the local municipal administration (Ortsgemeindeamt); the agencies of the district municipality shall be the district municipal council and the district municipal administration (Gebietsgemeindeamt).

(2) Elections to all municipal councils shall take place in 
accordance with the principles of proportional representation and by the equal, direct, secret, and personal suffrage of all Austrian citizens who have their domicile within the territorial jurisdiction of the municipal council to be elected. The legislative bodies of the states shall issue the election regulations. In these election regulations the limitations upon the right to vote or to be elected may not be more restricted than in the regulations for elections to the Landtag. The election regulations may prescribe that the voters shall exercise their suffrages in election districts which must be contiguous. A division of the voters into other electoral bodies shall not be permissible. For elections of the territorial municipal council the judicial district shall be the election district. The number of deputies must be apportioned among the election districts on the basis of the number of citizens.

(3) Only persons who have their domicile in the district municipality and who are eligible for election to the Landtag may be elected members of the district municipal council.

(4) The municipal councils may, in accordance with the principles of proportional representation, elect from among their members, for the different branches of administration, special administrative committees, which may, in so far as definite professional interest or groups are concerned, be enlarged by the admission of representatives of such professional interest or groups.

(5) The director of the district municipal administration must be a legally trained administrative official.

Art. 120. (1) Additional fundamental principles for the organization of general public administration in the states shall be prescribed by federal constitutional law in accordance with Articles 115-119. Supplementary laws shall be enacted by the states.

(2) Federal and state laws respectively shall, within their scope of authority as defined by the constitution, determine what matters of administration, as to subject matter and administrative organization, shall be administered by representative assemblies, administrative committees, and administrative officials respectively.

(3) The local municipalities, however, shall be guaranteed scope of authority as to original jurisdiction in respect to the following matters:

(a) Security of person and property (local security police). 
(b) First aid and life saving.

(c) Maintenance of streets, roads, public squares, and bridges of the municipality.

(d) Local street police.

(e) Protection and policing of the fields.

(f) Market and food police.

(g) Sanitary police.

(h) Building and fire police.

\section{CHAPTER V}

Control over the Expenditures of the Federal State

Art. 121. (1) An Independent Court of Audit shall be empowered to examine the expenditures of each and every agency of the Federal State as well as the expenditures of the endowments, foundations, and institutions administered by agencies of the Federal State. It may also be entrusted with the examination of expenditures of enterprises in which the Federal State is financially interested.

(2) The Independent Court of Audit shall draft the balance sheet of the federal budget and present it to the Nationalrat.

(3) All documents concerning debts of the State (financial and administrative debts) must, in so far as they authenticate a liability of the Federal State, be countersigned by the President of the Independent Court of Audit. Such countersignature certifies only the legality of the expenditure and its correctness as to accounting.

Art. 122. (1) The Independent Court of Audit shall be directly subordinate to the Nationalrat.

(2) The Independent Court of Audit shall consist of a president and the necessary officials and employees.

(3) The president of the Independent Court of Audit shall be elected by the Nationalrat on nomination by the main committee.

(4) The president of the Independent Court of Audit may not be a member of any general representative body and may not have been a member of the Federal Ministry or any state ministry within the last five years.

Art. 123. (1) In respect to responsibility the president of the Independent Court of Audit shall have the same status as members of the Federal Ministry. 
(2) He may be relieved of office by resolution of the Nationalrat.

Art. 124. (1) The president shall be represented by the official of the Independent Court of Audit who is next highest in rank.

(2) In case of representation of the president, the provisions of Article 123 shall apply to his representative.

Art. 125. (1) The Federal President shall appoint the offcials of the Independent Court of Audit on nomination by, and with the countersignature of, the president of the Independent Court of Audit; the same shall apply to the conferring of titles of office. The Federal President, however, may empower the president of the Independent Court of Audit to appoint officials of certain classes.

(2) The president of the Independent Court of Audit shall appoint its employees.

Art. 126. No member of the Independent Court of Audit may take part in the direction or administration of enterprises which must render an account to the Federal State or to the states or which receive a subvention from, or have a contract with the Federal State or a state, except enterprises the exclusive object of which is the advancement of humanitarian endeavors or the betterment of the economic conditions of public employees or their dependents.

Art. 127. In regard to the expenditures of a state the constitutional laws of a state may assign to the Independent Court of Audit the same functions as are conferred upon it by this law in regard to the expenditures of the Federal State.

Art. 128. Detailed regulations concerning the activities of the Independent Court of Audit shall be prescribed by federal law.

\section{CHAPTER VI}

\section{Constitutronal and Administrative Guarantees}

A. The Supreme Administrative Court

Art. 129. (1) Any person who claims to have been aggrieved by an erroneous decision or decree of an administrative authority may, after having exhausted his administrative appeals, take his complaint to the Supreme Administrative Court.

(2) If, in matters referred to in Articles 11 and 12, the com- 
petent federal minister considers the interests of the Federal State injured by an erroneous decision or decree of an authority of a state he also may, in the name of the Federal State, take his complaint against such violation of law before the Supreme Administrative Court.

(3) A violation of law does not exist, in so far as an administrative authority has been empowered by the provisions of the law to render a discretionary decision or decree and has exercised such discretion within the meaning of the law.

Art. 130. In matters concerning which complaints may be taken to the Supreme Administrative Court, administrative appeals may be shortened by federal or state law in accordance with the provisions of Articles 10-15 determining spheres of authority.

Art. 131. From the jurisdiction of the Supreme Administrative Court are excluded any matters:

(a) which fall within the jurisdiction of the Supreme Constitutional Court;

(b) which fall within the jurisdiction of the ordinary courts;

(c) which are to be decided or decreed by a collegiate authority, which, whether acting in an inferior or superior capacity, shall have among its members at least one judge.

Art. 132. Every senate (Senat) of the Supreme Administrative Court which renders judgment upon an appeal from a decision or decree of an administrative authority of a state shall as a rule have among its members a judge who formerly belonged to the judicial or administrative service of that state.

Art. 133. (1) A judgment of reversal by the Supreme Administrative Court operates to set aside an erroneous decision or decree.

(2) The Administrative authorities when rendering a new decision or decree are bound by the judicial opinion of the Supreme Administrative Court.

(3) The Supreme Administrative Court may itself determine a matter in so far as the administrative authority is not, in accordance with the provisions of the law, empowered to decide such matter at its own discretion.

Art. 134. (1) The Supreme Administrative Court shall have its seat in the federal capital, Vienna.

(2) It shall consist of a president, a vice-president, and the necessary number of senate presidents (Senatspräsidenten) and counselors. 
(3) At least one-half of the members must have the qualifications for the office of judge.

Art. 135. The president, the vice-president and the members of the Supreme Administrative Court shall be appointed by the Federal President upon nomination by the Federal Ministry. The nomination by the Federal Ministry shall require, for the president and one-half of the members, the assent of the main committee of the Nationalrat; for the vice-president and the other half of the members, the assent of the Bundesrat.

Art. 136. The administrative jurisdiction and the organization of the Supreme Administrative Court shall be regulated by federal law.

\section{B. The Supreme Constitutional Court}

Art. 137. The Supreme Constitutional Court shall render judgment upon all claims against the Federal State, the states, or the municipalities, which cannot be brought before the regular courts.

Art. 138. The Supreme Constitutional Court shall also render judgment upon conflicts of jurisdiction:

(a) between courts and administrative authorities;

(b) between the Supreme Administrative Court and the courts, and in particular between the Supreme Administrative Court and the Supreme Constitutional Court itself;

(c) between the states themselves, as well as between a state and the Federal State.

Art. 139. (1) The Supreme Constitutional Court shall render judgment upon the illegality of ordinances of a federal or state authority on the application of a court; but if such an ordinance shall constitute the basis of a judgment of the Supreme Constitutional Court, it may render judgment on its own responsibility.

It shall also render judgment upon the illegality of ordinances of a state authority on application of the Federal Ministry. It shall also render judgment upon the illegality of ordinances of a federal authority on application of a state ministry.

(2) The judgment of the Supreme Constitutional Court, by which an ordinance is annulled as being illegal, shall obligate the competent authority to publish the annulment immediately. The annulment shall become effective on the day of publication.

Art. 140. (1) The Supreme Constitutional Court shall render 
judgment, on application of the Federal Ministry, upon the unconstitutionality of state laws; on application of a state ministry, upon the unconstitutionality of federal laws; but if such a law constitutes the basis of a judgment of the Supreme Constitutional Court, it may render judgment upon its own responsibility.

(2) The application mentioned in Paragraph 1 may be made at any time; the ministry that makes the application must communicate it immediately to the competent state ministry or the Federal Ministry, as the case may be.

(3) The judgment of the Supreme Constitutional Court by which a law is annulled as being unconstitutional, shall obligate the Federal Chancellor or the competent chief executive officer of a state to publish the annulment immediately; the annulment shall become effective on the day of the publication, unless the Supreme Constitutional Court determines a period of time at the expiration of which the annulment shall become effective. This period of time may not exceed six months.

(4) The provision of Article 89, Paragraph 1, shall not apply to the examination into the constitutionality of laws by the Supreme Constitutional Court.

Art. 141. The Supreme Constitutional Court shall render judgment concerning contested elections to the Nationalrat, to the Bundesrat, to the Landtags, or to any other general representative body; and on application of one of these representative bodies, it shall render judgment in respect to the declaration that one of its members has lost his seat.

Art. 142. (1) The Supreme Constitutional Court shall render judgment in impeachment proceedings to determine the constitutional responsibility of the highest federal or state authorities for wrongful violations of law in the exercise of their offices.

(2) Impeachment proceedings may be brought:

(a) against the Federal President on account of violation of the federal constitution: by resolution of the Bundesversammlung.

(b) against members of the Federal Ministry, or those authorities having the same status in regard to responsibility, on account of violation of a law: by resolution of the Nationalrat.

(c) against members of a state ministry, or those authorities having according to a state constitution the same status in regard to responsibility, 
on account of violation of a law: by resolution of the competent Landtag;

(d) against the chief executive officer of a state on account of violation of a law, as well as noncompliance with the ordinances or other decrees of the Federal Ministry in matters of indirect federal administration: by resolution of the Federal Ministry.

(3) Judgment by the Supreme Constitutional Court pronouncing a conviction shall decree loss of office, and under specially aggravating circumstances, temporary loss of political rights; in the event of minor violations of law in the cases mentioned in Paragraph 2, Clause D, the Supreme Constitutional Court may limit itself to pronouncing that a violation of law exists.

Art. 143. Impeachment proceedings 'against the persons enumerated in Article 142 may also be brought on account of penal offences connected with the official activities of the accused. In such case only the Supreme Constitutional Court shall be competent; the proceedings pending in the regular criminal courts shall be transferred to it. In such cases the Supreme Constitutional Court may also apply, in addition to Article 142, Paragraph 3, the provisions of the criminal law.

Art. 144. (1) The Supreme Constitutional Court shall decide in respect to complaints of a violation of constitutionally guaranteed rights by reason of a decision or a decree of an administrative authority, after administrative appeals have been exhausted.

(2) A judgment of reversal by the Supreme Constitutional Court operates to set aside an unconstitutional decision or decree. The authorities when rendering a new decision or decree are bound by the judicial opinion of the Supreme Constitutional Court.

Art. 145. The Supreme Constitutional Court shall render judgment upon violations of international law in accordance with the provisions of a special federal law.

Art. 146. The Federal President shall execute the judgments of the Supreme Constitutional Court.

Art. 147. (1) The Supreme Constitutional Court shall have its seat in Vienna.

(2) It shall consist of a president, a vice-president, and the necessary number of members and substitute members.

(3) The president, the vice-president, and one-half of the 
members and substitute members shall be elected for life by the Nationalrat; the other half of the members and substitute members shall be elected for life by the Bundesrat.

Art. 148. The detailed organization and the procedure of the Supreme Constitutional Court shall be regulated by federal law.

\section{CHAPTER VII \\ Concluding Provisions}

Art. 149. (1) In addition to this law [the federal constitution] the following laws shall, within the meaning of Article 44, Paragraph 1, be regarded as constitutional laws with due consideration for the changes necessitated by this law;

Fundamental Law of the State, of December 21, 1867, National Law Gazette, No. 142, concerning the general rights of citizens for the kingdoms and territories represented in the Reichsrat.

Law of October 27, 1862, National Law Gazette, No. 87, for the protection of personal liberty.

Law of October 27, 1862, National Law Gazette, No. 88, for the protection of the inviolability of the home.

Resolution of the provisional Constituent Assembly of October 30, 1918, State Law Gazette No. 3.

Law of April 3, 1919, State Law Gazette, No. 209, concerning the expulsion and the taking over of the property of the house of Hapsburg-Lorraine.

Law of April 3, 1919, State Law Gazette, No. 211, concerning the abolition of the nobility, of the secular orders of knights or of ladies, and certain titles and honors.

Law of May 8, 1919, State Law Gazette, No. 257, concerning the coat of arms and the Seal of State of the Republic of German Austria with the changes effected by Articles 2, 5, and 6 of the Law of October 21, 1919, State Law Gazette, No. 484.

Section V of Part III of the Treaty of St. Germain, of September 10, 1919, State Law Gazette, 1920, No. 303.

(2) Article 20 of the Fundamental Law of the State of December 21, 1867, National Law Gazette, No. 142, as well as the Law of May 5, 1869, National Law Gazette, No. 66, promulgated by reason of the aforementioned Article, shall cease to be in force.

Art. 150. The transition to this constitution of the Federal State shall be regulated by a special constitutional law, which shall become effective at the same time as this law. 
Art. 151. (1) This law shall become effective on the day of the first sitting of the Nationalrat, except as otherwise provided by the law referred to in Article $\mathbf{1 5 0 .}$

(2) The provisions, however, of Article 50, Paragraph 1, and of Article 66, Paragraph 2 shall become effective on the day of publication; and thereupon, until the other provisions of this law come into force, the power of ratification shall be exercised by the Constituent Assembly instead of the Nationalrat.

Art. 152. The execution of this law shall be entrusted to the Ministry of the State.

MAYR, M. P.

Hanusch, M. P.

RENNER, M. P.

BREISKY, M. P.

REISCH, M. P.

Heinl, M. P.
SEITZ, M. P.

Haueis, M. P.

Deutsch, M. P.

Ellenbogen, M. P.

ROLLER, M. P.

Pesta, M. P.

GrüNberger, M. P.

CONSTITUTIONAL LAW OF OCTOBER 1, 1920, CONCERNING THE TRANSITION TO THE CONSTITUTION OF THE FEDERAL STATE

The Constituent Assembly has resolved:

\section{General Provisions}

Section 1. All laws and executive directions (ordinances) of the State $\mathrm{e}^{1}$-including such imperial laws of the former State of Austria as have been put in force for the Republic in accordance with Section 16 of the resolution of October 30, 1918, State Law Gazette, No. 1, concerning the fundamental organization of political power-as well as all laws and executive directions (ordinances) of the states shall continue to be in force, in so far as they are not in conflict with the provisions of the law of October 1, 1920, State Law Gazette, No. 450, whereby the Republic of Austria is established as a Federal State (federal constitution).

Sec. 2. In the matters enumerated in Articles 10 and 11 of the federal constitution, the laws of the State, including the former imperial laws, as well as the laws of the states-these

1"Staat" as used in this transitional law is translated "State" and is capitalized. It refers to the State of German-Austria between the fall of the Empire in 1918 and the creation of the Federal State by this constitution. 
latter for the state in which they were enacted-shall become federal laws within the meaning of the federal constitution.

Sec. 3. (1) The laws of the states regulating the matters enumerated in Article 12 of the federal constitution shall continue to be laws of the states within the meaning of the federal constitution. But as soon as fundamental principles have been prescribed by federal law in respect to these matters, such laws of the states must be amended in accordance with Article 15, Paragraph 2, within the terms prescribed by federal law.

(2) If, however, the matters enumerated in Article 12 have been regulated entirely by laws of the State, including former imperial laws, any such law shall continue to be in force as a federal law for a period of three years computed from the date fixed in Section 42, Paragraph 1, of this law, unless it has been previously abolished by a federal law regulating the same matter within the meaning of Article 12. At the expiration of these three years such laws shall cease to be in force; thereupon state legislation may freely regulate such a matter as long as the Federal State does not exercise the power of legislation conferred upon it by Article 12.

Sec. 4. (1) Laws of the states concerning matters in which the states, according to Article 15, Paragraph 1, of the federal constitution, have the exclusive power of legislation, shall continue to be laws of the states within the meaning of the federal constitution.

(2) In so far as such matters have been regulated hitherto by laws of the State, including former imperial laws, such laws shall be considered in every state as laws of the state within the meaning of the federal constitution.

Sec. 5. The provisions of Sections 2-4 [of this transitional law] concerning laws shall apply as far as may be, to executive directions (ordinances) enacted pursuant to these laws.

Sec. 6. (1) In so far as the laws and the executive directions (ordinances) referred to in Section 1 [of this transitional law] are in conflict with the provisions of the federal constitution regulating organization-especially those concerning the competence and organization of the authorities as well as their character as federal or state authorities-they shall be considered as amended in accordance with the meaning of the federal constitution. Particularly in matters in which the states shall henceforth exercise the power of execution, appeal shall not lie beyond the state. 
(2) In so far as doubts arise by reason of this rule of construction, the Federal Ministry or the competent State Ministry, according to the provisions of the federal constitutional regulating competence, shall regulate such matters by ordinance until the enactment of a law within the meaning of the federal constitution.

Sec. 7. (1) The powers hitherto conferred by law on the agencies of the State or the states shall be taken over by the agencies of the Federal State or the states who are authorized to exercise analogous authority, in so far as the competence of these agencies has not been otherwise regulated by the federal constitution. Accordingly the Nationalrat shall take the place of the Constituent Assembly; the Federal President shall take the place of the President of the Constituent Assembly in so far as matters of government were entrusted to the latter; the Federal Ministry shall take the place of the Ministry of the State; the federal ministers shall take the place of the secretaries of state; the secretaries of state shall take the place of the under-secretaries of state; the Independent Court of Audit shall take the place of the Independent Court of Audit of the State.

(2) The Federal Ministry as well as the individual federal ministers shall take over the powers vested in the Ministry by the law of July 24, 1917, National Law Gazette, No. 307, by which the Ministry was authorized to take in regard to economic problems measures necessitated by the extraordinary conditions due to the state of war.

Sec. 8. (1) The authorities of the State-exclusive of those of general political administration in the states (state ministries, chief authorities of the districts [Bezirkshauptmannschaften]), including therein the special branches of service attached to these authorities (construction and forestry, public health, veterinary service, archives and libraries, audit) and the agricultural authorities of original and appellate jurisdiction (district agricultural authorities and state agricultural authorities)shall become federal authorities.

(2) The status of such authorities of the State as are excepted by Paragraph 1 shall be regulated by the federal constitutional law concerning the organization of administration in the states (Article 12, Paragraph 1, and Article 120, Paragraph 1, of the federal constitution).

(3) The hitherto autonomous administrative authorities of 
the states shall become authorities (officials) of the states within the meaning of the federal constitution.

(4) The institutions of the State shall be taken over by the Federal State; the institutions of the states shall be institutions of the states; the institutions of the districts, the municipalities, or other public corporations shall be institutions of these corporations.

Sec. 9. (1) The employees of the authorities of the State that become federal authorities in accordance with Section 8 , Paragraph 1 [of this transitional law], shall become federal employees.

(2) The status of employees of such authorities of the State as are excepted in Section 8, Paragraph 1 [of this transitional law], shall be regulated in connection with the federal constitutional law concerning the organization of administration in the states.

Sec. 10. (1) The existing police authorities of the State shall become federal authorities and shall administer their previous functions as functions of the Federal State.

(2) The existing gendarmerie shall be the federal gendarmerie.

Sec. 11. (1) Properties, including funds and institutions, belonging to, or administered by, the states in their capacity as formerly autonomous corporations, shall be properties of the states or shall be taken over by the administration of the states within the meaning of the Federal Constitution. In respect, however, to school funds administered by the states, the prevailing conditions shall continue until the promulgation of the federal constitutional law concerning the spheres of competence of the Federal State and the states in matters pertaining to schools, education, and popular instruction (Article 14 of the federal constitution).

(2) The entire remaining property of the State shall be federal property; the final settlement in regard to the property of the State shall be regulated by the federal constitutional law concerning the financial settlement between the Federal State and the states.

\section{Provisions in Regard to Special Articles of the Federal Constitutional Law}

Sec. 12, in regard to Article 2.

(1) As soon as it has manifested its intention, Burgenland 
shall be incorporated in the Federal State as an autonomous state having equal rights with the other states.

(2) Detailed regulations concerning the status of Burgenland in the Federal State as an autonomous state, having equal rights with the other states, shall be prescribed by special federal constitutional law.

Sec. 13, in regard to Article 4.

(1) Restrictions on or interference with interstate or intrastate passenger or freight traffic shall be permissible only as long as the extraordinary conditions mentioned in Article 10, Paragraph 15, continue (Section 17 of this transitional law), and may be enacted only by the Federal State.

(2) Existing restrictions on traffic, not imposed by the State, shall cease to be in force no later than June 30, 1921, unless they have been approved by the State or have been subsequently approved by the Federal State.

Sec. 14, in regard to Article 6.

(1) Every citizen of the Republic shall be a citizen of the state of which his native municipal district is a part and shall be at the same time a citizen of the Federal State.

(2) Persons being Austrian citizens without having domiciliary rights (Heimatrecht) in any municipality of the Republic shall be citizens of the Federal State. Federal law shall prescribe in what municipality they may acquire domiciliary rights and thereby the prerequisites for citizenship in a state. The Federal State shall have regulatory powers in respect to persons who, without having obtained domiciliary rights, have acquired national citizenship through option by virtue of the Treaty of St. Germain, or by virtue of a simple declaration in accordance with Section 2 of the Law of December 5, 1918, State Law Gazette, No. 91, concerning the right of national citizenship.

Sec. 15, in regard to Article 10, Paragraph 9.

Until the promulgation of the federal law provided for in Article 10, Paragraph 9, relative to the designation of highways as federal highways, the administration of highways of the State (former national highways) shall be exercised in accordance with the existing provisions at the expense of the Federal State by the agencies hitherto entrusted with this administration.

Sec. 16, in regard to Article 10, Paragraph 10.

The designation of those waters the regulation and maintenance of which is the function of the Federal State according to 
Article 10, Paragraph 10, shall take place with the consent of the individual states. Until such settlement the regulation and maintenance of these waters shall be continued in accordance with the existing provisions by the agencies hitherto entrusted therewith, with reservations as to a subsequent apportionment of the expenses incurred.

Sec. 17, in regard to Article 10, Paragraph 15.

(1) In conformity with Article 10, Paragraph 15, the Fcderal State shall have powers of legislation and execution concerning such measures as are necessary to assure a uniform conduct of economic affairs for the duration of the extraordinary conditions caused by the events of the War of 1914-1918.

(2) The date from which the aforementioned extraordinary conditions shall be considered settled shall be determined by federal law.

Sec. 18, in regard to Article 15, Paragraph 3.

(1) In the matters enumerated in Articles 11 and 12, such special provisions relative to the competence of the central authorities as are contained in the hitherto existing laws and executive directions (ordinances) shall, notwithstanding the provisions of Section 6 [of this transitional law], remain in force for the cases provided for in Article 15, Paragraph 3, until new federal laws shall have been enacted.

(2) In matters enumerated in Articles 11 and 12, in which the existing laws and executive directions (ordinances) do not regulate cases of the aforementioned kind, the provision of Article 15, Paragraph 3, shall become effective at once.

Sec. 19, in regard to Article 23.

Until the promulgation of the law necessary for the carrying out of the provisions of Article 23, the provisions of the Law of July 12, 1872, National Law Gazette, No. 112 (law concerning syndicates), shall remain in force with the changes effected by Section 12, Paragraph 2, of the Fundamental Law of November 22, 1918, State Law Gazette, No. 38, concerning judicial power.

Sec. 20, in regard to Article 24.

(1) The Constituent Assembly, elected by virtue of the Law of July 20, 1920, State Law Gazette, No. 316, concerning regulations for the elections to the Constituent Assembly, shall be the first Nationalrat within the meaning of the federal constitution.

(2) The laws of July 20, 1920, State Law Gazette, No. 317, concerning the election and convocation of the Constituent Assembly, and of July 20, 1920, State Law Gazette, No. 316, con- 
cerning regulations for elections to the Constituent Assembly, shall remain in force for the first Nationalrat. The term of the first Nationalrat shall remain fixed thereby at three years and shall begin with the day of its first meeting.

(3) Until a new regulation by law, the members of the $\mathrm{Na}$ tionalrat shall have the rights and duties of members of the Constituent Assembly, except as otherwise provided by the federal constitution. They shall, upon summons by the President of the Constituent Assembly, and by roll call, take an oath, using the formula "I swear," to be unalterably faithful to the Republic, to observe constantly and wholly the constitutional laws as well as all other laws, and to discharge their duties conscientiously.

(4) The officials and employees of the Constituent Assembly shall be employees of the office of the President of the Nationalrat; they shall have the same status, duties, and rights as the federal employees.

Sec. 21, in regard to Articles 34 and 36.

(1) The states shall be represented in the first Bundesrat as follows:

$\begin{array}{lrc}\text { Vienna } & 12 \text { members } \\ \text { State of Lower Austria } & 10 & \text { “ } \\ \text { Styria } & 6 & 6 \\ \text { Upper Austria } & 6 & \text { “، } \\ \text { Tyrol } & 3 & \text { “ } \\ \text { Carinthia } & 3 & \\ \text { Salzburg } & 3 & \\ \text { Vorarlberg } & 3 & \end{array}$

(2) As soon as Burgenland has elected a Landtag, the number of members to be deputized to the Bundesrat from Burgenland shall be determined by the Federal President in accordance with Article 34 .

(3) The Bundesrat shall assemble for its first sitting on the 21st day after the first meeting of the Nationalrat, in the hall of the parliament building designated by the Federal Chancellor. The member elected to the first place from Vienna shall act as the first presiding officer.

Sec. 22, in regard to Article 49.

(1) Until the promulgation of the law provided for in Article 49, Paragraph 2, the provisions of the Law of November 12, 1918, State Law Gazette, No. 7, concerning the publication of laws and ordinances in the State Law Gazette shall, in so far as 
they have not been changed by the federal constitution, apply, as far as may be, to the Federal Law Gazette; and thereupon Section 6 of this law is to be applied.

(2) The Federal Constitution and this law as well as the proclamation mentioned in Section 41 [of this transitional law] shall be republished in the first number of the Federal Law Gazette. The text of the laws thus republished shall be the standard.

Sec. 23, in regard to Article 54.

The Law of April 13, 1920, State Law Gazette, No. 180, concerning participation of the Constituent Assembly in the fixing of railroad, postal, telegraph, and telephone rates and of prices of articles subject to monopoly, as well as of salaries of persons employed in enterprises of the State, shall be considered as the federal constitutional law provided for in Article 54; and thereupon Section 6 of this law shall be applied.

Sec. 24, in regard to Articles 60 and 62.

(1) For the first election of a Federal President, the Bundesversammlung (Article 38) shall meet, without special convocation, on the 28th day after the first sitting of the Nationalrat at eleven o'clock in the morning in the parliament building.

(2) In case the oath of office cannot be administered to the newly elected Federal President at the same sitting of the Bundesversammlung, the Federal Chancellor must call the Bundesversammlung together at the next possible date for the administering of the oath of office to the Federal President.

(3) Until the oath of office has been administered to the Federal President the last President of the Constituent Assembly shall perform all the functions assigned to the Federal President.

Sec. 25, in regard to Article 65, Paragraph 3.

(1) The Law of February 26, 1920, State Law Gazette, No. 94, whereby Article 7 of the Law of March 14, 1919, State Law Gazette, No. 180, concerning the Ministry of the State is amended, shall be considered as an ordinary federal law within the meaning of Article 65, Paragraph 3.

(2) The rights of confirmation conferred upon the President of the Constituent Assembly by the hitherto existing laws shall be transferred to the Federal President, in so far as such provisions may not be considered changed by the transition to the Federal State.

(3) Without prejudice to the new regulation of the law of the public service of federal employees, the Federal President shall 
also be empowered to cancel and to mitigate disciplinary penalties pronounced by the disciplinary authorities against federal employees, to remit the legal consequences of such penalties, as well as to direct that disciplinary proceedings shall not be commenced or that disciplinary proceedings commenced should be discontinued.

Sec. 26, in regard to Article 69.

(1) Until the promulgation of the federal law provided for in Article 77, Paragraph 2, the Chancellor of the State and the Ministry of the State shall, as Federal Chancellor and Federal Ministry respectively, carry on their business provisionally, with their previous instructions and powers.

(2) The Ministry of the State shall be the first Federal Ministry within the meaning of the federal constitution.

Sec. 27, in regard to Article 79.

The army created by virtue of the Law of National Defence of March 18, 1920, State Law Gazette, No. 122, shall be the federal army within the meaning of the federal constitution.

Sec. 28, in regard to Articles 82-94.

The provisions actually regulating the jurisdiction and organization of the civil and criminal courts shall remain in force until further provisions have been enacted.

Sec. 29, in regard to Article 95.

The existing representative assemblies in the states shall be the first Landtags withın the meaning of the federal constitution.

Sec. 30 , in regard to Article 98.

(1) Article 98 shall also be applied to laws of the states enacted before the federal constitution goes into effect, in so far as the Ministry of the State has not yet taken any steps within the meaning of Articles 14 and 15 of the Law of March 14, 1919, State Law Gazette, No. 179, concerning representative assemblies, and in so far as the term prescribed in the last mentioned Articles has not yet expired. For computing the term prescribed in Article 98, Paragraph 2, the day on which the law has been filed in the competent office of the Ministry of the State shall be regarded as the day of its being filed in the office of the competent federal minister.

(2) Protests of the Ministry of the State against laws of the states, concerning which protests the Landtag has not yet passed a resolution prior to the date on which the federal constitution becomes effective, shall be considered as protests of the Federal Ministry. 
Sec. 31 , in regard to Article 98.

In so far as they are not considered as changed by the federal constitution, the state constitutions (state ordinances) at present in force shall be regarded provisionally as the state constitutions provided for in the federal constitution.

Sec. 32, in regard to Article 101.

(1) The former state ministries shall be considered as the state ministries within the meaning of the federal constitution.

(2) Within fourteen days after assuming office the Federal President shall call the chief executive officers of the states together to administer to them the aath of office (Article 101, Paragraph 4). The chief executive officer of a state already in office shall, however, even before he takes the oath of office, exercise the functions of a chief executive officer of a state within the meaning of the federal constitution.

(3) Salaries of members of the state ministries which fall due after the date fixed in Section 42, Paragraph 1 [of this transitional law], shall be paid by the states.

Sec. 33, in regard to Articles 108-114.

(1) The existing Landtag of Lower Austria shall be the Landtag of Lower Austria within the meaning of the federal constitution. The deputies of the Landtag elected in the municipal district of Vienna shall form the city curia; the remaining deputies of the Landtag shall form the state curia.

(2) The legislative and executive power in matters pertaining to the formerly autonomous provincial administration, as well as the remaining power of legislation hitherto conferred on the Landtag shall continue to be exercised by the agencies hitherto competent, until the agencies provided for in the common state constitution have been chosen. In particular, the present state ministry shall exercise the functions of the administrative commission (Article 113) until the election of the latter. The matters, however, described in Article 111, Paragraphs 1 and $\mathcal{2}$, shall, in respect to legislation and execution, be subject immediately to the competence of the two divisions of the state.

(3) In regard to Vienna the municipal council shall assume, within the meaning of the federal constitution, the functions of the Landtag; likewise the city Senate shall assume the functions of the state ministry and the Bürgermeister shall assume the functions of the chief executive officer of the state.

(4) Until the election of a new state ministry in the state of Lower Austria, the members of the present state ministry who 
have not been elected in an election district in Vienna, and the members of the present state council shall exercise provisionally the functions of the state ministry within the meaning of the federal constitution; and likewise any deputy of the chief executive officer of the state, provided such deputy has not been elected in an election district in Vienna, shall exercise provisionally the functions of the chief executive officer of the state.

(5) Until the promulgation of the federal constitutional law concerning the organization of administration in the states (Article 12, Paragraph 1), the functions of the indirect federal administration as to original and appellate jurisdiction shall for Vienna be combined in one jurisdiction. In all those matters, however, in which, by virtue of special legal provisions, no appeal lies beyond the state, the competent officer of the Magistrat shall decide in first instance, and the Bürgermeister, in his capacity as chief executive officer of the state, shall decide on appeal. These provisions shall apply to decisions in appellate proceedings pending on the date on which this law becomes effective.

(6) The existing legal provisions concerning salaries of the commissioners of the people in the states shall not apply to Vienna.

Sec. 34, in regard to Articles 115-119.

(1) Until the organization of general public administration in the states in accordance with the provisions of Articles 115119, the existing district administration shall continue; but in the jurisdiction of each district administration (Bezirkshauptmannschaft) a district council shall be elected. The sphere of action of this district council shall be determined by federal legislation and by state legislation within their legislative competences as prescribed by constitutional law.

(2) In cities governed under their own charters the municipal council shall assume at the same time the functions of the district council. These functions may be transferred to a special committee of the municipal council, and in Vienna to the district councils existing there or to committees thereof.

(3) The election of the district councils shall take place in accordance with the principles of proportional representation and by the equal, direct, secret, and personal suffrage of all Austrian citizens, who have their domicile in the territory of the district administration. The number of the members of the district councils shall be apportioned among the judicial 
districts on the basis of the number of their citizens. The provisions of Article 119, Paragraph 2, shall be duly applied.

(4) Only persons who have their domicile in the district and who are eligible for election to the Landtag shall be eligible for the district council.

(5) Detailed regulations for carrying out these elections shall be prescribed by state law.

(6) Further fundamental principles for the reorganization of the existing district administration in accordance with the preceding provisions shall be prescribed by federal law. Supplementary laws shall be enacted by the states. The federal law must be promulgated within four months after the federal constitution becomes effective; the state laws must be promulgated within four additional months after the federal law becomes effective.

Sec. 35, in regard to Article 122.

(1) The hitherto existing Independent Court of Audit of the State shall become the Independent Court of Audit within the meaning of the federal constitution.

(2) Until the election of the president of the independent Court of Audit his functions shall be performed by the last president of the Independent Court of Audit of the State.

Sec. 36, in regard to Article 131.

(1) The Supreme Administrative Court shall not become competent in administrative criminal matters until the general provisions of administrative criminal law and of administrative criminal procedure have been reënacted. This reënactment must take place before July 1, 1921 .

(2) The provisions contained in any laws concerning administration expressly exempting certain cases from the jurisdiction of the Supreme Administrative Court shall remain in force provisionally.

Sec. 37, in regard to Articles 134 and 135.

(1) The hitherto existing Supreme Administrative Court shall become the Supreme Administrative Court within the meaning of the federal constitution.

(2) Its president and the members shall remain in office until new appointments have been made in accordance with Article 135. These new appointments must be made before January $1,1921$.

(3) Within this period of time the president and the members of the Supreme Administrative Court may, within the meaning 
of Article 88, Paragraph 2, be retired without the formalities otherwise prescribed, unless they have been reappointed in conformity with Article 135.

Sec. 38, in regard to Article 136.

In so far as it has not been amended by the provisions of the federal constitution and of this law, the Law of February 6, 1919, State Law Gazette, No. 88, concerning the creation of a GermanAustrian Supreme Administrative Court, shall remain in force as the federal law provided for in Article 136 until further provisions have been enacted; in which case Section 6 of this law must be applied.

Sec. 39, in regard to Article 147.

(1) The hitherto existing Supreme Constitutional Court shall become the Supreme Constitutional Court within the meaning of the federal constitution.

(2) Its president, vice-president, members, and substitute members shall remain in office until new appointments have been made in accordance with Article 147.

Sec. 40, in regard to Article 148.

The laws regulating the organization and the procedure of the hitherto existing Supreme Constitutional Court shall be regarded as the federal law provided for in Article 148 until further provisions have been enacted.

Sec. 41, in regard to Article 151.

As soon as the Constituent Assembly to be elected on October 17, 1920, in conformity with Section 3 of the Law of July 20, 1920, State Law Gazette, No. 317, has been called together, the office of the Chancellor of the State shall fix by proclamation in the State Law Gazette the day on which the federal constitution and this law become effective.

\section{Concluding Provisions}

Sec. 42. (1) In so far as they do not relate to matters pertaining to the formerly autonomous administration of the states, Articles 10-13 inclusive and Article 15 of the Federal Constitution shall not become effective until the day on which the following laws come into force:

(a) The federal constitutional law concerning the financial settlement between the Federal State and the states or the municipalities. 
(b) The federal constitution law concerning the scope of authority of the Federal State and the states in regard to schools, education, and popular instruction (Article 14 of the federal constitution).

(c) The federal constitutional law concerning the organization of general public administration in the states (Article 120 of the federal constitution).

(2) Until such laws come into force, the following provisions shall be effective:

(a) In legislative and executive matters, the division or jurisdiction between the Federal State and the states shall not be changed from the existing division of jurisdiction bctween the State and the states.

(b) All matters pertaining to the formerly autonomous administration shall be administered by the states within their autonomous sphere of action.

(c) All other executive matters shall be administered by the states as matters of indirect federal administration within the meaning of the federal constitution, in so far as they do not come within the competence of special federal authorities (Article 102 of the federal constitution); Sec. 33, Paragraph 5 [of this transitional law], shall apply to the conduct of this indirect federal administration in Vienna.

(d) The authorities excepted in Section 8, Paragraph 1 [of this transitional law], shall be provisionally federal authorities; the employees described in Section 9, subdivision 2, [of this transitional law], shall be provisionally federal employees. Such powers concerning matters of personnel relative to employees described ir Section 9, Paragraph 2 [of this transitional law], as have been conferred upon the chief executive officers of the states and the state ministries in accordance with regulations hitherto in force, shall continue.

(e) The provisions of Section 6, Paragraph 1 [of this transitional law], shall be applied only in so far as they are not in conflict with the provisions of this Section.

(f) In regard to schools and education the national laws, including the former imperial laws, may be amended only by concurrent laws of the Federal State and the states affected thereby; except those legal provisions which concern institutions of higher learning or the fixing of teachers' salaries. The existing state laws may be amended only by 


\section{NEW CONSTITUTIONS OF EUROPE}

concurrent laws of the state affected thereby and of the Federal State.

Sec. 43. (1) This law shall become effective at the same time as the federal constitution.

(2) It shall be executed by the Ministry of the State.

SEITZ, M. P.

MAYR, M. P.

Haueis, M. P.

Hanusch, M. P.

Deutsch, M. P.

RENNER, M. P.

Ellenbogen, M. P.

BREISKY, M. P.

ROLler, M. P.

Reisch, M. P.

Pesta, M. P.

HeINL, M. P.

GrüNBERGER, M. P. 


\section{CHAPTER XIII \\ CZECHOSLOVAKIA}

\section{HISTORICAL NOTE}

The new state of Czechoslovakia, as its boundaries were defined by the Peace Conference, contains, with some modifications, the territory of the ancient kingdom of Bohemia and the lands of Moravia, Silesia, and Slovakia. ${ }^{1}$ From the standpoint of the mapmaker the formation of this state was a sensational settlement, comparable only to that of Poland. These two great medieval states have been revived in forms appropriate to the twentieth century; longcherished national aspirations have been accorded political recognition. The future will show whether Hegel was right when he said that the only lesson of history is that men learn nothing from history; whether the new states will avoid the weaknesses and blunders that were fatal to them in the past.

In some respects the record of Bohemia is quite unique. Here is a nation in the very centre of Europe, which after playing a memorable part in the field of political and religious progress, and becoming thoroughly imbued with western civilization, was crushed ruthlessly out of existence, lay like a corpse for two whole centuries, and then arose once more to recover, almost unaided, its lost nationhood. Poland, though at times far more brutally treated, never sank so low; and even the supreme crime of partition had at least the one advantage that it rendered a uniform system of denationalization impossible and, by imparting to Polish culture a certain quality of quicksilver, saved it from utter extinction. But Bohemia-her nobility well nigh exterminated, her middle class driven into exile, her peasantry reduced once more to serfdom, her national faith suppressed,

\footnotetext{
${ }^{1}$ Bohemia, Moravia, and Silesia were provinces of the Austrian part of the Dual Monarchy; Slovakia was an integral part of Hungary.
}

Composition of Czechoslovakia

Record of Bohemia under Austrian rule 


\section{8 \\ NEW CONSTITUTIONS OF EUROPE}

her hierarchy and administration alike in the hands of foreigners - seemed by the beginning of last century lost beyond all possibility of recovery. It is told that Jungman, one of the pioneers of Czech philology, was in the habit of meeting a small group of other patriots in a Prague inn, and that on one occasion he exclaimed, "If this roof should fall, there would be an end of the Czech national movement." The truth of this anecdote has been seriously challenged, and even if true, it exaggerates the actual situation of that day; but none the less it may stand as symbolic of the dire straits into which the nation had fallen.1

Czech and

Slovak

revivals
President Wilson and Czechoslovakia
The origins of the Czech and Slovak national revivals, the repression of the Czech patriots within Austria, the inclusion of the liberation of the Czechoslovaks in the Allied war aims, ${ }^{2}$ and the Congress of Oppressed Nationalities held in Rome in April, 1918, make an interesting but exceedingly complicated story. ${ }^{3}$ In the summer of 1918 , the United States and England offered some encouragement, and on October 14, the Allied Governments were notified that a provisional Czechoslovak government had been formed under the Presidency of Professor Masaryk. On October 16, Emperor Charles issued a manifesto addressed "To My Peoples" and announcing the federalization of Austria (not Austria-Hungary). ${ }^{4}$ In place of Austria there were to be four national states-German, Czech, Jugoslav, and Ukrainian. Trieste was to be a free port and the Poles of Galicia were to be allowed to unite with Poland. Morituri te salutamus.

The final death blow, however, was dealt by President Wilson's note of October 18. ${ }^{5}$ He told Count Burian that the United States had materially modified the position

\footnotetext{
'Temperley, Ed., A History of the Peace Conference of Paris, Vol. IV, p. 237 (London, 1921).

${ }^{2}$ The Allied note to President Wilson (January 10, 1917) demanded "the liberation of the Italians, as also of the Slavs, Rumanians, and Czechoslovaks from foreign domination." Baron Sonnino, relying on the Secret Treaty of London, opposed the inclusion of the Jugoslavs in this enumeration.
}

${ }^{3}$ See Temperley, op. cit., Vol. IV, Ch. IV.

${ }^{4}$ See above, p. 252.

'See above, p. 252. 
taken in the Fourteen Points by recognizing the belligerent Czechoslovak Government. On October 27 Count Andrássy (who had succeeded Burián as Joint Foreign Minister) accepted "President Wilson's standpoint on the Czechoslovak and Jugoslav questions as a basis for negotiation" and "annihilated at one blow not merely the Dual System, but the whole structure of political, dynastic, and constitutional theory upon which "AustriaHungary' had rested for two generations."'

On October 18, the independence of Czechoslovakia was proclaimed in Paris by the Czechoslovakia National Council under the leadership of Masaryk, Beneš, and Stefanik. And ten days later the Czech National Committee in Declaration of Independence, 1918 Prague took over the administration of civil and military affairs in Bohemia. The Paris proclamation, the first constitutional law of free Czechoslovakia, was a rather liberal document; it rejected the divine right of kings for "the principles of Lincoln and of the Declaration of the Rights of Man and the Citizen." It went on to declare that "Our democracy shall rest on universal suffrage; women shall be placed on an equal footing with men politically, socially, and culturally, while the right of the minority shall be safeguarded by proportional representation. National minorities shall enjoy equal rights. The government shall be parliamentary in form and shall recognize the principles of initiative and referendum. The standing army will be replaced by militia. The Czechoslovak nation will carry out far-reaching social and economic reforms. The large estates will be redeemed for home colonization, and patents of nobility will be abolished. . . . On the basis of democracy mankind will be reorganized. . . . We believe in democracy, we believe in liberty and liberty for evermore.",

'Temperley, op. cit., Vol. IV, p. 265.

2Ibid., pp. 260-267. 
The National Assembly and the Constitution

A provisional constitution was promulgated by the National Committee on November 13, 1918. It provided for an enlargement and transformation of the National Committee into a National Assembly of $256 \mathrm{mem}$ bers. From the former Austrian provinces the members were coöpted (not elected) in proportion to the strength of the existing political parties, according to the number of votes polled by each at the last election of the Reichsrat. From Slovakia 55 members were coöpted on the advice of The Slovak National Council. The task of the National Assembly was legislation and the control of the executive; but it was understood although not stated that the Assembly would also frame a permanent constitution. ${ }^{1}$ Compromises were at length reached on all debated points, and the constitution was promulgated on February 29, 1920.2

\section{THE CONSTITUTION OF CZECHOSLOVAKIA}

\section{THE LAW OF FEBRUARY 29, 1920}

WHEREBY THE CONSTITUTIONAL CHARTER OF THE CZECHOSLOVAK REPUBLIC IS INTRODUCED

We, the Czechoslovak nation, desiring to consolidate the perfect unity of our people, to establish the reign of justice in the Republic, to assure the peaceful development of our native Czechoslovak land, to contribute to the common welfare of all citizens of this State and to secure the blessings of freedom to coming generations, have in our National Assembly this 29th day of February 1920 adopted the following Constitution for the Czechoslovak Republic; and in doing so we declare that it will be our endeavor to see that this Constitution together with all the laws of our land be carried out in the spirit of our history as well as in the spirit of those modern principles embodied in

\footnotetext{
'Dedek, "The Constitution of Czecho-Slovakia," Journal of Comparative Legislation and International Law, Third Series, Vol. III, p. 116 (January, 1921).

'The translation here used is an English version printed in Prague and issued by the Societé de l'effort de la Tchécoslovaquie, apparently with official sanction. It has excellent introductions and translations of the electoral laws. Other versions appeared in Current History, July, 1920, and the Contemporary Reviev, September, October, and November, 1920.
} 
the idea of self-determination, for we desire to take our place in the Family of Nations as a member at once cultured, peaceloving, democratic, and progressive.

\section{[INTRODUCTORY LAW]}

Article I. (1) Enactments which are in conflict with the constitutional charter or with laws which may supplement or amend it are invalid.

(2) The constitutional charter may be altered or amended only by laws specifically designated as constitutional laws.

Art. II. A Constitutional Court shall decide as to whether the laws of the Czechoslovak Republic and of the Diet of Carpathian Ruthenia (Russinia) conform with Article I.

Art. III. (1) The Constitutional Court shall consist of seven members, two of whom shall be appointed by the High Court of Administration and two by the High Court of Justice; the remaining two members and the chairman shall be nominated by the President of the Republic.

(2) The appointment of representatives of the abovementioned courts to the Constitutional Court, the tenure of office, the rules of procedure and the definition of its jurisdiction shall be established by a specific enactment.

Art. IV. (1) The present National Assembly shall sit until the convocation of Parliament (the Senate and the Chamber of Deputies).

(2) Such laws as may have been enacted by the National Assembly but not made public in the official record by the day of the assembling of Parliament, shall not be promulgated if returned by the President of the Republic to the National Assembly.

(3) Regulations of the provisional constitution, limiting the period of exercise of the rights of the President of the Republic (Article 11 of the provisional constitution) and delimiting the duty of the Government to publish the law enacted shall remain valid as to laws enacted by the present National Assembly.

Art. V. The present President shall remain in office until a new election takes place. The duties and obligations of the President, as defined in the constitutional charter, become effective simultaneously with the adoption of the constitutional charter.

Art. VI. Until the election of the full number of members 
of Parliament, as required by the constitutional charter, the number of members actually elected shall determine the quorum necessary for the enactment of legislation.

Art. VII. (1) The provisions of Articles I, II, III, Paragraph 1 , and VI shall be an integral part of the constitutional charter, as set forth in Article 33 of that charter.

(2) Provisions as to the execution of laws, as postulated in the constitutional charter, shall not form part of that charter, as set forth in the preceding paragraph, unless the charter provides otherwise.

Art. VIII. (1) The constitutional charter shall become valid on the day of its proclamation.

(2) Article 20 does not apply to members of the present National Assembly.

Art. IX. On the day designated in Article VIII, Paragraph 1, all laws and regulations in conflict with the spirit of this charter and the republican form of the state, as well as all previously enacted constitutional laws, shall become invalid, even if part of the latter are not opposed to the constitutional laws of the Czechoslovak Republic.

Art. X. The foregoing nine articles shall become valid simultaneously with the constitutional charter. The execution of these enactments is hereby placed in the hands of the Government.

\section{THE CONSTITUTIONAL CHARTER OF THE CZECHOSLOVAK REPUBLIC}

\section{SECTION I}

\section{General Provisions}

Article 1. (1) The people are the sole source of all state power in the Czechoslovak Republic.

(2) This constitutional charter determines through what organs the sovereign people shall express their will in laws, provides for the execution of these laws, and guarantees to the people their rights and liberties. Such limitations are imposed upon these organs of government, as shall preserve to the people all rights guaranteed by this charter.

Art. 2. The Czechoslovak state shall be a Democratic Republic, the head of which shall be an elected President.

Art. 3. (1) The territories of the Czechoslovak Republic 
shall form a united and indivisible unit, the frontiers of which may be altered only by constitutional law.

(2) The autonomous territory of Carpathian Russinia, which shall receive the widest measure of self-government compatible with the unity of the Czechoslovak Republic, shall be an integral part of this unit by the terms of its voluntary declaration as set forth in the Treaty between the Allied Powers and the Czechoslovak Republic of September 10, 1919.

(3) Carpathian Russinia shall have its own Diet, which shall elect its presiding officer and other officials.

(4) This Diet shall legislate in linguistic, educational, and religious matters, in matters of domestic administration, and in such other matters as may be assigned to it by the laws of the Czechoslovak Republic. Laws enacted by this Diet, and signed by the President of the Republic, shall be published in a separate series and shall be counter-signed by the Governor of Russinia.

(5) Carpathian Russinia shall be represented in Parliament by Deputies and Senators elected according to the general suffrage law of the Czechoslovak Republic.

(6) The head of Russinia shall be a Governor, appointed by the President of the Czechoslovak Republic on the recommendation of the Government, and he shall be responsible also to the Diet of Russinia.

(7) Public officials in Russinia shall be, in so far as possible, selected from the population of Russinia.

(8) Details as to the right of suffrage and eligibility to the Diet shall be defined by special legislation.

(9) The law enacted by the Parliament defining the frontiers of Carpathian Russinia shall form part of the constitutional charter.

Art. 4. (1) Citizenship in the Czechoslovak Republic is single and uniform.

(2) The law regulates the conditions governing the acquisition, the rights and duties, and the termination of citizenship in the Czechoslovak Republic.

(3) A citizen or subject of a foreign state cannot at the same time be a citizen of the Czechoslovak Republic.

Art. 5. (1) The capital of the Republic is Prague.

(2) The colors of the Republic are white, red, and blue.

(3) Official emblems and flags shall. be determined upon by law. 


\section{NEW CONSTITUTIONS OF EUROPE}

\section{SECTION II}

\section{Legislative Powers, Constitution and Competency of Parliament and of Both Its Chambers}

Art. 6. (1) The legislative power of the whole Czechoslovak Republic shall rest in the hands of Parliament, which shall be composed of a Chamber of Deputies and a Senate.

(2) The seat of both chambers shall be at Prague. In case of urgent necessity, Parliament may be temporarily summoned to some other locality in the Czechoslovak Republic.

Art. 7. (1) The legislative and administrative powers of the former Diets is hereby abolished.

(2) Unless they provide otherwise, enactments of Parliament shall be binding throughout the Czechoslovak Republic.

Art. 8. The Chamber of Deputies shall be composed of 300 nembers, elected according to a general, equal, direct and secret suffrage, on a basis of proportional representation. Elections shall be held on Sundays.

Art. 9. The right to vote for the Chamber of Deputies appertains to all citizens of the Czechoslovak Republic without distinction of sex, who are 21 years of age and who comply with the other provisions of the electoral regulations.

Art. 10. All citizens of the Czechoslovak Republic without distinction of sex who are 30 years of age and who comply with the conditions of the suffrage law may be elected as Deputies to the Chamber.

Art. 11. The term for which the Chamber of Deputies is elected shall be six years.

Art. 12. Details as to the exercise of suffrage rights and the manner of carrying out elections are set forth in the provisions dealing with elections to the Chamber of Deputies.

Art. 13. The Senate shall consist of 150 members elected according to general, equal, direct, and secret suffrage on a basis of proportional representation. Elections shall be held on Sundays.

Art. 14. The right to vote for the Senate appertains to all citizens of the Czechoslovak Republic without distinction of sex who are 26 years of age and who comply with the other provisions of the law concerning the constitution and the rights and powers of the senate.

Art. 15. All citizens of the Czechoslovak Republic without distinction of sex who are 45 years of age and who comply with 
the other conditions concerning the constitution and the rights and powers of the Senate are eligible to the Senate.

Art. 16. The term for which the Senate is elected shall be eight years.

Art. 17. Specific provisions as to the exercise of the suffrage and the manner of elections are set forth in the law governing the constitution and law of the Senate.

Art. 18. No person may be at the same time a member of both chambers.

Art. 19. (1) An electoral court shall pass upon the validity of elections to Parliament.

(2) Details shall be settled by law.

Art. 20. (1) If a civil servant become a member of Parliament, he shall be granted leave automatically pending his term in Parliament; he shall be entitled to his regular salary, but with no local allowances, and he shall retain from his official duties his right to seniority promotion. University professors are entitled to leave of absence; if they make use of this right, the same provisions apply to them as to other state servants.

(2) All other public servants and officials shall have the right to obtain leave pending their term as members of Parliament.

(3) Members of Parliament cannot enter the civil service until after the expiration of one year from the time they cease to be members.

(4) This provision does not apply to Ministers. The time limit in section 3 shall not affect deputies or senators who were civil servants before they became members of Parliament, provided that they return to the same department.

(5) District governors cannot become members of Parliament.

(6) Members of the Constitutional Court, commissioners of an electoral court and members of district assemblies cannot at the same time be members of Parliament.

Art. 21. Members of either chamber can resign their mandates at any time.

Art. 22. (1) Members of Parliament shall execute their functions in person. They shall not receive orders from anybody.

(2) They shall not address to public authorities requests in the personal interest of individuals, unless they do so in their professional capacity.

(3) At their first sitting, members of Parliament shall take 


\section{NEW CONSTITUTIONS OF EUROPE}

the following oath: "I pledge myself to be faithful to the Czechoslovak Republic, to uphold its laws and to carry out my mandate to the best of my knowledge and conscience." Refusal to take this oath or the making of any reservation thereto shall disqualify for membership in Parliament.

Art. 23. Members of Parliament shall not be prosecuted for the exercise of their functions as members. For statements made in the chamber, members shall be amenable only to the disciplinary statutes of the chamber.

Art. 24. (1) Only with the consent of the respective chambers shall members of Parliament become liable to civil or criminal prosecution. If this consent be not granted, such prosecution shall become permanently null and void.

(2) This provision does not apply to the legal liability of a member as responsible editor. ${ }^{1}$

Art. 25. If a member of either chamber be apprehended and arrested in the commission of a criminal act, the court or other authority having jurisdiction shall inform the Chairman of the respective chamber of the arrest. If the chamber or the committee defined under Article 54 does not within a fortnight give its consent to the arrest, it becomes null and void forthwith. If the committee does consent to the arrest, the chamber must give its decision within 14 days after its first sitting.

Art. 26. Members of either chamber shall have the right to refuse to give testimony in reference to matters confided to them as members of the chamber, even after they cease to be members. In the trial of a case of attempting to corrupt a member, testimony cannot be refused.

Art. 27. Members of either chamber shall have a right to remuneration as specified by law.

Art. 28. (1) The President of the Republic shall summon both chambers twice a year for a spring and an autumn session, the former to begin in March, the latter in October.

(2) Furthermore, he may summon Parliament for extraordinary sessions whenever he may deem it necessary. If at least one-half of the members of either chamber applies to the Prime Minister stating the object for summoning it, the President shall summon the Assembly within a fortnight from the date of such application; should he fail to do so, the Chairmen of both chambers shall convoke Parliament within the following fortnight.

(3) If four months shall have elapsed from the last ordinary

'In reference to libel and incitement to crime. 
session, the President is obliged to summon Parliament, if at least two-fifths of either chamber so desire, within a fortnight from the date of their application. Should he fail to do so, the Chairmen of both chambers shall, within the following fortnight, convoke Parliament.

Art. 29. The session of both chambers shall begin and end simultaneously.

Art. 30. (1) The President of the Republic shall declare the session of Parliament at an end.

(2) He may prorogue Parliament for not longer than a month, and not more frequently than once a year.

Art. 31. (1) The President shall have the right to dissolve Parliament.

(2) He shall not be allowed the exercise of this right during the last six months of his term of office. After the expiration of the electoral term, or after the dissolution of either chamber, new elections shall take place within 60 days.

(3) The dissolution of the Senate shall not stay criminal proceedings inaugurated before the Senate in accordance with Articles 67 and 79 .

Art. 32. Either chamber may function, unless otherwise provided in this law, if at least two-thirds of the members are present. Its decisions are valid should a majority of one-half of those present be obtained.

Art. 33. The decision as to a declaration of war or as to the amendment of this charter shall require a three-fifths majority of all the members of each chamber.

Art. 34. (1) The decision of the Chamber of Deputies for the impeachment of the President of the Republic, the Prime Minister, or other members of the Government, shall require a twothirds majority with two-thirds of the members present.

(2) The procedure before the Senate sitting as a court of prosecution shall be regulated by law.

Art. 35. Each chamber shall elect its own Chairman and other officers.

Art. 36. The sittings of both chambers shall be public. Sittings in camera may be held only where the rules of procedure so provide.

Art. 37. (1) The basic principles of the relations between both chambers and between the Government and Parliament and between the public and Parliament shall be regulated by specific law, which shall conform to the constitutional charter. 


\section{NEW CONSTITUTIONS OF EUROPE}

The internal order of each chamber shall be regulated by its own rules of procedure.

(2) So long as the Chamber of Deputies and the Senate do not create a new body of rules, the rules of procedure of the present National Assembly shall be binding upon them.

Art. 38. (1) Whenever both chambers meet in joint session as the National Assembly (Articles 56, 59,61,65), this body shall be governed by the rules of procedure of the Chamber of Deputies.

(2) Such a joint session shall be summoned by the Prime Minister, and its presiding officer shall be the Chairman of the Chamber of Deputies.

(3) The Chairman of the Senate shall act as Vice-Chairman of the National Assembly.

Art. 39. The ministers shall have the right to participate at any time in the meetings of either chamber or of committees. They shall be allowed to speak whenever they demand to be heard.

Art. 40. (1) At the request of either chamber or of a committee, a minister shall appear before that body.

(2) Otherwise he may be represented by an official of his department authorized by him.

Art. 41. (1) Proposals for legislation may originate either with the Government or in either chamber.

(2) Every proposal made by members of either chamber shall be accompanied by an estimate of the financial issue involved and by a proposal for the defraying of the necessary cost.

(3) Proposals of the Government for budget and army bills must first be presented to the Chamber of Deputies.

Art. 42. A constitutional law shall be valid only with the consent of both chambers. This applies also to other laws, unless otherwise provided by Articles 43, 44, and 48 .

Art. 43. (1) The Senate shall act on a bill proposed and passed by the Chamber of Deputies within six weeks, and on the budget and army bills within one month. The Chamber of Deputies shall act on a bill proposed and passed by the Senate within three months.

(2) These periods are counted from the day of presentation of printed bills by one chamber to the other, and may be altered by mutual consent; the Senate must act in all cases of budget and army bills within one month as set forth in the preceding paragraph.

(3) If during such a period, the term of the chamber which 
is to take action on the bill of the other expires, or if the chamber be prorogued or dissolved, the date is reckoned from the first day of its next sitting.

(4) If either chamber does not give its decision within the period specified, it is presumed that it gives its assent to the decision of the first chamber.

Art. 44. (1) A measure passed by the Chamber of Deputies shall become law, despite an adverse decision of the Senate, if the Chamber of Deputies declares by a majority of 50 per cent. of all its members that it adheres to its first decision. Should the Senate reject a draft bill passed by the Chamber of Deputies by a majority of all its members, the bill becomes law provided that the Chamber of Deputies reënacts its decision by a threefifths majority of all its members.

(2) Proposals of the Senate shall be referred to the Chamber of Deputies: Should the Chamber of Deputies reject a proposal of the Senate and if the latter reënacts its bill by a 50 per cent. majority of all its members, the bill shall be referred back to the Chamber of Deputies. Should the Chamber of Deputies reject the bill for the second time by a majority of 50 per cent. of all its members, the bill shall not become law.

(3) Bills so rejected may not be presented to either chamber until after the lapse of one year.

(4) Should either chamber amend a bill originating in the other chamber, its action shall be deemed a rejection of the bill.

Art. 45. Should either chamber have under consideration a bill already passed by it or a bill passed by the other chamber (Article 44, Paragraph 2), and should it be dissolved or its term of office expire before action has been taken, its new decision shall be considered its second action in accordance with Article 44 .

Art. 46. (1) Should Parliament reject a bill presented by the Government, the latter can proclaim a referendum, but this action on the part of the Government must be unanimous.

(2) All citizens qualified to vote for the Chamber of Deputies shall be qualified to vote at the referendum.

(3) The method of referendum shall be determined by law.

(4) Referendum is inadmissible in respect of such government bills as amend the constitution. (Article I, Introductory Law.)

Art. 47. The President of the Republic shall have the right to return with comments any bill passed by Parliament within a month of its presentation to the Government. 
Art. 48. (1) Should both chambers, by ballot, taken on roll call, affirm the returned bill by a majority of 50 per cent. of all their members, the bill shall become law.

(2) Should the bill not receive a majority of votes in both chambers, the bill becomes law, provided that the Chamber of Deputies in the new ballot, taken by roll call, passes it by a three-fifths majority of all its members.

(3) Should it be a bill for the adoption of which the presence of a larger number of members and a larger majority is required, it is necessary that such presence and majority be obtained for the adoption of the returned bill.

(4) Provisions under Article 45 apply accordingly.

Art. 49. (1) For a bill to become valid as law, it must be made public as specified by statute.

(2) For the proclamation of all laws the following preamble must be prefaced: "The Parliament of the Czechoslovak Republic has resolved upon the following law."

(3) The law shall be published within eight week days from the expiration of the period laid down in Article 47. Should the President make use of his right referred to in Article 47, the law shall be issued within eight week days of the announcement of its reënactment by Parliament to the Government (Article 48).

Art. 50. In every law it shall be specified to which member of the Government its execution is entrusted.

Art. 51. (1) The law shall be signed by the President of the Republic, the Prime Minister, and the minister entrusted with its execution. If the President be incapacitated or ill, and there is no Vice-President, the Prime Minister may sign on behalf of the President.

(2) The Prime Minister may be represented for the purposes of signing laws as specified by Article 71.

Art. 52. (1) Each chamber shall have the right to put questions to the Prime Minister and other members of the Government on matters within the scope of their competence, to enquire into administration, to elect committees to whom the ministers shall provide information, and to adopt proclamations and resolutions.

(2) The Prime Minister and the members of the Government shall answer questions put to them.

Art. 53. The exercise of control of the financial administration and of the state debt shall be regulated by law. 
Art. 54. (1) During the period elapsing between the dissolution of either chamber and its reassemblage or between the expiration of its term of office and its convocation and during the period of adjournment, there shall sit a committee of twentyfour members. Sixteen members of this committee, with an equal number of alternates, shall be chosen by the Chamber of Deputies from its members, and eight members, with an equal number of alternates, shall be chosen by the Senate from its members. Each alternate shall represent only the member of the committee, as the alternate to whom he has been chosen. This committee shall act on all matters of immediate urgency, even if in ordinary circumstances they should require the enactments of legislation and shall exercise control of all government and executive powers. The term of office of the committee is one year.

(2) The first election shall take place immediately after both chambers organize. Presiding officers of both chambers shall vote. When a chamber shall meet after election, the members of the committee of twenty-four shall be elected by the newly organized chamber even if the term of office of preceding members of the committee of twenty-four has not expired.

(3) Elections shall be based on the principle of proportional representation. Party coalition is admissible. Should all parties agree on the choice of candidates, the committee shall be elected by the vote of the chamber. Should more than twenty Deputies and ten Senators oppose such election, it shall be carried out as at first provided.

(4) Members of the committee shall remain in office until a new committee is elected. Alternates take the place of members unable temporarily or permanently to carry out their duties. Should a member or alternate be incapacitated for service, while Parliament is in session, bye-elections to fill his post for the balance of the term of the committee shall be held. The new member must belong to the same political group as the old member, unless that group decides not to present a candidate or to refrain from voting.

(5) A member of the Government shall not be a member or alternate of the committee of twenty-four.

(6) When the committee has been elected, it shall elect its chairman and second vice-chairman from among the members elected by the Chamber of Deputies and a first vice-chairman from among the members elected by the Senate. 
(7) The members of the committee shall be subject to the provisions in Articles 23 to 27 of the constitutional charter.

(8) The committee shall be competent in all matters falling within the legislative and administrative powers of Parliament excepting:

(a) The election of the President or the Vice-president of the Republic.

(b) The amendment of the constitutional charter (see Article I of the Introductory Law) and the changing of the competence of public officials, unless it be a question of widening the scope of their activities by new duties.

(c) Burdening the citizens in the state with permanent financial obligations, increasing the military duties of the citizens or disposing of state property.

(d) Giving consent to a declaration of war.

(9) Provisions which under ordinary circumstances would require the enactment of legislation or expenditures apart from the budget, require the assent of half of all the members.

(10) In all other cases the presence of half of the members shall be sufficient. and a 50 per cent majority of those present shall be decisive. The chairman shall vote only to cast the decisive vote.

(11) Urgent provisions which under ordinary circumstances could be promulgated only by enactments of legislation, are admissible only on the recommendation of the Government approved by the President of the Republic.

(12) Provisions of the committee referred to in the last paragraph shall have the provisional validity of law only if published in the official record with reference to Article 54 of the constitutional charter and if signed by the President of the Republic, by the Prime Minister or his Deputy and half of the members of the Government. Provisions to which the President has refused to assent cannot be entered on record.

(13) The Constitutional Court shall have jurisdiction over such provisions of this committee as under ordinary circumstances would require the enactment of legislation, and therefore all such provisions shall be laid before it by the Government simultaneously with their publication in the record.

(14) The chairman and the vice-chairman of the committee shall report at the next meeting of the Chamber of Deputies and of the Senate the activities of the committee, even if mean- 
while their terms of office as members of Parliament shall have expired.

(15) Provisions not approved by both chambers within two months after their first session shall lose their validity.

\section{SECTION III}

\section{Governmental and Executive Powers}

Art. 55. Decree shall be issued only for the execution and within the limitations of each specific law.

\section{President of the Republic}

\section{I}

Art. 56. (1) The President of the Republic shall be elected by the National Assembly (Article 38).

(2) Any citizen of the Czechoslovak Republic, eligible to the Chamber of Deputies and not less than 35 years of age, may be elected President of the Republic (Article 67).

Art. 57. (1) The election shall be valid only if half of all members of both chambers shall be present and if a majority of three-fifths of those present shall be obtained.

(2) Should two ballots produce no result, a third ballot shall be cast to decide between those two candidates who at the previous balloting obtained the greatest number of votes. The candidate who obtains the largest number of votes shall be elected. In the case of a tie, the decision shall be made by lot.

(3) Details shall be determined by law.

Art. 58. (1) The period of office shall be counted from the day when the new President takes his oath according to Article 65.

(2) The term of office shall be seven years.

(3) Elections shall be held during the last four weeks prior to the expiration of the President's term of office.

(4) No one shall be elected more than twice in succession. He who has been elected President twice in succession cannot again be elected until the expiration of seven years from his last term of office. This provision, however, does not apply to the first President of the Czechoslovak Republic.

(5) The President remains in office until his successor shall be elected. 


\section{NEW CONSTITUTIONS OF EUROPE}

Art. 59. Should the President die or resign his position during his term of office, a new election shall be held according to Articles 56 and 57. The President so elected shall serve seven years. The National Assembly shall be convened for this purpose within fourteen days (Article 38).

Art. 60. Until a new President is elected (Article 59) or should the President be unable to execute the duties of his office, the execution of his functions shall appertain to the Government which may invest the Prime Minister with the specific functions.

Art. 61. (1) Should the President be unable to execute the duties of his office for more than six months (Article 60), and should the Government in the presence of three-quarters of its members so decide, the National Assembly (Article 38) shall elect a Vice-president who shall remain in office until the President shall be able to resume his functions.

(2) Disqualifications for presidential office (Article 58) shall apply to the office of Vice-president.

Art. 62. The same provisions as to the election of the President shall apply to the election of the Vice-president.

Art. 63. (1) The President of the Republic shall not be at the same time a member of Parliament. Should a member be elected Vice-president, he shall not during his service as Vicepresident fulfil his mandate as member of Parliament.

(2) The President's official residence shall be in Prague.

\section{II}

Art. 64. (1) The rights and duties of the President of the Republic are as follows:

(a) He shall represent the state in its relations with other states, shall negotiate and ratify international treaties. Commercial treaties, and treaties which for the state or its citizens entail financial or personal burdens, especially military burdens, as well as treaties affecting the territories of the state, require the affirmation of Parliament. The affirmation of Parliament takes the form of a constitutional law (Article $I$ of the Introductory Law);

(b) He shall receive and appoint diplomatic representatives;

(c) He shall declare the existence of a state of war, shall declare war with the previous consent of Parliament, 
and shall lay before Parliament for approval peace treaties which have been concluded;

(d) He shall convoke, prorogue, and dissolve Parliament (Articles 28-31) and shall proclaim its sessions at an end;

(e) He shall have the right to return with comment any law enacted by Parliament (Article 47). He shall sign all laws enacted by Parliament (Article 51), all laws enacted by the Diet of Carpathenian Ruthenia (Article 3) and the ordinances of the committee of twenty-four (Article 54 );

(f) He shall report verbally or in writing to the National Assembly on the state of the Republic, and shall recommend for consideration measures which he deems necessary and useful;

(g) He shall appoint and dismiss Cabinet ministers and define their number;

(h) He shall nominate university professors, judges, all state officials and army officers of the sixth class upward;

(i) $\mathrm{He}$ shall grant donations and pensions in special cases on the recommendation of the Government;

(j) He shall be commander-in-chief of the armed forces of the Republic;

(k) He shall grant pardon as per Article 103.

(2) All governmental and executive power, in so far as it does not or shall not explicitly appertain to the President according to the constitutional charter and the laws adopted after November 15, 1918, shall be reserved to the Government (Article 70).

\section{III}

Art. 65. The President of the Republic shall take an oath before the National Assembly (Article 38) on his honor and conscience to look to the welfare of the Republic and its people, and to abide by the constitution and laws.

Art. 66. The President of the Republic shall not be answerable at law in the exercise of his functions. The Government shall be answerable for all the President's official utterances.

Art. 67. (1) He may be prosecuted only for high treason before the Senate upon an indictment found against him by the Chamber of Deputies (Article 84). The only punishment 
shall be the loss of his office and permanent disqualification for the Presidency.

(2) Details shall be determined by law.

Art. 68. Every governmental or executive act of the President shall also bear the signature of the member of the Government responsible for its execution.

Art. 69. The same provisions shall apply to the Vicepresident that apply to the President of the Republic.

\section{The Government}

Art. 70. (1) The Prime Minister and other ministers of the Government shall be appointed and dismissed by the President of the Republic.

(2) The official seat of the Government shall be in Prague (Article 6, Paragraph 2).

Art. 71. The Government shall choose from among the members a Deputy Prime Minister. Should this Deputy fail to attend, he shall be represented by the oldest member of the Government.

Art. 72. The President of the Republic shall determine as to which member of the Government shall direct each department.

Art. 73. The members of the Government shall take an oath before the President on their honor and conscience that they will conscientiously and impartially perform their duties and abide by the constitution and other laws of the Republic.

Art. 74. No member of the Government shall be a member of the board of directors or controllers or a representative of any limited liability company, carrying on a business for profit.

Art. 75. The Government shall be responsible to the Chamber of Deputies, which may vote its lack of confidence in the Government. Such a vote shall be valid if more than half of all the members are present, if a 50 per cent. majority be obtained, and if the vote be taken by roll call.

Art. 76. Every motion for a vote of lack of confidence shall be signed by not less than a hundred deputies and shall be referred to a committee which must report thereon within eight days.

Art. 77. The Government may bring forward before the Chamber of Deputies a proposal for a vote of confidence. Such 
proposal shall be acted upon without being referred to a committee.

Art. 78. (1) Should the Chamber of Deputies vote lack of confidence in the Government or should it reject the Government's proposal for a vote of confidence, the Government shall resign to the President. The President shall then determine who shall direct governmental afiairs until a new Government be formed.

(2) Should the Government resign at a time when there is no President or Vice-president, the decision as to the resignation and as to the direction of governmental affairs shall be referred to the committee defined under Article 54 .

Art. 79. (1) Should the Prime Minister or any other member of the Government either consciously or from gross neglect violate the constitution or other laws while acting in his official capacity, he shall be responsible at law.

(2) The right of prosecution shall be reserved to the Chamber of Deputies (Article 34). The trial shall be conducted by the Senate.

(3) Details shall be determined by law.

Art. 80. The Government shall be competent to act as a body if in addition to the Prime Minister or his Deputy more than half the Ministers be present.

Art. 81. The Government shall decide in session:

(a) Government draft bills for Parliament, Government decrees (Article 84), as well as any proposals that the President may make in the exercise of his right defined under Article 47;

(b) All matters of a political nature;

(c) Appointments of judges, state officials, and army officers of the eighth class and higher grades, so far as such appointments shall fall under the jurisdiction of the central authorities; as well as proposals for appointments of officials nominated by the President of the Republic (Article 64, Paragraph 1, Subdivision H).

Art. 82. The President of the Republic shall have the right to be present at and to preside over meetings of the Government and to demand from the Government or its individual members written reports on any matter in their jurisdiction.

Art. 83. The President of the Republic shall have the right to call the Government or its members to conference.

Art. 84. Every Government decree shall be signed by the 
Prime Minister or his deputy and the Minister invested with its execution. It must be signed by at least half of the members of the Government.

\section{Ministries and Subordinate Administrative Offices}

Art. 85. The competence of Ministries shall be determined by law.

Art. 86. In subordinate administrative offices the citizens must so far as possible be represented, and the widest protection of the rights and interests of the citizens shall be assured.

Art. 87. (1) No one may hold at the same time an elective subordinate office and an office which has jurisdiction over the former.

(2) Exceptions to this rule shall be determined by law.

Art. 88. (1) A court composed of independent judges, having jurisdiction throughout the Republic, shall hear final appeals for protection against administrative rulings.

(2) Details shall be determined by law.

Art. 89. The lower offices of state administration shall be defined in principle by law, the detail execution of which may be regulated by decrees in council.

Art. 90. State offices charged with financial functions but without executive power shall be established and organized by Government decrees.

Art. 91. The constitution and competence of local autonomous governing bodies shall be determined by special laws.

Art. 92. Special laws shall provide for the guarantee by the state against damages caused by unlawful execution of public offices.

Art. 93. State officials in their official functions shall abide by the constitution and other laws. The same shall apply to non-official members of administrative bodies.

\section{SECTION IV}

\section{Judicial Powers}

Art. 94. (1) The law shall be administered by public law courts whose organization, jurisdiction, and procedure shall be regulated by law.

(2) No one shall be tried other than before his legal judge.

(3) Only in cases of criminal procedure, may courts be estab- 
lished for a limited period in cases specified in advance by law.

Art. 95. (1) Jurisdiction in civil matters shall be reserved to civil courts, either ordinary or extraordinary, and courts of arbitration; jurisdiction in criminal matters shall be reserved to public criminal courts, so far as it shall be not reserved by special law for courts martial or so far as these matters cannot be dealt with according to general regulations in police or financial prosecutions.

(2) A single Supreme Court of Justice shall be established for the whole Czechoslovak Republic.

(3) The competence and functions of juries shall be determined by special laws.

(4) Trial by jury may be temporarily suspended in cases provided for by law.

(5) The jurisdiction of courts martial may be extended to the civil population according to legal regulations in times of war only and for acts committed at such times only.

Art. 96. (1) Judicial power in all courts shall be separated from administrative power.

(2) Solution of disputes as to competence between courts and administrative authorities shall be determined by law.

Art. 97. (1) Conditions as to the qualification of judges shall be determined by law.

(2) The conditions of service of the judges shall be determined by law.

Art. 98. (1) All judges shall be independent in the exercise of their conscience and they shall be bound only by law.

(2) When taking the oath of office judges shall pledge themselves to abide by the law.

Art. 99. (1) Judges shall be appointed permanently; they may be transferred, dismissed, or pensioned against their will, only if a new juridical organization be set up for a time specified by law, or on the grounds of lawful disciplinary proceedings; they may be also pensioned after a valid finding when they have attained the age stated by law. Details shall be determined by a special law which shall also define the conditions under which judges may be suspended.

(2) Senates at law courts of the first and second instance shall be permanent for one year except where specified by law.

Art. 100. Judges shall not perform other paid functions permanent or temporary, except where permitted by law. 
Art. 101. (1) Verdicts shall be given in the name of the Republic.

(2) Proceedings before law courts shall be verbal and public. Verdicts in criminal matters shall always be proclaimed in public. The public may be excluded during the proceedings only under circumstances defined by law.

(3) In criminal proceedings the principle of prosecution shall be adopted.

Art. 102. The judges shall have the right, in determining a point of law, to inquire into the validity of a governmental decree; in the case of a law they can inquire only as to whether it was properly promulgated (Article 51).

Art. 103. (1) The President of the Republic shall have the right to grant an amnesty or pardons, to mitigate a sentence and the legal consequences of verdicts of criminal courts, especially the loss of the suffrage right to the National Assembly and other representative bodies; he shall also have the right to order the abolition or the suspension of criminal legal proceedings with the exception of proceedings in which the action is brought by private individuals.

(2) These rights shall not be exercised by the President in the case of members of the Government accused or sentenced according to Article 79.

Art. 104. A special law shall define the responsibility of the state and judges for any damages caused by the latter's breach of right in performing their duties.

Art. 105. (1) In cases of private property claims, coming for adjudication before an administrative authority, in which the plaintiff is dissatisfied with the decision of the latter, he may, after exhausting corrective efforts, appeal to the courts.

(2) Details shall be determined by law.

\section{SECTION $\mathbf{v}$}

Rights, Liberties, and Duties of the Citszen

Equality

Art. 106. (1) Privileges due to sex, birth, or occupation shall not be recognized.

(2) All persons residing in the Czechoslovak Republic shall enjoy within its territory in equal measure with the citizens of 
this Republic complete and absolute security of life and liberty without regard to origin, nationality, language, race, or religion. Exceptions to this principle may be made only so far as is compatible with international law.

(3) Only such titles may be conferred as designate official rank or a profession. This enactment in no way affects academic honors.

\section{Personal Freedom and Freedom of Property}

Art. 107. (1) Personal freedom shall be guaranteed. Details shall be laid down by an enactment which shall form part of this constitutional charter.

(2) No person shall be deprived of personal liberty or restricted in the enjoyment of the same except upon legal grounds. Public authorities can demand personal services from a citizen only on legal grounds.

Art. 108. (1) Every citizen of the Czechoslovak state may take up his abode wheresoever he will in the Czechoslovak Republic, may acquire there real property and carry on any calling for the purpose of earning profits within the limits of the law.

(2) This right shall suffer restriction only in the public interests and on the basis of law. law.

Art. 109. (1) Private ownership may be restricted only by

(2) Expropriation is possible only on the basis of law. Compensation shall be given in all cases unless it is or shall be provided by law that no compensation be given.

Art. 110. The right to emigrate abroad may be restricted only by law.

Art. 111. (1) Taxation and public levies generally may be imposed only by law.

(2) Likewise only by law may fines and punishments be prescribed and imposed.

\section{Domestic Liberty}

Art. 112. (1) Domestic rights are inviolable.

(2) Details shall be laid down by a law which shall form part of this constitutional charter. 


\section{Freedom of the Press, the Right of Free} Assembly and Association

Art. 113. (1) Freedom of the press as well as the right to assemble peaceably and without arms and to form associations is guaranteed. It is therefore in principle inadmissible to place the press under preliminary ${ }^{1}$ censorship. The manner in which the right of forming associations and the right of free assembly shall be exercised shall be determined by law.

(2) An association may be dissolved only when its conduct violates the law of the land or disturbs public peace and order.

(3) Restrictions may be imposed by law especially in cases of assembly in places which serve as public thoroughfares, in cases of the establishment of associations for the purpose of profit, and in cases of the participation of foreigners in political associations. The law shall also state what restrictions shall be placed on the principles of the foregoing paragraphs in time of war or in case of events taking place within the state which seriously threaten the republican form of government, the constitution, or public peace and order.

Art. 114. (1) The right of association to safeguard and ameliorate conditions of employment and economic conditions shall be guaranteed.

(2) All acts of individuals or societies which constitute an intentional violation of this right, are prohibited.

\section{The Right of Petition}

Art. 115. The right to petition shall be enjoyed by every person. Legal persons and corporations shall enjoy this right only within the bounds of their competence.

\section{Postal Inviolability}

Art. 116. (1) Inviolability of matter entrusted to the mail is guaranteed.

(2) Details shall be determined by enactment.

\footnotetext{
'Under the Austrian régime publications were submitted to the censor before being issued.
} 
Liberty of Instruction and of Conscience;

Liberty of Expressing Opinion

Art. 117. (1) Every person may within the limits of the law express his or her opinion by word, in writing, in print, by picture, etc.

(2) The same applies to legal persons within the limits of their competence.

(3) No one shall suffer in the sphere of his work or employment for exercising this right.

Art. 118. Scientific research and the publication of its results, as well as art, are free so far as they do not violate the penal code.

Art. 119. Public instruction shall be given so as not to be in conflict with the results of scientific investigation.

Art. 120. (1) Private establishments for instruction and education are permitted to be set up only within the limits of the law.

(2) The supreme authority and control over all instruction and education shall be in the hands of the state.

Art. 121. Liberty of conscience and religious creed is guaranteed.

Art. 122. All inhabitants of the Czechoslovak Republic enjoy in the same degree as the citizens of the Republic, the right to profess and exercise publicly and privately any creed, religion, or faith whatsoever, so far as the exercise of the same is not in conflict with public law and order or with morality.

Art. 123. No one shall be compelled either directly or indirectly to take part in any religious rite or ceremony whatsoever, rights pertaining to paternal or guardian authority being nevertheless respected. law.

Art. 124. All religious confessions shall be equal before the

Art. 125. The performance of specific religious rites may be prohibited if they are in conflict with public order or public morals.

\section{Marriage and Family}

Art. 126. Wedlock, family, and motherhood shall be under the special protection of the law. 


\section{Military Service}

Art. 127. (1) Every able-bodied citizen of the Czechoslovak Republic shall undergo military training and shall obey the summons when called upon for the defence of the state.

(2) Details shall be settled by enactment.

\section{SECTION VI}

Protection of National, Religious, and Racial Minorities

Art. 128. (1) All citizens of the Czechoslovak Republic shall be in all respects equal before the law and shall enjoy equal civic and political rights whatever be their race, their language, or their religion.

(2) Difference in religion, belief, confession, or language shall within the limits of the common law constitute no obstacle to any citizen of the Czechoslovak Republic particularly in regard of entry into the public services and offices, of attainment to any promotion or dignity, or in regard to the exercise of any trade or calling.

(3) Citizens of the Czechoslovak Republic may, within the limits of the common law, freely use any language they choose in private and business intercourse, in all matters pertaining to religion, in the press and in all publications whatsoever, or in public assemblies.

(4) This, however, does not affect the rights conferred on the state organs in these matters by laws already in force or to be passed in the future with a view to public order, the security of the state, or effective control.

Art. 129. The principles on which the rights as to language in the Czechoslovak Republic are based shall be determined by a special enactment which shall form part of this constitutional charter.

Art. 130. In so far as citizens of the Czechoslovak Republic are entitled by the common law to establish, manage, and administer at their own cost philanthropic, religious, or social institutions, they are all equal, no matter what be their nationality, language, religion, or race, and may, in such institutions, make use of their own language and worship according to their own religious ceremonies.

Art. 131. In towns and districts in which there lives a considerable fraction of Czechoslovak citizens speaking a language 
other than Czechoslovak, the children of such Czechoslovak citizens shall, in public instruction and within the bounds of the general regulations relating thereto, be guaranteed a due opportunity to receive instruction in their own tongue. The Czechoslovak language may at the same time be prescribed as a compulsory subject of instruction.

Art. 132. In towns and districts where there is living a considerable fraction of Czechoslovak citizens belonging to some minority, whether in respect of religion, or nationality, or language, and where specific sums of money from public funds as set out in the state budget or in the budget of local or other public authorities, are to be devoted to education, religion, or philanthropy, a due share in the use and enjoyment of such sums shall be secured to such minorities within the limits of the general regulations for public administration.

Art. 133. The method of carrying out the principles embodied in Articles 131 and 132, and especially the interpretation to be assigned to the expression "considerable fraction," shall be determined by special enactment.

Art. 134. Every manner whatsoever of forcible denationalization is prohibited. Non-observance of this principle may be proclaimed by law to be a punishable act.

Follow the Signatures:

T. G. Masaryk Tusar Staněk Houdek

\section{THE LAW OF FEBRUARY 29, 1920}

IN PURSUANCE OF ARTICLE 129 OF THE CONSTITUTIONAL CHARTER ESTABLISHING THE PRINCIPLES OF LANGUAGE RIGHTS WITHIN THE CZECHOSLOVAK REPUBLIC

Article 1. The Czechoslovak language shall be the state, official language of the Republic (Article 7 of the Treaty made between the leading Allied and Associated Powers and the Czechoslovak Republic and signed at St. Germain-en-Laye on September 10, 1919).

It is thus in particular the language:

(1) In which the work of all the courts, offices, institutions, undertakings, and organs of the Republic shall be conducted, in which they shall issue their proclamations and notices as well as their inscriptions and designations. (Exceptions to 
this section are laid down in Article 2 and Article 5 as well as in Article 6 relating to Russinia.)

(2) In which the principal text on state and other banknotes shall be printed.

(3) Which the armed forces of the country shall use for the purpose of command and as the language of the service; in dealings with men and companies not knowing this language their mother tongue may also be used.

Detailed regulations will be issued as to the duty of state officials and employees, as well as of officials and employees of state institutions and undertakings, to know the Czechoslovak language.

Art. 2. In respect of national and language minorities (Chapter I, Treaty of St. Germain) the following rules shall apply:

It shall be the duty of courts, offices, and organs, of the Republic whose competence relates to a jurisdictional district in which according to the latest census at least 20 per cent. of the citizens speak the same language-and that a language other than Czechoslovak - to accept (in all matters which they have to settle on the ground of their competence applying to such a district) from any member of this minority any complaints in this language and to deal with complaints not only in the Czechoslovak language but also in that in which the complaint itself is presented. Where there are several district courts in one community, that whole community shall be deemed to be a single jurisdictional district.

It shall be laid down by regulation to what extent and for what courts and offices it will be possible to restrict the settlement of cases to the language of the parties themselves. These courts and offices are those whose competence is limited to one district, namely a district with such a national minority, as well as courts and offices immediately subordinate to them.

Under similar conditions, it is the duty of the public prosecutor to frame the charges against an accused speaking another tongue in this language, too, or even in this language alone.

The executive authority shall determine in such cases what language shall be used.

If the party to any matter is not the initiator of the proceedings, he shall (if the other conditions of Article 2 are fulfilled) be entitled on the same principles to have his case dealt with also in his own language, or even in it alone so far as it is known, or otherwise at his request. 
In districts where there lives a national minority in the terms of Article 2, the language of the national minority shall be used concurrently with the Czechoslovak language in proclamations and notices issued by the state courts, offices, and organs and for their inscriptions and designations.

Art. 3. It is the duty of autonomous offices, representative councils, and all public corporations in the state whatsoever to accept and to deal with oral or written matter in the Czechoslovak language.

It shall always be possible to make use of this language in meetings and conferences; proposals and suggestions put forward in this language must be dealt with.

The state executive authority shall determine upon the language to be used for public proclamations and notices and for the inscriptions and designations for which the autonomic offices are responsible.

It is the duty of the autonomous offices, representative councils, and public corporations to accept-under the conditions of Article 2-all matters presented to them in a language other than Czechoslovak, and to deal with the same, and also to permit the use of another language in meetings and conferences.

Art. 4. The state offices, using the state official language, shall, in their official proceedings in those parts of the Republic which before October 28, 1918, pertained to the Kingdoms and Lands represented in the Imperial (Austro-Hungarian) Council or to the Kingdom of Prussia, use regularly the Czech language, in Slovakia regularly the Slovak language.

Matters presented in the Czech language and officially dealt with in Slovak or presented in Slovak and dealt with in Czech shall be deemed to have been dealt with in the language in which they were presented.

Art. 5. The instruction in all schools established for members of a national minority shall be given in their language. Likewise educational and cultural institutions set up for them shall be administered in their language. (Article 9, Treaty of St. Germain.)

Art. 6. The Diet which shall be set up for Russinia shall have the right reserved to it for settling the language question for this territory in a manner consonant with the unity of the Czechoslovak State. (Article 10, Treaty of St. Germain.)

Until this settlement has been made this law shall apply, 
due regard, however, being paid to the special circumstances of that territory in respect of language.

Art. 7. Disputes regarding the use of a language in the courts, offices, institutions, undertakings, and organs of the state, as well as in the autonomous offices and public corporations, shall be settled by the competent organs of state control as matters of state administration detached from the causes out of which they arose.

Art. 8. Details as to the carrying out of this law shall be fixed by the state executive authority which will, in the spirit of this law, lay down rules regulating the use of languages for autonomous offices, representative bodies, and public corporations, as well as for those offices and public organs whose competence extends to districts which are less than jurisdictional districts, or for organs which have no district of their own.

The rules shall also prescribe what measures shall be taken towards facilitating the dealings of officials with persons who do not speak the language in which the court, office, or organ conducts its business in the sense of this law. They shall also prescribe the measures to be taken to protect the different parties from legal damage which might accrue to them from ignorance of the language in question.

Exceptions to the terms of this act necessary for securing undisturbed administration may also be made by regulation for the period of five years commencing from the day on which this law comes into force.

Finally, rules shall be laid down which are essential for securing the successful carrying out of this law.

Art. 9. This law shall come into force on the day on which it is promulgated. It abrogates all rules relating to language which were in force previous to October 28, 1918.

All the Ministers are entrusted with the execution of this law.

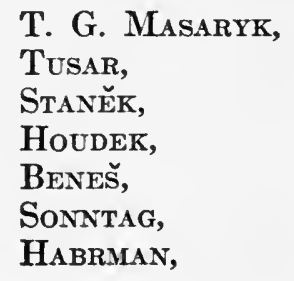

T. G. MAsaryK,

TUSAR,

STANĚK,

HOUDEK,

BENES,

HaBRMAN,
PRĀšĚK,

VESELT,

KLOFĀ̄̌,

HEIDLER,

WINTER,

Franke,

HAMPL. 


\title{
THE LAW OF FEBRUARY 29, 1920
}

\author{
SETTING FORTH THE CONSTITUTION AND JURISDICTION \\ OF THE SENATE
}

\section{SECTION I}

\section{The Constitution of the Senate}

Article 1. The Senate of the Czechoslovak Republic shall consist of 150 elected members. No one may be at the same time a member of the Chamber of Deputies and of the Senate.

If the elections to the one chamber follow within four weeks at the latest after the elections to the other, no one may stand as candidate for both chambers. The election of a candidate in defiance of this enactment is invalid.

Any one who, in any other case than that just referred to, being a member of the Chamber of Deputies, is elected Senator, or vice versa, being a member of the Senate is elected to the Chamber of Deputies, shall take his seat in that chamber to which he has been last elected.

Art. 2. The rules of franchise laid down for elections to the Chamber of Deputies shall be applicable to elections for the Senate except in such cases as this law otherwise provides.

Art. 3. All citizens who have the right to vote at elections to the Chamber of Deputies are entitled to vote at elections to the Senate if they have attained on the day of the publication of the standing lists of voters (Law of December 19, 1919, No. 663, Code of Laws and Regulations) the age of 26 years.

Art. 4. Citizens of the Czechoslovak Republic without regard to sex may be elected to the Senate if, on the day of election, they have attained the age of 45 years, have been for at least ten years citizens of the Czechoslovak Republic, and are not excluded from the franchise. For elections which shall take place up to the end of the year 1928, this condition of ten years' citizenship shall not be required.

Art. 5. The Senate shall be elected for a period of eight years.

Art. 6. If the elections to the Senate take place within four weeks at the latest of the day on which the elections to the Chamber of Deputies took place, the polling committees of the constituencies and the central polling committee which were in 
charge of the elections of the Chamber of Deputies shall also take charge of the elections to the Senate.

Representatives of parties who have not put forward valid lists of candidates for the Senate may not be members of these committees; on the contrary these committees shall be composed of representatives of those parties which put forward no candidates for the Chamber of Deputies but presented valid lists of candidates for the Senate. Article 9 and Article 11 of the rules of franchise for the Chamber of Deputies are to be applied in this matter.

Except in the case stated in Paragraph 1, the polling committees of the constituencies and the central polling committee must be constituted anew.

Art. 7. In every constituency which elects members to the Senate a district polling committee shall be set up. The rules of franchise for elections to the Chamber of Deputies relating to district polling committees apply by analogy thereto.

A district polling committee for elections to the Senate has the same competence in the matter of elections to the Senate as a district polling committee, set up in pursuance of Article 10 of the rules of franchise for election to the Chamber of Deputies, has in respect of elections to the Chamber of Deputies.

Art. 8. In the case stated in Article 6, Paragraph 1, citizens who are not entitled to vote at the elections to the Senate may be members of a committee which has charge of elections to the Senate.

Art. 9. The constituencies electing Senators shall be composed of constituencies which elect members to the Chamber of Deputies.

(Here follows an enumeration of the electoral districts. There are in all 13 senatorial constituencies electing respectively 23, $11,15,14,15,17,16,10,7,5,9,4$, and 4 Senators.)

Art. 10. If the Senate be dissolved by the President of the Republic or if the term for which it was elected expire, the Minister of the Interior shall cause new elections to take place within sixty days.

Art. 11. The Minister of the Interior shall issue to an elected Senator a letter of credence which shall entitle him to enter the Senate and to take part in its proceedings. This right shall lapse should the election of such a Senator be declared invalid by the electoral court.

Art. 12. At its first assembly which shall be opened by the 
Prime Minister and presided over by the senior Senator, the Senate shall elect from among its own members a Chairman and two Deputy Chairmen.

The proceedings of the Senate shall be regulated within the limits of the law relating to rules of procedure, by rules of procedure determined upon by the Senate itself. Until such rules shall be determined upon, the rules of procedure passed by the hitherto existing National Assembly shall remain in force.

Art. 13. At the first assembly of the Senate and previous to the elections of Chairman and Deputy Chairmen, the Senators shall take the oath in the presence of the Prime Minister as provided by Article 22 of the constitutional charter. Refusal to take the oath or the taking of it with reservation shall entail the immediate loss by the member of his seat (Article 22 of the constitutional charter).

The same applies to Senators who subsequently enter the Senate; they take the oath in the presence of the Chairman of the Senate.

Art. 14. Senators are entitled to such remuneration as shall be fixed by law.

\section{The Jurisdiction of the Senate}

Art. 15. The Senate shall coöperate in the exercise of legislative authority as laid down by the constitutional charter.

Art. 16. The Senate is entitled to pass judgment where an accusation is brought by the Chamber of Deputies:

(1) Against the President of the Republic for high treason (Article 67 of the constitutional charter);

(2) Against members of the Government for violation of constitutional or other laws (Article 79 of the constitutional charter).

\section{SECTION II}

The first elections to the Senate of the Czechoslovak Republic shall take place to the exclusion of the 12th and 13th constituencies as well as to the exclusion of the district of Hlučín from the 7 th constituency, the district of Vitoraz from the 5 th constituency, the district of Valcice from the 6 th, and to the exclusion of the territories of Spiš and Orava which are the subject of a plebiscite.

The second and third scrutinies [under the scheme of pro- 


\section{NEW CONSTITUTIONS OF EUROPE}

portional representation] shall take place for the other elections without regard to elections in these last mentioned districts.

The territories excluded from the first elections shall, for the first period for which the Senate is elected, elect their Senators later in a manner which will be fixed by regulation.

The Government shall take steps to secure for legionaries the exercise of their franchise rights and shall assign to them seats which may happen to be superfluous in some of the electoral districts.

\section{SECTION III}

This law shall come into force simultaneously with the law which served as the introduction to the constitutional charter.

The execution of it shall be entrusted to the Minister of the Interior.
T. G. MasaryK
Tusar
STANĚK 


\section{CHAPTER XIV}

\section{JUGOSLAVIA}

\section{HISTORICAL NOTE}

ONE of the most important and complex problems of nationality confronting the Peace Conference was that of the Jugoslavs or South Slav peoples. They reached their present seats during the great migration period of the sixth and seventh centuries, A. D., and the main body of them never split up irremediably. ${ }^{1}$ In 1914 these Jugoslavs were divided among four separate kingdomsMontenegro, Serbia, Hungary, and Austria. In AustriaHungary itself the Jugoslavs lived under five distinctadministrations. Bosnia-Herzegovina was under joint AustroHungarian administration; Slovenia, Istria, and Dalmatia were controlled directly by Austria; the Kingdom of Croatia, including both Serbs and Croats, was subject to Hungary; Fiume was a separate district under Hungary; while the Serbs of South Hungary were under direct Hungarian control. ${ }^{2}$

The problem of the Jugoslavs was acute before the beginning of the war. A thoroughgoing solution would have necessitated the break-up of the Austro-Hungarian kingdom, or at least concessions by it of a high degree of national autonomy. Since these contingencies seemed

Proposed solutions of Jugoslav problem

1For brief histories of the southern Slavs and accounts of the development of the problem that existed upon the outbreak of the war, see Arnold Toynbee, Nationality and the War, pp. 167-216 (London, 1915) and Stoddard and Frank, The Stakes of the War, Chapter XI (New York, 1918).

'Temperley, Ed., A History of the Peace Conference of Paris, Vol. IV, p. 171, ff. (London, 1921). This chapter, "The Liberation of the New Nationalities," has been largely relied upon in the preparation of this introductory note. 


\section{NEW CONSTITUTIONS OF EUROPE}

outside of the realm of practical politics, attention was devoted to three more limited proposals all of which were unsatisfactory. They would have done little to meet the demands which came from the growing and menacing sense of national solidarity among the Serbs, Croats, and Slovenes.

1. Repression

2. Trialism

3. Greater Serbia

The first proposed solution was Repression. It was believed in Austria-Hungary that the unrest among the Jugoslavs was largely fomented in Belgrade; but the apparently simple policy of treating manifestations of nationalism as treason and of using the sword against Serbia involved serious difficulties. Russia would naturally object to any harsh dealing with Serbia, and there would unquestionably be an increase of Jugoslav opposition within the Monarchy itself if this policy was attempted. The militarist party under Conrad von Hoetzendorff had long advocated this policy. His last memorandum urging it was dated June 21, 1914-the week before the death of Franz Ferdinand.

The second proposal went by the name of Trialism. The plans differed considerably in detail; but their common principle was that in place of the dualistic system of Austria-Hungary with two units dominated by the Germans and Magyars respectively, there should be three units with the Slavs in control of the third. Such a settlement, however, would not be satisfactory if the proposed third unit did not include the Slovenes; but the Magyars could not be persuaded to give up their hold on Croatia and Fiume, and the Serbs both in Serbia and AustriaHungary would have nothing to do with any proposal favored by the Hapsburg dynasty itself.

A third suggestion for the solution of the problem of Jugoslavia was a Greater Serbia. It proposed to bring into Serbia all the Jugoslavs who professed the orthodox religion and used the Cyrillic alphabet. But it was manifest that the creation of a Serbia of such dimensions could 
result only from military victory over the Hapsburg Monarchy.

The ultimate solution of the Jugoslav problem entered the field of practical politics only with the progress of the war. This solution was that all Jugoslavia be set wholly free from Austria and Hungary. Jugoslav patriots formed a committee in London in 1915 and issued their program for a united and free Jugoslavia, but the Entente as a whole had no policy. The hopes and fears of the Jugoslavs were variously affected by the Treaty of London of 1915, the declaration of war by Italy, the death of the Emperor Francis Joseph (November, 1916), the Allied war aims issued in December, 1916, when the Central Empires began their overtures for peace, the Russian Revolution, and the entrance of America into the war. ${ }^{1}$ In July, 1917, the Serbian Prime Minister and the President of the Jugoslav Committee issued the Manifesto (Pact) of Corfu which laid down the outlines of the future Kingdom of the Serbs, Croats, and Slovenes. This was after the Russian Revolution when there was no reason why the Serbian Government should not openly adhere to the program of a united Jugoslavia. This Manifesto was a decisive point in the Jugoslav movement; for while there was no official action, a favorable reception was accorded to it in Entente countries.

By August, 1918, the authority of the Austro-Hungarian government was coming to an end in Slovene lands. The connection with the Hapsburg Monarchy was denounced;

Assumption of political power

\footnotetext{
'For a full account of the Jugoslav movement during the war, see Temperley, Ed., op. cit., Vol. IV,pp. 176 ff. In 1917 the Austrian Government found itself in a position of great difficulty owing to the fact that in the Reichsrat the Slavs were in a small majority over any combination of the other racial representatives. The passage of the budget was necessary, and consequently the Government issued a number of hints as to local autonomy. When the Reichsrat met (May S0, 1917) the Jugoslav Club issued a declaration demanding "the unification of all territories of the monarchy inhabited by Slovenes, Croats, and Serbs in one independent political body free from all foreign domination and founded on a democratic basis under the sceptre of the Hapsburg Dynasty." In subsequent Jugoslav declarations the reference to the House of Hapsburg was usually omitted.
}

Jugoslar movement during the war 
Jugoslavia or Greater Serbia

Constituent assembly of 1920

and local councils were organized in the provinces to take over the direction of affairs from the imperial and royal authorities. The Jugoslav parts of the Monarchy united and the government automatically passed into their hands. For the moment Jugoslavia was recognized by no one beyond its own frontiers except the Austrian Emperor, who on October 31 sanctioned the transference to it of the Austro-Hungarian fleet on the Adriatic.

All Austrian and Hungarian solutions of the Jugoslav question were now impossible. The problem was whether the mutual jealousies of the Serbs and Croats were still strong enough to force the creation of a Greater Serbia and a separate Croatia, or whether the unity of the race would at last produce a united Jugoslavia. Union was decided upon. In November a joint Cabinet was instituted and the military forces were merged into one army. On December 4 the Kingdom of the Serbs, Croats, and Slovenes was proclaimed. It was formed of the former Kingdom of Serbia, to which were joined the former Kingdom of Montenegro ${ }^{1}$ and the districts of Bosnia, Herzegovina, Croatia, Dalmatia, Slavonia, a part of western Bulgaria, and part of the Banat of Temesvár. ${ }^{2}$ The Croats and Slovenes wished to call their state Jugoslavia, but the Serbs opposed this energetically. They did not wish an appellation in which the word Serb would disappear. ${ }^{3}$

Elections for a constituent assembly to draft a constitution were held on November 28, 1920, and resulted as follows: Democrats, 94; Radicals, 93; Communists, 58; Radich (Croatian autonomy), 50; Bosnian Moslems, 24; Catholic Popular party, 23; Peasants, 39; Social Democrats, 10; National Socialists (Slovene), 2; minor parties,

\footnotetext{
'For the attitude of Montenegro, see Temperley, Ed., op. cit., Vol. IV, p. 203.

'Bowman, The New World, p. 253 (Yonkers 1922). 1921.

'Albert Mousset, "La Constitution Yougoslave," L'Europe Nouvelle, July 30
} 
26. ${ }^{1}$ Work on the constitution was delayed because of disagreement on a number of issues, the chief of which was that of a federal versus a unitary state. ${ }^{2}$ A constitutional monarchy was determined upon, but the peasant and clerical parties of Croatia desired to set up a republic. ${ }^{3}$ The constituent assembly, however, completed its work, and the constitution went into effect on June 28, 1921.

The new constitution owes a great deal to the Serbian Constitution of 1888 , which was reënacted in 1903 , and which, in turn, is heavily indebted to the Belgian Constitution. In fact, as two recent writers point out, "the more one compares the constitutions of Serbia ${ }^{4}$ and Jugoslavia, the less one is inclined to call the latest promulgation a new constitution at all; it seems to be rather an extension of the old instrument to cover new territory, rather than a totally new instrument for the administration of government.

"The older document provided for representative parliamentary government under, of course, the same Monarch, Peter I (1903), who was the King upon the passage of the present constitution. It emphasized, as this does, the parliamentary type of government. There was then,

1"Record of Political Events," Political Science Quarterly, Supplement, p. 97. September, 1921.

2See above, pp. 77-78.

${ }^{3 A}$ Committee which signs itself "the 63 Delegates of Croatia, Slavonia, Dalmatia, and Bosnia-Herzegovina united in the "Croatian Block," issued a manifesto dated February, 1922, and addressed "to all free civilized nations and to the delegates at the Conference of Genoa." The manifesto declared that the Croatian nation was not represented in the Constituent Assemblythe majority of the Croatian national deputies having decided not to send representatives-and that "the Croatian Nation will neither recognize this Assembly nor accept its decisions brought against the will of the Croatian people and ir the absence of its delegates." It is charged that the Constitution "was forced upon the Croatian nation in a fraudulent manner and has no moral or legal basis." See also M. W. Fodor, "A New Country but Old Mistakes," Foreign Affairs, April, 1922.

The Serbian Constitution of 1903 appears in French translation in British and Foreign State Papers, Vol. 81, p. 508 and Vol. 108, p. 566; Dareste, Les Constitutions Modernes, Vol. II, p. 257 (3d ed., Paris, 1910), and Wright, The Constitutions of the States at War, 1914-1918, p. 553 (Washington, 1919).

Constitution of 1921 similar to Serbian Constitution of 1903 
also, but a single chamber in the legislative branch. The provisions in regard to budgetary control, and even for the sessions of the legislature, resembled those provided for in 1921. In this year again reappears the Court of Accounts, the Council of State, and you find similar provisions for the jury in 1921 as in 1903 . The earlier constitution, like the later, provides for proportional representation in elections and the scrutin de liste.

"Still more important it is to note that the great space given to the detailed Bill of Rights in the Jugoslav constitution goes back to the many clauses in the Serbian constitution, which seemed to have caused as much remark then as these same provisions do now."1

\section{CONSTITUTION OF THE KINGDOM OF THE SERBS, CROATS, AND SLOVENES (JUGOSLAVIA)}

Adopted by the National Assembly in Belgrade on June 15, 1921, and Proclaimed by the King on June 28, 1921

\section{SECTION I}

\section{General Provisions}

Article 1. The government of the Kingdom of the Serbs, Croats, and Slovenes is a constitutional parliamentary and hereditary monarchy. The official title of the government is the Kingdom of the Serbs, Croats, and Slovenes.

Art. 2. The coat of arms of the Kingdom is a double-headed white eagle with wings widespread upon a red shield; the crown of the Kingdom is directly above both heads of the doubleheaded white eagle; upon the breast of the eagle is a shield having thereon the Serbian coat of arms, consisting of a white cross

'Wolfe and Andrews, "The Jugoslav Constitution," Current History, February, 1922. The translation of the Jugoslav Constitution that follows was made by John R. Palandech, a Serbian publisher, and appeared in the Chicago Daily News Almanac and Year Book for 1992, page 711. It has been revised by the Legation of the Kingdom of the Serbs, Croats, and Slovenes in Washington and corrections suggested by the Legation have been incorporated. Another English translation by Howard Webster Wolfe and Arthur Irving Andrews appeared in Current History, February, 1922. An excellent French version was published in L'Europe Nouvelle, July 30 and August 6, 1921. 
upon a red shield, with one jewel in each angle of the cross; the Croatian coat of arms, consisting of a shield with twenty-five squares alternately of red and silver color; the Slovenian coat of arms, consisting of three gold six-angled stars upon a blue shield. Under this is a white half moon.

The flag is blue, white, and red, in horizontal stripes against an upright spear.

Art. 3. The official language of the Kingdom is SerboCroatian-Slovene.

\section{SECTION II}

\section{Fundamental Rights and Duties of Citizenship}

Art. 4. The right of citizenship is equal (uniform) in the entire kingdom. All the citizens are equal before the law. All enjoy equal protection of the authorities. Nobility and titles are not recognized, neither are any privileged rights of birth.

Art. 5. Personal liberty is guaranteed. No one can be held responsible or imprisoned or deprived of his liberty by any one except in cases provided by law. No one can be imprisoned for any crime without written statements giving the reasons and facts substantiating the charges of the competent authorities. The charges must be submitted to the party accused at the time of arrest, or, if that is not possible, at the latest within twenty-four hours from the time of imprisonment. Against an order for imprisonment an appeal can be made within three days to the competent court. If there is no appeal filed within this period the prosecuting authorities must send their decision to the court within twenty-four hours. The court must make its findings in the period of two days from the time it received the decision. The findings of the court are supreme. Organs of the authorities who violate these provisions shall be punished for unlawful deprivation of liberty.

Art. 6. No one can be tried except by a competent court.

Art. 7. No one can be sentenced until he has been authoritatively heard or has been summoned to defend himself according to law.

Art. 8. Punishment can be dealt only by law and applied only to the acts for which the law provides and prescribes such punishment.

Art. 9. The death penalty cannot be inflicted for purely political crimes, except in cases of accomplished or attempted 
assassination of the ruler and of members of the royal house, for which the death penalty is provided in the criminal code. Exceptions are made in addition to the above in cases where with purely political crimes some other criminal act is committed for which the death penalty is provided in the criminal code, and also in cases which the military law punishes with the death penalty.

Art. 10. No citizen can be exiled from the country. A citizen cannot be forcibly moved within the border of the country from one place to another, nor can he be confined in one place, except in cases for which the law explicitly provides. Under no condition can any one be driven out from his native place without due process of law.

Art. 11. The home is inviolable. The authorities cannot attempt any search or investigation in the home of a citizen except in cases authorized by law and in the manner prescribed by law. Before any search can be made the authorities are in duty bound to give the person whose home is being searched a written notice from the competent authorities on the strength of which the search is made. Against this order there is an appeal to the court of first instance. However, the appeal does not delay the process of search. The search must always be made in the presence of two citizens. Immediately after the search is completed the authorities are bound to give the person whose home was searched a statement of the results of the search and a signed list of all articles taken for the purpose of further investigation. At night the police can enter a private home only in cases of extreme necessity or when they are appealed to for help from the home. To that act a representative of the community or two citizens should be present, except in cases where an appeal for help is made. Agents (officials) of the authorities who violate these orders will be punished for an unlawful violation of the home.

Art. 12. Freedom of faith and conscience is guaranteed. Acknowledged religious denominations are equal before the law and are at liberty to profess their faith publicly. Enjoyment of civil and political right is independent of any religious belief. No one can be exempt from his civic and military duties and responsibilities upon the grounds of his religious belief. Creeds that have secured lawful recognition in any part of the kingdom are sanctioned. Other creeds can be recognized only by the law. Authorized and recognized creeds govern their internal 
church activities, affairs, and administration independently, and manage their property and funds within the boundary of the law. No one is compelled publicly to confess his religious belief. No one is compelled to take a part in religious activities, feasts, ceremonials, and exercises, except at national holidays and celebrations, within the manner provided by law for persons who are subordinate to parental, guardian, or military authorities. Authorized and recognized denominations may preserve the ties of their faith with the religious heads outside of the borders of the country in so far as the necessity of spiritual regulations of the different creeds require. The manner in which these ties should be preserved will be regulated by law. The disbursement which the national budget provides for lawful religious purposes will be divided among lawful and recognized spiritual bodies, according to the number of their faithful and actually shown necessity. Spiritual representatives cannot employ their spiritual authority outside of their spiritual edifices or outside of their spiritual character, or in any act while doing their official duty in partisan affairs.

Art. 13. Freedom of press is guaranteed. No measure can be instituted that would prevent printing, selling, and distributing of literature and newspapers. Censorship can be enforced only in time of war or mobilization and that for measures foreseen by law. Distribution and selling of newspapers or printed matter which contain libel on the ruler or the members of the royal house, foreign ruling heads, national assembly, indirectly calling upon the citizens to change the constitution or the national laws by force, or which contain offense against public morals, are forbidden. However, in these cases the authorities are bound to take the matter to court within twenty-four (24) hours after the suspension, and the court is in duty bound to sustain or dismiss the charge within twenty-four hours; otherwise the suspension is considered as rescinded. Courts of proper jurisdiction decide the matter of damages independently of court's decision regarding the suspension. For an offense committed by the press the following are responsible: The writer, editor, printer, publisher, and distributor. By special law for the press it will be decided when and in what cases and in what manner any of the above-mentioned persons will be responsible for the offense committed through the press. All offenses committed by the press will be tried by courts of proper jurisdiction. 
Art. 14. Citizens have the right of assembly, meetings, and conferences. Additional regulations regarding this will be provided by law. No person will be permitted to carry arms to meetings. Holding of open-air meetings must be announced to the proper authorities at least twenty-four hours beforehand. Citizens have the right of assembly for any objects that are not punishable by law.

Art. 15. Citizens have the right to petition. Petition can be signed by one or more of them, as well as all judicial persons. Petitions can be submitted to any of the authorities without exception.

Art. 16. Learning and arts are free and enjoy the protection and support of the government. University education is free. Education is national. Education is based upon the same foundation throughout the country, adapting itself to the localities for which it is intended. All schools must teach moral uplift and broad national ideals in the spirit of national unity and religious tolerance. Elementary education is national, general, and compulsory. Religious training is given according to the wishes of the parent or elders, based on their creeds and in accordance with their religious beliefs. Technical schools will be established according to the needs of vocations. Education is given by the government without entrance fees, tuition, or other taxes. The manner in which private schools, their like, and under what conditions they shall be permitted will be provided by law. All institutions for education are under government control. The government will aid the work of national education. Minorities of race and language are given elementary education in their mother tongue, under provisions which will be prescribed by law.

Art. 17. The secrecy of letters, telegrams, and telephone communication is inviolable, except in cases of criminal investigations, mobilization, or war. All those who are guilty of violating the secrecy of postal, telegraph, or telephone communication will be punished according to law.

Art. 18. Every citizen has the right directly and without any one's approval to bring complaint to the court against the governmental or self-governing bodies for criminal acts which they may commit against him in their official capacity. For ministers, judges, and soldiers under colors, special provisions apply. For damages done to citizens by governmental or self-governing bodies by illegal performance of their duties, the government or 
self-governing bodies are responsible before the proper court. The agent in question is responsible to them. Limitation for damages expires in nine months.

Art. 19. To all positions in all branches of government service all citizens are equally eligible under the provisions of the law, those by birth as well as those who become naturalized, who are of the Serbo-Croat-Slovene nationality. Other naturalized citizens can obtain government positions only if they are residents of the country for ten years, and by special permission of the government's council upon the prior recommendation of the competent minister.

Art. 20. Every citizen enjoys the protection of the government in foreign countries. Every citizen is at liberty to withdraw from citizenship after he has fulfilled his obligations to the government. Extradition of citizens is forbidden.

Art. 21. Every citizen is obliged to obey the law, serve the interest of national unity, defend his native country, and carry the national burden according to his earning ability, according to the provisions of the law.

\section{SECTION III}

\section{Social and Economic Regulations}

Art. 22. The government will endeavor to create for its citizens equal opportunity to prepare themselves for profitable vocations to which they are inclined. In that direction it will establish educational trade organizations and arrange for permanent assistance for education of worthy poor children.

Art. 23. The laboring classes are under the protection of the government. Women and minors must be protected from work dangerous to their health. The law provides separate measures for the welfare and protection of the workman and prescribes working hours in all undertakings.

Art. 24. Inventions are the property of the inventor and enjoy the protection of the government.

Art. 25. Freedom of negotiation and organization in business affairs is recognized in so far as it does not interfere with social interests.

Art. 26. The government has, in the interest of the whole and based upon the spirit of the law, the right and duty to intervene in the economic affairs of its citizens in the spirit of justice and for the prevention of social adversity. 


\section{NEW CONSTITUTIONS OF EUROPE}

Art. 27. The government will take care: (1) To improve general hygienic and social conditions, which are essential to national health; (2) to give special protection to mothers and small children; (3) to guard the health of all citizens; (4) to check and prevent all the acute and chronic contagious diseases, as well as to check the harmful use of alcohol; and (5) to furnish free medicine and other necessities for the protection of national health to poor and needy citizens.

Art. 28. Marriage is under the protection of the government.

Art. 29. The state aids materially national associations; also the state aids materially other national economic organizations that are not for profit. To such associations and to such economic organizations priorities are given in the transaction of business upon equal terms with other private institutions. Laws will be formulated as regard the associations which will apply to the entire country.

Art. 30. By special legislation betterment of the agrarian conditions will be provided.

Art. 31. Protection of workmen in case of accident, illness, lack of work, incapability, old age, or death will be provided by special legislation.

Art. 32. Invalids, war orphans, war widows, the poor and those incapable of work, parents of the killed or those who died in the war, enjoy special protection of the state and assistance as a mark of appreciation. The question of rehabilitation of the invalid and the education of war orphans for work and the future will be regulated by law.

Art. 33. The rights of the workingmen to organize for the purpose of improving working conditions is guaranteed.

Art. 34. To navigation and fisheries will be given special attention. The welfare of the seaman in case of sickness, invalidity, old age, and death will be provided for by special law.

Art. 35. The state will supervise the building and maintaining of all transportation facilities wherever the general national interest demands.

Art. 36. Usury of every description is forbidden.

Art. 37. Property is guaranteed. Property creates responsibilities. The use of property must not be to the detriment of the whole. Contents, size, and limits of private property are fixed by law. Expropriation of private property in the public interest is permissible according to law, with just compensation.

Art. 38. Fidei commissum is abolished. Bequests with 
general advantageous purposes are recognized. It will be determined by legislation what changes of the bequests can be made in accordance with change of conditions.

Art. 39. By the inheritance tax law the government will be assured of its participation in the inheritance, having in mind the interests of the relations between the heir and the deceased and the value of the inheritance.

Art. 40. The supplying of provisions and other necessities for the army is carried out for just compensation.

Art. 41. Large private forest tracts are expropriated according to law and become the property of the state or its selfgoverning bodies. The law will provide how large forest tracts can be property of other lawful public bodies that now exist or will be created. Natural forestry, whose cultivation is necessary for climatical and cultural purposes, also passes over, according to the law of expropriation, to the ownership of the state or its self-governing bodies, in so far as forestation cannot be done by other means. Large forest tracts which foreign powers have given to individual persons become, according to law, the property of the state or municipality without any compensation to those persons. The forestry law will make provisions under which farmers and those who are indirectly occupied with tilling the land can benefit by wood-cutting for building and fuel; also for grazing purposes in the state forests.

Art. 42. The feudal system is abolished from the day of the liberation from foreign authority. In so far as before that time injustice was committed by the feudal system or by its transformation to self-justification, these conditions must be corrected by law. Land tenants and land workers in general who cultivate lands in tenancy are considered freeholders of government lands without any compensation for the same, and they will receive title to the property.

Art. 43. Expropriation of large estates and their apportionment to ownership to those who till the lands will be regulated by law. The law will provide the kind of compensation that will be given expropriated estates. For large estates which belong to members of the former alien dynasty and those which the foreign powers have granted to individuals, no compensation will be given. Land settlements will be carried out primarily by the aid of organized colonization societies, seeing that the inheritors must be provided with necessary means for successful production. In colonization and in apportionment of ex- 
propriated lands, needy soldiers have first choice, meaning those who have fought for the liberation of the Serbs, Croats, and Slovenes and their families. The law will provide the maximum possession of property and the cases in which the minimum of land cannot be alienated from them.

Art. 44. For the framing of social and economic legislation the economic council is created. Its regulations, duties, and competence will be designated by law.

\section{SECTION IV}

\section{Government Authorities}

Art. 45. All government functions are carried out according to this constitution.

Art. 46. Legislative power is vested in the King and National Assembly together.

Art. 47. Executive power is administered by the King, through his responsible ministers, according to the provisions of the constitution.

Art. 48. Judicial power is administered by the courts. Their rulings and sentences are pronounced and administered in the name of the King, according to law.

\section{SECTION $\mathrm{v}$ \\ The King}

Art. 49. The King approves and proclaims the laws, appoints government officials, and gives military titles as prescribed by law. The King is the supreme commander of the entire military forces. He gives decorations and other honorary distinctions.

Art. 50. The King has the right to grant amnesty for political and military offenses. Amnesty nullifies the legal consequences of punishable acts, but amnesty cannot interfere in damages allowed to individual persons. Amnesty can be given before the beginning of the proceedings, during the proceedings, or after the decision is given. Amnesty is general or individual. For amnesty to the ministers it is necessary first to have the concurrence of the National Assembly. However, no amnesty can be given to ministers until after the sentence is pronounced. The King has the power to pardon. He can pardon, reduce, or lighten the sentence. The right to pardon for the crime of the 
defendant, on personal appeal, will be provided by the law of court procedure in criminal acts.

Art. 51. The King represents the nation in all intercourse with foreign governments. He declares war and makes peace. If the country is not attacked or war is not declared against it by some other nation, it is necessary first to have the consent of the National Assembly to declare a war. If war is declared against the country or the country is attacked, the National Assembly must be convened at once.

Art. 52. The King calls the National Assembly in regular or extra sessions. He opens and closes the sessions in person with a message from the throne or through the Council of Ministers by a message or a decree. The message from the throne, communication, or decree must be signed by all the ministers. The decree by which one session is adjourned must contain the order for the date of calling a new session. The King can at all times, in case of national emergency, convene the National Assembly which has adjourned. The King has the right to dismiss the National Assembly, but the decree of its dismissal must contain an order for new election, at the latest within three months' time, and an order for convening of the National Assembly, at the latest within four months from the day of the dismissal of the assembly. The decree to dissolve the National Assembly is attested to by all ministers.

Art. 53. The King cannot rule over some other state at the same time without the consent of the National Assembly. If the King should, notwithstanding this act, accept the crown of some other country it will be considered that he has resigned the rulership of the Kingdom of the Serbs, Croats, and Slovenes.

Art. 54. No act of the King's authority is valid nor can it be executed unless it has been signed by the competent minister. For all King's actions, verbal or written, signed or unsigned, as well as for all his acts of political nature, the competent minister is responsible. For the actions of the King, as the commander in chief of the army, the minister of war and navy is responsible.

Art. 55. The King and the heir to the throne are of age when they attain 18 years. The King's person is immune. He cannot be held responsible nor can a complaint be brought against him. This does not apply to the King's personal property.

Art. 56. In the Kingdom of the Serbs, Croats, and Slovenes the ruler is Peter, the first Karagorgjevich. King Peter's successor is Crown Prince Alexander and his male issue from a legal 
marriage in order first born. When the King has no male issue he will select for himself his heir from the royal line, with the approval of the National Assembly. For this act it is therefore required a majority of one-half, plus one vote of the entire membership of the National Assembly.

Art. 57. The royal household is made up of the Queen Wife, the living ancestors and heirs to the King in direct line, with their wives, full brothers and their heirs, with their wives, and the sisters of the ruling King. Relatives and prerogatives of the members of the royal household will be defined by statute. No member of the royal household can become a minister or a member of the National Assembly.

Art. 58. The King takes oath before the National Assembly, which is as follows:

"I, [name], ascending the throne of the Kingdom of the Serbs, Croats, and Slovenes, and accepting the royal power, do hereby swear in the name of Almighty God that I will guard the union of the people, independence of the nation, and the entity of the national authority; that I will keep the constitution inviolable; that I will rule by the constitution and the law, and that I will endeavor to have the welfare of the people before me, so help me God. Amen."

Art. 59. The King resides in the country permanently. Should it be necessary for the King to leave the country for a short time, the heir to the throne will represent him. If the heir to the throne is a minor or prevented from acting by any reason, the King will be represented by the Council of Ministers. Representation is conformed to according to the instructions given by the King within the bounds of the constitution. This applies also in case of the King's disability when it is not of a permanent nature. During the absence of the King or the heir to the throne the Ministers' Council has no right to adjourn the National Assembly. The King can be represented by the Ministers' Council at the most for six months. Upon the expiration of that time the provision made by constitution relative to substitutes becomes effective.

\section{SECTION VI}

\section{SUbstitution}

Art. 60. The royal prerogatives are performed by substitutes: First, when the King is a minor, and second, when he is 
mentally or physically permanently incapable of performing royal acts. The creation and suspension of substitutes will be done by National Assembly by secret ballot. When the Council of Ministers finds that the King is disabled, they report to the National Assembly, together with an opinion from three physicians taken from the national medical faculties. The same procedure is followed in the case of the heir to throne.

Art. 61. The right to substitute for the King belongs to the heir of the throne if he is of age. If the heir to the throne, because of the reasons set forth in Article 60, cannot perform the duties of substitute, the National Assembly elects by secret ballot three royal substitutes. The royal substitutes are elected for four years. After that in case the substitution has to be prolonged for at least one year, there must be a new election. If the substitution is to last longer the election is again for four years. The substitutes must be born Serbian, Croatian, or Slovenian, 45 years of age, and of higher education. Before they assume the royal authority the substitutes will take an oath before the National Assembly that has elected them, that they will be faithful to the King and that they will rule according to the constitution and the laws of the country.

Art. 62. If one of the three substitutes is temporarily absent, the other two can perform the governmental functions without him.

Art. 63. The substitutes will supervise the education of the minor King. The property of the minor King will be supervised by guardians named in the King's will. If the deceased King has not named a guardian, they will be named by the substitutes in coöperation with the Council of State.

Art. 64. Until the substitutes are elected, the Council of Ministers will temporarily execute royal authority under their own responsibility.

Art. 65. In case of death or abdication of the King, the heir to the throne, if he is of age, immediately takes authority and announces the same to the people by proclamation. Within ten days he takes the prescribed oath before the National Assembly. If the National Assembly has adjourned earlier and the new Assembly is not elected, the old National Assembly is reconvened.

Art. 66. If at the time of the King's death there is no male issue, but the Queen is enceinte at the time of his death, the national assembly will elect temporary substitutes who will exe- 
cute the King's authority only to the time of the birth. The government is obliged to put before the national assembly the opinion of three physicians taken from medical faculties of the nation as to the Queen's prospects of becoming a mother. This also applies in case of the death of the Crown Prince if his wife should be pregnant at the time of the King's death.

Art. 67. In case the throne in accordance with this constitution is left without an heir, the Council of Ministers will take charge of the royal powers and at once call the National Assembly in special session, which will decide the matter of succession.

Art. 68. The civil list of the King will be appropriated by law. The civil list once established cannot be enlarged without the consent of the National Assembly, nor diminished without the consent of the King. The King's substitutes will receive from the state treasury for the time they perform their duties the amount allowed by the National Assembly at the time of their election.

\section{SECTION VII}

\section{National Assembly}

Art. 69. The National Assembly is composed of representatives freely chosen by the people by general, equal, direct, and secret ballot with representation of the minority. For every 40,000 inhabitants one representative is chosen. If the excess of inhabitants in one elective district is more than 25,000 , one additional representative will be chosen for that excess. The National Assembly is elected for four years. Other regulations for the election will be prescribed by law.

Art. 70. The right to vote belongs to every citizen by birth or naturalization if he is 21 years of age. Officers, active or out of service, as well as non-commissioned officers and soldiers under the colors, cannot have the privilege of voting, nor can they be candidates for office. The law will provide for woman suffrage.

Art. 71. The franchise is denied temporarily to those (1) who are sentenced to prison, until their rights are restored; (2) who are sentenced to lose their citizenship for the duration of the sentence; (3) who are public charges; and (4) who are under guardianship.

Art. 72. For representative to the National Assembly only a person who has right to vote, regardless of whether his name 
appears on the ballot, can be elected. Every candidate must comply with the following: (1) That he is a citizen by birth or naturalization of the Kingdom of the Serbs, Croats, and Slovenes; a naturalized citizen if he is not of the nationality of Serbs, Croats, and Slovenes, must be a resident at least ten years from the date of naturalization; (2) that he is 30 years of age; and (3) that he speaks and writes the national language. A national assemblyman cannot at the same time be a government supply agent or government contractor.

Art. 73. Police, customs, and forestry officials, as well as the officials of the agrarian reforms, cannot be candidates unless they have resigned one year prior to the call for the election. Other officials who perform public duty cannot be candidates in the election districts of their territorial jurisdiction. Officials who are elected to the National Assembly must resign their office for the time of their tenure as Assemblyman. Ministers, active and at large, and university professors may be candidates and, if elected, hold their positions.

Art. 74. Every National Assemblyman represents all the people and not only those who have elected him. The voters cannot give, nor the National Assemblyman accept, commanding and obligatory instructions. All National Assemblymen take an oath that they will faithfully uphold the constitution.

Art. 75. The National Assembly meets at the capitol Beograd (Belgrade), in regular session annually on the 20th day of October, unless it has been previously called by the King's decree in special session. If, in case of war, the capital is moved, the National Assembly meets in the place of the temporary capital. Regular call of the National Assembly cannot be made until the national budget is passed. In time of war the National Assembly is permanently in session unless the Assembly rules otherwise.

Art. 76. The National Assembly verifies the credentials of its members and passes on them. The National Assembly prescribes its own rules of order.

Art. 77. The National Assembly elects from its membership its officers for every session.

Art. 78. Legislative measures are submitted by the Ministers' Council or individual ministers with the authority of the King. The right to present legislative measures is a privilege of each member of the National Assembly.

Art. 79. The King concludes treaties with foreign nations. However, for confirmation of those treaties the concurrence 
of the National Assembly is necessary. For approval of purely political agreements, if they are not contrary to the constitution and the law, it is not necessary to have the confirmation of the National Assembly. A treaty to allow a foreign army to occupy the territory of the Kingdom or to pass over the country is not valid without first being confirmed by the National Assembly. The National Assembly can, when the national interests demand it, by resolution in advance authorize the Ministerial Council to take measures for immediate acceptance of the submitted treaty. National territory cannot be alienated or exchanged without the sanction of the National Assembly.

Art. 80. The King proclaims the laws by a decree which contains also the laws adopted by National Assembly. The decree is signed by all ministers. The minister of justice attaches to it the government seal and publishes the law in the "official organ." The law becomes effective fifteen days after publication in the "official organ" unless the law specifies otherwise. The day of publication in the "official organ" is counted.

Art. 81. The National Assembly has the right of inquiry and also of investigation in elections and purely administrative questions.

Art. 82. Every member of the National Assembly has the right to direct questions and interpellations to the ministers. The ministers are obliged to reply during the same session within the time prescribed by the rules of order.

Art. 83. The National Assembly communicates directly with the ministers only.

Art. 84. The National Assemblymen, members of the Government and Government representatives are the only ones having right to speak in the National Assembly.

Art. 85. The National Assembly can legally function if onethird of all the Assemblymen are present at the sessions. To carry a motion it is necessary to have a majority of the Assemblymen present. In case of equal division of votes the motion is considered lost.

Art. 86. No legislative motion can be debated in the National Assembly until it first has gone through the proper committees. Voting in the National Assembly is public; only the elections are carried out by secret ballot. Votes can be cast only in person. On every legislative motion two votes must be taken in the same session of the National Assembly before it can be finally carried.

Art. 87. At no time can anyone hold an Assemblyman re- 
sponsible for the vote he has given as a member of the National Assembly. For all statements and conduct of the National Assemblymen in performing their duty in sessions of the National Assembly, in committees, in special sessions, or in special duties delegated to them by the Assembly, the Assemblymen are responsible only to the National Assembly according to the rules of order.

Art. 88. Without the authority of the National Assembly its members cannot be held for any offense regardless of its nature, nor can they be deprived of their freedom by any authority or for any cause as long as their mandates have not expired, except when they are apprehended in the act of actual crime or transgression. However, even in the latter case, the National Assembly, if in session, is at once informed, and the National Assembly gives or rejects the authority to have the trial continued during the session. The right of immunity of the National Assemblyman begins on the day of his election. If anyone becomes Assemblyman before the sentence is pronounced on him for any offense the authorities that have the matter in charge will inform the National Assembly, which will give or refuse permission to prolong the action. Members of the National Assembly can be held responsible only for the acts of which they are accused.

Art. 89. The National Assembly has the exclusive right to preserve order at its meetings through its President. No armed force can be placed in the building of the National Assembly nor its grounds without the permission of the President of the National Assembly; without its permission no government agents can perform any of its functions in the National Assembly. No one carrying arms can enter the grounds of the National Assembly except persons who are authorized to carry weapons and are on duty at National Assembly.

\section{SECTION VIII}

\section{Administrative Authority}

Art. 90. The Ministerial Council is composed of all the ministers and stands immediately under the King. The King names the President and members of the Ministerial Council. Ministers are placed at the heads of respective branches of the government authority. A minister can be without portfolio. State under-secretaries can be appointed in the ministries should a need require them for a specified part of duties in that branch 
of government service. The state under-secretaries, if they are taken from the National Assembly, do not lose their mandates. The ministers name subordinate government officials according to the provisions of the law. The ministers take an oath before entering upon their duties of fidelity to the constitution and the King.

Art. 91. The ministers are responsible to the King and the National Assembly. The King and the National Assembly can accuse ministers for violation of the constitution and the country's laws while in official positions. For damages done by ministers, by unlawful acts, the state is responsible.

Art. 92. A minister can be accused during the time of his service and for five years after leaving office. A motion to accuse the minister must be made in writing and contain the charges. When the National Assembly accuses a minister a decision as to whether or not the minister shall be placed on trial must be brought by two-thirds of the votes of the members present.

Art. 93. The ministers are tried before the State Court. The State Court is composed of six state counselors and six Supreme Court judges, who are chosen by their respective bodies by a ballot in a plenary meeting. The president of the Supreme Court is the president of the State Court. For deeds which are not provided for in the criminal code the punishment will be fixed by the law of ministerial responsibilities. More detailed directions regarding ministers' responsibilities are to be embodied in a separate law.

Art. 94. Administrative authority can issue ordinances necessary for the application of the law. Administrative authority may, with an ordinance of legal force, regulate conditions only on the basis of lawful authority, which is to govern separately in every instance. The ordinances must not be contrary to the constitution or the law in behalf of whose application they are given. They cannot be contrary to the legislative provisions on the grounds of which they have been prescribed. The National Assembly can by a resolution place the ordinances issued by the authority of the law out of force in whole or part. The ordinances must be published and in them must always be indicated the law on the ground of which they were given.

Art. 95. The administration in the Kingdom is executed by provinces, districts, counties, and municipalities. Division of governments is done by law, in accordance with natural 
social and economical conditions. A province can have at the most 800,000 inhabitants. Two or more smaller provinces can unite in one larger one. The final decision rests with the provincial conventions of the said provinces, and such a province cannot have more than 800,000 inhabitants. At the head of every province is a governor, who is appointed by the King and governs through the state's agencies the affairs of the state administration in the province.

Art. 96. For the affairs of a local character in the municipalities, counties, districts, and provinces, a municipal, county, district, and provincial home rule is established and organized upon the principle of elections. For the home rule and self-administration of cities a special law will be enacted. In the line of provincial home rule authorities are these duties:

(1) Provincial finances: (a) making of provincial budget; (b) disposition of provincial taxation which is payable according to law to cover the provincial expenditures.

(2) Provincial public works; also building laws.

(3) Attending to advancement of provincial economic interests-farming, stock raising, wine growing, fruit growing, forestry, river and lake fishing, hunting-as well as technical and agricultural betterments.

(4) Administration of provincial property.

(5) Supervision of the national health in the province and making all provisions for the betterment of health conditions in the province.

(6) Supervision of social tasks in the province.

(7) The humanitarian institutions in the province.

(8) Transportation institutions in the province.

(9) Contributions to the advancement of culture in the province.

(10) Contributions to special education in the province.

(11) Instituting and maintaining organizations for savings, mutual benefits, and insurance.

(12) Giving opinions at the request of the Government as to the advisability of proposed laws that have to do with the province and in general in all other objects for which the Government asks their opinion. Other matters also can be intrusted by law to the home rule authorities of the province.

If in some of the enumerated conditions the province cannot perform by its own means, the Government will, upon the application of the provincial assembly and according to the decision 


\section{NEW CONSTITUTIONS OF EUROPE}

of the National Assembly, give the necessary means, or will itself carry out the undertakings.

Art. 97. Home rule units have their own yearly budgets. The administration of the home rule units is under the supervision of the minister of finances and the supreme controller, and will be regulated by special law.

Art. 98. Agencies of the provincial administration are the provincial assembly and the provincial committee. The provincial and county assemblies elect their own presidents, who preside at their meetings; they choose also the local provincial and county committees. According to law, with exceptions, combined authority can be provided for the same objects of state and home rule competence in the province. The governor is the supreme authority of the general state administration in the province, in so far as there do not exist, according to law, for special affairs of state, special administrative authorities for one or more provinces. The law provides which of the states' functions are decided by the governor, with the advice of the provincial committee. Detailed regulations regarding organization and competent home rule bodies, of municipality, county, district, and province, will be enacted by special legislation.

Art. 99. The provincial assembly has the right to establish provincial regulations in all questions within its jurisdiction. Provincial regulations are proclaimed by the governor. The provincial governor will not proclaim regulations which he finds are not based upon the constitution and the law. In that case he sends such regulations with his opinion to the State Council for decision and advises the competent minister. If the State Council finds that the order is not based on the constitution or some law, it will not be proclaimed or published. The State Council is bound to make its decision within two months. If the State Council does not make the decision in that time it becomes operative.

Art. 100. The provincial committee prescribes regulations for performing the provincial functions.

Art. 101. The state administrative authorities supervise the activities of the home rule authorities through the provincial governor and other special organs. The provincial governor has the power to suspend the enforcement of any decision of the home rule officers that is not based upon the constitution, the law, or the provincial regulations. A complaint can be filed 
against the decision of the governor with the State Council, within the time provided by law. If the State Council renders no decision within a month from the date of its submission then the decision of the provincial governor becomes operative.

Art. 102. For disagreements of an administrative nature administration courts are established. The law will provide their locality, jurisdiction, and organization.

Art. 103. The State Council is the Supreme Administrative Court. Members of the State Council are appointed by the King on the motion of the President of the Council of Ministers and in the following manner: One-half of the members are named by the King from twice the number of names submitted by the National Assembly; the National Assembly elects the other half from a like number and in a like manner submitted by the King. The filling of vacant places in the State Council will be done by especially formulated laws, which may obviate the above principles. For members of the State Council only the higher public officials or men in public life who have a higher education and have been for ten years in government service or public work can be appointed. At least two-thirds of the members of the State Council must have diplomas of qualification as having finished law studies. Members of the State Council can be removed from their places, moved to other branches of the government service and placed on pension only upon the judgment of the court. When they arrive at the age of 70 years or when through illness they cannot perform their duties, they will be placed on pension.

The duties of the State Council are: (1) As the Supreme Administrative Court it decides conflicts of an administrative nature. Conflicts based on complaints against the decrees and ministerial decisions are decided by the State Council in the first and last instance. (2) As the administrative organ of the supreme state administration it decides acts of administrative nature for which it is necessary to have its consent by special laws. (3) It performs supervising duties over the home rule bodies by order of the law. (4) It decides conflicts of jurisdiction between the state and the administrative authorities, and also decides conflicts of jurisdiction between the state and the home rule authorities. (5) It also decides other questions that are placed by the law in its jurisdiction. Detailed regulations regarding the composition of jurisdictions and procedure in the State Council will be prescribed by special law. 


\section{NEW CONSTITUTIONS OF EUROPE}

Art. 104. State jurisdictions are established by and according to rules prescribed by law.

Art. 105. The law will prescribe the manner in which the officials will be appointed.

Art. 106. Professions in government service, rights and duties, salaries and pensions of government officials in all branches, will be regulated by law for officials.

Art. 107. Government employees are agents of the whole government and are obliged to work in the common interest of the state. The use of authority and position by the government employees for partisan aims, as well as the use of influence by the supervisors of government employees in that direction, will be punished by law.

Art. 108. Any employee who is guaranteed a permanent position by the law cannot be discharged against his wish without being sentenced by a regular criminal or disciplinarian court.

\section{SECTION IX}

\section{The Courts' Authority}

Art. 109. The courts are independent. In dealing justice they do not stand under any authority, but administer justice by law. Courts and court jurisdictions can be established only by law. Under no circumstances can special courts be established as commissions for investigations. In family and inheritance matters of the Mohammedans, justice is administered by the Sheriatha's Courts (religious).

Art. 110. For the entire Kingdom only one Supreme Court exists, with sittings at Zagreb. The Supreme Court has also authority to decide conflicts of competency between administrative, civil, or military authorities and judicial authorities. In the same manner it is competent to decide conflicts of jurisdiction between administrative and regular courts.

Art. 111. The appointment of Supreme and Appellate Court judges and the presidents of lower courts is done by the King's decree on the motion of the minister of justice, from the number of candidates which are chosen by the nominating body, whose composition will be closely defined by law.

Art. 112. Judges of all courts are permanent. A judge cannot be deprived of his position nor for any reason be removed from his duty against his will, without a sentence by the regular courts or the Supreme Court. A judge cannot be accused in 
respect to his judicial duty without the permission of the competent Appellate Court. For members of the higher courts this permission is given by the Supreme Court. A judge cannot be placed even temporarily to perform any other paid or unpaid public service, without his consent and the approval of the Supreme Court. A judge can be transferred only by his own consent. A judge can be in service to the end of his 65 th year, and presidents of the Supreme and Appellate Courts to the end of their 70th year. Before that time a judge can be placed on pension only by written application or when he is physically disabled or mentally unable to perform his duties. Decision as to pensioning in this last instance is given by the Supreme Court.

\section{SECTION $\mathrm{X}$}

\section{The Government Finances}

Art. 113. Every year the National Assembly approves the state budget, which is good for one year. The budget must be submitted to the National Assembly at the latest one month from the date it convenes. At the same time with the budget must be submitted to the National Assembly for examination and approval the final report for the last past fiscal year. The National Assembly cannot increase the submitted items, but it can lower or omit them. The budget is approved by sections. The form of making and executing of the budget is prescribed by law. Saving from one item of the budget or of the budget year cannot be used for payment of other items or for another year, without the consent of the National Assembly.

Art. 114. Until it has approved the submitted budget the National Assembly can approve one-twelfth of the budget for one or more months. If the National Assembly is adjourned before the budget is decided, the budget of the expiring fiscal year is prolonged by decree, at the longest for four months.

Art. 115. Government taxes and general government incomes are regulated by law. State loans are decided by $\mathrm{Na}-$ tional Assembly. The Government is obliged to submit to the National Assembly a true certified report approved by the supreme controller if the agreement for the loan is made and executed according to law.

Art. 116. Tax obligations are general and all the government taxes are equal for the entire country. Taxes are paid according to taxable capacity and progressively. The King and the heir to 
the throne pay government tax on private property. No aid, permanent or temporary, nor gifts or compensation, can be given out of the government's treasury if they are not based on the law.

Art. 117. The minister of finance directs the state property in so far as the law does not provide otherwise. Special laws will be enacted for the disposal of government property. The right of monopoly appertains to the state. Minerals and natural water powers are property of the state. Special laws will be enacted for the giving of mining, industrial, or any other concessions.

Art. 118. For auditing state accounts and supervising the execution of state and provincial budgets there exists a chief controller as the supreme accounting court. The president and members of the supreme control are chosen by the National Assembly from the nominating list, which is arranged by the State Council and on which there are nominated twice as many candidates as there are vacant places. The president and onehalf of the members of the supreme control must be jurists. Other members must have been ministers of finance or they must have ten years of executive financial service. The president and members of the supreme control enjoy the same right of being irremovable as the members of State Council. Detailed regulations as to construction and competent procedure of the supreme control will be enacted by separate law. In what cases, against the decision of the supreme control, a complaint to the Supreme Court will have a place will be decided by law. The supreme control inspects, corrects, and liquidates accounts of general administration and of all those obliged to render accounts to the state treasury. It sees that no expenditures are made in excess of the budget and that no part of the budget is transferred from one section of the budget to the other. It closes the accounts of all state administrations and is obliged to collect all necessary evidence and information. Final state accounts are submitted to the National Assembly for approval with remarks of the supreme controller, and that, at the latest, within one year, counting from the end of each fiscal year.

\section{SECTION XI}

The Army

Art. 119. Military service is general as prescribed by law. The organization and strength of the army and navy are also 
prescribed by law. The formation of units is ordered by the King at the suggestion of the minister of war and the navy. The size of the standing army shall be determined each year at the time of making the budget.

Art. 120. Military courts are independent. In the execution of justice they are under no other authority, but their judgments shall be according to law. Judges of the military court of appeals are appointed for life. The tenure of office of judges of the first-instance military courts will be prescribed by law. Judges of the first-instance military courts cannot be impeached for their judicial acts without the sanction of the military court of appeals, nor judges of the appellate court without the consent of the Supreme Court. Judges of the military court of appeals may be transferred only at their own request or if elevated to a higher office and judges of the first-instance military courts according to law. The findings of the military courts are to be reviewed by the Supreme Court as the court of last resort.

Art. 121. Law violations committed by citizens and soldiers together will be tried before civil tribunals, except in time of war, when they will be tried by military courts.

Art. 122. No one over 20 years of age shall be eligible to appointment under the government or remain in the same unless he has complied with the rules of the military authorities as to military service performed or has been exempted from such service by the same authorities.

Art. 123. The army can be employed for the preserving of law and order in local affairs only upon the request of local authorities.

Art. 124. Aliens shall not be recruited as soldiers of the nation, nor can the army of the nation be placed in the service of any other nation without having previously obtained the sanction of the National Assembly.

\section{SECTION XII}

\section{Amendments to the Constitution}

Art. 125. Amendments to the constitution shall be made by the National Assembly with the consent of the King.

Art. 126. Motions to amend or alter the constitution shall be made by the King and the National Assembly. When such a motion to amend or alter the constitution is made, all such amend- 
ments or changes must be presented in writing. If the motion to amend is made by the King it will be communicated to the National Assembly and the National Assembly will then adjourn and a new one will be called at the latest within four months. If such a motion is introduced by the National Assembly it shall be enacted in the manner contemplated for the solution of statutory laws by a three-fifths majority vote of the entire membership. When such a motion is passed the National Assembly will be dissolved and a new one shall be called within four months of the passage of such motion. In either event the National Assembly can only discuss the amendments or changes in the constitution as per original call. The vote of the National Assembly shall be based on a majority of one-half, plus one, of the total number of its membership.

Art. 127. In the event of war or general mobilization, the National Assembly may for the whole of the national territory, or in the case of armed insurrection for the insurgent district, enact temporary emergency laws abrogating the following rights of citizens: The right of assembly, free speech, liberty of movement, immunity of domicile, correspondence, and telegraphic communication. In the same manner the freedom of the press may be abridged in case of armed insurrection in the district so affected.

\section{SECTION XIII}

\section{General Instructions}

Art. 128. At the first meeting of the National Assembly after the proclamation of the constitution the heir to the throne, Alexander, as the representative of King Peter I, as per Article 58 of the constitution, will take the following oath:

"In the name of his majesty King Peter I, I swear before the Almighty God that I will uphold the constitution without any mental reservations, that $I$ will rule by it and by the laws, that I will safeguard the liberties of the people, the independence of the state and the entity of the national authorities, and that in all my actions and deeds I will have before me the welfare of the people. So help me God. Amen."

Art. 129. After this each of the national representatives in meeting assembled and before the speaker of the house will take the following oath:

"I [name] swear before the Almighty God and all that is 
under the law most sacred to me and in this world the most precious that I will in the discharge of my legislative duties have the welfare of the nation before me as the paramount issue and will fulfill my duties that the welfare of the king and pcople and the sovereignty of the nation may be executed to the best of my knowledge and belief."

Art. 130. Temporary laws, rules, regulations, and findings of the Council of Ministers and all other acts and decisions of a definite duration which are of a statutory nature are in force from Dec. 1, 1918, until the day of the proclamation of this constitution; said laws will be in force until they are amended or repealed. Within thirty days from the promulgation of the constitution it will be the duty of the Government to give to the legislative body for examination all such provisional laws, rules, regulations, statutes, and decisions. The committee, divided into sections according to the branch of the national administration, after passing upon them, will pass in committee of the whole on which of said laws shall remain in force without change, which are to be amended, and which repealed. The unreported temporary laws, rules, regulations, and decisions of the Council of Ministers and all other acts and laws of a temporary legal nature are hereby repealed. The findings of the committee will be proclaimed as law. Those upon which the committee does not report will remain in full force until such time as they are changed in the regular legislative manner. All temporary laws, rules, statutes, and decisions which are of a legal nature of the Ministerial Council with reference to the agrarian problem of the nation, the national banks of the Serbs, Croats, and Slovenes, and the liquidation of the moratorium, liquidation of the legal status created by the war, and the reparation for damages caused by the war, rules pertaining to the loan and the simplifying of the judiciary, can only be changed in a legislative manner.

Art. 131. Until such time as the constitution goes into effect the administration of the Ministry, of the National Council, of the supreme control, of the rules of order in the National Council and of the ministerial responsibilities, the laws now existing in the Kingdom of Serbia are hereby extended to the rest of the country, with such amendments and additions as will be enacted in the manner as preseribed in Article 133.

Art. 132. In accordance with Article 57 of this constitution, until the new statutes are in force the ones enacted by order of 


\section{NEW CONSTITUTIONS OF EUROPE}

the King on Aug. 30, 1909, and published in the "Serbian Press" Feb. 26, 1911, will be in effect.

Art. 133. For the equalization and administration of the laws in the land a shorter method is the following: All legal motions which have as their basis the coördination of laws and administration will be introduced either by the Government or by individual representatives to the legislative committee through its chairman. The report of the legislative committee relative to the motion which the committee has adopted is sent to the National Assembly for final action. Of these legal motions the Assembly votes the bill in its entirety with a roll-call vote and first reading before the full house, whether they are passed or rejected. Before voting is in order, one representative from each parliamentary group may address the house upon the motion with a limited speech. Such a shorter method for the uniformity of legislation and administration in the nation may be for five years from the time that this constitution goes into effect, but such time may be extended legally. During the sitting of the Constituent Assembly as a legislative body the constitutional committee will fulfill the duties of the legislative committee.

Art. 134. After the constitution goes into effect the present provisional authorities will remain as such temporarily, each with a provisional governor named by the King on the recommendation of the minister of the interior. The provisional governor will administer the province through and with the chiefs of the department and under the immediate supervision of the minister of the interior and as the agent of competent ministers, and upon the basis of the existing laws and regulations. Laws enacted after this constitution goes into effect shall not give the provisional administration new duties. In the gradual transfer of the affairs of the administration of the provinces to the several ministries and authorities as per rules issued in Article 135, the Council of Ministers after due representation from the provisional governor will decide. As long as the provisional administration is in force the bureaus of the several ministries in the provinces are bound to confer and learn the views of the province's representatives as to their bills which are of a general character or that have any bearing on civil service employees before the ministerial decision. The parties have the right to be heard before the National Council relative to administrative contentions, which are decided by the temporary provisional 
administration as the first and last. For this duty the National Council will prepare whatever is necessary. Administrative contention may exist only between a private individual or a person of the legal calling on the one side and the administrative authorities on the other; and it exists then where through an order or decision of the administrative authorities the rights of the private individual or of the individual of the legal calling are interfered with in contravention of law. However, the issue will not arise in cases where the law has provided that the provincial or district authorities shall proceed, consider, or decide the case.

Art. 135. The government law relating to the division of the land into provinces and the regulation of provinces as per Articles 95 and 96 , as well as the transfer of the present provincial sovereignty to the ministry and provincial administrations as per Article 134, shall be brought by the government before the National Assembly for passage. If the National Assembly does not pass these laws within three months they will be brought up according to Article 133 for the uniformity of the code and administration of the land, and if even after this shorter method these laws are not enacted within two months, then the Crown will issue an order whereby the land shall be divided within one month, together with the apportionments on the provincial administration as per Articles 95 and 96 of the constitution. This order may be changed only by legislative action. If the division of the land is not accomplished either according to the first or second part of this Article, but according to the third, then there shall be established in Croatia and Slovenia four administrative authorities. If a division of the land is to be carried out according to the resolutions of this Article then Montenegro, within the frontiers of 1913, with the Bokokotorski district, but without the districts of Plevlja and Belopolje, shall be considered as one department and will be administered by the provincial authorities as per this constitution. With the law of the division of authority Bosnia and Herzegovina will be divided in authority in their present borders. Until the passage of such a law the counties in Bosnia and Herzegovina will be considered as the de facto authority. The amalgamation of these authorities will be accomplished by the decision of the provincial assemblies of the said provinces and carried by a majority of two-thirds votes, according to the provision in the third section of Article 95 of the constitution. Each municipality or district may secede from its present allegiance and join a different municipal 
authority in the present borders of Bosnia and Herzegovina or outside of them if that is accepted by their self-governing representatives by a vote of three-fifths, and if such a decision is authorized by the National Assembly. The counties will remain as units of the national administration until such time as they are abolished by law; their authority will be regulated by law. The self-governing districts will terminate their administration in the interest of the provincial and county districts as soon as the organization of the departments is completed.

Art. 136. Until the new law affecting the employees (government officials), as per Article 106 of the constitution, the laws now in effect shall be the law governing their duties and rights. The new law shall embody the temporary orders with the object of revision and coördination of the personnel of the administrative officials and must be brought up for action not later than two years after the passage of the constitution, by which time the revision and coördination of the government officials must be completed.

Art. 137. The president of tribunals (chief justices) and all other judges whose appointment under the constitution or the statutes is of a permanent nature shall not be removed, but they will retain their positions and fulfill their duties in the judiciary as heretofore. In the other parts of the nation, except what was originally Serbia proper, the tenure of office of individual judges may be terminated within one year from the enactment of this constitution. In that time the minister of justice will form the commissions of the higher tribunals of these districts and together they will decide which of the judges are to be considered as not coming under the provision of the law excluding them from the permanent tenure of office. The necessary filling of the places thus made vacant by chief justices and other judges will be done according to the statutes now existing. Judges who were or will be appointed under the provision of the statutes for temporary appointment to official positions during the war, or under any other law or ordinance, are directed within one and one-half years from the enactment of this constitution to take the examination for judges. Those who fail to do so in the prescribed time will by such failure forfeit their positions. The Supreme Court of Beograd (Belgrade), the court of seven in Zagreb, the high court of Sarajevo, the high court of Podgoriza and the branch of the Supreme Court of Novi Sad will function as heretofore until the formation of the 
Supreme Court for the whole nation. In the interim they will be considered as branches of the Supreme Court.

Art. 138. The publication and distribution of newspapers and printed matter may be prohibited which advocate hatred toward the government as a whole, religious or class hatred, and also when they appeal to the citizenry to resort to violence having for its object the overthrow of the constitution or the laws of the land by force, if from the contents it is plainly implied that the intent is to bring about such overthrow by citizenry. Section 13, Article 3, of the law as to the enforcement of the prohibition is valid in this instance. When the necessity for these measures ceases to exist these laws may be repealed in the legal way.

Art. 139. Until such time as a law is enacted relative to privileges (grants or concessions) as to Article 117 of the constitution, all such privileges (grants or concessions) until the time of the enactment of the constitution shall be revised in the manner as provided in Article 133 of the constitution. The privilege for the clearing of the national forests shall be revised in so far as the price (or tax) shall have retroactive value from Dec. 1, 1918.

Art. 140. When this constitution becomes effective the Constituent Assembly, elected on the 28th day of November, 1920, automatically (ipso facto) becomes the regular legislative assembly, with a definite time for its sittings as provided in the election laws for the Constituent Assembly.

Art. 141. Until such time as a new code is enacted relative to the election of national representatives the law under which the election of November, 1920, was held shall be held valid, with the changes which shall be brought in harmony with the constitution. These changes will be brought in the manner as contemplated in Article 133 of this constitution and will become valid when they receive the King's sanction. The committee may make the necessary changes in terms which the law contemplates, and besides that it is empowered to prescribe the manner in which the division of the mandates shall be made on each list of candidates according to the number of voters.

\section{SECTION XIV}

\section{Final Rules}

Art. 142. This constitution with the orders becomes a law when it is countersigned by the King, and it gets its binding 


\section{NEW CONSTITUTIONS OF EUROPE}

strength when it is published in the "official organs." From that day all other laws or regulations which are contrary to it are hereby revoked. For the execution of this constitution the President and all the ministers of the Ministerial Council shall be responsible. We recommend to the ministers that this constitution be given publicity and to see that it is carried out. To the authorities, then, we command that they shall govern according to it and to all and everybody to obey it.

June 28, 1921, in Beograd (Belgrade).

(Signed) Alexander. 


\section{CHAPTER XV}

\section{RUSSIA}

\section{HISTORICAL NOTE}

The most striking political changes due to the war have taken place in Russia. The most reactionary government in Europe has become the most radical. A communist state has been set up and political and industrial organization have been united in a manner that has never been tried before. For the last five years there has been a steady stream of volumes dealing with the Russian Revolution: soldiers, newspaper correspondents, college professors, Czarists, Bolsheviki, governesses, novelists, and sculptresses have contributed accounts of their prejudices and observations. The result is obscurity as to the chain of events that marked the transformation from the old to the new régime, and as to the manner in which the new régime is working. Violent controversies over facts are available; but there are few if any trustworthy discussions of one of the most interesting and important political experiments that the world has ever seen.

There is no adequate history of the beginnings of the socialist democratic movement in Russia. Before the revolution of March, 1917, the censorship was so strict that most of the reliable literature on socialist agitation

Socialist Democratic Labor Party, 1898 was subterranean. Prior to 1898 there was no serious attempt to form an all-Russian socialist organization. In that year, however, the various groups met at Minsk and joined in a single organization to be known as the Russian Socialist Democratic Labor Party. The organization made great progress; its branches were rapidly increased;

Literature of the Russian Revolution of 1917 
it was probably true that "every workingman's vote in Russia was cast for Socialism,"' a situation that was not duplicated in any other country.

The second congress of the party was held in Brussels and London in July and August, 1903, and radical differences of opinion developed.

Origin of term "Bolsheviki"
The revolution of 1905
One party, headed by Lenin, demanded a more thorough centralization of power in the hands of the Executive Committee, a rigorous suppression of all independent activities, and a severer code of rules for membership of the party. The other group, led by Martoff, defended the democratic principle of organization and desired a further development of independence on the part of the local organizations. Further differences of opinion existed regarding the policy to be adopted in the event of a successful revolution. The supporters of the Martoff group were prepared to concede to the Liberal bourgeoisie at any rate a temporary justification of their existence, but Lenin maintained that the overthrow of Tsardom by the aid of the bourgeoisie and the establishment of a democratic republic would not only [not?] weaken the domination of the capitalists but would actually increase it. These differences of opinion led to a definite breach and as, at this particular Congress, the majority or "bolshinstvo" of the delegates voted with Lenin, they were known subsequently as the "bolsheviki" while the minority or "menshinstvo" were labelled "mensheviki." This is the real origin of the Bolsheviks and, although the word "Bolshevism," which has been created to describe the doctrine of the Bolsheviks has an entirely different signification, "Bolshevik" in its original sense has no further meaning than that which has just been explained. ${ }^{2}$

The two wings remained apart during the revolution of 1905 when public disorders were so serious that the Czar was compelled to convoke a national assembly. ${ }^{3}$ There was, however, no approach to parliamentary govern-

${ }^{1}$ Bolshevik Aims and Ideals, p. 9 (New York, 1919; a reprint of articles from The Round Table, March and June, 1919).

${ }^{2}$ Ibid.,pp. 10-11.

'See E. A. Goldenweiser, "The Russian Duma," Political Science Quarterly, September, 1914; S. N. Harper, The New Electoral Law for the Russian Duma (Chicago, 1908); Paul Vinogradoff, Self Government in Russia (London, 1915). 
ment. Revolutionary agitation continued in spite of the censorship and police suppression; and the different parties opposing the autocracy of the Czar's régime squandered some of their strength in factional struggles among themselves. Then came the war; and the mystery is that the government lasted as long as it did. It was stupid and corrupt; demands for extensions of the franchise were refused; repressive measures engendered further popular discontent; high officials were in league with the enemy; the war and its professed purposes were not popular with the masses; and the court was dominated by the fanatic Rasputin. The result was the revolution of March, 1917. ${ }^{1}$ A provisional government which was liberal rather than socialist and aimed at middle-class rule lasted until November, 1917, when the Bolsheviki came into power. ${ }^{2}$

Entirely apart from the economic philosophy of Bolshevism the new régime in Russia is of great significance in the development of representative institutions; for, as has already been said, the constitution links political and municipal with industrial organization. The seizure of political power by the Bolsheviki in November, 1917, was simply a military coup d'état. Trotsky announced that "Kerensky's government no longer existed and that, pending the decision of the All-Russian Congress of Soviets, the government authority would be assumed by the Military Revolutionary Committee." The Constituent Assembly, which had been elected in November, 1917, was dissolved in January, 1918, because, in spite of the fact Bolshevist coup d'état November, 1917

Constituent Assembly dissolved that the leaders of the middle-class Liberals had been arrested and other measures of repression taken, an antiBolshevik candidate was elected to the presidency of the

\footnotetext{
${ }^{1}$ On the facts of the revolution, which are still obscure, see Dillon, The Eclipse of Russia (London, 1918); Kerensky, The Prelude to Bolshevism (New York, 1919); Olgin, The Soul of the Russian Revolution (New York, 1917); and Levine, The Russian Revolution (New York, 1917).

See Vandervelde, Three Aspects of the Russian Revolution (New York, 1919); Goode, Bolshevism at Work (New York, 1920); Trotsky, Our Recolution (New York, 1918); Russell, Bolshevism in Theory and Pracice (New York, 1920).
}

The revolution of 1917 
Origin of Soviet idea

Assembly, and a series of anti-Bolshevik resolutions were carried. The Assembly was, therefore, abandoned, and the Bolsheviki relied for their support on the Soviets or Councils of Workmen's, Peasants', and Soldiers' Deputies. These bodies, containing no representatives of the middle classes, were lured by the revolutionary battle-cry, "All Power to the Soviets."

The Soviet idea may be said to have originated in England. One of the followers of Robert Owen produced a plan for "a new set of boroughs when the unions are organized: every trade shall be a borough and every trade shall have a council of representatives to conduct its affairs." But the Grand National Consolidated Trades Union which Owen headed collapsed. So also the Luxembourg Commission (1848) elected by the various trades from the workshops to represent the Paris proletariat, was but a flash in the pan. ${ }^{1}$ The Soviet did not emerge until the Russian revolution of 1905 , when the Soviets came into being more or less spontaneously. They were in essence strike committees employed to bring pressure to bear upon the government to grant parliamentary institutions. They vanished almost at once with the reaction, only to reappear, however, early in 1917. At first they were under a moderate Socialist influence; but Lenin was quick to see their possibilities, and by the time of the November revolution, the Bolsheviki had control of the Petrograd and Moscow Soviets. The meeting of the First Congress of Soviets in Petrograd on November 7 was made the occasion of the Bolshevist coup. The Third AllRussian Congress of Soviets proclaimed the Russian So-

Constitution of 1918 cialist Federated Soviet Republic. The Fifth All-Russian Congress of Soviets adopted a constitution in July, 1918.

The Soviet Government is extremely complicated, as the constitution and the accompanying chart will indicate.

'See R. W. Postgate, The Bolshevik Theory, p. 132 ff. (London, 1920). 


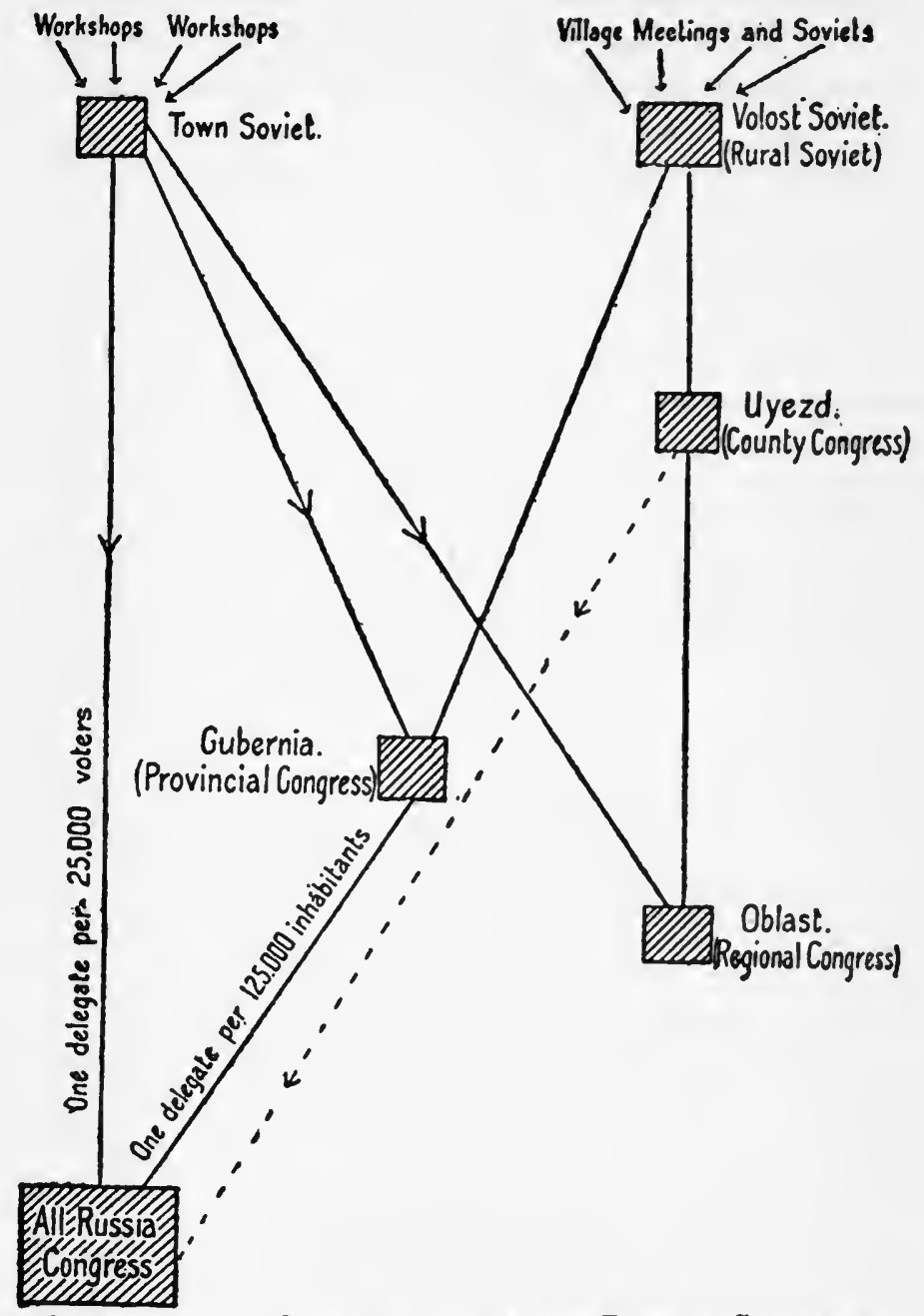

Governmental Organization of the Russian Socialist Federated Soviet Repubut ${ }^{1}$

'From R. W. Postgate, The Bolshevik Theory, p. 146 (London, 1980). 


\section{NEW CONSTITUTIONS OF EUROPE}

Dictatorship of a minority
Occupational representation
The bourgeois elements of the population are completely disfranchised. Though kept in power by the acquiescence of the peasants, the Bolshevist government does not trust the peasants, and the Soviet hierarchy is so arranged that their vote counts for only one-fifth of its numerical strength. ${ }^{1}$ The controlling organs are not in touch with the people since they result from a series of indirect elections "so complicated as to need a genealogical tree to make them intelligible." 2 The Communists, nevertheless, remain in control: a party of 600,000 members, only a fraction of whom are active, maintains a dictatorship over more than $125,000,000$ people. $^{3}$

According to Lenin, the government thus instituted is an "immeasurably higher form of democracy" than the world has previously witnessed. Lenin himself, however, leaves in the background the feature of the soviet system which has attracted the sympathetic attention of foreign observers. According to these writers, "its essential characteristic consists in its occupational constituencies. These, they say, represent real groups with common purposes, in contrast to merely geographical constituencies, which they assert are meaningless conglomerations." "4 Since occupational representation is being discussed in Western countries entirely apart from the radical changes that have been made in the basis of private property in Russia, ${ }^{5}$ the organization and working of the Soviet system are of great interest to the student of politics. ${ }^{6}$

'See Articles 23, 25, and 53.

${ }^{2}$ Ashley, op. cit.

${ }^{3}$ See an interesting article by M. J. Olgin, "Mechanics of Power in Soviet Russia," The New Republic, June 15, 1921.

"William Ashley, "Bolshevism and Democracy," Quarterly Review, January, 1921.

SSee above, Chapter VI.

-The text of the constitution which follows has been reprinted, by permission, from The Nation of January 4, 1919. This translation, says The Nation, was "made from an official printed text embodying the latest revisions, and required by law to be posted in all public places in Russia." 


\section{THE RUSSIAN CONSTITUTION}

\section{The Russian Socialist Federated Soviet Republic}

Resolution of the Fifth All-Russian Congress of Soviets, adopted on July 10, 1918

The declaration of rights of the laboring and exploited people (approved by the Third All-Russian Congress of Soviets in January, 1918), together with the constitution of the Soviet Republic, approved by the Fifth Congress, constitutes a single fundamental law of the Russian Socialist Federated Soviet Republic.

This fundamental law becomes effective upon the publication of the same in its entirety in the "Izvestia of the All-Russian General Executive Committee." It must be published by all organs of the Soviet Government and must be posted in a prominent place in every Soviet institution.

The Fifth Congress instructs the People's Commissariat of Education to introduce in all schools and educational institutions of the Russian Republic the study and explanation of the basic principles of this constitution.

\section{SECTION I}

\section{Declaration of Rights of the Laboring and} Exploited People

\section{Chapter One}

Article 1. Russia is declared to be a Republic of the Soviets of Workers', Soldiers', and Peasants' Deputies. All the central and local power belongs to these Soviets.

Art. 2. The Russian Soviet Republic is organized on the basis of a free union of free nations, as a federation of Soviet national Republics.

\section{Chapter Two}

Art. 3. Bearing in mind as its fundamental problem the abolition of exploitation of men by men, the entire abolition of the division of the people into classes, the suppression of exploiters, the establishment of a Socialist society, and the victory of socialism in all lands, the Third All-Russian Congress of Soviets of Workers', Soldiers', and Peasants' Deputies further resolves: 
(1) For the purpose of realizing the socialization of land, all private property in land is abolished, and the entire land is declared to be national property and is to be apportioned among husbandmen without any compensation to the former owners, in the measure of each one's ability to till it.

(2) All forests, treasures of the earth, and waters of general public utility, all implements whether animate or inanimate, model farms and agricultural enterprises, are declared to be national property.

(3) As a first step toward complete transfer of ownership to the Soviet Republic of all factories, mills, mines, railways, and other means of production and transportation, the Soviet law for the control by workmen and the establishment of the Supreme Soviet of National Economy is hereby confirmed, so as to assure the power of the workers over the exploiters.

(4) With reference to international banking and finance, the Third Congress of Soviets is discussing the Soviet decree regarding the annulment of loans made by the Government of the Czar, by landowners and the bourgeoisie, and it trusts that the Soviet Government will firmly follow this course until the final victory of the international workers' revolt against the oppression of capital.

(5) The transfer of all banks into the ownership of the Workers' and Peasants' Government, as one of the conditions of the liberation of the toiling masses from the yoke of capital, is confirmed.

(6) Universal obligation to work is introduced for the purpose of eliminating the parasitic strata of society and organizing the economic life of the country.

(7) For the purpose of securing the working class in the possession of the complete power, and in order to eliminate all possibility of restoring the power of the exploiters, it is decreed that all toilers be armed, and that a Socialist Red Army be organized and the propertied class be disarmed.

\section{Chapter Three}

Art. 4. Expressing its absolute resolve to liberate mankind from the grip of capital and imperialism, which flooded the earth with blood in this present most criminal of all wars, the Third Congress of Soviets fully agrees with the Soviet Government in its policy of breaking secret treaties, of organizing on a 
wide scale the fraternization of the workers and peasants of the belligerent armies, and of making all efforts to conclude a general democratic peace without annexations or indemnities, upon the basis of the free determination of the peoples.

Art. 5. It is also to this end that the Third Congress of Soviets insists upon putting an end to the barbarous policy of the bourgeois civilization which enables the exploiters of a few chosen nations to enslave hundreds of millions of the toiling population of Asia, of the colonies, and of small countries generally.

Art. 6. The Third Congress of Soviets hails the policy of the Council of People's Commissars in proclaiming the full independence of Finland, in withdrawing troops from Persia, and in proclaiming the right of Armenia to self-determination.

\section{Chapter Four}

Art. 7. The Third All-Russian Congress of Soviets of Workers', Soldiers', and Peasants' Deputies believes that now, during the progress of the decisive battle between the proletariat and its exploiters, the exploiters cannot hold a position in any branch of the Soviet Government. The power must belong entirely to the toiling masses and to their plenipotentiary representatives-the Soviets of Workers', Soldiers', and Peasants' Deputies.

Art. 8. In its effort to create a league-free and voluntary, and for that reason all the more complete and secure- of the working classes of all the peoples of Russia, the Third Congress of Soviets merely establishes the fundamental principles of the federation of Russian Soviet Republics, leaving to the workers and peasants of every people to decide the following question at their plenary sessions of their Soviets: whether or not they desire to participate, and on what basis, in the federal government and other federal Soviet institutions.

\section{SECTION II}

General Provisions of the Constitution of the Russian Socialist Federated Soviet Republic

\section{Chapter Five}

Art. 9. The fundamental problem of the constitution of the Russian Socialist Federated Soviet Republic involves, in view of 
the present transition period, the establishment of a dictatorship of the urban and rural proletariat and the poorest peasantry in the form of a powerful All-Russian Soviet authority, for the purpose of abolishing the exploitation of men by men and of introducing Socialism, in which there will be neither a division into classes nor a state of autocracy.

Art. 10. The Russian Republic is a free Socialist society of all the working people of Russia. The entire power, within the boundaries of the Russian Socialist Federated Soviet Republic, belongs to all the working people of Russia, united in urban and rural Soviets.

Art. 11. The Soviets of those regions which differentiate themselves by a special form of existence and national character may unite in autonomous regional unions, ruled by the local Congress of the Soviets and their executive organs.

These autonomous regional unions participate in the Russian Socialist Federated Soviet Republic upon the basis of a federation.

Art. 12. The supreme power of the Russian Socialist Federated Soviet Republic belongs to the All-Russian Congress of Soviets, and, in periods between the convocation of the Congress, to the All-Russian Central Executive Committee.

Art. 13. For the purpose of securing to the toilers real freedom of conscience, the church is to be separated from the state and the school from the church, and the right of religious and anti-religious propaganda is accorded to every citizen.

Art. 14. For the purpose of securing the freedom of expression to the toiling masses, the Russian Socialist Federated Soviet Republic abolishes all dependence of the press upon capital, and turns over to the working people and the poorest peasantry all technical and material means of publication of newspapers, pamphlets, books, etc., and guarantees their free circulation throughout the country.

Art. 15. For the purpose of enabling the workers to hold free meetings, the Russian Socialist Federated Soviet Republic offers to the working class and to the poorest peasantry furnished halls, and takes care of their heating and lighting appliances.

Art. 16. The Russian Socialist Federated Soviet Republic, having crushed the economic and political power of the proper- 
tied classes and having thus abolished all obstacles which interfered with the freedom of organization and action of the workers and peasants, offers assistance, material and other, to the workers and the poorest peasantry in their effort to unite and organize.

Art. 17. For the purpose of guaranteeing to the workers real access to knowledge, the Russian Socialist Federated Soviet Republic sets itself the task of furnishing full and general free education to the workers and the poorest peasantry.

Art. 18. The Russian Socialist Federated Soviet Republic considers work the duty of every citizen of the Republic, and proclaims as its motto: "He shall not eat who does not work."

Art. 19. For the purpose of defending the victory of the great peasants' and workers' revolution, the Russian Socialist Federated Soviet Republic recognizes the duty of all citizens of the Republic to come to the defense of their Socialist Fatherland, and it, therefore, introduces universal military training. The honor of defending the revolution with arms is given only to the toilers, and the non-toiling elements are charged with the performance of other military duties.

Art. 20. In consequence of the solidarity of the toilers of all nations, the Russian Socialist Federated Soviet Republic grants all political rights of Russian citizens to foreigners who live in the territory of the Russian Republic and are engaged in toil and who belong to the toiling class. The Russian Socialist Federated Soviet Republic also recognizes the right of local Soviets to grant citizenship to such foreigners without complicated formality.

Art. 21. The Russian Socialist Federated Soviet Republic offers shelter to all foreigners who seek refuge from political or religious persecution.

Art. 22. The Russian Socialist Federated Soviet Republic, recognizing equal rights of all citizens, irrespective of their racial or national connections, proclaims all privileges on this ground, as well as of national minorities, to be in contradiction with the fundamental laws of the Republic.

Art. 23. Being guided by the interests of the working class as a whole, the Russian Socialist Federated Soviet Republic deprives all individuals and groups of individuals of rights which could be utilized by them to the detriment of the Socialist Revolution. 


\author{
SICTION III \\ Constrectiox of the Soviet Power \\ A. Organization of the Central Power \\ Chapter Sir
}

The All-Rusvian Congress of Soriets of Workers', Peasants', Cassacks, and Red Army Deputies

Art. 24. The All-Russian Congress of Soviets is the supreme power of the Russian Socialist Federated Soviet Republic.

Art. 25. The All-Russian Congress of Soviets is composed of representatives of urban Soviets (one delegate for 25,000 roters), and of representatives of the provincial (Gubernia) congresses of Soviets (one delegate for 195,000 inhabitants).

Nors 1. In case the Provincisl Congress is not called before the All-Russian Congress is convoked, delegates for the latter are sent directly from the county (Owerd or Cyurd) Congress.

Nore 2. In case the Regional (OMart) Congress is conroked indirectly, prerious to the couvocation of the All-Russian Congress, delegstes for the Litter may be sent by the Regional Congress.

Art. 26. The All-Russian Congress is conroked by the AllRussian Central Executive Committee at least twice a year.

Art. 27. A special All-Russian Congress is conroked by the All-Russian Central Executive Committee upon its own initiative, or upon the request of local Soviets having not less than one-third of the entire population of the Republic.

Art. 2S. The All-Russian Congress elects an All-Russian Central Executive Committee of not more than 200 members.

Art. 99. The All-Russian Central Executive Committee is entirely responsible to the All-Russian Congress of Soviets.

Art. 30. In the periods between the convocation of the Congresses, the All-Russian Central Executive Committee is the supreme power of the Republic.

\title{
Chapier Secen
}

The All-Russian Central Erecutire Committee

Art. 31. The All-Russian Central Executire Committee is the supreme legislative, executive, and controlling organ of the Russian Socialist Federated Soviet Republic. 
Art. 32. The All-Russian Central Executive Committee directs in a general way the activity of the Workers' and Peasants' government and of all organs of the Soviet authority in the country, and it coördinates and regulates the operation of the Soviet constitution and of the resolutions of the All-Russian Congresses and of the central organs of the Soviet power.

Art. 33. The All-Russian Central Executive Committee considers and enacts all measures and proposals introduced by the Soviet of People's Commissars or by the various departments, and it also issues its own decrees and regulations.

Art. 34. The All-Russian Central Executive Committee convokes the All-Russian Congress of Soviets, at which time the Executive Committee reports on its activity and on general questions.

Art. 35. The All-Russian Central Executive Committee forms a Council of People's Commissars for the purpose of general management of the affairs of the Russian Socialist Federated Soviet Republic, and it also forms departments (People's Commissariats) for the purpose of conducting various branches.

Art. 36. The members of the All-Russian Central Executive Committee work in the various departments (People's Commissariats) or execute special orders of the All-Russian Central Executive Committee.

\section{Chapter Eight}

\section{The Council of People's Commissars}

Art. 37. The Council of People's Commissars is entrusted with the general management of the affairs of the Russian Socialist Federated Soviet Republic.

Art. 38. For the accomplishment of this task the Council of People's Commissars issues decrees, resolutions, orders, and, in general, takes all steps necessary for the proper and rapid conduct of government affairs.

Art. 39. The Council of People's Commissars notifies immediately the All-Russian Central Executive Committee of all its orders and resolutions.

Art. 40. The All-Russian Central Executive Committee has the right to revoke or suspend all orders and resolutions of the Council of People's Commissars.

Art. 41. All orders and resolutions of the Council of People's Commissars of great political significance are turned over for 
consideration and final approval to the All-Russian Central Executive Committee.

Note. Measures requiring immediate execution may be enacted directly by the Council of People's Commissars.

Art. 42. The members of the Council of People's Commissars stand at the head of the various People's Commissariats.

Art. 43. There are seventeen People's Commissars:

(1) Foreign Affairs.

(2) Army.

(3) Navy.

(4) Interior.

(5) Justice.

(6) Labor.

(7) Social Welfare.

(8) Education.

(9) Post and Telegraph.

(10) National Affairs.

(11) Finances.

(12) Ways of Communication.

(13) Agriculture.

(14) Commerce and Industry.

(15) National Supplies.

(16) State Control.

(17) Supreme Soviet of National Economy.

(18) Public Health.

Art. 44. Every Commissar has a College (Committee) of which he is the President, and the members of which are appointed by the Council of People's Commissars.

Art. 45. A People's Commissar has the individual right to decide on all questions under the jurisdiction of his Commissariat, and he is to report on his decision to the College. If the College does not agree with the Commissar on some decisions, the former may, without stopping the execution of the decision, complain of it to the executive members of the Council of People's Commissars or to the All-Russian Central Executive Committee.

Individual members of the College have this right also.

Art. 46. The Council of People's Commissars is entirely responsible to the All-Russian Congress of Soviets and the All-Russian Central Executive Committee.

Art. 47. The People's Commissars and the Colleges of the 
People's Commissariats are entirely responsible to the Council of People's Commissars and the All-Russian Central Executive Committee.

Art. 48. The title of People's Commissar belongs only to the members of the Council of People's Commissars, which is in charge of general affairs of the Russian Socialist Federated Soviet Republic, and it cannot be used by any other representative of the Soviet power, either central or local.

\section{Chapter Nine}

Affairs in the jurisdiction of the All-Russian Congress and the All-Russian Central Executive Committee

Art. 49. The All-Russian Congress and the All-Russian Central Executive Committee deal with questions of state, such as:

(1) Ratification and amendment of the constitution of the Russian Socialist Federated Soviet Republic.

(2) General direction of the entire interior and foreign policy of the Russian Socialist Federated Soviet Republic.

(3) Establishing and changing boundaries, also ceding territory belonging to the Russian Socialist Federated Soviet Republic.

(4) Establishing boundaries for regional Soviet unions belonging to the Russian Socialist Federated Soviet Republic, also settling disputes among them.

(5) Admission of new members to the Russian Socialist Federated Soviet Republic, and recognition of the secession of any parts of it.

(6) The general administrative division of the territory of the Russian Socialist Federated Soviet Republic and the approval of regional unions.

(7) Establishing and changing of weights, measures, and money denominations in the Russian Socialist Federated Soviet Republic.

(8) Foreign relations, declaration of war, and ratification of peace treaties.

(9) Making loans, signing commercial treaties, and financial agreements.

(10) Working out a basis and a general plan for the national economy and for its various branches in the Russian Socialist Federated Soviet Republic. 
(11) Approval of the budget of the Russian Socialist Federated Soviet Republic.

(12) Levying taxes and establishing the duties of citizens to the state.

(13) Establishing the bases for the organization of armed forces.

(14) State legislation, judicial organization and procedure, civil and criminal legislation, etc.

(15) Appointment and dismissal of the individual People's Commissars or the entire Council; also approval of the President of the Council of People's Commissars.

(16) Granting and cancelling Russian citizenship and fixing rights of foreigners.

(17) The right to declare individual and general amnesty.

Art. 50. Besides the above-mentioned questions, the All-Russian Congress and the All-Russian Central Executive Committee have charge of all other affairs which, according to their decision, require their attention.

Art. 51. The following questions are solely under the jurisdiction of the All-Russian Congress:

(1) Ratification and amendment of the fundamental principles of the Soviet constitution.

(2) Ratification of peace treaties.

Art. 52. The decision of questions indicated in Paragraphs 3 and 8 of Article 49 may be made by the All-Russian Central Executive Committee only in case it is impossible to convoke the Congress.

\section{B. Organization of Local Soviets Chapter Ten}

\section{The Congresses of the Soviets}

Art. 53. Congresses of Soviets are composed as follows:

(1) Regional: of representatives of the urban and county Soviets, one representative for $\mathbf{2 5 , 0 0 0}$ inhabitants of the county, and one representative for 5,000 voters of the cities-but not more than 500 representatives for the entire region-or of representatives of the provincial Congresses, chosen on the same basis, if such a Congress meets before the regional Congress.

(2) Provincial (Gubernia): of representatives of urban and rural (Volost) Soviets, one representative for 10,000 inhabit- 
ants from the rural districts, and one representative for 2,000 voters in the city; altogether not more than 300 representatives for the entire province. In case the county Congress meets before the provincial, election takes place on the same basis, but by the county Congress instead of the rural.

(3) County: of representatives of rural Soviets, one delegate for each 1,000 inhabitants, but not more than 300 delegates for the entire county.

(4) Rural (Volost): of representatives of all village Soviets in the Volost, one delegate for ten members of the Soviet.

Note 1. Representatives of urban Soviets which have a population of not more than 10,000 persons participate in the county Congress; village Soviets of districts of less than 1,000 inhabitants unite for the purpose of electing delegates to the county Congress.

Note 2. Rural Soviets of less than ten members send one delegate to the rural (Volost) Congress.

Art. 54. Congresses of the Soviets are convoked by the respective Executive Committees upon their own initiative, or upon request of local Soviets comprising not less than one-third of the entire population of the given district. In any case they are convoked at least twice a year for regions, every three months for provinces and counties, and once a month for rural districts.

Art. 55. Every Congress of Soviets (regional, provincial, county, and rural) elects its Executive organ-an Executive Committee the membership of which shall not exceed:

(1) for regions and provinces, 25; (2) for a county, 20; (3) for a rural district, 10. The Executive Committee is responsible to the Congress which elected it.

Art. 56. In the boundaries of the respective territories the Congress is the supreme power; during intervals between the convocations of the Congress, the Executive Committee is the supreme power.

\section{Chapter Eleven}

\section{The Soviet of Deputies}

Art. 57. Soviets of Deputies are formed:

(1) In cities, one deputy for each 1,000 inhabitants; the total to be not less than 50 and not more than 1,000 members.

(2) All other settlements (towns, villages, hamlets, etc.) of less than 10,000 inhabitants, one deputy for each 100 inhabi- 


\section{NEW CONSTITUTIONS OF EUROPE}

tants; the total to be not less than 3 and not more than 50 deputies for each settlement.

Term of the deputy, three months

Nore. In small rural sections, whenever possible, all questions shall be decided at general meetings of voters.

Art. 58. The Soviet of Deputies elects an Executive Committee to deal with current affairs; not more than 5 members for rural districts, one for every 50 members of the Soviets of cities, but not more than $\mathbf{1 5}$ and not less than 3 in the aggregate (Petrograd and Moscow not more than 40). The Executive Committee is entirely responsible to the Soviet which elected it.

Art. 59. The Soviet of Deputies is convoked by the Executive Committee upon its own initiative, or upon the request of not less than one-half of the membership of the Soviet; in any case at least once a week in cities, and twice a week in rural sections.

Art. 60. Within its jurisdiction the Soviet, and in cases mentioned in Article 57, Note, the meeting of the voters, is the supreme power in the given district.

\section{Chapter Twelve}

\section{Jurisdiction of the local organs of the Soviets}

Art. 61. Regional, provincial, county, and rural organs of the Soviet power and also the Soviets of Deputies have to perform the following duties:

(1) Carry out all orders of the respective higher organs of the Soviet power.

(2) Take all steps toward raising the cultural and economic standard of the given territory.

(3) Decide all questions of local importance within their respective territory.

(4) Coördinate all Soviet activity in their respective territory.

Art. 62. The Congresses of Soviets and their Executive Committees have the right to control the activity of the local Soviets $(i . e$. , the regional Congress controls all Soviets of the respective regions; the provincial, of the respective province, with the exception of the urban Soviets, etc.); and the regional and provincial Congresses and their Executive Committees in addition have the right to overrule the decisions of the Soviets 
of their districts, giving notice in important cases to the central Soviet authority.

Art. 63. For the purpose of performing their duties, the local Soviets, rural and urban, and the Executive Committees form sections respectively.

\section{SECTION IV}

\section{The Right to Vote}

\section{Chapter Thirteen}

Art. 64. The right to vote and to be elected to the Soviets is enjoyed by the following citizens, irrespective of religion, nationality, domicile, etc., of the Russian Socialist Federated Soviet Republic, of both sexes, who shall have completed their eighteenth year by the day of election:

(1) All who have acquired the means of living through labor that is productive and useful to society, and also persons engaged in housekeeping, which enables the former to do productive work, $i$. e., laborers and employees of all classes who are employed in industry, trade, agriculture, etc.; and peasants and Cossack agricultural laborers who employ no help for the purpose of making profits.

(2) Soldiers of the army and navy of the Soviets.

(3) Citizens of the two preceding categories who have to any degree lost their capacity to work.

Note 1. Local Soviets may, upon approval of the central power, lower the age standard mentioned herein.

Note 2. Non-citizens mentioned in Article 20 (Section II, Chapter 5) have the right to vote.

Art. 65. The following persons enjoy neither the right to vote nor the right to be voted for, even though they belong to one of the categories enumerated above, namely:

(1) Persons who employ hired labor in order to obtain from it an increase in profits.

(z) Persons who have an income without doing any work, such as interest from capital, receipts from property, etc.

(3) Private merchants, trade and commercial brokers.

(4) Monks and clergy of all denominations.

(5) Employees and agents of the former police, the gendarme corps, and the Okhrana [Czar's secret service], also members of the former reigning dynasty. 
(6) Persons who have in legal form been declared demented or mentally deficient, and also persons under guardianship.

(7) Persons who have been deprived by a Soviet of their rights of citizenship because of selfish or dishonorable offenses, for the period fixed by the sentence.

\section{Chapter Fourteen}

\section{Elections}

Art. 66. Elections are conducted according to custom on days fixed by the local Soviets.

Art. 67. Election takes place in the presence of an electoral committee and the representative of the local Soviet.

Art. 68. In case the representative of the Soviet cannot be present for valid causes, the chairman of the electoral committee takes his place, and in case the latter is absent, the chairman of the election meeting replaces him.

Art. 69. Minutes of the proceedings and results of elections are to be compiled and signed by the members of the electoral committee and the representative of the Soviet.

Art. 70. Detailed instructions regarding the election proceedings and the participation in them of professional and other workers' organizations are to be issued by the local Soviets, according to the instructions of the All-Russian Central Executive Committee.

\section{Chapter Fifteen}

The checking and cancellation of elections and recall of the deputics

Art. 71. The respective Soviets receive all the records of the proceedings of the election.

Art. 72. The Soviet appoints a commission to verify the elections.

Art. 73. This commission reports on the results to the Soviets.

Art. 74. The Soviet decides the question when there is doubt as to which candidate is elected.

Art. 75. The Soviet announces a new election if the election of one candidate or another cannot be determined.

Art. 76. If an election was irregularly carried on in its entirety, it may be declared void by a higher Soviet authority. 
Art. 77. The highest authority in relation to questions of elections is the All-Russian Central Executive Committee.

Art. 78. Voters who have sent a deputy to the Soviet have the right to recall him, and to have a new election, according to general provisions.

\section{SECTION V}

\section{The Budget}

\section{Chapter Sixteen}

Art. 79. The financial policy of the Russian Socialist Federated Soviet Republic in the present transition period of dictatorship of the proletariat, facilitates the fundamental purpose of expropriation of the bourgeoisie and the preparation of conditions necessary for the equality of all citizens of Russia in the production and distribution of wealth. To this end it sets forth as its task the supplying of the organs of the Soviet power with all necessary funds for local and state needs of the Soviet Republic, without regard to private property rights.

Art. 80. The state expenditure and income of the Russian Socialist Federated Soviet Republic are combined in the state budget.

Art. 81. The All-Russian Congress of Soviets or the AllRussian Central Executive Committee determine what matters of income and taxation shall go to the state budget and what shall go to the local Soviets; they also set the limits of taxes.

Art. 82. The Soviets levy taxes only for the local needs. The state needs are covered by the funds of the state treasury.

Art. 83. No expenditure out of the state treasury not set forth in the budget of income and expense shall be made without a special order of the central power.

Art. 84. The local Soviets shall receive credits from the proper People's Commissars out of the state treasury, for the purpose of making expenditures for general state needs.

Art. 85. All credits allotted to the Soviets from the state treasury, and also credits approved for local needs, must be expended according to the estimates, and cannot be used for any other purposes without a special order of the All-Russian Central Executive Committee and the Soviet of People's Commissars.

Art. 86. Local Soviets draw up semi-annual and annual esti- 
mates of income and expenditure for local needs. The estimates of urban and rural Soviets participating in county congresses, and also the estimates of the county organs of the Soviet power, are to be approved by provincial and regional congresses or by their executive committees; the estimates of the urban, provincial, and regional organs of the Soviets are to be approved by the All-Russian Central Executive Committee and the Council of People's Commissars.

Art. 87. The Soviets may ask for additional credits from the respective People's Commissariats for expenditures not set forth in the estimate, or where the allotted sum is insufficient.

Art. 88. In case of an insufficiency of local funds for local needs, the necessary subsidy may be obtained from the state treasury by applying to the All-Russian Central Executive Committee or the Council of People's Commissars.

\section{SECTION VI}

\section{The Coat of Arms and Flag of the Russtan Socialist Federated Soviet Republic}

\section{Chapter Seventeen}

Art. 89. The coat of arms of the Russian Socialist Federated Soviet Republic consists of a red background on which a golden scythe and a hammer are placed (crosswise, handles downward) in sun-rays and surrounded by a wreath, inscribed:

\section{Russian Socialist Soviet Federated Republic Workers of the World, Unite!}

Art. 90. The commercial, naval and army flag of the Russian Socialist Federated Soviet Republic consists of a red cloth, in the left corner of which (on top, near the pole) there are in golden characters the letters R. S. F. S. R., or the inscription: Russian Socialist Federated Soviet Republic.

Chairman of the fifth All-Russian Congress of Soviets and of the All-Russian Central Executive Committee: J. Sverdofoff.

Executive Officers, All-Russian Central Executive Committee: T. I. Teodorowitch, F. A. Rosin, A. P. Rosenholz, A. C. Mitrofanoff, K. G. Maximoff.

Secretary of the All-Russian Central Executive Committee: V. A. Avanessofr. 


\section{CHAPTER XVI POLAND}

\section{HISTORICAL NOTE}

AFTER the celebrated constitution of May 3, 1791, Poland had no fundamental law meriting the name of a constitution until, on March 17, 1921, she adopted her present charter of government. In the history of political institutions, Poland is associated almost exclusively with the "liberum veto," by which, from 1650 onward, a single member of the Polish diet could by refusing assent defeat a resolution otherwise unanimously agreed upon. Hamilton in The Federalist (No. xxii) used this analogy when he complained that "Congress, from the non-attendance of a few states, have been frequently in the situation of a Polish diet, where a single vote has been sufficient to put a stop to all their movements." Voltaire described, not only the constitutional arrangement, but also its practical politics when he said:

Each deputy enjoys the right which the tribunes of the people had at Rome, of opposing the laws of the senate. A single gentleman who says, I protest, invalidates by this one word the The liberum veto unanimous resolutions of the rest, and if he departs from the place where the diet is being held, it must then dissolve. The remedy provided for the disorders which arise from this law is more dangerous still. Poland is seldom without two factions. Unanimity in the diets being thus impossible, each party forms a confederation, in which they decide by a plurality of votes, without any regard to the protests of the minority. These assemblies, illegal, according to the laws, but authorized by the laws, are held in the king's name, although often without his consent, and against his interests. When the dissensions are

Polish Constitution of 1791 


\section{NEW CONSTITUTIONS OF EUROPE}

Partitions of Poland

Proposed restoration

over, it belongs to the general diets to confirm or to annul the acts of these confederations. ${ }^{1}$

\section{The internal stagnation resulting from this liberum} veto was in part responsible for Poland's misfortunes. ${ }^{2}$ The first dismemberment took place in 1772. Reduced in limits, Poland abolished her ancient government and in 1791 adopted a constitution copied in part from the constitution that had been recently adopted in France. May 3 - the day of the adoption of the constitution-is still celebrated in Polish history. ${ }^{3}$ But a year later the second partition took place; and in 1795 the remainder of Poland was divided among the rulers of Prussia, Russia, and Austria. From the date of the final partition until the end of the World War, Poland and the Poles were subject to a tripartite alien domination.

The restoration of Poland was, from the first, on the political tapis of the settlements after the war. On August

'J. de Boisjoslin, "Poland," Lalor's Cyclopadia of Political Science, Vol. III, p. 204. Calhoun used Poland as an example of government by a "concurrent majority"- an extreme example "that would be thought impracticable had it never existed." In Poland the principle was carried so far "that, in the election of her kings, the concurrence or acquiescence, of every individual of the nobles and gentry present, in an assembly numbering usually from one hundred and fifty to two hundred thousand, was required to make a choice; thus giving to each individual a veto on his election. So, likewise, every member of her Diet (the supreme legislative body), consisting of the king, the senate, bishops and deputies of the nobility, and gentry of the platinates, possessed a veto on all its proceedings; - thus making an unanimous vote necessary to enact a law, or to adopt any measure whatever. And, as if to carry the principle to the utmost extent, the veto of a single member not only defeated the particular bill or measure in question, but prevented all others, passed during the session, from taking effect. Further, the principle could not be carried. It, in fact, made every individual of the nobility and gentry a distinct element in the organism; -or, to vary the expression, made him an Estate of the kingdom. And yet this government lasted, in this form, more than two centuries; embracing the period of Poland's greatest power and renown." "A Disquisition on Government," Works, Vol. I, p. 71.

2See Levinski-Corwin, The Political History of Poland, Chapter XIV (New York, 1917). The power which "diplomacy by conference" necessarily grants to dissenting minority states, or to a single state if it is of sufficient importance in international affairs, resembles in some respects this liberum veto.

'Polish historians are fond of quoting Burke's eulogy of the constitution of 1791. "In contemplating that change, humanity has everything to rejoice and glory in; nothing to be ashamed of, nothing to suffer. So far as it has gone, it probably is the most pure and defecated public good which has ever been conferred on mankind." Appeal from the New to the Old Whigs. 
14, 1914, the Grand Duke Nicholas announced that one of the war aims of Russia was to secure the autonomy of the reunited Polish territories under the Romanoff sceptre. On November 5, 1916, the German and Austrian Emperors proclaimed the creation of a Polish kingdom, united to the Central Powers and including the territories that had been dominated by Russia. To execute this act, a Provisional Council of State was created; but it exercised only a very nominal legislative and administrative authority, although it took some steps toward the framing of a constitution under a proposed monarchical form of

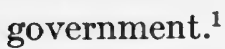

On September 12, 1917, a Council of Regency was created, which was invested with supreme power in the state. On February 4, 1918, this Council promulgated a law creating a new Council of State with some legislative competence. This body began its work on June 22, and some days later the Government submitted to it two laws -one relating to the convocation of a Polish diet and the other to elections. In November a brief and tentative constitution was adopted ("the Polish Republic" being substituted for the "Council of Regency"), and General Joseph Pilsudski was provisionally appointed Chief of State.

Elections for a constituent assembly were held in January, 1919. Universal suffrage and proportional representation were used. One-third of the populationbetween five and six millions-went to the polls, and $\mathbf{4 1 2}$ deputies were returned. ${ }^{2}$ The assembly met at once and appointed a commission on the constitution. A number of proposals were made by different Polish jurists and polit-

${ }^{1}$ Michel Potulicki, Constitution de la republique de Pologne du 17 Mars, 1921, p. 7 (Paris, 1921).

2There were 70 circumscriptions and the apportionment was one representative for 50,000 inhabitants or for a fraction exceeding 25,000 . This would have given 528 representatives; but elections did not take place in circumscriptions in Prussian Poland. Blociszewski, "La constitution polonaise du 17 Mars, 1921." Revue des Sciences Politiques, Vol. XLV, p. 32 (Janvier-Mars, 1922).

Constituent Assembly of

1919

Council of Regency, 1917 


\section{NEW CONSTITUTIONS OF EUROPE}

ical parties, and on January 21, 1920, a preliminary draft was finally adopted by the commission as a basis for discussion. On July 8, 1920, the commission made a majority report.

Contested questions

There were five questions that were most bitterly discussed. The Left wished no Senate at all, even though in the draft proposed the veto of the upper chamber could be overridden by a three-fifths vote in the lower house. The minority adopted obstructionist tactics, and the articles relating to the Senate were not voted until January 27 and 28, 1921. The minority wanted the Chief of the State elected by popular vote and not by the two chambers. The relations between the Church and the State were also a source of difference. The minority desired to have a separation guaranteed by the constitution, but the draft proposed to leave the relations of Church and State to be determined by law. With regard to the revision of the constitution, the draft proposed revision every twenty-five years, with the proviso that the first revision might take place after ten years. Various solutions were proposed, particularly with respect to the first revision. ${ }^{1} \quad$ Finally, difficulties arose in respect to the provisions concerning eminent domain. The parties of Constitution the Right wanted a constitutional declaration that propof 1921 erty could not be taken for public use without compensation. But the Socialists, citing the provisions of the German and Czechoslovak constitutions, demanded that the legislature be free to expropriate property needed in the public interest. ${ }^{2}$ In the end all differences were reconciled and the constitution was adopted on March 17, 1921. ${ }^{3}$

${ }^{1}$ See Article 125 and note.

'See Article 99.

3Blociszewski, op. cit. The text of the constitution used here is that of the official translation issued by the Polish Information Bureau (New York City). It appeared also in Current History, May, 1921. There are a number of French translations, the best being that of Potulicki, op. cit. 


\section{CONSTITUTION OF THE REPUBLIC OF POLAND}

In the name of Almighty God!

We, the Polish Nation, thankful to Providence for freeing us from a servitude of a century and a half; remembering gratefully the courage and steadfastness of the self-sacrificing struggle of generations which have unceasingly devoted their best efforts to the cause of independence; taking up the glorious tradition of the memorable Constitution of the Third of May; having in mind the weal of our whole, united, and independent mothercountry, and desiring to establish her independent existence, power, safety, and social order on the eternal principles of right and liberty; desirous also of ensuring the development of all her moral and material forces for the good of the whole of renascent humanity, and of securing equality to all citizens of the Republic, and respect, due rights, and the special protection of the state to labor;- do enact and establish in the Legislative Sejm of the Republic of Poland this constitutional law.

\section{SECTION I}

\section{The Republic}

Article 1. The Polish State is a Republic.

Art. 2. Sovereignty in the Republic of Poland belongs to the nation. The organs of the nation are: in the domain of legislation, the Sejm and the Senate; in the domain of executive power, the President of the Republic, jointly with the responsible ministers; in the domain of the administration of justice, independent courts.

\section{SECTION II}

\section{Legislative Power}

Art. 3. The domain of state legislation comprises the establishment of all public and private laws, and the manner of their execution.

There can be no statute without the consent of the Sejm, expressed in a manner conforming to the Standing Orders.

A statute voted by the Sejm comes into force at the time determined in the statute itself.

The Republic of Poland, basing its organization on the prin- 


\section{6 NEW CONSTITUTIONS OF EUROPE}

ciple of broad territorial self-government, will delegate to the bodies representing this self-government the proper domain of legislation, especially in administrative, cultural, and economic fields, to be defined more fully by statutes of the state.

Ordinances by public authorities, from which result rights or duties of citizens, have binding force only if issued by the authority of a statute, and with a specific reference to the same.

Art. 4. A statute of the state will determine annually the budget of the state for the ensuing year.

Art. 5. The establishment of the numerical strength of the army, and permission for the annual draft of recruits, can be determined only by statute.

Art. 6. The contracting of a state loan, the alienation, exchange or pledging of immovable property of the state, the imposition of taxes and public dues, the determination of customs duties and monopolies, the establishment of the monetary system and the taking over by the state of a financial guarantee, can take place only by the authority of a statute.

Art. 7. The Government will present annually for parliamentary confirmation the accounts of the state for the past year.

Art. 8. The manner of exercising parliamentary control over the debts of the state will be defined by a special statute.

Art. 9. The control of the whole state administration as regards finances; the examination of the accounts of the state; the annual submission to the Sejm of its motion for the granting or refusing of its absolutorium to the Government, are in the hands of the Supreme Board of Control, which is organized on the basis of collegiality and judicial independence of its members, the latter being removable only by a vote of the Sejm representing a majority of three-fifths of those actually voting. The organization of the Supreme Board of Control and its method of procedure will be defined in detail by a special statute.

The President of the Supreme Board of Control enjoys a position equal to that of a Minister, but he is not a member of the Council of Ministers and is directly responsible to the Sejm for the exercise of his office and for the officials who are his subordinates.

Art. 10. Measures can originate either with the government or with the Sejm. Motions and bills which involve expenditure from the state treasury must state the manner of their raising and expenditure. 
Art. 11. The Sejm is composed of deputies elected for a term of five years to be counted from the day of the opening of the Sejm, by secret, direct, equal, and proportional voting.

Art. 12. The right to vote belongs to every Polish citizen without distinction of sex, who, on the day of the proclamation of the elections, is twenty-one years of age, is in full possession of civil rights, and is a resident of the electoral district at least from the day preceding the proclamation of the elections in the Journal of Laws. The right to vote can be exercised only in person. Members of the army in active service do not possess the right to vote.

Art. 13. Every citizen having the right to vote is eligible for election to the Sejm, independently of his place of residence, if he is at least twenty-five years of age, not excepting members of the army in active service.

Art. 14. Citizens convicted of offenses which the law of elections may define as involving temporary or permanent loss of the right to vote, of eligibility, or of being a deputy, may not enjoy the electoral right.

Art. 15. Administrative, revenue, and judicial officials of the state may not be elected in the districts in which they are performing their official duties. This rule does not apply to officials employed in the central departments.

Art. 16. State and self-government employees obtain leaves of absence at the moment of being elected deputies. This rule does not apply to ministers, under-secretaries of state, and professors in academic schools. The years spent in the exercise of the duties of a deputy are considered as years of service.

Art. 17. A deputy loses his seat on being appointed to a paid office of the state. This rule does not apply to appointment as minister, under-secretary of state, or professor in an academic school.

Art. 18. The law of elections will define the manner of electing deputies to the Sejm.

Art. 19. The validity of unprotested elections is verified by the Sejm. The validity of protested elections is decided upon by the Supreme Court.

Art. 20. The deputies are representatives of the whole nation and are not bound by any instructions given by the voters.

The deputies make to the Marshal the following vow in the presence of the Chamber: "I do solemnly vow, as deputy to the Sejm of the Republic of Poland, to work honestly, according to 
the best of my understanding and in conformity with my conscience, for the sole good of the Polish State as a whole."

Art. 21. Deputies cannot be made responsible, either during their term of office or after it has expired, for their activities in or out of the Sejm appertaining to the exercise of their office as deputies. For their speeches, utterances, and manifestations in the Sejm, deputies are responsible only to the Sejm. For violation of the rights of a third person, they may be made to answer before a court of law, if the judicial authority obtains the consent of the Sejm thereto.

Criminal, penal-administrative, or disciplinary proceedings instituted against a deputy before his election, may, at the demand of the Sejm, be suspended until the expiration of his term of office.

Prescription in criminal proceedings against a deputy does not run while he retains his office. While he retains his office, a deputy may not, without the permission of the Sejm, be made to answer before a criminal court, penal-administrative authority, or a disciplinary court, or be deprived of his freedom. If a deputy is caught in the act of committing a common felony, and if his arrest is necessary to insure the administration of justice, or to avert the consequences of the offense, the court is bound to notify immediately the Marshal of the Sejm in order to obtain the consent of the Sejm to his arrest and to further criminal proceedings. Upon demand of the Marshal, the arrested deputy must be liberated at once.

Art. 22. A deputy may not, either in his own name or in the name of another, buy, or acquire the lease of, any real property of the state, contract for public supplies or government works, or obtain from the government any concessions or other personal benefits. A deputy is also debarred from receiving from the government any decorations other than military.

Art. 23. A deputy may not be the responsible editor of a periodical publication.

Art. 24. The deputies receive compensation the amount of which is determined by the standing orders, and are entitled to the free use of the state means of communication for travelling over the whole territory of the Republic.

Art. 25. The President of the Republic convokes, opens, adjourns, and closes the Sejm and Senate. The Sejm must be convoked to assemble on the third Tuesday after election day, and every year, at the latest in October, to an ordinary session 
for the purpose of voting the budget, the numerical strength and recruiting of the army, and other current affairs.

The President of the Republic may, at his own discretion, convoke the Sejm to an extraordinary session at any time and is bound to do this within two weeks upon request of one-third of the total number of deputies.

Other cases in which the Sejm assembles in extraordinary session are determined by this constitution.

An adjournment requires the consent of the Sejm, if previous adjournment has taken place during the same ordinary session, or if the interruption is to last for more than thirty days.

The Sejm, when convoked in October for its ordinary session, may not be closed before the budget has been voted.

Art. 26. The Sejm may be dissolved by its own vote, passed by a majority of two-thirds of those voting. The President of the Republic may dissolve the Sejm with the consent of threefifths of the statutory number of members of the Senate in the presence of at least one-half of the total membership. ${ }^{1}$ In both cases the Senate is automatically dissolved at the same time.

Elections will take place within forty days from the date of dissolution, the precise date to be determined either in the resolution of the Sejm or in the message of the President, on the dissolution of the Sejm.

Art. 27. The deputies exercise all their rights and duties in person.

Art. 28. The Sejm elects from among its members, the Marshal, his deputies, the secretaries, and committees.

The Marshal and his deputies continue in office after the dissolution of the Sejm until the new Sejm shall have elected its officers.

Art. 29. The standing rules of the Sejm define the mode and order of the proceedings of the Sejm, the type and number of the committees, the number of marshals and secretaries, the rights and duties of the Marshal. The employees of the Sejm are appointed by the Marshal, who is responsible to the Sejm for their actions.

Art. 30. The meetings of the Sejm are public. On the motion of the Marshal, of a Government representative, or of thirty deputies, the Sejm may vote the secrecy of its meetings.

Art. 31. No one may be called to account for a truthful

'There is an inconsistency here which is not explained by the Polish text. 
report of an open meeting of the Sejm or a committee of the Sejm.

Art. 32. A vote is valid only when carried by an ordinary majority in the presence of at least one-third of the total statutory number of deputies, in so far as provisions of this constitution do not contain other rules.

Art. 33. The deputies have the right of addressing interpellations to the Government or to individual ministers, in the manner prescribed by the standing rules. A minister is bound to answer, within six weeks, orally or in writing, or submit a statement wherein he justifies his failure to give an answer to the point. At the request of those addressing the interpellation, the answer must be communicated to the Sejm. The Sejm may make the answer the subject of debate and vote.

Art. 34. The Sejm may form and appoint for the investigation of individual cases, extraordinary committees empowered to hear the interested parties, as well as to summon witnesses and experts. The competence and powers of such committees will be determined by the Sejm.

Art. 35. Every bill passed by the Sejm will be submitted to the Senate for consideration. If the Senate, within thirty days from the day on which a passed bill has been delivered to it, does not raise any objections to the bill, the President of the Republic will direct the publication of the statute. Upon the motion of the Senate, the President of the Republic may direct the publication of the statute before the lapse of the thirty days.

If the Senate decides to alter or reject a bill passed by the Sejm, it must announce this to the Sejm within the aforesaid thirty days, and must return the bill to the Sejm with the proposed changes within the following thirty days.

If the Sejm approves by an ordinary majority, or rejects by a majority of eleven-twenticths of those voting, the changes proposed by the Senate, the President of the Republic will direct the publication of the statute in the wording determined by the second vote of the Sejm.

Art. 36. The Senate is composed of members elected by the individual Voyevodships, by universal, secret, direct, equal, and proportional voting. Every Voyevodship forms one constituency and the number of senators is equal to one-fourth of the number of members of the Sejm, in proportion to the number of inhabitants. The right of electing to the Senate is enjoyed by 
every elector for the Sejm who, on the day of the proclamation of the elections, is thirty years of age and has on that day been a resident of the electoral district for at least one year; the right of voting is not lost by newly settled colonists who have left their former place of residence, availing themselves of the agrarian reform; neither is that right lost by workmen who have changed their place of residence as a result of changing their place of occupation, or by the state officials transferred by their superior authorities. Eligibility is enjoyed by every citizen who has the right of voting for the Senate, not excluding members of the army in active service, provided that citizen is forty years of age on the day of the proclamation of the elections.

The term of the Senate begins and ends with the term of the Sejm.

No one may be at the same time a member of the Sejm and of the Senate.

Art. 37. The provisions contained in Articles 14, 15, 16, 17, $19,20,21,22,23,24,27,28,29,30,31,32$, and 33 have analogous application to the Senate and to its members respectively.

Art. 38. No statute may be in opposition to this constitution or violate its provisions.

\section{SECTION III}

\section{Executive Power}

Art. 39. The President of the Republic is elected for seven years by the absolute majority of the votes of the Sejm and the Senate united in National Assembly. The National Assembly is convoked by the President of the Republic in the last three months of his seven years' term of office. If the convocation has not taken place thirty days before the end of the seven years' term, the Sejm and the Senate, upon the invitation of the Marshal of the Sejm and under his chairmanship, unite automatically in National Assembly.

Art. 40. Should the President of the Republic be unable to perform the duties of his office, or should the office of the President of the Republic become vacant through death, resignation, or some other reason, the Marshal of the Sejm will act as his deputy.

Art. 41. In case the office of the President of the Republic becomes vacant, the Sejm and the Senate, upon the invitation of the Marshal of the Sejm and under his chairmanship, at once 
unite automatically in a National Assembly for the purpose of electing a President.

Should the Sejm be dissolved at the moment when the office of President of the Republic becomes vacant, the Marshal of the Sejm will direct without delay new elections to the Sejm and the Senate.

Art. 42. If the President of the Republic does not perform the duties of his office for three months, the Marshal will without delay convoke the Sejm and submit to its decision the question whether the office of the President of the Republic is to be declared vacant.

The decision to declare the office vacant is taken by a majority of three-fifths of the votes in the presence of at least one-half of the statutory number of deputies; that is, the number prescribed by the Law of Election.

Art. 43. The President of the Republic exercises the executive power through ministers responsible to the Sejm and through officials subordinated to the Ministers.

Every official of the Republic must be subordinate to a minister, who is responsible to the Sejm for the former's actions.

The President of the Council of Ministers countersigns the appointment of officials of the civil cabinet of the President of the Republic, and is responsible for their actions to the Sejm.

Art. 44. The President of the Republic signs the statutes jointly with the competent ministers, and directs the publication of the statutes in the Journal of the Laws of the Republic.

The President of the Republic has the right to issue, for the purpose of executing the statutes and with reference to the statutory authorization, executive ordinances, directions, orders and prohibitions, and to insure their execution by the use of force.

The ministers and the authorities subordinate to them have the same right in their respective fields of jurisdiction.

Every governmental act of the President of the Republic requires for its validity the signature of the President of the Council of Ministers and of the competent minister, who, by countersigning the act, assume the responsibility therefor.

Art. 45. The President of the Republic appoints and recalls the President of the Council of Ministers; on the latter's motion he appoints and recalls ministers, and on the motion of the Council of Ministers makes appointments to the civil and military offices reserved by statutes. 
Art. 46. The President of the Republic is at the same time the supreme head of the armed forces of the state, but he may not exercise the chief command in time of war.

The Commander-in-Chief of the armed forces of the state, in case of war, is appointed by the President of the Republic, on the motion of the Council of Ministers, presented by the minister of military affairs who is responsible to the Sejm for the acts connected with the command in time of war, as well as for all affairs of military direction.

Art. 47. The right to reprieve and to mitigate punishment, and to destroy the consequences of criminal conviction in individual cases, belongs to the President of the Republic.

The President may not exercise this right in the case of ministers convicted upon impeachment by the Sejm.

Amnesty may be granted only by statute.

Art. 48. The President of the Republic in foreign relations, receives diplomatic representatives of foreign states, and sends diplomatic representatives of the Polish State to foreign states.

Art. 49. The President of the Republic makes treaties with other states and brings them to the notice of the Sejm.

Commercial and customs treaties, as well as treaties which impose a permanent financial burden on the state, or contain legal rules binding on the citizens, or change the frontiers of the state, also alliances, require the consent of the Sejm.

Art. 50. The President of the Republic may declare war and conclude peace only after obtaining the consent of the Sejm.

Art. 51. The President of the Republic is not responsible either to Parliament or at civil law.

For betraying the country, violating the constitution, or for criminal offenses, the President of the Republic may be made responsible only by the Sejm by a vote of a majority of threefifths in the presence of at least one-half of the statutory number of deputies. The cause is heard and the sentence given by the Court of State, according to the rules of a special statute. Immediately upon his impeachment before the Court of State, the President of the Republic is suspended from office.

Art. 52. The President of the Republic receives a salary according to the rules of a special statute.

Art. 53. The President of the Republic may not hold any other office or be a member of the Sejm or the Senate.

Art. 54. Before assuming office, the President of the Republic takes his oath in the National Assembly, in the following terms: 


\section{NEW CONSTITUTIONS OF EUROPE}

"I swear to Almighty God, One in the Holy Trinity, and I vow to Thee, Polish Nation, that while holding the office of President of the Republic I will keep and defend faithfully the laws of the Republic and above all the constitutional law; that I shall serve devotedly, with all my power, the general good of the nation; that I will a vert, watchfully, from the state all evil and danger; that I will guard steadfastly the dignity of the name of Poland; that I will hold justice toward all citizens without distinction as the highest virtue; that I will devote myself individually to the duties of office and service. So help me God and the Holy Martyrdom of His Son. Amen."

Art. 55. The ministers form the Council of Ministers under the chairmanship of the President of the Council of Ministers.

Art. 56. The Council of Ministers bears the joint constitutional and parliamentary responsibility for the general direction of the activities of the government.

Apart from that, each minister is individually responsible, in his domain, for his activities in office; that is, as well for their conformity with the constitution and the other statutes of the state, and for the activities of the subordinate organs, as for the direction of his policies.

Art. 57. Within the same limits, the ministers are jointly and individually responsible for the governmental acts of the President of the Republic.

Art. 58. The parliamentary responsibility of the ministers is enforced by the Sejm by an ordinary majority. The Council of Ministers or any individual minister will resign at the request of the Sejm.

Art. 59. The constitutional responsibility of the ministers and the way of its realization will be determined by a special statute.

The decision to impeach a minister can be made only in the presence of at least one-half the statutory number of deputies and by a majority of three-fifths of the votes cast.

The causes are heard and judgment is passed by the Court of State. A minister cannot evade his constitutional responsibility by resigning his office. Immediately upon his impeachment, the minister is suspended from office.

Art. 60. The ministers and officials delegated by them have the right to take part in the meetings of the Sejm, and to speak out of the turn of those figuring on the list of speakers; they may take part in the vote if they are deputies.

Art. 61. The ministers may not hold any other office or 
participate in the governing or controlling bodies of societies and institutions which work for profit.

Art. 62. Should the office of a minister be held by a provisory head of the ministry, he will be subject to all the rules concerning the office of a ministry. The President of the Council of Ministers will, in case of need, appoint one of the ministers his deputy.

Art. 63. A special statute will determine the number, competence, and mutual relation of the Ministers, as well as the competence of the Council of Ministers.

Art. 64. The Court of State is composed of the First President of the Supreme Court as chairman, and of twelve members, eight of whom are elected by the Sejm and four by the Senate from outside their own membership.

To membership in the Court of State are eligible persons who do not hold any State office, and are in full possession of civil rights.

The election of the members of the Court of State is carried out by the Sejm and the Senate immediately upon the election of their officers for the whole term of the Sejm.

Art. 65. For administrative purposes, the Polish State will be divided by statute into Voyevodships, districts, and urban and rural communes, which will at the same time be the units of territorial self-government.

The units of self-government may combine into unions in order to accomplish tasks which belong to the domain of selfgovernment.

Such unions may obtain the character of bodies of public law only by special statute.

Art. 66. The administration of the state will be organized on the principle of decentralization, organs of state administration in the individual territorial units being, as far as possible, joined in one official body under one superior, and on the principle that within the limits determined by statutes, citizens elected for this purpose shall participate in the discharge of the duties of such official bodies.

Art. 67. The right of determining affairs belonging to the domain of self-government rests with elected councils. The executive functions of 'Voyevodship and district self-government rests with organs formed by adding to boards elected by representative bodies, representatives of State administrative authorities, under the chairmanship of the latter. 


\section{6}

NEW CONSTITUTIONS OF EUROPE

Art. 68. A special statute will create, in addition to territorial self-government, economic self-government for the individual fields of economic life; namely, chambers of agriculture, commerce, industry, arts and crafts, hired labor and others, united into a Supreme Economic Council of the Republic, the collaboration of which with state authorities, in directing economic life and in the field of legislative proposals, will be determined by statutes.

Art. 69. The sources of revenue of the state and of selfgovernment organizations respectively, will be strictly deliminated by statutes.

Art. 70. The state will exercise supervision over selfgovernment activities through superior self-government boards; such supervision may, however, be partially delegated by statute to administrative courts.

Statutes will determine the cases in which decisions of selfgovernment organs may exceptionally require confirmation by superior self-government organs or by ministries.

Art. 71. An appeal from decisions of state and self-government organs will be allowed only to one superior body, unless other provisions are made by statutes.

Art. 72. Statutes will put into effect the principle that from penal decisions of administrative authorities, made in the first instance, the parties concerned will have the right to appeal to the competent court.

Art. 73. For the purpose of passing upon the legality of administrative acts in the field of state, as well as of selfgovernment administrative, a special statute will create administrative courts, basing their organization on the coöperation of (lay) citizens and (professional) judges, and culminating in a Supreme Administrative Cóurt.

\section{SECTION IV}

\section{JUDICIARY}

Art. 74. The courts administer justice in the name of the Republic of Poland.

Art. 75. The organization, jurisdiction, and procedure of all courts will be defined by legislation.

Art. 76. The President of the Republic appoints the judges, 
unless a different provision is made by statute, but justices of the peace are, as a rule, elected by the population.

Judicial office is accessible only to persons who possess the qualifications required by law.

Art. 77. In the exercise of their judicial office, the judges are independent, and subject only to statutes.

Judicial decisions may not be changed either by the legislative power or by the executive power.

Art. 78. A judge may be removed from office, suspended from office, transferred to a different place of office, or pensioned, against his own will, by judicial decision only, and only in cases provided by statute.

This rule does not apply in the case of the transfer of a judge to a different place, or his pensioning owing to a change in the organization of the courts decided upon by statute.

Art. 79. Judges may not be criminally prosecuted or be deprived of their freedom without the previous consent of the court assigned by statute, unless they are caught in the act, but even in this last case the court may demand that the arrested judge be freed without delay.

Art. 80. A special statute will define the peculiar position of the judges, their rights and duties, as well as their compensation.

Art. 81. The courts have not the right to inquire into the validity of duly promulgated statutes.

Art. 82. The hearings before a determining court, as well in civil as in criminal cases, are public, except when statutes provide otherwise.

Art. 83. Courts with juries will be called upon to determine cases of felonies entailing more severe punishment, and cases of political offenses. Statutes will define in detail the jurisdiction of courts with juries, the organization of such courts, and their procedure.

Art. 84. A Supreme Court for judicial causes, civil and criminal, is hereby created.

Art. 85. Special statutes will define the organization of military courts, their jurisdiction, procedure, and the rights and duties of the members of such courts.

Art. 86. A special Competence Court ${ }^{1}$ will be created by a statute to determine conflicts of jurisdiction between the administrative authorities and the courts.

\footnotetext{
Tribunal of Conflicts.
} 


\section{SECTION $\mathbf{v}$ \\ General Duties and Rights of Citizens}

Art. 87. A Polish citizen may not be at the same time a citizen of another state.

Art. 88. Polish citizenship is acquired:

(1) By birth if the parents are Polish citizens.

(2) By naturalization granted by the competent state authority.

Special statutes define other rules as to Polish citizenship, its acquisition and loss.

Art. 89. Fidelity to the Republic of Poland is the first duty of a citizen.

Art. 90. Every citizen has the duty of respecting and obeying the constitution of the state and other valid laws and ordinances of the state and self-government authorities.

Art. 91. All citizens are subject to military service; the character and manner, order and term of service, exemption from such duty, and any duties, contributions or services for military purposes, will be defined by legislation.

Art. 92. It is the duty of all citizens to submit to any public burdens, services, and duties imposed by virtue of statute.

Art. 93. All citizens are bound to respect legitimate authority and to facilitate the performance of its duties, as well as to perform conscientiously public duties to which they may be appointed by the nation or the proper authority.

Art. 94. It is the duty of citizens to bring up their children as righteous citizens of the mother country, and to secure to them at least elementary education.

This duty will be defined more in detail by a special statute.

Art. 95. The Republic of Poland guarantees on its territory, to all, without distinction of extraction, nationality, language, race, or religion, full protection of life, liberty, and property.

Foreigners enjoy, on condition of reciprocity, rights equal to those of citizens of the Polish State, and have duties equal to those of such citizens, unless statutes expressly require Polish citizenship.

Art. 96. All citizens are equal before the law. Public offices are accessible in equal measure to all, on conditions prescribed by the law.

The Republic of Poland does not recognize privileges of birth or of estate, or any coats of arms, family or other titles, with 
the exception of those of learning, office, or profession. A Polish citizen may not accept foreign titles or orders without the permission of the President of the Republic.

Art. 97. Limitations of personal liberty, especially search of person and arrest, are admissible only in cases prescribed by law, and in the manner defined by statutes, by virtue of an order from judicial authorities.

In case a judicial order cannot be issued immediately, it should be served, at the latest, within forty-eight hours, with a statement of the reasons of the search or arrest.

Arrested persons who have not been served within forty-eight hours with a written statement of the cause of arrest, signed by a judicial authority, regain their freedom at once.

The means of compulsory service by which the administrative authorities may enforce their orders are determined in statutes.

Art. 98. No one may be deprived of the court to which he is subject by law. Exceptional courts are admissible only in cases determined by statutes, which statutes must have been issued before the offense was committed. A citizen may be prosecuted and punishment inflicted only by virtue of a statute actually in force. Punishments involving physical suffering are not permitted, and no one may be subjected to such punishment.

No statute may deprive a citizen of access to the courts for the purpose of demanding reparation for injury or damage.

Art. 99. The Republic of Poland recognizes all property, whether belonging personally to individual citizens or collectively to associations of citizens, institutions, self-government organizations, or the state itself, as one of the most important bases of social organization and legal order, and guarantees to all citizens, institutions, and associations, protection of their property, permitting only in cases provided by a statute the abolition or limitation of property, whether personal or collective, for reasons of higher utility, against compensation. Only a statute may determine to what extent property, for reasons of public utility, shall form the exclusive property of the state, and in how far rights of citizens and of their legally recognized associations to use freely land, waters, minerals, and other treasures of nature, may be subject to limitations for public reasons.

The land, as one of the most important factors of the existence of the nation and the state, may not be the subject of unre- 
stricted transfer (commerce). Statutes will define the right of the state to buy up land against the will of the owners, and to regulate the transfer of land, applying the principle that the agrarian organization of the Republic of Poland should be based on agricultural units capable of regular production and forming private property.

Art. 100. The home and hearth of the citizen are inviolable. Infringements of this right by entering the home, searching it and taking papers or movables may, apart from the necessity of executing administrative orders based on a specific statutory authorization, take place only by order of judicial authorities, in the manner and in the cases prescribed by the protection statute.

Art. 101. Every citizen has the liberty of selecting on the territory of the state his place of residence and abode, to move about and to emigrate, as well as to choose his occupation and profession, and to transport his property.

These rights may be restricted only by statute.

Art. 102. Labor is the main basis of the wealth of the Republic, and should remain under the special protection of the state.

Every citizen has the right to state protection for his labor, and in case of lack of work, illness, accident, or debility, to the benefits of social insurance which will be determined by a special statute.

The state has the duty of making accessible also moral guidance and religious consolation to citizens under its immediate care in public institutions, such as educational institutions, barracks, hospitals, prisons, and charitable homes.

Art. 103. Children without sufficient parental care, neglected with respect to education, have the right to state care and aid within the limits to be determined by statute.

Parents may not be deprived of authority over their children except by judicial decision.

Special statutes determine the protection of motherhood.

Children under fifteen years of age may not be wage-earners; neither may women be employed at night, or young laborers be employed in industries detrimental to their health.

Permanent employment of children and young people of school age for wage-earning purposes is forbidden.

Art. 104. Every citizen has the right to express freely his ideas and convictions in so far as he does not thereby violate legal provisions. 
Art. 105. Freedom of the press is guaranteed. Censorship, or the system of licensing printed matter, may not be introduced. Daily papers and other matter printed in the country may not be debarred from the mails, nor may their dissemination on the territory of the Republic be restricted.

A special statute will define the responsibility for the abuse of this freedom.

Art. 106. The secrecy of letters and other correspondence may be infringed upon only in cases provided by law.

Art. 107. Citizens have the right of presenting individual or collective petitions to all state and self-government representative bodies and public authorities.

Art. 108. Citizens have the right of combining, meeting, and forming associations and unions.

The exercise of these rights is defined by statutes.

Art. 109. Every citizen has the right of preserving his nationality and developing his mother-tongue and national characteristics.

Special statutes of the state will guarantee to minorities in the Polish State the full and free development of their national characteristics, with the assistance of autonomous minority unions, endowed with the character of public law organizations, within the limits of unions of general self-government.

The state will have, in regard to their activity, the right of control and of supplementing their financial means in case of need.

Art. 110. Polish citizens belonging to national, religious, or linguistic minorities have the same right as other citizens of founding, supervising, and administering at their own expense, charitable, religious, and social institutions, schools and other educational institutions, and of using freely therein their language, and observing the rules of their religion.

Art. 111. Freedom of conscience and of religion is guaranteed to all citizens. No citizen may suffer a limitation of the rights enjoyed by other citizens, by reason of his religion and religious convictions.

All inhabitants of the Polish State have the right of freely professing their religion in public as well as in private, and of performing the commands of their religion or rite, in so far as this is not contrary to public order or public morality.

Art. 112. Religious freedom may not be used in a way contrary to statutes. No one may evade the performance of public 
duties by reason of his religious beliefs. No one may be compelled to take part in religious activities or rites unless he is subject to parental or guardians' authority.

Art. 113. Every religious community recognized by the state has the right of organizing collective and public services; it may conduct independently its internal affairs; it may possess and acquire movable and immovable property, administer and dispose of it; it remains in possession and enjoyment of its endowments and funds, and of religious, educational, and charitable institutions. No religious community may, however, be in opposition to the statutes of the state.

Art. 114. The Roman Catholic religion, being the religion of the preponderant majority of the nation, occupies in the state the chief position among enfranchised religions. The Roman Catholic Church governs itself under its own laws. The relation of the state to the church will be determined on the basis of an agreement with the Apostolic See, which is subject to ratification by the Sejm.

Art. 115. The churches of the religious minorities and other legally organized religious communities govern themselves by their own laws, which the state may not refuse to recognize unless they contain rules contrary to law.

The relation of the state to such churches and religions will be determined from time to time by legislation after an understanding with their legal representatives.

Art. 116. The recognition of a new, or hitherto not legally recognized religion, may not be refused to religious communities whose institutions' teachings and organization are not contrary to public order or public morality.

Art. 117. Learned investigations and the publication of their results are free. Every citizen has the right to teach, to found a school or educational institution, and to direct it if he complies with the requirements laid down by statutes concerning the qualifications of teachers, the safety of the child entrusted to him, and a loyal attitude toward the state. All schools and educational institutions, public as well as private, are subject to supervision by state authorities within the limits prescribed by statutes.

Art. 118. Within the limits of the elementary school, instruction is compulsory for all citizens of the state. A statute will define the period, limits, and manner of acquiring such education. 
Art. 119. Teaching in state and self-government schools is gratuitous.

The state will insure to pupils who are exceptionally able, but not well-to-do, scholarships for their maintenance in secondary and academic schools.

Art. 120. Instruction in religion is compulsory for all pupils in every educational institution, the curriculum of which includes instruction of youth under eighteen years of age, if the institution is maintained wholly or in part by the state, or by self-government bodies. The direction and supervision of religious instruction in schools belongs to the respective religious communities, reserving to the state educational authorities the right of supreme supervision.

Art. 121. Every citizen has the right to compensation for damage inflicted upon him by civil or military organs of state authorities, by an official act not in accordance with the right or duties of the service. The state is responsible for the damage, jointly with the guilty organs; action may be brought against the state and against officials, independently of any permission by a public authority. Communes and other selfgovernment bodies, as well as their organs, are responsible in the same manner.

Special statutes will define the application of this principle.

Art. 122. The rules as to citizens' rights apply also to persons belonging to the armed force. Special military statutes define exceptions to this principle.

Art. 123. Armed force may be used only by request of a civil authority under strict obedience to statutes, for the purpose of putting down disturbances, or of enforcing the execution of legal rules. Exceptions to this principle are admissible only by virtue of statutes on the state of siege and of war.

Art. 124. A temporary suspension of citizen's rights; of personal liberty (Article 97), of inviolability of home and hearth (Article 100), of freedom of the press (Article 105), of secrecy of correspondence (Article 106), of the right of combining, meeting, and forming associations (Article 108), may take place for the whole territory of the state or for localities in which it may prove necessary for reasons of public safety.

Such suspension may be directed only by the Council of Ministers, by permission of the President of the Republic, during a war or when an outbreak of war threatens, as well as in case of internal disturbances or of widespread conspiracies which 
bear the character of high treason and threaten the constitution of the state or the safety of the citizens.

Such a decision of the Council of Ministers, if made while the Sejm is in session, must be immediately submitted to the Sejm for confirmation. If such a decision, to apply on a territory which comprises more than one Voyevodship be issued during an interval between meetings of the Sejm, the Sejm meets automatically within eight days from the publication of the decision in order to take the proper step.

Should the Sejm refuse confirmation, the state of siege immediately loses its binding force. If the Council of Ministers directs a state of siege after the expiration of the term of the Sejm, or after dissolution of the Sejm, the decision of the Government must be submitted to the newly elected Sejm without delay, at its first meeting.

These principles will be defined more in detail by a statute on the state of siege.

A statute on the state of war will define the principles of a temporary suspension of the above enumerated rights of citizens in time of war on the territory affected by war operations.

Art. 125. A change in the constitution may be voted only in the presence at least of one-half the statutory number of Deputies or Senators respectively, by a majority of two-thirds of the votes.

The motion to change the constitution must be signed by at least one-fourth of the total statutory number of Deputies and notice of such a motion must be given at least fifteen days in advance.

The second Sejm, which will meet on the basis of this constitution, may revise this constitutional law by its own vote, taken by a majority of three-fifths, in the presence of at least one-half the statutory number of Deputies.

Every twenty-five years after the adoption of the present constitution, revision shall take place following the decision of the Sejm and the Senate, united in a National Assembly and voting by an ordinary majority. ${ }^{1}$

Art. 126. This constitution has binding force from the day of its publication, or in so far as the realization of its individual

'This whole article is omitted in the official draft issued by the Polish Information Bureau. The last paragraph (relating to revision every twenty-five years) does not appear in the Current History translation (May, 1921). It is found, however, in Potulicki, Constitution de la republique de Pologne du 17 Mars 1921, p. 80 (Paris, 1921). 
provisions is dependent on the issuing of special statutes on the day of their going into force.

All legal rules and institutions now in force, which do not agree with the rules of this constitution, will, within a year from the voting of this constitution, be submitted to the legislative body in order to be brought into harmony with the constitution by legislation. 


\section{CHAPTER XVII \\ THE FREE CITY OF DANZIG}

\section{HISTORICAL NOTE}

Wilson's

"thirteenth point"

The Danzig corridor

Controversies at the Peace Conference

IT was the ambition of the Poles that the independent Polish State to be erected at the Peace Conference should include more than "the territories inhabited by indisputably Polish populations." President Wilson's "thirteenth point" stipulated that the new state "should be assured a free and secure access to the sea," and it was the hope of the Poles that they would be allotted the whole of a wide corridor along the Vistula that the Germans had for many years been attempting to colonize.

This corridor had been so completely Germanized that a strip only fifty miles across could be given to Poland on ethnic grounds. In Danzig, the coastal end of the corridor, the Polish population had been reduced until the Poles numbered but 10 per cent. of the total of $170,000 .^{1}$ The solution of the Peace Conference, therefore, was to create a Free City under the protection of the League of Nations. This was in part a return to the status that Danzig had enjoyed from 1454 to 1793 . It was then a free republic, voluntarily united to Poland and under Polish sovereignty. It had autonomy in local affairs, although Poland had the right to defend it from attack, and, on "great occasions," the City was represented in the Polish diet.

The decision of the Peace Conference was reached only after the Conference had considered alternative proposals. The Commission on Polish affairs, appointed by the Su-

\footnotetext{
'Bowman, The New World Problems, p. 337.
} 
preme Council, proposed that the corridor to the Baltic should include Danzig and a narrow belt of Germanspeaking territory around Marienwerder, on the east bank of the Vistula. In the case of Danzig, the Commission thought that "the only clean-cut solution of the problem was to annex the city outright to Poland." Mr. Lloyd George, however, was dissatisfied. He believed that "with the frontiers proposed the number of Germans to be incorporated in Poland was dangerously large, and ought, if ever possible, to be reduced. As a result of a first intervention on his part the Supreme Council decided that the Marienwerder district should not be transferred to Poland outright, but should also be subjected to a plebiscite.

"Soon after, the British Prime Minister proposed a second change, of much greater consequence to the Poles, in the matter of Danzig. President Wilson was persuaded to agree to his suggestions; and M. Clemenceau, quite certainly against his own inclinations, was induced to acquiesce. The upshot was an entirely new plan, which was intended to insure Poland's economic interests in the port of Danzig and at the same time to avoid the inconvenience of annexing that German-speaking city to Poland. According to this plan, Danzig and the small adjacent district were to form a free city under the protection of the League of Nations."

The new semi-independent state is one of the most interesting political creations of the Peace Treaty. It is one of the few cases in which the Peace Conference assumed responsibility for passing on constitutions and providing

Provisions of Peace Treaty in re Danzig governmental tutelage. ${ }^{2}$ By Article 100 of the Peace Treaty, "Germany renounces in favor of the Principal Allied and Associated Powers all rights and title over the

\footnotetext{
1R. H. Lord, "Poland," in House and Seymour, What Really Happened at Paris, p. 79 (New York, 1921).
}

See above, p. 5 , note 1 ; p. 83 , note 2 . 
territory comprised within" certain specified limits. This territory and the city of Danzig are established as a Free City, "under the protection of the League of Nations". ${ }^{1}$ With regard to the government of the city the Treaty provided:

A constitution for the Free City of Danzig shall be drawn up by the duly appointed representatives of the Free City in agreement with a High Commissioner to be appointed by the League of Nations. This constitution shall be placed under the guarantee of the League of Nations.

The High Commissioner will also be entrusted with the duty of dealing in the first instance with all differences arising between Poland and the Free City of Danzig in regard to this Treaty or any arrangements or agreements made thereunder.

The High Commissioner shall reside at Danzig. ${ }^{2}$

Constituent Assembly of 1920

Subsequent provisions of the treaty dealt with Poland's access to the sea; with the conduct of Danzig's foreign relations by Poland; and with such matters as nationality, property, and finance. ${ }^{3}$

A constituent assembly, composed of one hundred and twenty members, was elected in May, 1920, on a basis of universal suffrage. The assembly consisted "of sixtythree Conservatives and Moderates, ten Liberals, fifty Socialists, and seven Poles. Its election marked a sharp

\footnotetext{
${ }^{1}$ Article 102.
}

${ }^{2}$ Article 103.

${ }^{3}$ Germany, in her observations dated May 29, 1919, objected to "the cession of the purely German Hanseatic town of Danzig and of its surroundings, which are likewise purely German ${ }_{0}$ as demanded in Articles 100 to 108 " of the Treaty. "Even the Poles do not seriously deny that Danzig has always been German in character. The attempt to make Danzig a free city and to surrender its means of communication and the representation of its rights abroad to the Polish State would lead to violent opposition and to a continuous state of war in the East. And withal, economic measures have been taken to make al communication between Danzig and Germany extremely difficult-evidently with the purpose of making this purely German territory Polish in the course of time by means of economic pressure."

The Allies replied that "the proposed settlement for Danzig . . . will preserve the character which Danzig held during many centuries and, indeed, until forcibly and contrary to the will of the inhabitants it was annexed to the Prussian State." Temperley, Ed., A History of the Peace Conference at Paris, Vol. II, pp. 291-292 (London, 1920). 
swing from Socialism to German nationalism, two-thirds of the Poles kecping away entirely, and its temper was on the whole conservative. Yet the document finally adopted by a vote of sixty-eight Conservatives and Liberals to forty-four Socialists and Poles would undoubtedly in this country be held dangerously radical." I The constitution was adopted on August 11, 1920, and the Executive Council of the League of Nations, at a meeting on November 17, 1920, gave the document its approval. The most serious objection of the Council was to the use (unauthorized by the Peace Treaty) of the word "Hanseatic" in the legal title of the city. ${ }^{2}$ In many of its artieles the Danzig constitution makes a verbatim copy of articles of the German constitution. ${ }^{3}$ Naturally, however, there are many differences in the forms of government of the two states.

\section{CONSTITUTION OF THE FREE AND HANSEATIC CITY OF DANZIG ${ }^{4}$}

\section{PART I}

\section{Organization of the State}

\section{General}

Article 1. The City of Danzig and the territory attached thereto shall form a Free State under the name of the "Free and Hanseatic City of Danzig."

'Edwin Björkman, "The Constitution of a City State," The Freeman, December 15,1920 .

2The text of the constitution used is that of the official translation prepared for the Executive Council of the Ieague of Nations, Document du Conseil, 81 A. The affairs of Danzig have been frequently before the League of Nations. For the details up to January, 1922, see Societé des Nations: Journal Officiel, III Année, No. 3, p. 241, and references (March, 1922).

3The English versions of such articles here given are not always identical, for the reason that it has seemed best not to attempt to modify the official (League of Nations) translation of the Danzig constitution, so as to make it conform to the unofficial translation of the German constitution, nor vice versa.

"Sce below for the resolution of the Council of the League of Nations with reference to the use of the word "Hanseatic." 
Art. 2. The arms of the state shall be: On a red shield, two silver crosses one above the other, above which is placed a golden crown.

The state flag and the mercantile flag shall be on a red ground: in the first third, counting from the mast, and parallel thereto, two white crosses, one above the other, and surmounted by a yellow crown.

Art. 3. The sovereign power in the state resides in the people.

Art. 4. The official language shall be German.

Art. 5. The Polish speaking portion of the population shall have its free racial development both by law and the administration, in particular as regards the use of its mother tongue in the schools and in the internal Administration, as well as in the administration of justice. Details will be determined by law.

\section{Popular Assembly}

Art. 6. The Popular Assembly shall consist of one hundred and twenty members.

Art. 7. The members of the Popular Assembly shall be representatives of the whole people. They shall be responsible to their own conscience only, and shall not be bound by any mandate.

Art. 8. The members shall be elected by the universal, equal, direct, and secret vote of all citizens, both men and women, who have attained the age of 20 years, in accordance with the principles of proportional representation.

Any person entitled to vote, who shall have completed his twenty-fifth year, shall be eligible as a member.

The following shall be excluded from the exercise of the franchise:

(1) Persons placed under guardianship, whether permanently or provisionally, or persons placed under educational supervision.

(2) Persons deprived by a decision valid in law of their rights as citizen.

Art. 9. The Popular Assembly shall be elected for four years. Elections shall take place on a Sunday in November. The newly elected Assembly shall enter on its duties from January lst of the year following that of the election. Details will be settled by the election act. 
Art. 10. All petitions against the validity of the election of members shall be decided by the Supreme Court of the Free and Hanseatic City of Danzig. The cases shall be dealt with in public sessions.

Any persons entitled to vote shall have the right to present a petition. The petition shall be presented to the Supreme Court of the Free and Hanseatic City, corroborated by evidence within four weeks of the official return of the result of the election.

The documents relating to the election of members shall, when completed, be laid before the Popular Assembly.

If any doubt shall arise as to whether the legal requirements for membership have been fulfilled the Supreme Court of the Free and Hanseatic City of Danzig shall at the request of the Popular Assembly, give the final decision.

Art. 11. The Popular Assembly shall choose its own President, Vice-President, and clerks; it shall decide its own rules of procedure.

Art. 12. The Popular Assembly shall meet when summoned by its President. It must be summoned at the demand of the Senate, or on a written application stating the purpose of the summons, made by at least one-sixth of the members of the Assembly.

It shall meet for the first time on the summons of the Senate, and not later than January the 15th.

Art. 13. The President shall exercise authority and disciplinary power within the Assembly building. The internal administration shall be placed under his orders; he shall administer the receipts and expenditure of the Assembly in accordance with the provisions made by the budget, and shall represent the Free and Hanseatic City of Danzig in all transactions of a legal nature, and in lawsuits which may arise in connection with his administration.

Art. 14. The business of the Popular Assembly shall be conducted in public. The public may be excluded on the proposal of the Senate, or on that of at least one-sixth of the members of the Assembly adopted by a two-thirds majority.

Art. 15. The publishing of accurate reports of proceedings at a public session shall be free from all penalty.

Art. 16. The Assembly shall not vote unless at least onehalf of the elected members are present.

Art. 17. Decisions of the Popular Assembly shall be by a 
majority of votes, except so far as the constitution provides otherwise.

Art. 18. The Senate shall be invited to be present at every meeting of the Popular Assembly.

Members and persons authorised by the Senate, shall be given a hearing at any time during the meetings. They shall be subject to the authority of the President.

The Popular Assembly and its committees may demand the presence of any member of the Senate.

Art. 19. The Popular Assembly shall be authorized to demand information from the Senate on all affairs of the state, to satisfy itself regarding the execution of its decisions and the administration of the state revenues. The subjects regarding which information is asked for shall be previously communicated to the Senate in writing.

When the legality or propriety of any governmental or administrative measures are called in question, the Popular Assembly shall have the right, and on the proposal of one-fifth of its members shall be bound, to appoint a committee of enquiry. Committees of enquiry shall not interfere in legal or disciplinary proceedings which are still pending. These committees shall demand such proofs in public sessions as they, or the proposer of the motion, shall consider necessary.

The public may be excluded from the meetings of a committee of enquiry, if a two-thirds majority so determine. The standing orders shall determine the procedure of the committee and shall fix the number of its members. The judicial and administrative authorities shall be bound to comply with demands of these committees for information. Documents in possession of these authorities shall be laid before such committees, if they so desire. The law of evidence as laid down in the regulations for criminal procedure shall, so far as its nature permits, be applied by these committees and by the authorities instructed by them, but the secrecy of communications by letter, telegram, and telephone shall not be effected.

Art. 20. No one shall be prosecuted or be subject to any disciplinary measures, or be called to account in other ways outside the Assembly for his vote, or for any statement made by him as a member in the execution of his office.

Art. 21. No member shall be prosecuted or arrested, without the approval of the Assembly, for any offense, unless he be arrested while committing such act, or at the latest during the 
course of the following day. A similar approval shall be necessary for any other encroachment upon his personal liberty by which the execution of his duties as a member may be affected.

Any criminal or disciplinary proceedings against a member, and any arrest or other limitation of personal liberty shall, at the request of the Popular Assembly, be suspended for the period of his membership.

Art. 22. Members shall have the right to refuse to give evidence in regard to persons who have communicated information to them in their capacity as members, or to whom they have made such communications in the exercise of their office as members, and also with regard to the facts themselves which formed the subject of such communications. Further, regarding the seizure of documents, members shall have the status of persons possessing a legal right to refuse evidence.

Judicial searches or seizures can be undertaken in the building of the Popular Assembly only with the approval of the President of the Assembly.

Art. 23. Members shall receive compensation in accordance with the provisions of a special law.

Art. 24. Officials, employees, and workmen, shall require no special leave for the purpose of fulfilling their duties as members of the Popular Assembly, the district and municipal councils, or any public offices and bodies.

If any such person be nominated as a candidate for election, he shall be granted the necessary leave from the time at which the writs for the election are issued, for the purpose of preparing for the election.

\section{The Senate}

Art. 25. The Senate shall consist of the President as chairman, the Vice-President as vice-chairman, and 20 Senators.

The President and seven Senators, acting as the Main Standing Committee, shall be elected by the Popular Assembly for twelve years. The Vice-President and 13 Senators, acting in a secondary capacity (Nebenamt), shall be elected by the Popular Assembly for an indefinite period.

The vote shall be secret and shall be by ballot. The majority of votes recorded shall determine the election. If an absolute majority be not secured at the first ballot, the two persons who have secured the most votes shall be voted for a second time. If both candidates at the second ballot receive an equal 
number of votes, the decision shall be taken by lot, to be drawn by the President of the Popular Assembly.

Art. 26. Any person shall be eligible for membership of the Senate who shall have completed his twenty-fifth year. A member may be re-elected.

The following are ineligible:

(1) Persons placed under guardianship, whether permanently or provisionally, or persons whose legal rights have been restricted [or who have been placed under provisional guardianship].

(2) Persons deprived by a decision valid in law of their rights as citizens.

(3) Undischarged bankrupts.

Art. 27. No person shall be obliged to accept election as a member of the Senate. A member may resign at any time.

Art. 28. At the next meeting of the Popular Assembly after the election, the newly elected member shall be installed in his office in the presence of the Senate by the President of the Senate, or his deputy.

The new member shall take the following oath:

"I will faithfully carry out my duty as a member of the Senate and will conscientiously perform the work of my office. I will observe the constitution and the laws, I will keep silence in all matters in which I am ordered so to do, and will use my best endeavors to promote the welfare of the Free and Hanseatic City of Danzig."

The addition of a religious oath shall be admitted.

Art. 29. The members acting in a secondary capacity are responsible to the Popular Assembly in the performance of their duties, and shall be answerable to the Assembly for all their official acts. Such members from whom the Popular Assembly shall have withdrawn its confidence by a deliberate resolution to that effect shall resign from the Senate.

Art. 30. A member shall cease to hold office in the Senate when any of the cases mentioned in Article 26, which render him ineligible for election, shall arise.

Art. 31. If the whole Senate resign, it shall continue to discharge its duties until the election of the new Senate.

Art. 32. A member of the Senate may, on a resolution of the Popular Assembly, be prosecuted for any infringement of the constitution, or of a law. The motion of the institution of such proceedings shall be signed by at least one-quarter of the mem- 
bers of the Popular Assembly. Judgment shall be given by the Supreme Court of the Free and Hanseatic City. Details shall be determined by special legislation.

Art. 33. The members of the Main Standing Committee of the Senate shall receive the salary determined by law. Special legislation shall provide for pensions and allowances to their widows and dependents.

The members of the Senate acting in a secondary capacity shall receive a subsistence allowance determined by special legislation.

Art. 34. The members of the Main Standing Committee of the Senate shall hold no other public office, nor shall they, without the approval of the Senate, follow any other profession; the other members shall hold public office only with the approval of the Senate.

Membership of a board of managers or of directors of a commercial company shall require the approval of the Senate.

Art. 35. The Senate shall determine the conduct of its business and the distribution of duties amongst its members.

Art. 36. The President of the Senate shall direct and shall exercise general supervision over the work of the Administration.

In all cases where requirement of previous decision by the Senate would involve a detrimental loss of time, the President shall himself, for the time being, carry out the duties which devolve on the Senate, in consultation with the Vice-President, or, in his absence, with the senior Senator; he shall nevertheless inform the Senate at the next meeting, in order that it may approve his action, or take some other decision.

Art. 37. The meetings of the Senate shall not be open to the public. At least one-half of its members shall form a quorum. Decisions shall be by majority vote.

In case of a tie the chairman shall have a casting vote.

A member shall not take part in the discussion or voting upon any subject which concerns his own affairs, or those of persons belonging to his family; he shall withdraw from the chamber during such discussion.

Art. 38. The Senate shall direct the policy of the government and be responsible for it to the Popular Assembly.

Art. 39. The Senate is the highest authority in the land. Its particular duties are as follows:

(1) It shall publish all laws within a month of their adoption, and shall issue all regulations necessary to ensure their execution. 
(2) It shall of its own authority conduct the administration of the state in accordance with the provisions of the constitution, of the laws, and of the budget, and shall exercise control over all the state authorities.

(3) It shall draft the budget.

(4) It shall administer the property and revenues of the state. It shall give directions regarding ways and means and expenditure, and it shall represent the rights of the state.

(5) It shall nominate public servants, so far as is not otherwise provided by the constitution or by law.

(6) It shall provide for the safety and common welfare of the state and all persons belonging thereto, within the limits of the constitution and the laws, and shall issue all regulations necessary thereto.

Art. 40. The Senate shall have the right of remission of punishment and of pardon.

Art. 41. The Senate shall represent the Free and Hanseatic City of Danzig in its external relations.

Official documents shall be signed in the name of the Free and Hanseatic City of Danzig by the President or Vice-President and by one other member of the Senate.

\section{Legislation}

Art. 42. Concurrent decisions of the Popular Assembly and of the Senate are required for the passing of a bill into law. If the Senate does not concur within two weeks in a decision taken by the Popular Assembly regarding a bill, the bill shall be sent back to the Popular Assembly.

If the Popular Assembly adheres to its decision, the Senate shall accept the decision within one month, or appeal to the decision of the people (Volksentscheid).

Art. 43. Laws shall come into force on the eighth day after the day on which they are published in the official Gazette for the Free and Hanseatic City of Danzig, unless it shall be otherwise provided by statute.

Art. 44. Legislation shall likewise be required for:-

(1) The annual budget.

(2) The issue of loans.

(3) The introduction of monopolies and the concession of privileges.

(4) The alteration of boundaries of the municipalities. 
(5) A general amnesty.

(6) The conclusion of treaties with other states.

Art. 45. Bills shall be introduced by the Senate, or by legally constituted bodies representing the various professions and trades.

Bills dealing with economic or social questions shall be submitted to these bodies for their approval.

Art. 46. A popular vote shall be taken on the demand of onetenth of the electorate accompanied by the full text of the bill. The bill shall be laid before the Popular Assembly by the Senate, with a statement of its views on the bill. The popular vote shall not be taken if the bill is accepted without amendment by the Popular Assembly.

Art. 47. A popular vote shall not be taken on the budget, or on legislation imposing taxation, or on decrees regulating salaries except at the request of the Senate.

All citizens qualified to vote for the Popular Assembly may take part in a popular vote. The decision shall be by a majority of the votes recorded. A decision of the Popular Assembly can be reversed by a popular vote only if the majority of the electorate take part in the voting.

The procedure with regard to the popular vote shall be determined by law.

Art. 48. An amendment to the constitution emanating from the Popular Assembly shall require for adoption a two-thirds majority and a quorum of at least two-thirds of the elected representatives at two readings. These readings shall be held at an interval of at least one a month.

The agreement of the majority of the electorate shall be required for the adoption of an amendment to the constitution by referendum.

\section{Administration}

Art. 49. An annual statement of all proposed receipts and expenditures of the state shall be drawn up in advance, and embodied in the budget.

The financial year shall date from the lst of April to the 31st of March.

Art. 50. If, before the end of the financial year, the budget for the following year shall not have passed into law, the Senate shall be bound to submit a provisional budget. It shall only 
be entitled to impose taxes previously in existence and other duties for six months from the close of the financial year, and shall authorise only such expenditure as may be required for the maintenance of lawfully established institutions, or for the transaction of matters legally provided for; it shall be further authorized to meet all legal obligations of the state, to carry on public works, and other undertakings, which have already been sanctioned by the budget of the previous year.

Art. 51. Money shall be obtained by credit only in cases of exceptional need, and in general only for expenditure for productive purposes.

Art. 52. Decisions of the Popular Assembly which involve expenditure additional to the budget shall include provisions for the meeting of this expenditure.

Art. 53. If the amount of the budget is to be exceeded, or if any expenditure not provided for in the budget is to be undertaken, further approval by the Popular Assembly shall be necessary. This shall be given only in cases of unforeseen and unavoidable necessity.

Art. 54. Budget accounts shall be audited and approved by an independent auditor.

The general budget accounts for each year, including a review of state indebtedness, accompanied by a statement from the Auditor, shall be laid before the Popular Assembly for approval of the action of the Senate.

Art. 55. The approval of the Financial Council shail be required:

(1) For fresh taxation.

(2) For the issue of loans and the acceptance of securities.

(3) For expenditure not already covered, or which is to te covered by a loan.

If the Financial Council does not give its approval, it shall communicate the fact to the Senate within two weeks, and shall state its reasons in writing within a further period of two weeks. The Popular Assembly shall then take a fresh decision.

The constitution and procedure of the Financial Council shall be determined by special legislation.

Art. 56. The railway, postal, telegraph, and telephone services of the Free and Hanseatic City shall be matters of state concern, without prejudice to the agreement arrived at in accordance with Article 104 of the Peace Treaty of the 28th June, 1919. 
Art. 57. Offices shall be established for the permanent administration or supervision of different branches of the public services. Citizens entitled to vote may be attached to these in an honorary capacity as members. The offices shall be in all respects subject to the control of the Senate. Details will be determined by law.

Art. 58. Committees may be established for the discharge of duties of a temporary nature.

Art. 59. The representatives of the Free and Hanseatic City of Danzig to be appointed on international committees established by international convention, for the administration of undertakings or institutions, or for the fulfilment of permanent or temporary obligations, shall be elected by the Popular Assembly. The Popular Assembly may delegate the appointment of such representatives to one of its committees or to the Senate.

\section{Administration of Justice}

Art. 60. Judges shall be independent and subject only to the law.

Art. 61. The establishment of extraordinary tribunals shall not be permitted. No man shall be withdrawn from the jurisdiction of his lawful judge.

Art. 62. The constitution and the competence of the courts shall be prescribed by law.

Art. 63. The judges of the regular judicial administration shall be elected for life by a special committee consisting of the President and one member of the Senate, the three Presidents of the Popular Assembly, the President of the High Court of Justice, three judges elected by the whole body of judges, and two advocates elected by the whole body of advocates of the Free and Hanseatic City of Danzig.

Further provisions, especially as regards the provision of substitutes for members of the committee who are prevented from attending, and as regards the procedure of election and the methods of voting, will be provided for by legislation.

Art. 64. Judges shall be removed from their office or transferred to another post or placed in retirement against their will, whether permanently or temporarily, only as a result of a decision of a court of law, and only for the reasons and in the manner laid down by law. The law may fix the age of retirement for judges. 
Provisional removal from office as provided for by law shall not be affected by the above.

If any changes be made in the organization of the courts or the districts administered by them, judges may be compulsorily transferred to another court or removed from their office by the commissions described in Article 63, but they shall continue to receive the whole of their emoluments.

These provisions shall not apply to judges of the commercial court, aldermen, and jurymen.

Art. 65. Conditions as to the eligibility of judges for election and as to their official status shall be determined by special legislation, which may be amended only in the manner specified by Article 48 .

\section{Communal Organization}

Art. 66. The territory of the state shall be divided into town districts and rural districts.

Art. 67. Rural districts, towns, and municipalities shall have powers of self-government under the supervision of the Senate, in accordance with the provisions of special legislation. Matters of state administration may also be entrusted to them.

Art. 68. The City of Danzig is a separate municipality of the state, with its own property.

The local affairs of the City of Danzig shall rank as affairs of the state, and shall be directed by the Senate and Popular Assembly.

For the management of the local affairs of the City of Danzig a city council shall be elected by the Popular Assembly from its members and from other citizens of the city. Its composition and competence shall be determined by special legislation.

Art. 69. The principles governing elections to the Popular Assembly shall apply also to town, district, and municipal elections, but six months' residence shall be necessary to secure the right to vote.

\section{PART II}

\section{Fundamental Rights and Duties}

Art. 70. Fundamental rights and duties shall form the basis for the direction and the limits of legislation, administration of justice, and government. 


\section{Individuals}

Art. 71. Citizenship of the state shall be acquired and forfeited in accordance with the provisions laid down by law.

Art. 72. All citizens of the Free and Hanseatic City shall be equal before the law. No legislation which provides for exceptions shall be admissible.

Persons of both sexes shall have the same civil rights and duties.

There shall be no legal privileges or disqualifications due to birth, position, or creed.

Titles - with the exception of academic degrees-shall not be awarded except when they denote an office or a profession.

Orders and decorations may not be awarded by the Free and Hanseatic City.

No citizen of Danzig may accept titles or decorations.

Titles of nobility shall be regarded only as a part of a name, and shall no longer be awarded.

Art. 73. Personal liberty shall be inviolable.

A limitation or deprivation of personal liberty by the public authorities shall be admitted only in accordance with the law.

Persons deprived of their liberty shall be informed on the following day, at the latest, of the authority ordering such deprivation of liberty and of the grounds for the same; opportunity shall immediately be given them to bring forward objections against the deprivation of their liberty.

Art. 74. All citizens shall enjoy freedom of movement in the Free and Hanseatic City and shall have the right to establish themselves, and to settle at any place they may choose, to acquire real property, and to pursue any calling. Limitations of this right shall require the sanction of the legislature.

Art. 75. Every citizen shall be entitled to emigrate to other countries. Emigration can be restricted only by legislation.

Every citizen, both within and without the territory of the state, shall have the right to clain its protection in relation to foreign countries.

No citizen shall be delivered up to a foreign government for prosecution or punishment.

Art. 76. Establishments set up by the state at the public expense in the interests of interior colonization shall not be used to the prejudice of any particular nation. 
Art. 77. The secrecy of correspondence by letter, and the secrecy of the post, telephone, and telegraph services shall be inviolable. Exceptions can be sanctioned only by law.

Art. 78. Every man shall have the right within the limits of the law to express his own opinion in word, writing, or any other manner. This right shall not be restricted by any conditions of employment or appointment, and no man shall be in any way prejudiced by the exercise of this right.

Censorship shall not be permitted.

Different provisions may be established by law regarding cinematographs.

Legal measures shall be adopted to combat obscene and trashy literature, and to protect young persons at public performances and exhibitions.

Art. 79. Marriage as the foundation of family life shall be placed under the special protection of the state. It shall be based on the principle of equal rights for both sexes.

Large families shall have a claim to compensatory support.

Motherhood shall have a claim to the protection and support of the state.

Art. 80. The education of children to physical, intellectual, and social efficiency is the highest duty and natural right of parents.

The state shall supervise the execution of these duties.

Art. 81. The legislation shall extend similar conditions of physical, intellectual, and social development to illegitimate children as for children born in wedlock.

Art. 82. Young persons shall be protected against exploitation and also against moral, intellectual, or bodily neglect. Provisions for reformatory education can be made only by law.

Art. 83. All citizens shall have the right to meet together in a peaceful manner and unarmed, without giving notice and without special permission. Notice shall be given of open-air meetings, and permission may be withheld in the case of direct danger to public safety. Special provisions may be made for the protection of the Popular Assembly. Notification of religious processions shall not be necessary.

Art. 84. All citizens shall have the right to form unions or associations for purposes not in defiance of the criminal laws. This shall also apply to religious unions and associations. Every union shall be entitled to acquire legal status in accordance with the provisions of the civil law. This recognition shall not be 


\section{CITY OF DANZIG}

withheld on the ground that the union has a political, social, or religious object.

Art. 85. The house of every citizen shall be for him an inviolable sanctuary. Exceptions shall only be permitted in accordance with the law.

Art. 86. It is the duty of every citizen to protect the constitution against unlawful attacks.

Art. 87. All citizens without distinction shall take their share in proportion to their means in all public burdens, in accordance with the provisions of the law.

Art. 88. All citizens shall be bound in accordance with the provisions of the law to give personal service to the state and the municipality.

Art. 89. All citizens shall be bound in accordance with the law to undertake official duties of an honorary nature.

\section{Public Servants}

Art. 90. All citizens of either sex shall be eligible for public appointments, in accordance with their qualifications and previous work.

Immediately after the coming into force of the constitution of the Free and Hanseatic City, special legislation shall be adopted with regard to the rights and payments of officials. The existing officials' organizations shall take part in the drafting of these laws.

Art. 91. Officials shall be appointed for life, except so far as is otherwise provided by the constitution or by law. Pensions and allowances to widows and dependents shall be fixed by law. Vested rights of officials shall be inviolable. Officials shall have the right to claim the assistance of the courts in the matters that concern their pecuniary interests.

Officials can be provisionally removed from their office, discharged, or transferred, whether temporarily or permanently, to the retired list, or to another office with a lower salary, only in accordance with the conditions and formalities established by law. An opportunity for protest and for a reopening of the case shall be provided in the case of any penalty inflicted in connection with official duties. No entries of unfavourable facts shall be made in the record of an official before that official shall have had an opportunity to furnish an explanation. Every official shall have the right to look at his own record. 
Art. 92. Officials are servants of the community and not of a party. Freedom of political opinion and freedom of association shall be assured them. They shall not be subjected to any restriction in this regard.

Art. 93. The officials shall have their own representation in accordance with more detailed provisions to be made by law.

Art. 94. Teachers of both sexes in the state schools shall be direct officials of the state. The obligation to maintain schools shall not be hereby affected.

\section{Religion and Religious Associations}

Art. 95. Full freedom of creed and conscience shall be established. Unhindered observance of religious rites shall be assured and shall be placed under the protection of the state. Enjoyment of civil and national rights and eligibility for public offices shall be independent of creed.

No one shall be compelled to declare his religious convictions. The authorities shall enquire as to membership of any particular religious association only in so far as rights and duties are attached thereto, and for the purpose of drawing up a census ordered by law.

No one shall be forced to take part in any religious ceremony or celebration.

Where the existing law provides for the taking of an oath according to a religious formula, the oath may also be validly administered if the swearer shall omit the religious formality and shall declare "I swear." Apart from this, the nature of the oath as prescribed by law shall remain unchanged.

Religious associations which are accustomed to use a form of solemn declaration in place of the oath shall be entitled to do so.

Art. 96. Religious associations which are corporate bodies recognized by the law shall be authorized to collect contributions from their members, based on the civil taxation lists.

Art. 97. The property and other rights of religious associations and religious unions shall be guaranteed them for the purpose of maintaining institutions, foundations, and other undertakings of religious, educational, or charitable purposes.

Art. 98. In so far as the need arises for religious services and ministrations in infirmaries, prisons, and other public institutions, the religious associations shall be allowed to perform ceremonial acts, but all compulsion shall be excluded therefrom. 
Art. 99. Sunday and the public holidays recognized by the state shall be protected by law as days of rest and spiritual edification.

\section{Education and Schools}

Art. 100. Arts and sciences and their teachings shall be free. The state shall provide for their protection and shall be bound to promote their interests in a liberal manner.

Art. 101. The entire administration of schools shall be governed by legislation, which shall be drafted in coöperation with the existing organization of the teaching profession.

The entire administration of schools shall be placed under state supervision. Inspection of schools shall be carried out by expert officials.

Art. 102. Education shall be compulsory for all. It shall be afforded primarily by the primary school, at which eight years of attendance at least shall be required, and also by the continuation or technical schools for young persons of both sexes up to the end of their eighteenth year. The maintenance of the state schools is the affair of the state; it may associate the municipalities in these duties.

Instruction and materials required for education in the primary and continuation schools shall be free of charge.

Art. 103. The public administration of schools shall be organized according to a uniform principle. Existing schools of another type shall remain unchanged. The legitimate wishes of parents or students shall also be taken into account as regards any new organization of such schools, provided that the orderly conduct of the schools is not prejudiced thereby.

The entire system of primary, secondary, and advanced schools shall start from a common primary school for all. In establishing this system regard shall be had to the varied nature of occupations and professions. In receiving a child into any particular school, consideration shall be paid to the disposition and inclination of the child as well as to the wishes of its parents or guardians, and not to the economic or social position of its parents.

Instruction and the materials required for education shall also be provided free of charge in the secondary and advanced schools for gifted children of poor parents. Gifted children of poor parents shall be provided with assistance from public funds to attend advanced schools and universities.

Art. 104. Private schools as substitutes for state schools 
shall require state authorization and shall be subject to state legislation. Such sanction shall be granted only when the private school is not inferior to the state school in its educational aims and equipment and also in the educational qualifications of its teaching staff, and when a division of pupils according to the wealth of their parents is not thereby encouraged. Sanction shall also be refused when insufficient provision is made for the civil and economic position of the staff.

No further private preparatory schools shall be established, and those which exist shall be closed.

In every case compensation shall be awarded for the closing of established private schools, including preparatory schools. Further provision will be prescribed by law.

Art. 105. Religious instruction is a recognized school subject. It shall be given in accordance with the principles laid down by the religious associations without prejudice to the state's right of supervision.

The giving of religious instruction and the practice of religious observances shall be subject to the teachers' expressed willingness to undertake such duties; the right to withdraw a child from religious instruction, celebrations, or acts shall be granted in accordance with the expressed wishes of the person authorized to decide as to the child's religious upbringing.

Art. 106. In the course of instruction in the state schools care shall be taken not to offend the susceptibilities of those of a different way of thinking.

Art. 107. Civic rights and duties shall be a subject of instruction in schools. Every scholar at the end of his school period shall be given a copy of the constitution.

Art. 108. Works of artistic, historical, and natural interest, and the beauties of the country shall be under the protection and care of the state.

It is the duty of the state to prevent the removal of works of art to foreign countries.

\section{Economic Life}

Art. 109. The rights of property shall be assured. Expropriation shall take place only in accordance with the provisions of the law in the public interest and in return for due compensation; in case of dispute recourse may be had to the decision of the courts. 
Article 110. The soil and natural resources shall be placed under legislation which shall prevent all misuse, and which shall enable every family of the Free Hanseatic City to obtain a homestead, or, if suitably trained, a farm permanently secured to meet their needs. Large families, those disabled by the war, and those physically affected as a result of their employment, shall be given special consideration in the housing legislation which is to be passed.

The unearned increment which arises from landed property without any expenditure of labor or capital shall be applied to the use of the community.

Art. 111. Special legislation may provide for the transference of private industrial undertakings to public ownership in return for compensation, in so far as the public welfare may demand.

Art. 112. Freedom of association for the purpose of guaranteeing and promoting the interests of labor and industrial conditions shall be assured to every man and to every occupation. Any conventions or provisions which attempt to limit or restrain such freedom shall be contrary to law.

Art. 113. In order to promote health and efficiency for work, to protect motherhood and to provide against the economic consequences of old age, weakness, and the vicissitudes of life, including unemployment, the state shall provide a comprehensive system of insurance, in the drafting of which the insured shall have a determining influence.

Art. 114. Workers and employees shall establish from amongst their number separate trades councils for workmen and employees. These shall enjoy equal standing, and shall coöperate with the employers in the regulation of questions concerning pay and labor conditions. Details will be determined by legislation.

The organizations of both sides and their mutual agreements shall be recognized.

In order to secure the social and economic interests of workers and employees and to promote the collective economic development of productive efficiency, a Labor Office shall be established in accordance with Article 45, Paragraph 2.

\section{Final and Transitional Provisions}

Art. 115. The constitution of the German Empire of the 11th August, 1919, shall be abolished. 
All laws and decrees which are valid in the territory of the Free and Hanseatic City of Danzig at the time of the coming into operation of this constitution shall remain in force in so far as they are not suspended by this constitution or by law.

The Popular Assembly shall, as soon as it meets, immediately appoint a committee to reëxamine all decrees which have been proclaimed since the 10th January, 1920.

Art. 116. The Constituent Assembly, within three months at the latest from the establishment of the Free and Hanseatic City shall declare itself to be the first Popular Assembly to hold office up to the 31st December, 1923, or shall fix its dissolution at a date to be determined by it and shall issue a decree for new elections; in the latter case it shall continue to be the legislative body until the meeting of the first Popular Assembly.

Until the constitution of the Senate, the Council of State in existence at the time of the establishment of the Free and Hanseatic City shall continue its duties as the provisional government.

The City Council and the Bench of Magistrates of the City of Danzig shall remain in office until such time as their duties are taken over by the Municipal Corporation and the Senate.

The present constitution of the Free and Hanseatic City of Danzig has been adopted by the Constituent Assembly in its 22nd plenary session on August 11th, 1920.

(Signed) D. Reinhard, President.

Danzig, August 14th, 1920

\section{RESOLUTION ADOPTED BY THE COUNCIL OF THE LEAGUE OF NATIONS, NOVEMBER $17,1920 .^{1}$}

I. The Council of the League of Nations approves of the conclusions of the annexed report by the Japanese Representative, and declares:

That the Free City of Danzig, from the time of its establishment by the Principal Allied Powers in accordance with Article 102 of the Treaty of Peace of Versailles, will be placed under the protection of the League of Nations, and:

'Journal of the First Assembly of the League of Nations, Geneva, 1920, No. 6, 20 th November, 1920, p. 32. For the Report to the Council by His Excellency, Viscount Ishii, Japanese Representative, see ibid., p. 33. 
That the constitution of the Free City of Danzig, drawn up by the duly appointed representatives of the Free City, will at the same time be placed under the guarantee of the League of Nations.

The Council decides that:

The Polish Government appears particularly fitted to be, if the circumstances require it, entrusted by the Ieague of Nations with the duty of ensuring the defence of the Free City.

The Permanent Advisory Commission on Military, Naval and Air Questions is instructed to consider the measures which will ensure the most effective defence of Danzig in the cases mentioned in the Japanese Representative's Report.

II. The acting High Commissioner of the Ieague of Nations is authorized to communicate the foregoing, together with the text of annexed report, to the Constituent Assembly of the Free City of Danzig. He will add that the Constituent Assembly is asked to submit to him within three weeks the final text of the constitution, revised as follows:

(a) that the word "Hanseatic" should be omitted in all the articles of the constitution where it occurs.

(b) that Articles 4 and 5 of the constitution should form one article.

(c) that a clause should be inserted in the constitution to the effect that the provisions of Articles 41 and 44 (Paragraph 6) should be understood to affect in no way the provisions of article 104, No. 6, of the Treaty of Peace of Versailles.

(d) that a clause should be inserted in the constitution to the effect that the amendments to the constitution cannot come into force before they have been communicated to the League of Nations and before the League has declared that it has no objection to make.

(e) that a clause should be inserted in the constitution to the effect that the Government of Danzig shall submit for the examination of the League of Nations, within six months following the High Commissioner's communication, the principles of the draft of the law provided for by Article 71 of the constitution which deals with citizenship of the state of Danzig.

(f) that a clause should be inserted in the constitution to the effect that the League of Nations has the right to require at any time from the government of Danzig au- 
thentic information on the public affairs of the Free City, and that effect should always be given to such a request.

(g) that a clause be inserted in the constitution to the effect that the Free City of Danzig shall not be used as a military or naval base, that it must not put up fortifications, nor authorize the manufacture of munitions or war materials within its territory without having obtained in each case the consent of the League of Nations.

III. The High Commissioner shall notify at the same time the Constituent Assembly at Danzig that the Council of the League of Nations has taken cognizance of the Draft Convention between the Free City of Danzig and the Polish Government, which in accordance with Article 104 of the Treaty of Peace of Versailles, has been negotiated by the Principal Allied Powers. He will further notify the Constituent Assembly that no modification contrary to the Statute of the Free City shall be introduced into this convention without the previous assent of the League.

IV. The functions of the provisional High Commissioner, Sir Reginald Tower, having come to an end by the Constitution of the Free City, and in view of the fact that he has expressed his intention of not accepting a definitive appointment, the Council of the League of Nations requests the Secretary-General to convey to Sir Reginald Tower the thanks of the League of Nations for the services he has rendered in his position as High Commissioner.

V. The acting President of the Council, together with the Japanese Representative and the Secretary-General, are asked to make proposals to the Council as to the choice of a High Commissioner of the Ieague of Nations. The Council will appoint a High Commissioner for a period of three years. The appointment of the High Commissioner may be renewed.

The High Commissioner can always be dismissed by the Council of the League of Nations. The salary of the Permanent High Commissioner shall be fixed at 100,000 gold francs per annum. The High Commissioner shall in addition receive an allowance sufficient to cover expenses of official journeys, correspondence, the maintenance of his office, and the salaries of his staff.

The President of the Council, the Representative of Japan, and the Secretary-General are requested to bring about an agree- 
ment between the Polish Government and the Free City of Danzig, with regard to their respective contributions toward the upkeep of the post of High Commissioner of Danzig. The contributions of the Polish Government and the Free City of Danzig shall be paid into the funds of the League of Nations, which will place the necessary sums at the disposal of the High Commissioner. The accounts of the High Commissioner shall be audited by the Financial Administration of the Secretariat of the League of Nations.

VI. The expenses incurred until the Permanent High Commissioner takes up his duties, which have been advanced by the Secretariat of the League of Nations, shall be borne by the Free City.

VII. The Secretary-General is entrusted with the duty of communicating this resolution to all concerned. 


\section{CHAPTER XVIII}

\section{ESTHONIA}

\section{HISTORICAL NOTE}

Geography of Esthonia
Local selfgovernment in 1917
"The independent Republic of Esthonia is composed of the former Russian Government of Esthonia, the northern part (to Walk) of Livonia, the western corners of the Governments of Petrograd and Pskov and the adjacent islands. On the north and west it is bounded by the Baltic Sea (Gulf of Finland, Gulf of Riga), on the east by Russia, and on the south by Latvia. With an area of 47,500 kilometers, it contains very nearly $1,750,000$ inhabitants, of whom 90 per cent. are Esths, a race akin in ancestry and language to the Finns. Protestantism is the practically universal faith. The Esths have not been free since the day of heathenism. Germans, Danes, Swedes, Poles have all possessed the land as conquerors, and finally Russia absorbed the whole of the race into her Empire. In spite of age-long servitude, the depressing rule of the German landowners (Balts), and intense Russification, the Esthonian language and culture not merely maintained themselves but appreciably advanced, fostering, and being fostered, by that growing sense of nationalism that characterized the two decades before the war. The movement for autonomy was already important when the Russian revolution broke out. On April 12, 1917, a decree of the Russian Provisional Government provided for local self-government, under a National Council, for the Esthonian districts. This Council (Maapäew) met for the first time on July 14, and Esthonia virtually became a federal state in a Russian confederation. On the Bol- 
shevik coup d'état of November, the National Council declared itself the sovereign power in Esthonia until a constituent assembly could meet. On January 28, 1918, the Balts formally invited Germany to occupy the country, to which the Council, after protesting on February 7, replied on February 24 by declaring Esthonia an independent state, and constituting a provisional government under M. Paets. The provisional government was dissolved by the German invaders, and $\mathbf{M}$. Paets arrested; but the National Council maintained itself by missions abroad, and was recognized as a de facto governing body by Britain (May 3), France (May 15), and Italy (May 29), a recognition amplified by the British declaration of September 10. As soon as the German evacuation began, the National Council resumed power, reconstituted the provisional government, and held elections for the constituent assembly, which was opened on April 23, 1919, and on May 19 proclaimed Esthonia an independent Republic.

"A peace with Bolshevik Russia which recognized the de jure independence of Esthonia was signed at Tartu (Dorpat) on February 2, 1920. Finland recognized the republic as de jure independent, and by June 7, de facto recognition had been accorded by practically all the Powers.

"The first task of the assembly was to frame a constitution. The work was entrusted to a commission of fourteen members, representing six parties, and including two ladies. M. Jaan Poska ${ }^{1}$ acted as chairman. A short preliminary constitution-organic law-was drafted, submitted to the assembly on May 21, 1919, and passed on June 4. It came into force on July 9 , and remained in force till the State Assembly elected by the elections of November 27-29, 1920, met.

"The commission submitted a draft scheme to the constituent assembly on May 27, 1920, but it was greatly

\footnotetext{
1M. Poska died on March 7, 1920, and was succeeded as chairman by M. Anderkop.
} 
The Constitution of 1920

altered in particularly keen debates, lasting until June 15, when it was passed in its present form. The draft had at least the outstanding merit of being short and intelligible, and bears the mark of the politician's handiwork, as well as the jurist's. The commission spent a whole year on it in genuine hard work, in which they were assisted by the best jurists in Esthonia in exhaustive examination of foreign constitutions, notably those of the United States, France, and especially Switzerland. The draft scheme is simply a bold enough attempt at a democratic constitution on conventional lines. It is, in fact, little more than an amplification of the organic law of June, 1919, and has clear traces of imitation of the constitutions consulted. In its final form, however, it is radically changed, and has several important features of deep interest to the student.

"As it now stands, the constitution contains a preamble stating that the Esthonian people has drawn it up and accepted it through the constituent assembly."1

\section{THE CONSTITUTION OF THE ESTHONIAN REPUBLIC}

Passed by the Constituent Assembly, June 15, 1920

The Esthonian people with unshaken faith and the resolute will to create a State based on justice, law, and liberty, for the

\footnotetext{
1R. T. Clark, "The Constitution of Esthonia," Journal of Comparative Legislation and International Law, Vol. III, pp. 245, 246 (October, 1921).

This text of the constitution is reprinted from the Baltic Review, September and October, 1920 (Vol. I, pp. 67-70; 111-113). The origin of the text is not stated but it is identical (except for misprints) with the translation in $A d$ mission de l'Esthonie dans la société des nations, Memorandum du secrétaire général, Société des Nations, Document de l'Assemblée, No. 70, Annexe VI (November 24, 1920). This document includes a French translation also. A few obvious misprints have been corrected, but the awkward phrases which in some cases give the impression of error are in the original. The text of the organic law is published in the Bulletin d'Esthonie. No. 5; and No. 10 of the same periodical contains a summary of the draft of the constitution. The very important agrarian law is to be found in the Bulletin d'Esthonie, No. 5. A preliminary study of the constitution was made by Mr. Clark, "Baltic Politics: the Esthonian Constitution," New Europe, August 12, 1920. See also J. Sapas, "The Development of the Esthonian State," Baltic Review, December, 1920.
} 
defence of internal and external peace, and as a pledge for the social progress and general welfare of present and future generations, has drawn up and accepted tlirough the Constituent Assembly the Constitution as follows:-

\section{General Dispositions}

Article 1. Esthonia is an independent autonomous Republic in which the power of the state is in the hands of the people.

Art. 2. To the territory of Esthonia belong Harjumaa, Läänemaa, Järwamaa, Wirumaa, with the town of Narwa and district, Tartumaa, Wiljandimaa, Pärnumaa, the town of Walk, Wörumaa, Petserimaa and other border regions inhabited by Esthonians, the islands of Saaremaa (Oesel), Muhumaa (Moon), and Hiiumaa (Dago), and other islands and reefs situated in Esthonian waters.

The fixation of the Esthonian frontiers will be determined by international treaties.

Art. 3. The Esthonian state power cannot be exercised by anybody otherwise than on the basis of the constitution and the laws passed in accordance with the constitution.

Art. 4. The laws in force in Esthonia are those passed or recognized by her own institutions. The generally accepted precepts of international law are valid in Esthonia as an inseparable part of her juridical order.

Ignorance of the law can in no case be pleaded as an excuse.

Art. 5. The state language of the Esthonian Republic is Esthonian.

\section{Fundamental Rights of Esthonian Citizens}

Art. 6. All Esthonian citizens are equal in the eyes of law. There cannot be any public privileges or prejudices derived from birth, religion, sex, rank, or nationality. In Esthonia there are no legal class divisions or titles.

Art. 7. The Esthonian Republic confers no decorations or marks of distinction on its citizens, excepting members of the defence forces in time of war. Esthonian citizens have likewise no right to accept orders or distinctions from foreign states.

Art. 8. Personal inviolability is guaranteed in Esthonia. No one can be prosecuted except in cases and ways foreseen by the law. Unless caught in the act no person can be arrested or the personal liberty be restricted otherwise than by decision of 
the judicial authorities, and this decision, with all grounds, must be communicated to the person arrested at the latest three days after arrest. Any citizen has the right to demand the communication of the above decision to the imprisoned, if this has not been done in the period mentioned.

It is impossible to transfer any citizen against his will for trial by any other court than the one designated by the law.

Art. 9. No punishment can be inflicted on anybody for a deed not acknowledged by the law as punishable before the crime was committed.

Art. 10. The homestead is inviolable. No forcible entrance of the home or search there is allowed except in cases and in execution of the requirements indicated by law.

Art. 11. In Esthonia there is freedom of religion and conscience. Nobody is obliged to perform ritualistic acts or to be a member of a religious body or undertake public obligations in the interests of same.

The practice of religious acts is not hindered, provided it does not interfere with public order and morals.

Creed and outlook cannot be made the excuse for any offence or for the avoiding of the duties of a citizen.

There is no state religion in Esthonia.

Art. 12. Science, art, and the teaching of same are free in Esthonia. Education is compulsory for children arrived at the school age, and is gratuitous in elementary schools. The minority nationalities are guaranteed education in their mother tongue. Education is carried out under the control of government.

Autonomy is guaranteed to high schools within the limits foreseen by the statutes of the institutions passed in legislative way.

Art. 13. In Esthonia there is freedom for the expression of personal ideas in words, print, letters, pictures, and sculpture. This freedom can be restricted only in the defence of the state and morals.

There is no censorship in Esthonia.

Art. 14. In Esthonia is guaranteed the secrecy of messages and letters transmitted through the post, telegraph, telephone, and any other general means. Exception can be made only by the judicial authorities in cases foreseen by law.

Art. 15. The right to apply or address complaints to public departments is guaranteed in Esthonia. The applications or 
complaints must not be accompanied by coercive measures. The departments in question are bound to give the matter legal motion.

Art. 16. Previous permission need not be obtained for the arraignment of government officials.

Art. 17. Removal and change of domicile are free in Esthonia. In this freedom nobody can be restricted or hindered otherwise than by the judicial authorities.

In the interests of public health such freedom can be restricted also by other authorities in cases and in ways foreseen in the corresponding laws.

Art. 18. All Esthonian citizens have the right to hold public meetings unarmed, provided they are not disturbing to the public peace.

The forming of associations and unions is free in Esthonia.

Freedom to strike is guaranteed in Esthonia.

The law can restrict these rights only in the interest of public safety.

Art. 19. Liberty in the choice of occupation, the opening of business concerns and exploitation of same, as well in agriculture, commerce, and industry, as in other economic branches, is guaranteed in Esthonia. Nobody can be restricted or hindered in this freedom otherwise than on the basis and within the limits of the laws.

Art. 20. Every Esthonian citizen is free to determine his or her nationality. In cases where individual choice is impossible, it will be done in the way foreseen by law.

Art. 21. The members of minority nationalities within the confines of Esthonia may form corresponding autonomous institutions for the promotion of the interests of their national culture and welfare in so far as these do not run contrary to the interests of the state.

Art. 22. In those parts where the majority of the inhabitants are not Esthonian but consists of local minority nationals, the business language in the local self-government institutions can be in the language of these minority nationals, whilst everybody has the right to use the state language in such institutions. The local self-government institutions in which the language of the minority is used must in their intercourse with state institutions employ the state language, as also with other local self-government institutions where the language of this minority nationality is not used. 
Art. 23. Citizens of German, Russian, and Swedish nationality have the right to address themselves to the state central institutions in the writing of their own language. The use of the language of these nationals in court, as also in the institution of self-government, will be decided in detail by special law.

Art. 24. The right of private property is guaranteed in Esthonia to every citizen. Without the owner's consent it can be expropriated only in the common interest in accordance with the corresponding laws and in the ways foreseen in the laws.

Art. 25. The organization of the economic life in Esthonia must correspond with the principles of justice, the object of which is the securing of conditions of living worthy of human beings by corresponding laws relating to the acquiring of land for cultivation and a home, and the obtaining of employment, as well as the necessary support for the protection of maternity, labor, youth, old age, disability, and in cases of accident.

Art. 26. The rights and freedom of citizens referred to in Articles 6-24 do not exclude other rights emanating from the principles of this constitution or which are in agreement with it.

Extraordinary restrictions of the freedom and fundamental rights of the citizens come into force in the event of the proclamation of a state of defence during a stated period, announced in the legal way on the basis and within the limits of the corresponding laws.

\section{The People}

Art. 27. The supreme executor of the state power in Fsthonia is the people itself, through the medium of the citizens having the right to vote. Every citizen arrived at the age of twenty and of Esthonian citizenship for a consecutive period of at least one year has the right to vote.

Art. 28. Citizens are not enfranchised:

(1) who in a legal way are pronounced to be idiots or lunatics; and

(2) the blind, deaf-mutes, and persons considered as wasters when they have been placed under guardianship.

The vote will be withheld from certain categories of criminals according to the electoral law of the State Assembly.

Art. 29. The people exercises the state power:

(1) by plebiscite;

(2) by their initiative in legislation; and

(3) by the election of the State Assembly. 
Art. 30. Every law passed by the State Assembly remains unpromulgated for a period of two months dating from the day of its passing, if one-third of the legal number of members of the State Assembly requires it. If during this period 25,000 enfranchised citizens demand that this law be submitted to a plebiscite for acceptance or rejection, the promulgation or non-promulgation of this particular law will depend on the results of this plebiscite.

Art. 31. The procedure followed in the legislative initiative of the people is that 25,000 of the enfranchised citizens have the right to require that a law shall be passed, changed, or cancelled. The respective request in the form of an elaborated draft will be submitted to the State Assembly. The State Assembly can either pass this draft as a law or reject it. In the latter case the draft will be submitted to the people in the form of a plebiscite for acceptance or rejection. If in the plebiscite the majority decide in the favor of the law in question, it acquires the force of a law.

Art. 32. If the people reject a law passed by the State Assembly or accept a law rejected by the Assembly, new elections of the State Assembly will be proclaimed, these elections to take place not later than seventy-five days after the plebiscite.

Art. 33. Plebiscites must be conducted under the control of the Presidium of the State Assembly. The basis and procedure of the plebiscite are ordained by a special law.

Art. 34. The budget, the raising of loans, income tax laws, declaration of war and the making of peace, declaration of a state of defence and termination of same, declaration of mobilization and demobilization, as well as treaties with foreign states, are not subject to a plebiscite and cannot be decided by a plebiscite.

\section{The State Assembly}

Art. 35. As the representative of the people the State Assembly exercises the legislative power.

Art. 36. The State Assembly consists of 100 members elected by universal, equal, direct, and secret suffrage on the principle of proportional representation. The State Assembly has the right to augment the number of its members. The law established in regard to this will come into force at the next elections of the State Assembly. The electoral law of the State Assembly will be passed as a special law. 
Art. 37. Every enfranchised citizen has the right to participate in the election of the State Assembly or allow himself to be elected a member of the State Assembly.

Art. 38. The members of the State Assembly, with the exception of deputies of members of the Republican Government, cannot be appointed to any office by the Republican Government or its institutions.

Art. 39. Every three years elections of the State Assembly are to take place. The beginning of the powers of the members of the State Assembly dates from the declaration of the results of the election.

Art. 40. In the event of a member of the State Assembly losing his vote or of his detention by consent of the State Assembly or his death or resignation, he will be replaced by a new member, according to the electoral law, until the term mentioned in the foregoing paragraph.

Art. 41. The State Assembly meets for ordinary sessions on the first Monday of October of each year.

Art. 42. The Presidium of the State Assembly can summon the State Assembly for extraordinary sittings when necessitated by circumstances. They are obliged to do this if it is demanded by the Republican Government or one-fourth of the legal number of members of the State Assembly.

Art. 43. The State Assembly elects the President and the other members of the Presidium at the first meeting after the elections. This meeting is presided over by the chairman of the previous State Assembly until the election of the President.

Art. 44. The State Assembly issues its standing orders which shall be promulgated as law.

Art. 45. The members of the State Assembly are not bound by mandates.

Art. 46. The State Assembly can act when at least onehalf of the legal number of members are present.

Art. 47. The meetings of the State Assembly are public. Only in extraordinary cases, if two-thirds of the members agree, the sitting of the State Assembly can be declared secret.

Art. 48. The members of the State Assembly have no responsibility for their political declarations in the State Assembly or in its committees, except that foreseen in the standing orders.

Art. 49. Without the consent of the State Assembly its members cannot be arrested except in case they are detected 
flagrante delicto. In such cases the arrest, together with its reasons, must be communicated at the latest forty-eight hours after to the Presidium of the State Assembly, which will submit it to the decision of the State Assembly at its next meeting.

The State Assembly has the right to postpone the imprisonment or any other restriction of one of its members until the Assembly vacation or until the expiration of his membership.

Art. 50. Members of the State Assembly are exempted from defence service during the period of their membership.

Art. 51. Members of the State Assembly are in receipt of salaries and travelling expenses, the amount of which is fixed by law and can only be altered by the State Assembly for the subsequent Assemblies.

Art. 52. The State Assembly passes laws, fixes the budget, the state revenue, and expenditure, and decides about loans and other matters on the basis of the constitution.

Art. 53. The laws passed by the State Assembly are promulgated by the Presidium of the State Assembly.

Art. 54. If the day and date are not foreseen in the law itself, it becomes operative on the tenth day after its promulgation in the State Journal (Riigi Teataja).

Art. 55. The State Assembly through its corresponding institutions controls the economic life of the state enterprises and institutions as well as the carrying out of the state budget.

Art. 56. Each member of the State Assembly has the right to put questions at the sittings of the Assembly to the Government. One-fourth of the legal number of members of the State Assembly has the right to interpellate, on which an explanation must be given.

\section{The Government}

Art. 57. The Republican Government executes the governing power in Esthonia.

Art. 58. The Government consists of the State Head (Riigiwanem) and ministers. The number of the latter, their office, and detailed order of business are to be established by special law.

Art. 59. The State Assembly forms the Government and accepts its resignation. On the resignation of a minister, his duties are to be performed by a member of the Government who is nominated by the latter, until a new minister enters into office. Art. 60. The Republican Government direct the home and 
foreign policy, attend to the internal and external security and the observance of the laws. They:

(1) Prepare the estimates of the expenditure and revenue of the State and submit them to the State Assembly for approbation.

(2) Appoint military and civil officials to post and dismiss them, in so far as this duty is not confided by the laws to other institutions.

(3) Conclude treaties with other states on behalf of the Esthonian Republic, and lay them before the State Assembly for ratification.

(4) Declare war and conclude peace on the basis of the corresponding decisions of the State Assembly.

(5) Proclaim a state of defence as well in single parts as in the whole of the state, which they submit to the State Assembly for approbation.

(6) Present the drafts of bills to the State Assembly.

(7) Issue regulations and orders on the basis of the laws.

(8) Decide petitions for mercy.

Art. 61. The State Head represents the Esthonian Republic, leads and unifies the activities of the Republican Government, presides over the meetings of the Government, and is authorized to interpellate any particular minister.

Art. 62. The Republican Government appoints a member of the Government to deputize for the State Head.

Art. 63. The meetings of the Government are secret. Only on special solemn occasions can they be declared public.

Art. 64. The Republican Government must possess the confidence of the State Assembly. The Government or its members have to resign if the State Assembly expresses a direct declaration of absence of confidence in them.

Art. 65. The State Chancery is established by the Republican Government and superintended by the State Head. The State Chancery is directed by the State Secretary, appointed by the Republican Government.

Art. 66. All acts of governing issued by the Government must bear the signatures of the State Head, the respective minister, and the state secretary.

Art. 67. The State Head and ministers can be brought to trial for the usual delinquencies on the basis of the respective decision of the State Assembly only. The examination is within the jurisdiction of the State Court. 


\section{Courts of Justice}

Art. 68. The Administration of justice in Esthonia is exercised in the courts of justice, which are independent in their activities.

Art. 69. The supreme judicial power in Esthonia is exercised by the State Court of Justice, formed of state judges elected by the State Assembly.

Art. 70. These judges, who, according to laws, are not elected, are appointed by the State Court.

Art. 71. Judges can be dismissed only by the Court. Judges can be replaced against their will only in cases depending on the execution of the law.

Art. 72. Judges cannot hold, except in cases foreseen in the law, any other paid engagement.

Art. 73. According to the basis and ways of the corresponding laws, certain categories of criminal acts come under the jurisdiction of the assize court. The previous paragraph is not binding on jurymen.

Art. 74. Extraordinary courts are allowed within the limits of the corresponding laws only in time of war, during a state of defence, and on men-of-war.

\section{Self-Government}

Art. 75. Through the self-government bodies the state power exercises the local governing so far as there is no special institution created by law.

Art. 76. The representative bodies of self-government units are elected by universal, equal, direct, and secret suffrage on the principle of proportional representation.

Art. 77. The self-government units are entitled, for the accomplishment of their object, to levy rates and impose duties within the limits and ways fixed in the law.

\section{Defence of the State}

Art. 78. All Esthonian citizens are obliged, on the basis and ways laid down in the law, to take part in the defence of the Republic.

Art. 79. For the defence of the Republic defence forces are formed, the organization of which will be fixed by special law. 
Art. 80. On the order of mobilization, as also on the beginning of war, the command of the defence forces of the Republic goes from the Republican Government to the special commanderin-chief, the limit of whose power is fixed in a special law.

Art. 81. The Republican Government is entitled, on the basis and ways foreseen in a special law, to pass regulations and instructions concerning the defence forces.

Art. 82. The State Assembly decides as to the order of mobilization of the troops of the Republic.

The Republican Government is empowered to order mobilization without awaiting the decision of the State Assembly if a foreign state has declared war, commenced war activities, or ordered mobilization against the Republic.

\section{State Taxes and Budget}

Art. 83. No public tax or duty can be imposed on anybody unless on the basis of the law.

Art. 84. Out of the expenses of the state no pension, grant, or other remuneration can be allowed unless on the basis of the corresponding law.

Art. 85. For every year the general budget of income and expenditure will be composed for the state. Its validity can be partly prolonged in the legislative way until the passing of the new budget.

\section{Alteration of the Constitutional Law}

Art. 86. The constitution is the unshaken rule for the actions of the State Assembly, courts, and the government institutions.

Art. 87. The initiative for the alteration of the constitution belongs to the people in the way of the initiative of the people, as also to the State Assembly in the ordinary way.

Art. 88. The alteration of the constitution, whether initiated in the way of the people's initiative or by the State Assembly, is decided by the people by way of plebiscite.

Art. 89. The project of the alteration of the constitution must be communicated to the people at least three months before the day of the plebiscite. 


\section{CHAPTER XIX}

\section{FINLAND}

\section{HISTORICAL NOTE}

Upos her reunion with Russia in 1809 Finland was not debased to the status of a province of the Empire. Alexander I entered into a solemn engagement to respect the rights, liberties, and privileges of the country; and his guarantee in this respect was repeated by successive Czars down to Nicholas II in 1891. In theory, therefore, Finland was quasi-independent. The country was governed in so far as applicable under the Swedish constitution of 1772 which had been fundamentally altered by the Act of Union and Security of 1789 . The Czar, as Grand Duke of Finland, merely took the place of the King of Sweden.

But this was all that was necessary for complete Russian domination. The constitution was sufficiently autocratic for the most exacting needs of the Empire. Provision was Actual Russian domination made for a diet or Landtag of four estates-the nobility, the clergy, the bourgeoisie, and the peasants, each estate sitting as a separate house. This diet could be assembled and dissolved at the pleasure of the Government. In point of fact, it was seldom convoked and played little part in the governance of Finland prior to 1863 . In 1869 an organic law of the Diet (amended in 1879 and 1886) was enacted which required convocation of the Diet at least every five years. Even after 1869, however, almost complete political control of the country was in the hands of an appointed Senate which had been established in $\mathbf{1 8 0 9}$.

During the latter half of the nineteenth century the policy of the Russian bureaucracy was to impose upon

Theoretical autonomy after 1809 
"One law, Finland the triple yoke of political autocracy, religious one church, one tongue"

Fundamental laws of 1906,1907 orthodoxy, and linguistic homogeneity-"one law, one church, one tongue." But the spirit of the liberty-loving Finns was not easily broken. They steadily demanded more, not less, self-government. A constitutional crisis was precipitated when in $\mathbf{1 8 9 9}$ an imperial manifesto reduced the Diet to the status of a provincial assembly. This was followed in the next few years by ordinances establishing control over the press and public assemblies, practically incorporating the Finnish troops into the Russian army, and finally in 1903 setting up a dictatorship. But the reverses of Russia in the war with Japan in 1904-05, as well as the revolutionary unrest that was stirring elsewhere in Russia, played into the hands of the Finnish constitutionalists. In November, 1904, following a "national strike," an imperial manifesto "for the establishment of legal order in the country" restored Finland to the political and legal status quo ante 1899. Moreover, this manifesto directed the Senate of Finland to prepare (1) a new organic law of the Diet; (2) a constitution recognizing the power of the national representative assembly and the legality of acts of ministers, and guaranteeing to citizens freedom of speech and of assembly; and (3) a law governing freedom of the press. These three laws were enacted by the Diet in 1906 and 1907.

In 1908 strained relations with the Russian Empire again arose over an order of the Russian ministry which declared that Finnish affairs that concerned also the interests of the Empire must be controlled by the Russian Government. From this time down to the opening of the war in 1914 there was almost constant friction between the Finnish constitutionalists and the Russian bureaucracy. The exigencies of the war finally led to a complete suspension of the Finnish constitution.

In the spring of 1917 the Russian revolution broke. Among the important reforms effected by the coalition 
Cabinet headed by Prince Lvov was the restoration of the constitution of Finland on March 21, 1917. A secessionist movement, however, immediately developed in Finland. It was already well under way when in July Kerensky ousted Lvov and became virtual dictator of Russia. Needless to say this movement was not checked during the months of military and political chaos that followed. In November the proletarian revolution in Russia, led by Lenin and Trotsky, overthrew the Kerensky Government. In December the Finnish Government declared the independence of Finland. Civil war ensued -war between the "Red Guards" or radicals and the "White Guards" or constitutionalists. The latter, assisted by German forces, ultimately triumphed. The government of Finland under Dictator Svinhufvud was completely dominated by German influence. In June, 1918, the government proposed the establishment of a hereditary monarchy; and in October the Diet, from which all Social Democrats had been expelled, elected as King of Finland Prince Frederick of Hesse, brother-in-law of the German Emperor.

The Prince never ascended the throne. For with the military collapse of the Central Powers in 1918 the grip of Germany upon Finland was loosened. In December General Mannerheim, commander of the White Guard, became Regent. Some weeks later Finland was declared to be a Republic. As such the independence of the country was recognized by Great Britain and the United States in May, 1919, as well as by the Peace Conference at Versailles. In July, 1919, a new constitution, drafted by the existing diet, was promulgated. It was not, however, a complete constitution. It was rather in the nature of an amendment of, and an elaborate supplement to, the organic law of 1906, most of the provisions of which are still in force. ${ }^{1}$

\footnotetext{
'The text of the constitution which follows has been translated from the official French version issued at Helsingfors in 1920 . It has been compared with an English text furnished by the Finnish legation in Washington.
}

Secession and independence, 1917

German domination

Constitution of 1919 


\section{THE CONSTITUTION OF FINLAND}

Given at Helsingfors, July 17, 1919

Whereas Finland has become an independent and sovereign state, it has been deemed necessary to develop and consolidate its constitution by new statutes having the character of fundamental laws which, at the same time that they confirm the necessary authority to the executive power, enlarge also the powers of national representation and guarantee the constitutional rights and liberties of citizens. Therefore the present act, in conformity with the decision of the diet taken in accordance with the procedure prescribed by Article 60 of the organic law of the diet of July 20, 1906, gives sanction to the constitution of Finland, the text of which follows.

\section{TITLE I}

\section{General Provisions}

Article 1. Finland is a sovereign Republic, its constitution being established by this law relating to the form of government and by the other fundamental laws.

Art. 2. Sovereign power in Finland belongs to the people, represented by their delegates assembled in a Chamber of Representatives (in Finnish, Eduskunta, in Swedish, Riksdag).

Supreme executive power is vested in the President of the Republic. In addition to the President there shall be for the general government of the state a Council of State (Council of Ministers), consisting of a Minister of State (President of the Council) and of such number of ministers as may be desired.

The judicial power shall be exercised by independent tribunals, and, in final instance, by the Supreme Court and the Supreme Administrative Court.

Art. 3. The territory of the Finnish Republic shall be indivisible. Its boundaries may be modified only with the consent of the Chamber of Representatives.

Art. 4. Finnish nationality appertains as a matter of right to every person born of Finnish parents and to a woman of foreign nationality who has married a Finnish citizen.

A citizen of another country may be admitted to Finnish 
citizenship in accordance with the conditions and procedure specifically regulated by law.

TITLE II

\section{General Rights and Constitutional Protection of Finnish Citizens}

Art. 5. Finnish citizens shall be equal before the law.

Art. 6. Every Finnish citizen shall be protected by law in his health, his honor, his personal liberty, and his property.

The labor power of citizens shall be under the special protection of the state.

Expropriation for public utility purposes with full compensation shall be regulated by law.

Art. 7. Every Finnish citizen shall have the right of sojourn in his country, of freely choosing his place of domicile, and of travelling from one place to another, unless otherwise provided by law.

The right of Finnish citizens to leave the country shall be limited by such special regulations as may be applicable.

Art. 8. Every Finnish citizen shall have the right to worship in public and in private upon condition that he does not violate the law or good morals; he shall be at liberty also, in conformity with the special regulations governing the matter, to leave the religious communion to which he belongs and to join another such communion.

Art. 9. Profession of religion or the fact of belonging to no religion shall have no influence upon the rights and duties of Finnish citizens. In respect to public offices, legal restrictions which are not in conflict herewith shall remain in force until otherwise provided by law.

Art. 10. Finnish citizens shall enjoy freedom of speech and the right of printing and publishing written or pictorial representations without any previous restraint being imposed. They shall also have the right of assembly without previous authorization, for the discussion of public affairs and for all other legitimate purposes, and the right of creating associations for purposes not contrary to the law or good morals.

The rules governing the exercise of these rights shall be established by law.

Art. 11. The domicile of Finnish citizens shall be inviolable. 
The conditions under which domiciliary searches may be ordered and carried out shall be determined by law.

Art. 12. The secrecy of postal, telegraphic, and telephonic communication shall be inviolable.

Art. 13. No Finnish citizen shall be tried by any other tribunal than that which has jurisdiction over him in accordance with the law.

Art. 14. Finnish and Swedish shall be the national languages of the Republic.

The right of Finnish citizens to use their mother tongue, whether Finnish or Swedish, before the courts and the administrative authorities, and to receive papers and decisions in such language, shall be guaranteed by law; care shall be taken that the rights of the Finnish population and the rights of the Swedish population of the country shall be protected in accordance with identical principles.

The state shall provide for the intellectual and economic needs of the Finnish and Swedish populations in accordance with identical principles.

Art. 15. No title of nobility nor other hereditary dignity shall be conferred in the Republic.

Art. 16. These provisions concerning the general rights of Finnish citizens shall constitute no obstacle to the establishment by law of restrictions which are necessary in time of war or insurrection, and in respect to persons in the military or naval service, as well as in other cases.

\section{TITLE III}

\section{Legislation}

Art. 17. The organization and powers of the Chamber of Representatives are regulated by the organic law of the Chamber of Representatives.

Art. 18. The right to propose a new law or the modification, construction, or repeal of a law in force shall be vested in the President as well as in the Chamber of Representatives.

The President of the Republic shall exercise his right of initiating laws by submitting proposals of law to the Chamber. Proposals of law shall be elaborated by the Council of State. The advice of the Supreme Court or of the Supreme Administrative Court or of both of these courts may be requested upon the subject of the proposals thus submitted. The exercise of 
the right of initiating laws by the Chamber itself is determined by the organic law of the Chamber of Representatives.

Art. 19. Laws adopted by the Chamber shall be presented to the President of the Republic for his approval. The President may request the advice of the Supreme Court or of the Supreme Administrative Court or of both of these courts in respect to the subject of such a law, according to the nature of the question involved.

The law must be approved in the text adopted by the Chamber. If a law is not approved by the President, it shall nevertheless be enforced without his approval if the Chamber, after a new election, readopts it without alteration by an absolute majority. Otherwise the law shall be regarded as having lapsed.

If the President, within three months after a law has been presented for his approval, has not approved the same it shall be regarded as having been disapproved.

Art. 20. The preamble of every law shall indicate that it has been enacted in conformity with the decision of the Chamber, and, if the law has been enacted in accordance with the procedure required for the enactment of fundamental laws, the same shall be indicated.

Every law, whether it be approved or whether it be in force without the approval of the President, shall be signed by the President and countersigned by the proper Minister, after which it shall be published in the Bulletin of Laws of Finland.

Art. 21. The right of the President to promulgate ordinances is determined by Article 28.

Art. 22. Laws and ordinances, as well as proposals of law submitted by the Government to the Chamber and the responses, statements, and other addresses by the Chamber to the Government, shall be written in the Finnish and the Swedish languages.

\section{TITLE IV}

\section{Government and Administration}

Art. 23. The President of the Republic shall be elected by the people of Finland from among the citizens of Finland for a term of six years.

The election of the President shall be made by three hundred presidential electors. The regulations in force for elections to the Chamber of Representatives shall apply in respect to the 
right of suffrage and the qualifications of voters in these elections as well as, in so far as these regulations are applicable, to the mode of election, the procedure of voting, and the designation of alternates.

The election of electors shall take place on the fifteenth and sixteenth of January; and on the fifteenth of February following the electors shall assemble under the presidency of the President of the Council in order to proceed to the election of the President. The vote shall be by secret ballot. If a candidate obtains more than half of the votes cast, he shall be declared elected; if this does not result, a new ballot shall immediately be taken, and if no candidate obtains an absolute majority this time, another ballot shall be taken between the two candidates who obtain the highest number of votes on the second count. In case of a tie vote the decision shall be by lot.

If a member of the Chamber is elected President his mandate as deputy shall cease. A public functionary who is elected President shall be regarded as having vacated his office by resignation.

If a day fixed in Paragraph $\mathbf{3}$ of this Article or elsewhere in this constitution falls upon a holiday, the next following work day shall be substituted for it.

Art. 24. The President shall enter upon his duties on the first day of the month of March following his election, and in the presence of the Chamber of Deputies shall make at this time the following solemn declaration:

"I, N. N., elected by the people of Finland President of the Finnish Republic hereby affirm that in the exercise of my presidential functions I will obey and support with loyalty and fidelity the constitution and the laws of the Republic and that I will labor with all my power for the welfare of the Finnish people."

Art. 25. In case of impeachment the functions of the President shall be exercised by the President of the Council. If the impeachment results in conviction, a new President shall be elected as soon as possible, who shall enter upon his duties immediately after the election.

Art. 26. For the exercise of his functions the President shall receive an annual salary, the amount of which shall be fixed by law, which amount shall be neither increased nor diminished during his term of office.

Art. 27. The President shall have power to convoke the 
Chamber of Representatives in extraordinary session, to issue orders for the holding of parliamentary elections, to open and close the Chamber, as well as to decide upon new elections and to dissolve the Chamber.

Art. 28. In cases not otherwise provided for in this constitution, or in case the right has net been vested in the Council of State, the President shall have the right to promulgate ordinances upon matters which have heretofore been regulated by administrative rules, as well as ordinances regulating details in the application of the laws, the administration of the State domains, as well as the organization and operation of administrative services and public institutions. Ordinances shall not contain any regulation implying a modification of the law.

Ordinances shall be given and published as provided in Article 20, Paragraph 2, in respect to the subject of laws.

Art. 29. In particular cases the President may, after having secured the advice of the Supreme Court, exercise the pardoning power by remitting or reducing a penalty. In respect, however, to the pardon of a member of the Council or of the Chancellor of Justice, special stipulations must be complied with. A general amnesty may be granted only by a special law.

The President may also grant exemption from the requirements of the law in case the law permits the granting of such exemption.

Art. 30. The President shall be Commander-in-Chief of the armed forces of Finland; he shall have power in time of war to transfer his command to another.

Art. 31. The President may grant Finnish nationality to a citizen of another country and may release a Finn from his Finnish nationality.

Art. 32. The President shall supervise the administration of the state, and for this purpose he may demand explanations from the chiefs or directors of administrative services and public institutions, and he may cause inspections to be made.

Art. 33. The relations of Finland with foreign powers shall be conducted by the President. Every treaty with a foreign power must be ratified by the Chamber of Representatives if it contains stipulations falling within the domain of legislation or if the constitution requires such ratification for other reasons. Decisions in respect to peace and war shall be taken by the President with the consent of the Chamber.

All communications to foreign powers or to the diplomatic 
representatives of Finland abroad must be made through the minister having jurisdiction over foreign affairs.

Art. 34. The decision of the President shall be made in the Council of State (Council of Ministers) upon the report of the minister to whose department the question involved belongs.

The decisions of the President in order to be valid must be signed by the President and countersigned by the minister who is in charge of the matter. This rule, however, shall not apply to the matters referred to in Articles 32 and 47.

If the decision of the President concerns the entire Council it shall be countersigned by the reporter of the Council. In respect to military questions touching the command, military nominations, and the counter signature of decisions of the President in these matters, special regulations shall be laid down.

The Minister who countersigns a decision of the President shall be responsible for the correctness of the report thereof.

Art. 35. If a Minister regards a decision of the President as contrary to law, he shall inform the Council of State which shall thereupon proceed as is set forth in Article 45. If the decision is contrary to a fundamental law the minister must refuse his counter signature.

Art. 36. The members of the Council of State, who must enjoy the confidence of the Chamber of Representatives, shall be chosen by the President from among the citizens of Finland who are native born and who are known for their honesty and their competence.

The minister under whose jurisdiction affairs relating to the administration of justice are placed, and at least one other minister must be profoundly learned in the law.

Art. 37. The Council of State must have a Chancellor of Justice who must be profoundly learned in the law. The Chancellor of Justice shall be assisted by a Deputy Chancellor of Justice, who in case of need shall take the place of the Chancellor.

Art. 38. The Council of State (Council of Ministers) shall consist of as many ministers as are necessary for the different branches of administration. Each department shall be directed by a minister.

The number of ministers and the general extent of their jurisdiction shall be fixed by law, but the detailed rules governing the apportionment of business among the ministers and the organization of the Council in all other respects shall be decreed by ordinance. 
Art. 39. The Prime Minister shall be President of the Council; in case of impeachment he shall be succeeded by the incumbent minister who is first in point of precedence. When the President of the Republic is present he shall preside over the Council.

Art. 40. The business of the Council of State shall be considered in full session, except in cases in which the decision of certain questions has been, by ordinance, committed to one of the ministers in his capacity as head of a department.

A quorum of the Council shall consist of five members.

Art. 41. The Council shall have power to execute the decisions of the President and to decide matters which it must decide under the terms of the law, as well as other questions of government and administration which have not been reserved to the President in the present constitution or in any other law or ordinance, and which have not been committed to a minister in his capacity as head of a department or to an inferior authority.

Special regulations shall indicate the extent to which matters relating to the administration of justice, the University of Helsingfors, and the military organization are withdrawn from the competence of the Council.

Art. 42. If the Council of State is in doubt as to its competence definitively to decide any matter, the President of the Republic shall settle this question of competence.

Art. 43. The members of the Council of State shall be responsible to the Chamber of Representatives for their administrative acts.

Every member of the Council who has participated in the settlement of any matter by the Council shall be responsible for the decision reached, unless he shall have expressed a different opinion recorded in the minutes.

Art. 44. The questions considered by the Council of State must have been prepared by the department having jurisdiction.

Each minister shall supervise the administration within his sphere of powers and shall take measures to enforce the laws, ordinances, and decisions of the Council.

Art. 45. If it happens that a decision of the President which is presented to the Council for execution is found to be contrary to the law, the Council, after taking the advice of the Chancellor of Justice, must address to the President a request that he withdraw or modify his decision, and, if the President 
nevertheless maintains his ground, the Council must declare that the decision can not be enforced.

Art. 46. The Chancellor of Justice must see that the authorities and functionaries comply with the law and perform their duties to the end that no person shall suffer injury to his rights.

It shall be the duty of the Chancellor of Justice to represent the public authorities in the Supreme Court and in the Supreme Administrative Court, and to look after the interests of the state in these courts, as well as to assist or cause to be assisted prosecutions in other tribunals when he shall deem it necessary. In his capacity as supreme public prosecutor, the Chancellor of Justice must also exercise supervision over those who hold public office, and they must obey his decisions.

The Chancellor of Justice shall have a seat in the sessions of the Council of State, as well as in the sessions of all administrative tribunals and departments, and shall receive reports in writing from the ministers, tribunals, and other authorities.

Art. 47. If the Council of State or one of its members acts contrary to the law in the exercise of his functions, it is incumbent upon the Chancellor of Justice to make a declaration upon the subject, and at the same time to indicate in what respect the act is illegal. If the member is not restrained by this declaration, the Chancellor of Justice shall cause his opinion to be inscribed upon the minutes of the Council and shall also have the right to advise the President in respect to it. If the illegality is of a nature to involve a prosecution against the member in interest before the High Court mentioned in Article 59, and if the President directs the arraignment, the latter shall be supported by the Chancellor of Justice. If the President finds that there is no ground for the arraignment, the Chancellor of Justice shall be free to pursue the case before the Chamber of Representatives. If the President decides upon an arraignment of the Chancellor of Justice, the indictment shall be prosecuted by the person designated by the President for that purpose.

If the President in the exercise of his functions is about to commit illegal acts, the Chancellor of Justice must make a declaration upon the subject as provided above. If the Chancellor of Justice or the Council of State finds that the President is guilty of high treason or of treason, the Chancellor or the Council shall report this fact to the Chamber of Representatives. And in case the Chamber, by a three-fourths majority vote, decides to arraign the President, the Chancellor must prose- 
cute him before the Supreme Court, and in the meantime the President shall abstain from the exercise of his functions. Except in the cases above provided the President shall not be arraigned for his administrative acts.

Art. 48. The Chancellor of Justice must make each year to the President as well as to the Chamber of Representatives a report upon the measures that he has taken and upon his accomplishments in respect to the enforcement of the laws.

The Chancellor of Justice upon request must give the Chamber of Representatives and the Council of State information and advice.

Art. 49. At each regular session the Chamber of Representatives shall elect in accordance with the procedure provided for the election of its own President, a person distinguished in the law who shall be the Solicitor of the Chamber. The Solicitor, in conformity with the instructions given him by the Chamber, shall supervise the enforcement of the laws in the proceedings of courts and other authorities. There shall be elected also, in accordance with the same procedure, a Deputy Solicitor who shall act for the Solicitor in case of the latter's disability.

The Solicitor shall have the same right as the Chancellor of Justice to be present at the sessions of the Council of State and the sessions of administrative tribunals and departments, the right to receive written reports from the Council of State, ministers, tribunals, and other authorities, and, under the responsibility imposed by law upon public authorities, the right to prosecute or cause to be prosecuted complaints for malfeasance or nonfeasance in office.

The Solicitor must make annually to the Chamber of Representatives a report of the manner in which he has performed his functions, of the state of the administration of the law, and of the defects which he has noticed in legislation.

Art. 50. From the point of view of general administration, Finland shall remain divided into departments, judicial districts, and parishes.

Every modification in respect to the number of provinces shall be made by law; the Council of State shall decide all other changes in reference to administrative divisions not otherwise provided by law.

In case of new delimitations of districts the new districts, wherever the circumstances permit, must be so formed as to 
include populations speaking only one language, Finnish or Swedish, or so that the minority speaking the other language shall be as small as possible.

Art. 51. The provinces shall be administered by governors. The administration of the communes shall be established upon the principle of local autonomy in accordance with the regulations prescribed by special laws. The manner and extent of local autonomy to be applied in districts wider than communes shall be regulated by law; the regulations contained in Article 50, Paragraph 3, shall be followed in fixing the boundaries of these districts.

Art. 52. Administrative services now existing or hereafter created for different branches of the administration of the state shall be governed by special regulations.

\section{TITLE V \\ The Judiciary}

Art. 53. The Supreme Court is the court of final resort in suits at law; moreover it shall supervise judges and executive authorities in their administration of justice.

Art. 54. The Supreme Court shall be composed of a Chief Justice and of the necessary number of associate justices.

Matters pertaining to the judicial administration which, by reason of special regulations, fall within the jurisdiction of the Supreme Court shall be prepared by the department to which questions concerning the administration of justice are assigned. The head of the department shall participate in deliberations of the Supreme Court upon such matters.

In the Supreme Court questions may be examined and decided by five members, provided however that for the examination and decision of certain questions a larger or smaller number of members may be provided by special law.

Art. 55. Tribunals of first instance and of appeal shall be established by law.

Art. 56. The court of last resort in suits involving administrative law shall, except as otherwise specially provided, be the Supreme Administrative Court, which shall also supervise inferior authorities in their administration of justice in the field of administrative law.

Art. 57. The Supreme Administrative Court shall be composed of the President and of the necessary number of associate 
administrative justices. The provisions of Article 54, Paragraph 3, shall apply also to this court.

Art. 58. The Supreme Court and the Supreme Administrative Court shall have the right, when they think that a modification or interpretation of a law or ordinance is necessary, to address to the President a note requesting that such legislation be enacted.

Art. 59. In case of the arraignment of a minister, of a member of the Supreme Court or of the Supreme Administrative Court, or of the Chancellor of Justice, for an illegal act committed in the exercise of their functions, the case shall be tried by a special court called the High Court which shall be established by special regulations having the character of a fundamental law.

If the Chamber of Representatives makes the arraignment, it shall be prosecuted by the Solicitor of the Chamber.

Art. 60. Special tribunals other than that mentioned in Article 59 shall be provided for by law.

No extraordinary tribunal shall be established.

TITLE VI

\section{Public Finance}

Art. 61. Imposts including customs duties shall be prescribed by law for a limited or indeterminate period. In the same way the abolition or modification of a previously established impost and of compulsory public services shall be regulated by law.

An impost established for a limited period shall not be collected beyond such period except in the case provided in Article 69, Paragraph 1.

Art. 62. The general principles in respect to fees for acts of public authorities, and for documents, as well as in respect to taxes to pay for the use of the post, the railroads, the canals, the hospitals, the schools, and other public establishments belonging to the state, shall be regulated by law.

Art. 63. Revenue producing properties and enterprises belonging to the state shall be exploited and utilized according to general principles established by law.

Art. 64. The consent of the Chamber of Representatives shall be necessary for the issue of a loan.

Art. 65. The principles governing new budgets for administrative services and public institutions, as well as the modifica- 
tion and abrogation of principles previously established, shall be regulated by law, as shall also the matter of pension rights. New employments and services shall be created only within limits of the annual budget.

New extraordinary pensions or subventions shall be granted only upon credits voted for this purpose by the Chamber of Representatives.

Art. 66. The annual budget proposal, in which must be included the receipts and expenses for the budgetary year, shall be adopted by the Chamber of Representatives and promulgated in the same manner as is required for the promulgation of laws. Special regulations shall determine whether a fund which does not aim to meet the annual expenses of the state shall be excluded from the budget proposal.

Art. 67. In the budget proposal of any fixed year, no impost or other revenue may be passed over, which, according to the laws or ordinances in force for the year in question, must be collected.

Art. 68. Interests and annuities for the amortization of debts and other funds designated for some state obligation, as well as expenses which must be paid in accordance with regulations in effect during the budgetary year, must be carried, without deductions, as part of the budget proposal. This proposal must also include amounts covering expenses based upon laws or ordinances but not carried in the budget proposal as special items, as well as necessary credits placed at the disposal of the Government for unexpected needs.

Other expenses included within the budget proposal shall be subject to examination and decision by the Chamber of Representatives for a single budgetary year at a time.

Credits voted by the Chamber of Representatives upon parliamentary initiative shall be conditionally inserted in the budget proposal.

The budget proposal must show resources sufficient to cover expenses.

Art. 69. If the budget is not adopted by the Chamber of Representatives before the beginning of the year, although the proposal has been submitted by the Government at least two months prior to the expiration of the Parliamentary session, the expenditures mentioned in Article 68, Paragraph 1, shall be paid, and the revenues necessary for this purpose shall continue to be collected provisionally. 
If modifications in the approved budget proposal appear to be absolutely necessary, a supplementary budget proposal shall be presented to the Chamber of Representatives.

Art. 70. The credits carried in the budget proposal shall not be exceeded, nor shall they be carried over from one financial year to another, unless provisions for this are made in the budget proposal, nor shall a credit be transferred from one part of the budget proposal approved by the Chamber of Representatives to another part of the budget.

Independently of the budget every person shall have the right to demand from the state treasury what is legally due him.

Art. 71. For the examination of treasury accounts there shall be a bureau of audit of accounts, which must satisfy itself that the figures carried in the accounts are correct, that the receipts and expenditures are legally entered, and that the budget proposal is complied with.

At every regular session of the Chamber of Representatives provision shall be made for five auditors of state finances who shall be charged on behalf of the Chamber with seeing that the budget proposal is complied with and with examining the condition and administration of the treasury. These auditors shall be under instructions prescribed by the Chamber and shall have power to receive from the competent authorities information and documents. They shall be elected by the members of the Chamber according to the method of proportional representation. In the same manner there shall be elected also the necessary number of alternates.

Art. 72. The currency of Finland shall be regulated by law.

Art. 73. The Bank of Finland shall be placed under the guarantee and protection of the Chamber of Representatives and under the supervision of directors elected by the Chamber of Representatives.

The Bank of Finland shall be administered in accordance with procedure prescribed by law.

The Chamber shall determine how the profits of the Bank shall be used for the needs of the state.

Art. 74. Landed property, funds, imposts, or revenue-producing rights of the state shall not be alienated or hypothecated except as authorized by law.

The occupier of a crown domain shall nevertheless have the right to purchase such domain for inheritance in accordance with special regulations upon this subject. 
TITLE VII

\section{National Defense}

Art. 75. Every Finnish citizen is required to participate in the defense of the country or to make his contribution to the defense in accordance with the requirements of law.

Every conscript, unless he otherwise desires, shall if possible be incorporated into a troop the members of which speak his own mother tongue (Finnish or Swedish), and shall receive his instruction in that language. Finnish shall be the language of command of the armed forces.

Art. 76. If it becomes necessary to put troops upon a war footing the President shall present an ordinance for this purpose at a session of the Council of State. When this order has been given, the Council shall take under consideration the necessary measures to cover the expenditures which result, and the Chamber of Representatives shall be convoked in case it is not in session.

\section{TITLE VIII}

\section{Education}

Art. 77. The University of Helsingfors shall retain its right of autonomy.

New regulations in respect to the principles of organization of the University shall be promulgated by law; but details in respect to the University shall be regulated by ordinance. In both cases the Consistory of the University must be previously consulted.

Art. 78. The state shall promote the study of, and higher instruction in, the technical, agricultural, and commercial sciences and other applied sciences, as wcll as the practice of, and higher instruction in, the fine arts, by supporting and creating for all of these branches special schools of higher learning in so far as these are not represented at the University, or by giving grants in aid to private institutions created for this purpose.

Art. 79. Institutions giving scientific instruction or general intermediate instruction or higher primary instruction shall be supported at the expense of the state or, if need be, by grantsin-aid. The principles of organization of the secondary schools of the state shall be established by law.

Art. 80. The principles of organization of primary instruc- 
tion and in respect to the obligations of the state and municipalities to support primary schools, as well as on the subject of compulsory education, shall be determined by law.

Instruction in the primary schools shall be free to all.

Art. 81. The state shall support, or in case of need shall give grants-in-aid to, institutions for instruction in the technical professions, in agriculture and its allied pursuits, in commerce and navigation, and in the fine arts.

Art. 82. The right to establish private schools or other private institutions of instruction and to organize instruction therein shall be regulated by law.

Instruction given at home shall be subject to no supervision by the authorities.

\section{TITLE IX}

\section{Religious Associations}

Art. 83. The organization of the Evangelical Lutheran Church and its administration shall be regulated by ecclesiastical law.

Other existing religious associations shall be governed by rules which are or shall be prescribed in respect to them.

New religious associations shall be established in accordance with the requirements of law.

\section{TITLE $\mathbf{X}$}

\section{Public Offices}

Art. 84. Except as otherwise provided in this Article only Finnish citizens shall be appointed to public office.

Employments of a technical nature, teaching positions in the University or other schools of higher learning, positions of professor of modern languages in the schools, and of translators in the administrative services, as well as non-remunerative consular posts and the posts of clerical assistants and other special positions in legations and consulates, may be held by other than Finnish citizens.

Art. 85. Examinations for appointment to public office shall be regulated by ordinance except where such matters are regulated by law. Exemption from the prescribed merit requirements may for special reasons be granted by the Council of 
State; this concession, however, shall not apply to employments in the judicial service.

Art. 86. The general principles upon which appointment to public offices of the state may be made shall be merit, capacity, and proved civic virtue.

Art. 87. The President of the Republic shall appoint:

(1) The Chancellor of Justice and his Deputy;

(2) The Archbishop and Bishops and the Chancellor of the University;

(3) The Chief Justice of the Supreme Court and the President of the Supreme Administrative Court, and upon nomination by the Supreme Court, the members of that court and the presidents of the courts of appeal as well as, upon nomination by the Supreme Administrative Court, the members of that court;

(4) The members of the courts of appeal and the professors in the University and in the Technical High School;

(5) The heads of the central administrative offices and the governors, upon nomination by the Council of State, and also members of the central administrative offices;

(6) The officers in the President's Chancery and, upon nomination by the proper authority, the reporters to the Council of State, to the Supreme Court, and to the Supreme Administrative Court, and finally;

(7) Ministers plenipotentiary and consuls, upon nomination by the Council of State.

Art. 88. Judges of rural tribunals of first instance, burgomasters, and presidents of land-partition courts shall be appointed by the Supreme Court.

In compliance with special regulations appointment to certain employments shall be made as follows:

(1) to tribunals, by the Supreme Court or the superior court in whose jurisdiction the employment falls, and to the Supreme Administrative court, by that court; and

(2) in administrative offices and schools, by the Council of State, the minister, the provincial government, or the head of the office to which the employment belongs.

Appointment to other offices shall be made by the Council of State, unless the right of appointment has been reserved to the President or committed to some other authority.

Art. 89. In filling vacancies in the central administrative offices and the employments mentioned in Article 87, Para- 
graph 4, and in Article 88, and subject to the reservation of different regulations prescribed in Article 90, the position shall first be declared open for the declaration of candidacies. A proposal shall thereupon be prepared, to serve as a basis for the appointment, in which the official who has received the applications of candidates shall place the three candidates best qualified in accordance with the principles established. When it is a matter of filling a vacancy in the membership of a court of appeal, the opinion of the Supreme Court shall be requested on the subject of this proposal.

If the appointment is made by the same authority to whom the applications are addressed, no nomination is made. In accordance with special regulations certain other administrative employments may also be provided for in a manner other than that indicated in Paragraph 1.

Art. 90. The procedure of making appointments to office in the University, in the Evangelical Lutheran Church and the Greek Orthodox Church, to the office of burgomaster and of aldermen in cities, and to offices and employments in the Bank of Finland shall be governed by special regulations.

Officers of the army and of the navy shall be appointed by the President. Regulations governing promotion and military instruction shall be established by special acts.

Art. 91. No judge shall be deprived of his office except by a lawful trial and judgment. The transfer of a judge shall take place only upon the reorganization of the judicial establishment or at his own request.

The right of other officers to retain their offices shall be regulated by a special law.

The law may impose, even for irremovable officers, an obligation to retire at a fixed age or because of infirmity involving incapacity for work.

Special regulations shall define the rights and duties of officers whose offices are abolished.

Art. 92. In the exercise of public functions the law must be strictly followed upon penalty of the officer's being held accountable.

If an ordinance regulation is contrary to a fundamental or other law, it shall not be enforced by a judge or other officer.

Art. 93. Every officer is responsible for the measures that he takes or to which he contributes in his capacity as a member of a collegiate administrative office. A reporter is likewise 
responsible for a decision taken upon his report unless he has recorded his dissenting opinion in the proceedings.

Whoever suffers a violation of his right or injury as a result of an illegal measure or of the negligence of an officer has the right to demand that this officer be condemned to pay a penalty and damages or to lay an information against him demanding his arraignment in accordance with the formalities prescribed by law.

The responsibility of the state for damages caused by an officer shall be governed by special regulations.

TITLE XI

\section{Final Provisions}

Art. 94. The election of the first President of the Republic shall be made by the Chamber of Representatives and shall take place immediately after the present constitution goes into effect. The election shall be by secret ballot. If a candidate obtains more than half of the votes cast he shall be proclaimed elected. If this does not result, a new ballot shall immediately be taken, and if no person obtains this time an absolute majority, another ballot shall be taken between the two candidates who on the second count obtain the largest number of votes. In case of a tie vote it shall be decided by lot.

Art. 95. The present constitution shall be in all of its parts an irrevocable fundamental law. It may be modified, explained, or repealed, and may be departed from only in accordance with procedure provided for the alteration of fundamental laws in general.

The following laws are repealed by the present law: The Form of Government of August 21, 1772, and the Act of Union and of Security of February 21 and April 3, 1789, as well as of provisions that appear in other laws and regulations which are in conflict with the present constitution.

The provisions necessary to put the present constitution into effect shall be promulgated by law.

Notice of this constitution is hereby given to whom it may concern to be followed and obeyed.

Helsingfors, July 17, 1919.

Regent:

MaNNerhem

Minister of Justice: SöDERHOLM. 


\section{EXCERPTS FROM THE ORGANIC LAW OF THE LANDTAG ${ }^{1}$}

July 20, 1906

\section{CHAPTER I}

\section{General Principles}

Article 1. The Landtag of the Grand Duchy (Republic) of Finland shall represent the people of Finland.

Art. 2. The Landtag shall consist of a single chamber of two hundred members.

Art. 3. The election of members of the Landtag shall take place every three years, at the same time throughout the country. The mandate of the members of the Landtag shall begin as soon as they have been declared elected and shall continue until the next election shall have been held. The Emperor and Grand Duke (the President of the Republic) shall always have the right, if he deems it necessary, to order new elections prior to the expiration of the triennial period mentioned in the first sentence of this Article. In such case, a dissolution of the Landtag shall take place and the mandate of the newly elected members shall continue for three years.

Art. 4. The members of the Landtag shall be elected by a direct vote of the people and according to the principles of proportional representation. The country shall be divided for these elections into not less than twelve nor more than eighteen electoral districts. When local circumstances necessitate a derogation from the principle of proportional representation, there may be established in addition to the number mentioned above one or two districts for the election of single members of the Landtag. All the electors shall have equal voting rights. The right to vote shall not be exercised by proxy. Special regulations in respect to electoral districts, and the time at which and the manner in which elections shall be held, shall be established by a separate electoral law. ${ }^{2}$

\footnotetext{
'Translated from Dareste, Les constitutions modernes, Vol. II, p. $204 \mathrm{ff}$. (\$d ed., Paris, 1910). Essential changes in this law, by reason of the constitution of 1919, are indicated in parentheses.

2This electoral law was promulgated on the same day in which the organic law of the Landtag was enacted. It embraced eighty articles and embodied the principle of proportional representation. See above, p. 96.
} 
Art. 5. The right to participate in the election of members of the Landtag shall belong to every Finnish citizen, man or woman, who has attained the age of twenty-four years prior to the year of the election. The following persons shall not enjoy the right to vote:

(1) Those who are in the active military service;

(2) Those who are under guardianship;

(3) Those who for three previous years have not been registered in Finland;

(4) Those who for any cause other than lack of resources, certified by attestation of the communal administration, have failed to pay the taxes imposed upon them for the two previous years;

(5) Those who have personally received poor relief except where such relief was purely accidental;

(6) Those who have gone into bankruptcy for the satisfaction of creditors, until they shall have declared under oath that satisfaction has been made;

(7) Those who have been condemned to public work on account of vagrancy, until the expiration of the third year following their release;

(8) Those who by reason of a regular adjudication have been declared discredited or unworthy to be employed in the service of the state or to solicit such employment for others;

(9) Those who have been convicted of having bought or sold votes at a Landtag election or of having attempted to do so, or of having voted in place of another voter, or of having interfered with the freedom of the vote by violence or intimidation, until the expiration of the sixth year after that in which the final judgment has been rendered.

Art. 6. Every elector shall be eligible to a seat in the Landtag without respect to his place of domicile.

Art. 7. Every functionary who attempts to use his authority in order to influence an election to the Landtag shall lose his office. Whoever shall by promises or bribery interfere with freedom of voting shall be punished by imprisonment for not more than three years. In case of violence or intimidation the punishment shall be imprisonment for not less than a month nor more than a year. If the guilty person is a functionary he shall in addition lose his office. An employer who does not give to his employees, as far as possible, full opportunity to exercise the right of voting shall be punished by fine. 
Art. 8. Those who, in conformity with the electoral law, have been declared elected as members of the Landtag shall not resign their mandate unless they can present a legitimate excuse or some other reason satisfactory to the Landtag.

Art. 9. The members of the Landtag shall be held to perform their duties in accordance with right and truth. They are in consequence compelled to observe the constitutional laws and are not bound by any other restriction.

Art. 10. Members of the Landtag may not refuse to attend the Landtag and to exercise their functions.

Art. 11. Members of the Landtag may not be indicted nor deprived of their liberty because of the opinions expressed by them, nor in general because of their conduct during debates, unless the Landtag shall authorize such action by a vote of at least five-sixths of the members present.

Art. 12. During the sessions of the Landtag no member shall without authorization of the Landtag be arrested for a misdemeanor, unless his arrest has been ordered by a judge, or unless he has been taken in an act punishable by at least six months' imprisonment. If a member of the Landtag is arrested on his way to the Landtag for an offense other than that set forth in the first sentence of this paragraph he shall be set at liberty, provided the Landtag shall so decide. Notice of the arrest of any member of the Landtag shall immediately be given to the President.

Art. 13. If in proceeding to or returning from the Landtag, or during its sessions, a member shall be insulted or assaulted, and if the offense shall have been committed with full knowledge of his membership in the Landtag, or if, after the session, the member is the victim of violence because of the manner in which he has exercised his powers, the fact that the misdemeanor has been committed against a member of the Landtag shall be considered as a peculiarly aggravating circumstance. The same shall apply in respect to the secretaries and employees of the Landtag.

Art. 14. The members of the Landtag shall receive a salary payable out of public funds and in addition their expenses in travelling to and from the Landtag. Their salary shall be fourteen hundred marks for every regular session, or if the Landtag is dissolved or if its business has been completed less than ninety days after the opening of the session, the salary shall be fifteen marks per day. During regular sessions which are held 
after a dissolution of the Landtag, and after new elections have taken place at a period other than the regular period, as well as during extraordinary sessions, the salary shall be determined as indicated in the second instance above, but the salary shall not exceed a total of four hundred marks.

Art. 15. If a member of the Landtag fails to present himself upon the day prescribed for the opening of the session, or if he fails to attend the meetings without permission of the Landtag, and if he can not present an excuse satisfactory to the Landtag, he may be condemned by the Landtag to a loss of fifteen marks of his salary for each day of his absence and in addition to a fine which must not exceed fifteen marks. If such a member fails to pay his fine, the Landtag may declare his mandate forfeited.

\section{CHAPTER II}

\section{Opening, Dissolution, and Adjournment of the} LANDTAG

Art. 16. The opening of the Landtag shall take place at the capital of Finland (Helsingfors), except when an invasion by the enemy or some other serious obstacle renders this impossible or dangerous to the security of the State, in which case another place of meeting shall be indicated by the Emperor and Grand Duke (the President of the Republic).

Art. 17. The Landtag shall assemble every year in regular session upon a call specially issued for each occasion on the first day of the month of February, unless the Emperor and Grand Duke (the President of the Republic) fixes another day of the year, and it shall adjourn under a standing order the ninetieth day following, unless the Emperor and Grand Duke (the President of the Republic), pursuant to his own personal judgment or in conformity with a request of the Landtag, decides that the adjournment of the session shall be advanced or deferred. If one of the dates mentioned in the preceding sentence or in any other article in this law falls upon a holiday, the first day following the holiday shall be taken for the date fixed.

Art. 18. If the Emperor and Grand Duke (the President of the Republic) calls a new election during the course of a regular session, the Landtag shall adjourn to a day fixed by the Emperor and Grand Duke (the President of the Republic). In such case the Landtag shall reassemble again in regular session after the new elections on the first day of the month that commences 
immediately after the ninetieth day following the dissolution, or upon an earlier date fixed by the Emperor and Grand Duke (the President of the Republic). If a new election is ordained after the adjournment of the regular session, and if the election can not be held before the first day of the month of February following, the reassembling of the Landtag in regular session shall be postponed to the first day of the month which follows the proclamation of the result of the vote.

Art. 19. The Emperor and Grand Duke (the President of the Republic) shall have power to convoke the Landtag in extraordinary session and to decide when it must adjourn. The Landtag may not be called in extraordinary session upon less than fifteen days' notice, and the session can not be prolonged beyond the last day, not a holiday, preceding the opening of the regular session. In an extraordinary session the Landtag may deal only with those matters for which it was convoked or which are submitted to it by the Emperor and Grand Duke (the President of the Republic), as well as with such questions as are inseparably connected with those matters.

Art. 20. The orders of the Emperor and Grand Duke (the President of the Republic) mentioned in Articles 16, 18, and 19 shall be published in the manner prescribed for the promulgation of the laws in Finland. The order calling for new elections shall moreover be transmitted to the governors and to authorities or councils charged with the conduct of the elections.

Art. 21. On the day on which the Landtag assembles the members of the Landtag shall present their credentials, beginning at eleven o'clock in the morning, in the order which shall be determined by a posted placard, to the person or persons designated by the Emperor and Grand Duke (the President of the Republic) for the purpose of verifying these credentials. When credentials are presented for the first time, they shall be examined to see whether they have been drawn up by a competent authority and in the form prescribed. A list of the members duly seated shall be returned to the Landtag on the next day, before ten o'clock in the morning. Every member of the Landtag who arrives after the beginning of the session shall take his seat after having presented to the President of the Landtag his credentials, regularly verified as required in the first sentence of this Article.

Art. 22. When the credentials of a member of the Landtag have been refused, the Landtag shall have the right to inquire 
whether there is any justification for the seating of such a member. If in the course of the session a contest, founded upon this law, is raised in respect to the qualification of a member of the Landtag to take his seat, the examination of this contest shall always be undertaken by the Landtag, unless this same contest has already been or may still be submitted to the decision of the competent authority by way of an election appeal. The question of the validity of elections may not be otherwise debated in the Landtag, unless the contest turns upon a manifestly unlawful act which took place at the time of the election or of the electoral procedure, or upon an indisputable error in the proclamation of the result of the vote. In such case, when it is evident, not only that the offense or error may have exercised an influence upon the result of the vote, but also that it could not possibly be remedied by way of appeal, the Landtag may for this purpose take any measures that are compatible with the provisions of the electoral law. The member of the Landtag whose seat is under contest shall continue, nevertheless, to exercise his mandate until it shall have been declared invalid.

Art. 23. On the day following, the Landtag shall assemble at ten o'clock in the morning in full session, which shall be opened by calling the roll upon the list mentioned in Article 21. In this full session the Landtag shall elect from among its own members a President (Talman) and two Vice-Presidents. Thereupon the President and the Vice-Presidents, one after the other, in the presence of the assembled Landtag, shall make the following affirmation: "I, N. N., promise that in the exercise of my duties as President, I will maintain with all my power the right of the Emperor and Grand Duke (the President of the Republic), as well as of the Landtag and of the people of Finland, in conformity with the constitutional laws." Until these formalities shall have been observed, the oldest member of the Landtag shall act as President. The minutes shall be taken by such person as this oldest member shall choose for this purpose. The secretaries and the personnel of the secretariat shall be named in such manner as may be determined by the Landtag. Upon the day and at the hour fixed by the Emperor and Grand Duke (the President of the Republic) the members of the Landtag, after divine service, shall assemble in the hall of the throne, where the Emperor and Grand Duke (the President of the Republic) or his delegate shall welcome the Landtag and declare 
the session open, after which the Landtag, speaking through its President, shall express its respects.

Art. 24. At the close of the session the members of the Landtag shall assemble, after divine service, on the day and at the hour fixed by the Emperor and Grand Duke (the President of the Republic) in the hall of the throne, where the President of the Landtag in the presence of the Emperor and Grand Duke (the President of the Republic) or his delegate shall express the respects and good wishes of the Landtag and shall present the minutes of the Landtag; whereupon the Emperor and Grand Duke (the President of the Republic) or his delegate shall declare the session closed.

CHAPTER III

Concerning the Introduction of Business in the Landtag

CHAPTER IV

Concerning the Apportionaent of Business

CHAPTER V

Discussion of Business in Full Session and in the Committee of the Whole

CHAPTER VI

Measures Concerning the Bank of Finland

\section{CHAPTER VII}

Concerning the Communication of the Decisions and Declarations of the Landtag

Art. 75. When the Landtag shall enact a law, upon the proposal of the Emperor and Grand Duke (the President of the Republic), directed toward the establishment, modification, interpretation or abrogation of a constitutional law, or upon a proposal or motion concerning one of those other laws which require the coördinate decision of the Emperor and Grand Duke (the President of the Republic) and of the Landtag, the proposal shall be transnitted with a mcssage by the Landtag for examination 


\section{NEW CONSTITUTIONS OF EUROPE}

by the Emperor and Grand Duke (thePresident of the Republic), in order to receive his sanction and be converted into law. If the project is not approved without amendment by the Emperor and Grand Duke (the President of the Republic), and if in consequence it fails entirely, notice to this effect shall be given to the Landtag at the first session which follows the decision of the Emperor and Grand Duke (the President of the Republic) in respect to the matter. All other decisions and declarations made by the Landtag in response to proposals and requests made by the Emperor and Grand Duke (the President of the Republic), as well as all petitions to the Emperor and Grand Duke (the president of the Republic) voted by the Landtag shall likewise be transmitted to the Emperor and Grand Duke (the President of the Republic) in the form of messages from the Landtag.

Art. 76. Messages emanating from the Landtag and the minutes of the Landtag shall be drawn up and dispatched by a special committee called the committee of dispatch. No dispatch shall be delivered as proceeding from the Landtag until it shall have been approved by the Landtag or by a committee of revision. Committees of dispatch and of revision shall be composed of nine members each and of the necessary number of alternates.

Art. 77. The minutes of the Landtag, as well as petitions emanating from it, shall be signed by all the members of the Landtag; other messages shall be signed only by the President and the Vice-President.

CHAPTER VIII

\section{Special Provisions}

Art. 78. Proposals from the Emperor and Grand Duke (the President of the Republic), reports of committees, messages from the Landtag to the Emperor and Grand Duke (the President of the Republic), the journal and the minutes of the Landtag shall be printed and published.

Art. 79. The expenses of the Landtag shall be paid by the treasury department.

CHAPTER IX

Final Provision

This organic law of the Landtag, which repeals the organic law of the Landtag of Finland of April 15, 1869, the manifes- 
tos of March 2, 1879, June 25, 1886, and December 14, 1897, shall be as to all of its provisions an inviolable constitutional law until it shall have been amended or repealed by concurrent decision of the sovereign (the President of the Republic) and of the Landtag of Finland.

All of the provisions of law that are in force in respect to the States of Finland shall apply to the Landtag created by this constitutional law, except such provisions as are contrary to this organic law. 



\section{APPENDICES}





\section{APPENDIX I}

\section{BELGIUM}

\section{HISTORICAL NOTE!}

“'The Protocol of June 21, 1814² united Belgium with Holland, and the constitutional law of the Netherlands, promulgated on August $27,1815,{ }^{3}$ was therefore common to the two countries until the Belgian revolution of August 25,11830. A National Congress of Belgians was convened on November 10, 1830, but even before it met, the provisional government of Brussels, by

\footnotetext{
1The Belgian constitution had a material influence on the provisions of the new European constitutions and has recently been subjected to a considerable revision. For these reasons it is included in the present volume. The changes effected in 1921 are translated from the French text, "La Constitution belge revisée," Revue du droit public et de la science politinue, Vol. XXXIII, p. 553 (Octobre-Nov.-Déc. 1921). The articles revision of which was proposed by the legislature in 1919 were the following: 26,27 clause $2,39,47,48,49,50,51,52$, $53,54,55,56,56 \mathrm{~A}, 57,59,69,95$ clause $1,104,105,106,108$ clause 2 , paragraph $2,122,123,131$. Articles that were actually revised by the new legislature in 1921 were: $47,48,50,51,52,53,55,56,56 \mathrm{~A}, 57,108$ clause $\&$, paragraph 2 , and 122. Articles 27 clause 2 and 123 were abrogated. The transitional provisions in Articles 47, 52, 53,56A, and the whole of Articles 56B and 56C were added.

The text of the articles which were not amended in 1921 is that given by H. F. Wright, Ed., The Constitutions of the States at War, 1914-1918, p. 43 (Washington, Government Printing Office, 1919). This "translation is based upon W. F. Dodd, Modern Constitutions, Vol. I, pp. 126-148 (Chicago, 1909), which is based in part on the translation of J. M. Vincent and A. S. Vincent in the Supplement to the Annals of the American Academy of Political and Social Sciences, May, 1896, pp. 309-333 (Philadelphia, 1896)." English translation (by Francis B. Lee) of the Constitution of 1831 without the amendments of 1893 appears in Foreign Constitutions [The Convention Manual of the Sixth New York State Constitutional Convention, 1894, Part 2, Vol. 3] pp. 35-54 (Albany, 1894). French text in Dareste, Les constitutions modernes, Vol. I, pp. 74-95 (Paris, 1910), and a German translation in Paul Posener, Die Staatscerfassungen des Erdballs, pp. 2-16 (Charlottenburg, 1909).

In the translation of the new provisions the idiom of the old text has in some cases been adopted even though it may differ from that used in the other constitutions specially translated for this volume. The footnotes, with the exception of those relating to the 1921 revision, are taken from Wright, op cit., as are the quoted paragraphs of this historical introduction.
}

2Signed at Vienna on June 14 and approved at Paris on June 21. French text in Martens, Nouveau Recueil, Supp. 1: p. 330; English translation in Hertslet, Map of Europe by Treaty, Vol. I. p. 40 (London, 1875).

${ }^{3}$ French text in British and Foreign State Papers, 3: pp. 16-43. 
decrees of October $6,7,8,9$, and 14, 1830, named a committee of twelve to prepare an outline of a constitution. This committee declared itself in favor of the adoption of a constitutional monarchy as the form of government. The National Congress proclaimed the independence of Belgium on November $18,{ }^{1}$ and adopted the monarchical form of government and the bicameral system of representation on November 22. The constitution was drafted on the basis of the outline adopted by the committee of twelve and was passed in its entirety on February 7, 1831, which is the date officially given to it, although it was not promulgated until February 11.2 Leopold of Saxe-Coburg became King in June of the same year. The Belgian constitution of 1831 remained unaltered for over 60 years, and proposals for its revision were rejected by large majorities in 1871, 1883, and 1887.

"In 1892, however, the three powers of the state united in asking for the revision of 13 articles of the constitution, the special object of the reform being the electoral system of the two houses. New houses were elected on June 14 following, in conformity with Article 131 of the constitution. A series of decrees, all dated September 7, 1893, promulgated the text of the revised articles. ${ }^{3}$

"In accordance with a treaty signed at Brussels on November 28, 1907,4 the administration of Congo Free State was taken over by Belgium, and, by a royal decree of November 4, 1908, the date November 15 was fixed for the actual assumption of the exercise of the sovereign rights. On October 18, 1908,5 a separate constitutional law for the Congo was sanctioned by the King." 6

The revision of 1921 was proposed by the chambers elected in 1919. They decided on the abandonment of plural voting, introduced proportional representation into the constitution, ${ }^{7}$ and refused to propose the referendum; but they found difficulty in agreeing upon a new organization for the Senate. The plan finally adopted is, in the phrase of a Belgian writer, a "hybrid

\footnotetext{
1 French text of the Proclamation in British and Foreign State Papers, 17: p. 1241.

${ }^{2}$ French text of the Proclamation in British and Foreign State Papers, 1s: p. 1052.

${ }^{3}$ French text of the decrees, each of which contains one revised article, in British and Foreign State Papers, 85: pp. 783-788.
}

-French text in British and Foreign State Papers, 100: pp. 705-706.

'French text of the Law of October 18, 1908, in British and Foreign State Papers, 101: pp. 739-742, and Dareste, op. cit., vol. I, pp. 98-104.

'These introductory paragraphs [in Wright, op. cit.] are based on Dareste, op. cit.s pp. 73 and 96-97.

'See above, p. 93. 
formula," which embodies elements of different solutions in order to conciliate different.groups. ${ }^{1}$

\section{CONSTITUTION OF BEIGIUM, FEBRUARY 7, 1831, WITH AMENDMENTS OF 1893 AND 1921}

\section{Title I. The Territory and Its Divisions}

Article 1.2 Belgium is divided into provinces.

These provinces are: Antwerp, Brabant, West Flanders, East Flanders, Hainaut, Liège, Limbourg, Luxembourg, Namur.

If there should be occasion for it, the territory may be divided by law into a greater number of provinces.

The colonies, possessions beyond the sea, or protectorates which Belgium may acquire shall be governed by special laws. The Belgian forces required for their defense shall be recruited only by voluntary enlistment.

Art. 2. Subdivisions of the provinces shall not be made except by law.

Art. 3. The boundaries of the state, of the provinces, and of the communes shall not be changed or rectified except by law.

\section{Title II. Belgian Citizens and Their Rights}

Art. 4. Belgian nationality is acquired, retained, and lost according to regulations established by the civil law.

The present constitution and the other laws relating to political rights determine what other conditions are necessary for the exercise of these rights.

Art. 5. Naturalization is granted by the legislative power.

Full naturalization alone admits foreigners to equality with Belgians in the exercise of political rights.

Art. 6. There shall be no distinction of classes in the state.

All Belgians are equal before the law; they alone are admissible to civil and military offices, with such exceptions as may be established by law for particular cases.

Art. 7. Individual liberty is guaranteed.

No one may be prosecuted except in cases provided for by law and in the form therein prescribed.

\footnotetext{
${ }^{1}$ See Hermann Dumont, "La vie politique et parlementaire en Belgique," Revue politique et parlementaire, Vol. cx, p. 470 (10 Mars, 1922). The changes in the organization of the Senate are indicated below, Chapter I, Section II.

${ }^{2}$ As amended September 7, 1893. The boundaries of the Kingdom of Belgium were definitively fixed by the treaty of April 19, 1839. The provision regarding colonies was introduced in 1893 to give the government power to administer the Congo Free State when it should become a Belgian possession.
} 
Except when one is taken in the commission of an offense no one may be arrested without a warrant issued by a magistrate, which ought to be shown at the time of arrest, or at the latest within twenty-four hours thereafter.

Art. 8. No person shall be removed against his will from the jurisdiction of the judge to whom the law assigns him.

Art. 9. No penalty shall be established or enforced except by virtue of a law.

Art. 10. The private domicile is inviolable; no search of premises shall take place except in the cases provided for by law and according to the form therein prescribed.

Art. 11. No one may be deprived of his property except for a public purpose and according to the forms established by law, and in consideration of a just compensation previously determined.

"Art. 12. Punishment by confiscation of property shall not be established.

Art. 13. Total deprivation of civil rights (mort civile) is abolished and shall not be reëstablished. ${ }^{1}$

Art. 14. Religious liberty and the freedom of public worship, as well as free expression of opinion in all matters, are guaranteed with the reservation of power to suppress offenses committed in the use of these liberties.

Art. 15. No one shall be compelled to join in any manner whatever in the forms of ceremonies of any religious denomination, nor to observe its days of rest.

Art. 16. The state shall not interfere either in the appointment or in the installation of the ministers of any religious denomination whatever, nor shall it forbid them to correspond with their superiors or to publish their proceedings, subject, in the latter case, to the ordinary responsibility of the press and of publication.

Civil marriage shall always precede the religious ceremony, except in cases to be established by law if found necessary.

Art. 17. Private instruction shall not be restricted; all measures interfering with it are forbidden; the repression of offenses shall be regulated by law.

Public instruction given at the expense of the state shall likewise be regulated by law.

Art. 18. The press is free; no censorship shall ever be established; no security shall be exacted of writers, publishers, or printers. $^{2}$

\footnotetext{
${ }^{1} \mathrm{La}$ mort civile is abolished as a punishment by itself. The condition follows as a secondary consequence of condemnation to death, hard labor, or transportation for life.
}

2See also Articles 96 and 98 which relate to trials of offenses of the press. 
In case the writer is known and is a resident of Belgium, the publisher, printer, or distributor shall not be prosecuted.

Art. 19. Belgians have the right, without previous authorization, to assemble peaceably and without arms, conforming themselves to the laws which regulate the exercise of this right.

This provision does not apply to assemblies in the open air, which remain entirely under the police laws.

Art. 20. Belgians have the right of association; this right shall not be restricted by any preventive measure.

Art. 21. Anyone has the right to address petitions to the public authorities, signed by one or more persons.

Legally organized bodies alone have the right to petition under a collective name.

Art. 22. The privacy of correspondence is inviolable. The law shall determine who are the agents responsible for the violation of the secrecy of letters entrusted to the post.

Art. 23. The use of the languages spoken in Belgium is optional. This matter may be regulated only by law and only for acts of public authority and for judicial proceedings. ${ }^{1}$

Art. 24. No previous authorization is necessary to bring action against public officials for the acts of their administration, except as provided for ministers. ${ }^{2}$

\section{Title III. Concerning Power}

Art. 25. All powers emanate from the people.

They shall be exercised in the manner established by the constitution.

Art. 26. The legislative power shall be exercised collectively by the King, the House of Representatives, and the Senate. ${ }^{3}$ Art. 27. Each of the three branches of the legislative power shall have the right of initiative.

[Nevertheless, all laws relating to the revenues or expenditures of the state or to the army contingent must be voted first by the House of Representatives]. ${ }^{4}$.

Art. 28. The authoritative interpretation of the laws shall belong only to the legislative power.

Art. 29. The executive power is vested in the King, subject to the regulations of the constitution.

\footnotetext{
${ }^{1}$ Laws and royal decrees are published in French in the Moniteur; the French text is the only official text. Flemish may be used in some official documents (see Dareste, op. cit., p. 77, note 1).
}

${ }^{2}$ See below, Articles 63, 90, and 134.

${ }^{8}$ This article was proposed far revision in $\mathbf{1 9 2 1}$ but was left unchanged.

4Stricken out in 1921. 
Art. 30. The judicial power shall be exercised by the courts and the tribunals.

Decrees and judgments shall be executed in the name of the King.

Art. 31. Exclusively communal or provincial affairs shall be regulated by the communal or provincial councils, according to the principles established by the constitution.

\section{CHAPTER I. THE HOUSES}

Art. 32. The members of the two houses shall represent the nation, and not the province alone, nor the subdivision of the province which elected them.

Art. 33. The sessions of the houses shall be public.

Nevertheless, each house may resolve itself into a secret committee upon the demand of its President or of ten members.

It shall then decide by vote of an absolute majority whether the session shall be resumed in public upon the same subject.

Art. 34. Each house shall judge of the qualifications of its own members, and shall decide all contests which arise upon that subject.

Art. 35. No person shall at the same time be a member of both houses.

Art. 36. Any member of either of the two houses, who shall be appointed by the government to any other salaried office except that of minister, and who accepts the same, shall vacate his seat immediately, and may resume his duties only by virtue of a new election..$^{1}$

Art. 37. At each session, each of the houses shall elect its President, its Vice-President, and shall form its bureau. ${ }^{2}$

Art. 38. An absolute majority of the votes shall be necessary to pass any resolution except as otherwise established by the rules of the houses in regard to elections and nominations. ${ }^{3}$

In case of an equal division of votes, the proposition under consideration is rejected.

Neither of the two houses shall pass a resolution unless a majority of its members are present.

Art. 39. The votes shall be viva voce or by rising and sitting; the vote on a law as a whole shall always be by roll call and viva

\footnotetext{
'As amended 7 September, 1893. By the original article ministers were also required to seek reëlection. The principle laid down in this article, developed in Articles 238 and 239 of the Electoral Code, were not changed in the Code revision of 1919.

"The term "bureau" is used to refer to all other officers of the legislative body, e. g., secretaries, etc.

${ }^{3}$ For questions requiring a two-thirds vote, see Articles 27, 61, 62, and 131.
} 
voce. The election and nomination of candidates shall be by secret ballot. ${ }^{1}$

Art. 40. Each house has the right to investigate the conduct of public affairs. ${ }^{2}$

Art. 41. A proposed law shall not be passed by either of the houses unless it has been voted upon article by article.

Art. 42. The houses have the right to amend and to divide the articles and amendments proposed.

Art. 43. To present petitions in person to the houses is forbidden.

Each house has the right to send to the ministers the petitions which are addressed to it. The ministers are obliged to give explanations upon the contents of such petitions whenever the house demands.

Art. 44. No member of either house shall be arrested or prosecuted on account of opinions expressed or votes cast by him in the performance of his duties.

Art. 45. No member of either house shall during the continuance of the session be prosecuted or imprisoned after trial, except by the authority of the house of which he is a member, unless he be apprehended in the commission of an offense.

No member of either house shall be arrested during the session, except by the same authority.

The detention or the prosecution of a member of either house shall be suspended during the session and for the entire term, if the house so demands.

Art. 46. Each house shall determine by its own rules the manner in which it is to exercise its powers. ${ }^{3}$

BECTION 1. THE HOUSE OF REPRESENTATIVE

Art. 47.4 The members of the House of Representatives shall be elected directly by citizens who have reached the age of 21 years, have resided for at least six months in the same commune, and are not otherwise excluded by law.

\footnotetext{
'Proposed for revision in 1921 but left unchanged.

${ }^{2} \mathrm{Law}$ of May 3,1880, to regulate the form of parliamentary investigations.

'See F. Moreau et J. Delpech, Les réglements des assemblées législatives, Vol. 1. pp. 617 and 637 (Paris, 1906).

The 1921 revision of Article 47 struck from the constitution the provisions for plural voting. These gave one additional vote (1) to a citizen 35 years of age, who was married or a widower with legitimate offspring, and who paid to the state a tax of not less than five francs as a householder, unless exempt on account of his profession; and (2) to a citizen, aged 25 years, who owned real estate valued at 2,000 francs, or had income from land corresponding to such valuation, or who had government bonds or savings bank deposits bearing 100 francs interest. Two additional votes were allotted citizens possessing certain educational qualifications. No one was allowed more than three votes. These were the provisions under the amendments of 1893 .
} 
Each elector has a right to only one vote.

Under the same conditions, the right of suffrage may be extended to women by law. This law must receive at least a two-thirds majority vote.

Transitional provision. Women who, fulfilling the conditions prescribed by this Article, belong to one of the categories enumerated in Article 2 of the law of May 9, 1919, shall be admitted to the right of suffrage concurrently with the citizens covered by Article 47 of the constitution. ${ }^{1}$

Art. 48. ${ }^{2}$ The constitution of the electoral colleges shall be regulated by law for each province.

Elections shall be held according to the system of proportional representation determined by law.

Voting is obligatory and secret. It shall take place in the commune, when not otherwise determined by law.

Art. 49. ${ }^{3}$ The number of representatives shall be determined by law, according to the population; this number shall not exceed the proportion of one representative for 40,000 inhabitants. The qualifications of an elector and the process of election shall also be determined by law.

Art. 50.4 To be eligible it is necessary:

(1) To be a Belgian citizen by birth, or to have received full naturalization.

(2) To enjoy civil and political rights.

(3) To have reached the age of 25 years.

(4) To be a resident of Belgium.

${ }^{1}$ Article 2 of the electoral law of May 9, 1919, reads as follows:

"Art. 2. The following shall likewise be permitted to vote at the next renewal of the legislative house, upon the same conditions in respect to nationality, age, and residence:

"(1) Unmarried widows of soldiers who died in the course of the war before January 1, 1919, and, in default of their voting, the widowed mothers of such deceased soldiers, as well as the widowed mothers of deceased soldiers who were unmarried.

"(2) The unmarried widows of Belgian citizens who were shot or killed by the enemy in the course of the war, and, in default of their voting, the widowed mothers of such slain citizens, as well as the widowed mothers of slain citizens who were unmarried.

"(3) Women who were condemned to prison or internment on account of their patriotic motives."

${ }^{2}$ Article 48 was amended in 1893 . The obligation of voting was sanctioned by Article 223 of the Electoral Code. In the legislative elections of 1900, the proportion of absentees averaged 6 per cent. The provision as to secrecy is new (1921) and proportional representation (provided for by the law of December 29,1899$)$ is guaranteed in the constitution.

${ }^{3}$ Proposed for revision in 1921 but left unchanged.

${ }^{4}$ In the Revue du droit public edition of the constitution of 1921, this Article is listed among those subjected to revision. The only alteration, however, appears to be a minor change in phraseology. See Dareste, op. cit., Vol. I, p. 81 . 
No other condition of eligibility shall be required.

Art. 51. ${ }^{1}$ The members of the House of Representatives shall be elected for a term of four years.

The House shall be renewed every four years.

Art. 52. Each member of the House of Representatives shall receive an annual compensation of 12,000 francs. ${ }^{2}$

He shall have, in addition, the right of free transportation of all state or concessionary railways.

The means of transport, apart from those specified above, which Representatives may use gratuitously, shall be determined by law.

An annual indemnity chargeable to the appropriation designed to cover the expenses of the House of Representatives may be allowed the President of that assembly.

The House shall determine the amount that may be withheld from the indemnity for contribution to the retirement or pension funds that it may deem proper to establish.

Transitional provision. The provision of Article 52, clause 1, shall be applicable to the session of $1919-1920 .^{3}$

\section{BECTION II. THE SENATE}

Art. 53.4 The Senate shall be composed:

(1) Of members elected in proportion to the population of each province, conformably to Article 47. The provisions of Article 48 are applicable to the election of these Senators.

(2) Of members elected by the provincial councils, in the proportion of one senator for 200,000 inhabitants. Any excess of at least 125,000 inhabitants shall entitle the province to one additional Senator. Nevertheless, each provincial council shall name at least three Senators.

(3) Of members elected by the Senate with the concurrence of half the number of Senators elected by the provincial councils. If this number is odd, it shall be increased by one unit.

These members are chosen by the Senators elected by the application of clauses 1 and 2 of this Article.

${ }^{1}$ The provision before 1921 was that one-half of the House of Representatives should be elected every two years and that in case of dissolution the House should be entirely renewed.

2Increased in 1921 from 4,000 francs. The right to free railway transportation is now not limited to journeys from the place of the deputy's residence to the city where the session is held.

3The last four clauses of Article 52 were added in 1921.

The method of electing the Senate, as provided by the revision of 1921, is almost entirely new. Suffrage qualifications are changed; there is a new apportionment of members elected by provincial councils, and a new, third group, of Senators is to be coöpted. The election of Senators by the provincial councils was an innovation of 1893 . 
The election of Senators elected by the application of clauses 2 and 3 shall take place according to the system of proportional representation determined by law.

Transitional provision. Women granted the right to vote for the House of Representatives, concurrently with the citizens referred to in Article 47 of the constitution, shall be permitted likewise to participate in the election of members of the Senate referred to in Article 53, clause 1.

Art. 54.1 The number of Senators to be elected directly by voters shall be equal to one-half the number of members of the House of Representatives.

Art. 55.2 Senators shall be elected for a term of four years. The Senate shall be entirely renewed every four years.

Art. 56. ${ }^{3}$ In order to be elected Senator, it shall be necessary :

(1) To be a Belgian citizen by birth, or to have received full naturalization.

(2) To enjoy civil and political rights.

(3) To be a resident of Belgium.

(4) To be at least 40 years of age.

Art. 56A.4 To be eligible to be elected Senator by the application of clause 1 of Article 53, it is necessary, moreover, to belong to one of the following categories:

(1) Ministers, former ministers, and ministers of state.

(2) Members and former members of the House of Representatives and of the Senate.

(3) Those possessing a diploma for completion of studies granted by one of the institutions of higher learning, the list of which shall be determined by law.

(4) Former superior officers of the army and navy.

${ }^{1}$ As amended in 1893. Proposed for revision in 1921 but left unchanged.

'Under the 1893 provisions Senators were elected for eight years, one-half being elected every four years. In case of dissolution the whole Senate was renewed.

'In the 1893 revision this Article included a fifth paragraph imposing the property qualification which is now (the tax of 1,200 francs being increased to 3,000 francs) clause 13 of Article $56 \mathrm{~A}$. The increased number of categories made unnecessary the following provision that appeared in the 1893 constitution: "In the provinces where the number of those eligible does not reach the proportion of one for every 5,000 inhabitants, the list shall be completed by the addition of as many of the highest taxpayers of the province as may be necessary to make this proportion. The citizens on this supplementary list are eligible only in the province where they reside."

4 Arts. 56A, 56B, and 56C, which are articles added by the revisions of 1893 and 1921, are, in the French, designated, " 56 bis," " 56 ter," and " 56 quater."

Art. $56 \mathrm{~A}$ in the old constitution read as follows: "The Senators elected by the provincial councils shall be exempt from all property qualification; they shall not be members of the assembly which elects them, nor have been members of it during the year of the election nor during the two preceding years." In a modified form this is now Article 56B. Article 56C is new. 
(5) Titular nembers and former members of the commerce courts who have been invested with at least two commissions.

(6) Those who have, for at least ten years, exercised the functions of a minister of one of the religions whose members enjoy emoluments from the state.

(7) Titular members and former members of one of the royal academies, and professors and former professors of one of the institutions of higher learning, the list of which shall be determined by law.

(8) Former provincial governors; members and former members of permanent deputations; former commissioners of an arrondissement.

(9) Members and former members of provincial councils who have been invested with at least two commissions.

(10) Burgomasters and former burgomasters, aldermen and former aldermen of communes, of capitals of arrondissements, and of places having more than 4,000 inhabitants.

(11) Former Governors-General and Vice-Governors-General of the Belgian Congo, members and former members of the Colonial Council.

(12) Former directors-general, directors, and inspectors-general of the different departments.

(13) Proprietors and usufructuaries of real estate situated in Belgium the assessed income of which amounts to at least 12,000 francs; taxpayers paying annually into the treasury of the state at least 3,000 francs in direct taxes.

(14) Those who, in the capacity of delegated administrator, director, or with an analogous title, have been placed for five years at the head of the daily management of a Belgian commercial joint-stock society, whose capital is paid up to the amount of at least a million francs.

(15) Chiefs of industrial enterprises employing, on a permanent basis, at least 100 workmen and of agricultural enterprises including at least 100 acres.

(16) Those who, in the capacity of managing director or with an analogous title, have been placed for three years at the head of the daily management of a Belgian coöperative society numbering for the last five years at least 500 members.

(17) Those who, in the capacity of effective members, have exercised for five years the functions of president or secretary of a mutual society or a mutual federation, numbering for the last five years at least 1,000 members.

(18) Those who, in the capacity of effective members, have exercised for five years the functions of president or secretary of a professional, industrial, or agricultural association, including for the last five years at least 500 members. 
(19) Those who for five years have exercised the functions of president of a chamber of commerce or of industry, numbering for the last five years at least 300 members.

(20) Members of industrial and labor councils, provincial agricultural commissions, and councils of experts who have been invested with at least two commissions.

(21) Elected members of one of the consultative councils established in connection with ministerial departments.

New categories of eligibles may be created by a law, which must receive at least a two-thirds majority vote.

Transitional provision. The term of five years in the categories numbered 14, 17, 18, and 19 and that of three years in category numbered 16 are reduced to two years for the first application of these provisions.

Art. 56B. Senators elected by provincial councils may not belong to the assembly which elects them, nor may they have been members of it during the year of election or the two preceding years.

Art.56C. In case of a dissolution of the Senate, the King may dissolve the provincial councils.

The act of dissolution shall include the convocation of the provincial electors within forty days and of the provincial councils within two months.

Art. 57. Senators shall not receive a salary.

They have the right, nevertheless, to be indemnified for their expenses; this indemnity is fixed at 4,000 francs a year. ${ }^{1}$

They have the right, moreover, of free transportation on all state and concessionary railways.

The means of transport, apart from those specified above, which they may use gratuitously, shall be determined by law.

Art. 58.2 The sons of the King, or if there be none, the Belgian princes of the branch of the royal family designated to succeed to the throne, shall be by right Senators at the age of 18 years. They shall have no deliberate vote until the age of 25 .

Art. 59.3 Every meeting of the Senate which may be held at any other time than during the session of the House of Representatives shall be null and void.

\section{CHAPTER II. THE KING AND THE MINISTERS}

SECTION I. THE KING

Art. 60.4 The constitutional powers of the King are hereditary in the direct descendants, natural and legitimate, of His

${ }^{1}$ Prior to 1921 no grant for expenses was allowed.

2As amended September 7, 1893.

${ }^{3}$ Proposed for revision in $\mathbf{1 9 2 1}$ but left unchanged.

'Paragraphs 2 and 3 were added September 7, 1893. 
Majesty Leopold George Christian Frederick of Saxe-Coburg from male to male, in the order of primogeniture, and to the perpetual exclusion of females and of their descendants.

The prince who shall marry without the consent of the King, or of those who in his absence exercise his authority as provided by the constitution, shall forfeit his rights to the crown.

Nevertheless, with the consent of the two houses, he may be relieved of this forfeiture by the King or by those who, in his absence, exercise his authority according to the constitution.

Art. 61. In default of male descendants of His Majesty Leopold George Christian Frederick of Saxe-Coburg, the King may name his successor, with the consent of the houses expressed in the manner prescribed by the following article.

If no nomination has been made after the manner described below, the throne will be vacant.

Art. 62. The King shall not at the same time be the head of another state, without the consent of the two houses.2

Neither of the houses shall deliberate upon this matter unless two-thirds, at least, of the members who compose it are present, and the resolution must be adopted by at least two-thirds of the votes cast.

Art. 63. The person of the King is inviolable; his ministers are responsible.

Art. 64. No decree of the King shall take effect unless it is countersigned by a minister, who, by that act alone, renders himself responsible for it.

Art. 65. The King appoints and dismisses his ministers.

Art. 66. He confers the grades in the army. ${ }^{3}$

He appoints the officers of the general administration and for foreign relations, except as otherwise established by law.

He appoints other governmental officials only by virtue of an express provision of law.

Art. 67. He shall issue all regulations and decrees necessary for the execution of the laws, without power to suspend the laws themselves, or to dispense with their execution.

Art. 68. The King commands the forces both by land and sea, declares war, makes treaties of peace, of alliance, and of commerce. He shall give information to the two houses of these acts as soon as the interests and safety of the state permit, adding thereto suitable comments.

Treaties of commerce, and treaties which may burden the

${ }^{1}$ As amended September 7, 1893. Only the form of this article was changed.

${ }^{2}$ King Leopold II was authorized by the House of Representatives (April 28, 1885) and the Senate (April 30, 1885) to be the sovereign of the Congo Free State.

${ }^{3}$ See below, Article 124. 
state, or bind Belgians individually, shall take effect only after having received the approval of the two houses.

No cession, exchange, or addition of territory shall take place except by virtue of a law. In no case shall the secret articles of a treaty be destructive of those openly expressed.

Art. 69. The King approves and promulgates the laws. ${ }^{1}$

Art. 70. The houses shall assemble each year, the second Tuesday in November, unless they shall have been previously summoned by the King.

The houses shall remain in session at least $\mathbf{4 0}$ days each year.

The King pronounces the closing of the session.

The King shall have the right to convene the houses in extraordinary session.

Art. 71. The King shall have the right to dissolve the houses either simultaneously or separately. The act of dissolution shall order a new election within 40 days, and summon the houses within two months.

Art. 72. The King may adjourn the houses. In no case shall the adjournment exceed the term of one month, nor shall it be renewed in the same session, without the consent of the houses.

Art. 73. He shall have the right to remit or reduce the penalties pronounced by the judges of courts, except such as are fixed by law in the case of ministers.

Art. 74. He shall have the right to coin money, in accordance with the law.

Art. 75. He shall have the right to confer titles of nobility, but without the power of attaching to them any privilege.

Art. 76. He may confer military orders in accordance with the provisions of the law.

Art. 77. The civil list shall be fixed by law for the duration of each reign. ${ }^{2}$

Art. 78. The King shall have no other powers than those which the constitution and the special laws, enacted under the constitution, formally confer upon him.

Art. 79. At the death of the King the houses shall assemble without a summons, at the latest on the tenth day after his decease. If the houses shall have been previously dissolved, and if in the act of dissolution the reassembling had been fixed for a day later than the tenth day, the former members shall resume their duties until the assembling of those who should replace them.

If only one house shall have been dissolved, the same rule shall be followed with regard to that house.

\footnotetext{
${ }^{1}$ Law of April 18, 1898. Proposed for revision in 1921 but left unchanged.

2The civil list of the present King, Albert, was fixed by law of December 30, 1909 , at $3,300,000$ francs.
} 
From the date of the death of the King and until the taking of the oath by his successor to the throne, or by the agent, the constitutional powers of the King shall be exercised, in the name of the Belgian people, by the ministers united in council and upon their responsibility.

Art. 80. The King is of age when he shall have completed the age of 18 years.

He shall not take possession of the throne until he shall have solemnly taken, before the united houses, the following oath:

"I swear to observe the constitution and the laws of the Belgian people, to maintain the national independence and the integrity of the territory."

Art. 81. If, at the death of the King, his successor is a minor, the two houses shall unite in one assembly, for the purpose of providing for the regency and guardianship.

Art. 82. If the King becomes incapacitated to reign, the ministers, after having ascertained this incapacity, shall immediately convene the houses. The houses shall provide for the regency and guardianship.

Art. 83. The regency shall be conferred upon one person.

The regent shall enter upon his duties only after having taken the oath prescribed by Article 80 .

Art. 84. No change in the constitution shall be made during a regency.

Art. 85. In case there is a vacancy of the throne, the houses deliberating together shall arrange provisionally for the regency, until the first meeting of the houses after they have been wholly renewed. That meeting shall take place at the latest within two months. The new houses deliberating together shall provide definitely for the vacancy.

\section{SECTION II. THE MINISTERS}

Art. 86. No person shall be a minister unless he is a Belgian by birth, or has received full naturalization.

Art. 87. No member of the royal family shall be a minister.

Art. 88. Ministers shall have no deliberative vote in either house unless they are members of it.

They shall have admission to either house, and are entitled to be heard when they so request.

The houses shall have the right to demand the presence of ministers.

Art. 89. In no case shall the verbal or written order of the King relieve a minister of responsibility.

Art. 90. The House of Representatives shall have the right to accuse ministers and to arraign them before the Court of Cassation, which, sitting in full bench, alone shall have the right 
to judge them, except in such matters as shall be established by law respecting a civil suit by an aggrieved party and respecting crimes and misdemeanors committed by ministers when not in the performance of their official duties.

The law shall determine the responsibility of ministers, the penalties to be imposed upon them, and the method of proceeding against them, whether upon accusation made by the House of Representatives or upon prosecution by the aggrieved parties. ${ }^{1}$

Art. 91. The King shall not have power to grant pardon to a minister sentenced by the Court of Cassation except upon request of one of the two houses.

\section{CHAPTER III. THE JUDICIAL POWER}

Art. 92. Actions which involve questions of civil right belong exclusively to the jurisdiction of the courts.

Art. 93. Actions which involve questions of political rights belong to the jurisdiction of the courts, except as otherwise determined by law.

Art. 94. No tribunal nor contentious jurisdiction shall be established except by virtue of a law. ${ }^{2}$ No commissions or extraordinary tribunals under any title whatever shall be established.

Art. 95.3 There shall be a Court of Cassation for the whole of Belgium.

This court shall not consider questions of fact except in the trial of ministers.

Art. 96. The sessions of the courts shall be public, unless this publicity is declared by a judgment of the court to be dangerous to public order or morals.

In cases of political offenses and offenses of the press closed doors shall be enforced only by a unanimous vote of the court.

Art. 97. Every judgment shall be pronounced in open court, and the reasons therefor stated.

Art. 98. The right of trial by jury shall be established in all criminal cases and for all political offenses and offenses of the press.

Art. 99. The justices of the peace and the judges of courts shall be appointed directly by the King.

The members of the courts of appeal and the presidents and vice-presidents of the courts of original jurisdiction shall be

\footnotetext{
${ }^{1}$ See below, Article 134.
} 1879.

2Law of June 18, 1869, on the organization of the judiciary, amended April 1,

${ }^{3}$ Clause 1 proposed for revision in 1921 but left unchanged. 
appointed by the King from two double lists, presented the one by these courts and the other by the provincial councils.

The members of the Court of Cassation shall be appointed by the King from two double lists presented one by the Senate and one by the Court of Cassation.

In both cases the candidates named upon one list may be named also upon the other.

All the names shall be published at least fifteen days before the appointment.

The courts shall choose their presidents and vice-presidents from among their own number.

Art. 100. Judges shall be appointed for life.

No judge shall be deprived of his office or suspended until after trial and judgment.

The removal of a judge from one place to another shall take place only by means of a new appointment and with his consent.

Art. 101. The King appoints and removes the state officials serving in the courts and tribunals.

Art. 102. The salaries of the members of the judiciary shall be fixed by law.

Art. 103. No judge shall accept from the government any salaried office, unless he perform the duties thereof gratuitously, and not then if it is contrary to the law of incompatibility. ${ }^{1}$

Art. 104. ${ }^{2}$ There shall be three courts of appeal in Belgium.

Their jurisdiction and the places where they shall be held shall be determined by law.

Art. 105.3 Special laws shall govern the organization of military tribunals, their powers, the rights and obligations of the members of these tribunals and the duration of their functions.

There shall be commercial courts in places which shall be designated by law. Their organization, powers, the method of appointment of their members, and the duration of their term of office shall also be determined by law.

Art. 106. The Court of Cassation shall decide conflicts of jurisdiction, according to the method prescribed by law.

Art. 107. The courts and tribunals shall enforce executive decrees and ordinances, whether general, provincial, or local, only so far as they shall conform to the laws.

CHAPTER IV. PROVINCIAL AND COMMUNAL INSTITUTIONS

Art. 108. Provincial and communal institutions shall be regulated by law.

'Laws of May 26, 1848, and June 18, 1869.

'Law of June 15, 1909.

'Proposed for revision in 1921 but left unchanged. 
The law shall establish the application of the following principles:

(1) Direct election, except in the cases which may be established by law with regard to the chiefs of the communal administration and government commissioners acting in the provincial councils.

(2) The relegation to provincial and communal councils of all provincial and communal affairs, without prejudice to the approval of their acts, in the cases and according to the procedure determined by law.

Several provinces or several communes may act in concert or associate together under the conditions and according to the manner to be determined by law, in order to regulate and manage in common subjects of provincial or communal interest. Nevertheless, several provincial councils or several communal councils may not be permitted to deliberate in common. ${ }^{1}$

(3) The publicity of the sittings of the provincial and communal councils within the limits established by law.

(4) The publicity of budgets and of accounts.

(5) The intervention of the King or of the legislative power to prevent provincial and communal councils from exceeding their powers and from acting against the general welfare.

Art. 109. The keeping of the civil register is exclusively the duty of the communal authorities.

\section{Title IV. Finances}

Art. 110. No tax for the benefit of the state shall be imposed except by law.

No provincial charge or tax shall be imposed without the consent of the provincial council.

No communal charge or tax shall be imposed without the consent of the communal council.

The law shall determine the exceptions which experience shall show to be necessary in regard to provincial and communal taxes.

Art. 111. Taxes for the benefit of the state shall be voted annually.

The laws which impose such taxes shall remain in force for one year only unless they are reënacted. taxes.

Art. 112. No privilege shall be established with regard to

No exemption or abatement of taxes shall be established except by law.

This paragraph, authorizing joint administration, was inserted by the 1921 revision. 
Art. 113. Beyond the cases expressly excepted by law, no payment shall be exacted of any citizen other than taxes levied for the benefit of the state, of the province, or of the commune. No change shall be made in the existing system of polders ${ }^{2}$ and wateringen ${ }^{2}$ which remain subject to ordinary legislation.

Art. 114. No pension or gratuity shall be paid out of the public treasury without the authority of law.

Art. 115. Each year the houses shall enact the law of accounts and vote the budget.

All the receipts and expenditures of the state shall be contained in the budget and in the accounts.

Art. 116. The members of the Court of Accounts shall be appointed by the House of Representatives and for a term fixed by law.

This court shall be entrusted with the examination and settlement of the accounts of the general administration and of all persons accountable to the public treasury. It shall see that no item of the expenditures of the budget is overdrawn and that no transfer takes place. It shall audit the accounts of the different administrative organs of the state, and shall gather for this purpose all information and all necessary vouchers. The general accounts of the state shall be submitted to the House with the comments of the Court of Accounts.

This court shall be organized by a law. ${ }^{3}$

Art. 117. The salaries and pensions of the ministers of religion shall be paid by the state; the sums necessary to meet this expenditure shall be entered annually in the budget."

\section{Title V. The Public Force}

Art. 118. The method of recruiting the army shall be determined by law. The laws shall also regulate the promotion, the rights, and the duties of soldiers. ${ }^{5}$

\footnotetext{
'Polders are lands reclaimed from the sea by dikes. The owners of these lands are grouped into associations for the maintenance of the dikes and are required by law to bear the expense of such maintenance.

2Wateringen are associations formed for the purpose of irrigating and draining lands reclaimed from the sea. They have powcr to raise funds by taxing the lands affected by such improvements.
}

'Law of October 29, 1846.

-This clause is interpreted to apply only to the denominations recognized by law in Belgium in 1830; these are the Catholic, Protestant Evangelical, Anglican, and Jewish; almost the whole of the Belgian population is Catholic. No minister is entitled to a salary (1) if he must receive license from a person practicing a profession without legal authorization, ( $(2)$ if, being a foreigner, he performs the ministerial functions without the permission of the government.

-The organization of the Belgian Army is governed by the Laws of April 5, 1868, June 3, 1870, August 16, 1873, and March 21, 1902. 
Art. 119. The army contingent shall be voted annually. The law which fixes it shall remain in force for one year only, unless reënacted.

Art. 120. The organization and the attributions of the armed police shall be regulated by a law.

Art. 121. No foreign troops shall be admitted into the service of the state, to occupy or to cross its territory except by virtue of a law.

Art. 122. There shall be a citizen militia, the organization of which shall be regulated by law.

[The offices of all grades, at least as high as that of captain, shall be chosen by the militia, with such exceptions as may be judged necessary for accountants. $]^{1}$

[Art. 123. The militia shall not be brought into active service except by virtue of a law].2

Art. 124. Soldiers shall not be deprived of their grades, honors, or pensions except in the manner prescribed by law.

\section{Title VI. General Provisions}

Art. 125. The Belgian nation adopts for its colors, red, yellow, and black, and for the coat of arms of the Kingdom, the Belgian lion, with the motto, "Union Gives Strength."

Art. 126. The city of Brussels is the capital of Belgium and the seat of government.

Art. 127. No oath shall be imposed except by virtue of law. The form of the oath shall also be determined by law.

Art. 128. Every foreigner within the territory of Belgium shall enjoy protection of his person and property, except as otherwise established by law.

Art. 129. No law, ordinance, or regulation of the general, provincial, or communal government shall be obligatory until after having been published in the manner prescribed by law.

Art. 130. The constitution shall not be suspended, either in whole or in part.

\section{Title VII. The Revision of the Constitution}

Art. 131.3 The legislative power has the right to declare that a revision of such constitutional provisions as it shall designate is in order.

After this declaration, the two houses are ipso facto dissolved.

'This paragraph was stricken out by the 1921 revision.

'Article 123 was stricken out by the 1921 revision; but the succeeding articles were not renumbered.

${ }^{3}$ Proposed for revision in 1921 but left unchanged. 
Two new houses shall then be summoned, in conformity with Article 71.

These houses, with the approval of the King, shall then act upon the points submitted for revision.

In this case the houses shall not deliberate unless at least twothirds of the members of each are present, and no amendment shall be adopted unless it is supported by at least two-thirds of the votes.

\section{Title VIII. Transitional Provisions}

Art. 132. For the first choice of a head of the state the first provision of Article 80 may be neglected.

Art. 133. Foreigners established in Belgium before January 1, 1814, and who continue to reside therein, shall be considered Belgians by birth, upon condition that they declare their intention to take advantage of this provision.

Such declaration shall be made within six months after this constitution goes into effect, if the foreigners are of age, and if they are minors, within the year after attaining their majority.

This declaration shall be made before the provincial authority of the province where they reside.

It shall be made in person or by an agent having a special and authentic authorization.

Art. 134. Until further provision by law, the House of Representatives shall have discretionary power to accuse a minister, and the Court of Cassation to try him, find the offense, and fix the penalty.

Nevertheless the penalty shall not extend farther than removal from office, without prejudice to the cases expressly provided for by the penal laws. ${ }^{1}$

Art. 135. The personnel of the courts shall be maintained as it now exists, until further provision has been made by law.

Such a law shall be enacted during the first legislative session.

Art. 136. A law, passed during the first legislative session, shall provide for the manner of the first nomination of members of the Court of Cassation.2

Art. 137. The fundamental law of August 24, 1815, and the provincial and local statutes are abolished. However, the provincial and local authorities shall retain their powers until a law shall make other provision.

Art. 138. As soon as this constitution goes into effect, all laws, decrees, orders, regulations, and other instruments contrary thereto are abrogated.

'This transitional legislation is still in force, no organic law having determined the cases of ministerial responsibility.

${ }^{2}$ Article 99 provides for subsequent appointments. 


\section{Supplementary Provisions}

Art. 139. The National Congress declares that it is necessary to provide for the following objects, by separate laws and as soon as possible:

1. The press. ${ }^{1}$

2. The organization of the jury. ${ }^{2}$

3. The finances. ${ }^{3}$

4. Provincial and communal organization. ${ }^{4}$

5. The responsibility of ministers ${ }^{5}$ and of other officers.

6. The judicial organization. ${ }^{6}$

7. The revision of the pension list.

8. Measures proper to prevent the abuse of cumulative officeholding.

9. The revision of the laws of bankruptcy and of suspension.

10. The organization of the army, the rights of advancement and of retirement, and the military penal code. ${ }^{7}$

11. The revision of the codes.

The executive power is charged with the execution of the present decree.

'Decree of July 20, 1831, amended by the Penal Code in many of its provisions. ${ }^{2}$ See above, Article 94.

${ }^{3} \mathrm{Law}$ of May 15, 1846, on the compatibility of the state.

"See above, Article 108.

'See above, Article 134.

'See above, Article 94.

${ }^{3}$ Military Penal Code of May 27, 1870. See above, Article 118. 


\section{APPENDIX II}

\section{FRANCE}

\section{HISTORICAL NOTE}

"Since 1789 France has undergone numerous changes in government, and each change has been embodied in constitutional documents. It will suffice here to enumerate the several constitutions which were in force before the definite establishment of the Third Republic:

"1. The constitution of September 3, 1791, established a limited monarchy, but disappeared with the fall of the King in the succeeding year.

"2. The republican constitution of June 24, 1793, had not been put in force before the fall of the Jacobins who framed it, and was disregarded by those who succeeded to their power.

" 3 . The constitution of August 22, 1795, vested the executive power in five Directors, and the legislative power in a Council of Five Hundred and a Council of Ancients. It represents the conservative reaction from the Jacobin principles of 1793 .

" 4 . The usurpations of the Directory and the coup d'stat of November 9, 1799, put an end to the constitution of 1795 . Under the constitution of December 13, 1799, Napoleon gained as First Consul the supreme executive power to which he aspired.

"5. The senatus-consulta of August 2 and 4, 1802, proclaimed Napoleon First Consul for life with extended powers, and on May 18, 1804, the Consulate was replaced by the Empire. The constitution was altered by several other less important acts between 1804 and 1814 . Intimately connected with the first imperial constitution is the additional act of April 22, 1815, which by its liberal principles attempted to outbid the Bourbon charter of 1814; the additional act disappeared with the defeat of Napoleon at Waterloo.

"6. Upon the restoration of the Bourbons the constitutional Charter of June 4, 1814, ${ }^{1}$ was issued by Louis XVIII; with this constitution was first established the parliamentary system with ministerial responsibility; the legislature was composed of two houses, one appointive, the other elective, but with a very limited electorate.

${ }^{1}$ French text in the British and Foreign State Papers, 1: pp. 960-966. 
"7. The constitution of August 14, 1830,1 and the organic laws of 1831 came as a result of the July revolution of 1830 . The constitution of 1814 remained almost unchanged, except for a limited extension of the suffrage and the abolition of hereditary peerages.

"8. The republican constitution of November $4,1848,{ }^{2}$ introduced universal suffrage, with a unicameral legislature, and an elective president chosen for four years and ineligible to succeed himself.

" 9 . The constitution of January $14,1852,{ }^{3}$ extended for 10 years the power of Louis Napoleon Bonaparte as President of the Republic; the senatus-consultum of November 7,4 ratified by the plebiscite of November 21 and 22, 1852, reëstablished the Empire. Between 1852 and 1870 the constitution was altered by numerous senatus-consulta, the most important of which was that of September 8, 1869, establishing ministerial responsibility.

"10. The senatus-consultum of May 21, 1870, a codification of constitutional changes since 1860 , was really a new imperial constitution, and was submitted to a vote of the people as such.

"11. Imperial institutions in France were now destined to be of short duration; the Empire disappeared on September 4, 1870, when news reached Paris of the French disaster at Sedan. The Government of the National Defense, which succeeded the Empire, gave way in February, 1871, to a National Assembly which chose Thiers chief of the executive power of the French Republic.

"For two years after 1871 nothing was done by the National Assembly toward the permanent establishment of the republic. In fact the majority of the Assembly were monarchists; the overthrow of Thiers and the election of Marshal de MacMahon as President were considered the first steps toward the restoration of monarchy, but the attitude of the Comte de Chambord wrecked the hopes of his supporters. Definite steps toward a constitutional organization were not taken until hope of a restoration of the Bourbons had disappeared.

"Even after the failure to reëstablish the monarchy the majority of the National Assembly hoped to prevent the permanent establishment of the republic. But the provisional organization of the Government could not continue forever, nor could the Assembly, elected to meet the national crisis of 1871, expect

1French text in the British and Foreign State Papers, 17: pp. 1013-1018.

IIbid., 36: pp. 1072-1085.

${ }^{3}$ Ibid., 41 : pp. 1085-1090.

${ }^{4} I$ bid., 41: pp. 1095-1098. 
much longer to remain in power. The constitutional and organic laws were finally enacted in 1875; and the elections of 1876 proved that the people of France were ready to support republican institutions. In addition to these laws, some subsequent laws bearing upon constitutional matters have been included here"," the last being the electoral law of 1919 .

\section{FUNDAMENTAL LAWS OF FRANCE}

\section{CONSTITUTIONAL LAW OF FEBRUARY 25, $1875^{2}$}

\section{On the Organization of tile Public Powers}

Article 1. The legislative power shall be exercised by two assemblies: The Chamber of Deputies and the Senate.

The Chamber of Deputies shall be elected by universal suffrage, under the conditions determined by the electoral law.

The composition, the method of election, and the attributions of the Senate shall be regulated by a special law.

Art. 2. The President of the Republic shall be chosen by an absolute majority of votes of the Senate and Chamber of Deputies united in National Assembly. He shall be elected for seven years. He shall be eligible for reëlection.

Art. 3. The President of the Republic shall have the initiative of laws, concurrently with the members of the two houses. He shall promulgate the laws when they have been voted by the two houses; ${ }^{3}$ he shall look after and secure their execution.

He shall have the right of pardon; amnesty may only be granted by law.

He shall dispose of the armed force.

He shall appoint to all civil and military positions.

'These introductory paragraphs are quoted from Wright, The Constitution of the States at War, pp. 191, 192 (Washington, Government Printing Office. 1919). They are "based upon W. F. Dodd Modern Constitutions, Vol. I, pp. 283-285 (Chicago, 1909). There is also a very good account in Dareste Les constitutions modernes, Vol. I, pp. 1-9 (3d edition, Paris, 1910)."

${ }^{2}$ Promulgated in the Journal officiel of February 28, 1875. The translation of this and the following laws, except the electoral law of 1919, is based upon Wright, op. cit., pp. 193 ff., which uses Dodd, Modern Constitutions, Vol. I, pp. $286 \mathrm{ff}$., which in turn was based upon the translation by C. F. A. Currier in the Supplement to the Annals of the American Academy of Political and Social Science, March, 1893 (Philadelphia, 1893), and in Foreign Constitutions [The Convention Manual of the Sixth New York State Constitutional Convention, 1894, Part 2, Vol. 3] pp. 230-255 (Albany, 1894). French text in Dareste, op. cit., Vol. I., pp. 10-37, and a German version in Paul Posener, Die Staatsverfassungen des Erdballs, pp. 564-587 (Charlottenburg, 1909).

${ }^{8}$ See Article 7 of the Constitutional Law of July 16, 1875, on p. 527. 
He shall preside over Senate functions; envoys and ambassadors of foreign powers shall be accredited to him.

Every act of the President of the Republic shall be countersigned by a minister.

Art. 4. As vacancies occur on and after the promulgation of the present law, the President of the Republic shall appoint, in the Council of Ministers, the councilors of state in regular service.

The councilors of state thus chosen may be dismissed only by decree rendered in the Council of Ministers. ${ }^{1}$

Art. 5. The President of the Republic may, with the advice of the Senate, dissolve the Chamber of Deputies before the legal expiration of its mandate.

In that case the electoral colleges shall be assembled for new elections within the space of two months and the Chamber within the ten days following the close of the elections. ${ }^{2}$

Art. 6. The ministers shall be collectively responsible to the houses for the general policy of the government, and individually for their personal acts.

The President of the Republic shall be responsible only in case of high treason. ${ }^{3}$

Art. 7. In case of vacancy by death or for any other reason, the two houses assembled together shall proceed at once to the election of a new President. ${ }^{4}$

In the meantime the Council of Ministers shall be vested with the executive power.

Art. 8. The houses shall have the right by separate resolutions, taken in each by an absolute majority of votes, either upon their own initiative or upon the request of the President of the Republic, to declare a revision of the constitutional laws necessary. ${ }^{5}$

After each of the two houses shall have come to this decision, they shall meet together in National Assembly to proceed with the revision.

The acts effecting revision of the constitutional laws, in whole or in part, shall be passed by an absolute majority of the members composing the National Assembly. ${ }^{6}$

\footnotetext{
1The Council of State is governed by the Laws of May 24, 1872, and July 13, 1879. Clause 3 of the above article has been omitted, because it ceased to have application after 1881 .

${ }^{2}$ As amended by Article 1 of the Constitutional Law of August 14, 1884.

${ }^{3}$ See Article 12 of the Constitutional Law of July 16, 1875, on p. 527.

'See Article 3 of the Constitutional Law of July 16, 1875, on p. 526.

${ }^{5}$ Article 8 has been put into practice twice, in 1879 and in 1884 .

'The clause following this, concerning the presidency of Marshal de MacMahon, is now without object.
} 
The republican form of government shall not be made the subject of a proposed revision. ${ }^{\text {I }}$

Members of families that have reigned in France are ineligible to the Presidency of the Republic. ${ }^{1}$

Art. 9.2

\section{CONSTITUTIONAL LAW OF FEBRUARY $24,1875^{3}$}

\section{On the Organization of the Senate}

Articles 1-7.4

Art. 8. The Senate shall have, concurrently with the Chamber of Deputies, the power to initiate and to pass laws. Money bills, however, shall first be introduced in and passed by the Chamber of Deputies. ${ }^{5}$

Art. 9. The Senate may be constituted a court of justice to try either the President of the Republic or the ministers, and to take cognizance of attacks made upon the safety of the state.

Art. 10. Elections to the Senate shall take place one month before the time fixed by the National Assembly for its own dissolution. The Senate shall organize and enter upon its dutics the same day that the National Assembly is dissolved.

Art. 11. The present law shall be promulgated only after the passage of the law on the public powers.

\section{CONSTITUTIONAL LAW OF JULY $16,1875^{6}$}

\section{On Relations of the Public Powers}

Article 1. The Senate and the Chamber of Deputics shall assemble each year on the second Tuesday of January, unless convened earlier by the President of the Republic.

${ }^{1}$ Added by Article 2 of the Constitutional Law of August 14, 1884.

${ }^{2}$ Repealed by the constitutional law of June 21, 1879. Article 9 originally read: "The seat of the executive power and of the two houses shall be at Versailles." See Law of July 22, 1879, on p. 540.

3Promulgated in the Journal officiel of February 28, 1875.

"These seven articles, concerning the composition of the Senate and of the electoral body which names the Senators, were deprived of their constitutional character by Article 3 of the Law of August 14, 1884, and were repealed by Article 9 of the Law of December 9,1884 . See below, pp. 529 and 541 , respectivcly.

bThis text is an almost literal reproduction of Article 15 of the Charter of 1830 , which in turn was borrowed from the Charter of 1814 (Articles 17 and 47). The Senate and the Chamber since 1876 have frequently been in disagreement upon the interpretation to be given to Article 8, the former maintaining that no exception for money bills is made to the general principle of the equality of the two houses in the passage of laws, the latter claiming exclusive control of budgetary rights.

'Promulgated in the Journal officiel of July 18, 1875. 
The two houses shall continue in session at least five months each year. The sessions of the two houses shall begin and end at the same time. ${ }^{1}$

Art. 2. The President of the Republic pronounces the closing of the session. He may convene the houses in extraordinary session.

He shall convene them if, during the recess, an absolute majority of the members of each house request it.

The President may adjourn the houses. The adjournment, however, shall not exceed one month, nor take place more than twice in the same session.

Art. 3. One month at least before the legal expiration of the powers of the President of the Republic, the houses shall be called together in National Assembly to proceed to the election of a new President.

In default of a summons, this meeting shall take place, as of right, the fifteenth day before the expiration of these powers.

In case of the death or resignation of the President of the Republic, the two houses shall assemble immediately, as of right. ${ }^{2}$

In case the Chamber of Deputies, in consequence of Article 5 of the Law of February 25, 1875, is dissolved at the time when the Presidency of the Republic becomes vacant, the electoral colleges shall be convened at once, and the Senate shall assemble as of right.

Art. 4. Every meeting of either of the two houses which shall be held at a time when the other is not in session is ipso facto illegal and void, ${ }^{3}$ except in the case provided for in the preceding Article, and in case the Senate meets as a court of justice; in the latter case, judicial duties alone shall be performed.

Art. 5. The sittings of the Senate and of the Chamber of Deputies shall be public.

Nevertheless, either house may meet in secret session, upon the request of a fixed number of its members, determined by the rules. ${ }^{4}$

It shall then decide by absolute majority whether the sitting shall be resumed in public upon the same subject.

Art. 6. The President of the Republic communicates with the houses by messages, which shall be read from the tribune by a minister.

\footnotetext{
1The third paragraph of this article, repealed by Article 4 of the Law of August 14, 1884, prescribed public prayers on the Sunday following the convening of the houses.

${ }^{2}$ See Article 7 of the Constitutional Law of February 25, 1875, on p. 524.

${ }^{3}$ See above, Paragraph 2 of Article 1.

The number of members required for such action is 5 for the Senate and 20 for the Chamber.
} 
The ministers shall have entrance to both houses, and shall be heard when they request it. They may be assisted, for the discussion of a specific bill, by commissioners named by decree of the President of the Republic.

Art. 7. The President of the Republic shall promulgate the laws within the month following the transmission to the government of the law finally passed. He shall promulgate, within three days, laws the promulgation of which shall have been declared urgent by an express vote of each house.

Within the time fixed for promulgation the President of the Republic may, by a message with reasons assigned, request of the two houses a new discussion, which cannot be refused.

Art. 8. The President of the Republic shall negotiate and ratify treaties. He shall give information regarding them to the houses as soon as the interests and safety of the state permit.

Treaties of peace and of commerce, treaties which involve the finances of the state, those relating to the status of the persons and to the right of property of French citizens in foreign countries, shall be ratified only after having been voted by the two houses. No cession, exchange, or annexation of territory shall take place except by virtue of a law.

Art. 9. The President of the Republic shall not declare war without the previous consent of the two houses.

Art. 10. Each house shall be the judge of the eligibility of its members and of the regularity of their election; it alone may receive their resignation.

Art. 11. The bureau ${ }^{2}$ of each house shall be elected each year for the entire session, and for every extraordinary session which may be held before the regular session of the following year.

When the two houses meet together as a National Assembly, their bureau shall be composed of the President, Vice-Presidents and secretaries of the Senate.

Art. 12. The President of the Republic may be impeached only by the Chamber of Deputies and may be tried only by the Senate.

The ministers may be impeached by the Chamber of Deputies for offenses committed in the performance of their duties. In this case they shall be tried by the Senate.

The Senate may be constituted into a court of justice, by a decree of the President of the Republic issued in the Council of Ministers, to try all persons accused of attempts upon the safety of the state.

\footnotetext{
${ }^{1}$ A decree of April 6, 1876, governs the formula of promulgation of laws.
}

2The bureau of the Senate consists of a president, 4 vice-presidents, 8 secretaries, and 3 questors; the bureau of the Chamber of Deputies has the same composition. 
If proceedings should have been begun in the regular courts, the decree convening the Senate may be issued at any time before the granting of a discharge.

A law shall determine the method of procedure for the accusation, trial, and judgment. ${ }^{1}$

Art. 13. No member of either house shall be prosecuted or held responsible on account of any opinions expressed or votes cast by him in the performance of his duties. ${ }^{2}$

Art. 14. No member of either house shall, during the session, be prosecuted or arrested for any offense or misdemeanor, unless upon the authority of the house of which he is a member, except in the case of flagrante delicto.

The detention or prosecution of a member of either house shall be suspended for the session, and for the entire term of the house, if the chamber requires it.

\section{LAW OF JUNE 21, $1879^{3}$}

\section{Revising Article 9 of the Constitutional Law of February 25, 1875}

Sole Article. Article 9 of the Constitutional Law of February 25,1875 , is repealed. ${ }^{4}$

\section{LAW OF AUGUST 14, $1884^{5}$}

\section{Partially Revising the Constitutional Laws ${ }^{6}$}

Article 1. Paragraph 2 of Article 5 of the Constitutional Law of February 25, 1875, on the organization of the public powers, is amended as follows:

In that case the electoral colleges shall meet for new elections within 2 months and the Chamber within the 10 days following the close of the elections.

\footnotetext{
'Law of April 10, 1889.

${ }^{2}$ Article 41 of the Law of July 29, 1881, on the press develops and completes this provision.

${ }^{3}$ Promulgated in the Journal officiel of June 22, 1879.

This article fixed the seat of government at Versailles (see above, p. 525). The seat of government was removed from Versailles to Paris by a Law of July 22, 1879 (see below, p. 540).

'Promulgated in the Journal officiel of August 15, 1884.

The amendments to the constitutional laws have also been inserted in their proper places.
} 
Art. 2. To Paragraph 3 of Article 8 of the same law of February 25, 1785, is added the following:

The republican form of government shall not be made the subject of a proposed revision.

Members of families that have reigned in France are ineligible to the Presidency of the Republic.

Art. 3. Articles 1 to 7 of the Constitutional Law of February 24,1875 , on the organization of the Senate, shall no longer have a constitutional character. ${ }^{1}$

Art. 4. Paragraph 3 of Article 1 of the Constitutional Law of July 16,1875 , on the relation of the public powers, is repealed.

\section{ORGANIC LAW OF AUGUST 2, $1875^{2}$ \\ ON the Election of Senators}

Article 1. A decree of the President of the Republic, issued at least six weeks in advance, shall fix the day for the elections to the Senate, and at the same time that for the choice of delegates of the municipal councils. There shall be an interval of at least one month between the choice of delegates and the election of Senators.

Art. 2. In each municipal council the election of delegates shall take place without debate and by secret ballot, by scrutin de liste and by an absolute majority of votes cast.

After two ballots a plurality shall be sufficient and in case of an equality of votes the oldest is elected.

The procedure and method shall be the same for the election of alternates.

Councils having 1, 2, or 3 delegates to choose shall elect 1 alternate.

Those choosing 6 or 9 delegates shall elect 2 alternates.

Those choosing 12 or 15 delegates shall elect 3 alternates.

Those choosing 18 or 21 delegates shall elect 4 alternates.

Those choosing 24 delegates shall elect 5 alternates.

The municipal council of Paris shall elect 8 alternates.

The alternates shall take the place of delegates in case of refusal or inability to serve, in the order determined by the number of votes received by each of them.

The choice of the municipal councils shall not extend to a deputy, a general councilor or an arrondissement councilor.

'These articles were repealed by way of ordinary legislation on December 9 , 1884 (see below, p. 541).

${ }^{2}$ Promulgated in the Journal officiel of August 13, 1875. 
All communal electors, including the municipal councilors, shall be eligible without distinction. ${ }^{1}$

Art. 3. In communes where the duties of the municipal council are performed by a special delegation organized by virtue of Article 44 of the Law of April 5, 1884, the senatorial delegates and alternates shall be chosen by the former council. ${ }^{2}$

Art. 4. If the delegates were not present at the election, notice shall be given them by the mayor within 24 hours. They shall, within 5 days, notify the prefect of their acceptance. In case of refusal or silence, they shall be replaced by the alternates, who shall then be placed upon the list as the delegates of the commune. ${ }^{2}$

Art. 5. The official report of the election of delegates and alternates shall be transmitted at once to the prefect; it shall state the acceptance or refusal of the delegates and alternates, as well as the protests raised, by one or more members of the municipal council, against the legality of the election. A copy of this official report shall be posted on the door of the town hall. ${ }^{2}$

Art. 6. A statement of the results of the election of delegates and alternates shall be drawn up within a week by the prefect; this statement shall be given to all requesting it, and may be copied and published.

Every elector may, at the bureau of the prefecture, obtain information and a copy of the list, by communes, of the municipal councilors of the department, and, at the bureaus of the subprefectures, information and a copy of the list, by communes, of the municipal councilors of the arrondissement.

Art. 7. Every communal elector may, within the next three days, address directly to the prefect a protest against the regularity of the election.

If the prefect deems the proceedings irregular, he may request that they be set aside.

Art. 8. Protests concerning the election of delegates or of alternates shall be decided, subject to an appeal to the Council of State, by the council of the prefecture, and, in the colonies, by the privy council.

Delegates whose election is annulled because they do not fulfill some one of the conditions demanded by law, or on account of informality, shall be replaced by the alternates.

In case the election of a delegate and of an alternate is annulled or in the case of the refusal or death of both of them after their

'As amended by Article 8 of the Law of December 9, 1884 (see below, p. 543). The original text provided that each municipal council elect one delegate and one alternate.

${ }^{2}$ As amended by Article 8 of the Law of December 9, 1884 (see below, p. 543). The amendments of Articles 4 and 5 merely substitute "delegates" and "alternates" for "delegate" and "alternate." 
acceptance, new elections shall be held by the municipal council on a day fixed by an order of the prefect. ${ }^{1}$

Art. 9. One week, at the latest, before the election of Senators the prefect, and, in the colonies, the director of the interior, shall arrange the list of the electors of the department in alphabetical order. The list shall be communicated to all who request it, and may be copied and published. No elector shall have more than one vote.

Art. 10. The deputies, the members of the gencral council, or of the arrondissement councils, whose elections have been announced by the returning committees, but whose powers have not been verified, shall be enrolled upon the list of electors and shall take part in the voting.

Art. 11. In each of the three departments of Algeria the electoral college shall be composed:

(1) Of the deputies.

(2) Of the members of the general councils of French citizenship.

(3) Of delegates elected by the French members of each municipal council from among the communal electors of French citizenship.

Art. 12. The electoral college shall be presided over by the president of the civil tribunal of the seat of government of the department or colony. In the Department of Ardennes it shall be presided over by the president of the tribunal of Charleville. ${ }^{3}$

The president shall be assisted by the two oldest and the two youngest electors present at the opening of the meeting. The bureau thus constituted shall choose a secretary from among the electors.

If the president is prevented from presiding, his place shall be taken by the vice-president [of the civil tribunal], and, in his absence, by the oldest judge.

Art. 13. The bureau shall divide the electors in alphabetical order into sections of at least 100 voters each. It shall appoint the president and inspectors of each of these sections. It shall decide all questions and contests which may arise in the course of the election, without power, however, to depart from the decisions rendered by virtue of Article 8 of the present law.

Art. 14. The first ballot shall begin at $80^{\prime}$ clock in the morning and close at noon. The second shall begin at 2 o'clock and close at 5 o'clock. The third shall begin at 7 o'clock and close at 10 o'clock. The results of the ballotings shall be canvassed by

\footnotetext{
${ }^{1}$ As amended by Article 8 of the Law of December 9, 1884 (see below, p. 543). The amendment to this article merely substitutes "delegates" and "alternates" for "delegate" and "alternate."

"This sentence was added by the Law of February 1, 1898.
} 
the bureau and announced immediately by the president of the electoral college. ${ }^{1}$

Art. 15. No one shall be elected Senator on either of the first two ballots unless he receives (1) an absolute majority of the votes cast and (2) a number of votes equal to one-fourth of the total number of electors registered. On the third ballot a plurality shall be sufficient, and, in case of an equality of votes, the oldest is elected.

Art. 16. Political meetings for the nomination of Senators may be held from the date of the promulgation of the decree summoning the electors up to the day of the election, inclusive.

The declaration prescribed by Article 2 of the Law of June 30, $1881,{ }^{2}$ shall be made by two voters at least.

The forms and regulations of this Article, as well as those of Article 3, shall be observed.

The members of Parliament elected or electors in the department, the senatorial electors, delegates and alternates, and the candidates or their representatives may alone be present at these meetings.

The municipal authorities shall see to it that no other person is admitted.

Delegates and alternates shall present as a means of identification a certificate from the mayor of the commune; candidates or their representatives, a certificate from the official who shall have received the declaration mentioned in Paragraph 2.3

Art. 17. Delegates who take part in all the ballotings shall, if they demand it, receive from the state, upon the presentation of their letter of summons, countersigned by the president of the electoral college, a remuneration for traveling expenses, which shall be paid to them upon the same basis and in the same manner as that given to jurors by Articles 35, 90 and following of the decree of June 18, 1811.

A public administrative regulation shall determine the manner of fixing the amount and the method of payment of this remuneration. ${ }^{4}$

Art. 18. Every delegate who, without lawful reason, shall not take part in all the ballotings, or, having been hindered, shall not have given notice to the alternate in sufficient time, shall, upon the demand of the public prosecutor, be fined 50 francs by the civil tribunal of the seat of government.

The same penalty may be imposed upon the alternate who,

${ }^{1}$ As amended by Article 8 of the Law of December 9, 1884 (see below, p. 543).

${ }^{2} \mathrm{Law}$ on the freedom of assembly. The Law of March 28, 1907, concerning public gatherings, suppressed the formality of a previous declaration.

${ }^{3}$ As amended by Article 8 of the Law of December 9, 1884 (see below, p. 543).

${ }^{4}$ Decree of December 26, 1875. 
after having been notified by letter, telegram, or notice personally delivered in due time, shall not have taken part in the election.

Art. 19. Every attempt at corruption or constraint by the employment of means enumerated in Articles 177 and following of the Penal Code, to influence the vote of an elector or to keep him from voting, shall be punished by imprisonment of from three months to two years and by a fine of from 50 to 500 francs, or by either of these penalties.

Article 463 of the Penal Code is applicable to the penalties provided by the present Article. ${ }^{1}$

Art. 20. There is incompatibility between the functions of Senator and those:

Of councilor of state and maître des requêtes, prefect and subprefect, except the prefect of the Seine and the prefect of the police.

Of member of the courts of appeal ${ }^{2}$ and of tribunals of first instance, except the public prosecutor before the court of Paris.

Of paymaster general, of special receiver, of official and employee of the central administration of the ministries. ${ }^{3}$

Art. 21. No one of the following officers shall be elected by the department or the colony included wholly or partially in his jurisdiction during the exercise of his duties or during the six months following the cessation of his duties by resignation, dismissal, change of residence, or other cause:

(1) The first presidents, presidents, and members of the courts of appeal.

(2) The presidents, vice-presidents, examining magistrates and members of the tribunals of first instance.

(3) The prefect of police, prefects and subprefects and secretaries general of prefectures; the governors, directors of the interior, and secretaries general of the colonies.

(4) The engineers in chief and of the arrondissement and road surveyors in chief and of the arrondissement.

(5) The rectors and inspectors of academies.

(6) The inspectors of primary schools.

(7) The archbishops, bishops, and vicars general.4

1As amended by Article 8 of the Law of December 9, 1884 (see p. 543).

${ }^{2}$ France is divided into 26 judicial districts, in each of which there is a court of appeal. There are similar courts in Algeria and the colonies. The Court of Cassation is the supreme court of appeal for all France, Algeria, and the colonies.

${ }^{3}$ This article was implicitly repealed by the Law of December 26, 1887 (see below, p. 545). By Article 3 of the Law of November 16, 1897, the governor and undergovernor of the Bank of France are ineligible as Deputies or Senators.

'This clause was implicitly repealed by Article 2 of the Law of December 9, 1905, on the separation of Church and State. 
(8) The officers of all grades of the land and naval forces.

(9) The division commissaries and the military deputy commissaries.

(10) The paymasters general and special receivers of money.

(11) The superintendents of direct and indirect taxes, of registration and of public property, and of posts.

(12) The commissioners and inspectors of forests.

Art. 22. A Senator elected in several departments shall make known his choice to the president of the Senate within 10 days following the verification of the elections. If a choice is not made in this time, the question shall be settled by lot in open session.

The vacancy shall be filled within one month and by the same electoral body.

The same holds true in case of an invalidated election.

Art. 23. Vacancies caused by the death or resignation of Senators shall be filled within three months; however, if the vacancy occurs within six months preceding the triennial election it shall not be filled until those elections. ${ }^{1}$

Art. 24-25.2

Art. 26. Members of the Senate shall receive the same salaries as members of the Chamber of Deputies. ${ }^{3}$

Art. 27. All provisions of the electoral law relating to the following matters are applicable to elections of senators:

(1) To cases of unworthiness and incapacity.

(2) To offenses, prosecutions, and penalties.

(3) To election proceedings, in all matters not contrary to . the provisions of the present law.

Art. 28-29.4

\section{ORGANIC LAW OF NOVEMBER $30,1875^{5}$}

\section{ON the Election of Deputies}

Article 1. The Deputies shall be chosen by the voters registered:

(1) Upon the lists drawn up in accordance with the Law of July $7,1874$.

${ }^{1}$ As amended by Article 8 of the Law of December 9, 1884 (see below, p. 543).

${ }^{2}$ Articles 24 and 25 were repealed by Article 9 of the Law of December 9, 1884 .

${ }^{3}$ See Article 17 of the Organic Law of November 30, 1875, p. 538 below.

4Articles 28 and 29 of this law contained transitional provisions.

'Promulgated in the Journal officiel of November 31, 1875. This law has been amended or supplemented by the Iaws of June 16,1885, February 13, 1889, and July 17, 1889, and July 12, 1919 (see below, pp. 545 and 546, respectively). 
(2) Upon the supplementary list including those who have lived in the commune six months. ${ }^{1}$

Registration upon the supplementary list shall take place conformably to the laws and regulations now governing the political electoral lists, by the committees and according to the forms established by Articles 1, 2, and 3 of the Law of July 7, 1874.

Appeals relating to the formation and revision of either list shall be brought directly before the Civil Chamber of the Court of Cassation.2

Art. 2. The soldiers of all ranks and grades, of both land and naval forces, shall not take part in any vote when they are with their regiment, at their post, or on duty. Those who, on election day, are in private residence, on the non-active list, or in possession of a regular leave of absence, may vote in the commune on the lists of which they are duly registered. This last provision shall apply equally to officers on the unattached list or on the reserve list. ${ }^{3}$

Art. 3. During the electoral period, circulars and platforms signed by the candidates, electoral placards and manifestoes signed by one or more voters, may, after being deposited with the public prosecutor, be posted and distributed without previous authorization.

The distribution of ballots shall not be subject to the formality of deposit."

Every public or municipal officer is forbidden to distribute ballots, platforms, or circulars of candidates.

The provisions of Article 19 of the Organic Law of August 2, 1875,5 on the election of Senators shall apply to the election of Deputies.

Art. 4. The balloting shall last one day only. The voting shall occur in the chief town of the commune; each commune may nevertheless be divided, by order of the prefect, into as many sections as local circumstances and the number of voters may require. The second ballot shall take place on the second Sunday following the announcement of the first ballot, in ac-

\footnotetext{
'There is now only a single list, common to the political and municipal elections, since municipal electors are subject to only six months' residence (Article 14 of the Law of April 5, 1884).

${ }^{2}$ Here follows a transitional provision, concerning the electoral lists of 1875 , omitted here.

3See Article 9 of the Law of March 21, 1905.

The Law of December 20, 1878, dispensed with the formality of deposit of ballots in all elections. The printer was dispensed from the deposit of these ballots by the Law of July 27, 1881 .
}

see above, p. 533. 
cordance with the provisions of Article 65 of the Law of March 15, 1849.

Art. 5. The voting shall take place in accordance with the provisions of the organic and regulating decrees of February 2, 1852 .

The ballot shall be secret.

The voting lists used at the elections in each section, signed by the president and secretary, shall remain deposited for one week at the secretary's office at the town hall, where they shall be communicated to every voter requesting them.

Art. 6. Every voter shall be eligible, without any property qualification, at the age of 25 years. ${ }^{1}$

Art. 7. No soldier or sailor in active service on land or sea may, whatever his rank or position, be elected a member of the Chamber of Deputies.

This provision applies to soldiers and sailors on the unattached list or the inactive list, but does not extend to officers of the second section of the list of the general staff, nor to those who, kept in the first section for having been commander-in-chief in the field, have ceased to be actively employed, nor to officers who, having gained the right to retire, are sent to or kept at their homes while awaiting the settlement of their pension.

The decision by which the officer shall have been permitted to establish his rights on the retired list shall become, in this case, irrevocable.

The rule laid down in the first paragraph of the present article shall not apply to the reserve of the active army or to the territorial army:

Art. 8. The exercise of public duties paid for out of the treasury of the state is incompatible with the office of Deputy. ${ }^{2}$

Consequently every official elected shall be superseded in his duties if, within one week following the verification of his powers, he has not signified that he does not accept the office of deputy.

There are excepted from the preceding provisions the duties of minister, undersecretary of state, ambassador, minister plenipotentiary, prefect of the Seine, prefect of police, first president of the Court of Cassation, first president of the Court of Accounts, first president of the Court of Appeal of Paris, attorney general of the Court of Cassation, attorney general of the Court of Accounts, attorney general of the Court of Appeal of Paris,

\footnotetext{
'Exceptions to eligibility are to be found in the Laws of June 16, 1885, June 22, 1886, July 17, 1889 (see below, p. 546), July 20, 1895, and March 21, 1905.

"To these must be added the duties of administrator of concessionary companies of maritime postal service (Law of June 28, 1883, Article 10), administrators of railways (Law of November 20, 1883, Article 5) and governor and undergovernor of the Bank of France (Law of November 17, 1897, Article 3).
} 
archbishop and bishop, consistorial presiding pastor in consistorial districts the seat of government of which has two or more pastors, chief rabbi of the central consistory, chief rabbi of the consistory of Paris. ${ }^{1}$

Art. 9. There are also excepted from the provisions of Article 8:

(1) Titular professors of chairs which are filled by competition or upon the nomination of the bodies where the vacancy occurs.

(2) Persons who have been charged with a temporary mission. All missions continuing more than six months cease to be temporary and are governed by Article 8 above. ${ }^{2}$

Art. 10. The officer preserves the rights which he has acquired to a retiring pension, and may, after the expiration of his mandate, be restored to active service.

The civil officer who, having had 20 years of service at the date of the acceptance of the mandate of Deputy, shall be 50 years of age at the time of the expiration of his mandate, may establish his rights to an exceptional retiring pension.

This pension shall be regulated according to the third paragraph of Article 12 of the Law of June 9, 1853. ${ }^{3}$

If the officer is restored to active service after the expiration of his mandate, the provisions of Article 3, Paragraph 2, and Article 28 of the Law of June 9, 1853, shall apply to him.

In duties where the rank is distinct from the employment, the officer, by the acceptance of the mandate of Deputy, loses the employment and preserves the rank only.

Art. 11. Every Deputy appointed or promoted to a salaried public position shall cease to belong to the Chamber by the very fact of his acceptance; but he may be reëlected, if the office which he occupies is compatible with the mandate of Deputy.

Deputies who become ministers or undersecretaries of state shall not be required to seek reëlection.

Art. 12. The following officers shall not be elected by the arrondissement or the colony included wholly or partially in their jurisdiction, during the exercise of their duties or for six months following the cessation of their duties, because of resignation, dismissal, change of residence, or any other cause:

${ }^{1}$ These religious officials were made ineligible for 8 years by Article 40 of the Law of December 9, 1905, on the separation of Church and State.

2See Law of December 26, 1887.

3The Law of March 29, 1897, added that, for officials subject (as concerns the pension) to the Law of August 22,1790 , this pension shall be regulated at the rate of one thirtieth (per year of service) of the pension which would have been settled upon them for 30 years of service. The same law also makes these provisions applicable to the case provided for by the second paragraph of the sole article of the Law of December 26, 1887. 
(1) The first presidents and members of the courts of appeal.

(2) The presidents, vice-presidents, titular judges, examining magistrates, and members of the tribunals of first instance, as well as titular justices of the peace. ${ }^{1}$

(3) The prefect of police, the prefects and secretaries general of prefectures; the governors, directors of the interior, and secretaries general of the colonies.

(4) The engineers in chief and of the arrondissement and road surveyors in chief and of the arrondissement.

(5) The rectors and inspectors of academies.

(6) The inspectors of primary schools.

(7) The archbishops, bishops, and vicars general. ${ }^{2}$

(8) The paymasters general and special receivers of money.

(9) The superintendents of direct and indirect taxes, of registration and of public property, and of posts.

(10) The commissioners and inspectors of forests.

The sub-prefects and councilors of the prefecture ${ }^{3}$ shall not be elected in any of the arrondissements of the department in which they perform their duties.

Art. 13. Every attempt to bind deputies by instructions is null and void.

Art. 14.4

Art. 15. Deputies shall be chosen for four years.

The Chamber shall be renewed integrally.

Art. 16. In case of vacancy by death, resignation, or otherwise, a new election shall be held within three months of the date when the vacancy occurred. ${ }^{5}$

In case of option, ${ }^{6}$ the vacancy shall be filled within one month. Art. 17. Deputies shall receive an indemnity.

The legislative indemnity is fixed at fifteen thousand $(15,000)$

\footnotetext{
'The Law of March 30, 1902, added the phrase "as well as titular justices of the peace."

'Implicitly repealed by Article 40 of the Law of December 9, 1905, on the separation of Church and State.

'The Law of March 30, 1902, added the phrase "and councilors of the prefecture."

'This article was repealed by the Law of June 16, 1885 (see below, p. 545), which established the ballot by ticket (scrutin de liste) in place of the separate ballot (scrutin individuel) or system of single districts. It was reënacted almost word for word by the Law of February 13, 1889, Article 2; which law was repealed by the Law of July 12, 1919 (see below, p. 546).
}

See Article 7 of the Law of June 16, 1885, p. 545 .

- $I$. e., when a deputy has been elected from two or more districts, and decides which one he will serve. 
francs ${ }^{1}$ per year, beginning with January 1,1907 . It is regulated by the second paragraph of Article 96 and by Article 97 of the Law of March 15, 1849, as well as by the provisions of the Law of February 16, 1872.

Art. 18. No one shall be elected on the first ballot unless he receives:

(1) An absolute majority of the votes cast.

(2) A number of votes equal to one-fourth of the number of voters registered.

On the second ballot a plurality is sufficient. In case of an equality of votes, the oldest is elected.2

Art. $19 .{ }^{3}$

Art. 20. The voters living in Algeria in a place not yet made a commune shall be registered on the electoral list of the nearest commune.

When it is necessary to establish electoral districts, either for the purpose of grouping mixed communes in each of which the number of voters is insufficient, or to bring together voters living in places not formed into communes, the decrees for fixing the seat of these districts shall be issued by the governor general, upon the report of the prefect or of the general commanding the division.

Art. 21.4

Art. 22. Every violation of the prohibitive provisions of Article 3, Paragraph 3, of the present law shall be punished by a fine of from 16 francs to 300 francs. Nevertheless, the criminal courts may apply Article 463 of the Penal Code.

The provisions of Article 6 of the Law of July 7, 1874, shall apply to the political electoral lists. ${ }^{5}$

The Decree of January 29, 1871, and the Laws of April 10, 1871, May 2, 1871, and February 18, 1873, are repealed.

Paragraph 11 of Article 15 of the Organic Decree of February 2,1852 , is also repealed, in so far as it refers to the Law of

1As amended by the Law of November 23, 1906; before the passage of this law deputies and senators received 9,000 francs per year. The Law of February 16, 1872 , prohibits the adding of the indemnity to state salaries (plurality of offices). Article 96 of the Law of March 15, 1849, treats of the same subject. Article 97 permits the seizure of the entire indemnity.

2This article should be considered as implicitly repealed by Article 5 of the Law of June 16, 1885, which repeats the terms of this article almost word for word.

sThis article, concerning the representation of Algeria, was implicitly repealed by Article 3 of the Law of February 13, 1889 (see below, p. 546).

This article, concerning the representation of the colonies, was implicitly repealed by Article 3 of the Law of February 13, 1889 (see below, p. 546).

The Law of July 7, 1874, concerns the municipal electorate. Article 6 of that law punishes fraudulent registrations on the electoral lists. 
May 21, 1836, on lotteries, reserving, however, to the courts the right to apply Article 42 of the Penal Code to convicted persons.

The provisions of the laws and decrees now in force, not in conflict with the present law, shall continue to be applied.

Art. 23. The provisions of Article 12 of the present law by which an interval of six months must elapse between the cessation of duties and election shall not apply to officials other than prefects and sub-prefects, whose duties shall have ceased either before the promulgation of the present law or within 20 days thereafter.

\section{LAW OF JULY 22, $1879^{1}$}

On the Seat of the Executive Power and of the Two Houses at Paris

Article 1. The seat of the executive power and of the two houses shall be at Paris.

Art. 2. The Palace of the Luxemburg and the Palais-Bourbon are assigned, the first to the use of the Senate and the second to that of the Chamber of Deputies.

Nevertheless, each of the houses is authorized to choose, in the city of Paris, the palace which it wishes to occupy.

Art. 3. The various parts of the palace of Versailles now occupied by the Senate and the Chamber of Deputies shall preserve their arrangements.

Whenever, according to Articles 7 and 8 of the Law of February 25,1875 , on the organization of the public powers, a meeting of the National Assembly takes place, it shall sit at Versailles, in the present hall of the Chamber of Deputies.

Whenever, according to Article 9 of the Law of February 24, 1875 , on the organization of the Senate, and Article 12 of the Constitutional Law of July 16, 1875, on the relations of the public powers, the Senate shall be called upon to constitute itself a court of justice, it shall indicate the town and place where it proposes to sit.

Art. 4. The Senate and Chamber of Deputies shall sit at Paris on and after November 3, next.

Art. 5. The Presidents of the Senate and of the Chamber of Deputies are charged with the duty of securing the internal and external safety of the houses over which they preside.

For this purpose they shall have the right to call upon the armed forces and upon all the authorities whose assistance they consider necessary.

Such requisitions may be addressed directly to all officers,

${ }^{1}$ Promulgated in the Journal officiel of July 23, 1879. 
commanders, or officials, who are bound to obey immediately, under the penalties established by the laws.

The Presidents of the Senate and of the Chamber of Deputies may delegate to the questors or to one of them their right of demanding aid.

Art. 6. Every petition to either of the houses shall be made and presented only in writing. It is forbidden to present them in person or at the bar.

Art. 7. Every violation of the preceding article, every provocation, by public speeches, by writings, or printed matter, posted or distributed, to a crowd upon the public ways, having for its object the discussion, drawing up, or carrying to the houses or to one of them, of petitions, declarations, or addresses shall be punished by the penalties enumerated in Paragraph 1 of Article 5 of the Law of June 7, 1848, whether or not any results follow from such actions.

Art. 8. The preceding provisions do not diminish the force of the Law of June 7, 1848, on riotous assemblies.

Art. 9. Article 463 of the Penal Code is applicable to the offenses mentioned in the present law.

\section{LAW OF DECEMBER 9, 1884}

\section{Amending the Organic Laws on the Organization of the} Senate and the Election of Senators

Article 1. The Senate shall be composed of 300 members, elected by the departments and the colonies.

The present members, without any distinction between Senators elected by the National Assembly or by the Senate and those elected by the departments and colonies, shall retain their offices during the time for which they have been chosen.

Art. 2. The Department of the Seine shall elect 10 Senators.

The Department of the Nord shall elect 8 Senators.

The Departments of Côtes-du-Nord, Finistère, Gironde, Illeet-Vilaine, Loire, Loire-Inférieure, Pas-de-Calais, Rhône, Saôneet-Loire and Seine-Inférieure shall elect 5 Senators each.

Aisne, Bouches-de-Rhône, Charente-Inférieure, Dordogne, Haute-Garonne, Isère, Maine-et-Loire, Manche, Morbihan, Puy-de-Dôme, Seine-et-Oise and Somme shall elect 4 Senators each.

Ain, Allier, Ardèche, Ardennes, Aube, Aude, Aveyron, Calvados, Charente, Cher, Corrèze, Corse, Côte-d'Or, Creuse, Doubs, Drôme, Eure, Eure-et-Loir, Gard, Gers, Hérault, Indre, Indre-et-Loire, Jura, Landes, Loir-et-Cher, Haute-Loire, Loiret,

\footnotetext{
'Promulgated in the Journal officiel of December 10, 1884.
} 
Lot, Lot-et-Garonne, Marne, Haute-Marne, Mayenne, Meurtheet-Moselle, Meuse, Nièvre, Oise, Orne, Basses-Pyrénées, HauteSaône, Sarthe, Savoie, Haute-Savoie, Seine-et-Marne, DeuxSèvres, Tarn, Var, Vendée, Vienne, Harte-Vienne, Vosges and Yonne shall elect 3 Senators each.

Basses-Alpes, Hautes-Alpes, Alpes-Maritimes, Ariège, Cantal, Lozère, Hautes-Pyrénées, Pyrénées-Orientales, Tarn-et-Garonne and Vaucause shall elect 2 Senators each.

The territory of Belfort, the three departments of Algeria, the four colonies of Martinique, of Guadeloupe, of Réunion and of the French Indies shall elect 1 Senator each. ${ }^{1}$

Art. 3. In the departments where the number of senators is increased by the present law, the increase shall take effect as vacancies occur among the irremovable Senators.

For this purpose, within a week after the vacancy occurs, it shall be determined by lot in public session what department shall be called upon to elect a Senator.

This election shall take place within three months of the determination by lot. However, if the vacancy occurs within six months preceding the triennial election, the vacancy shall not be filled until that election.

The mandate thus conferred shall expire at the same time as that of the other Senators belonging to the same department.

Art. 4. No one shall be a Senator unless he is a French citizen at least 40 years of age and in the enjoyment of civil and political rights. ${ }^{2}$

Members of families that have reigned in France are ineligible to the Senate.

Art. 5. The soldiers of the land and naval forces shall not be elected Senators.

There are excepted from this provision:

(1) The marshals of France and admirals.

(2) The general officers maintained without limit of age in the first section of the list of the general staff and not provided with a command.

(3) The general officers placed in the second section of the list of the general staff.

(4) Members of the land and naval forces who belong either to the reserve of the active army or to the territorial army.

Art. 6. Senators shall be elected by scrutin de liste, by a college meeting at the capital of the department or of the colony and composed:

'This redistribution was not effective until after the death of the last irremovable Senator (see Article 3 of this law).

${ }^{2}$ By the Law of July 20, 1895, no one may become a member of either house unless he has complied with the law regarding military service. 
(1) Of the deputies.

(2) Of the general councilors.

(3) Of the councilors of the arrondissement.

(4) Of delegates elected from among the voters of the commune by each municipal council.

Councils composed of 10 members shall elect 1 delegate.

Councils composed of 12 members shall elect 2 delegates.

Councils composed of 16 members shall elect 3 delegates.

Councils composed of 21 members shall elect 6 delegates.

Councils composed of 23 members shall elect 9 delegates.

Councils composed of 27 members shall elect 12 delegates.

Councils composed of 30 members shall elect 15 delegates.

Councils composed of 32 members shall elect 18 delegates.

Councils composed of 34 members shall elect 21 delegates.

Councils composed of 36 members or more shall elect 24 delegates.

The municipal council of Paris shall elect 30 delegates.

In the French Indies the members of the local councils shall take the place of councilors of the arrondissement. The municipal councils of Pondichéry shall elect 5 delegates. The municipal council of Karikal shall elect 3 delegates. All of the other communes shall elect 2 delegates each. ${ }^{1}$

Art. 7. Members of the Senate shall be elected for 9 years.

The Senate shall be renewed every 3 years according to the order of the present series of departments and colonies.

Art. 8. Articles 2 (Paragraphs 1 and 2), 3, 4, 5, 8, 14, 16, 19 , and 23 of the Organic Law of August 2, 1875, on the elections of Senators are amended as follows:

Article 2 (Paragraphs 1 and 2 ). In each municipal council the election of delegates shall take place without debate and by secret ballot, by scrutin de liste, and by an absolute majority of votes cast.

After two ballots a plurality shall be sufficient, and in case of an equality of votes the oldest is elected.

The procedure and method shall be the same for the election of alternates.

Councils having 1,2 or 3 delegates to choose shall elect 1 alternate.

Those choosing 6 or 9 delegates shall elect 2 alternates.

Those choosing 12 or 15 delegates shall elect 3 alternates.

Those choosing 18 or 21 delegates shall elect 4 alternates.

Those choosing 24 delegates shall elect 5 alternates.

The municipal council of Paris shall elect 8 alternates.

The alternates shall take the place of delegates in case of refusal or inability to serve, in the order determined by the number of votes received by each of them.

Art. 3. In communes where the duties of the municipal council are performed by a special delegation organized by virtue of Article 44 of the Law of April 5, 1884, the senatorial delegates and alternates shall be chosen by the former council.

\footnotetext{
1 As amended by the Law of December 17, 1908, which repealed a last paragraph worded as follows: "The balloting shall take place at the seat of government of each district."
} 
Art. 4. If the delegates were not present at the election, notice shall be given them by the mayor within 24 hours. They shall, within 5 days, notify the prefect of their acceptance. In case of refusal or silence, they shall be replaced by the alternates, who shall then be placed upon the list as the delegates of the commune.

Art. 5. The official report of the election of delegates and alternates shall be transmitted at once to the prefect. It shall state the acceptance or refusal of the delegates and alternates, as well as the protests raised, by one or more members of the municipal council, against the legality of the election. A copy of this official report shall be posted on the door of the town hall.

Art. 8. Protests concerning the election of delegates or of alternates shall be decided, subject to an appeal to the Council of State, by the council of the prefecture, and, in the colonies, by the privy council.

Delegates whose election is annulled because they do not fulfill some one of the conditions demanded by law, or because of informality, shall be replaced by the alternates.

In case the election of a delegate and of an alternate is annulled, or in the case of the refusal or death of both of them after their acceptance, new elections shall be held by the municipal council on a day fixed by an order of the prefect.

Art. 14. The first ballot shall begin at 8 o'clock in the morning and close at noon. The second shall begin at 2 o'clock and close at 5 o'clock. The third shall begin at $7 o^{\prime}$ clock and close at $10 o^{\prime}$ clock. The results of the balloting shall be canvassed by the bureau and announced immediately by the president of the electoral college.

Art. 16. Political meetings for the nomination of Senators may be held from the date of the promulgation of the decree summoning the electors up to the day of the election, inclusive.

The declaration prescribed by Article 2 of the Law of June 30,1881,1 shall be made by two voters at least.

The forms and regulations of this article, as well as those of Article 3, shall be observed.

The members of Parliament elected or electors in the department, the senatorial electors, delegates and alternates, and the candidates or their representatives may alone be present at these meetings.

The municipal authorities shall see to it that no other person is admitted.

Delegates and alternates shall present as a means of identification a certificate from the mayor of the commune; candidates or their representatives, a certificate from the official who shall have received the declaration mentioned in Paragraph 2.

Art. 19. Every attempt at corruption or constraint by the employment of means enumerated in Articles 177 and following of the Penal Code, to influence the vote of an elector or to keep him from voting, shall be punished by imprisonment of from three months to two years and by a fine of from 50 to 500 francs or by either of these penalties.

Article 463 of the Penal Code is applicable to the penalties provided by the present article.

Art. 23. Vacancies caused by the death or resignation of Senators shall be filled within three months; however, if the vacancy occurs within six months preceding the triennial elections, it shall not be filled until those elections.

Art. 9. The following are repealed:

(1) Articles 1-7 of the Law of February 24, 1875, on the organization of the Senate.

${ }^{1}$ See above, p. 532 , note 2 . 
(2) Articles 24 and 25 of the Law of August 2, 1875, on the elections of Senators. ${ }^{1}$

\section{LAW OF JUNE $16,1885^{2}$}

\section{Amending the Electoral Law}

Articles 1-3.3

Art. 4. Members of families that have reigned in France are ineligible to the Chamber of Deputies. ${ }^{4}$

Art. 5. No one shall be elected on the first ballot unless he receives:

(1) An absolute majority of the votes cast.

(2) A number of votes equal to one-fourth of the total number of voters registered.

On the second ballot a plurality shall be sufficient.

In case of an equality of votes, the oldest of the candidates is elected.

Art. 6. Subject to the case of a dissolution provided for and regulated by the constitution, the general elections shall take place within the 60 days preceding the expiration of the powers of the Chamber of Deputies.

Art. 7. Vacancies which occur in the six months preceding the renewal of the Chamber shall not be filled.

\section{LAIV OF DECEMBER 26, $1887^{5}$}

\section{On Parliamentary Incompatibilities}

Until the passage of a special law on parliamentary incompatibilities, Articles 8 and 9 of the Law of November 20, 1875, shall be applicable to senatorial elections. ${ }^{6}$

Every officer affected by this provision who has had 20 years

1The transitional provisions of this law are omitted, because they are practically repeated in the Law of December 26, 1887, on parliamentary incompatibilities (see below, this page).

${ }^{2}$ Promulgated in the Journal officiel of June 17, 1885.

${ }^{3}$ Articles 1,2 , and 3 of this law were repealed by the Law of February 13,1889 , which in turn was repealed by the Law of July 12, 1919 (sce below, p. 546).

${ }^{4}$ For similar provisions regarding the Presidency of the Republic and the Senate, see Article 2 of the Law of August 14, 1884, and Article 4 of the Law of December 9,1884 (see above, pp. 529, 542). Article 4 of the Law of June 22, 1886, prohibited every elective office to the members of families that have reigned in France.

5Promulgated in the Journal officiel of December 28, 1887.

'See this law, p. 534 above; see also Article 20 of the Iaw of August 2, 1875, p. 533 above. 
of service and is 50 years of age at the time of his acceptance of the office of Senator, may establish his rights to a proportional retiring pension, which shall be governed by the third paragraph of Article 12 of the Law of June 9, 1853.

\section{LAW OF FEBRUARY 13, $1889^{1}$}

\section{ReËstablishing Single Districts for the Election of Deputies}

\section{LAW OF JULY 17, $1889^{2}$ \\ On Multiple Candidates}

Article 1. No one shall be a candidate in more than one district.

Arts. 2-6.3

\section{LAW OF JULY 12, 19194}

To Amend the Organic Laws on Election of Deputies and to Establish Scrutin de liste with Proportional

\section{Representation}

Article 1. Members of the Chamber of Deputies shall be elected by scrutin de liste by departments.

Art. 2. Each department shall elect one deputy for every 75,000 inhabitants of French nationality, a remainder exceeding 37,500 giving the right to an additional Deputy.

Each department shall elect at least three Deputies.

Provisionally and until a new census has been taken each department shall have the same number of seats [in the Chamber of Deputies] as at present.

Art. 3. Each department shall form a single electoral area. Provided that when the number of Deputies to be elected by a department is greater than six the department may be divided into electoral areas each of which shall be entitled to elect at least three Deputies. Such division shall be enacted by law.

Notwithstanding the foregoing provision the Departments

'Promulgated in the Journal officiel of February 14, 1889; repealed by the Law of July 12, 1919 (see below, this page).

${ }^{2}$ Promulgated in the Journal officiel of July 18, 1889.

${ }^{3}$ Formalities imposed upon candidates and penalties for their violation, omitted here.

4Promulgated in the Journal officiel of July 12, 1919. This translation is taken from Representation, No. 34, October, 1919, pp. 18-20. A practically identical translation is found in Sait, Government and Politics of France, p. 450 (Yonkers, 1920). For a discussion of this law, see above, pp. 105-108. 
of the Nord, the Pas de Calais, the Aisne, the Somme, the Marne, the Ardennes, the Meurthe-et-Moselle, and the Vosges shall not be divided for the next election.

Art. 4. No person can be a candidate in more than one electoral area, and the law of July 17, 1889, relating to multiple candidatures shall apply to elections under this act; declarations of candidature may nevertheless be either individual or collective.

Art. 5. Lists are constituted for any particular electoral area by groups of candidates who sign a legally authenticated declaration.

Declarations of candidature shall indicate the order in which candidates are presented.

If the declarations of candidature are presented on separate sheets they must specify the candidates in conjunction with whom the signatory or signatories stand and who agree by joint and duly authenticated declaration to put the names of the signatories on the same list as their own.

A list shall not include a number of candidates greater than the number of deputies to be elected in the electoral area. An individual candidature shall be considered as forming a separate list. In such case the declaration of candidature shall be supported by one hundred electors of the electoral area, whose signatures shall be authenticated and shall not be used in support of more than one candidature.

Art. 6. The lists shall be deposited at the prefecture after the commencement of the electoral period and at latest five days before the day of the election.

The list and the title of the list shall be registered by the prefecture.

Registration shall be refused to any list bearing more names than there are deputies to elect or bearing the name of any candidate belonging to another list already registered in the electoral area unless such candidate has previously withdrawn his name in accordance with the procedure laid down in Article Seven.

Registration shall be accorded only to the names of candidates who have made a declaration in conformity with the terms of Articles 4 and 5 .

A provisional acknowledgment of the deposit of a list shall be given to each of the candidates who compose it.

The definite receipt shall be delivered within the next twentyfour hours.

Art. 7. A candidate inscribed upon a list cannot be struck off unless he notifies the prefecture of his desire to withdraw by statutory declaration (par exploit d'huissier) five days before the day of the election.

Art. 8. Vacancies on any list may be filled at latest five days 
before the day of the election by the names of new candidates who make the declaration of candidature prescribed by Article 5 .

Art. 9. Two days before the commencement of the poll the prefectoral authorities shall cause the registered candidatures to be posted on the doors of the polling-booths.

Art. 10. Any candidate who obtains an absolute majority shall be declared elected provided that the number of seats to be filled is not exceeded. ${ }^{1}$ Any seats that remain to be filled shall be allotted in accordance with the following procedure:

The electoral quotient shall be determined by dividing the number of voters, excluding blank or spoiled ballots, by the number of deputies to be elected.

The average figure for each list shall be determined by dividing by the number of its candidates the total number of votes which they have obtained.

To each list shall be allotted a number of seats equal to the number of times which its average figure contains the electoral quotient.

The remaining seats, if any, shall be allotted to the list with the highest average figure.

Within each list the seats obtained shall be allotted to the candidates who have received most votes.

Art. 11. An independent candidate, provided that he has not obtained an absolute majority of the votes, shall not be eligible for allotment of a seat until the candidates belonging to other lists who have obtained more votes than he has obtained shall have been declared elected.

Art. 12. In case of equality of votes the eldest candidate shall be elected.

${ }^{1}$ The proviso contained in the last words of this paragraph becomes necessary owing to the fact that each voter has as many votes as there are deputies to be elected, and that cross-voting (panachage) is permitted. Thus the following might be the result of an election of five deputies by 10,000 voters. The absolute majority is 5001. Two lists are presented with candidates A, B, C, D, E, and $P, Q, R, S, T$, respectively, and the voting is as shown:

\begin{tabular}{|c|c|c|c|c|c|c|c|c|c|c|c|}
\hline \multirow{2}{*}{\multicolumn{2}{|c|}{$\begin{array}{l}10,000 \text { voters } \\
\text { (by groups) }\end{array}$}} & \multicolumn{10}{|c|}{ Votes received by candidates } \\
\hline & & A & B & $\mathrm{C}$ & D & E & $\mathrm{P}$ & $\mathbf{Q}$ & $\mathbf{R}$ & $\mathrm{S}$ & $\mathbf{T}$ \\
\hline \multirow{3}{*}{$\begin{array}{c}\text { Group of } \\
\text { “؛ } \\
\text { “ }\end{array}$} & 4900 & 4900 & 4900 & 4900 & 4900 & 4900 & & $\overline{80}$ & - & - & - \\
\hline & 100 & 100 & 100 & 100 & 100 & & 40 & 30 & 20 & 10 & 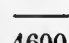 \\
\hline & 400 & 100 & 80 & 60 & 40 & 120 & 400 & 400 & 400 & 400 & \\
\hline Totals & 10,000 & 5100 & 5080 & 5060 & 5040 & 5020 & 5040 & 5030 & 5020 & 5010 & 4600 \\
\hline
\end{tabular}

Thus nine candidates out of ten can, if there is cross-voting, receive an "absolute majority," even though there are only five seats to distribute. 
If more lists than one have an equal title to a seat, the seat is allotted to that one of the candidates eligible who has received most votes or, in case of equality of votes, to the eldest candidate. A candidate shall not be declared elected unless the number of votes obtained by him exceeds half the average of the votes of the list to which he belongs.

Art. 13. When the number of voters is not greater than half the number of registered electors, or if no list has obtained the electoral quota, no candidate shall be declared elected, and the electors of the area shall be summoned to a new election on the fifteenth day following. If at this new election no list obtains the electoral quotient, the seats shall be assigned to the candidates who have received most votes.

Art. 14. The reports on the proceedings at the election in each commune shall be prepared in duplicate. One copy shall be deposited at the secretariat of the Mairie; the other shall be at once posted under sealed cover addressed to the prefect for transmission to the counting commission (commission de receusement).

Art. 15. The votes shall be counted for each electoral area at the chief town of the department in public session at latest on the Wednesday following the day of the poll. The operation shall be performed by a commission composed of the president of the civil tribunal, and the president and the four members of the general council, not being candidates at the election, who have longest held office. In case of equal length of office the eldest shall be appointed.

If the president of the civil tribunal is unable to serve, his place shall be filled by the vice-president and failing him by the senior judge. In case of inability to serve, the places of the members of the general council shall be filled by other members of the same body in order of seniority.

The operations of the count shall be recorded in a report.

Art. 16. In case of a vacancy through death, resignation, or otherwise, an election shall take place within a period of three months counting from the day on which the vacancy took place.

Art. 17. Vacancies occurring within the six months preceding the next general election of the Chamber shall not be filled.

Art. 18. The present act shall apply to the departments of Algeria and to the colonies which shall retain their present number of Deputies.

Further legislation shall make provision for the application of the present act to the territory of Belfort and for the redistribution of Alsace and Lorraine.

Art. 19. Any previous legislation conflicting with the present act is hereby repealed. 


\section{APPENDIX III}

\section{ITALY}

\section{HISTORICAL NOTE}

"The victorious campaigns of Napoleon in 1796 and 1797 constituted the starting point of a series of political revolutions in Italy which ended in the successive annexation of all the parts of Italy to the Kingdom of Sardinia and the formation of the Kingdom of Italy in 1861. From 1797 to 1849 there were 23 constitutions or statutes in force in Italy. Of all of these the Statuto fondamentale of the Kingdom of Sardinia of March 4, 1848, was the only one to survive and it still forms the constitution of the Kingdom of Italy. This Statute, promised by King Charles Albert in a famous proclamation of February 18, 1848 , was published the following month and was put into force in the annexed territories by successive decrees. ${ }^{1}$ Many of the provisions of this Statute have fallen into disuse, although not expressly repealed. In this number are generally classed Articles 1, 28 (Paragraph 2), 53, 62 (Paragraph 2), 76, 77, and 80. A Law of March 17, 1861, conferred on Victor Emmanuel II, and his successors the title of King of Italy, and a Law of February 3,1871 , transferred the capital of the Kingdom to Rome. The position of the Holy See is governed by the Law of May 13, 1871 , called the "Law of Guarantees," which was declared to be a fundamental law of the Kingdom by the Council of State (March 2, 1878). Nevertheless, since the Holy See has not ceased to protest against the annexation of the Papal States, this law has remained the unilateral work of the Italian Government.",2

'Lombardy, Decree of December 7, 1859;'Emilia, Decree of March 18, 1860, and Law of April 15, 1860; Tuscany, Decree of March 22, and Law of April 15, 1860; Sicily, Marches, Umbria and Neapolitan Provinces, Law of December 17, 1860; Province of Venice, Decree of July 28, 1866; Roman Provinces, Decree of October 9, and Law of December 31, 1870.

This introductory paragraph is quoted from Wright, The Constitutions of the States at War, 1914-1918, p. 337 (Washington, Government Printing Office, 1919), and is based upon Dareste, Les constitutions modernes, Vol. I, pp. 67\&674 (3d edition, Paris, 1910). 


\section{FUNDAMENTAL STATUTE OF MARCH 4, $1848^{1}$}

We, Charles Albert, by the Grace of God, King of Sardinia, Cyprus, and Jerusalem, Duke of Savoy, Genoa, etc., etc., Prince of Piedmont, etc., etc., etc., with the fidelity of a king and the affection of a father, are about to-day to fulfill all that we promised our most beloved subjects in our proclamation of the eighth of last February, whereby we desired to show, in the midst of the extraordinary events then transpiring throughout the country, how much our confidence in our subjects increased with the gravity of the situation, and how, consulting only the impulse of our heart, we had fully determined to make their condition conform to the spirit of the times and to the interests and dignity of the nation.

We, believing that the broad and permanent representative institutions established by this Fundamental Statute are the surest means of cementing the bonds of indissoluble affection that bind to our Italian crown a people that has so often given us ample proof of their faithfulness, obedience, and love, have determined to sanction and promulgate this Statute, in the belief that God will bless our good intentions, and that this free, strong, and happy nation will ever show itself more deserving of its ancient fame and thus merit a glorious future.

Therefore, we, with our full knowledge and royal authority and with the advice of our Council, have ordained and do hereby ordain and declare in force the fundamental perpetual and irrevocable Statute and law of the monarchy as follows:

Article 1. The Catholic, Apostolic, and Roman religion is the only religion of the state. ${ }^{2}$ Other cults now existing are tolerated, in conformity with the law.

Art. 2. The state is governed by a representative monarchical government. The throne is hereditary according to the Salic Law. ${ }^{3}$

Art. 3. The legislative power shall be exercised collectively

1This translation is taken from Wright, op. cit., pp. $337 \mathrm{ff}$., who borrows from Dodd, Modern Constitutions, Vol. II, pp. 5-16, whose translation is based on that by S. M. Lindsay and L. S. Rowe in the Supplement to the Annals of the American Academy of Political and Social Science, November, 1894 (PhiladelAmerican Academy of Political and Social Science, November, 1894 (Philadel-
phia, 1894). French translation in Dareste, op. cit., pp. 674-685. German phia, 1894). French translation in Dareste, op. cit., pp. 674-685. German
translation in Paul Posener, Die Staatsverfassungen des Erdballs, pp. 64\&-656 (Charlottenburg, 1909).

2See below, the Law of May 13, 1871. The Law of June 19, 1848, reads as follows: "Difference of religion shall entail no distinction as regards the enjoy-" ment of civil and political rights and eligibility to civil and military positions."

'Law of July $\&, 1890$, on the status of the royal family. 
by the King and two houses, the Senate and the Chamber of

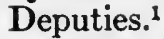

Art. 4. The person of the King is sacred and inviolable.

Art. 5. To the King alone belongs the executive power. He is the supreme head of the state; commands all land and naval forces; declares war; makes treaties of peace, alliance, commerce and other treaties, communicating them to the houses as soon as the interest and security of the state permit, accompanying such notice with opportune explanations. Treaties involving financial obligations or alterations of the territory of the state shall not take effect until after they have received the approval of the houses.

Art. 6. The King appoints to all of the offices of the state, and makes the necessary decrees and regulations for the execution of the laws, without suspending their execution or granting exemptions.

Art. 7. The King alone approves and promulgates the laws.

Art. 8. The King may grant pardons and commute sentences. ${ }^{2}$

Art. 9. The King convokes the two houses every year. He may prorogue their sessions and dissolve the Chamber of Deputies, but in the latter case he shall convoke another within a period of four months.

Art. 10. The initiative in legislation shall belong both to the King and to each of the two houses. All bills, however, levying imposts or contributions or approving the budgets or accounts of the state shall first be presented to the Chamber of Deputies.

Art. 11. The King attains his majority upon the completion of his 18th year.

Art. 12. During the King's minority, the prince who is his nearest relative in the order of succession to the throne, shall be regent of the Kingdom, provided he be 21 years of age.

Art. 13. Should the prince upon whom the regency devolves be still in his minority and this duty pass to a more distant relative, the regent who actually takes office shall continue in the regency until the King becomes of age.

Art. 14. In the absence of male relatives the regency shall devolve upon the Queen Mother.

Art. 15. In default also of a Queen Mother, the regent shall be elected by the legislative houses, convened within 10 days by the ministers.

In case of political necessity, the Italian Government frequently takes legislative measures by means of law decrees, and this procedure is considered justified by the commentators on this Statute.

zThe King also exercises the right of amnesty (Code of Penal Procedure, Article 830). 
Art. 16. The preceding provisions with reference to the regency are applicable in case the King who has attained his majority is physically incapable of reigning. Under such circumstances, if the heir presumptive to the throne be 18 years of age, he shall be regent of full right.

Art. 17. The Queen Mother shall be guardian of the King until he has completed his 7th year; from this time his guardianship shall pass into the hands of the regent.

Art. 18. All rights pertaining to the civil power in matters of ecclesiastical benefices and in the execution of all regulations whatsoever coming from foreign countries shall be exercised by the King. ${ }^{1}$

Art. 19. The civil list of the crown shall remain, during the present reign, at an amount equal to the average for the past 10 years.

The King shall continue to have the use of the royal palaces, villas, and gardens and their appurtenances, and also of all chattels without distinction pertaining to the crown, of which a speedy inventory shall be made by a responsible ministry.

In future the above-mentioned civil list shall be fixed for the duration of each reign by the first legislature subsequent to the King's accession to the throne. ${ }^{2}$

Art. 20. The property which the King now possesses in his own right, together with that to which he may hereafter acquire title, either for a consideration or gratuitously in the course of his reign, shall form his private patrimony.

The King may dispose of his private patrimony either by acts during his life or by will, without being bound by the provisions of the civil law which limit the amount disposable. In all other cases, the King's patrimony shall be subject to the laws that govern other property.

Art. 21. The law shall provide an annual civil list for the hereditary prince when he has attained his majority, and even earlier in case of his marriage; for the allowances to the princes of the royal family and of royal blood, under the above-mentioned conditions; for the dowries of the princesses and for the dowries of the queens.

Art. 22. Upon ascending the throne, the King, in the presence of the houses, in joint session, shall take the oath to observe faithfully the present Statute.

Art. 23. The regent, before entering on the duties of that

1'The clause, "regulations from foreign countries," refers to papsl decrees, ecclesiastical ordinances and orders; at the time of the adoption of this Statute Rome was foreign territory.

'At present the civil list has been fixed at $16,050,000$ lire. 
office, shall take the oath to be faithful to the King and to observe faithfully this Statute and the laws of the state.

\section{The Rights and Duties of Citizens}

Art. 24. All inhabitants of the Kingdom, ${ }^{1}$ whatever their rank or title, are equal before the law.

All shall equally enjoy civil and political rights and shall be eligible to civil and military office, except as otherwise provided by law.

Art. 25. All shall contribute without distinction to the burdens of the state, in proportion to their possessions.

Art. 26. Individual liberty is guaranteed.

No one shall be arrested or brought to trial except in the cases provided by law and in the forms which it prescribes.

Art. 27. The domicile is inviolable. No domiciliary search shall take place except by virtue of law and in the forms which it prescribes.

Art. 28. The press shall be free, but the law may suppress abuses of this freedom. ${ }^{2}$

Nevertheless, bibles, catechisms, liturgical and prayer books shall not be printed without the previous consent of the bishop. ${ }^{3}$

Art. 29. All property, without exception, is inviolable.

Nevertheless, when the public interest, legally ascertained, requires it, a person may be bound to give it up, in whole or in part, upon payment of a just indemnity in accordance with the law.4

Art. 30. No tax shall be levied or collected without the consent of the houses and the approval of the King.

Art. 31. The public debt is guaranteed.

All obligations of the state to its creditors are inviolable.

Art. 32. The right to assemble peaceably and without arms is recognized, subject, however, to the laws that may regulate its exercise in the interest of the public welfare. ${ }^{5}$

This provision is not applicable to meetings in public places or places open to the public, which remain entirely subject to police laws.

\section{The Senate}

Art. 33. The Senate shall be composed of members, appointed for life by the King without limit of numbers, who have at-

'Law of May 17, 1906, on naturalization.

'Edict of March 26, 1848, amended by many later laws.

'The second paragraph of this Article has been practically abrogated.

'Law of June 25, 1865.

'Law of December 23, 1888, on public security, coördinated with the new Penal Code by the Decree of June $30,1889$. 
tained the age of 40 years and who have been chosen from the following categories of citizens:

(1) Archbishops and bishops of the state.

(2) The President of the Chamber of Deputies.

(3) Deputies after having served in three legislatures, or after six years of service.

(4) Ministers of state.

(5) Ministers secretaries of state.

(6) Ambassadors.

(7) Envoys extraordinary, after three years of such service.

(8) The first presidents and presidents of the Courts of Cassation and of the Court of Accounts.

(9) The first presidents of the courts of appeal.

(10) The attorney general of the Courts of Cassation, and the prosecutor general, after five years of service.

(11) The presidents of the chambers of the courts of appeal, after three years of service.

(12) The councilors of the Courts of Cassation and of the Court of Accounts, after five years of service.

(13) The attorneys general and fiscals general of the courts of appeal, after five years of service.

(14) General officers of the land and naval forces.

Major generals and rear admirals, however, should have five years of active service in that grade.

(15) The councilors of state, after five years of service.

(16) The members of the councils of division, ${ }^{1}$ after three elections to their presidency.

(17) The intendants general, ${ }^{2}$ after seven years of service.

(18) Members of the Royal Academy of Sciences, ${ }^{3}$ after seven years of membership.

(19) Regular members of the Superior Council of Public Instruction, after seven years of service.

(20) Those who by their services or eminent merit have done honor to their country.

(21) Persons who, for at least three years, have paid direct property or business taxes to the amount of 3,000 lire.

Art. 34. The princes of the royal family are, by that very fact, members of the Senate. They shall take rank immediately after the president. They shall enter the Senate at the age of 21 and have a vote at 25.4

\footnotetext{
"At the time of the adoption of this Statute the "division" in Piedmont corresponded to the "province" in modern Italy. The councils of division are therefore the elective representative bodies of the provinces, now known as the provincial councils.

"Now called "prefects."

"This provision has been extended to six other academies.

4n 1916 there were 395 senators and 6 members of the royal family.
} 
Art. 35. The President and Vice-Presidents of the Senate shall be appointed by the King. ${ }^{1}$

The Senate shall choose its own secretaries from among its own members.

Art. 36. The Senate may be constituted a High Court of Justice by decree of the King to try crimes of high treason and attempts upon the safety of the state, and to try ministers impeached by the Chamber of Deputies. ${ }^{2}$

In this case, the Senate is not a political body. It shall not then occupy itself with any other judicial matters than those for which it was convened, under penalty of nullity.

Art. 37. No Senator shall be arrested except by virtue of an order of the Senate, except in case of flagrante delicto. It alone is competent to judge of the imputed misdemeanors of its members.

Art. 38. Legal documents as to births, marriages, and deaths of members of the royal family shall be presented to the Senate and deposited by that body among its archives.

\section{The Chamber of Deputies}

Art. 39. The elective house shall be composed of Deputies chosen by the electoral colleges in conformity with the law. ${ }^{3}$

Art. 40. No Deputy shall be admitted to the Chamber who is not a subject of the King, 30 years of age, in the enjoyment of civil and political rights, and in the possession of the other qualifications required by law. 4

Art. 41. Deputies represent the nation as a whole, and not the several provinces in which they were elected.

No binding instructions shall be given to them by the electors.

Art. 42. Deputies are elected for five years; their mandate ceases ipso facto at the expiration of this period.

Art. 43. The President, Vice-Presidents, and secretaries of the Chamber of Deputies are chosen by the Chamber from among

'Law of June 6, 1889, fixes the term of office.

${ }^{2}$ Regulation of December 20, 1900, on the procedure before the Senate constituted as a High Court of Justice.

'The election of deputies was formerly regulated by the Decree of March 28, 1895 , which was a consolidation of all laws in force passed before that date. This electoral law received slight modifications by the Laws of December 5,1897 , April 7, 1898, and May 19, 1901. By the Law of June 30, 1912, manhood suffrage was introduced, increasing the electorate from three and one-half millions to more than eight and one-half millions. The Law of August 15, 1919, introduced proportional representation. For a discussion of this law, see above, pp. 102-104.

'Parliamentary incompatibilities are governed by the Law of July 5, 1887. 
its own members at the beginning of each session, for the entire session.

Art. 44. If a Deputy ceases for any reason to perform his duties, the college which elected him shall be called upon at once to proceed with a new election.

Art. 45. During the sessions no Deputy shall be arrested except in case of flagrante delicto, nor be proceeded against in criminal matters without the previous consent of the Chamber.

Art. 46. No warrant of arrest for debts ${ }^{1}$ shall be executed against a Deputy during the sessions of the Chamber, nor within a period of three weeks preceding or following the same.

Art. 47. The Chamber of Deputies has the right to impeach ministers of the King and to bring them to trial before the High Court of Justice.

\section{Provisions Common to Botir Houses}

Art. 48. The sessions of the Senate and of the Chamber of Deputies begin and end at the same time.

Every meeting of one house at a time when the other is not in session is illegal and its acts are entirely void.

Art. 49. Senators and Deputies before being admitted to the exercise of their functions take the oath to be faithful to the King, to observe faithfully the Statute and the laws of the State, and to perform their functions with the inseparable welfare of King and country as the sole end in view. ${ }^{2}$

Art. 50. The office of Senator or Deputy shall not carry with it any compensation or indemnity. ${ }^{3}$

Art. 51. Senators and Deputies shall not be called to account for opinions expressed or votes given in the houses.

Art. 52. The sessions of the houses are public.

Nevertheless, upon the written request of 10 members secret sessions may be held.

Art. 53. Sessions and deliberations of the houses are not legal or valid if an absolute majority of their members is not present.

Art. 54. Action on any question shall be taken only by a majority of the votes cast.

Art. 55. All bills shall first be submitted for preliminary examination to committees elected by each house. Any proposition discussed and approved by one house shall be trans-

\footnotetext{
'The Mancini Law of December 6, 1877, has done away with personal arrest for debts.

2Iaw of December 30, 1882, on the political oath.

${ }^{3}$ Senators and deputies receive free passage on the railroads (Decree of December 26,1861 ).
} 
mitted to the other for its consideration and approval; and then it shall be presented to the King for his approval.

Bills shall be discussed article by article.

Art. 56. Any bill rejected by one of the three legislative powers shall not again be introduced during the same session.

Art. 57. Every person who has attained his majority has the right to send petitions to the houses, which shall order them to be examined by a committee and, on report of the committee, shall decide whether such petitions are to be taken into consideration; in case of an affirmative decision they shall be referred to the competent minister or deposited in the offices ${ }^{1}$ for action at the proper time.

Art. 58. No petition may be presented in person to either house.

Legally organized bodies alone shall have the right to petition under a collective name.

Art. 59. The houses shall not receive any deputation, nor give hearing to others than their own members, ministers, and commissioners of the government.

Art. 60. Each house shall be the sole judge of the qualifications and elections of its own members.

Art. 61. The Senate and the Chamber of Deputies shall make their own rules and regulations respecting their methods of procedure in the performance of their respective duties. ${ }^{2}$

Art. 62. The Italian language is the official language of the houses. The use of French shall, however, be permitted to the members coming from districts where French is used, and in replying to them. ${ }^{3}$.

Art. 63 . Votes shall be taken by rising and sitting, by division, or by secret ballot.

The latter method, however, shall always be employed for the final vote on a law and in all cases of a personal character.

Art. 64. No one shall at the same time be Senator and Deputy.

\section{The Ministers}

Art. 65. The King appoints and dismisses his ministers. ${ }^{4}$

Art. 66. The ministers have no vote in either house unless they are members thereof.

1The Chamber of Deputies is divided into 9 sections (uffizi), among which legislative business is divided by the President of the Chamber.

'The Internal Regulations of the Senate bear the date of April 17, 1883 (amended in 1900 and 1902); those of the Chamber of Deputies are of July 1, 1900 (amended in 1901 and 1904).

${ }^{3}$ This clause applied principally to Savoy and Nice, which became a part of France by the terms of the Treaty of March 24,1860 .

${ }^{4}$ Decree of August 25, 1876, on the attributions of the Council of Ministers. Law of February 12, 1888, reorganizing the central administration of the state 
They shall have entrance to both houses and shall be heard upon request.

Art. 67. The ministers are responsible.

Laws and governmental acts shall not take effect until they shall have received the signature of a minister.

\section{The Judrciary}

Art. 68. Justice emanates from the King and shall be administered in his name by the judges whom he appoints.

Art. 69. Judges appointed by the King, except cantonal judges, shall be irremovable after three years of service. ${ }^{1}$

Art. 70. Courts, tribunals, and judges shall be retained as at present existing. No modification shall be introduced except by law. 2 .

Art. 71. No one shall be withdrawn from his ordinary legal jurisdiction.

It shall, therefore, not be lawful to create extraordinary tribunals or commissions. ${ }^{3}$

Art. 72. The proceedings of courts in civil cases and the hearings in criminal cases shall be public, as provided by law.

Art. 73. The interpretation of the laws, in the form obligatory upon all citizens, belongs exclusively to the legislative power.

\section{General Provisions}

Art. 74. Communal and provincial institutions and the boundaries of the communes and provinces shall be regulated by law. ${ }^{4}$

and providing under-secretaries of state for each ministry. Law of May 3, 1888, on the reëlection of ministers and under-secretaries of state. Law of April 8, 1906, determining the composition of the staffs of the President of the Council, of the minjsters, and of the under-secretaries of state.

1Two decrees, dated October 10, 1907, instituted a Superior Council on the Magistracy and fixed the method of promotion of judicial personnel. Law of July 14, 1907, on the guarantees and discipline of the magistracy.

2The Law on the Organization of the Judiciary dates from December 6, 1865 (amended by the Laws of July 18, 1904, and July 14, 1907). Organic Law of June 8, 1874, on the jury and the Court of Assizes. Organic Law of August 14, 1862 , on the Court of Accounts.

${ }^{3}$ The Code of Penal Procedure, however, in Article 766 provides that, in case of reasonable suspicion, or on the grounds of public safety, a person may be removed for trial from the regularly constituted jurisdiction.

"All of the laws relating to provincial and communal organizations were codified first by the Decree of February 10, 1889, secondly by the Decree of May 4, 1898 , and thirdly by the Decree of May 21, 1908. The Kingdom is divided into provinces, circondari, mandamenti, and communes, and the system of provincial and communal government is to a large extent copied from France. 
law. ${ }^{1}$

Art. 75. Military conscriptions shall be regulated by

Art. 76. A communal militia shall be established upon a basis fixed by law. ${ }^{2}$

Art. 77. The state retains its flag, and the blue cockade is the only national one. ${ }^{3}$

Art. 78. The knightly orders now in existence shall be maintained with their endowments, which shall not be used for other purposes than those specified in the acts by which they were established.

The King may create other orders and prescribe their constitutions.

Art. 79. Titles of nobility shall be borne by those who have a right to them. The King may confer new titles.

Art. 80. No one may receive decorations, titles, or pensions from a foreign power without the authorization of the King.

Art. 81. All laws contrary to the present Statute are abrogated.

\section{Transitional Provisions}

Art. 82. This Statute shall go into effect on the day of the first meeting of the two houses, which shall take place immediately after the elections. Until that time urgent public service shall be provided for by royal ordinances according to the mode and form now in vogue, excepting, however, the authentications and registrations in the courts which are from now on abolished.

Art. 83. In the execution of this Statute the King reserves to himself the right to make the laws for the press, elections, communal militia, and the reorganization of the Council of State.

Until the publication of the laws for the press, the regulations now in force on this subject shall remain valid.

Art. 84. The ministers are entrusted with and are responsible for the execution and full observance of these transitional provisions.

IThe laws on the organization of the army were codified by the Decree of July 14, 1898 (amended by the Laws of July 7, 1901, and December 24, 1908). By Decrees of November, 1919 (No. 2,143) and April 20, 1920 (No. 451) the army was fundamentally reorganized.

'The National Guard has been suppressed.

'The Italian tricolor of green, white, and red was adopted by the Proclamation of March 23, 1848 - an act regarded as legal, because the Statute was not in force according to the terms of Article 82 . 


\section{LAW OF GUARANTEES OF MAY 13, $1871^{1}$}

Law on the Prerogatives of the Supreme Pontiff and of the Holy See and on the Relations of the State WITH THE ChURCh

\section{TITLE I. PREROGATIVES OF THE SUPREME PONTIFF} AND OF THE HOLY SEE

Article 1. The person of the Supreme Pontiff is sacred and inviolable.

Art. 2. Any attempt against the person of the Supreme Pontiff and the provocation to commit such an attempt shall be punished with the same penalty as similar offenses against the person of the King.

Public offenses and insults committed directly against the person of the Supreme Pontiff, by speech, by act or by the means indicated in Article 1 of the Law on the Press shall be punished with the penalty fixed by Article 19 of the said law.

The crimes above mentioned shall be proceeded against by the public prosecutor and tried by the Courts of Assizes.

The. discussion of religious matters shall be entirely free.

Art. 3. The Italian government grants to the Supreme Pontiff, within the Kingdom, sovereign honors, and guarantees to him the preëminence customarily accorded to him by Catholic sovereigns.

The Supreme Pontiff may maintain the usual number of guards for his person and for the custody of the palaces, without prejudice to the obligations and duties of such guards, according to the laws in force in the Kingdom.

Art. 4. The dotation of an annual income of 3,225,000 lire is reserved for the Holy See.

With this sum, equal to that of the Roman budget for "holy apostolic palaces, sacred college, ecclesiastical congregations, secretary of state, and diplomatic corps abroad," it is intended to provide for the Supreme Pontiff and for the various ecclesiastical needs of the Holy See, for the ordinary and extraordinary maintenance and custody of the apostolic palaces and their annexes, for the compensation and pensions of the guards mentioned in the preceding article and of the attaches of the pontifical court, and for casual expenses; as well as for the regular maintenance and custody of the museums and library attached to the apostolic palaces, and for the compensation and pensions of their employees.

\footnotetext{
${ }^{1}$ English translation in Wright, op. cit., pp. 347-350, in Dodd, op. cit., pp. 1621, and in the British and Foreign State Papers, 65: pp. 638-642. French translation in Dareste, op. cit., pp. 685-690.
} 
This dotation shall be entered in the great book of the public debt as a perpetual and inalienable income in the name of the Holy See, and during the vacancy of the See, it shall continue to be paid to supply all the needs of the Roman Church during such interval.

It shall remain exempt from every form of state, provincial, or communal taxation or other burden, and shall not be diminished even in case the Italian Government should later decide to assume the expenses of the museums and of the library.

Art. 5. Besides the dotation mentioned in the preceding article the Supreme Pontiff shall have the use of the apostolic Vatican and Lateran palaces with all buildings, gardens, and lands appertaining thereto, and also the villa of Castel Gandolfo with all its appurtenances.

These palaces, the villa, and its annexes, as well as the museums, the library, and the collections of art and of archrology connected therewith, are inalienable and are exempt from all taxation or charges and from seizure for a public purpose.

Art. 6. During the vacancy of the pontifical chair no judicial or political authority shall for any reason hinder or limit the personal liberty of cardinals.

The government shall see to it that assemblies of conclave and of ecumenical councils are not disturbed by external violence.

Art. 7. No public official or agent of the public force in the performance of the duties of his office shall enter the places or palaces which are the permanent or temporary residence of the Supreme Pontiff, or in which a conclave or ecumenical council is in session, without the authorization of the Pope, conclave, or council.

Art. 8. Papers, documents, books, or registers deposited in pontifical offices or congregations, invested with a purely spiritual character, shall be free from the legal processes of visit, search, or sequestration.

Art. 9. The Supreme Pontiff shall be entirely free to fulfill all the functions of his spiritual ministry, and to this end may affix to the doors of basilicas and churches of Rome notices relating to such ministry.

Art. 10. Ecclesiastics at Rome who officially take part in the promulgation of acts pertaining to the spiritual ministry of the Holy See shall not on this account be subjected to any examination, investigation, or control by the civil authorities.

Every foreigner invested with ecclesiastical office at Rome shall enjoy all the personal guarantees competent to Italian citizens, in accordance with the laws of the Kingdom.

Art. 11. Envoys of foreign governments to the Holy See 
shall be entitled within the Kingdom to all the prerogatives and immunities accorded to other diplomatic agents, according to the usages of international law.

All offenses against them shall be subject to the same penalties as are provided for offenses against envoys of foreign powers to the Italian Government.

Envoys of the Holy See to foreign governments shall, within the territory of the Kingdom, be entitled to privileges and immunities of the same character while going to or returning from their mission.

Art. 12. The Supreme Pontiff corresponds freely with the episcopacy and with the whole Catholic world, without any interference from the Italian Government.

To this end he shall have the right to establish his own postal and telegraph offices at the Vatican or at any of his other residences, served by employees chosen by himself.

The pontifical post office may transmit sealed packages of correspondence directly to foreign offices, or may send them through the Italian offices. In either case, transmission of dispatches or correspondence bearing the papal stamp shall be exempt from all taxation or charges within Italian territory.

Couriers sent out in the name of the Supreme Pontiff are, within the Kingdom, placed on an equal footing with couriers of foreign governments.

The pontifical telegraph office shall be connected with the telegraphic system of the state at the expense of the state.

Telegrams sent by the pontifical office with pontifical authentication shall be received and transmitted within the Kingdom in the same manner as telegrams of state and without charge.

Telegrams of the Supreme Pontiff or sent by his order, which bear the papal stamp, shall enjoy the same privileges if presented to any telegraph office of the Kingdom.

Telegrams addressed to the Supreme Pontiff shall be exempt from the tax imposed upon those who receive telegrams.

Art. 13. Within the city of Rome and within the six suburbicarian sees, the seminaries, academies, colleges, and other Catholic institutions founded for the education and training of ecclesiastics shall continue under the sole control of the Holy See, without any interference from the educational authorities of the Kingdom.

TITLE II. RELATIONS OF THE STATE WITH THE CHURCH

Art. 14. Every special restriction upon the exercise of the right of members of the Catholic clergy to assemble is abolished.

Art. 15. The government renounces the right to an apostolic 
legation in Sicily, and to appointment or nomination in the presentation of the major benefices throughout the Kingdom.

Bishops shall not be required to swear fidelity to the King.

Major and minor benefices may be conferred only upon Italian citizens, except in the city of Rome and in the suburbicarian sees.

Nothing is changed with respect to the presentation of benefices of royal patronage.

Art. 16. The exequatur and royal placet and all other forms of government authorization for the publication or execution of ecclesiastical acts are abolished.

But, until otherwise provided by a special law mentioned in Article 18, such exequatur and royal placet shall be required for acts disposing of ecclesiastical property and for appointments to major and minor benefices, except those in the city of Rome, and in the suburbicarian sees. ${ }^{1}$

The provisions of the civil laws relating to the creation and management of ecclesiastical institutions, and to the sale of their property, remain unchanged.

Art. 17. In spiritual and disciplinary matters there shall be no claim or appeal against decisions of ecclesiastical authorities, nor shall such decisions be recognized or executed by the civil authorities.

The determination of the legal effects of such decisions and of other acts of the ecclesiastical authority shall belong to the civil authorities.

If, however, such acts are contrary to the laws of the state or opposed to public order, or encroach upon the rights of individuals, they shall be of no effect, and, if they constitute offenses, shall be subject to the criminal laws.

Art. 18. A future law shall provide for the reorganization, preservation, and administration of the ecclesiastical property within the Kingdom. ${ }^{2}$

Art. 19. In all the matters which form the object of the present law, regulations now in force contrary to this law are repealed.

\footnotetext{
'Decree of June 25, 1871, containing provisions for the exequatur and the royal placet.

${ }^{2}$ See the Law of June 19, 1873, on the suppression of religious corporations in Rome, etc.
} 


\section{APPENDIX IV}

\section{THE RECOGNITION OF NEW STATES SINCE 1913"}

\section{Note on Recogntion of Certain States (Poland, Serb-Croat-Slovene State, Czechoslovaku)}

1. Recognizing Authorities. The doctrine of recognition of states has always been somewhat disputed, but it has usually been admitted that recognition of a new state by an important state is bound ultimately to involve recognition by the general family of nations. But, at present, both the Supreme Council and the League of Nations possess great authority for the purpose of recognizing states, and yet sometimes conflict with one another in their use of it. E. g., Esthonia and Latvia were refused admission to the League by the Assembly on the 17th December, 1920, but received recognition de jure from the Supreme Council on the 26th January, 1921. Albania was admitted to the League on the 17th December, 1920, but so far (end March, 1921) she has not been recognized de jure by the Supreme Council or by any important state.

No attempt can be made here to solve these difficulties, but a short description will be given of the circumstances attending the recognition of Poland, the Serb-Croat-Slovene State, and Czechoslovakia, which raise some new and important points.

2. Three Conditions Necessary to the Existence of a State. According to doctrines generally accepted in international law "statehood itself is independent of recognition." 2 The existence of the state itself is a question of fact, but recognition is necessary to admit a state into the common family of nations, for international law cannot take notice of an unrecognized state. The conditions necessary for the existence of a state have been much disputed, but on three there is universal agree-

1From Temperley, Ed., A History of the Peace Conference of Paris, Vol. V, pp. $157 \mathrm{ff}$. (London, 1921). The note and the list here quoted were written by Mr. Temperley himself.

'See Oppenheim, International Law, 1905, Vol. I, p. 110; see also Hall, International Law (7th edition), 1917, pp. 85-88; T. J. Iawrence, Principles of International Law (1898), pp. 84-90; and A. S. Hershey, Article in American Journal of International Law, October, 1920, who gives full reference to American authorities. 
ment among international lawyers. A state must have (a) a definite territory, (b) a population inhabiting this territory, and (c) a sovereignty exercised on this territory, both internally in the sense of being imposed on the inhabitants of the territory by legal measures, and externally in that it is not interfered with and rerdered impossible in fact, or irregular in law, by the sovereignty of another state.

During the late war certain utterances were made by the Allied (or Enemy) Powers with a view to creating or assisting the formation of a state by propaganda, and these utterances have been, inaccurately, termed recognition. In fact, recognition only becomes operative when the above-named three conditions are fulfilled.

3. Poland. A case might be made out to show that Poland had received recognition before the war had ended, because public utterances were made before the end of the war by the Powers, whether Central or Allied, of her right to independence. ${ }^{1}$ It would appear, however, that her internal conditions were unstable. On the 5th November, 1916, the independence of Russian Poland had been declared by Germany and AustriaHungary. But the Polish Regency Council, which ruled Russian Poland, was certainly under German or Austro-Hungarian control until the 11th November, 1918, and, after that date, a period of something like anarchy ensued, which was certainly not ended until the 30th December, 1918. Consequently, Poland did not, in fact, fulfill the conditions of a state until that date, or perhaps until some days later. It might reasonably be held that the formal admission of Poland's plenipotentiaries to the Peace Conference (18th January, 1919)2 was the earliest date at which such recognition really came into force. Some authorities even place that date as late as the signature of the German treaty (28th June, 1919). The Polish boundaries are not even yet [1921] everywhere defined.

4. Serb-Croat-Slovene State. This case presents more difficulty because Serbia was already a sovereign independent state, and the question arises as to when the new state, remodelled and including the three races, came into existence. It could hardly be said that a substantial part of both Croat and Slovene territory was under the control of the Serb-CroatSlovene Government until the petitions and representatives of these areas reached Belgrade, and the Regent signified his

\footnotetext{
${ }^{1}$ See references and quotations, Temperley, Ed., op. cit., Vol. I, pp. 181, 18381, 199.

${ }^{2}$ Most international lawyers would think this enough, for the form of recognition does not matter. "Any act is sufficient which indicates intention," see T. J. Lawrence, International Lav, p. 98 (1898).
} 
assent to union by decree (1st December, 1918), confirmed by Act of Serbian Skupshtina in conjunction with a national representative convention (16th December, 1918), and until a combined national and representative ministry was appointed. ${ }^{1}$ Much of the Slovene and Croat territory was, by that time, liberated. The Great Powers, however, refused to admit Serb-Croat-Slovene plenipotentiaries to the Peace Conference (18th January, 1919), recognizing them as purely Serbian representatives. The United States recognized the Serb-CroatSlovene State on the 5th February. On the 1st May credentials for the German treaty were verified, and these were accepted in the name of the Serb-Croat-Slovene State, not of Serbia. This was done in the absence of Italy, but on the 2nd and 6th June respectively Great Britain and France publicly recognized the new state, and the recognition of Italy and all other signatory Powers of the treaty with Germany must date from the signature of that treaty (28th June, 1919), which mentions the Serb-Croat-Slovene State by name in the Preamble and in certain articles thereof. In practice, however, recognition would appear to have been really accorded on the 1st May.

In this case, owing to the opposition of Italy, the recognition of a new state was deferred beyond the time at which it had, in fact, fulfilled the three necessary conditions required. The time at which these were fulfilled was evidently on the 1st or 16th December, 1918.

5. Czechoslovalia. This case presents almost as great a difficulty as that of Poland. For though at different times various Powers recognized the existence of a Czechoslovak army, of a provisional government, and even of a nation, and recognized them also as belligerents, these actions do not necessarily involve, at least in international law, the recognition of the Czechoslovak State. That depended on the legal situation in 1914 and on its alteration by events up to and during 1918. It is quite impossible to contend that the Kingdom of Bohemia, the Markgraviate of Moravia, etc., were separate states in 1914, though the Austrian and Czechoslovak governments have both made such contentions. Even less is it possible to contend thus with regard to the Slovak area of Hungary. These different regions were not under a single administrative head and possessed no proper and single sovereignty. It is true that there was mutiny among Czech regiments and insurrection among Czech subjects, but neither movement achieved the liberation of Czech, and still less of Slovak, territory at any time previous to the end of October, 1918. On

\footnotetext{
' ${ }^{1}$ For the special case of Montenegro, see Temperley, Ed., op. cit., Vol. IV, pp. 201-04.
} 
the 9th October Zahradnik, a Czech Deputy, announced that the Czech members had definitely left the Parliament of Vienna. This utterance shows that, up till then, they were not independent but a part of that Parliament. Outside Czechoslovakia in Paris a Czechoslovak National Council was formed, consisting of distinguished Czechoslovak exiles, and ultimately Czechoslovak volunteers were formed into three armies in France, Italy, and Siberia. Recognition by the Allied Powers of the control of the Czechoslovak National Council over its army, or declarations of sympathy with Czechoslovak national aspirations, did little more than indicate that a Czechoslovak state might arise in the future, though they helped to create conditions favorable to that end.

The utterances of the Allied Powers would, themselves, show this. M. Pichon, on behalf of the French Republic, in a letter of the 29th June, 1918, recognized "publicly and officially the (Czechoslovak) National Council as the governing organism of the general interests and as the just basis of the future Czechoslovak Government. Mr. Balfour, on the 9th August, 1918, wrote: "Great Britain regards the Czechoslovaks as an allied nation . . . recognizes the unity of the three Czechoslovak armies as an allied and belligerent army . . . recognizes the rights of the Czechoslovak National Council, as the supreme organ of the Czechoslovak national interests, and as the present trustee of the future Czechoslovak Government." On the 2nd September, 1918 (published 3rd), President Wilson went further: "the Czechoslovaks having in the prosecution of their struggle for independence in the present war confided the supreme political authority to the Czechoslovak National Council, the Government of the United States recognizes tha a state of belligerency exists between the Czechoslovaks thus organized and the German and Austro-Hungarian Empires."

It has been claimed for all these utterances, and more particularly for the last, that they constituted a recognition of an independent Czechoslovak state. It is, however, obvious from the italicized passages that they did nothing of the sort, and that they all struck a futurist note, recognizing only the efforts of armies, and the existence of an embryonic government striving to achieve independence. For it was true even on the 3rd September, 1918, that the independence of Czechoslovakia depended on the victory of the Allies.

On the 15th October, 1918, M. Pichon struck a new and important note at the moment at which the Czechoslovak National Council of Paris issued its decree of independence. He published a statement that he "unreservedly recognizes

IPublished 11th August, 1918. 
the new government and adds an expression of his profound satisfaction." A similar utterance was made by Baron Sonnino on the 24th October, 1918. These utterances are definite, and the verbal recognition is practically complete, but the condition of statehood and of national independence remained to be achieved. There had not been a de facto liberation of the territory and population of the Czechoslovak State. ${ }^{1}$

It does not appear that this liberation had already taken place. On the 1st November all Hungarian troops were ordered to lay down their arms; on the 3rd November Austria-Hungary signed an armistice with the Powers. It was not till the 5th November, 1918, that the Czech deputies from the National Council of Paris arrived at Prague, or that the first session of the National Committee took place, which was in fact the first appearance of a provisional government and assembly sitting in the capital of the areas liberated and in direct connection with the National Council of Paris. It would appear therefore that this liberation of territory could not have taken effect until the 28th of October, and perhaps not until the 5th November.

As regards recognition therefore it seems safe to contend that the utterances of the Powers, previous to the 28th of October or the 5th November, were in truth anticipations of the fact of statehood and not a recognition of a fait accompli. It cannot be contended that any of these utterances coincided with the actual fact of liberation. It might, however, be held that some of them (particularly the utterances of Mr. Balfour (9th August), President Wilson (3rd September), M. Pichon (15th October), and Baron Sonnino (24th October) came into force as a recognition of the Czechoslovak State at the moment that the actual liberation was accomplished (28th of October or 5 th November). If that hypothesis be not adopted, full, final, and complete recognition was accorded on the 18th January, 1919, by admission of Czechoslovak plenipotentiaries to the Plenary Session of the Peace Conference.2

IIn response to a noce of $M$. Beneš, Secretary of the Czechoslovak National Council, M. Pichon quotes three incidents subsequent to President Wilson's utterance of the 3rd September, 1918: (i) constitution of a National Council in agreement with chiefs left behind in Czechoslovakia, $i$. e., of a provisional government; (ii) announcement of Deputy Stany in Parliament of Vienna that the Czech Parliamentary Club had summoned the National Council at Paris to represent the Czechoslovak nation at the Peace Conference; (iii) utterance of Zahradnik (9th October, 1918) above quoted. These three incidents show that, in fact, $\mathbf{M}$. Beneš conceived the situation as altered in favor of the independence of Czechoslovakia by events subsequent to the 3rd September, 1918.

2On 15th April, 1921, the Reparation Commission stated the date of Czechoslovakia'c belligerency (and consequently their opinion of the date of her independence) as 28th October, 1918 (cf. Temperley, Ed., op. cit., Vol. IV, p. 113, for events in Prague on that day). 
2. List of Recogntion of New States, Admission to League, Territorial Changes, Etc. Recognized to END of March, $1921^{1}$

Abbreviations used: U. S. A. (United States); G. B. (Great Britain); Fr. (France); It. (Italy); S. C. (Supreme Council); L. of N. (League of Nations).; [P. A. and A. Powers (Principal Allied and Associated Powers); S. C. S. State (Serbo-CroatSlovene State)].

\section{DATES}

Albania . . . . . . Resolution Ambassadors' Conference 29 July 1913 (independence); admitted L. of N. 17 Dec. '20.

Austria (new Govt. and terri- Austrian Treaty 10 Sept. '19, torial changes) . . . . admitted L. of N. 16 Dec. '20.

Belgium (new status) . . . German Treaty 28 June '19.

Bessarabia (transferred to Ru- Bessarabian Treaty 28 Oct. mania)

Bulgaria (new Govt. and terrl. changes) '20 (U.S.A. not a Party).

Bulgarian Treaty 27 Nov. '19; admitted L. of N. 16 Dec. '20.

Costa Rica (not admitted Conf.) .

Admitted L. of N. 16 Dec. '20. Czechoslovakia

Danzig (Free City of) . . S. C. (Plenary Session of Conf. 18 Jan. '19).

German Treaty 28 June '19, S. C. Act 27 Oct. '20, accepted by Danzig 9 Nov. '20.

Dodecanese (Terrl. changes) .

Turkish Treaty 10 Aug. '20 (Cession to Italy; GrecoItalian Treaty cedes De. to Greece 10 Aug. '20).

Esthonia

De facto G. B. 3 May '18; commercial agreement 20 July '20: not admitted L. of N. 16 Dec. '20; de jure S.C. 26 Jan. '21.

\footnotetext{
1For the recognition of new states and territorial changes, etc., in Asia and Africa, see Temperley, Ed., op. cit., Vol. VI.
} 


\section{Dates}

Finland . . . . . . De jure G. B. 5 May '19; ad-

Fiume (Free State) mitted L. of N. 16 Dec. '20.

Fiume (Free State) . . . Rapallo Treaty (It. and S. C.S. State), 12 Nov. '20; G. B. 14. Feb. '21.

Hungary (new govt. and terrl. changes)

Hungarian Treaty June 4'20. "Certain frontiers" (transfer of terry. from P. A. and A. Powers) and "New States" Treaties 10 Aug. '20.

Latvia . . . . . . De facto G. B. 11 Nov. '18; not admitted L. of N. 16 Dec. '20; de jure S. C. 26 Jan. '21.

Liechtenstein . . . . Not admitted L. of N. 17 Dec. '20

Lithuania . . . . . Not admitted L. of N. 16 Dec. '20.

Luxemburg (new status) . . German Treaty 28 June '19; admitted L. of N. 16 Dec. '20.

Memel . . . . . . German Treaty 28 June '19 (status not defined).

Montenegro (new status) 26 Nov. '18 Podgorica Assy. deposes King Nicholas and sends petn. for union to Serb Regent, who issues decree 1 Dec. confirmed by Act of Assembly 16 Dec. '18; G. B. cancels exequaturs of Montenegrin consuls in view of union 17 Mar. '21.

Poland . . . . . . S. C. (18 Jan. '19) admission to Plenary session of conference; de jure G. B. 23 Feb. '19; German Treaty 28 June '19.

Russia-Soviet . . . De facto G. B. Commercial agrt. 16 Mar. '21. 


\section{Dates}

Saar Territory . . . . . German Treaty 28 June '19. Serb-Croat-Slovene State . . U. S. A. 5 Feb. '19; S. C. (in absence of Italy) verification of credentials 1 May '19; G. B. 2 June '19; Fr. 6 June '19; It. (in German Treaty'

Schleswig (transfer of terri- is June '19). tory from P. A. and A. Powers to Denmark). . . . Slesvig Treaty (5 July '20), U. S. A. not a party.

Ukraine . . . . . Not admitted L. of N. 17 Dec. '20.

West Indies (Danish) . . . U.S.A. note of cession by Denmark 7 May' '17. 


\section{APPENDIX V \\ REPORT OF THE SECOND CHAMBER CONFERENCE ${ }^{1}$}

\section{PART I}

\section{Dear Prime Mintster:}

1. I have much pleasure in informing you that the Second Chamber Conference ${ }^{2}$ appointed by you on the 25th of August, 1917, has now completed its work, and that $I$ am authorized to report to you the conclusions at which it has arrived. The examination, begun on October 2nd, 1917, of the numerous and intricate questions which it raised has occupied us more than six months, within which period we were able, although most of us were also occupied by work connected with the War, to hold forty-eight sittings, discussing these questions in their practical aspects and endeavoring to reach practical conclusions. The problems we had to deal with presented difficulties which can hardly be appreciated except by those who have steadily applied themselves to a prolonged study of the various issues involved. We had to adapt an ancient institution to new needs, fitting it in to a system which presents new conditions, and seeking to overcome prejudices and antagonisms which generations of party conflict had made acute. In particular we have been obliged to undertake the grave task of finding a basis for any Second Chamber which should be different in type and composition from the popular assembly, by including other elements which might be complementary to those which give its character to the House of Commons. Not less difficult was it to adjust the respective functions and powers of the two Chambers, vesting in the Second Chamber strength sufficient to enable it to act

\footnotetext{
${ }^{1}$ Conference on the Reform of the Second Chamber: Letter from Viscount Bryce to the Prime Minister, 1918. Cmd. 9038.

'The terms of reference were: "To inquire and report-

(1) as to the nature and limitations of the legislative powers to be exercised by a reformed Second Chamber.

(2) as to the best mode of adjusting differences between the two Houses of Parliament.

(3) as to the changes which are desirable in order that the Second Chamber may in future be so constituted as to exercise fairly the functions appropriate to a Second Chamber."
} 
as a moderating influence in the conduct of national affairs, and yet not so much power of delay as to clog the machinery of Government, or dispose that Chamber to embark on controversies for the sake of asserting its own power. These were problems which, although frequently and carefully examined, had still remained unsolved, nor had the mind of the nation ever been fully addressed to them.

4. The Scheme here submitted requires some explanation and comments. These may be conveniently given if I begin by setting forth in the first place the matters in agreement from which the Conference started, by then proceeding to trace the lines upon which its deliberations moved, and by indicating the considerations which led it to the recommendations embodied in the Scheme.

5. The Conference entered on its task by considering how far its members were agreed as to the functions appropriate to a Second Chamber, as to the elements that ought to be present in it, and as to the place it ought to fill in the scheme of the Constitution, and it was found that agreement existed upon the following points:-

\section{Functions Appropriate to a Second Chamber}

6. (1) The examination and revision of Bills brought from the House of Commons, a function which has become more needed since, on many occasions during the last thirty years, the House of Commons has been obliged to act under special rules limiting debate.

(2) The initiation of Bills dealing with subjects of a comparatively non-controversial character which may have an easier passage through the House of Commons if they have been fully discussed and put into a well-considered shape before being submitted to it.

(3) The interposition of so much delay (and no more) in the passing of a Bill into law as may be needed to enable the opinion of the nation to be adequately expressed upon it. This would be specially needed as regards Bills which affect the fundamentals of the Constitution or introduce new principles of legislation, or which raise issues whereon the opinion of the country may appear to be almost equally divided.

(4) Full and free discussion of large and important questions, such as those of foreign policy, at moments when the House of Commons may happen to be so much occupied that it cannot find sufficient time for them. Such discussions may often be 
all the more useful if conducted in an Assembly whose debates and divisions do not involve the fate of the Executive Government.

\section{Elements that Ought to Find a Place in the Second Chamber}

7. (1) Persons of experience in various forms of public work, such as judicial work, Local Government work, Civil Service work, Parliamentary work; persons possessing special knowledge of important departments of the national life, such as Agriculture, Commerce, Industry, Finance, Education, Naval and Military Affairs; and persons who possess a like special knowledge of what are called Imperial Questions such as Foreign Affairs and matters affecting the Overseas Dominions.

(2) Persons who, while likely to serve efficiently in a Second Chamber, may not have the physical vigour needed to bear the increasing strain which candidacy for a seat in the House of Commons and service in it involve.

(3) A certain proportion of persons who are not extreme partizans, but of a cast of mind which enables them to judge political questions with calmness and comparative freedom from prejudice or bias. No Assembly can be expected to escape party spirit, but the excesses of that spirit usually can be moderated by the presence of a good many who do not yield to it.

\section{Position which the Second Chamber Odght to Hold in our Constitutional System}

8. It was agreed that a Second Chamber ought not to have equal powers with the House of Commons, nor aim at becoming a rival of that assembly. In particular, it should not have the power of making or unmaking Ministries, or enjoy equal rights in dealing with finance. This was prescribed not only by longestablished custom and tradition, but also by the form of our Constitution, which makes the Executive depend upon the support of the House of Commons, and would be seriously affected in its working by extending to a Second Chamber the power of dismissing a Government.

All precautions that could be taken ought to be taken to secure that in a Reformed Second Chamber no one set of political opinions should be likely to have a marked and permanent predominance, and that the Chamber should be so composed as not to incur the charge of habitually acting under the influence of party motives.

The Second Chamber should aim at ascertaining the mind and views of the nation as a whole, and should recognize its full 
responsibility to the people, not setting itself to oppose the people's will, but only to comprehend and give effect to that will when adequately expressed.

It should possess that moral authority which an assembly derives not only from the fact that its members have been specially chosen to discharge important public duties but also from their personal eminence, from their acknowledged capacity to serve the nation, and from the confidence which their characters and careers are fitted to inspire.

It should, by the exercise of this authority, and especially by evincing a superiority to factious motives, endeavour to enlighten and influence the people through its debates, and be recognized by the people as qualified, when a proper occasion arose, to require the reconsideration of important measures on which their opinion had not been fully ascertained.

Lastly, the Conference was also of opinion that it would enhance the authority of the Second Chamber, and would be in line with the whole constitutional history of this country, which has been marked by a steady and gradual development, broken by no sudden and violent change, that so far as is possible a continuity should be preserved between the ancient House of Lords and the new Second Chamber, the best traditions of the former being handed on to the new body, so as to enhance its dignity, and make a seat in it an object of legitimate ambition. The Great Council of the Nation from which the House of Lords directly descends, the House of Commons having been added to it in the thirteenth century, is the oldest and most venerable of all British institutions, reaching back beyond the Norman Conquest, and beyond King Alfred, into the shadowy regions of Teutonic antiquity.

\section{Composition of the Second Chamber}

9. Of the three topics to which the Reference directed its attention, the Conference thought it best to begin with that which relates to the composition of the Second Chamber. It is the most difficult of these topics. It was debated at the greatest length, and it provided the most frequent occasions for reconciling divergent views.

10. The principle of endeavouring to preserve some real measure of continuity between the House of Lords and the new Second Chamber, a principle accepted by all, though some members attached more importance to it than did others, suggested that a certain portion of the Chamber should be taken from the existing peerage, but the other principle that three important requisites for the strength of the Chamber would be found in its having popular authority behind it, in its opening to the whole 
of His Majesty's subjects free and equal access to the Chamber, and in its being made responsive to the thoughts and sentiments of the people, also prescribed that the large majority of the members should be so chosen as to enjoy that popular authority. It is with the constitution of this majority that this narrative begins.

11. The Conference rejected the idea of having a Chamber elected on the basis of a property qualification, possessed by a privileged class of voters, and also that of requiring a property qualification for the persons to be elected, restrictions which have been adopted in some countries, but which were deemed unsuitable to modern conditions. Neither was it thought that the plan (sometimes suggested) that the persons chosen to sit should be taken from certain prescribed categories (e. g., from those who had filled some public office) would work well, for it would be very difficult to draw up any satisfactory list of categories which might not be either too large to be useful, or too restricted to permit many men of eminence and worth to be admitted as nominees. The Conference then proceeded to examine five methods that might be adopted for constituting that popular element in the Chamber which it had been agreed to make predominant.

\section{Various Alternative Methods of Composition}

\section{NOMINATION}

12. The first method was that of nomination by the Crown acting through its ministers. This plan appeared unlikely to find favour with the country, because it did not provide any guarantees for the fitness of the persons who might be nominated, and because it would be liable to be frequently employed as a rewardfor political party services. Nor was it held that a provision requiring that the persons to be nominated should be taken from certain prescribed categories would furnish an answer to these objections. ${ }^{1}$

\section{DIRECT ELECTION}

13. The second method was Direct Election by the same voters as those who choose the House of Commons. Strong arguments were advanced for this plan.

It would produce a Chamber both homogeneous and directly responsible to the people, and with the weight of their will be-

1 For the use of nomination in recruiting the Italian and Canadian Senates, see A. L. Lowell, Governments and Parties in Continental Europe, Vol. I, p. 155 (Boston, 1896), and A. B. Keith, Responsible Governments in the Dominions. Vol. I, p. 514 (Oxford, 1912). 
hind it. Coming straight from the people it would enjoy their confidence and mirror their views and ideas. If the elections took place frequently, there would be a constant ascertainment and renewal of the most recent public opinion, refreshing and strengthening the Second Chamber.

14. On the other hand, it was forcibly urged that a Chamber elected on the same franchise as the House of Commons would inevitably become a rival of the House of Commons, and would, because it had an equal "mandate" from the people, be likely to claim equal financial powers, and tend to fall into conflict with that principle of the Constitution which assigns to the House of Commons the function of making and unmaking Administrations. Ministers would have two masters to serve and to fear. The persons directly elected would be presumably of the same general type as those elected to the House of Commons, so that no new element such as is admittedly desirable would thereby be introduced into the Legislature. The Second Chamber would in fact be little more than a duplicate of the House of Commons, and might either, as being the less attractive body, come to be composed mainly of the surplus material of the latter, or (alternatively) by the longer tenure of its members become ultimately the more attractive, possibly the more influential legislative body. The constituencies which would have to be created for a comparatively small body such as the new Second Chamber would be so much larger than the constituencies which now elect members to the House of Commons, that they would be more readily controlled by party organizations. As the expense of contesting these larger constituencies would also be heavier, an advantage would thus be given to wealthy candidates. ${ }^{1}$

\footnotetext{
1 The Bryce Conference does not seem to have paid much attention to Professor Ramsay Muir's suggestion of an Upper Chamber based on proportional representation. Professor Muir thinks that the break-up of the two party system is too high a price to pay for the more truly representative House of Commons which might be secured by proportional representation. Consequently, he says, "We must have, not above, but alongside of, the House of Commons, a Second Chamber, in which the varied currents of national thought will get representation, and which shall be able to rectify the rough partisan justice which is all that can be yielded by the confused elections for the Commons House" (p. 133). Professor Muir would continue the Commons in a position to make government by any group of men not possessing its confidence impossible, and to this end "the power of the House of Commons to refuse supplies must be undivided and final." Such a lower chamber, however, could represent only "the general preference of the nation as between the program and methods of one party and another." This inherent defect could be rectified by a Second Chamber possessing wide "powers of discussion, amendment, and rejection." Qualification by services in the great offices of state would provide a useful element of a Second Chamber but could be relied upon only for a small proportion of its members; nomination for life or for a period of years is inadvisable, since the party
} 
These considerations led the Conference as a whole to decide against the scheme of Direct Election, and we accordingly passed on to consider methods of Indirect Election. Several such methods presented themselves.

\section{ELECTION BY LOCAL AUTHORITIES}

15. It was suggested that the choice of members of the Second Chamber might be entrusted to Local Authorities, grouped in local areas of suitable size. The Councils of counties and of county boroughs, possible with the addition of Councils of the larger non-county boroughs, urban districts, and rural districts, might constitute such electing bodies, or delegates from these Local Authorities might be formed into what are called "electoral colleges" for certain local territorial areas. In this way an electorate of picked men, chosen by the people in their several local government areas, and in so far qualified to represent the people, might be created; and these would select for the Second Chamber men of local influence and practical experience in affairs. Such elections might be conducted without the cost and the partisanship which seem inseparable from direct elections, and might give as good, or even a better, result in the quality of the persons selected.

16. Although this plan had the great attraction of providing a new basis for a Second Chamber, several objections were taken to it. It was argued that it would certainly introduce party politics into the elections of those County Councils and Borough Councils which had hitherto been conducted on non-party lines, and would intensify party spirit in those local elections where that spirit already existed in a mild form, or in those which turn upon issues different from the issues raised in Parliamentary contests. The result would be to lead local government voters

\footnotetext{
cleavage in the House of Commons would be accentuated instead of corrected; indirect election would have a disastrous effect on the bodies exercising the function, and the party test could not be avoided; the use of a limited franchise would have the Second Chamber "stand primarily for class interests and tend to exacerbate class conflicts," and "it would inevitably awaken the suspicion or hostility of the unrepresented majority." The only remaining alternative, according to Professor Muir, is the election of a Second Chamber on a democratic franchise, but in such a way as not to reproduce the character and organization of the House of Commons. This could be avoided by proportional representation (the single transferable vote), the country electing, say, 200 members of a Second Chamber from 20 constituencies. To this membership not more than fifty life peers could be added selected on the basis of service in high public places. Professor Muir thinks disputes unlikely, for the Ministry would give weight to the opinions of such a chamber; deadlocks could not continue long, for Upper Chamber would have to stand for reëlection, and in other cases "it would be easy enough for the two chambers to settle the matter in a joint session." Peers and Bureaucrats, pp. 225-243 (London, 1910).
} 
to think, when they were voting, more of a candidate's political opinions than of his fitness for local work, while it would cause the Councils themselves to be divided, in the discharge of their proper functions of local administration, upon party lines, and would thus impair their efficiency. As the members of local government bodies are now selected for duties which have little to do with national politics, there was no solid ground for thrusting upon them the very different duty of choosing a body fitted to discharge the political functions of a Second Chamber. In many large districts of Great Britain, the local borough and county councils are composed predominantly of members of some one political party, so that in those districts that party, whichever it was, would capture almost the whole of the representation in the Second Chamber, the men of merit who did not belong to that party being passed over, and the voters belonging to it being left unrepresented. Even the adoption of proportional representation would not remedy this evil.

These latter arguments ultimately prevailed.

\section{SELECTION BY A JOINT STANDING COMMITTEE OF BOTH HOUSES}

17. A fourth plan was then examined. It was that of placing the selection of the Second Chamber in the hands of some weighty, impartial, and independent authority, constituted in accordance with the proposal made in paragraph 27 of this Report for the selection of those Members of the Second Chamber who will be taken in the first instance from the Peerage.

Those who supported these views recommended that the Members of the Second Chamber, whether selected from the Peerage or not, might be chosen by a Committee of Selection, drawn in equal or nearly equal numbers, from both Houses of Parliament; that this Committee or Commission should be a small one, not exceeding 20 in number, that its Members might, in the first instance, be selected by agreement, and that the names of the original Members might be given in a schedule of the Bill for reconstituting the Second Chamber, and thus obtain the sanction of both Houses of Parliament. Two Members of the Commission might, it was thought, retire every year, and the vacancies thus created, as well as casual vacancies, might be filled by coöption. The names of the new Members should be laid upon the Table of both Houses for 30 days in order to afford Parliament an opportunity of taking exception to the proposed selection. If, in either House, a motion were made and carried that the nomination be not approved, it could be cancelled and a fresh nomination required.

18. While the scheme thus outlined found considerable sup- 
port in the Conference, the majority thought it essential to provide a broader basis for the Second Chamber than election by any Commission, even one set up and renewed by Parliament, could furnish. These members sought that broader basis in the election of a Second Chamber by Parliament itself. They urged that, while a commission such as that proposed would no doubt bring into the Second Chamber men of personal eminence, this fact alone was not sufficient to justify the method, as it was universally admitted that both high ability and personal eminence were to be amply found in the existing House of Lords. Nor, in their view, was it enough to secure that the new Second Chamber should be a balanced body. What was necessary was that it should be as far as possible a representative body. They held that since direct election by the voters had been ruled out by difficulties (already indicated) which had been deemed insuperable, the nearest approach to the advantages claimed for the method of direct election was to vest the selection of the bulk of members of the Second Chamber in the persons whom the voters had chosen to represent them in Parliament.

\section{ELECTION BY THE HOUSE OF COMAONS}

19. There were two ways in which this might be done. The House of Commons might vote as a whole for the election of a Second Chamber, or it might be divided into groups, each of which would be entrusted with the election of a certain number of members of the Second Chamber. It was objected to the former course that an election by the whole of the House of Commons must inevitably become a purely party contest, a contest which would be managed by the party Whips and would turn upon the party pledges or party services of the persons to be elected, too little regard being paid to their personal qualifications. Proportional Representation, it was thought, would not remove this objection, as it would not be practicable if applied to an election in which the list of candidates might contain several hundred names, ${ }^{1}$ and in which the quota would be so low that a very few electors could, by combining together, secure the return of any candidate. Such an

'Thomas Hare's original plan for proportional representation proposed a single constituency for the whole of the United Kingdom for the election of 654 members to the House of Commons. It did not seem to Hare an insuperable objection that the elector would have two or three thousand candidates to choose from. The Election of Representatives, Chapter II (sd ed., London, 1865). For some interesting facts with regard to the difficulty of securing information concerning candidates for office in the United States, see A. M. Kales, Unpopular Gocernment in the United States, p. 37 (Chicago, 1914). 
election would, therefore, fail to secure the kind of Chamber which the country is believed to desire.

:0. On the other hand, if the members of the House of Commons were to be divided into groups representing certain large divisions of the country, and were to meet in such groups to elect the persons they beld to be best fitted for the Second Chamber, the dangers just referred to would be less likely to arise. The members of Parliament composing the groups might be expected to knom the men best fitted to represent the needs and wisbes of the parts of the country from which they themselves come, and they would act under a sense of responsibility to their constituents which could not be enforced upon the House of Commons as a whole. They would be able to meet, in numbers not too large for friendly discussion and compromise, to select persons who would better represent the different political parties, and they might also reserve a number of seats for men who were not active party politicians, but seemed qualified to regard current questions in a fair and impartial spirit.

21. These considerations secured a marked preponderance in the Conference for this plan over that of an election by the House of Commons acting as a whole, and when the question came to be between this second or "Group" scheme and the fourth plan, described in paragraph 1\%, that of election by an electoral Commission of Members of both Houses, the scheme of election by geographical groups of Members of the House of Commons obtained the larger support.

22. Those, bowerer, who supported this fourth plan remained unconvinced by the arguments used in favor of election by the House of Commons, even acting by gnoups, and desired to have it placed on record that they were opposed on the following grounds to the method of composition recommended by the majority of the Conference.

23. They held it improbable that election by groups of Members of Parliament would produce a body of men possessing the attributes required for a Second Chamber, or well qualified to assume the functions assigned to that body. Elected by men who were themselves ineritably partisans, they could (so it was thought) scarcely be expected to be themselves free from partisanship. Thes would almost inevitably be chosen as party men and feel themselves bound by party ties. Apart from this it was feared-so these members argued-

The zumes of these members are as follows:

Duke of Ruthand. Marquess of Iansdowne, Earl of Danraver, Eerl of Ioreburn, Lord Baltour of Beleigh, Land Sydentram, Lard Hugh Cecil.

Sir George Younger, whele not supporting the fourth plan, desines to join in this disseat. 
that the system would lend itself to transactions and bargains of the most undesirable kind. A very small number of the electors could by proportional machinery choose a member of the Second Chamber. There would often be an irresistible temptation to choose persons, not because of their eminence or their fitness to take part in the business of the Second Chamber, but because it was desired to reward them for party services, political or pecuniary, or even because of personal friendship. If it were open to the groups to choose sitting Members of the House of Commons, the opportunity could be used to place the seats of such Members at the disposal of party candidates, or in other cases, to get rid of a Member whose popularity was waning in order to replace him by one more enterprising and useful to his party. They apprehended that in all these transactions, which might take an infinite variety of shapes, the Party organization, supported by the large funds, derived from various sources, which it controls, would tend to make itself more felt than ever. They further urged that if the functions and position of the Second Chamber were to be those which the Conference had decided to assign to it, it ought to be different from the House of Commons in character and unlikely to become its rival, and that it would therefore be unmise to set up alongside of the House of Commons a Second Chamber founded upon the same elective principle as that which gives authority to the House of Commons, but possessing that authority in slighter measure and working through a machinery open to grave criticism. Being itself a creation of the House of Commons it would furnish an insufficient check on that body.

24. In reply to these arguments it was contended that the responsibility of Members of the House of Commons, electing in groups, to their own constituents and to the great mass of voters of the large area which they would for this purpose represent, would restrain that partisanship which was so much feared. The groups would be anxious to return persons of high political standing, and also to study local sentiment. Thus they would not be subservient to the control of party managers and Whips, and this responsibility would give a guarantee against the exercise of the kind of undue influence which was apprehended. Supposing such a centre of corrupting influences to exist, it might reasonably, they argued, be maintained that a small Electoral Commission, even one appointed under the authority of Parliament and from members of Parliament, would be not less open to the action of such influences than would be the numerous and considerably larger electing bodies composed of members of the House of Commons which form the basis of the scheme here recommended. 
As to the need of a principle of differentiation between the Second Chamber and the House of Commons, which would prevent any tendency of the former to become a rival of the latter, they were agreed. They found such a principle not only in the indirectly representative character of a Second Chamber based upon election by the House of Commons but also in the other differences which were features of the scheme as a whole and are detailed below-the proposed longer tenure, the different legislative and financial powers and the smaller size of that body. Moved by these considerations, the majority of the Conference adhered to the method of election by members of the House of Commons grouped in territorial areas which will be found set out in Part II of the report.

\section{Method of Composition Adopted}

25. The method of election by Members of the House of Commons grouped in large territorial areas having been thus adopted by the large majority of the Conference, the next step was to constitute the proposed geographical groups to which the function of electing should be assigned, and to settle the number of seats in the Second Chamber which each group should elect, the respective populations of the areas of these geographical groups being taken as the basis for the number of seats to be allotted to each area. It was necessary that the areas should be comparatively few, that the boundaries of counties should be respected, and that their respective populations should, so far as possible, be nearly equal. The plan of voting by Proportional Representation, which was adopted because it would help to secure a due representation of all political parties, made it desirable that the number of seats to be filled by each group should be not less than five at each election. Thus, assuming that the Chamber should be (as hereafter explained) renewed by one-third at a time, the total number of seats to be allotted to the area of each group would be not less than fifteen. These considerations and an examination of the economic conditions, agricultural, manufacturing, and commercial, of the different parts of Great Britain, and of the respective characters and affinities of their inhabitants, led us to a division of the Island into thirteen areas for the election of the Second Chamber. All, or nearly all, of these areas have the advantage of being what may be called "natural entities," the counties which compose each area having a certain natural connection with one another, and some of them even a measure of distinctive racial quality, corresponding to those ancient divisions of the country out of which the United Kingdom has grown. . . The total number of members of the Second 
Chamber who would be chosen on this plan for Great Britain is 246. The number to be allotted to Ireland, and the method by which Members of the Second Chamber coming therefrom were to be chosen was reserved, pending a settlement of the questions which affect the representation of Ireland in the House of Commons.

26. The large majority of the Second Chamber having been thus constituted upon a principle which was deemed such as would give a thoroughly popular character to the Chamber as a whole, the Conference had next to consider the means by which the historical continuity of the reconstructed Second Chamber with the ancient House of Lords could be preserved. Two arguments enforced the desirability of avoiding a complete breach with the past. One has already been adverted to. The respect which it is desirable that the nation should feel for the Second Chamber will be all the greater if it be regarded as an ancient institution remodelled in accordance with modern views and feelings rather than as a brand-new creation. The other consideration was, that among the existing peers there are many men of distinguished ability and long experience in legislation and administration, men whose services the country would desire to retain. It was accordingly determined, some few dissenting, that a part of the Second Chamber should be chosen from the peers. It was also deemed proper (though again with some difference of opinion) that among those to be thus selected a certain small number should be taken from the Episcopal bench. The Spiritual peers constitute one of the most ancient elements of the Great Council of the Nation, having sat in that Council before the Norman Conquest and formed at some moments before the Reformation (including the mitred abbots) about one-half of it. Thus, as the principle of continuity suggested their presence, so it was also urged by some members that the legal position which the Church of England holds, Parliament being the body which legislates for it, made it proper to have in the legislature persons entitled to speak on its behalf and directly conversant with the works, ocial as well as religious, which it performs. In fixing the number to be taken from the existing House of Lords it was thought proper to make it somewhat larger at the outset, in order to find room for those peers who had been taking an active share in public business, than it need continue to be in the future years. Accordingly the Conference recommends that the number of this Section should be fixed at eighty-one, that, in the first instance, the whole Section should be chosen from the Peers, but that subsequently, the number of Peers in this Section should be gradually reduced, in the manner described in paragraph 36 , to 
thirty, the remaining fifty-one seats being thus thrown open to persons who need not be Peers. As will presently be seen, it is thought necessary that both numbers, the temporary and the permanent, should be divisible by three.

27. For the election of these Peerage Members two alternative courses were open. One was to let them be chosen by the whole body of Peers. This was rejected largely for the same reasons as had prevailed against the election of Members of the Second Chamber by the House of Commons as a whole, namely, that the election would be likely to fall under the control of party motives and party managers. The alternative course was to create a Committee of Parliament, specially qualified for this delicate function. The Conference accordingly proposes that a Joint Standing Committee of both Houses of Parliament be set up to be composed of men of authority and experience, and representing every political party. Those members of this Commission, who would come at the first election from the present House of Lords, and thereafter from the new Second Chamber, would be chosen by the Committee of Selection in that House. The members coming from the House of Commons might be chosen by the Speaker. It is suggested that five persons from each House would form a sufficiently large Electoral Commission or Committee. It would be set up at the beginning of each Parliament, and such vacancies as may occur in its membership would be filled up by the Second Chamber Committee of Selection, or by the Speaker of the House of Commons, as the case might be. Such a Committee might be trusted to see to it that due representation was given to every shade of political opinion.

\section{Period of Tenure of a Seat in the Second Chamber}

28. From the principle, generally accepted in this country and universally acted upon in other countries, that a Second Chamber shall, as compared with the larger and directly elected House, represent the more permanent mental attitude and tendencies of the nation, and be more exempt from sudden and violent fluctuations of opinion, two conclusions seemed to follow:

First. That the tenure of a member of the Second Chamber shall be longer than that of a member of the House of Commons. 1 Secondly. That the Second Chamber shall not be renewed in its entirety all at once, but as to a part only, a proportion of its members retiring at stated intervals.

29. It is therefore recommended, applying these conclusions, that the tenure of a seat in the Second Chamber be fixed at 
twelve years for both the above-mentioned Sections; and that one-third of each Section shall retire every fourth year.

This plan seems to offer two advantages-

(a) that the Second Chamber, while not suddenly changing as a whole under a momentary popular impulse, shall be kept in constant touch with public opinion in a way which could not be secured under a scheme of Life Tenure, and

(b) that it will always contain a considerable section of members who will have acquired legislative experience and a mastery of public affairs by a service of some length.

30. The following table shows the proposed composition of the Second Chamber:

\begin{tabular}{c|c|c}
\hline SEction & NUMBER & PERIOD OF TENURE OF SEATs \\
\cline { 2 - 3 } $\begin{array}{c}\text { I.-Persons elected by Members } \\
\text { of the House of Commons } \\
\text { grouped in territorial areas }\end{array}$ & 246 & $\begin{array}{l}12 \text { years (one-third to retire } \\
\text { every 4 years) }\end{array}$ \\
$\begin{array}{c}\text { II.-Persons elected by a Joint } \\
\begin{array}{c}\text { Standing Committee of } \\
\text { both Houses }\end{array}\end{array}$ & 81 & $\begin{array}{l}12 \text { years (one-third to retire } \\
\text { every 4 years) }\end{array}$ \\
\hline
\end{tabular}

Necessary Modifications in the Case of the Second Chamber to Be First Constituted

31. The system here set forth for the composition of the Second Chamber does not admit of being applied in its entirety to the composition of the Second Chamber to be first constituted. An essential feature of this system is that not more than onethird of the major portion of the Chamber should be elected at any one time or by a single House of Commons. It is proposed to meet this difficulty which arises in the case of the initial constitution of the Second Chamber as follows:

\section{AS REGARDS THE SECTION TO BE ELECTED BY THE HOUSE OF COMMONS}

32. One-third of this section should be elected by members of the present House of Commons grouped in territorial areas according to the plan proposed for all subsequent elections of the Second Chamber. This third should retire at the end of four years.

One-third of this portion of the Second Chamber should be similarly elected by members of the next House of Commons, and retire at the end of eight years. 
The remaining thind would be elected by the Joint Committee of both Houses already provided for the purpose of electing that portion of the Second Chamber in which members of the Peerage are to be represented.

This remaining third should sit for the full period of twelve years. (See the Table below.)

On this system, at the end of four years the machinery of election by the House of Commons existing at the time when each quadrennial period ended would come into full operation, and at the end of twelve sears, the whole of the Second Chamber would have been constituted according to the method here proposed, every elected member sitting for twelve years, and the Chamber being renewed by one-third every four rears.

33. It will be seen that it is assumed that a start will be made with the compusition of the new Second Chamber during the lifetime of the present House of Commons. If legislation for the constitution of the Chamber mere to be deferred until the next Parliament, certain modifications would obviously have to be made.

34. The question arises which of the three electing agencies proposed should elect its quota of a third of the Second Chamber first. It is conceived that the Joint Standing Commission should elect first, on the ground that such a body mould be well qualified to have regard in making its choice to the country as a whole, and thus include persons of eminence who might not have any connection with particular geographical areas.

\section{AS REGARDS THE SECTION TO BE ELECTED BY THE JOLT STANDING COMOMSSION}

35. As the whole of this section is to be elected, on the first as on future occasions, by the Joint Commission, the Conference think that it may be left to the Commission to assign to the persons chosen a term of four, eight, or twelve years, respectively, as it may think fit.

36. As stated above the election on this first occasion would be from the Peers exclusively.

At the second and third elections, howerer, the principle above referred to, of gradually throwing open the section to other persons besides Peers, should be put into operation, and at these elections half only of the vacancies should be reserved for Peers, while at subsequent elections the choice of the Joint Committee should be unrestricted, subject only to the provision that the number of Peers so selected sitting in the Second Chamber should not fall below thirty. 
37. Thble Shomtig Method Proposed for the Coyposmox of the Second Chauber at the OtTset

\begin{tabular}{|c|c|c|c|}
\hline & secrsox & METHOD OT CONPOSTIION & $\begin{array}{l}\text { PLRTOD OF TES- } \\
\text { TRE OF STATS }\end{array}$ \\
\hline & Majority of House, \$\$6 & $\begin{array}{l}\text { 1. Election by Members } \\
\text { af present House of } \\
\text { Commons, S? } \\
\text { 2. Election by Members } \\
\text { of next Horse of } \\
\text { Commons, S? } \\
\text { \&. Election by Joint } \\
\text { Standing Commis- } \\
\text { sion of toth Houses, } \\
\text { S? }\end{array}$ & $\begin{array}{l}4 \text { years } \\
8 \text { years } \\
12 \text { rears }\end{array}$ \\
\hline II. & $\begin{array}{l}\text { Section chosen br Joint } \\
\text { Standiog Commission } \\
\text { of toth Houses, \$1 }\end{array}$ & $\begin{array}{l}\text { Election by Joint } \\
\text { Standing Commis- } \\
\text { sios of both Houses. }\end{array}$ & $\begin{array}{l}\text { 4, S, and } \\
12 \text { reass }\end{array}$ \\
\hline
\end{tabular}

Geveral Protisions Reliting to the Composition of the Second Chlimber

35. Some other points relating to the composition of the Second Chamber remain to be mentioned. One of these relates to the Law Lords, who sit under the Appellate Jurisdiction Acts, 1876 and 1857. It is thought, that if and so long as the Second Chamber continues to discharge the judicial functions now discharged by the House of Lords as Supreme Court of Appeal, these high judicial personages should continue to sit as ex officio members. Their presence will add to its deliberations an element of special knowledge and long experience which will doubtless be available in the future, as it has been in the past, for the purpose of revising Bills and securing that the form in which they pass shall be legally correct. The same considerations apply to the Lord Chancellor and to those exLord Chancellors who take part in the judicial business of the House. It is suggested that they ought to remain ex offeio members while they sit as Judges of Appeal. It has long been the practice that nembers of the Royal House, created Peers, should sit in that capacity, though for some generations past they have neither joined in debate nor otherwise taken part in political life. ${ }^{1}$ The Conference thought that this practice

In March, 1929, during the debstes on the Irisb Free State (Asreement) Bil, the House of Londs discussed the propsiety of Law Lands moking party speeches to the country. I and Birkenbead (the Lond Cbancellor) "isperted 
might be so far continued as to allow the sons and grandsons of a Sovereign to sit in the Second Chamber.

39. Doubts arose as to whether the Lord Chancellor should continue to act as Chairman of the Second Chamber by appointment of the Crown for, though he puts the question in the House of Lords, he is not responsible for keeping order there and does not call upon members to rise and speak, and, being a member of the Cabinet, he joins in debate on behalf of the Government, and votes in a division. The view, however, prevailed that the traditions of his high office should continue to add dignity to the position of Speaker of the Chamber.

40. Several other questions relating to the composition of the Second Chamber require a brief mention.

The disqualifications for membership of the House of Commons now by law existing, ought, for the most part, to be applied to the Second Chamber also, excepting, however, those which exclude the Clergy of the Established Churches of England and Scotland, and of the Roman Catholic Church. ${ }^{1}$ Whether the provisions which exclude, with certain important exceptions, persons holding offices of profit under the Crown, individuals or members of firms holding contracts with the Government, and also the holders of pensions paid out of public funds, should be applied to the Second Chamber-these are questions which deserve serious examination. They are, however, of so delicate a nature, the law as regards contractors being in particular intricate, and in some points obscure, that it was thought better not to enter minutely into them, but to be content with commending them to the attention of His Majesty's Government, when they and their legal advisers proceed to draft a Bill for dealing with the matter.

It was conceived that Peers who have not been elected to the

that it was one of the unwritten conventions that a Law Lord, and other Judges, should avoid an active part in politics, and the question provoked a debate of great interest. Lord Carson denied that he had, consciously or unconsciously, broken any rule or tradition of the House of Lords by his speeches. An attempt, he said, was being made to draw an artificial line between Law Lords and other Peers" and he cited the political activities of the Lord Chancellor.

The Lord Chancellor replied that "since Law Lords were introduced into the House 50 years ago, a tradition had grown up that they should not take part in purely party debates. Only one recent instance to the contrary had occurred. He argued that the office of Lord Chancellor was exceptional-it was an anomaly tolerated for centuries by constitutional law. If Lord Carson's view prevailed, the result would be that when a Prime Minister had to make an appointment as Judge he would have to consider the question of a man's political opinions, and not his ability." The London Times (weekly edition), April 7, 1922.

II clergymen of the Protestant Episcopal Church in Ireland are now disqualified (a point which seems to be in doubt) their disqualification also ought to be removed. 
Second Chamber ought to be allowed to stand for the House of Commons, as Peers of Ireland have been since the Union in 1800. The case of Lord Palmerston is a familiar one.

There seemed to be no reason why the ancient rule which requires a Member of the House of Commons desiring to resign his seat to do so by the fiction of accepting such an obsolete office as that of the stewardship of the Chiltern Hundreds, or the stewardship of the Manor of Northstead, should be applied to the new Second Chamber; and it is accordingly suggested that its Members may retire by the simple method of addressing a formal letter of resignation to the President or Speaker of that Chamber.

41. Three other points deserve careful consideration. They are these:

(a) Whether Ministers of the Crown ought to be allowed to speak in both Houses of Parliament, of course with no right of voting except in the House to which they belong.

(b) Whether salaries similar to those now paid to the Members of the House of Commons should be paid to Members of the Second Chamber also.

(c) What provisions should be made for the period of transition from the existing House of Lords to the new Second Chamber so that the regular working of our constitutional machinery should go on through this period.

These points, since they raise issues which the Conference did not seem called upon, or perhaps even empowered by the Terms of Reference, to deal with, are submitted to the judgment of His Majesty's Government, and it was left to them to deal with various minor non-controversial matters relating to the requirements necessary for carrying out in detail the Scheme whose main lines have been laid down in Part II of this Report. Among these would be the dates to be fixed for the election by the several groups of the Members of the House of Commons and the details to be settled respecting the filling up of vacancies, both casual and those which will arise at the expiring of the three quadrennial periods. In order not to encumber the scheme by these minor matters they are submitted to the judgment of the Government and of Parliament. Some of them might, perhaps, be usefully dealt with by an order in Council.

42. Upon one interesting question which was discussednamely that of the possibility of turning the Second Chamber to good account for the purpose of including in it persons who might be qualified both to express the views of the Self-Gov- 
erning Dominions and other parts of the British Overseas possessions, and to join with full knowledge in discussing questions affecting them, it was held by the Conference, after the matter had been debated with a full recognition of its importance, that they were precluded by their Terms of Reference from making recommendations which, if adopted, might affect the relations of the Parliament of this country with outlying parts of the Empire. ${ }^{1}$ But the hope was expressed in the course of the discussion that this matter would receive the careful consideration of His Majesty's Government.

The Conference then passed on to another of the three topics set out in the Terms of Reference, viz., the legislative functions which the Second Chamber ought to exercise.

\section{Legishative Functions of the Second Chamber}

43. Only in one respect does this subject present any serious difficulty. It has always been understood in this countryand this is the practice in nearly every country where a Second Chamber exists ${ }^{2}$ that the Second Chamber should be entitled to full power in the sphere of such legislation as is not of a financial character. It may revise and amend, and in some cases refuse to proceed with, a Bill brought to it from the other House. It may initiate ordinary Bills both Public and Private. It may discuss all questions of general domestic and imperial policy. In financial matters alone is its range of action limited by the long established superior rights of the popular House. Accordingly, it was with questions of finance and with these only that the Conference found it had to deal.

44. The Conference was agreed in declining to attempt to recast as a whole the old rules which have determined the privileges of the House of Commons with regard to Finance. These are now a sort of labyrinth of historical, constitutional, and legal controversies. Thus it was resolved to deal with one branch only of the subject-the distinction to be drawn between Bills which are purely financial in effect as well as in form and those which though containing some financial provisions, are also calculated to attain non-financial objects, the method of discriminating between these two classes of bills,

\footnotetext{
'A similar remark applies to a suggestion made by one of our members that, were a federation of the United Kingdom to be effected, it might by a transfer of legislative powers to subordinate parliaments so reduce the likelihood of disagreements between the two Houses as to make any large change in the composition of the Second Chamber unnecessary. This also was deemed to lie outside of the Terms of Reference.
}

2 This is by no means true as to the Second Chambers established by many of the new constitutions of Europe. See above, Chapter III. 
and the consequences which ought to follow from such discrimination.

45. It is recognized on all hands that Bills of a purely financial nature belong to the House of Commons alone and ought not to be rejected or amended by the Second Chamber.

But what is a purely financial Bill?

A Bill brought into the House of Commons whether to raise revenue or to appropriate revenue for particular public purposes may, while purporting to be concerned only with the raising and spending of money, have effects-industrial, commercial, social, or political effects - more important and far reaching than would be its direct financial effects. Many large changes-indeed some revolutionary changes-might be carried through by measures purporting to be financial. The Conference thought that, if the new Second Chamber, elected as proposed, is to be of real service, its views ought to be heard regarding such changes. It would appear to be required, in the interests of the people, and that not merely as taxpayers, but as citizens also, that such measures should not be hastily hurried into law without due consideration: and a Second Chamber constituted as proposed would seem fitted to furnish a safeguard for this purpose. The jealousies and antagonisms which have in time past attached to the action of a non-representative House confined to the members of one, and that, for the most part, a wealthy class, need not be expected to apply to the action, strictly limited as the Conference think it slould be, of a Second Chamber so much changed in its composition and so popular in its character as it will be under the Scheme hereinbefore described. If this be admitted, the question is raised: How are purely financial Bills to be discriminated from others which, while to some extent and for some purposes financial, are also much more important in their non-financial effects than in those that relate merely and directly to the raising and spending of money?

46. The obvious method might appear to be to find a clear and precise definition which could be inserted in a statute for distinguishing these two kinds of Bills. The Conference spent many hours in trying to find such a definition, but without success. Some proved to be too wide, others too narrow. The complexity of the problem, and the variety of the cases which had to be provided for, were baffling; and very high authoirites who were consulted declared that this had been their experience also. But an examination of the cases of doubt which had arisen in this country and elsewhere showed that most, perhaps nearly all of them, could have been disposed of after a not very protracted discussion round a table by a dozen practical, fairminded men; and the Conference was thus led to believe that 
the best method of treating these doubtful and disputable Bills would be to refer them to a small, carefully selected Joint Standing Committee of both Houses of Parliament, making its decision final. Such an arrangement for deciding these delicate questions seemed preferable to that contained in the Parliament Act, which does not cover all the cases likely to arise, and which places on the Speaker responsibilities with which it is not desirable to load an office whose perfect impartiality everyone desires to preserve. The Conference accordingly recommends that such a Finance Committee, which ought not to exceed in number seven members from each House, be set up at the beginning of each Parliament, and that either House should be entitled to refer to it any financial Bill containing provisions which raise serious issues that may be thought to be not solely of a financial nature. It would be the duty of such a Committee to consider not only the professed objects, but also the underlying purpose and the probable effects of such a Bill, in order to determine its character and to report which (if any) of its clauses are, as being strictly financial, fit to be dealt with by the House of Commons alone, and which (if any) may properly be subjected to examination and amendment by the Second Chamber in respect of the economic or social results to be expected from them, these being matters of general national policy. Should the Committee report in the latter sense, such provisions as were declared to be non-financial would be open to rejection and amendment by the Second Chamber, subject always to the ancient rule that no amendments should be made by the Second Chamber which could increase any charge upon the people. If amendments were made in bills declared to be non-financial, and these were not accepted by the House of Commons, the differences between the two Houses would fall to be adjusted in the manner (to which I now pass) provided for the case of an ordinary nonfinancial Bill.

\section{Adjustment of Differences Between the Two Houses}

47. The Conference then reached the last of the three subjects mentioned in our Terms of Reference, viz., the Adjustment of Differences between the two Houses. This has long been regarded as one of the most difficult of all the questions affecting the position and powers of a Second Chamber. It divides itself into two branches:

(a) The methods of conciliation and compromise by which differences may be settled without any ultimate trial of strength.

(b) Some plan for final settlement when no compromise has been found attainable. 
48. (a) Conferences between the two houses to settle their differences have been an old part of Parliamentary machinery. They have, however, been of comparatively slight value, and little used in recent years, because the rules which governed them were stiff and cumbrous. It is therefore proposed to apply a simpler and more elastic method, which is really new, though it may fitly be called by the old name of Free Conference. The suggestion is that a small number of the most experienced, most judicious and most trusted members of each House be chosen at the beginning of each Parliament, due representation being given to all the parties that may exist in each House, to form a Standing Conference Committee, and that another smaller number be added by each House of persons who, while possessing the same merits as belong to the permanent element, should also possess in addition a special knowledge of the particular matter to be dealt with in the particular controversy. The permanent number might, it was thought, be twenty from each House, in order that the body should not be too large for easy and informal discussion and should be not liable to be moved by that warmth of feeling which is apt to increase with the numbers of any assembly. The number of additional members to be added pro re natâ in respect of special knowledge would be determined by the magnitude of the issue involved, but ought not (it was deemed) to exceed ten from each House, so that the total number of the body should not in any case exceed sixty.

49. When the Free Conference Committee thus constituted had been set up, any amendments made by either House to a Bill passed by the other, would, if they were not accepted by that other House, stand referred, at the request of either House, to the Free Conference. The Free Conference would then address itself to the solution of the controversy by friendly methods exploring the various points involved and seeking to find a way out of the difficulty either by compromise or by discovering some new plan which might prove more acceptable to both Houses than that contained in the Bill passed by one House, or in the amendments passed by the other. If and when agreement is reached by the Free Conference its terms would be reported to both Houses. Each House would then consider them and accept them or reject them. If they were accepted by both Houses en bloc the controversy would be at an end, and the Bill would be in a position to receive the assent of the Crown. If, however, the Bill (as reported by the Free Conference) was accepted by one House but rejected by the other, some further method of effecting an adjustment would be required. To this point I return below.

50. It may be asked whether the Free Conference should sit 
in private or in public. The view taken was that its proceedings should be conducted in secret, for only thus can perfect freedom of discussion be secured. Its members ought to be at liberty to make suggestions for compromise without prejudice to their own subsequent action in further sittings or when the matter comes before each House as a whole. A record of the proceedings would be kept, and would state, unless the Free Conference should otherwise determine, the numbers voting in each division, but would not give the names of Members voting. Whether this record should be published along with the Report might be left to the Free Conference to determine.

51. Another question is, Should it be open to either House to require the reference to the Joint Standing Committee of a Bill rejected in toto by the other House?

We hope and believe that when the system of Free Conferences has been established, rejections of a Bill will rarely occur. It would be generally felt more desirable that objections taken to a Bill should be set forth in amendments made to it. But if a Bill were rejected, and either House wished the issues raised to be referred to a Free Conference, it was thought that this method of endeavouring to secure agreement need not be ruled out.

52. (b) The question remains to be considered whether, in the event of a compromise having been found unattainable by means of a Free Conference, some other, and, if so, what plan should be resorted to for the purpose of obtaining a final settlement of differences between the two Houses.

Suppose, for instance, that the proposals for adjustment reported by the Free Conference have been accepted by one House and rejected by the other, what further steps would be required to solve the deadlock?

Three such methods were put forward for consideration and were very carefully examined.

53. The first was that the House which accepted the Bill as reported by the Free Conference should have the right of referring it to a Joint Sitting of both Houses. The Bill would then be discussed by the members of both Houses united together (as they were before the Lords and Commons began to sit apart) in the Great Council of the Nation in Parliament assembled, and, if not there settled by agreement, its fate would be decided by a vote of the whole united body. This plan had obtained influential support some years ago when the subject was considered by a Committee of the House of Lords. But though some advantages it presented were recognized, obvious objections presented themselves in respect of the great size of the united body, the various difficulties attending its procedure, and the possibility that its presence in the background might make agreement 
in a Free Conference less probable. Thus it finally failed to command general assent.

54. A second plan was that of referring the matters in controversy between the Houses to the country by means of a Referendum or popular vote of all the registered electors. This proposal received considerable support, and some who favoured it remain of opinion that it is the best method of solving deadlocks. They desire that when the two Houses have failed to agree to a Bill as reported from the Free Conference it should be open to the House of Commons to submit the Bill as approved by the Free Conference to a vote of the people. The vote might take place at a date to be fixed by Order in Council not less than sixty days after the House of Commons had passed the Resolution asking for a Referendum, or, if it were judged convenient by the Government, the Order in Council might fix the next General Election as the time for the vote. If the result of the vote were adverse to the Bill the Bill would be dead. If the result of the vote were favourable, the House of Commons would have authority to submit the Bill to Royal Assent without the concurrence of the Second Chamber. By this method, it was thought, the essential principle of self-government, that the people must in the last resort themselves decide what legislation they desire, would be applied without invading the representative character of the House of Commons or diminishing its proper authority as a representative assembly. It was further urged, in support of this plan, that the knowledge that the possibility of a reference to the people might ultimately be resorted to would greatly stimulate and strengthen conciliatory influences within the Free Conference and commonly lead to the adjustment of differences by mutual concession between the contending parties.

55. The majority of the Conference, however, did not approve this plan on the ground (among others) that the use of the Referendum once introduced could not be confined to the cases for which it was in this instance proposed, that it might tend to lower the authority and dignity of Parliament, and that it was unsuited to the conditions of a large country, and especially of the United Kingdom, for different parts of which different legislation is sometimes required.

56. When it appeared that the judgment of the Conference as a whole did not favour either of the two plans above stated, it became necessary to search for some other method of adjustment. This was at last discovered by returning to and carrying further that mode of proceeding by Free Conference which has been already outlined.

It has been already observed that if a Bill reported from a Free Conference had been accepted by one House but rejected 
by the other some further step would be required. This step would be to send the Bill back to the Free Conference, which would take up the matter again in the Session next following that in which the Bill originated. If the Free Conference should then, after further consideration, again report the Bill to the Houses in the same form in which it had been previously reported, the Houses would again consider the Bill.

If they both agreed to it, it would pass; if they both disagreed to it, or if the House of Commons alone disagreed, it would lapse. If, however, the House of Commons alone agreed to the Bill, and it had been reported by the Free Conference by a majority of not less than three of the members present and voting, it would be submitted for the Royal Assent.

Should the Free Conference, however, fail to agree to report the Bill again in the same form, or if the majority by which it agreed to report it should be less than three, the Bill would lapse, unless of course it was accepted by both Houses as reported.

57. It will be clear that the effect of this procedure would be on the one hand to secure that full opportunity should be given for reconciling different views by amendments and methods of compromise generally, and on the other hand to provide that nothing less than a majority of three in the Free Conference (which will itself consist of selected members of both Houses)a majority which would be substantial having regard to the numbers of the Conference-would suffice to determine the points in issue. This would, it is submitted, safeguard the rights of both Houses, for the Second Chamber would not be overruled, unless a considerable proportion of those who represented it in the Free Conference had voted in favour of the Bill, while the ultimate control of the more popular House would be respected.

58. It is believed that by this method of Free Conferences, applied in a calmer atmosphere than could be expected in either House as a whole, the arguments on which each party relied, would be better appreciated. Many controversies might thus be amicably settled, and even where they were not wholly settled, the matters in dispute would probably be reduced in number, so that when the plan proposed for decision in the last resort had to be applied, the issues to be submitted to such final arbitrament would have become fewer and more clearly defined.

59. In order to prevent any possibility of confusion between the three different Joint Committees of both Houses recommended for different purposes by the Conference, $i$. e.: 1 . The Joint Committee for the election of a portion of the Second Chamber, 2. The Joint Committee for deciding questions with regard to Financial Bills, 3. The Joint Committee (or Free Conference) for conferring about differences of opinion with 
regard to questions of general legislation, the following Table, in which their functions, method of composition, etc., are detailed, is given.

It may be added in support of this extended application of the machinery of Joint Committees that the Conference hoped that by such means there might be attained a better understanding and closer coöperation between the two Houses of Parliament, than it has in the past been found possible to secure.

Table of Jonst Standing Commttees Recommended to Be Set Up, Showing Their Compositions, Functions, etc.

\begin{tabular}{|c|c|c|c|c|}
\hline TITLE & rescrioss & NCYBER & METHOD OY COMPOBITION & DCRATION \\
\hline $\begin{array}{l}\text { Electing Joint } \\
\text { Committee or } \\
\text { Commission }\end{array}$ & $\begin{array}{l}\text { To elect one-quarter } \\
\text { of Second Cham- } \\
\text { ber }\end{array}$ & 10 & $\begin{array}{l}5 \text { to be chosen by Speaker, } \\
5 \text { to be chosen by Com- } \\
\text { mittee of Selection of } \\
\text { House of Lords and } \\
\text { afterwards of Second } \\
\text { Chamber }\end{array}$ & $\begin{array}{l}\text { One Parlia- } \\
\text { lisment }\end{array}$ \\
\hline $\begin{array}{l}\text { Financial Joint } \\
\text { Committee }\end{array}$ & $\begin{array}{l}\text { To decide whether } \\
\text { Bills, or provi- } \\
\text { sions, referred to } \\
\text { them are Financial }\end{array}$ & $\begin{array}{c}14 \text { or } \\
15\end{array}$ & $\begin{array}{l}7 \text { appointed by Committee } \\
\text { of Selection of each } \\
\text { House, with power to } \\
\text { coobpt Chairman from } \\
\text { outside }\end{array}$ & $\begin{array}{l}\text { One Parlia- } \\
\text { ment }\end{array}$ \\
\hline Free Conference & $\begin{array}{l}\text { To adjust differences } \\
\text { between the two } \\
\text { Houses with re- } \\
\text { gard to Bills (or } \\
\text { provisions in Bills) } \\
\text { other than Finan- } \\
\text { cial }\end{array}$ & 60 & $\begin{array}{l}\text { A. } 20 \text { appointed by Com- } \\
\text { mittee of Selection of } \\
\text { each House } \\
\text { B. } 10 \text { additional mem- } \\
\text { bers, similarly ap- } \\
\text { pointed, pro re nata, by } \\
\text { each House }\end{array}$ & $\begin{array}{l}\text { A. Ons } \\
\text { Parlia- } \\
\text { ment } \\
\text { B. For } \\
\text { proceed- } \\
\text { ings in } \\
\text { Confer- } \\
\text { ence on a } \\
\text { particu- } \\
\text { lar Bill }\end{array}$ \\
\hline
\end{tabular}

60. We are aware that not a few criticisms may be made upon the scheme here presented. Some of these will, it is to be hoped, be dropped, or reduced in force, when the explanations given have been duly considered and when each part of the scheme is regarded in its relation to the whole, and apart from any bias which may have arisen from former controversies. If other objections still remain, the best answer to them will be found in the fact that among the Second Chambers which exist in other countries there is not one whose composition cannot be attacked on grounds at least as grave as any that can be brought against this scheme, yet there is none among these Chambers which does not, in the opinion of its own people, contribute to the good government and tranquillity of the country where it exists. 
Perfection is not to be expected in any Chamber or in any frame of government. The true test is whether it is so constructed as to offer a reasonable prospect of so discharging the functions for which it is designed as to contribute to the excellence of legislation and welfare of the whole body politic.

61. Those who criticize will, we trust, appreciate the nature and weigh the difficulties of the task imposed upon us. We had to reconcile the sentiment of attachment to a venerable institution with the needs of new social conditions and the demands of new phases of thought. There were two principles on which a Second Chamber might be constructed. One was that of filling a House with the largest available number of capable and experienced men whose presence would win for it that kind of authority which comes from personal eminence. The other principle was that of creating a Chamber which should be most quickly responsive and most fully responsible to public opinion, drawing its strength from the fact that it had been popularly elected. It was impossible to give full scope and application to either of these principles and to secure in ample measure the benefit of either source of strength without losing some of the merits to be expected from the other. We had, therefore, to find means whereby to combine as many as possible of the advantages with as few as possible of the defects of either course, and we had to remember that a plan which philosophers might approve would not necessarily find like favour with the bodies by whose will it would have to pass into law. So, too, when the powers of the Second Chamber had to be defined, similar perplexities arose. It was generally agreed that a Second Chamber would be of little use unless it were strong enough to differ from the House of Commons when a proper occasion arose- a proper occasion being one in which there was reason to believe that some decision of the Commons did not express the full and deliberate will of the people. But it was also agreed that the Second Chamber ought not to be so strongly entrenched as to dispose it to engage in frequent contests with the House of Commons, so as to embarrass the Executive and clog the wheels of legislation. It thus became necessary to steer a middle course between these extremes, assigning to the Second Chamber such powers only as the interests of the nation seem to require and finding expedients by which differences between the Houses might be adjusted with the minimum of friction and delay, avoiding conflicts by methods of conciliation.

62. On a subject which presents so many aspects as that we have had to deal with there must needs be differences of opinion. All political parties were represented in the Conference. But such divergences of view as from time to time arose did not often 
spring from or correspond to divergences of political opinion. They were due rather to the greater or less weight which our members respectively attached to principles they all admitted, and also to the diverse conjectures that were formed about the probable working out in practice of the various plans presented. In such matters a diversity of views is inevitable among men of independent minds. It has not prevented the great majority of the Conference from recommending the scheme here drawn out, though some members dissent, as mentioned in paragraph 22, from the plan of election by Members of the House of Commons acting in geographical groups, and other members have respectively preferred various other methods of election which have not received the support of the majority of the Conference, while one or two members thought that the powers of the Second Chamber should be more restricted than the majority deemed requisite.

63. I may perhaps be permitted to add a word as Chairman of the Conference. One of the things that most struck me in presiding over the long and animated discussions of the Conference, was that every member was not only scrupulously careful to avoid recrimination over past controversies, but also recognized, above and beyond all differences of opinion, the fairness and goodwill of his colleagues, and gave to each and all of them the credit of honestly and sincerely seeking what was best for the country without thought of the special interest of his own class or party. Whatever judgment may be passed on our labours we hope that the Conference will be felt to have addressed itself with a single and an earnest mind to the duty that was assigned to it - the duty of trying to reconstruct upon lines fitted to the conditions of our time an important part of that ancient and famous Constitution which many nations have taken as a model and which has for more than seven centuries safeguarded the liberties and advanced the greatness of the British people.

Commending the conclusions embodied in this Report to the consideration of yourself and your colleagues,

I have the honour to be, my dear Prime Minister,

Very faithfully yours, BRYCE.

April, 1918. 


$$
\text { . }
$$




\section{IN DEX}

\section{To Introductory Chapters and Historical Notes}

Administration, control, 26, 34-37; in France, 30; democratization, 36.

Albania, has not yet adopted constitution, vi.

Albert, Prince Consort, influence over foreign affairs, 140-141.

Amendment of constitutions, in Germany, 71 ; in United States, 71, 154; in new states, 155.

Andrássy, Count Julius, 253.

Angell, Norman, quoted, 160, 162.

Arbeitsgemeinschaften, in Germany, $125,130$.

Aristotle, quoted, 57, 163.

Armistice, of November 11, 1918, 170.

Ashley, William, cited, 384 .

Asquith, Herbert, 29; quoted, 43.

Atherley-Jones, Judge, quoted, 20.

Ausgleich, between Austria and Hungary, 244-246, 248.

Austria-Hungary, a composite system, 3; resistance to constitutionalism, 9; little republican sentiment in, 15; monarchs and princes abdicate, 15 ; parts of, merged into Jugoslavia, 77,345 ; control over foreign affairs, 136; origin of Dual System, 241-244; Ausgleich, 244; nature of Union, 245-246; Delegations, 244-245; no responsible ministry, 245; results of Dualism, 245-246; economic interdependence, 246; effects of war, 250; offers to negotiate peace, 251 ; disintegration, 252, 309; status of Jugoslavs in, 343-345; authority of, comes to end in Jugoslavia, 345346.

Austrian Empire, executive power in 34, 52; part of, merged into Jugoslavia, 77, 345; representation in, 117; defeat of, by Prussia in 1866, 167,243 ; status of, prior to 1867 , 241 ; conflict of, races in, 241,247 ; Diploma of 1860, 242; Patent of 1861, 242; Patent of 1867, 243-244; part of Dual Monarchy, 244; ratifies Ausgleich, 244; Hungarian influence in, 246; severance from Hungary in 1918, 246; geography of, 246-247; Roman Catholic religion, 248; dissentious political history, 248; constitution of 1867 , 248; amendments of, 248-249. political parties, 249; problems in victory or defeat, 250; parliament of, suspended during war, 250-251: effect of Russian Revolution in, 251; reassembly of parliament in, 251 ; federalization promised, 252, 308; government of Jugoslavs in, 343; partition of Poland to, 402.

Austrian Republic, democratic government, 3; federal system, $39, \mathbf{7 4 -}$ 76 ; agricultural needs of, 59 ; relation to Petite Entente, 60-61; union with Germany prevented, 74, 187-188, 255; number of states, 75 ; position of Lower Austria, 75; legislative and administrative centralization, 75 76; proportional representation, 84, 114 ; functional representation, 195 ; judicial supremacy, 158-159; provisional government, 252-253; geography and population, 253-254; Provisional National Assembly, 254; political parties, 254-255; decentralization, 254; constituent assembly, 254-255; constitution of, 256-306.

Azerbaijan, 3, 4.

Baden, former control of executive, 35 ; proportional representation, 97-99; and North German Confederation, 169; government under constitution of 1919, 238-240.

Bagehot, Walter, cited, 12; quoted, 27, 28, 146.

Baltic States' Treaty, 61.

Banât, 77, 346.

Barker, Ernest, quoted, 18, 19. 
Barriéty, cited, 93.

Barthélemy, Joseph, cited, 150.

Bavaria, absorbs Coburg, 67; and North German Confederation, 169; government under constitution of $1919,233-236$.

Beard, C. A., cited, 117.

Belgium, constitutional monarchy, 7; despoilment of, 55,56 ; proportional representation, $84,92-95$; note on constitutional history, 499-501; constitution of, 501-520.

Belloc, Hilaire, quoted, 18.

Beněs, E., quoted, 61; leadership of, 309.

Benoist, Charles, cited, 118.

Bill of Rights, in new constitutions, 158-159; in Jugoslavia, 348.

Bismarck, Prince Otto von, influence on monarchy, 11-12; attitude toward cabinet responsibility, 53; attitude toward popular government, 167-168; quoted, 167-168.

Björkman, Edwin, cited, 429.

Blociszewski, cited, 403, 404.

Blunt, Wilfred S., quoted, 144.

Bluntschli, J. C., quoted, 7 .

Bohemia, 241, 247, 307-309.

Boisjoslin, J. de, cited, 402.

Bolsheviki, origin of term, 380; coup d'état, 382, 452-453; see also Russia.

Bolshevism, compared with socialization, 159; and the German revolution, 171.

Bosnia-Herzegovina, 343, 346.

Bowman, Isaiah, cited, $65,77,247$, $346,426$.

Brest-Litovsk, Treaty of, 251.

British Empire, foreign affairs, 2; a composite system, 3; influence of Crown, 12-14; proposals for federation, 78; Parliament of, 79; see also England and Great Britain.

Brockchausen, C., quoted, 36.

Brooks. R. C., cited, 152.

Brunet, René, quoted, 35, 69, 100 , 101, 123-124; cited, 62, 72, 98, 122, $125,129,151,175$.

Brusewitz, Axel, cited, 150.

Bryce, Lord, quoted, 3, 4, 5, 17-21, $48,57,58,59,85,87,136,146,156-$ 158, 163; report of for Second Chamber Conference, 44-54, 573601.

Bukowina, 241, 247.

Bulgaria, proportional representation, 81; signs armistice, 251; part merged into Jugoslavia, 346.
Bureau of Labor Statistics, U. S., report of, on German Factory Workers Councils, 126-128.

Burgenland, $75,254$.

Burian von Rajecz, Count Stephen, 253, 308.

Burke, Edmund, quoted, 163, 402.

Burns, C. D., cited, 34.

Cabinet, powers of, during war, 1; possible reform of English, 23; recent position of English, 28-29; tenure in France; see also under names of countries.

Calhoun, John C., quoted, 402.

Canada, influence of Crown in, 12; political influence of farmers in, 20; second chamber in, $45^{\circ}$ see also Dominions.

Carinthia, 77.

Carlyle, Thomas G., quoted, 163.

Carniola, 77.

Clarenoion, Lord, 141.

Clark, R. T., cited, 33; quoted, 452454.

Clemenceau, Georges, 29; views on Poland, 427.

Coburg, joins Bavaria, 67, 234.

Cole, G. D. H., cited, 118.

Commons, House of, influence of press on decline, 21-23; possible reforms in, 23; problems of, 23-24; recent relations of Cabinet to, 2829; relative decline in prestige, 44; legislative process, $49-50$.

Communism, encouraged by Peace Treaties, 161-162.

Communists, in Germany during revolution, 171, 175.

Conference on Devolution, 80-82.

Conference on Second Chamber, see Second Chamber Conference.

Congress of Oppressed Nationalities, 307.

Congress of Vienna, 167.

Constituent assembly, see under names of countries.

Constitutions, making of, 5 ; in 17th and 18th centuries, 5; in 19th century, 8; conception of, in United States, 154; conception of, in Europe, 155; written in new states, 155; written compared with customary, 156-158; flexible and rigid compared, 156-158; see also under names of countries.

Cook, Sir Edward T., cited, 139.

Corfu, Pact of, 345. 
Council system in Germany, 119-132.

Councils of Workmen's Peasants' and Soldiers' Deputies, in Russia, 382.

Courtney, Lord, quoted, 146.

Cowley, Lord, 141.

Croatia, 241, 244, 343, 344, 346.

Croatia-Slavonia, 77.

Croats, in Jugoslavia, 78; in Austria, $247,343,344,345,346$.

Currier, C. F. A., cited, 523.

Czechoslovakia, democratic government, 3, 15; powers of President, 32; control over executive, 34-35; democratization of administration, 36; agricultural need, 59 ; member of Petite Entente, 60; treaty with Austria, 61; no federal system, 7677 ; races, 76 ; proportional representation, 84, 108-109; amendment of constitution, 157; judicial supremacy, 158-159; recognition of, 251 ; independence of, 252-253; composition of, 307 ; a medieval state revived, 307 ; provisional government, 308-309; National Assembly, 310; constitution of, 310342.

Czechs, in Czechoslovakia, 76-77; in Austria, 241, 242, 246, 247, 252; national revival of, $307-308$.

Dalmatia, 77, 343, 346.

Danzig, proportional representation, 84, 115; functional representation, 135; corridor, 426; creation of Free City of, 426-428; under League of Nations, 427; High Commissioner, 427; relations with Poland, 428; constituent assembly, 428-429; constitution approved by League, 429, 448-451; constitution of, 429-448.

Dareste, F. R. and P., cited, 347, 499, $523,550,551$.

Deck, J., and Wendt, G., cited, 97.

Dedek, quoted, 157; cited, 310.

Delbrück, K. von, quoted, 122.

Delcroix, A., quoted, 95.

Denmark, nationality, 3 ; proportional representation, 84, 90-92.

Derby, Lord, 142.

d'Hondt method, in proportional representation, 92, 94, 98, 112 .

Dicey, A. V., quoted, 52; cited, 78.

Dillon, E. J., cited, 381.

Diplomacy, see Foreign affairs.

Disraeli, Benjamin, 142, 143, 146.

Dodd, W. F., cited, 499, 523, 551 .

Dominions, foreign affairs of, 2 ; adapted English constitution, 8; influence of Crown, 12, 13; political parties, 19; oppose imperial federation, 78 .

Dualism, origin in Austria-Hungary, 241-244; nature of, 245-246.

Duchesne, A. E., cited, 4.

Duggan, S. J., cited, 13.

Duguit, Léon, cited, 118 ,

Dunning, W. A., quoted, 8, 9, 10, 14 .

Dupriez, Léon, quoted, 95.

East Prussia, 63.

Ebert, Friedrich, 170, 174.

Economic Council of the German Reich, importance of, 121; possibilities of, 122; establishment of provisional, 122, 128; representation in provisional, 129-130; functions of, 130-132.

Economic Councils in Germany, District, 121, 132.

Economic problems, influence of, on monarchy, 11; emphasis on, in new states, 24; in England, 24-25; of small states, $55,59-60$; and the Council system in Germany, 119132; relation of, to democracy, 163 .

Edward VII, influence on foreign policy, 14, 143-146.

Egypt, 2, 57.

Empires, crumbling of, 2; segmentation of, 55 ; see also under names of countries.

England, discontent with representative government, 16; political influence of trade-unions, 20 ; decline of House of Commons, 21-23; reform of House of Commons, 23; emphasis on economic problems, 24-25; type of responsible government, 27-29; constitution avoided by most new states, 28 ; government contrasted with that of France, 29 30 ; reform of House of Lords, 4054; legislative process, 48-52; Cabinet domination, 54; functions of Parliament, 79; Crown Council for, 80-82; class representation in Lords, 117; control of foreign affairs, 136, 140-149; wartime socialism, 160; private property in, 160; see also British Empire and Great Britain.

English constitution, influence, 7-8; character, 7, 27; peaceful development, 8; flexibility, 146.

Erfurt Progranme, 171. 
Esher, Lord, quoted, 21, 22, 44-45, 144.

Esmein, A., cited, 151.

Esthonia, democratic government, 3,15 ; Swiss type of executive, 28, 32 ; initiative and referendum, 3233; unicameral legislature, 38; signs Baltic States' Treaty, 61; proportional representation, 84, 115; control of foreign affairs, 151; geography, 452; effect of Bolshevist coup d'état, 452-453; invaded by Germans, 453; recognition of, 453; constituent assembly, 453; treaty with Russia, 453; constitution of, 454-464.

Executive, powers during war, 1; separation of, 6,9 ; in new constitutions, 26-37.

Factory Workers Councils in Germany, 122-123; organization, 123124 ; powers, 124-125; and tradeunions, 125-126; election of, 126; results, 126-128.

Farrar, J. A., quoted, 141, 143.

Federal system, permits experiments, 58 ; in Germany, 62, 213-214; problem in new Germany, 62, 216; definition, 68, tests, 69; applied to Germany, 69-74; tendency toward centralization, 70; in Austria, 7476,256 ; not established in Crechoslovakia, 76; proposed for United Kingdom, 78-82; agitation for in Austria before 1867, 241-243; promised in Austria, 252, 308.

Finland, democratic government, 3; unicameral legislature, 38; signs Baltic States' Treaty, 61; proportional representation, 84, 9697; status of under Russia, 465-466; fundamental laws of 1906-07, 466; effect of Russian revolution on, 466467; independence of, 467; German domination ousted, 467; recognition of, 467; constitution of, 468-495.

Fisher, H. A. L., quoted, 10, 11, 12 , $13,56,57,58,59$.

Fiume, D'Annunzio's constitution not included, vi, Jugoslavs in, 343-344.

Foreign affairs, democratization of, 2, 136; of British Dominions, 2; in new states, 136-137, 150-151; control in United States, 138; control by monarchs, 139; influence of press, 139; former control in Russia, 139; in Germany, 139-140, 151; influence of Victoria, 140-143; of Edward VII, 143-146; of George V, 146; recent English practice, 147149; committee on, proposed in England, 147; Norwegian practice, 149-150; Swedish practice, 150; French practice, 150.

France, borrowed from English constitution, 8; lessons from, 9, republicanism, 11; discontent with representative government, 16 ; Socialist congresses in, 20; type of responsible government, $27,29-30$, 40; constitution borrowed by Czechoslovakia and Poland, 28; avoided by most new states, 29; government contrasted with that of England, 29-30; tenure of Cabinets, 30; President contrasted with German President, 30; with Polish President, 31; commissions in, 34; second chamber, 50-51, 53; attitude toward independent Rhenish state, 63; proportional representation, 84, 105-108; control of foreign affairs, 136, 150; wartime socialism, 160; defeat in 1870,169 ; recognizes Czechoslovakia, 251; Esthonia, 453; influence in Esthonia, 454; note on constitutional history, 521-523; text of fundamental laws, 523-549.

Franklin, Benjamin, quoted, 54.

Functional representation, an old idea, 117; theoretical proposals for, 118, 119; difficulties of working out, 119 ; under German Council system, 119 132; and agreement between German Government and trade-unions, 135; in Austria, 135, 242, 249; in Poland, 135; in Jugoslavia, 135; in Danzig, 135.

Gajac, Jean, quoted, 154.

Galicia, 241, 247, 250, 308.

Gardiner, A. G., quoted, 17, 22, 44.

Genoa Conference of 1922, Poland stands with Petite Entente, 61; Germany and Poland agree on Upper Silesia, 66.

Georg, Edouard, cited, 152, 153.

George, Lloyd, relations with press, 22; with House of Commons, 28-29; position on reform of House of Lords, 41-42; views on danger of small states, 55-56; on submission of treaties to Parliament, 148; on Poland, 427. 
George $V$, influence on foreign affairs, 146.

Georgia, 3.

Germans, in Czechoslovakia, 76-77; in Austria, 241, 247, 250, 308, 344; in the Danzig corridor, 426-427; invade Esthonia, 453.

Germany, a composite system, 3; type of monarchy, 7; Bismarck's influence, 11-12; little republican sentiment, 15; monarchs and princes abdicate, 15; type of government under new constitution, 28; executive in states of, 28, 32; President contrasted with French President, 30; powers of President, 30-31; dissolution of state legislatures, 33; control of executive, 35 ; constituent assembly, 35; former Bundesrat, 38, 53; former federal system, 39, 62; problem of federalism, 62-64; creation of new states, 64-65, 68; a mendment of constitution of in re Upper Silesia, 66; loses part of Upper Silesia, 66; number of states, 67; character of federal system, 68-71; legislative centralization, 69-70; administrative centralization, 70-71; amendment of constitution, 71; union with Austria prevented, 74, 187-188, 255; proportional representation, 84, 97-102; functional representation, 119-132; Council system, 119-132; revolution, 119; monarchist insurrection, 133; agreement of Government with trade-unions, 133-134; former control of foreign affairs, 136, 139-140; national control of industry encouraged by Peace treaties, 161-162; former confederation of states, 167-169; formation of constitution of $1871,167-169$; victory over France in 1870, 169; political effects of military collapse in 1918, 169; revolution of 1918, 170-172; Workers and Soldiers Councils, 170172, 174; constituent assembly, 172-173; provisional government, 173-174; adoption of constitution, 175; constitution of, 176-212; Prussia's position under Empire, 213214; new constitutions of states, 215, 233-240; offers to negotiate peace, 251; addressed by President Wilson, 252; renounces rights in Danzig, 427-428; control over Finland ousted, 467.
Giese, F., cited, 72, 175; quoted, 173.

Giolitti, Giovanni, proposal of, to submit treaties to Parliament, 149.

Gladstone, W. E., foreign policy of, 139; and Queen Victoria, 143; quoted, 147, 164.

Goblet, F., cited, 93.

Goldenweiser; E. A., cited, 380.

Gollomo, Joseph, cited, 175.

Gordon, J. W., cited, 175.

Grant, N. F., cited, 140.

Great Britain, recognition of Czechoslovakia, 251; of Esthonia, 453; of Finland, 467; see also British Empire and England.

Greece, 15, 84 .

Hainisch, Michael, 256.

Haldane, Lord, quoted, 46, 49.

Hall, Duncan, cited, 12,78 .

Hallam, Henry, quoted, 143.

Hamilton, Alexander, quoted, 401.

Hapsburgs, yield to constitutionalism, 9; Petite Entente opposes, 60; absolutism, 241; support at outbreak of war, 250; relation to Jugoslavs, 343-345.

Harper, S. N., cited, 380.

Hayes, C. J. H., quoted, 13.

Heatley, cited, 147.

Heidenstam, E. von, cited, 84 .

Hertling, Count von, 213.

Holcombe, Arthur N., cited, 175.

Hoetzendorff, Conrad von, 344.

Hoetzl, J., quoted, 34, 35, 36, 159.

Hohenlohe, Prince, 218.

Hohenzollerns, yield to constitutionalism, 9; defeated, 14; idiosyncrasies, 140; see also William $I I$.

Holland, nationality, 3; constitutional monarchy, 7; self-government, 57 ; proportional representation, 84,114 .

House, E. M., and Seymour, cited, 427.

Humphreys, J. H., cited, 84, 89, 93, 97, quoted, 92, 94, 98, 112.

Hungary, no new constitution in, vi, industrial need of, 59; check on, by Petite Entente, 60; parts merged into Jugoslavia, 77; common law constitution, 155; position prior to 1867, 241-242; proposed scheme of Dualism, 243; ratified Ausgleich, Q44; outweighed Austria in influence, 245-246; geography, 246; opposed annexation of Serbia, 250; opposed Mittel Europa, 250; food 
blockade against Austria, 250; deserts Austria, 252; government of Jugoslavs in, 343.

Hussarek, Baron Max, quoted, 251; resignation, 253.

Imperial federation, 78 .

Imperialism and monarchy, 12.

Initiative, and referendum in new constitutions, 10; in Esthonia, 3233; for creation of new states in Germany, 64-65; see also Referen dum.

Ireland, 2, 79 .

Istria, 77, 343.

Italians, in Austria, 241, 247, 251.

Italy, a composite system, 3; constitutional monarchy, 7; responsible government, 40 ; second chamber, 45 , 117; proportional representation, $84,102-104$; control of foreign affairs, 136, 149; Austro-Hungarian territory to, 251; recognizes Esthonia, 453; note on constitutional history, 550; constitution of, 551564.

Jackson, Sir Harry, quoted, 138-139. Jacobi, E., quoted, 70-73.

Jellinek, W., cited, 72.

Joachim, V., cited, 109.

Judicial supremacy, in United States, 154; under new constitutions, 155, 158-159.

Jugoslavia, constitutional monarchy, 3, 28; unicameral legislature, 38; industrial need, 59 ; member of Petite Entente, 60; composition, 77; proportional representation, 84, 114, 348; functional representation, 135 ; independence of, 252-253, 309, 345; recognition of, 346 ; constituent assembly, 346; constitution similar to former Serbian, 347-348; constitution of, 348-378.

Jugoslavs, in Austria-Hungary, 251, 308 , 343; proposed solution of problem, 343-345; union of, 346 .

Kant, Emanuel, quoted, 13.

Kapp, Wolfgang von, 133.

Kautsky, Karl, cited, 140.

Kelsen, Hans, cited, 254, 255.

Kerensky, Alexander F., 115, 467; cited, 381.

Krafft, A. F., and Leresch, A., quoted, 110, 111.
Laband, quoted, 168.

Lachapelle, G., cited, 93.

Lammasch, Heinrich, 253.

Lana, Treaty of, 60.

Lansdowne, Lord, 143.

Latvia, no constitution yet adopted, vi; signs Baltic States' Treaty, 61.

Law, Bonar, and the Mesopotamian mandate, 148-149.

League of Nations, and increased number of states, 55; and Upper Silesia, 66; and Mesopotamian mandate, 148; Swiss referendum on joining, 152; Danzig under protection of, 427; approves Danzig constitution, 429, 448-451.

Lee, Francis B., cited, 499.

Legislative power, during war, 1; separation of, 6,9 ; relation to executive in new constitutions, 2633; control over administration, 34-37; organization in new constitutions, 38-41.

Legislators, decline in character, 1721; control by party, 19; pay, 19, 29.

Lenin, Vladimir Ilich, 382, 383, 467.

Levinski-Corwin, cited, 402.

Liberty, individual, see Bills of Rights and Judicial supremacy.

Liebknecht, Karl, 171, 172.

Liechtenstein, 3, 15.

Lindsay, S. M., and Rowe, I. S., cited, 551 .

Little Entente, see Petite Entente.

London, Treaty of, 345 .

Iord, R. H., quoted, 427.

Lords, House of, discussion of, 40-54.

Loreburn, Lord, cited, 136, 147, 149.

Lowell, A. L., cited, 27.

Luittwitz, General von, 133.

Luxemburg, Rosa, 171, 172.

Lvov, Prince, 467.

MacDonald, J. R., cited, 17.

MacDonald, Murray, quoted, 79-82.

MacDonald, William, cited, 37.

McIlwain, C. H., quoted, 155.

McKechnie, cited, 43.

MacNeill, J. G. Swift, quoted, 145.

Magyars, and Petite Entente, 60; in Czechoslovakia, 76; dominated Hungary, 245-246; opposed annexation of Serbia, 250; and Trialism, 344.

Maine, Sir Henry, quoted, 8, 13, 14.

Mannerheim, C. G. E., 467.

Marriott, J. A. R., quoted, $22,26,43$, 58. 
Masaryk, Thomas G., 308, 309.

Masterman, C. F. G., quoted, 44-45. Matter, Paul, cited, 215.

Max von Baden, Prince, 170, 213.

Mellor, William, quoted, 16.

Mesopotamian mandate, 148-149.

Meuschel, Adelheid, paraphrased, 233-240.

Mill, John Stuart, cited, 153.

Minorities, under new constitutions, 10 ; treaties, 83; coalition of, necessary in European states, 89.

Monarchists, in Germany, 133, 171.

Monarchs, and foreign affairs, 139146.

Monarchy, strength of, 11-14.

Moneypenny and Buckle, cited, 142, 143.

Montenegro, 77, 343, 346.

Montesquieu, $5,7$.

Moravia, 241, 247, 307.

Morel, E. D., cited, 136, 149.

Morgan, J. H., quoted, 51-54.

Morley, Lord, quoted, 8, 25, 115, 116.

Mousset, Albert, cited, 346.

Muir, Ramsay, quoted, 42, 43, 45.

Munro, William Bennett, cited, 175.

Myers, D. P. cited, 140.

Nationalism, in 19th century, 8-9.

Nationality, principle of, 2 .

Nationalization, during war, 1; new constitutions invite, 159; philosophy of, 159-162.

Navaisky, cited, 176.

Neilson, F. cited, 136.

North German Confederation, 167169.

Norway, proportional representation, 114; control of foreign affairs, 136, 149-150.

Olgin, M. J., cited, 381, 384.

Ostrogorski, M., quoted, 87-88.

Owen, Robert, 382.

Paets, K., 453.

Palandech, J. R., 348.

Palmerston, Lord, 141.

Panachage, see Proportional representation.

Parliamentary government, under new constitutions, 26-33, 164; types of before war, 27; with two coequal chambers, 39-41; in France, 50-51.

Peace, legislatures declare, in new states, 150.

Peace Conference, creates new states,
2, 55; creates Free City of Danzig, 426-427; recognizes Finland, 467.

Peace treaties, encourage national control of industry, 161-162; see also under names of treaties.

Pedersen, Oscar, cited, 150.

Petite Entente, formation and purpose of, 60 ; future of, $60-61$.

Petitjean, T., cited, 93.

Pilsudski, Joseph, 403.

Plebiscite, in East Prussia, 63; in Upper Silesia, 63, 65-66.

Poetsch, cited, 72, 176.

Poincaré, Raymond, cited, 140.

Poland, democratic government, 3; character of constitution, 26, 28; powers of President, 31; and Petite Entente, 61; signs Baltic States' Treaty, 61; separates East Prussia from Prussia, 63; secures part of Upper Silesia, 66; proportional representation, 84, 113-114; functional representation, 135; medieval state revived, 307; constitution of 1791, 401-402; partitions of, 402; Russian proposal in re, 403; GermanAustrian proposal in re, 403; Council of Regency, 403; constituent assembly, 403; constitutional problems, 404; constitution of, 405-425; geography, 426; and Danzig, 428.

Poles, in Austria, 241, 246, 247, 250, 308; under alien domination, 402; ambition of, at Peace Conference 426.

Political parties, discipline, 19; number in France, 30; in new states 30,89 ; in England, attitude toward House of Lords, 42-44; basis of, 85-86; facts and theory, 86-87; and organization, 87; Bryce on, 87; Ostrogorski on, 87-88; two rs. many, 88; and proportional representation, 88; cohering agency of, 89 ; in Denmark, 92; in Belgium, 92; in Germany, 101, 170-174; in Italy, 104; in France, 106; in Czechoslovakia, 109; in Switzerland, 112113; in Poland, 114; in Prussia, 215; in Austria, 249, 254-255; in Jugoslavia, 346; in Russia, 379-380; in Danzig, 428.

Pollard, A. F., quoted, 7; cited, 78. Ponsonby, A., cited, 136, 147.

Portugal, 3, 7, 84 .

Posener, Paul, cited, 499, 523, 551.

Poska, Jaan, 453.

Postgate, R. W., cited, 382, 383. 
United States, a composite system, 3; discontent with representative government, 16; political influence of trade-unions, 20; type of government, 27-30; did not attract new states, 28; contrasted with French government, 30 ; legislative process, 49-50; admission of new states compared with German method, 68; amending process compared with German, 71; Bureau of Labor Statistics, 126-128; control of foreign affairs, 138; concept of constitution, 154; wartime socialism in, 160; Constitutional Convention, 168; recognition of Czechoslovakia, 251; attitude toward Czechoslovakia in Jugoslavia, 309; influence in Esthonia, 454; recognition of Finland, 467 .

Upper Silesia, possible separation from Prussia, 63-66; plebiscite, 63, 65-66; importance of, 65; InterAllied Commission on, 66; proposed Mixed Commission for, 66; agreement at Genoa Conference, 66.

Vandervelde, cited, 381.

Versailles, Treaty of, provision re Upper Silesia, 65; re union of Germany and Austria, 74; re Danzig, 427-428; see also Peace Treaties.

Victoria, Queen, influence on monarchy, 11; over foreign affairs, 140143.

Vienna, relation to Lower Austria, 75; see also Congress of Vienna.

Vincent, J. M. and A. S., cited, 499.

Vinogradoff, Paul, cited, 380.

Voltaire, quoted, 401-402.

Wales, separate legislature for, 79-82.

Wallas, Graham, cited, 12, 14 .

War, legislatures in new states declare, 150.

Webb, S. and B., cited, 12, 17, 37, 118, 119.
Weimar, 57, 173.

Wekerle, Santor, quoted, 252.

Wells, H. G., quoted, 14, 162; cited, 139.

Westphalia, Peace of, 2; and a Rhenish state, 63.

William II, of Germany, influence on foreign affairs, 14, 139-140; abdication of, 170, 214; Chancellors of, 213; see also Hohenzollerns.

Williams, Fisher, cited, 89.

Willoughby, W. W., and Rogers, L., cited, $7,13,21,30,34,52,82,140$, $143,147,175$.

Wilson, Woodrow, influence against monarchy, 15; "fourteen points," 251, 309; addresses German Chancellor, 252; ignores AustriaHungary, 252; demands independence of Czechoslovakia and Jugoslavia, 252, 308-309; on Poland, 426-427.

Wolfe, H. W., and Andrews, A. I., cited, 348.

Woman's suffrage, 1.

Workers Chambers, in Austria, 135.

Workers Councils in Germany, Factory, District, and Reich, 121, 130; of the Reich not yet established. 128; see also Factory Workers Councils and Soldiers and Workers Councils.

Works Councils, see Factory Workers Councils.

Wright, Herbert F., cited, 347; quoted, 499, 521-523; 550-551.

Wuirttemberg, proportional representation, 97 ; treaty with North German confederation, 169; government under constitution of 1919 , 236-237.

Young, George, quoted, 120, 173; cited, 175.

Yugoslavia, see Jugoslavia.

Zeuthen, F., quoted, 91. 

09208 


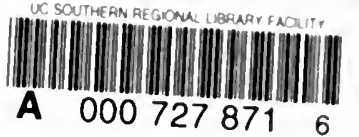


ini.

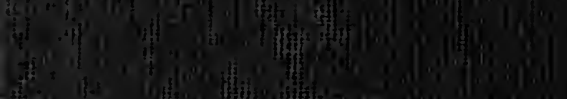

(1)

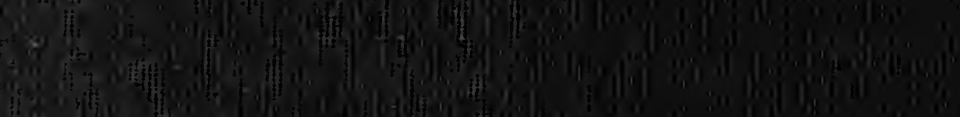

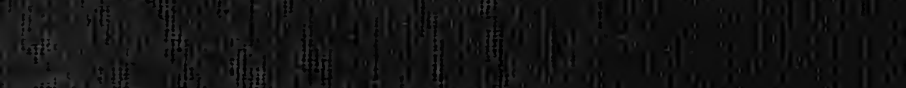

1.

(5)

5ith

1.

,

B.:

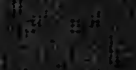

$\therefore$ i I I

1. 